


\section{Digitized by the Internet Archive}

in 2007 with funding from Microsoft Corporation 



\section{LIBRARY OF CONGRESS}

\section{GUIDE}

TO THE

\section{LAW AND LEGAL LITERATURE}

OF

\section{ARGENTINA, BRAZIL AND CHILE}

BY

EDWIN M. BORCHARD

PROFESSOR OF LAW,' YALE UNIVERSITY FORMERLY LAW LIBRARIAN, LIBRARY OF CONGRESS

(1911-1916)

WASHINGTON

GOVERNMENT PRINTING OFFICE 


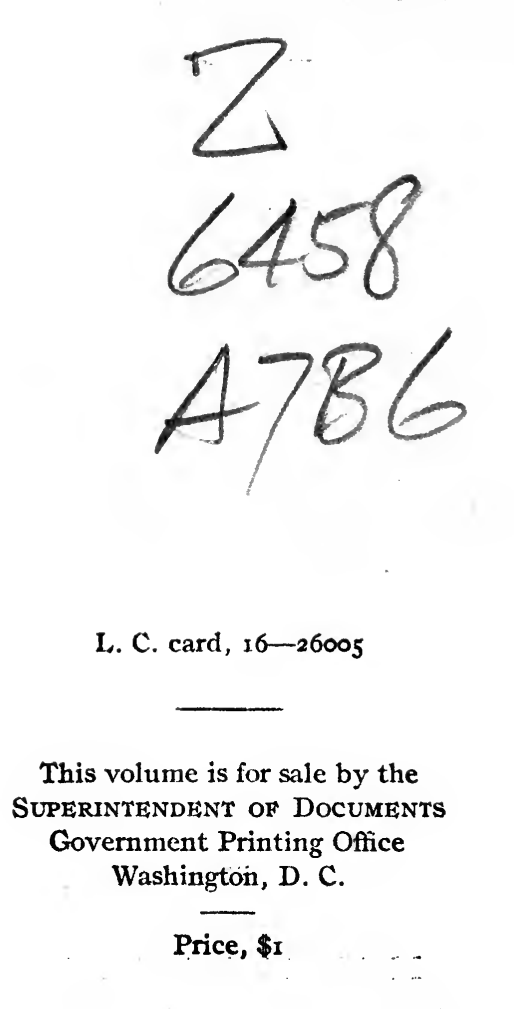




\section{P R E F A CE}

This is the fourth in the series of guides to foreign law published by the Library of Congress. Its immediate predecessor was the "Guide to the law and legal literature of Spain," in which country the foundations were developed, if not laid, for the institutions of private law of the Spanish American republics. The great source book of Brazilian law, the Codigo Philippino, was promulgated in 1603 during the time when the governments of Spain and Portugal were united under one sovereign. The common origin of Latin American private law in the Roman law has been especially manifested in Brazil, where until January I, I916, no civil code had been enacted. On that date Brazil joined her sister republics by promulgating what is admitted to be the most scientific and modern civil code of Latin America.

While Argentina, Brazil, and Chile in common with the other republics of Latin America have turned to European (particularly French and Spanish) models for their institutions of private law, the United States has been the prototype for their constitutions and much of their constitutional law. Indeed, the decisions of the United States Supreme Court and the contributions of our writers on constitutional law are familiar to South American courts and constitutional lawyers. To the political scientist, it is interesting to observe the result of the implantation of exotic institutions in new soil.

Argentina, Brazil, and Chile have, besides a common original source of their law, this feature in common: Each has produced one remarkable codifier, Dalmacio Velez Sarsfield in Argentina, Augusto Teixeira de Freitas in Brazil, and Andrés Bello in Chile, who have erected to themselves permanent legal monuments. The influence of their work has spread from these countries to the other republics of Latin America. Depending, as these countries have, upon foreign experience for the formulation of their law, they have, as an incident to 
the selection of the best, produced numerous noteworthy contributions to comparative law, a feature particularly prominent in Brazil in the literature on private law and in Argentina and Chile on public law.

In the preparation of this work the threefold aim of the undertaking of publishing these guides has been preserved: First, to furnish the lawyer and the student of comparative law with information as to the institutions and literature of the public and private law of the countries under discussion; secondly, to acquaint the legislator and the man of affairs with the recent development of legislation, particularly that designed to meet the social and economic problems of the day; and, thirdly, to give the jurist and the historian some guidance to the contributions made in these countries to the history, the theory, and the philosophy of law.

The work is the result of studies made in the foreign law collections of the Library of Congress and in Argentina, Brazil, and Chile. It is fitting to make special acknowledgment of the helpful service rendered to the enterprise by Dr: José Léon Suarez and other members of the Faculty of Law at Buenos Aires; Dr. Rodrigo Octavio and Senator Ruy Barbosa of Rio de Janeiro; and Señor Don Carlos Silva Cruz and Dr. Julio Philippi of Santiago de Chile.

The index has been prepared by Miss R. L. Love of the Law Division.

HERBERT PUTNAM

EDWIN M. BORCHARD

Librarian. of Congress

Octaber 27, 1916.

Law Librarian 


\section{CONTENTS}

Preface.

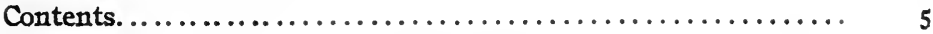

ARGENTINA

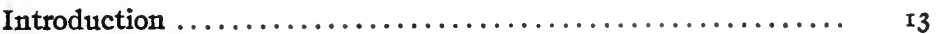

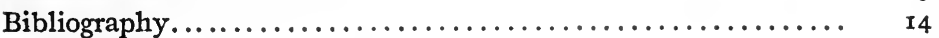

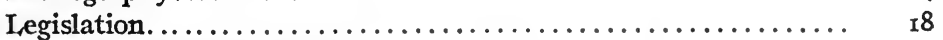

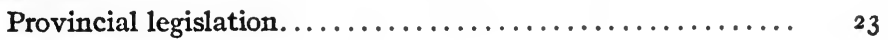

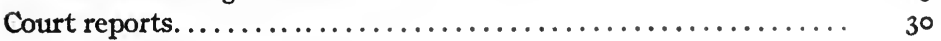

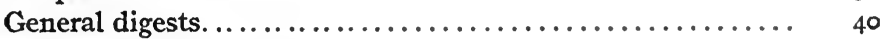

General works.................................... 4 I

Legal periodicals............................ 47

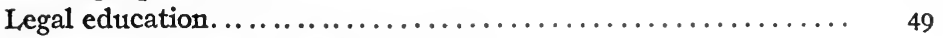

Jurisprudence and philosophy of law................... $5^{\circ}$

Legal history....................................... 53

Civil code..................................... 60

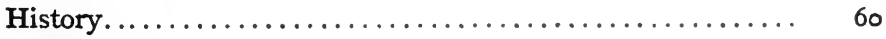

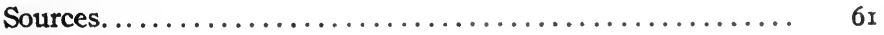

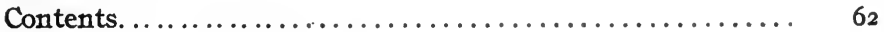

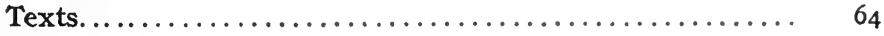

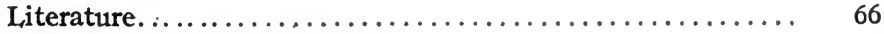

Incidental and related topics..................... 70

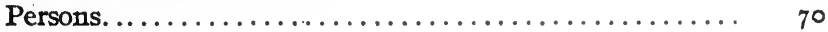

Legal liability............................ 70

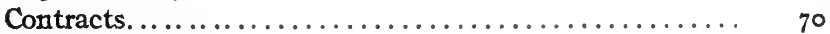

Possession................................... $7_{1}$

Real property............................. $\quad \eta^{\mathrm{I}}$

Mortgages.............................. $\eta_{I}$

Literary and industrial property................... $7^{2}$

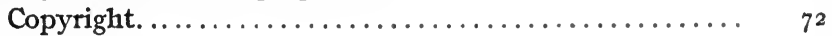

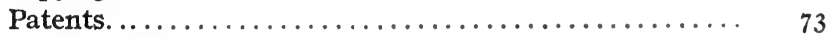

Trade-marks............................. 74

Commercial law.................................. ${ }_{76}$

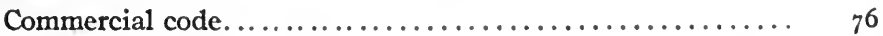

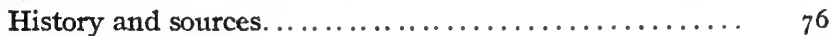

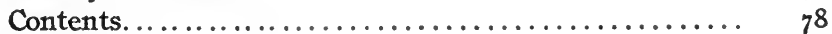

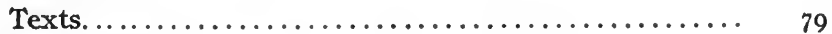

Literature................................ 80 
Commercial law-Continued. Page

Incidental and related topics. .................... $\quad \mathbf{8 4}_{4}$

Insurance............................. 85

Commercial documents. ................... 85

Bills of exchange........................... 86

Corporations............................. 86

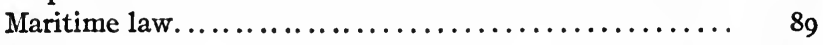

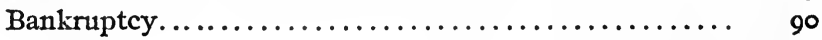

Consuls................................ 92

Judicial organization and civil procedure ................ 92

Judicial organization. .......................... $9^{2}$

Federal courts........................... 92

The capital............................. 93

The provinces........................... 94

Civil procedure............................. 94

Literature............................ ${ }_{96}^{96}$

Code of the capital ....................... 99

Province of Buenos Aires...................... I0I

Other provinces.......................... 103

Notaries public............................ I04

Criminal law.................................... 106

Penal code.............................. 106

History................................ 106

Literature............................. 108

Criminology $\ldots \ldots \ldots \ldots \ldots \ldots \ldots \ldots \ldots \ldots \ldots \ldots \ldots \ldots \ldots \ldots \ldots \ldots \ldots \ldots$

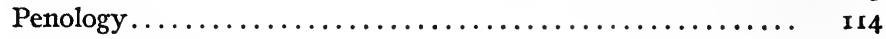

Legal medicine ................................ $\quad$ II $_{5}$

Criminal procedure............................. I15

Province of Buenos Aires...................... 118

Constitutional law.............................. II

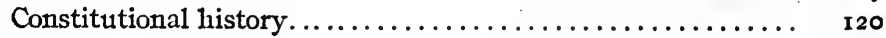

Source books.............................. I22

Texts..................................... 123

Literature............................... 123

Monographs................................. 130

Parliamentary government.................. I30

Executive power......................... I30

Judicial power......................... I $3 \mathbf{I}$

Constitutional guaranties..................... I I

Federal intervention. ........................ $\mathbf{I}_{3^{2}}$

Unconstitionality of legislation. ................ $\mathbf{I}_{32}$

Eminent domain .......................... ${ }_{133}$

Collected writings....................... 133

Citizenship............................... ${ }_{134}$

The provinces................................ ${ }_{134}$

Province of Buenos Aires..................... I35 $_{35}$

Province of Cordoba......................... $1_{36}$

Election law.......................... ${ }_{137}$ 


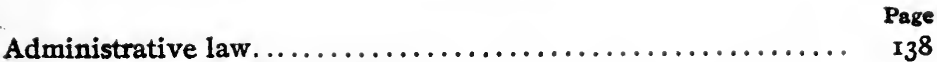

Administrative organization..................... I39 $_{39}$

Municipalities............................ $\mathbf{I}_{\mathbf{4}} \mathbf{I}$

Claims against the Government.................. $\mathbf{r 4 2}_{42}$

Immigration and colonization. .................... $\quad \mathbf{I}_{43}$

Public lands.................................. $\quad{ }_{43}$

Rural code.............................. $\mathbf{I 4}_{4}$

Mining law................................ ${ }_{14} 8$

Railroads.................................. 150

Public works.............................. ${ }_{1_{52}}$

Merchant marine............................. ${ }_{1_{52}}$

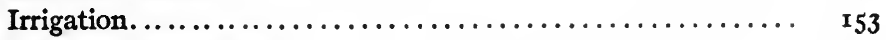

Posts and telegraphs........................... ${ }_{153}$

Weights and measures. . . . . . . . . . . . . . . . . . . . ${ }^{r_{55}}$

Social legislation. ............................ ${ }_{155}$

Labor laws............................... ${ }_{155}$

Civil pensions............................ I60

Sanitation and public hygiene.................. I6r

Educational law.............................. $\mathbf{1 6}_{2}$

Financial legislation......................... I64

Banking law and finance..................... 164

Debt and taxation........................... 167

Customs laws............................... 169

Military law................................ 171

Ecclesiastical law................................ 173

International law. ............................ I74

Treaties................................. ${ }_{7} 6$

Aliens and nationality.......................... ${ }_{17} 8$

Civil war claims........................... I80

Extradition............................. 180

International conferences........................ 180

Arbitration................................ I8I

Drago doctrine.......................... 182

Miscellaneous topics.......................... $\quad 183$

Diplomatic and consular service.................. $\quad 8_{4}$

Diplomatic history ......................... 185

Conflict of laws............................. 187

BRAZIL

Introduction. ............................... 191

Bibliography.................................... 193

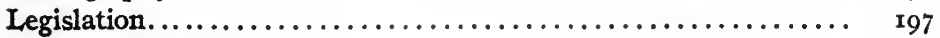

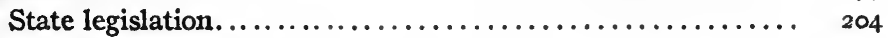

Court reports. ................................ 2II

General works................................. 218

Legal periodicals........................... $22 \mathrm{I}$

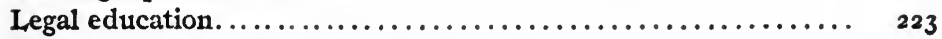

Jurisprudence and philosophy of law................... 224 


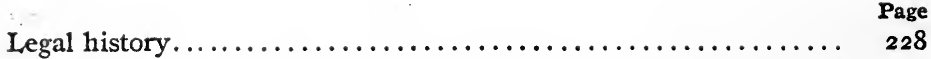

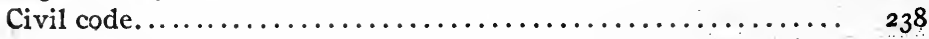

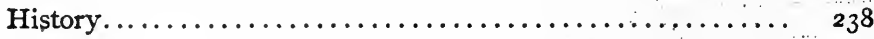

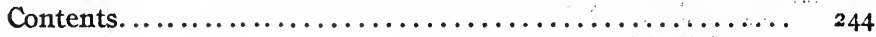

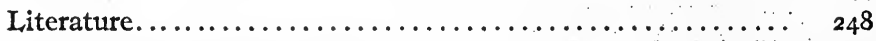

Incidental and related topics. .................... 252

General part of the code................. 252

Legal interpretation. ...................... 253

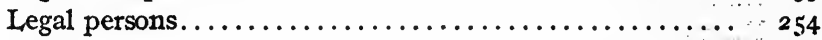

Legal acts. ............................ 254

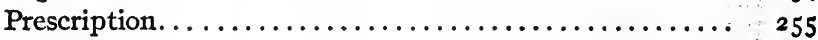

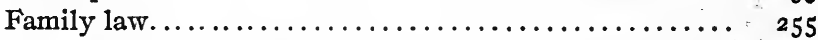

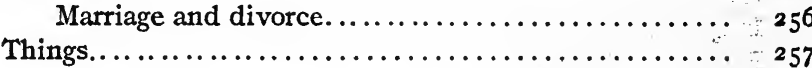

Possession. .............................. 258

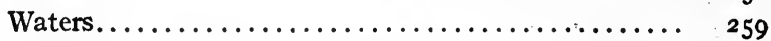

Partition .......................... 259

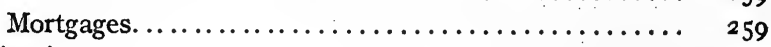

Obligations......................... 262

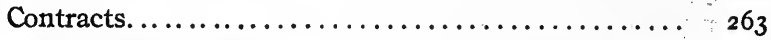

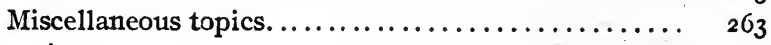

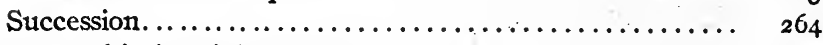

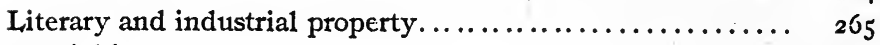

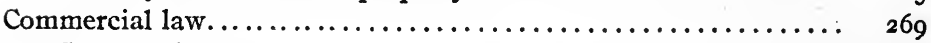

Commercial code.......................... 270

Contents and supplementary legislation........... 272

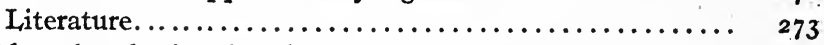

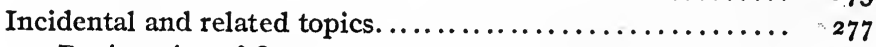

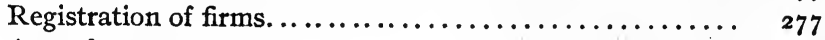

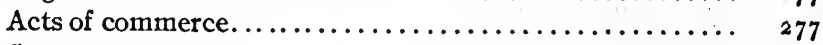

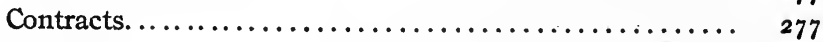

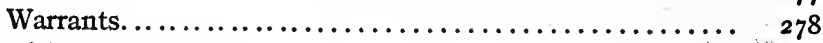

Bills of exchange...................... 279

Corporations.......................

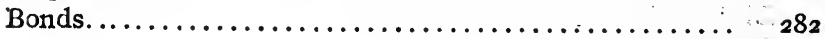

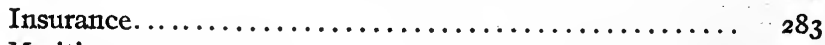

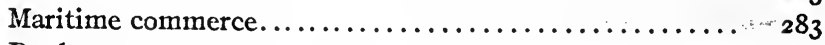

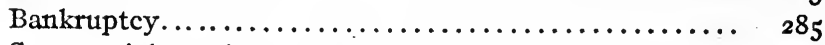

Commercial treaties...................... 286

Judicial organization and civil procedure .............. 286

Judicial organization. ...................... \&86

Federal courts. ....................... 286

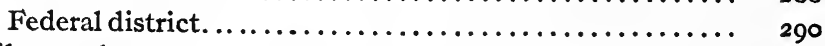

Civil procedure ............................ $29 \mathrm{n}$

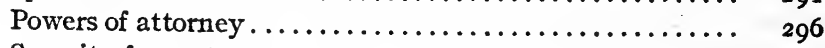

Security for costs. ..................... 297

Judicial costs. ........................ ${ }^{297}$

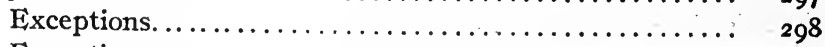

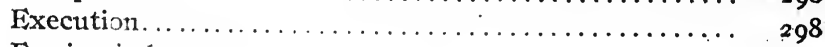

Foreign judgments. . . . . . . . . . . . . . . . 29 


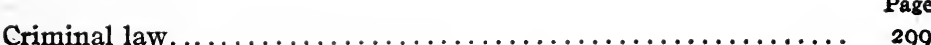

Penal code.............................. $\quad 299$

Literature of code of $1830 \ldots \ldots \ldots \ldots \ldots \ldots \ldots \ldots \ldots$ 30I

Contents of code of $1890 \ldots \ldots \ldots \ldots \ldots \ldots \ldots \ldots \ldots \ldots, \quad 302$

Literature............................. 302

Monographs............................ 304

Criminology ............................... 305

Legal medicine............................ 306

Criminal procedure........................... 307

District attorneys. ............................. 3 I0

Habeas corpus. ............................... 3 II

Jury system................................. 3 II

Constitutional law.................................... $3^{\text {II }}$

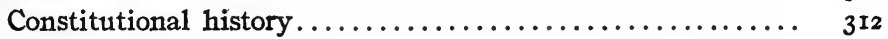

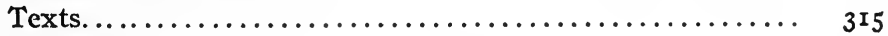

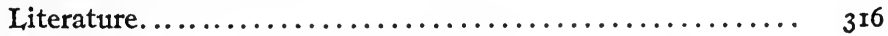

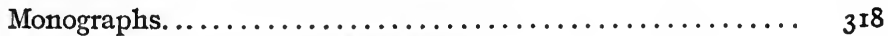

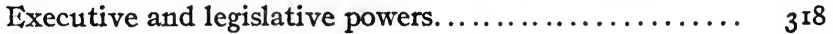

Judicial power........................... $3^{18}$

Unconstitutionality of legislation $\ldots \ldots \ldots \ldots \ldots \ldots \ldots, 318$

Federal system........................... 3 I9

Miscellaneous studies........................ 320

Federal intervention........................ $32 \mathrm{I}$

Minor topics........................... 32 I

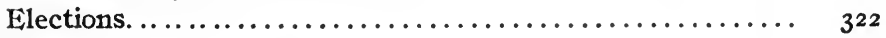

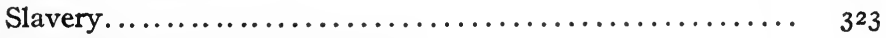

Citizenship and naturalization..................... $3^{24}$

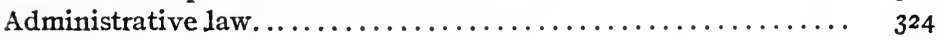

Judicial control of administration................. $3^{26}$

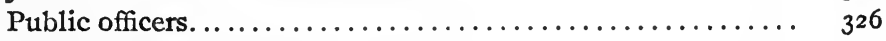

Claims against the state..................... 327

Executive departments......................... 327

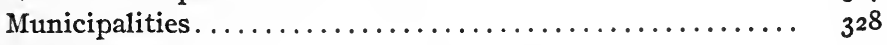

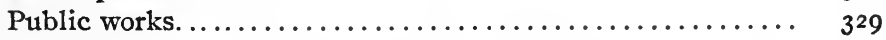

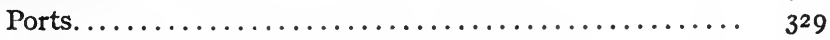

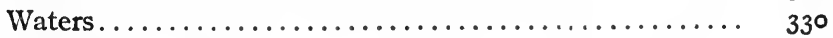

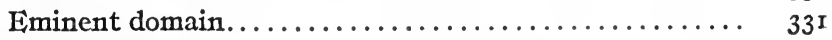

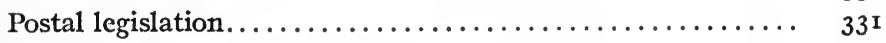

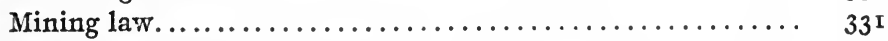

Immigration and colonization. ................... 333

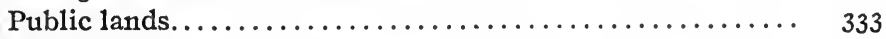

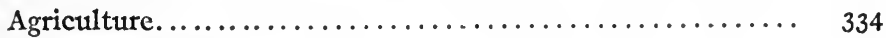

Educational law.............................. 334

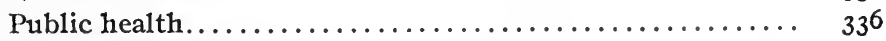

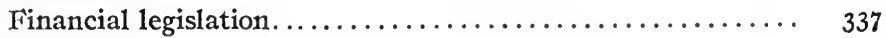

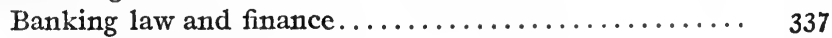

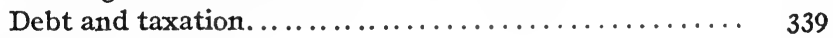

Court of accounts......................... 343

Customs laws............................ 344 
Military law.................................. 346

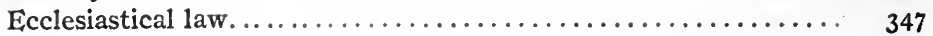

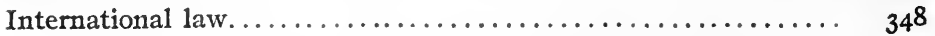

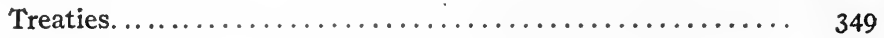

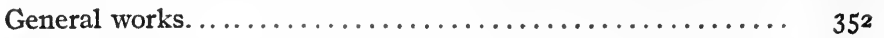

Monographs............................... 353

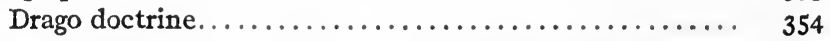

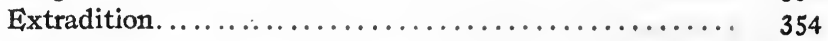

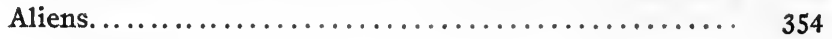

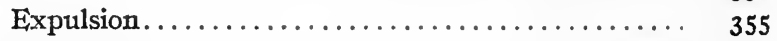

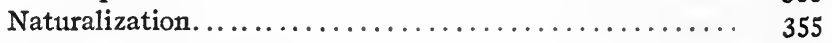

International conferences...................... 356

Diplomatic and consular service................ 357

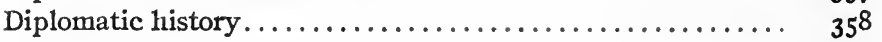

Conflict of laws............................ ${ }_{362}$

\section{CHILE}

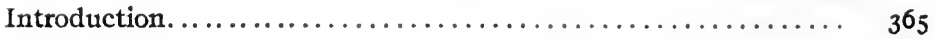

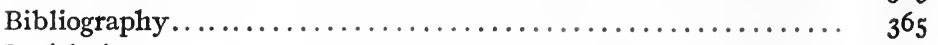

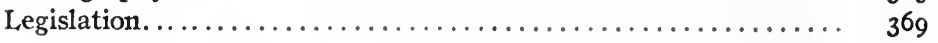

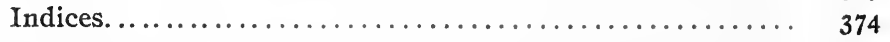

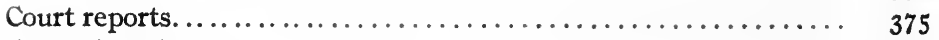

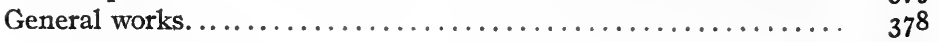

Collected codes............................. ${ }_{378}$

Legal encyclopedias........................ 378

Legal periodicals......................... 379

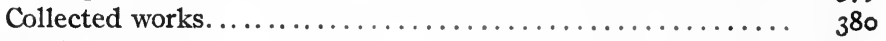

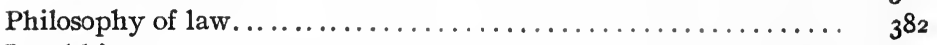

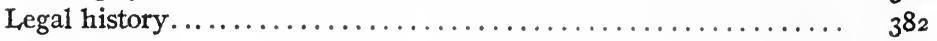

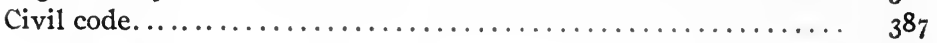

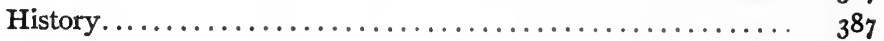

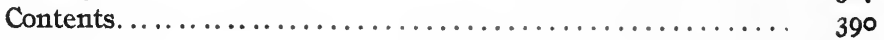

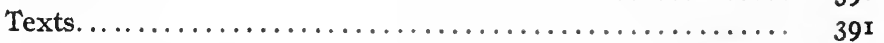

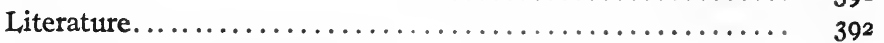

Incidental and related topics................... 394

Civil marriage......................... 394

Testamentary succession..................... 395

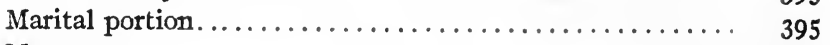

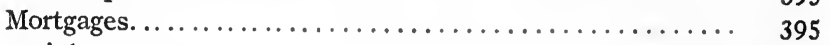

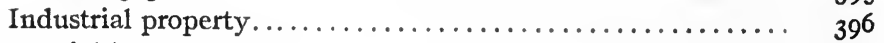

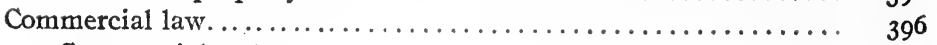

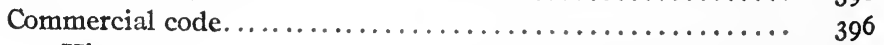

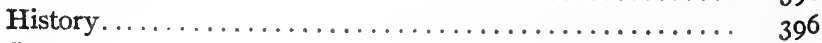

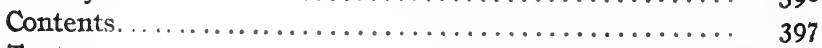

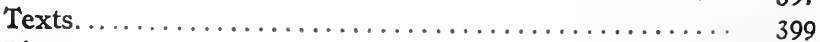

Literature......................... 400 
Commercial law-Continued.

Commercial code-Continued. Page

Special topics........................... 400

Commercial acts........................ 400

Corporations.......................... 400

Navigation.......................... $40 \mathrm{r}$

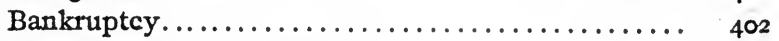

Judicial organization and civil procedure.............. 402

Judicial organization....................... 402

History of Act of $1875 \ldots \ldots \ldots \ldots \ldots \ldots \ldots \ldots \ldots, 402$

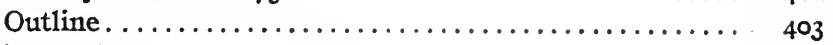

Civil procedure............................ 406

History............................. 406

Contents of code of $1902 \ldots \ldots \ldots \ldots \ldots \ldots \ldots \ldots \ldots .407$

Literature.............................. 409

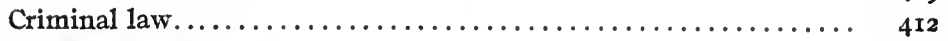

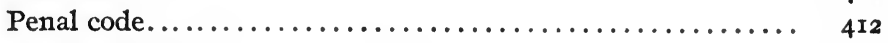

Criminal procedure............................ $4 \mathrm{I}_{4}$

Constitutional law.................................. 4 I6

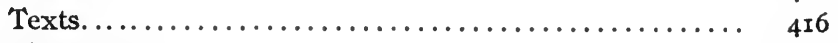

Literature............................. $4{ }^{17}$

Parliamentary law............................. 4

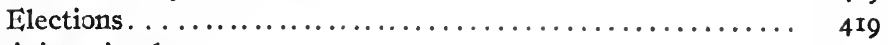

Administrative law............................ 420

Administrative organization. .................. 420

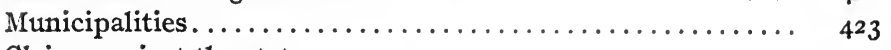

Claims against the state..................... 424

Immigration and colonization $\ldots \ldots \ldots \ldots \ldots \ldots \ldots \ldots, 425$

Agricultural and water laws . . . . . . . . . . . . . . 425

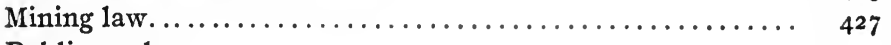

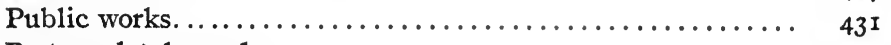

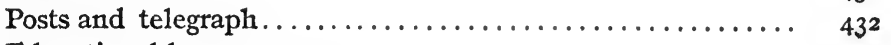

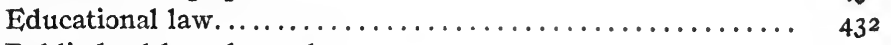

Public health and morals.................... 433

Financial legislation....................... 434

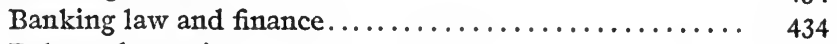

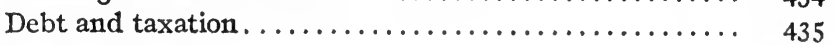

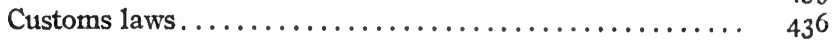

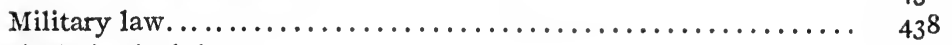

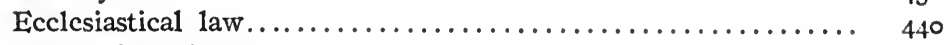

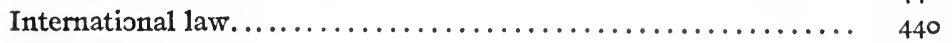

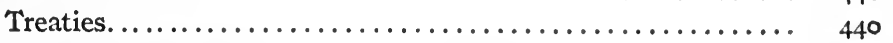

Consular legislation. ........................ $44 \mathrm{I}$

General treatises............................ 442

Uti possidetis. . . ........................ 443

Maritime war.............................. 443 
International law-Continued. Page

Claims.................................. 444

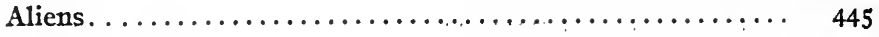

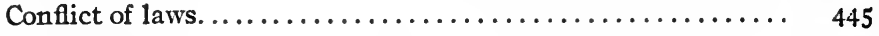

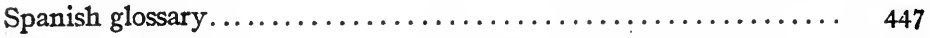

Portuguese glossary .......................... 472

Index. . . . . . . . . . . . . . . . . . . . . . . . . . . . 479 


\section{GUIDE TO THE LAW AND LEGAL LITERATURE OF ARGENTINA, BRAZIL, AND CHILE}

\section{ARGENTINA}

\section{INTRODUCTION}

The Argentine Republic is a federal government organized largely on the model of the United States. There is a central government with its capital at the city of Buenos Aires and fourteen provinces each with an independent provincial legislature. The provinces are Buenos Aires (with its capital at La Plata) Catamarca, Córdoba, Corrientes, Entre Rios, Jujuy, La Rioja, Mendoza, Salta, San Juan, San Luis, Santa Fé, Santiago del Estero, and Tucumán. Besides these there are the national territories analogous to the territories of the United States which have not yet been incorporated as states. The central government legislates for the territories. In the national capital, the municipality of Buenos Aires, there is an independent municipal council called Concejo deliberanta which enacts municipal ordinances for the city, and in addition the national government has enacted for the capital of Buenos Aires independent codes of procedure and judicial organization.

In a general way the constitution has divided jurisdiction between the central government and the provinces very much as is the case in the United States, namely, powers not granted to the federal government are reserved to the provinces. This principle, however, has some modifications. The central government has been granted authority to enact civil, commercial, penal, and mining codes, but the codes of procedure, both civil and criminal, in application of these codes, are provincial laws. 
Each province has its constitution, tax and license laws, its laws of stamped paper, its law of municipalities, its land laws, its laws for the registration of civil status and mortgages, its water laws, its codes of civil and criminal procedure, and its own judicial organization, and the larger cities publish their municipal ordinances. The constitutions and the procedural codes tend to approximate each other, and there is in fact but little difference between them. In appropriate sections these codes and statutes will be discussed.

The territory now known as the Argentine Republic was incorporated by Spain for administrative purposes, with some additional territory now included in Paraguay and Uruguay, in the vice-royalty of Peru until by letters patent of August Io, 1776, it was organized as the vice-royalty of the Rio de la Plata. On May 25, 1810, a revolution began which culminated in the independence of Argentina, proclaimed on July 9 , 1816, at Tucumán.

\section{BIBLIOGRAPHY}

The Argentine Republic, considering its importance and the extent of its literature, is rather poor in bibliographic publications. This dearth of bibliographic information is particularly marked in law. What was in its time a most useful bibliography is the Anuario bibliografico de la Repuiblica Argentina, published annually from 1879 to 1887 , first edited by its founder, Alberto Navarro Viola, ${ }^{1}$ a lawyer, and after his death, in 1885 , by Enrique Navarro Viola. The publication was divided into the various sciences, the first part being devoted to law. It included critical reviews of the books published during the year. No similar publication has taken its place. An interesting article by Ernesto Quesada, on Argentine bibliography, having particular reference, however, to the Anuario bibliografico, was published in the Nueva Revista de Buenos Aires, III (1881), pages 258-278. The Museo Social Argentino began in 1915 the publication of a monthly Boletin bibliografico mensual, as a supplement to its regular Boletin. It contains lists of books and articles relating to law and political and social science.

\footnotetext{
${ }^{1}$ Anuario bibliográfico de la República Argentina. Año 1-9; 1879-1887.
} Buenos Aires, r880-88. 9 v. 
Probably the best bibliography of Argentine legal literature is the catalogue ${ }^{1}$ of the library of the faculty of law of the University of Buenos Aires, published in 1898 , with a cumulative supplement in 1902 and annual supplements from 1903 to date. The original catalogue of 1898 is now exceedingly difficult to obtain.

A catalogue of the doctoral dissertations on law at the University of La Plata ${ }^{2}$ was published in I9I4.

There are a number of works, dealing with the history of printing, and the early bibliography of Buenos Aires and Argentina, which have some interest in law by their inclusion of early legal literature. One of the most useful of these publications is the history and bibliography of printing in the vice-royalty of Rio de La Plata, published by the renowned bibliophile, José Toribio Medina, ${ }^{3}$ of Santiago, Chile. Part III of the work includes the literature printed in Buenos Aires in the period $1780-1810$.

Another celebrated bibliophile, Antonio Zinny,, ${ }^{4}$ published in 1869 a bibliography of the periodicals issued in Buenos Aires from $1801-1852$, which is of some interest for legal literature. The same author also published, in 1875 , a résumé of the orders, notices, proclamations, and manifestos which appeared in the Gaceta de Buenos Aires from I810-1821. The same year he published his bibliographic history of the

1 Catálogo metódico de la biblioteca de la facultad de derecho. Buenos Aires, M. Biedma, I898. 426 p. Tercer suplemento. Buenos Aires, Biedma, r902. Annual supplements, I903-I9I4.

${ }^{2}$ La Plata. Universidad nacional. Catálogo de la colección de tesis jurídicas arreglada según clasificación decimal. Buenos Aires, Impr. de Coni herm., rgr4. Ior $\mathrm{p}$.

${ }^{3}$ Medina, José Toribio: Historia y bibliografía de la imprenta en el antiguo vireinato del Río de la Plata ... I a Plata, Taller de publicaciones del Museo; Buenos Aires, F. Lajouane; Londres, B. Quaritch, etc., r8gz. 4 pt. in I v.

- Zinny, Antonio: Efemeridografia argirometropolitana hasta la caida del gobierno de Rosas. Contiene el título, fecha de su aparicion y cesacion, formato, imprenta, número de que se compone cada coleccion, nombre de los redactores que se conocen, observaciones y noticias biográficas sobre cada uno de estos, y la biblioteca pública 6 particular donde se encuentra el periódico. Buenos Aires, Impr. del Plata, r869. $545 \mathrm{p}$. 
provinces of the Rio de La Plata from ${ }^{1780-1821}{ }^{1}$ as an appendix to the Gaceta de Buenos Aires. This work also contains much valuable information concerning the decrees, ordinances, and proclamations issued up to i821. Zinny also prepared a résume ${ }^{2}$ of the contents of the Gaceta mercantil, issued from 1823 to 1852 . While one volume was published in 1875 , the work has recently been reissued as a posthumous work in three volumes.

Of the catalogues that have been published by various institutions a few have an interest for law. The catalogue ${ }^{3}$ of the works of the Argentine provinces located in the public library of La Plata is a useful source of information for the official documents of the provinces of Argentina and of the productions of provincial authors.

The Library of the Ministry of Foreign Affairs ${ }^{4}$ has published a useful catalogue of its resources by way of maps, charts, official documents, and books, of which the books on law constitute a considerable number. The catalogue was first issued in 1902 and new editions appeared in 1905 and I9I0.

The catalogue of the Museo Mitre, ${ }^{5}$ probably the most valuable historical library in South America, published a catalogue in 1907 which includes many law books. The catalogue of

1 Zinny, Antonio: Bibliografía histórica de las provincias unidas del Rio de la Plata desde el año r780 hasta el de r82r. (Apéndice á la Gaceta de Buenos Aires.) Buenos Aires, Impr. Americana, I87.5. 476 p. +index.

2 Zinny, Antonio: La gaceta mercantil de Buenos Aires, I823-1852; resumen de su contenido con relación a la parte americana. Buenos Aires, Impr. Americana, I875. 384 p. Buenos Aires, J. Lajouane, 19r5. $3 \mathrm{v}$.

${ }^{3}$ Catálogo general razonado de las obras adquiridas en las provincias argentinas á las que se agregan muchas otras más ó ménos raras. San Martin, Escuela de artes y oficios de la provincia, r887. 344 p.

- Catálogo de la -biblioteca, mapoteca y archivo. Apéndice: Servicios prestados en la carrera diplomática y administrativa; r8ro-rgro. Buenos Aires, Impr. y casa editora "Juan A. Alsina," rgro. 3 d ed. ro53 $\mathrm{p}$.

5 "Museo Mitre." Catálogo de la biblioteca. Buenos Aires, Impr. de M. Biedma é hijo, 1907. $704 \mathrm{p}$. 
the library of the Faculty of Philosophy ${ }^{1}$ of the National University, published in ror2, contains a number of law items. The catalogue of the National Library ${ }^{2}$ is in course of publication. Several parts have already been issued, but the volume on law still awaits publication.

Various publishing houses have issued catalogues which have bibliographic interest. One of the best known is the Libreria Nacional of J. Lajouane and Co., which issues catalogues at periodical intervals, including their own publications and those they have for sale. Useful catalogues on special branches of the law are also issued by the publishing house of Abeledo. In I910 the Librería Rivadavia of Gustavo Mendesky and Son issued an extensive catalogue of Argentine and other South American works, with a supplement in I912. A considerable part of the catalogue is devoted to legal literature. The house of Lajouane publishes monthly a Boletin bibliográfico, a pamphlet of a few pages which contains a list of works recently published on law and other subjects. Up to December, I916, 229 numbers of the Boletin had been issued.

One of the most interesting productions of Argentine legal literature is the work on Argentine criminology of Eusebio Gómez ${ }^{3}$ which, besides its importance as a monograph (infra, p. 108) contains a valuable critical bibliography of the literature on criminal law, including the legislative drafts of the penal code, works on the penal code, the law of criminal procedure, and on the laws, decrees, orders, etc., relating to criminal matters or to criminal procedure, prison administration, etc.

1 Universidad Nacional. Facultad de filosofía y letras. Catálogo de la Biblioteca. Buenos Aires, Compañía sud-americana de billetes de banco, rgr2. $\quad 167 \mathrm{p}$.

${ }^{2}$ Biblioteca Nacional. Catálogo metódico de la Biblioteca Nacional seguido de una table alfabética de autores. Buenos Aires, Coni hermanos, r900-.

${ }^{3}$ Gómez, Eusebio: Criminología argentina: reseña bibliográfica, precedida de un estudio sobre el problema penal argentino. Buenos Aires, M. A. Rosas y cia., 1912. 286 p.

$71624^{\circ}-17-2$ 


\section{LEGISLATION}

The legislation of Argentina is to be found in the enactments of the various Congresses and in the decrees of its executive authorities. Until 1852, when the dictatorship of Rosas was brought to an end, these enactments are found scattered through the reports of the proceedings of various ephemeral legislative assemblies. During the period $1820-1824$ and $1827-1852$ one can hardly speak of a federal government. The administration of the dictator Rosas, who governed from 1829 to 1852 with little responsibility, was a period of practically no legislation. The legislative work of the first Congresses, however, which sat in the period between $181 \mathrm{I}$ and 1826 , were collected by U. S. Frias and published in 1882 in three volumes. Volume one covers the period $1811-1820$; volume two, 1824-1825; and volume three, January-April, $1826 .^{1}$

The complete proceedings of the Congress which met from December 6, 1824 to October Io, 1826 , were published in 1832 in twelve volumes. ${ }^{2}$ At the end of 1852 and as a consequence of the revolution of September i 1 of that year by the liberal party at Buenos Aires against General Urquiza, the conqueror of Rosas, the province of Buenos Aires created a state practically independent of the rest of the thirteen provinces, which, under the name of the Argentine Confederation, had constituted a central government in the city of Paraná, at present the capital of the province of Entre Rios. This separation lasted until 1860, when the federal Constitution was accepted by Buenos Aires; but the union was not finally achieved until I86I, when, after the successful battle of Pavon, September I6, 186r, General Bartolome Mitre reestablished a united government as the first constitutional president of the fourteen provinces. His term began on October 12,1862 , the date of commencement of the regular six-year presidential terms.

1 Trabajos legislativos de las primeras asambleas Argentinas, desde la junta de I8Ir hasta la disolución del congreso de 1827 , por Udalislao S. Frías. Buenos Aires, Imp. de la Universidad, 1882. 3 v.

${ }^{2}$ Diario de sesiones del congreso constituyente de las provincias unidas del Rio de la Plata de I824á 1826 (from Dec. 6, 1824 to Oct. 1o, 1826). Buenos Aires, Impr. de la Independencia, 1832 . $12 \mathrm{v}$. 
The legislation of the country from 1821 to 1852 is to be found in the Diario de Sesiones (record of legislative proceedings) of the province of Buenos Aires. The best repository of the official enactments of Rosas, including his decrees, senatusconsultos, the annual messages of the governor, the budgets of legislative appropriations, etc., is the Registro Oficial of the province of Buenos Aires, which was published from I82I to 1862 and has since been published annually.

In 1853 the Congreso Constituyente enacted the present constitution, which was amended in 1860 , I866, and 1898 . In I 854 the Chamber of Deputies and the Senate of the Confederation began to sit regularly and the Diario de Sesiones of each of these bodies has been published since that date with the exception of the Chamber of Deputies' proceedings for 1859,1860 , and I86I, and of the Senate for I860. The proceedings of the Chamber of Deputies for the period I 854 to 1858 were republished in two volumes in $1886,{ }^{1}$ and of the Senate from 1854 to 1861 in nine volumes in $1883 .{ }^{2}$ Since 1862 the proceedings of each House have been published separately in several annual volumes. An index of the proceedings of the Chamber of Deputies was published in 1900 by Dr. Juan R. Serú. ${ }^{3}$

The legislation of the country since 1810 is to be found in various compilations, both official and unofficial. The most complete of the official publications is the Registro Nacional, which ceased publication in 1906. In 1879 the government ordered the republication of the laws, decrees, and resolutions of national character enacted between 1810 and 1873 . The text was revised by a special commission named by the president and the work published in six volumes between 1879 and I884. Volumes $1-3$, covering the period $1810-1856$, bear the title Registro Oficial. This publication was continued in 1895 by the publication of volume 7 of the Registro Nacional, cover-

${ }^{1}$ Congreso Nacional. Actas de las sesiones de la Cámara de diputados, I854 á I858. Buenos Aires, I886-I89I. 2 v.

${ }^{2}$ Congreso Nacional. Cámara de senadores, actas de las sesiones del Paraná, correspondientes á los años de I854 á I86r. Buenos Aires, 1883-1888. $9 \mathrm{~V}$.

${ }^{3}$ Serú, Dr. Juan R.: Repertorio alfabetico del diario de sesiones de diputados (1854-1900). Buenos Aires, 1900. 
ing the laws and executive decrees enacted from 1874 on. The series ceased in 1890 with the publication of volume $13 .^{1}$

For the period between the fall of Rosas in $185^{2}$ and the reestablishment of a national government under General Mitre in 1862 , Dr. D. Ramon Ferreira ${ }^{2}$ published the laws and ministerial decrees in three volumes arranged chronologically.

The official Registro Nacional ${ }^{3}$ was established by the decree of April 16, 1862. It was to contain all the official enactments of the governor of Buenos Aires charged with the executive power, as well as the laws and other resolutions of the federal Congress. Its publication was continued until 1906.

In July, 1893, the official publication Boletin Oficial de la Republica Argentina, ${ }^{4}$ published daily, excepting on holidays, was begun. This publication contains not only the important decrees which appear in the Registro Nacional, but also those of special interest including army and navy orders, all public notices, trademark and patent applications, and other official records. Four to six volumes appear annually, some 80 volumes having been published up to 1915. During the period 1871-1872 an ephemeral collection Boletin Oficial de la nacion ${ }^{5}$ was published in two volumes for each year. It is probable that the Registro Nacional was suspended in 1906 by reason of the duplication of material in the Boletin Oficial.

${ }^{1}$ Registro nacional que comprende los documentos espedidos desde I8ro hasta I89o. v. I-6 (I810-1873), Buenos Aires, "La Republica," 1879-1884. v. 7 (1874)-v. I3 (1890). Buenos Aires, Taller Tip., 1895-99. Apéndice al Registro nacional de 1873 . Buenos Aires, Imp. del Mercurio, I874.

${ }^{2}$ Registro nacional de la Republica Argentina compilado por el Dr. D. Ramon Ferreira. v. I ( $\left.185_{5} \mathrm{I}-\mathrm{I} 855\right)$; v. 2 ( $\left.1856-\mathrm{r} 858\right)$; v. 3 (I859186r). Buenos Aires, Imp. del Orden, 1863-64. 3 v.

${ }^{3}$ Registro nacional de la Republica Argentina. Up to 1882 the Registro Nacional was published in one annual volume; from 1882 to 1896 in 2 vol. annually; from 1897 to 1903 in 3 vol. annually; 1904,4 vol. in 3 ; I905, 6 vol. in 3; I906, vol. I, Pt. I-II and vol. 2 Apr.-June. Up to 1892 the volumes are numbered, that year ending with vol. 42 . The imprint varies frequently. The laws and decrees are arranged by ministry and by month within each ministry.

${ }^{4}$ Boletin oficial de la Republica Argentina. Buenos Aires, Imp. del "Congreso," r894-.

'Boletin oficial de la nacion. Buenos Aires, Imp. Americana, $1871-72$. 
Inasmuch as the Registro Nacional contains not merely laws, but the administrative decrees, notices, and orders, it was found desirable to publish separately the laws enacted by Congress. With this idea in view the Senate has published under the title Leyes Nacionales ${ }^{1}$ the laws annually enacted by Congress, the publication having been extended so as to include the laws enacted since 1854 .

By reason of the fact that the official Leyes Nacionales were published with delays of a year or more, U.S. Fr'as conceived the idea in 1883 of publishing the annual laws of Congress immediately upon the adjournment of that body. As the laws did not bear any official date but were numbered, Frías's publication, also called Leyes Nacionales, began with law No. I270, a system which began in 1854 and has continued since. It is to be observed, however, that one numbering begins in I 854 and extends to No. 292 in I86I and a new numbering commences in 1862 . At that time the laws had no official title. Frías also gives citations to the discussions of the laws in the Diario de Sesiones. Frías's publication has been continued since 1892 until the editorship of Andrés Supeña, ${ }^{2}$ the secretary of the Chamber of Deputies.

The laws enacted by each Congress are also to be found at the end of the Diario de Sesiones of each year.

A compilation of the federal laws was edited by Máximo P. Gonzalez ${ }^{3}$ covering the years $1854-1894$ in five volumes, arranged chronogically. Each volume has a separate index for the period covered and a subject index and at the end of volume 3 there is a joint index for the period I854-I 887 .

1 Leyes nacionales. Publ. oficial de la Secretaria del Honorable Senado de la Nación. Buenos Aires, $1854-70$, I v.; I87 I-8I, I v.; r882-87, I v.; I888-9I, I v.; I892-94, I v.; 1895-97, I v.; I898-I900, I v.; I90I-3, I v.; I904-6, I v.; I907-8, I v.; I909-I0, I v.; I9II, I9I2, I9I3, I9I4, I9I5, I v. each (now published by J. Lajouane \& Cia).

${ }^{2}$ Leyes nacionales sancionadas en el periodo legislativo de I883. I vol. annually. Dirigida por U. S. Frías, ccntinued after 1892 by Andrés Supeña. Buenos Aires. Imprint changes almost annually.

${ }^{3}$ Recopilación de leyes nacionales sancionadas por el honorable Congreso argentino durante los años 1854 hasta 1894 por Máximo P. Gonzalez .. B Buenos Aires, Imprenta europea, $1887-94$. 5 v. v. I, I854-70; v. 2, I87I-8I; v. 3, I882-I887; v. 4, I888-9r; v. 5, I892-94. Imprint varies. 
Attention should also be directed to the important compilation of federal and provincial legislation edited by Carette, Ocantos, and Requena, ${ }^{1}$ in which the codes, laws, decrees, and resolutions of the Executive and the provincial legislative and administrative authorities (in Buenos Aires and Córdoba) in force in 1913 , and the principal ordinances of the municipal council and police authorities of Buenos Aires are arranged in the form of a dictionary. The text of the code, or law, or decree, is reprinted under its appropriate subject. Apparently all private legislation is omitted. The publication was begun in 1912 and was completed in 1916 in ro volumes, besides two large volumes of index, one alphabetical, the other chronological. Volume I of part 2 contains legislation of Buenos Aires and Córdoba. In order to keep the work up to date, the editors have begun the publication of the Revista de legislacion $y$ jurisprudencia (7 volumes to May, 1916), which is designed to supplement both the dictionary of legislation and the dictionary of court decisions, to which reference will be made hereafter.

The best and practically the only good index to the Argentine laws is that of José Giustinian; ${ }^{2}$ which was first published in 1906 to cover the years $1852-1905$. The work was republished in new editions in 1908 and in 1913, previously published supplements having been incorporated in the new editions. A supplement for 1915 has recently been issued. The work consists of an alphabetical subject index of the laws enacted during the period covered, with a table indicating by number the laws passed in each year. The second part of the work consists of a chronological list by title only, according to the number of the law, with an indication of the date of enactment. In the margin citation is made to the laws relating to stamped paper or the amendment or repeal of the law by subsequent laws.

${ }^{1}$ Carette, Augusto y Ocantos, Carlos Atwell y Requena, Valentin: Diccionario de legislación nacional y provincial de la Republica Argentina. ro v. +2 v. Index. Buenos Aires, F. Lajouane, Igr2-Igr5. Revista de legislación y jurisprudencia nacional y provincial de la Republ. Argentina. Buenos Aires, igr3-. 7 volumes to May, I9I6.

${ }^{2}$ Giustinian, José: Indice concordado de leyes de la Nación Argentina, desde el año $185^{2}$ hasta el año $19{ }^{1} 3$. Buenos Aires, Estab. tip. el Comercio, I9r4. Suplemento, año Igr5. $3^{I} \mathrm{p}$. 


\section{PROVINCIAL LEGISLATION}

The legislation of the provinces of the Argentine Republic is important for local matters in the fields of legislation within the jurisdiction of the provinces. For that reason an effort will be made to present succinctly the bibliography of provincial legislation.

Province of Buenos Aires.-Prior to I82I, when the Registro Oficial was initiated, what we may call the legislative material of Buenos Aires is scattered through various publications. The most valuable of these is the Gaceta de Buenos Aires, ${ }^{1}$ a semiofficial publication, published between 18 Io and 1821. By reason of its historical value, it was reprinted in a facsimile edition by the American Historical and Numismatic Society of Argentina in I9II. Original editions are practically unobtainable.

Another edition of all the legislative material promulgated in the province from 18 Io on was begun under official authority by Luis M. Gonnet ${ }^{2}$ in 1882 , of which, however, only the first volume, covering the years $1810-1814$, was published.

The Registro Oficial was begun in September, $182 \mathrm{I}$, and was designed to constitute an official gazette for laws and administrative decrees. "During i 858-59 it bore the title Registro oficial del Estado de Buenos Aires. The earlier volumes having proven difficult to obtain, a new edition covering the years $182 \mathrm{I}-\mathrm{I} 856$ was published in annual volumes in $1873^{-1} 875$, first by Russi and later by Mercurio. ${ }^{3}$ The volumes after 1860 are issued by vàrious publishers. Since 1882 the work has been published in the capital of the province at La Plata.

It is well to observe that the provincial legislation of Buenos Aires up to $185^{2}$, particularly during the dictatorship of Rosas, which ended in that year, is of more than provincial importance in Buenos Aires, for the country in that period was under the domination of Buenos Aires and of its dictator. A com-

${ }^{1}$ Gaceta de Buenos Aires (I8Io-1821). Reimprésion facsimile de la Junta de Historia y Numismatíca Americana. Buenos Aires, Comp. Sud-America, I9II-I $5.5 \mathrm{v}$.

2 Decretos, bandos, leyes y constituciones promulgadas en la Provincia de Buenos Aires, desde el año r8ro hasta la fecha. Compilación hecha con autorización legislativa por Luis María Gonnet. Buenos Aires, I882. V. I, I810-I8I4.

${ }^{3}$ Registro oficial de la Provincia de Buenos Aires, 1821-57; 1860-1915. 
pilation of the laws and decrees of the province from 18101835 , with an index, was published in three volumes in 1836 by Pedro de Angelis. ${ }^{1}$ An additional volun e, covering the years $1836-1840$, was published in 1841 . It is important for the decrees of Rosas. The compilation of Angelis was continued by a similar publication ${ }^{2}$ covering the years $184 \mathrm{I}-1858$.

There exist several unofficial publications of the laws and decrees of the province. The best known of these is the ninevolume compilation, covering the years $1810-1876$, collected and annotated by Aurelio Prado, ${ }^{3}$ formerly secretary of the Supreme Court and District Judge. Another edition, edited by Muzlera, ${ }^{4}$ covering the years $1810-1895$, was brought out in La Plata. Since 1895 Ernesto T. Martinez ${ }^{5}$ has edited the provincial laws in annual volumes, which appear somewhat sooner than the Registro Oficial.

In $1888-1890$ the province of Buenos Aires ${ }^{6}$ brought out an official publication of the laws and decrees relating to administrative matters and procedure in force at the time of pubication. The work appears in four volumes with annotations and is a valuable repository of the principal statutory material relating to the administration of the province. It

${ }^{1}$ Recopilacion de las leyes y decretos promulgados en Buenos Aires desde el 25 de mayo de 1810 hasta fin de diciembre de 1835 , con indice por Pedro de Angelis. Buenos Aires, Imprenta del Estado, I836-4I. 3 v. Same. Indice general, I810-1835. Buenos Aires, Imprenta del estado, 1836 . Tercera parte $(1836-40)$ has an index.

2 Recopilacion de las leyes y decretos promulgados en Buenos Aires, desde enero de $184 \mathrm{I}$ hasta la fecha. Buenos Aires, 1858 . 93I p.

${ }^{3}$ Leyes y decretos promulgados en la Provincia de Buenos Aires, desde el año I81o hasta el año I876. Recopilados y concordados por el doctor Aurelio Prado y Rojas. Buenos Aires, Impr. del Mercurio, r877-79. $9 \mathrm{v}$.

4 Murzlera, J. M.: Recopilación de leyes y decretos de la provincia de Buenos Aires, I81o á 1895. La Plata, I896. 3 v.

${ }^{5}$ Leyes provinciales sancionadas en el per. legislativo I905-1906, and cont.; por Ernesto T. Martinez. La Plata, Sese de Iarranaga, 1906I4. 9 v. to I9I4.

${ }^{6}$ Recopilación de leyes, decretos y resoluciones sobre organización y pro. cedimientos administrativos vigente en la provincia de Buenos AiresLa Plata, "Buenos Aires," I888-18go. 4 v. 
is a guide for public officials of all classes. It includes a summary of the decisions of the Supreme Court of the province on matters of contentious administrative jurisdiction.

Besides these publications attention may be called to the important newspaper Gaceta Mercantil which was first issued on October I, 1823, and continued publication until February 3 , I 852 , the date of the memorable battle at which Rosas was overthrown. It contains practically all the decrees and administrative orders published during the Rosas régime.

An index ${ }^{1}$ of the provincial laws enacted during the period I $852-1878$ was published in Buenos Aires in 1879 .

Some of the principal laws of current use in the province are published by Messrs. Lajouane \& Co., one of the leading publishers. This compilation includes codes and laws of customary application. A somewhat smaller edition of the national and provincial laws of daily use in the capital and province of Buenos Aires was published in 1914 by Abeledo, ${ }^{2}$ another well-known law publisher. It includes the provincial stamp laws and various tax laws.

The city of Buenos Aires is the capital of the country. Although a federal district, it has its own municipal council. Until I882, when it was reorganized, this council was known as the Concejo municipal, changing its title in that year to Concejo deliberante. Its ordinances, decrees, and proceedings are published annually. In I9II-I $2^{3}$ the proceedings covering the years $1856-1877$ were reprinted. Since 1882 the work has appeared in one volume annually. ${ }^{4}$

At various periods compilations of the municipal ordinances in force were published. Such publications under the title

${ }^{1}$ Indice de las leyes sancionadas por la legislatura de la Provincia de Buenos Aires formada por E. V. Fisher, años 1852-1878. Bucnos Aires, Casavalle, $1879.76 \mathrm{p}$.

${ }^{2}$ Petit colección de leyes de la capital y provincia de Buenos Aires, de uso diario para abogados y procuradores. Buenos Aires, Abeledo, I9I4. $199 \mathrm{p}$.

${ }^{3}$ Actas del concejo municipal de la ciudad de Buenos Aires, 1856-1877. Buenos Aires, I9II-I2.

+ Ordenanzas y resoluciones sancionadas por $\mathrm{cl}$ concejo deliberante de la ciudad de Buenos Aires, 1882 et seq. Buenos Aires, 1882 et seq. 
"digests" were issued in $1873,{ }^{1} 1884,{ }^{2} 1898,{ }^{3}$ and $1911 .{ }^{4}$ They cover such subjects as local taxation, public health, finance, police, education, streets and highways, and other matters ordinarily under municipal control. Other important cities throughout the Republic have followed the example of Buenos Aires by publishing at periodical intervals compilations of their municipal ordinances.

Province of Catamarca. - It has proved most difficult to secure accurate information concerning the source books of legislation of the provinces. So far as it has been obtained, it is presented herewith. For the years $1863-64$ the province of Catamarca appears to have published a Registro Oficial. On November 20, r87i, the publication of a Boletin Oficial commenced, which continued in annual volumes up to 1900. In that year a publication known as the Coleccion de leyes was issued and has continued publication to date.

Province of CóRDoBa.-This province which, after Buenos Aires, occupies the most conspicuous political position in Argentine history has systematically published its laws and decrees. In 1870 a compilation of the laws, decrees, and orders of the governing body called the Cámara de justicia was published in two volumes, with a third volume covering the period $1870-1873$, and a fourth volume the period $1874-1876$. In 1877 the title of the publication changed. It has since been pub.ished in annual volumes, volume 38 covering the year $1911 .^{5}$

1.Digesto de ordenanzas, reglamentos . . . de la ciudad. . . 1856-1873. . Buenos Aires, Impr. de la Soc. anonima "La nacion," I873.

${ }^{2}$ Digesto de ordenanzas, reglamentos, acuerdos y disposiciones de la municipalidad de Buenos Aires, por Manuel Obarrio. Buenos Aires, $r 884$.

${ }^{3}$ Digesto de leyes, ordenanzas, acuerdos y decretos . . . por Eugenio F. Soria. Buenos Aires, Impr. "Mariano Moreno," I8g8.

"Compilación de las leyes y decretos reglamentarios vigentes, que forman la ley orgánica de la Municipalidad de la Ciudad de Buenos Aires. Buenos Aires, rgrr.

${ }^{5}$ Compilación de leyes, decretos, acuerdos de la exma. Cámara de jus-

$\because$ ticia y demás disposiciones de carácter público dictadas en la provincia de Córdoba desde I8ro-rgir. Córdoba, Impr. del Estado, 1870-I9Ir. $38 \mathrm{v}$. in 37 . Title and imprint vary. No. 18 omitted in numbering, v. 25 and 28 ( 1898 and rgor), each published in $2 \mathrm{v}$. 
A Registro Oficial has existed in Córdoba since 1836 , but its principal contents have been reprinted in the Compilacion de leyes. A compilation ${ }^{1}$ of all the constitutions of the province issued between I82I and 1900 was published officially in $190 \mathrm{I}$.

PROVINCE OF CORRIENTES.-This province commenced to publish its Registro Oficial in 1825 , since which date the volumes have been published annually. In the period I874-1883 another official publication Boletin Oficial was issued, and in recent years a separate publication called Leyes promulgados durante el año has appeared. In 1902 a compilation of the laws and decrees in force ${ }^{2}$ was published, and in 1904 a two-volume compilation ${ }^{3}$ of the codes, laws, and decrees most frequently consu'ted. It includes, therefore, a considerable amount of federal legislation.

Province of Entre Rios.-Entre Rios began the publication of its laws in $182 \mathrm{I}$. For the period $182 \mathrm{I}-1878$ a reprint edition ${ }^{4}$ in 18 volumes was published in the city of Uruguay in 1875 and 1880 . The publication has been continued since with varying imprint. ${ }^{5}$ At different times a Boletin Oficial appears to have been published.

Province OF JUJUY.-Jujuy became an independent province in 1835 . While a Registro Oficial has been published annually, the most accessible source of legislation during the period $1835-1884$ is to be found in an official publication edited by order of Governor Eugenio Tello ${ }^{6}$ in three volumes. Since 1899 a Boletin Oficial has appeared.

Province of LA RIOJA.-The Registro Oficial of La Rioja seems to have appeared first in 1854 . A compilation in 7 vol-

${ }^{1}$ Constituciones de la provincia de Córdoba r821-1900. Córdoba, I9or.

2 Recopilación de leyes y decretos en vigencia de la provincia de Corrientes, 1902. Correnties, I902.

${ }^{3}$ Códigos, leyes y decretos de la provincia de Corrientes. Corrientes, I904. $2 \mathrm{v}$.

4 Recopilación de leyes, decretos y acuerdos de la Provincia de Entre Rios, I82 á r878. Uruguay, La Voz del Pueblo, I875-1880. I8 v.

${ }^{5}$ Same, 1879-r895 (v. x9-35). Paraná, r886-89; v. 30, Concepción, r892; v. 32; Buienos Aires, I905; v. 33-35, Paraná, I906-8. I7 v.

- Compilación de leyes y decretos de la Provincia de Jujuy desde el año r835 hasta el r884, formada y editada por orden del Gobernador de la Prov., D. Eugenio. Tello. Jujuy, 1885-I888. 3 v. 
umes covering the years $1854-1875$ was published in Buenos Aires in $1890 .{ }^{1}$

Province of Mendoza.-The Registro Oficial of Mendoza appeared first in 1822 and has since continued issue. A valuable compilation of laws and decrees by Manuel Ahumada ${ }^{2}$ was published in 1860 . It contains official documents from I 820 to November, 1860 , and is rare by reason of the fact that everything in the city of Mendoza was destroyed by the earthquake during the sixties. A compilation ${ }^{3}$ of the laws of the province for the period 1896-1910 was published in four volumes in I91 1 .

Province of Salta.-The Registro Oficial of Salta began issue in November, 1828 , and with the exception of a few years was published regularly until 1875 , the material for the years 1864 and 1867 being published in two volumes each. The legislation for $1876-1879$ was republished in one volume in 1904, and probably subsequent years have since been republished.

Province of San Juan.-The Registro Ministerial of San Juan began issue in 1825 , changing title in 1836 to Registro Oficial. Up to I 884 it appeared fairly regularly. In I870 a Boletin Oficial began to be published; it still appears to be issued regularly. In $1903^{4}$ a compilation of the laws in force was published.

Province of SAN LuIs.-A Boletin Oficial appeared for a brief period during 1875 . The publication was renewed in I905, since which time it has appeared regularly.

Province of Santa FÉ.-This province, containing the second largest city in the Republic, Rosario, began the publication of its Registro Oficial in 1815 . A reprint edition ${ }^{5}$ of the

${ }^{1}$ I a Rioja. Registro oficial, I854-I875. Buenos Aires, Coni, r89o. $7 \mathrm{v}$.

${ }^{2}$ Código de las leyes, decretos y acuerdos que sobre administración de justicia se ha dictado la provincia de Mendoza, mandado formar por el Excma. Gobierno en su decreto de I6 de enero de 1860 , por Manuel de Ahumada. Mendoza, I86o.

${ }^{3}$ Recopilación de leyes de la provincia de Mendoza,I896-rgro. Mendoza, I9rr. $4 \mathrm{v}$.

${ }^{4}$ San Juan. Leyes vigentes, I903. San Juan, I903.

${ }^{5}$ Santa Fé. Registro oficial: I8I5-99. $28 \mathrm{v}$. in $21 \mathrm{v}$. to 1899 and cont. Santa Fé, "La Revolucion," I888-rgo2. 
Kegistro from $1815^{-1} 899$ was published between the years I 888-1902 in 28 volumes, since which date the laws have been continued to be published in a volume known as Leyes promulgados durante el año. It is probable, however, that the Registro Oficial is also being published. A compilation ${ }^{1}$ of the laws in force in 1900 was published under official authority. It contains, however, merely the principal laws, such as the constitution, the law organizing the courts, the codes of procedure, etc.

Province of SANTIAgo DEL, ESTERo.-There appears to be no Registro Oficial in the province of Santiago del Estero. A compilation ${ }^{2}$ of the laws and decrees issued between 1883 and 1887 was published in Córdoba in r 896 and subsequently another compilation of the laws and decrees enacted between the years 1885 and I89o. A Boletin Oficial began issue in I903.

Province of TUCumÁn.-The Registro Oficial, founded by General Lamadrid, first appeared in I826. In I832, however, the volumes first began to be numbered, and since then the publication has appeared wich fair regularity. There has recently been published officially a compilation of laws, decrees, and governor's messages, from 1852 on. ${ }^{3}$ For the period I884-I900 a one-volume compilation of the laws enacted was published under the direction of Julio P. Avila. ${ }^{4}$ During the seventies a Boleiin Oficial appears to have been issued.

NATIONAL TERRITORIES.-These territories are governed by federal legislation to be found in the Registro Nacional (up to I906) and the Leyes Nacionales. Several compilations relating to the administration of the national territories were published, however, at various times. One such work ${ }^{5}$ was

${ }^{1}$ Colección de leyes vigentes en la Provincia de Santa Fé. Ed. autorizada por ley especial de las Cámaras. Rosario, I900.

${ }^{2}$ Santiago del Estero. Compilación de leyes y decretos de la provincia de Santiago del Estero, 1883-1887. Córdoba, I896-1897. 2 v.

${ }^{3}$ Compilación ordenada de ieyes, decretos y mensajes del periodo constitucional de la provincia, que comienza en el año $185^{2}$. Ed. oficial. Tucumán, ror6.

* Colección de leyes sancionadas desde r884 á I900 con un apendice. Pub. Of. dirigida por Julio P. Avila. Tucumán, I90o.

¿ Territorios nacionales. Disposiciones relativas á su administración. Buenos Aires, I884-I904. 2 v. 
first issued in 1884, with a second volume in 1904, another compilation of laws and decrees in $1900,{ }^{1}$ and a collection of decrees enacted between 1900 and $1902^{2}$ in 1902 .

Editions of collected codes will be discussed under "General Works," and the constitutions, which are fundamental to legislation, will be discussed under the head of "Constitutional Law" (infra, p. 123).

\section{COURT REPORTS}

The courts of Argentina are divided, like those of the United States, into, first, federal courts, and, second, State or provincial courts, as they are known in Argentina. The judicial hierarchy of the federal courts consists of $(a)$ a district judge, of whom there is one in each province, except in the more populous provinces, such as Buenos Aires and Santa Fé, in which there are two; and (b) the federal courts of appeal, first established in 1902, of which there are at the present time five, one in the capital at Buenos Aires, one in La Plata, one in Paraná, one in Córdoba, and one in Rosario. The last was established by Law No. 7099 of September 20, 1910. Above these federal courts of appeal is the federal Supreme Court, sitting in the capital, established by law of September Io, I 863 .

In addition to these federal courts separate courts were established for the city of Buenos Aires when the federal district was organized by the law of September 21, I880. There are in the capital. courts of first instance, and criminal and appellate courts with appellate jurisdiction over the lower courts. The appellate courts are divided into three chambers, one for commercial, one for civil, and one for criminal matters, into which jurisdictions the lower courts are likewise divided. For commercial matters affecting the economic life of Argentina, the decisions of the appellate courts of the capital and the federal courts of appeal are of the greatest importance.

1 Territorios nacionales. Leyes y decretos sobre su administración. Buenos Aires, 1900.

2 Territorios nacionales. Decretos referentes a los territorios nacionales, 1900-1902. Buenos Aires, 1902. 
Besides the federal courts and the courts of the capital of Buenos Aires there are the provincial courts of record, one of first instance and an appellate court, known sometimes as the court of appeals, sometimes as the superior tribunal, and sometimes as the supreme court of the province.

\section{FEDERAL, COURTS}

The decisions of the federal Supreme Court began to be published in 1864 . They were published in different series of which the first contains 9 volumes, the second $2 \mathrm{I}$ volumes, the third 20 volumes, and the fourth 28 volumes. They have now been renumbered chronologically, 123 volumes having been published ${ }^{1}$ up to 1916.

There are two indexes to the Supreme Court reports to which attention should be called. The first is that of Eugenio Pérez, ${ }^{2}$ a second edition of which was published in $1884-1889$ in two volumes. Volume $\mathrm{I}$ includes brief summaries by subject of the decisions handed down up to $188 \mathrm{r}$ and volume 2 , from $1882-1886$. The digest is alphabetical. A better index is that of Messrs. Dominguez and Frías ${ }^{3}$, published between r 897 and 1902 in three volumes. Volumes $\mathrm{I}-2$ digest the first 72 volumes of the Supreme Court reports covering the period r863-r896 and volume 3 the decisions rendered from 1896 to June 30, 1902. An appendix contains annotations of the decisions of the Supreme Court to the constitution and the various codes.

The decisions of the federal courts of appeal have been reported since 1902, the date of their organization. The most important federal court of appeals is that sitting at the Capital. Its decisions were published in 9 volumes from 1902 to 1909

1 Fallos de la suprema corte de justicia nacional. Buenos Aires, i864-. I23 v. to I9r6. Publication now edited by Drs. Eiduardo M. Zavalía and Carlos E. Madero, clerks of the court.

2 Pérez, Eugenio: Repertorio jurídico-alfabético de la jurisprudencia establecida por la Suprema corte federal en sus sentencias, por el Dr. D. Eugenio Pérez . . Buenos Aires, F. Lajouane, 1884-89. $2 \mathrm{~V}$.

${ }^{3}$ Domínguez, José E. y Frías, José A.: Digesto de los fallos de la Suprema corte de justicia federal. Buenos Aires, Impr. de P. E. Coni é hijos, r897-r9o2. $3 \mathrm{v}$. 
by Juan R. Seru. ${ }^{1}$ The reports ${ }^{2}$ of the federal court of appeals of Córdoba likewise cover 9 volumes, from 1902 to 1909 . The reports of the federal court of appeals at Parana ${ }^{3}$ have been published in 10 volumes and of the court at $\mathrm{La} \mathrm{Plata}^{4}$ in 16 volumes, edited by Dr. Eduardo Newton.

Since I9Io the decisions of the federal courts of appeal are no longer published separately, but are published together with the decisions of the Supreme Court in a new publication issued by the Department of Justice, entitled Jurisprudencia de los tribunales nacionales, ${ }^{5}$ published monthly, except in January. It is very analogous to our own Federal Reporter, except that it also includes the decisions of the Supreme Court.

Since 1889 a publication known as the Boletin judicial de la Republica Argentina has been published in from four to six volumes annually. It is issued daily and contains decisions of the federal courts and the provincial courts of Buenos Aires.

\section{COURTS OF THE CAPITAL.}

In the Capital at Buenos Aires the courts of appeal in their various chambers have jurisdiction of some of the most important cases decided in Argentina. The decisions of the civil chamber have now reached over 200 volumes; like the decisions of the Supreme Court they are divided into series,

1 Fallos de la Excma. Cámara federal de apelación de la capital. [rgo25.] Publicación dirigida por el Dr. Juan R. Serú. Buenos Aires, Taller tip. de la Penitenciaria nacional, r902-r9o9. $9 \mathrm{v}$.

${ }^{2}$ Fallos de la Cámara Federal de Apelaciones de Córdoba. [1902-06.] Córdoba, Domenici [and others], r903-1909. 9 v. (Publ. oficial, by Dr. Miguel A. Aleaga and Carlos Rodriguez de la Torre; first two v. by Arturo Bas and Gerónimo Cortés Funes).

${ }^{3}$ Fallos de la Cámara Federal de Apelación de Paraná y Buenos Aires, r903-1909. (ro v.) v. I-3 (edited by Victor M. Ruiz), v. 4-10 (edited by Manuel J. Area), v. I-4, published at Paraná, v. 5-10 at Buenos Aires, Impr. Adolfo Grau. [Igo2-6.]

* Fallos de la Cámara Federal de Apelación de La Plata. Publ. dirigida por Dr. Eduardo F. Newton. Buenos Aires, 1902-1904; La Plata, 1905-9. $16 \mathrm{v}$.

${ }^{5}$ Jurisprudencia de los Tribunales Nacionales. Publicación dirigida por la Inspección general de justicia desde el año rgio hasta la fecha. Buenos Aires, Tall. graf. de la Penitenciaría Nacional rgro-. Published montlily (except in January), beginning February, xgro. 
but have been renumbered chronogically. Every tenth volume contains an index of the preceding ro volumes. ${ }^{1}$ The decisions ${ }^{2}$ in the criminal and commercial chambers are reported in a set of several series which began in 1882 . Up to I910, when the decisions of the Court of Appeals were included in the Jurisprudencia de los tribunales nacionales, 106 volumes had been published.

Prior to the organization of the courts of the federal Capital in 1880 Manuel Ponce ${ }^{3}$ had published the decisions of the Court of Appeal of the Capital in a four volume collection.

Law 7055 of August 19, r910 established a second chamber of appeals in civil cases in the Capital and article 6 of the law provided for a joint session of the first and second chamber for the decision of certain doubtful cases. The decisions of the court in joint session were edited and published in 1915 by Miguel A. Garmendia ${ }^{4}$ in a volume including an introduction by the editor, and notes, commentaries, and concordances to the decisions reported.

The leading index to the civil decisions of the Court of Appeals of the federal Capital is the three volume work of $\mathrm{J}$. J. Hall. ${ }^{5}$ The first volume was published in 1899 and the second and third volumes, coming down to 1905 , are in the nature of supplements. The work covers the first $15 \mathrm{r}$ volumes of the series of decisions in civil cases. It is in the form of a brief

${ }^{1}$ Jurisprudencia civil. Fallos y disposiciones de la Exma. Cámara de apelaciones de la capital ... Buenos Aires, Imprenta del "Mercurio," I882-I9I4. About 208 v. Imprint varies. Series I, 9 v.; series 2, Io v.; series $3,13 \mathrm{v}$; series $4,15 \mathrm{v}$.; series $5,22 \mathrm{v}$; series $6, \mathrm{r} 8 \mathrm{v}$; ; then v.88-192; series 7 , I2 v.

${ }^{2}$ Fallos de la Cámara de apelaciones de la Capital en lo comercial, criminal y correccional. Buenos Aires, "Mercurio," r882-r9[08], 99 v.; followed by Recopilación de fallos de Cámara de apelaciones en lo criminal y comercial, Buenos Aires, I9[08]-igro. 7 v.

3once, Manuel: Fallos de las cámaras de apelación de la capital. Buenos Airs, Imp. del Mercurio and Rivadavia, 1877-79. 4v.

- Garmendia, Miguel Angel: Jurisprudencia unificada. Derecho civil y procesal. Fallos dictados por las Cámaras de Apelaciones constituidas en tribunal pleno. Buenos Aires, J. Lajouane, I9r5. 254 p.

${ }^{5}$ Hall, J. J.: Jurisprudencia civil. Repertorio jurídico-alfabético de los fallos de la Cámara de apelación de la capital. Buenos Aires, F. Lajouane, 1899-1905. $3 \mathrm{v}$.

$71624^{\circ}-17-3$ 
one or two line digest of the ruling of the court under the appropriate alphabetical heading in the index. Another index of the civil decisions, also published in 1899 , by F. A. Hernández ${ }^{1}$ covers series $\mathrm{I}-5$, or the first 69 volumes of the civil decisions. Adolfo Grau, ${ }^{2}$ the secretary of the court, has published an index of the civil decisions in the first series which consists merely of a joint index of the individual indexes published in each volume.

The decisions of the criminal and commercial chambers of the Court of Appeals of the Capital have been indexed by Adolfo Grau in two volumes ${ }^{3}$ published in 1899 ; they cover the first 60 volumes of the reports of this court in criminal and commercial cases. A better index-digest of the commercial decisions of this court has been published by A. J. Frias, ${ }^{4}$ the first volume, issued in 1898 , covering the first two series of reports, and the second volume, issued in 1909, covering series 2 to 6 .

An encyclopedia of the decisions of the Court of Appeals of the Capital in ro volumes, the first 4 covering the decisions and interlocutory decrees on the civil side, and the other 6 on the commercial and criminal side has been edited by Jose $\mathrm{J}$. $\mathrm{Hall}^{5}$ and published between $\mathrm{I} 887$ and $\mathrm{rgr}$. The work is analogous to the Repertorio of Pantoja for Spain and contains a summary of the court's decision and, in the form of notes,

${ }^{1}$ Hernández, F. A.: Repertorio de la jurisprudencia civil. Buenos Aires, Chacabuco, I899, 2 v.; Est. Poligrafico, I903, I v.

${ }^{2}$ Grau, Adolfo: Jurisprudencia civil. Indice general de los fallos y disposiciones de la Exma. Cámara de Apelaciones de la Capital. Buenos Aires, Buffet \& Bosch, 1888.

${ }^{3}$ Grau, Adolfo: Indice general de los fallos y disposiciones de la Exma. Cámara de Apelaciones en lo criminal correccional y comercial de la Capital. Tomos I-6o. Buenos Aires, I899. 2 v.

${ }^{4}$ Frías, J. A.: Repertorio de jurisprudencia comercial, que comprende las series I y 2 de los fallos de la Cámara de Apelaciones de la Capital Argentina. Buenos Aires, 1898. Same, series 3, 4, 5, y 6. Buenos Aires, A. Grau [r898, r9o9], 224 p.

${ }^{5}$ Instituta de la jurisprudencia establecida por las Exma. Cámaras de Apelaciones de la Capital de la Rep. Argentina en sus sentencias, por orden numérico y alfabético, por José J. Hall. Buenos Aires, Imp. de Mayo, J. E. Hall, r887-rgrr. I4 v. in ro. v. I, end ed. F. Lajouane, 1905 . 
an exposition of the reasons for the decision according to its importance, and annotations, particularly to the inconsistent decisions of the two chambers.

The opinions of various judges of first instance have at different times been collected, edited, and published. Such of these works as relate to a particular class of cases, such as criminal or commercial cases will be mentioned in their appropriate places hereafter. For the present attention will merely be directed to the more general collections of decisions of particular judges.

The opinions and decisions of Judge D. Cárlos Molina Arrotea, ${ }^{1}$ judge of first instance in civil matters in the Capital, were edited in four volumes, I884-1887, by José A. Novaro. Only those opinions were selected which discussed new points of law. The work includes a table showing whether the opinions were affirmed or reversed in the higher courts.

Another collection of decisions in civil and commercial matters of Dr. Luis M. Drago, ${ }^{2}$ the celebrated Argentine statesman, publicist, and jurist, rendered while he was judge of first instance in civil and commercial matters, was published in I 886 by Lajouane. The work contains numerous notes on doubtful points of law. A collection of decisions rendered by Judge Benjamin Basualdo, ${ }^{3}$ judge of first instance in civil matters, was published in I888. A collection of the decisions of Judge Lorenzo J. Aquino, ${ }^{4}$ of Corrientes, was published in 1894. Dr. Daniel Goytia, ${ }^{5}$ federal district judge in Santa Fé, published a collection of his decisions in two volumes, 1899

${ }^{1}$ Sentencias y autos interlocutorios dictados por el juzgado en lo civil de la capital á cargo del Dr. D. Cárlos Molina Arrotea. Buenos Aires, Imp. de M. Biedma, 1884-87. $4 \mathrm{v}$.

${ }^{2}$ Colección de fallos en materia civil y comercial, concordados con las sentencias de las cortes supremas de la nación y de la provincia, pronunciado por el Dr. Luis M. Drago. Buenos Aires, Lajouane, 1886. $436 \mathrm{p}$.

${ }^{3}$ Basualdo, Benjamin: Autos y sentencias por el juez de $\mathrm{I}^{\mathrm{a}}$ instancia en lo civil de la Capital. Buenos Aires, J. Peuser, r888. 330 p.

4 Aquino, Lorenzo J.: Colección de fallos en materia civil, comercial y criminal concordados con las sentencias de las cortes suprema de la nación y de la provincia de Buenos Aires. Corrientes, I894.

${ }^{5}$ Goytía, Daniel: Fallos dictados por el juez federal de Santa Fé, Dr. Daniel Goytía. Buenos Aires, Rosario, 1899-1902. 2 v. 
and 1902. Ricardo Seeber, ${ }^{1}$ in 1909, published a collection of his decisions as judge of first instance in civil and commercial cases.

\section{PROVINCIAL, COURTS}

The provincial courts, as already observed, have two instances, a judge of first instance and a court of appeals, called sometimes the supreme court, or superior court. The more important provinces have at different times, officially or unofficially, published the decisions of their highest courts.

PROVINCE OF BUENOS AIRES. - The most important province for legal and economic purposes is that of Buenos Aires. The decisions of the Supreme Court of the province of Buenos Aires from 1810-1880 were republished in Buenos Aires in ro volumes, $1875-1880 .{ }^{2}$ Since $188 \mathrm{r}$, when the capital of the province was removed to La Plata, the reports of the Supreme Court of the province have been regularly published in La Plata. The entire series now consists of some 70 volumes. An index to the decisions rendered by this court between I 875 and 1879 was published by Antonio L. Gil. ${ }^{3}$ It consists of an alphabetical compilation of the cases decided by the court, with a summary of the decisions and a citation to the complete opinion.

Various individuals have at different times undertaken to publish the opinions of the provincial courts of Buenos Aires. Luis Beláustegui, ${ }^{4}$ civil judge, published a collection of his decisions rendered between 1872 and 1874 , with notes as to the fate of the judgment in the higher courts. Juan A. Gonzáles ${ }^{5}$

${ }^{1}$ Seeber, Ricardo: Derecho civil y comercial. Sentencias. Buenos Aires, Arnoldo Moen y herm., I909. 422 p.

${ }^{2}$ Acuerdos y sentencias dictadas por la Suprema Corte de Justicia de la Provincia de Buenos Aires. I810-[1880]. Buenos Aires, 1875-1880. ro v. Series 2-5. I880-rgog. La Plata, I88I-rgo9. 40 v. Series 6-7. I909-I9I4. I2 V. and cont. Second edition of the first series published by J. Peuser, I892-.

${ }^{3}$ Repertorio de la jurisprudencia establecida por la Suprema Corte de Justicia de la provincia de Buenos Aires desde 1875 á 1879 , por el Dr. Antonio I. Gil. Buenos Aires, Impr. del "Porvenir," I880. I8I $\mathrm{p}$.

4 Fallos de los tribunales de Buenos Aires (1872-1874) por Luis Beláustegui. Buenos Aires, M. P. Gomar, 1874 .

${ }^{5}$ Gonzáles, Juan A.: Sentencias y autos interlocutorios dictados por los tribunales de la provincia de Buenos Aires. Buenos Aires, Impr. de Mayo, 1878 and 1879 . 6 pts. 
undertook to publish systematically the decisions of the provincial courts in 1878 . The enterprise, however, reached only 6 numbers. Another compilation of the decisions of the provincial courts was undertaken by J. F. Monguillot ${ }^{1}$ in 1876 . Only the first volume, covering civil cases, appeared.

For the province of Córdoba there is a five-volume collection of the decisions of the superior court, compiled by Dr. D. Juan Bialet, ${ }^{2}$ edited in two series, one the Superior Tribunal Pleno, and the other the Sala de lo Civil, or civil chamber. In 1904 Arturo M. Bas ${ }^{3}$ began the publication of the decisions of the civil chamber of the appellate court in Córdoba, edited with doctrinal notes. The work had reached four volumes up to igio. The decisions of Judge $F$. T. Garzón, ${ }^{4}$ rendered from 1886 to $\mathrm{x} 889$, were published in 1890 .

For the province of Corrientes there is a collection ${ }^{5}$ of the decisions of the Supreme Court and of the Court of Appeals rendered during the years $1896-1901$, published in 14 volumes. There appears also to exist a separate collection ${ }^{6}$ of the reports of the Supreme Court of Corrientes in nine volumes.

In the province of Entre Rios, Dr. Santiago Moritán undertook the publication of the decisions of the superior tribunal in two separate series. The one covering civil and commercial cases ${ }^{7}$ began in 1903 and the first volume covers the cases decided since the reorganization of the court in 1899 ; the other,

${ }^{1}$ Monguillot, J. F.: Jurisprudencia general. Recopilación de acuerdos, sentencias y resoluciones de los Tribunales de la Provincia de Buenos Aires. Civil, mercantil, criminal, correccional. v. I, Causas civiles. Buenos Aires, 1876 .

${ }^{2}$ Fallos y acuerdos del Superior Tribunal de Justicia de Córdoba con la relación de sus respectivas causas. Compiled by Dr. D. Juan Bialet y Massé. Córdoba, Imp. "El Interior" ["E1 Eco de Cordoba"], I880-83. 3 v., and $2 \mathrm{v}$. issued subsequently.

${ }^{3}$ Córdoba. Cámara de apelaciones en lo civil. Fallos y su doctrina by Arturo M. Bas. Córdoba, Domenici, r904-1910. 4 V.

" Córdoba. Resoluciones judiciales, r886 á I889, por F. T. Garzón. Cordoba, 1890. $2 \mathrm{v}$.

${ }^{5}$ Autos y sentencias del S. Tribunal de Justicia y de la Exma. C. de apelaciones. [r8g6-1901.] Corrientes, Heinecke, I90I-rgo6. 14 v.

${ }^{6}$ Corrientes. Fallos de la suprema corte de Corrientes. Buenos Aires. $9 \mathrm{v}$.

${ }^{7}$ Entre Rios. Superior tribunal de Entre Rios. Jurisprudencia civil y comercial. Publicación del Dr. Santiago Moritán. v. I begins 1903. 
covering criminal and administrative cases, ${ }^{1}$ began in 1905 and volume I also covers the decisions rendered since 1899 .

For the province of Jujuy ${ }^{2}$ there appears to be no regular set of decisions. A collection of the decisions of the superior court of the province was published in 1886 .

The province of San Juan publishes a Boletin Judicial ${ }^{3}$ which was instituted in 1899 and has continued ever since.

The province of Santa Fé revised its judicial organization in 1899 . The decisions of the highest court, then called the Supreme Court of Justice of the province, prior to the reorganization were edited in three volumes by Dr. Z. Martinez ${ }^{4}$ and others. The decisions rendered by the highest court subsequent to the reorganization, now called the Tribunal Superior, have been edited by Ramon J. Doldán. ${ }^{5}$ The first volume, published in 1907 , covers the decisions rendered from 1900 to 1906.

\section{OPINIONS OF ATTORNEY GENERAL}

Argentine institutions provide for a solicitor or law officer in each department of the government who is attached to the Attorney General's office. Besides these officers an officer of the Department of Justice is attached to the various higher courts as fiscales or attorneys general to look after the interests of the State and to see that the law is properly applied. This institution is unknown to Anglo-American law. The opinions of the attorneys general of the various governmental departments acting as advisers of the executive branch of the government were compiled in a publication ${ }^{6}$ of ro volumes

${ }^{1}$ Superior Tribunal de Entre Rios. Jurisprudencia criminal y administrativa. Publicación del Dr. Santiago Moritán. v. I begins 1905 .

${ }^{2}$ Jujuy. Acuerdos y reglamentos dictados por el superior tribunal de justicia para los juzgados y oficinas de su dependencia. Jujuy, 1886 .

${ }^{3}$ San Juan. Boletin judicial, I899 and cont. San Juan, Sarmiento, r899 et seq.

${ }^{4}$ Santa Fé. Fallos y acuerdos de la Corte Suprema de Justicia de la provincia de S. Fé, by D:. Z. Martinez, F Gigeien y Simeon S. Aliaga. Paraná, La Velocidad, 1897-1899. 3 v.

${ }^{5}$ Santa Fé. Superior Tribunal de justicia de la provincia de Santa Fé. Edited by Ramón J. Doldán. Paraná, r907. v. I and cont.

${ }^{6}$ Informes de los consejeros legales del poder ejecutivo . . Publication oficial. Buenos Aires, r890-1902. Io v. 
issued from 1890 to 1902 . The work includes opinions given to the heads of various executive departments from 1852 to I 893 by various solicitors and attorneys general. The opinions cover all branches of administrative law, including public lands, customs matters, pensions, public works, railroads, concessions, posts and telegraphs, public debts, relations between church and state, and claims against the government. It is a valuable repository of administrative law.

The opinions of various attorneys general have been published on different occasions. A collection of these opinions, compiled by C. Quiroga, ${ }^{1}$ was published in 1874 . Another collection compiled by Francisco Fernandez, ${ }^{2}$ containing particularly the opinions of the solicitors of the Treasury Department in matters of pensions, covering the period $1866-1875$, was published officially in $1881-1887$.

The opinions of the representatives of the attorney general's office in advising courts or as members of courts have been published at various times by different fiscals. A wellknown collection of these opinions is that of Ramon Ferreira, ${ }^{3}$ a well-known jurist of his time, published in 1864 . Another well-known fiscal of the Buenos Aires Court of Appeals was Benjamin Victoria. His opinions were edited and annotated by Dr. Aurrecoechea ${ }^{4}$ in a volume published in 1879 . It is of particular importance for its opinions in criminal cases.

The opinions of Dr. Isaac P. Areco were published by Francisco $\operatorname{Costas}^{5}$ in 1882 . They deal with administrative mat-

${ }^{1}$ Informes del procurador jeneral. Compilados por Cloromiro Quiroga. Buenos Aires, Imprenta Americana, 1874 .

${ }^{2}$ Fernandez, Francisco F.: Informes del procurador general de la nación y demás consejeros legales del poder ejecutivo (I866-1874) compilados por Francisco F. Fernandez. Publicación oficial. Buenos Aires, Impr. M. Biedma, I88ז-87. 5 v.

${ }^{3}$ Ferreira, R.: Collección de vistas fiscales y resoluciones en asuntos administrativos del culto, diplomáticos y civiles. Buenos Aires, I864.

4 Vistas fiscales del Dr. D. Benjamin Victorica, fiscal general de las Cámaras de Apelaciones. Annotated by Dr. M. S. Aurrecoechea. [Biblioteca selecta Argentina.] Buenos Aires, Imp. de la Pampa, I879. $300 \mathrm{p}$.

${ }^{5}$ Vistas fiscales del Dr. D. Isaac P. Areco, publicadas por el Dr. D. Francisco Costas. Buenos Aires, Imp. La Nacion, I882. I90 p. 
ters for the years $1873-1880$ and include questions of public works, tramway concessions, prolongation of railroads and public lands. The work includes some 80 opinions and indicates the decision taken by the government in each case.

One of the ablest of the more recent fiscals is Jeronimo Cortés ${ }^{1}$ a distinguished jurist. His opinions as fiscal of the Court of Appeals of the Capital have been published in five volumes, covering the period I 887-1910. Volume I contains an interesting introduction by Lucio V. Lopez. The work deals with civil, commercial, criminal, and administrative questions. Recently, the opinions of Cesar Reyes, ${ }^{2}$ fiscal of La Rioja in criminal cases, have begun to be published.

\section{GENERAL DIGESTS}

The best known general digest of decisions rendered by the highest courts of Argentina, both federal and provincial, is the dictionary of Argentine jurisprudence edited by Augusto Carette. $^{3}$ The main work was published in three large volumes in 1907-1909. A supplement or fourth volume published in 1910, contains the various codes and principal statutes of the country annotated by the decisions of the highest courts. A second supplement or fifth volume published in 1912 continues the main work with a digest of the reports published up to I9IO-II. The work will probably be continued by the publication of later supplements. Current decisions are digested in the Revista de legislacion y jurisprudencia, edited by Carette supra (p. 22). The principal work is the only general digest of the decisions of the higher courts.

I Cortés, Jerónimo: Vistas fiscales expedidas en el carácter de fiscal de las Cámaras de Apelaciones de la Capital, 1887-19ıo. Buenos Aires, Imp. Europea, 1887 (v. I-3). Córdoba, F. Domenici y Cia, I907-IO (v. 4-5).

${ }^{2}$ Reyes, Cesar: Vistas fiscales en materia criminal. v. I, La Rioaj, I9I6.

${ }^{3}$ Carette, Augusto: Diccionario de la jurisprudencia argentina, ó sintesis completa de las sentencias dictadas por los tribunales Argentinos. Buenos Aires, Libreria Nacional, La j ouane, I907-9. 3 v. v. 4, Suplemento conteniendo los códigos y leyes anotados. Buenos Aires, Lib. Nac. I9Io. $35^{2}$ p. v. 5, Suplemento, etc. Buenos Aires, Lajouane, I9I2. I205 p. 


\section{GENERAL WORKS}

ColleEcted Codes and LAWS. - The collected codes of Argentina have been published in a number of editions. One of the more recent of these is the publication of the house of Rodríguez Giles ${ }^{1}$ published in 1909, which contains, besides the constitution and the various national codes, the codes of procedure for the Federal Capital, the judiciary code, the codes of procedure in the province of Buenos Aires, the codes for the national territories and the province of Buenos Aires, and the code of military justice. A more elaborate publication, including, besides the codes, most of the more important laws of frequent use and application is that of the house of Lajouane. Besides the collected codes of national application, it contains the constitutions of all the provinces and numerous laws of an administrative character relating to public works, lands, colonization, immigration, railroads and similar matters, as well as special statutes affecting the various codes. The twelfth edition ${ }^{2}$ of this work was published in two volumes in 1912. There is also a 1914 edition ${ }^{3}$ of the codes in $12^{\circ}$.

A volume of the laws of frequent application was also published separately in 1906 by Lajouane. ${ }^{4}$ It contains the laws on such subjects as citizenship, expulsion, extradition, expropriation, law of municipalities, administration of justice, land laws, banking laws, currency, weights and measures,

, Códigos de la República Argentina. Buenos Aires, M. Rodríguez Giles, rgo9. ro86 p. Contains: Constitución; código de comercio; código penal; código civil; código de mineria; código de procedimientos en materia civil y comercial de la capital; organización de los tribunales de la cap.; código de procedimientos en lo criminal, código de procedimientos civil y comercial de la Provincia de Buenos Aires; código de procedimientos en materia penal de la Provincia de Buenos Aires; código rural para los territorios nacionales; código rural de la provincia de Buenos Aires; código de justicia militar.

${ }^{2}$ Códigos y leyes usuales de la Republica Argentina. I2th ed. Buenos Aires, F. Lajouane, I912. 2 v.

${ }^{2}$ Códigos de la Republica Argentina. $12^{\circ}$. Buenos Aires, I9I4.

- Colección de leyes usuales de la República Argentina con un extenso indice alfabético de todas las materias á que hacen referencia las leyes. Buenos Aires, J. Lajouane \& Co., I906. 988 p. 
authentication of documents, patents, trade-marks, tax laws, warrants and the treaties signed at Montevideo at the Conference of 1889 .

A colection of codes and laws governing the administration of Federal justice has been edited by Jose A. Frias ${ }^{1}$ in several editions, of which the most recent is that of 1905. A digest of laws on various subjects, including the law of accounting, budget, pensions, attachments, postal laws, letters rogatory, public works, judicial fees, corporations, administration of justice, prisons, and notaries was published under the title Digesto de justicia ${ }^{2}$ in 1899.

For the Province of Buenos Aires, Lajouane ${ }^{3}$ has published a collection of the provincial codes and gencral statutes in a volume which has had several editions, the latest of which is that of I9II. Lajouane has also published separately a collection of the laws of frequent application in the Province, including the constitution, laws governing municipalities, elections, administration of justice, education, expropriation, water laws, land laws, stamped paper, and other matters. ${ }^{4}$

A somewhat similar volume ${ }^{5}$ was published in I9I I by the Imprenta de Mayo.

A small handy volume of laws has been published recently by the house of Abeledo, ${ }^{6}$ which includes the tax and license and stamped-paper laws, certain laws of procedure and others

' Frias, José A.: Recopilación de codigos y leyes de justicia federal. Buenos Aires, r905. $55^{8} \mathrm{p}$.

2 Digesto de justicia: conteniendo las leyes de contabilidad, gastos, presupuesto, pensiones, jubilaciones, embargos, correo, publicaciones, exhortos, obras públicas, honorarios judiciales, sociedades en general, legislación, justicia federal, carceles, escribanías, etc. Buenos Aires, Penitenciaría nacional, I899. I 46 p.

${ }^{3}$ Colección de codigos y leyes usuales de la provincia de Buenos Aires. Buenos Aires, F. Lajouane, I9Ir.

${ }^{4}$ Colección de leyes usuales de la provincia de Buenos Aires. Nueva ed. cor. y aumentada, conteniendo todas las leyes sancionadas hasta la fecha. Buenos Aires, J. Lajouane \& Co., r907. 5 or p.

${ }^{5}$ Colección de leyes usuales de la provincia de Buenos Aires. Buenos Aires, Impr. de Mayo, J. E. Hall, I9II. 776 p.

6 Petit colección de leyes de uso diario para abogados, escribanos y procuradores. Buenos Aires V. Abeledo, 1914. 199 p. 
connected with the administration of justice, literary and artistic property, enrollment and elections. It includes the stampedpaper law and certain tax laws of the Province of Buenos Aires. A somewhat similar collection ${ }^{1}$ for the Province of Corrientes includes the provincial codes and the laws of daily application, besides certain Federal laws.

Attention has already been called to the fourth volume of Carette's ${ }^{2}$ dictionary of Argentine jurisprudence, or digest of of the court reports, which contains the principal codes and general statutes, annotated by the decisions of the courts.

TREATISES.-A general introduction to the study of law was published by the well-known jurist, J. J. Montes de Oca ${ }^{3}$ in 1877 , with a second edition in 1884 . It is in the nature of a text book, dealing in its first part with justice, law, and court decisions; in its second part with an outline of the different branches of the law or legal encyclopedia; and in its third part with a history of positive law.

Emilio Daireaux, who has written a well-known work describing the Argentine Republic and its institutions, including the law and the courts, ${ }^{4}$ has also published a small volume of the nature of "Every man his own lawyer," 5 dealing with the principal matters relating to civil, commercial, constitutional, administrative, penal, financial, and rural law, the principles governing international relations and the status of aliens and forms for the more customary legal acts. The twentieth edition of this work was published in 1915 .

${ }^{1}$ Recopilación completa de códigos, leyes y decretos reglamentarios vigentes de la provincia de Corrientes. Constitución nacional, ley electoral, ley de quiebras. Corrientes, Talleres gráficos de $\mathrm{T}$. Heinecke, 1904. $2 \mathrm{v}$.

2 Carette, Augusto, and Ocantos: Diccionario de la jurisprudencia argentina. $4^{\text {th }}$ vol.contains codes and general statutes as interpreted by the courts.

3 Montes de Oca, Juan José: Introducción general al estudio del derecho. Buenos Aires, Impr. de Mayo, 1884. 2 d ed. 2 v. in $x$. (ist ed. published in 1877. )

4 Daireaux, Emile: La vie et les moeurs à la Plata. Paris, Hachette, I888. 2 v.

- Daireaux, Emilio y Daireaux Molina, Jacques: El abogado de sí mismo. Tratado de derecho usual para la República Argentina. 2oth ed. Buenos Aires, Lajouane, I915. 636 p. 
Professor Carlés ${ }^{1}$ has published his lectures on the general principles of Argentine law in a small volume issued in r9r 3 . It constitutes a general survey or manual of public and private law, and has been very favorably reviewed.

A recent little work of Professor Alfredo Colmo ${ }^{2}$ on legal culture and the faculty of law at Buenos Aires is of interest in the study of Argentine legal conditions, particularly educational.

Professor Calandrelli ${ }^{3}$ has edited a four-volume collection of briefs and articles which he considered as important contributions on various subjects of the law.

The works of Juan B. Alberdi, ${ }^{4}$ one of the fathers of the Argentine constitution, and a jurist and diplomat of note, have been published in special editions. His complete works were published in 8 volumes in $1886-87$, and subsequently his posthumous writings ${ }^{5}$ were edited and published in 16 volumes. These essays and studies may more properly be classified in social and political science than in law. More recently some of his earlier works have been republished. Alberdi emigrated to Chile during the Rosas régime, and on his return to Argentina, after the fall of Rosas, published his "bases" of a draft of the constitution, which was sanctioned by the country and by the Congreso Constituyente de Santa Fé of 1853 . That classic work (infra, p. 123) has been published in numerous editions. Alberdi's life and works were critically studied in volumes published in 1857 by Martos $^{6}$ and in 1874 by Pelliza. ${ }^{7}$ The general catalogue of the library of La Plata, issued in 1887 (supra, p. I6), gives a very full bibliography of Alberdi's works.

${ }^{1}$ Carlés, M.: Nociones de derecho argentino. Buenos Aires, A. Garcia Santos, I9I3. $230 \mathrm{p}$.

2 Colmo, Alfredo: La cultura jurídica y la facultad de derecho. Buenos Aires, Martin Garcia, I9I5. 284 p.

${ }^{3}$ Calandrelli, A.: Enciclopedia jurídica argentina. Buenos Aires, "La Buenos Aires," I90I-2. 4 v.

${ }^{4}$ Alberdi, J. B.: Obras completas. Buenos Aires, 1886-87. 8 v.

${ }^{5}$ Alberdi, J. B.: Escritos póstumos. Buenos Aires, Impr. Europea, I895-I9or. I6 v. in I4.

${ }^{6}$ Martos, Cristino: Juicio sobre las obras de Alberdi. Valparaiso, 1857.

${ }^{7}$ Pelliza, Mariano A.: Alberdi, su vida y sus escritos. Buenos Aires, I874. 
Another noted jurist was José María Moreno (1835-1882), who was professor of civil law at the University of Buenos Aires, an attorney and minister of state, and who occupied a leading place in the legal and economic life of Argentina. The works of Moreno ${ }^{1}$ were published in three volumes in 1883 under the editorship of Antonio Malaver (1 835-1 897), another noted jurist, and Juan José Montes de Oca, already mentioned. Volume one contains a critical biographical study of Moreno, by Malaver, and Moreno's works on civil and administrative law; volume two, with a preface by Lucio V. Lopez, contains the works on commercial law, and volume three, the works on commercial law and procedure. Two Falguière statues of Moreno and Malaver adorn the campus of the faculty of law of the University of Buenos Aires.

The works of José Manuel Estrada, ${ }^{2}$ an historian and authority on constitutional law, were published in twelve volumes in $1897-1905$. Those of special interest in law are volumes $6-8$, which reprint his standard work on constitutional law.

The collected works of Domingo Faustino Sarmiento ${ }^{3}$ (I8II-I888), the distinguished statesman, publicist, and educator, who succeeded Bartolome Mitre as President of the Republic, have been published, mainly under governmental auspices, in 53 volumes. The majority deal with political questions, history, and education. Those having an interest in law are volume 8 , his "Commentaries on the constitution"; volume 9, on "South American institutions"; volume 27, a biography of Dalmacio Velez Sarsfield, the

${ }^{1}$ Moreno, José María: Obras jurídicas, por Malaver y de Oca. Buenos Aires, F. Lajouane, 1883 . $3 \mathrm{v}$.

${ }^{2}$ Estrada, José Manuel: Obras completas de José Manuel Eistrada. Buenos Aires, P. Igón y Co., I897-I905. I2 v.

${ }^{3}$ Sarmiento, Domingo Faustino: Obras de D. F. Sarmiento . . . Paris, Belin hermanos, I889-I909. 53 v. vol. I-6 "reimpresion," I909. vol. I-6 have imprint: Paris, Belin hermanos, I909; v. 7: Santiago de Chile, Impr. Gutenberg, r889; v. 8-49: Buenos Aires, Impr. "Mariano Moreno," I895-1900; v. 50-52: Buenos Aires, Marquez, Zaragoza y Cia., I902; Indice: Buenos Aires, Impr. Borzone, 1903. vol. $\mathrm{I}-7$, comp. by Louis Montt; v. 8-52 and index comp. and ed. by A. Belin Sarmiento. cf. "Advertencia," v. I. vol. 7-52, "publicadas bajo los auspicios del gobierno arjentino." 
draftsman of the civil code; volumes $3 x-33$, on "Constitutional practice"; and volume 36 , on "The position of the alien in America." A bibliography of Sarmiento was published by Ricardo Rojas, ${ }^{1}$ under the auspices of the University of La Plata. After an introduction of literary criticism, the work is divided into 52 chapters, corresponding to the 52 volumes of Sarmiento's collected works and giving a descriptive account of their contents. Some of his addresses 2 were published separately in 1883 .

The writings and speeches of Roque Saenz Peña, ${ }^{3}$ twice President of Argentina and a former justice of the Supreme Court, have been published in two volumes.

The academic addresses delivered in the faculty of law at Buenos Aires from 1880 to 1910 were published in $191 \mathrm{I}$, with an introduction by J. A. García. ${ }^{4}$ They deal with various branches of law.

Joaquin V. Gonzalez, one of the leading statesmen and jurists of Argentina, has beell a prolific contributor to legal literature. His writings on particular subjects will be mentioned in the course of this monograph. At this point attention may be directed to two volumes of collected essays on diverse subjects, one including questions of constitutional, electoral, international, and administrative law, ${ }^{5}$ and the other a collection of papers on questions of constitutional law, judicial organization, mining law, and international law. ${ }^{6}$

${ }^{1}$ Rojas, Ricardo: Bibliografía de Sarmiento. Buenos Aires, Coni herm., I9II. $5^{82} \mathrm{p}$.

${ }^{2}$ Sarmiento, Domingo Faustino: Los discursos populares de D. F. Sarmiento, 1839-1883. (Arreglados por A. Belin Sarmiento.) Buenos Aires, Impr. Europea, r883. 532 p.

${ }^{3}$ Saenz Peña, Roque: Escritos y discursos. Buenos Aires, Jacobo Peuser, rgr5. 2 v.

* Discursos académicos pronunciados en la Facultad de derecho y ciencias sociales de Buenos Aires ... Precedidos de una introducción por J. A. García. Tomo I, I880-rgro. Buenos Aires, Facultad de Derecho, rgrr. $574 \mathrm{p}$.

${ }^{5}$ Gonzalez, Joaquin V.: Jurisprudencia y política. Buenos Aires, Lib. La Facultad, de Juan Roldán, 19r4. 437 p.

${ }^{6}$ González, Joaquin V.: Escritos y opiniones en derecho-constitucional, judicial, minero é internacional. Buenos Aires, Penitenciaría nacional, $1907.2 \mathrm{v}$. 
The decisions rendered by Rafael Garcia, ${ }^{1}$ together with various articles, were collected by Nicolás Amuchastegui and published in three volumes in I888. Dr. Daniel Goytia, ${ }^{2}$ a justice of the Federal Court at La Plata and professor at the university of that city, has republished his decisions, amplified by discussions of legal doctrine in connection with them and a number of articles.

\section{LEGAL PERIODICALS}

Numerous legal periodicals have been published in Argentina, some of which have had but brief careers. Mention should be made, however, of those whose scientific and literary importance warrants their consideration as works of permanent value. In I 863 there was begun the celebrated La Revista de Buenos Aires, ${ }^{3}$ edited by M. Navarro Viola and V. G. Quesada. While not essentially a legal periodical, law is one of its departments and many scholarly articles on law are to be found in its pages. It was suspended in I 87 I after 24 volumes had been published. In I88I the publication was revived under the title of Nueva Revista de Buenos Aires, ${ }^{4}$ under the editorship of V.G. Quesada y E. Quesada. Thirteen volumes were published up to 1885 , when it ceased issue.

A scholarly periodical dealing largely with doctrinal discussions and criticisms of decisions and statutes was the Revista de lejislacion y jurisprudencia, ${ }^{5}$ edited by four of the leading jurists of Argentina, Moreno, Araujo, Malaver, and Montes de Oca. It was begun in I 869 , nine volumes having been published up to 1873 , when it was temporarily suspended. It was revived in 1877 , but only two additional volumes were issued.

${ }^{1}$ Garcia, Rafael: Fallos y escritos juridicos. Por Nicolás Amuchastegui. Buenos Aires, I888. 3 v.

${ }^{2}$ Goytia, Daniel: Repertorio juridico del Dr. Daniel Goytia . . . La Plata, Talleres gráficos de J. Sesé, 19ro. $476 \mathrm{p}$.

${ }^{3}$ La Revista de Buenos Aires: Historia americana, literatura y derecho. Dirección: M. Navarro Viola y V. G. Quesada. Buenos Aires, 1863I871. $24 \mathrm{v}$.

4 Nueva Revista de Buenos Aires: Dirigida por V. G. Quesada y E. Quesada. I881-I885. I3 v.

"Revista de lejislación y jurisprudencia publ. bajo la dirección de: José María Moreno, Ceferino Araujo, Antonio E. Malaver, and Juan José Montes de Oca. Buenos Aires, Impr. "Buenos Aires," 1869-1873, I $877-1878$. II V. 
Among the more recent periodicals several warrant special attention. One of the most important is that edited by E. S. Zeballos, a jurist of note in international law and a man of wide scholarly attainments. His Revista de derecho, historia $y$ letras began issue in $1898^{1}$ and consists of some three volumes a year, 46 volumes having been published up to the end of 1913 .

Another well-known periodical is the Revista juridica $y$ de ciencias sociales, ${ }^{2}$ now edited by M. A. Montes de Oca. It contains articles, important decisions, reviews of books, and notes and comments. It began issue in 1884 and in various series consists now of 36 volumes.

The Revista Argentina de ciencias politicas, edited monthly since r 9 Io by Dr. Rodolfo Rivarola ${ }^{3}$ is a repository of many important articles on law and political science. It enjoys high repute.

Some of the less known periodicals are the Anales $^{4}$ of the faculty of law, the first series of which was issued from 1902 to 1904. It contains a number of articles, official documents, certain important new laws and decrees, and notes of the faculty of law. A new series was begun in 1911 and has continued to date. From 1907 to I910 the faculty published what was known as a Revista, ${ }^{5}$ of which only two volumes were published. In 1915, a number of leading jurists organized an "Academy of law and social science," and began to issue

${ }^{1}$ Zeballos, E. S.: Revista de derecho, historia y letras. Buenos Aires, Imp. Lit. y Encuadernación de Jacobo Peuser, r898-. 46 v. to I913.

${ }^{2}$ Revista jurídica y de ciencias sociales. Buenos Aires, $1884^{-} .36 \mathrm{v}$. to rgí 5. Ist ser., r884-90, 7 v.; 2nd ser., I89r-94, 5 v.; 3rd ser., r895-96, 2 v.; $4^{\text {th }}$ ser., $1897-19$ rr, 14 v.; $5^{\text {th }}$ ser., I912-r $5,8 \mathrm{v}$.

${ }^{3}$ Revista Argentina de ciencias políticas. Derecho, administración, economía, política, sociología, historia y educación. Fundador y director, Dr. Rodolfo Rivarola. Buenos Aires, Dirección y Adm. de la Revista, Igro. 6 v. to Igr 5 .

${ }^{4}$ Anales de la Facultad de derecho y ciencias sociales. Buenos Aires, Facultad de derecho, 1902-1904, 191 x-. 2d series, ed. by Juan Agustín García, Igrr-. 3d series, v. I and 2 (rgr6).

- Revista de la Facultad de derecho y ciencias sociales. Director: Dr. Francisco J. Oliver, I909. Buenos Aires, 1907-rgro. (v. I, Aug. r907-I908; v. 2, May I909-I9ro.) All published. 
Anales ${ }^{1}$ as the organ of the Academy. 'The law student's organization, known as the Centro estudiantes de derecho, ${ }^{2}$ publishes a monthly magazine consisting of articles contributed by students and professors and translations of important articles in foreign periodicals. The college of notaries, a professional organization of notaries and not an institution of learning, publishes as its organ a Revista del notariado ${ }^{3}$ which is of some importance, for the notary plays a large part in the legal and economic life of the community.

Attention has already been directed to the Revista de legislacion y jurisprudencia published by Carette and his collaborators as a supplement to his Diccionario de legislacion. (Supra p. 22.)

In the general Anales ${ }^{4}$ of the University, published in five volumes, various legal articles of importance may be found.

\section{LEGAL EDUCATION}

The law, in Spanish-American education, has at all times ranked as a study of primary importance. It is pursued not only by those intending to practice at the bar, but by persons proposing to occupy administrative positions of various classes. As part of a liberal education, it is studied by many persons who have no intention of using their knowledge professionally. The course in Argentina, as in most SpanishAmerican countries, occupies five years, with an additional one or two years for the doctorate. Besides the usual branches of Roman law, the history of law, the philosophy of law, civil law, commercial law, criminal law, procedure, constitutional law, administrative law, and international law, it includes political economy, history, sociology, and other subjects of political science. The three principal law schools are at Buenos

1 Anales de la Academia de derecho y ciencias sociales. Buenos Aires, r9r5-. v. 1, r9r5.

${ }^{2}$ Revista del centro estudiantes de derecho. Director: Julian C. Alderete, José M. Saenz Valiente, and others. Buenos Aires, Imp. A. Grau, I907-.

3 Revista del notariado. Organo del colegio nacional de escribanos, I897-. Buenos Aires, I897-. I9 v. to I9I6.

- Bucnos Aires. Universidad Nacional: Anales de la Universidad de Buenos Aires. Buenos Aires, Impr. de M. Biedma, 1888-9o. 5 v. $71624^{\circ}-17-4$ 
Aires, Córdoba, and La Plata. The latter University was created as an institution for scientific research rather than a mere training school for the professions. It may here be mentioned that the teaching of law was not permitted by Spain in Buenos Aires and was there first established in $182 \mathrm{r}$.

A work dealing with the history of the teaching of the law and social sciences at the University of Buenos Aires was published in 1914 by Pestalardo. ${ }^{1}$ It is a history of the law school and its instructors and instruction from the beginning to the present time, divided by periods. A somewhat similar work for the University of C6rdoba was published by Martínez Paz. $^{2}$ A recent work by Colmo ${ }^{3}$ on juristic culture in Argentina and the Buenos Aires law faculty has been well received. It advocates reform in university methods, both professional and educational.

Some account of the law faculty at the University at Buenos Aires is to be found in a work giving a historical account of the various faculties of the University for the period 1821 to $1910 .{ }^{4}$ The by-laws of the faculty of law and social science, as of October 8 , 1900, with a plan of study are published in the Anuario Oficial of 1912, pages 891-916.

An interesting description of the early life of Buenos Aires and the position of the courts there, with some emphasis upon legal education, is to be found in the work of Emile Daireaux, La vie et les moeurs a la Plata, Paris, Hachette, I888, Volume I, pages $353-380$.

\section{GENERAL JURISPRUDENCE}

No indigenous schools of legal thought can be said to exist in Argentina. Much attention, however, is paid to the history and doctrines of the leading schools in the Latin countries of

i Pestalardo, Agustin: Historia de la enseñanza de las ciencias jurídicas y sociales en la Universidad de Buenos Aires. Buenos Aires, Imp. Alsina, rgr4. $25^{2} \mathrm{p}$.

${ }^{2}$ Martínez Paz, Enrique: La enseñanza del derecho en la Universidad de Córdoba. Córdoba, rgrz.

${ }^{3}$ Colmo, Alfredo: La cultura jurídica y la facultad de derecho. Buenos Aires, Martin García, I9r5. 284 p.

4 La Universidad nacional de Buenos Aires, r82r-rgro. Buenos Aires, Impr. Tragant-Belgrano, Igro. $299 \mathrm{p}$. 
Europe and the development in Germany is not unknown to a limited few. As in all countries of the civil law, however, courses in legal theory and general jurisprudence occupy a fundamental place in the curriculum, so that a number of works dealing with law as a science or the theory of law in general have been published. Among the best of the introductory works are Professor Juan J. Montes de Oca's ${ }^{1}$ general introduction to the study of law, first published in 1877 , and Professor Manuel Augusto Montes de Oca's ${ }^{2}$ lectures under the same title, reported by two of his students. A biography of Juan José Montes de Oca was published in $187 .^{3}$ Carlos C. Malagarriga, a prolific student publisher of notes of lectures delivered at the Faculty of Law has recently published ${ }^{4}$ the notes of the course on the introduction to the study of law.

A work of primary importance is Professor Juan Augustin Garcia's introduction to the study of the Argentine social sciences, ${ }^{5}$ about half of which is devoted to a study of the theory of law and general jurisprudence.

Wenceslao Escalante, former dean of the Faculty of Law, is the author of two works on the philosophy of law, both based on his lectures. ${ }^{6}$ The second work consists of notes taken by his students, and covers the history of the philosophy of law.

Antonio Dellepiane, Escalante's successor as professor of the philosophy of law at the University of Buenos Aires, is the author of an important work on the "philosophy of judicial proof," a work published in the form of lectures taken by

1 Montes de Oca, J. J.: Introducción general al estudio del derecho. 2 d ed. Buenos Aires, Imp. de Mayo, I884. 2 v. in I.

- Montes de Oca, Manuel Augusto: Introducción general al estudio del derecho. Notes taken by Adolfo Casabal y Francisco Sugasti. Buenos Aires, 1895 .

3 Apuntes biograficos del Dr. Juan José Montes de Oca. Buenos Airzs, "La Tribuna," I877. $13^{8} \mathrm{p}$.

"Malagarriga, C. C.: Apuntes de introducción general al estudio del derecho. Buenos Aires, rgr6. $333 \mathrm{p}$.

- Garcia, Juan Augustin: Introducción al estudio de las ciencias sociales argentinas. Buenos Aires, Pedro Igon, I899. $360 \mathrm{p}$.

- Escalante, Wenceslao: Lecciones de filosofía del derecho. $3^{\mathrm{d}}$ ed. Buenos Aires, "Europea," rgor. 472 p. Ibid., Apuntes de filosofía del derēcho, Parte histórica. 2 d ed. Buenos Aires, Europea [M. A. Rosas], rgo6. $25^{\mathrm{I}} \mathrm{p}$. 
several of his students. ${ }^{1} \quad$ After studying each one of the means of proof according to the code of civil procedure, a study is made of the relation between the theory of judicial proof and proof in general from a critical and philosophical standpoint. In 1907 Professor Dellepiane ${ }^{2}$ published his studies in sociology and legal and social philosophy, a work of some reputation. The notes of the course on the philosophy of law as given at the University were published in 1914 by Carlos Malagarriga, ${ }^{3}$ a law student. Mario Sáenz ${ }^{4}$ also published in I9Io notes of a course of lectures. The students in Argentina also use the recent translation into Spanish (Lima, 1909) of Professor Vanni's lectures on the philosophy of law, besides the works of Boistel, Ahrens, and Spencer.

A leading work on legal science is Professor Carlos Octavio Bunge's $E l$ derecho (The law), ${ }^{5}$ which reached its fourth edition in two volumes in $1915^{-16}$. The work deals with the relation between ethics and law, the classification of the schools of ethics and of law, the schools of positive law and political philosophy, political theories and the schools of legal method. The exposition of the integral theory and method, a complex of all the physical and psychical elements which enter into the concept of law, is in part quite original. The work finds its principal sources in the juristic thought of continental Europe.

An able article by Dr. Lisandro Segovia on German jurists and their influence on Argentine legal science was published in volume 2 of the Jahrbuch der Vereinigung für vergleichende Rechtswissenschaft (1896), pages 602-606. The author discusses the influence of Heineccius, Mackeldey, Savigny, Ahrens, Zachariae, Feuerbach, Mittermaier, and others.

1 Dellepiane, Antonio: Filosofía del derecho procesal: Ensayo de una teoría general de la prueba. Lectures of 1903 reported by Faustiro Infante, Daniel A. Infante, and C. C. Malagarriga. Buenos Aires, Impr. del Comercio, r9r3. $204 \mathrm{p}$.

2 Dellepiane, Antonio: Estudios de filosofía jurídica y social. Buenos Aires, V. Abeledo, 1907. 236 p.

3 Malagarriga, Carlos (Hijo): Apuntes de filosofía de derecho. Pt. I. Buenos Aires, Penitenciaría nacional, I9I4. 3 I4 p.

4 Saenz, Mario: Filosofía del derecho. Buenos Aires, IgIo.

5 Bunge, Carlos Octavio: E1 derecho. Ensayo de una téoria jurídica integral. 4th ed. Buenos Aires, V. Abeledo, 1915-16. 2 v. 


\section{LEGAL, HISTORY}

The present Republic of Argentina was incorporated by Spain for administrative purposes in the viceroyalty of Peru until by letters patent of August io, I776, a separate viceroyalty of the Rio de La Plata was organized, with its seat at Buenos Aires. The system of law in force in the viceroyalty was the same as that in the other colonies.

When the discovery of America had taken place the Kings of Spain put into force in their new dominions the various codes which had governed in Castile. They afterwards issued other codes in Spain, as well as special laws, decrees, and orders for the colonies in America with a view to regulating their political, administrative, ecclesiastical, and municipal affairs.

The codes which governed in Castile at the discovery of America were those which were issued in Gothic Spain and in the struggle for the conquest of the Arabs, for none of these abrogated anterior codes. The order of their preference in application was fixed by 'Title 28 of the Ordenamiento de Alcalá, which gave first place to that Ordenamiento, and the second to the Fuero Real and to the Fueros Municipales so far as they were preserved. They included the Fuero Juzgo, the only codification of the Visigothic monarchy, and others up to the Siete Partidas. The Catholic Kings later gave legal authority to the Ordenamiento de Montalvo, likewise known under the name of Ordenanzas Reales de Castilla.

After the discovery of America there were published the Leyes de Toro, petitioned from the Catholic Kings in the Cortes of To'edo of $\mathrm{r}_{502}$, and published in 1505 , after the death of Doña Isabel, in the Cortes of Toro, which had assembled to swear allegiance to Doña Juana. They did not constitute a code. They consist of 83 laws, which were designed to settle doubts and questions which had been raised by the coexistence of several codes which in many points were contradictory. In I 567 Philip II put into force the Nueva Recopilacion, the draft of which had been commenced about $\mathbf{r}_{544}$. It consists of nine books divided into titles and these into laws.

On July 15, I 805, Charles IV sanctioned the Novisima Recopilacion, giving obligatory force not only to the laws therein. but also to the footnotes. It consists of 12 books subdivided 
into titles and these into laws. To maintain the legislation in accord with the movement of the times it was provided that every year a supplement was to be published retaining the same order of books and titles as the principal work. Only the first supplement was published; it was drafted in 1808 and printed in 1829 , and contains the laws of 1805 and 1806 .

The order of preference of the various codes, according to the Novisima Recopilacion, is the following:

1. The Novisima Recopilacion, in so far as its laws were not expressly abrogated by others.

2. The Fuero real and the fueros municipales, in so far as these had been used and preserved and were not contrary to the Recopilacion.

3. The Partidas.

The special laws, called Ordenanzas, which were issued in Spain and were in force in Argentina are:

The Ordenanzas de Bilbao, issued in 1737 , which constituted the commercial code of Spain and its colonies. They governed in Argentina until the promulgation of the commercial code;

The Ordenanzas militares, issued in 1728 . Certain difficulties in practice having arisen new Ordenanzas were promulgated in 1782 ;

The Ordenanzas generales de la Armada Naval, issued by Charles IV in I793, which governed until the Ordenanza Naval was promulgated in ? 802 ;

The Ordenanza de Matriculas, issued on August 12, 1802, which dealt with the regulation and discipline of the sailors of the navy, the marines, and similar employees of the government.

The discovery of America having taken place and the Spanish dominions having been cemented, the Kings commenced to send orders for the government of their new dominions. These were communicated successively to certain representatives to enforce. After some time a Recopilacion of the cédulas transmitted to Mexico was ordered. This was completed in 1563 . Subsequently a similar commission was given to the viceroy of Peru, Don Francisco de Toledo, who prepared the Ordenanzas which bear his name. These Ordenanzas were in force in Peru, but not the Recopilacion. 
They were prepared during the general supervision which Toledo exercised by order of the King in matters of spiritual and temporal government, war, administration of public property, and other matters. The Spanish government confirmed these Ordenanzas de Toledo and ordered that they be faithfully observed so far as not abrogated by the laws of the Indies or other subsequent provisions.

About 1570 Philip II ordered that a general Recopilacion be made of the royal decrees and cedulas promulgated by the Crown of Spain and communicated to the Indies through the Council of the Indies (Consejo de Indias), a consultative body established by Charles V in 1524 for the better government of the remote regions in the colonies, in imitation of the Consejo de Castilla, which communicated the royal orders and decrees in the Peninsular. By later decrees there was prepared a code entitled Sumario de la Recopilación general de leyes which served until 1628 ; but as the Council of the Indies was daily sending out new cédulas, which abrogated prior ones, the necessity became apparent of bringing together in one code all the laws, orders, and decrees issued for the colonies, following the same system adopted for the general laws of Spain (Recopilacion de las leyes de España). With this purpose in view different commissions were named, and after prolonged study and labor Charles II promulgated on May I8, I680, the well-known Recopilación de las leyes de las regiones de las Indias which contains all the provisions relating to America issued from the time of the Conquest until the date of publication. It was amplified and amended from time to time by the issuance of further royal cedulas, decrees, and ordinances. Of the Recopilacion itself there have been several editions ${ }^{1}$ published respectively in $168 \mathrm{I}, 1756$, 1774 , I79I, and 184I. The last contains numerous valuable notes. As the Recopilación de las Indias was a special code, it was ordered that preference be given to it as against the laws of Castile which were to govern only in matters not regulated by the Recopilacion.

1 Recopilación de las leyes de los reinos de las Indias mandada imprimir y publicar por la Magestad Católica del Rey Don Carlos II. Madrid, I680. 2 v. 2 nd ed., $175^{6} ; 3^{\text {rd }}$ ed., 1774,4 v.; $4^{\text {th }}$ ed., 179 I; $5^{\text {th }}$ ed., I84I. 
The royal decrees (Reales cédulas) issued after 1680 were collected in an important work published by Padre Matraya ${ }^{1}$ in Lima in I819. This work has no legal authority, but its accuracy in reproducing chronologically the royal decrees issued after 1680 has practically given it the authority of a supplement to the Recopilacion.

The inconveniences due to the fact that the Spanish possessions constituted only two viceroyalties, that of Mexico and that of Peru, made it necessary that some changes should be made in the political subdivisions of the colonies and in the system of internal government. Two new viceroyalties were, therefore, created, one at Santa Fé and the other at Buenos Aires, in 1776. In place of the old Gobernadores and Correjidores, there were created the Intendentes and Subdelegados. For the purpose of embodying in one code the duties of the Intendentes and the other officials in the colonies, there was published a code of laws known as the Ordenanza de Intendentes, which was promulgated on January 21,1783 . Others were issued on December 4, 1786; but various difficulties having arisen, a new Ordenanza was promulgated on September 23, r8o3.

The Ordenanza de Intendentes had first place among the special laws issued for America. The next in order of application was the Recopilacion de las Indias; next, the Ordenanza de Toledo and the leyes municipales, and finally, the Spanish codes.

A chronological index of the Spanish colonial legislation for the colonies of the Indies from 1680 to $1847^{2}$ was published in Madrid in 1848 . The laws of the Indies with the colonial legislation subsequent to $168 \mathrm{o}$, so far as it was in force about r885, were collected under the auspices of the Spanish government by Miguel de la Guardia ${ }^{3}$ and published in $1888-1890$ in 13 volumes.

The sources of Argentine law are primarily the laws of the Indies with the subsequent decrees, ordinances, orders, and

${ }^{1}$ Matraya y Ricci, Joseph: El moralista filatélico americano. Lima, I8I9, folio.

${ }^{2}$ Indice cronológico de la serie de leyes, etc. . . . de las provincias de Indias desde $x 680$ hasta 1847 . Madrid, 1848.

${ }^{3}$ Guardia, Miguel de la: Las leyes de Indias con las posteriores á esta código, vigentes hoy . . Madrid, Nuñez, r888-189o. I3 v. 
royal cedulas, and subsidiarily, the legislation in force in Spain at the date of Argentine independence in $18 \mathrm{ro}$. This legislation is so complex and often so difficult to reconcile that, as already observed, a formal order of preference of the varions Spanish codes in their application by the courts and administrative officers was promulgated. This order of preference was: $\mathbf{r}$. The laws, decrees, and enactments communicated by the Council of the Indies to the colcnial authorities; 2. The laws or Recopilacion of the Indies; 3. The Nueva Recopilacion; 4. The laws of Toro; 5 . The royal ordinances of Castilla; 6 . The edict of Alcalá; 7. The Fuero juzgo; 8 . The Fuero real; 9. The Siete Partidas. In addition, the Ordinances of Bilbao were the principal source of commercial law. A brief outline of the laws in force in colonial Spanish-America is given by Charles E. Reis in an article on Spanish law in the British Empire published in No. 30 (January, I9r4) of the Journal of the Society of Comparative Legislation, pages 24,27 . The books in which the early Spanish codes are collected were discussed in the Guide to the law and legal literature of Spain (Washington, 1912) page $3 \mathrm{r}$ et seq. The contents of these Spanish codes of law are fully described in volume 2 of Bunge's excellent history of Argentine law, to be discussed presently.

One of the classic works in description of the administrative, political, and legal system in force in the Indies is the important work of Solórzano y Pereyra, ${ }^{1}$ last published in Madrid in I776, with valuable notes by Francisco Ramiro de Valenzuela, in two folio volumes. The work includes all matters which fell within the jurisdiction of the Council of the Indies in their government of the colonial possessions of the Crown of Spainpolitical, judicial, and administrative.

A valuable collection of source material for the colonial history of Argentina and of considerable interest for law is that edited by Pedro de Angelis, ${ }^{2}$ published in $\times 836$ and recently reprinted.

' Solórzano y Pereyra, Juan de: Política indiana. With notes by Francisco Ramiro de Valenzuela. Madrid, Impr. Real de la Gazeta, 1776. 2 v. folio.

${ }^{2}$ Angelis, Pedro de: Colección de obras y documentos relativos á la historia antigua de las provincias del Rio de la Plata. Buenos Aires, Imp. del Estado, $1836-37.6 \mathrm{v}$. folio. Reprinted in $5 \mathrm{v}$. by J. Lajouane [Igrc]. 
A third source of the law of Argentina, which, however, has exercised practically no permanent influence is the indigenous law prevailing among the aboriginal tribes of Argentina; and a fourth source, the Argentine legislation enacted subsequent to independence, the repositories of which have been described in a previous chapter (supra, p. I8.).

There is only one well-rounded treatise on the history of Argentine law, namely, Carlos Octavio Bunge's ${ }^{1}$ work, published in two volumes in 1912-13. The plan of the work is divided into four parts. Part I discusses the indigenous law among the Argentine tribes and utilizes ethnological studies, through which it seeks to discover the private and the public law of the local inhabitants in the precolonial period. The book is of particular importance because of its full discussion of the sources and the bibliography of the subject. Part II consists of a historical discussion of the Spanish law, the subsidiary law in force at the time of independence, much of which has found its way into the Argentine law of the present time. Bunge's discussion of the literature of the early Spanish law and of the sources, of the modern bibliography, and of sources of Spanish law is probably the best to be found in print. The bibliographic notes at the head of each chapter add to the value of his work. Up to the present time the two parts mentioned are the only ones that have appeared. Parts III and IV are to deal with the laws communicated to the colonies from Spain and with the legal history following the independence of Argentina.

In addition to the classic work of Solórzano, above mentioned, an important place must be assigned to the works of Juan Agustin García. ${ }^{2}$ His La ciudad indiana, a second edition of which was published in 1909, is a social, political, and economic study of Buenos Aires and the surrounding country from 1600 to the middle of the eighteenth century. It is a scholarly work of permanent value. Ricardo Levene ${ }^{3}$ has

${ }^{1}$ Bunge, Carlos Octavio: Historia del derecho argentino ... . Buenos Aires, Facultad de derecho y ciencias sociales, rgr2-r3. 2 v. (incomplete).

${ }^{2}$ García, Juan Agustin: La ciudad indiana. 2nd ed. Buenos Aires, Angel Estrada, 1909. $375 \mathrm{p}$.

${ }^{3}$ Levene, Ricardo: Introducción al estudio del derecho indiano. Buenos Aires, rgí6. 
recently published a work of introduction to the precolonial and colonial law.

A work of some importance has recently appeared, consisting of studies published by the Faculty of Law; it deals with the administration of justice in Buenos Aires during the seventeenth and eighteenth centuries and contains an account and report of a number of early criminal prosecutions instituted in Buenos Aires. The book is supplied with a valuable introduction by Dr. Tomás Jofré. ${ }^{1}$

The principal data of Argentine legal history are to be found also in Professor J. J. Montes de Oca's Introducción general al estudio del derecho, I884 (supra, p. $5 \mathrm{I}$ ), in the notes of the lectures under the same title delivered by Manuel Augusto Montes de Oca ${ }^{2}$ and reported by two of his students, and in Juan Agustin Garcia's ${ }^{3}$ Introducción al estudio de las ciencias sociales argentinas, about half of which is devoted to the theory of law and its history.

No other work besides that of Bunge appears to deal in any degree with the history of Argentine private law, the jurists and writers of that country confining themselves, like the civilian commentators and legists, to the elucidation of legislative texts. Argentina has produced almost no original legal institutions, so that the sources of the private law are sought in foreign legislation and institutions. Only in the study of constitutional law does attention appear to have been paid to historical antecedents and evolution. These works will be discussed hereafter.

Attention should be called to a catalogue of documents in the Archives of the Indies in Sevilla ${ }^{4}$ relating to the history of the Argentine Republic, published by the Argentine Ministry

${ }^{1}$ Causas instruidas en Buenos Aires durante los siglos XVII y XVIII. With an introduction by Dr. Tomás Jofré. Buenos Aires, Facultad de derecho, 1913. $375 \mathrm{p}$.

${ }^{2}$ Montes de Oca, Manuel Augusto: Introducción general al estudio del derecho. Notes taken by Adolfo Casabal y Francisco Sugasti. Buenos Aires, 1895 .

${ }^{3}$ García, Juan Augustin: Introducción al estudio de las ciencias sociales argentinas. Buenos Aires, Pedro Igon, 1899. $360 \mathrm{p}$.

4 Catálogo de documentos del Archivo de Indias en Sevilla referentes á la historia de la Republica Argentina, r514-r8ro. Publicados por el Ministerio de relaciones exteriores y culto. Buenos Aires, Taller tipo. de la Penitenciaria nacional, 1901. $640 \mathrm{p}$. 
of Foreign Affairs. The first volume was published in I90I and volume 3 , published in I910, covers the period 1778 to I 820. Another source book of some of the very early colonial legislation, from 1493 to 1540 , has been edited in three volumes by Antonio M. Fabie, ${ }^{1}$ with valuable historical introductions to each volume. The volumes are part of the important series of unpublished documents relating to the colonial possessions of Spain, edited in Madrid since 1885 .

\section{CIVIL, CODE}

\section{HISTORY}

The Argentine constitution of 1853 provided for the enactment of national civil, commercial, criminal, penal and mining codes to be enforced by the courts, federal and provincial, throughout the Republic. Urquiza, the conqueror of Rosas, accordingly appointed a commission to draft a civil code. Political disturbances in the country prevented any effective work, however, so that the actual draft was delayed until Bartolome Mitre became President of a united country in 1862 . A law of 1863 again authorized the executive to appoint code commissioners and Dr. Velez Sarsfield, one of the leading jurists and lawyers in the country, who had also participated in the prior codification under Urquiza, was appointed to draft a civil code. By I 868 the learned codifier had submitted the four books of his draft code. It was submitted to Congress on August 25, I869, and enacted into law on September 29, 1869. The code went into effect on January $\mathrm{I}, \mathrm{187} \mathrm{I}$. The fact that the draft was entrusted to a single person and approved without debate is a tribute to the codifier, which experience with the code appears to have in part confirmed. Some criticism has resulted from the fact that many of its articles are theoretical and are not likely ever to be applied by the courts. The fact that it was adopted without discussion in Congress has been vigorously

${ }^{1}$ Fabié y Escudero, Antonio María (1832-1899), ed: Documentos legislativos [de Indias]. Madrid, Est. tip. "Sucesores de Rivadeneyra," I890-97. 3 v. (Collección de documentos inéditos relativos al descubrimiento ... de las antiguas posesiones españoles de ultramar. Madrid, $185^{-}$. 2nd ser., v. 5, 9, 10.) v. I, 1493-1511; v. 2, I $5^{12-1529 ; ~ v . ~ 3, ~ I 530-1 ~} 540$. 
disapproved by supporters and approved by opponents of parliamentary debate of codes. An appreciation of Velez Sarsfield and his contributions to the code has recently been published by the well-known scholar, Enrique Martinez Paz, ${ }^{1}$ of Córdoba.

\section{SOURCES}

The code consists of 4,05 I articles taken from numerous sources. Dr. Lisandro Segovia, an erudite scholar and commentator of the civil and commercial codes, has undertaken to compute Dr. Velez Sarsfield's indebtedness to various foreign codes and authors in the draft of the code. His result is as follows: From Dr. Teixeira de Freitas's Esboso de codigo civil (Rio de Janeiro, I860-6I), the draft code of the celebrated Brazilian jurist whose work has influenced a number of South American codes, about I,200 articles were taken, used in the first three books of the Argentine code. Zachariae's Le droit civil fransais, translated from the Fifth German edition, annotated and arranged in accordance with the code Napoeleon by Massé and Vergé (Paris, I 845-1860, $5 \mathrm{v}$.), contributed about 70 articles. Dr. Segovia finds that Velez Sarsfield had at times confused the author Zachariae with his annotators Massé and Vergé. Aubry and Rau, the French editors of Zachariae (Cours de droit civil fransais d'après l'ouvrage allemand de C. S. Zachariae. 3 d ed., Paris, 1856-1858, 6 v.), contributed some 700 articles. The work of Florencio Garcia Goyena, one of the draftsmen and commentators of the Spanish code, Concordancias, motivos y comentarios del proyecto de código civil español (Madrid, r 852. 4 v.), the only Spanish work apparently used by Velez, contributed some 300 articles, with many citations to the Roman and Spanish codes and laws. To the civil code of Chile, drafted by Andrés Bello, Velez was indebted for 170 articles, with variations. From the French civil code, nearly one-half of which has been in some form reproduced, he borrowed textually 145 articles. The code of Louisiana contributed some 52 articles, 33 in Book III and 19 in Book IV. Even the Russian code appears to have been drawn upon for a few articles. Several learned commentators of the French Code

${ }^{1}$ Martinez Paz, Enrique. Dalmacio Velez Sarsfield y el código civil argentino. Córdoba [1915]. $435 \mathrm{p}$. 
Napoleon were responsible for various articles, as follows: Troplong, the successor of Toullier, contributed some 50 articles to Book III on contracts and wills; and Demolombe, some $5^{2}$ articles to Book IV and 9 articles to Book III. Chabot (Commentaire sur la loi des successions, 6th ed., Paris, I831, $3 \mathrm{v}$.), contributed some 18 articles to Book IV. Maynz, the Belgian jurist, (Cours de droit romain, Brussels, $1870,3 \mathrm{~d}$ ed., $3 \mathrm{v}$.), is responsible for $\mathrm{I} 3$ articles in Book III and 2 articles in Book II. Molitor, the Belgian Romanist, was responsible for some $\mathrm{r} 2$ articles from his works on possession, revindication and servitudes. Besides these, the celebrated French jurist, Pothier, the commentators Marcadé and Duranton, Savigny (on obligations), Eduardo Acevedo, the draftsman of the Uruguayan code, and a few other codes and jurists were laid under contribution for further articles.

\section{CONTENTS}

The code is divided into preliminary titles, dealing with the effect of laws, capacity, the conflict of laws and the computation of time, and then into four books. Book I, entitled "Persons," deals with natural persons and corporations, their birth or creation, and death or extinction, proof of birth, domicil, absent persons and presumptions of death, minors, incompetents, etc. The second part of Book I deals with personal rights in domestic relations and first with marriage, the original sections of which have been entirely replaced by the law of civil marriage of November 2, 1888 , amended on November 12, 1889, incorporated in the code under appropriate numbers. This part of the book deals further with divorce, legitimate children, patria potestas, legitimation, natural and illegitimate children, the obligations of parents and relatives, and guardianship, its form and administration.

Book II, divided into three sections and entitled "personal rights in their civil relations," deals with obligations, their creation, and extinction. The various forms of obligations, their conditions, form, and binding character constitute the subject matter of section I, part $\mathrm{I}$. The second part of section $\mathrm{I}$, dealing with the extinction of obligations, covers payment, novation, compensation, compromise, confusion, re- 
nunciation, remission of debt, and impossibility of payment. Section 2 of Book II deals with the facts and legal acts which bring about the acquisition, modification, transfer, or extinction of rights and obligations, and herein, among other matters, treats of public records and notarially sea'ed instruments, private instruments, and torts. Section 3 deals with obligations arising out of contract and covers contracts in general, their origin, form, proof, and effect, the matrimonial community of interest, purchase and sale, and the obligations of vendor and vendee in civil relations, assignment, hiring and letting, associations and partnerships, gifts, agency, suretyship, certain special contracts, the bailments of deposit and commodatum, etc., and quasi-contract.

Book III, entitled "real rights," or in general, property, deals among other matters, with possesion and its acquisition, the possessory actions, real rights, ownership, and the methods of acquiring it, the limitations upon ownership, coöwnership, actions in rem, usufruct, use and habitation, the various classes of servitudes, mortgages, pledge, and the civil law institution of anticresis.

Book IV, which is entitled "common provisions relating to real and personal rights," deals, first, with the transmission of rights, and particularly with succession and inheritance, both by will and intestacy, and covers the capacity to inherit, acceptance of the inheritance, the rights and obligations of heirs, division of inheritance, vacant succession, administration of intestate successions, distribution of decedents' estates, and all matters relating to wills and inheritance, including form, effect, and validity. Section 2 of this book deals with the order of preference among creditors upon the goods of a common debtor, and section 3 with prescription.

A complementary title deals with the application of the laws. There is also usually appended to the civil code the law on the registration of civil status of October 3I, I884, which may well have been incorporated in the code itself.

The code has been amended but rarely, the greatest change having been made by the law on civil marriage of 1888 , re- 
ferred to above, and by a law of September 9, I882, correcting errors in the code, to which reference will again be made.

\section{TEX'TS}

The original official edition ${ }^{1}$ of the code was published in New York and the enacting law of September 29, 1869 provided that the various courts were to report annually to the Minister of Justice any doubts and difficulties which they found to arise in its application. Whether this provision was carried out and enforced or not, it was not long before numerous errors, orthographic and others, were discovered by private students and lawyers. In 1879 Congress actively undertook the work of correcting errors. A valuable discussion of these errors by a leading member of the legislative commission, Dr. Benjamin Paz, ${ }^{2}$ has been published, and Ernesto Quesada $^{3}$ has issued a pamphlet which deals with the antecedents of the law of September 9, 1882, the law which ultimately corrected many of the errors at that time discovered.

Another official edition ${ }^{4}$ of the code, taking into account the law of September 9, 1882 , was issued in 1883 . Here it may be said that the important notes of Dr. Velez Sarsfield, which were appended to many sections of the code and which have constituted a valuable, although not official, source of interpretation, are included in practically all the published editions, official and unofficial, of the code.

${ }^{1}$ Código civil de la República Argentina redactado por el Dr. Dalmacio Velez Sarsfield y aprobado por el Honorable Congreso de la República el 29 de setiembre de 1869 . Edicion oficial. Nueva York, Hallet \& Breen, i870. $98 \mathrm{I}$ p.

${ }^{2}$ Cámara de senadores de la Nacion Argentina. Discusión de la fé de erratas y correcciones al código civil, propuestas por . . D Dr. D. Benjamin Paz y la Comision de legislación. Buenos Aires, Imp. de Obras de la Nacion, I879. 606 p.

${ }^{3}$ Quesada, Ernesto: Las reformas del codigo civil argentino (Antecedentes de la ley de setiembre 9 de r882). Buenos Aires, Imp. de Mayo, 1883. $73 \mathrm{p}$.

* Código civil . . . sancionado el 29 de setiembre de 1869 y corregido por ley de 9 de setiembre de 1882 . Edición oficial. Buenos Aires, "La pampa," ז883. $985 \mathrm{p}$. 
An edition published by the house of Lajouane ${ }^{1}$ in 1906 includes the law of 1888 on civil marriage as incorporated in the code, the law on registration of civil status of October 31 , I 884, and Velez Sarsfield's notes. The renumbering has increased the code to 4,085 articles. The agitation for the correction of errors discovered from time to time, now numbering several hundred, has not ceased. In I 900, the government entrusted the redraft of an official edition of the code to Drs. Guastavino and Vedia, two jurists of note, who availed themselves of their commission to suggest certain amendments to clear away doubts and errors. They proposed a further change in the omission henceforth of Velez's unofficial notes. Their draft, showing in parallel columns the changes suggested, and those suggested by a committee of the Faculty of Law at Buenos Aires which made a further report on the matter, with other relevant material was officially published in a volume issued in $1908 .^{2}$

In 1909 a Spanish translation was published of de Freitas's ${ }^{3}$ celebrated Brazilian draft code, which served to such an extent as a guide and source of the draft of Dr. Velez Sarsfield. It contains the important notes of the learned Brazilian jurist.

The Comparative Law Bureau of the American Bar Association has published an English translation, by the late Frank L. Joannini, of the Argentine civil code (Boston, 1917. $732 \mathrm{p}$.). The introduction to this code by Phanor $\mathrm{J}$. Eder was printed in volume I, No. I of the American Bar Association Journal

1 Código civil de la República Argentina sancionado por el Honorable Congreso el 29 de septiembre de 1869 y corregido por ley de 9 de septiembre de 1882. Nueva edicion conforme al texto oficial. Arreglada con la nueva numeración de los articulos con motivo de la incorporación de la nueva Ley del matrimonio civil en el texto del código. Seguida de un apéndice que comprende la Ley del registro civil [of Oct. 3x, 1884]. Buenos Aires, F. Lajouane \& Cia, rgo6. 4,085 arts.

${ }^{2}$ Guastavino, José M. y Vedia, Agustín de: Proyecto de correcciones al código civil de la República Argentina. Publicacion oficial. Buenos Aires, Imp. de G. Kraft, I908. 405 p.

- Freitas, Antonio Teixeira de: Código civil; obra fundamental del código civil argentino; traducción castellana... Buenos Aires, A. García Santos, I909. 2 v.

$71624^{\circ}-17-5$ 
(19I5), pages 91-103. It was prepared from various Argentine sources, and constitutes a succinct and valuable account of the preparation, sources, application, and bibliography of the code. Of particular interest is the explanation given of article $\mathrm{r} 6$ of the code, which provides:

If a question of civil law cannot be determined either by the text or by the spirit of the law, decision shall be had according to the principles of analogous laws; and if then the question be still doubtful, it shall be determined by the general principles of law, taking into consideration the circumstances of the case.

\section{LITERATURE}

Shortly after the publication of the draft of Velez Sarsfield in $\mathrm{r} 868, \mathrm{~J}$. B. Alberdi, ${ }^{1}$ who greatly underestimated the importance of a work of codification, published a severe criticism of the draft which, however, appears to have had little practical effect. Perhaps its greatest fault lies in its eminently scientific character in that it has often overlooked and disregarded the exigencies of practical life of the people for the regulation of whose interests and relations it was intended, many of its articles never having been applied by the courts.

The first synthetic work (Instituta) on the civil code, containing a doctrinal treatment of its various titles, was published in 1872 by Prof. Leguizamon in collaboration with $\mathrm{J}$. O. Machado, ${ }^{2}$ who later (1898-1903) published what is now the most exhaustive commentary on the code. The Instituta was the first work to call attention to numerous errors in the code and its notes are still of value.

In the next year Luis V. Varela ${ }^{3}$ undertook the ambitious work of textually reprinting the original sources cited by Velez Sarsfield in his notes and also numerous other sources not specifically mentioned. In all, the writings of some 500 jurists and a great many codes were drawn upon, the sources being subsumed under the various articles to which they relate. The

${ }^{1}$ Alberdi, J. B.: Carta critica al codigo civil. Buenos Aires, I868.

${ }^{2}$ Leguizamon O. y Machado, J. O.: Instituta del código civil arjentino. Buenos Aires, Lib. de Igon, 1872. 388 p.

${ }^{3}$ Varela, Luis V.: Concordancias y fundamentos del código civil . . [I87 I] Buenos Aires, H. \& M. Varela, I873-I875. I6 v. in 8 v. 
work contains a valuable introduction by José M. Moreno, together with a letter from Velez Sarsfield transmitting his draft to the Ministry of Justice, a document omitted from most of the codes. The work was completed in 1875 in 16 volumes.

The next work of importance is Lisandro Segovia's ${ }^{1}$ commentary and criticism (explicación y crítica) of the civil code, published in two volumes in $188 \mathrm{r}$. This is the first analytic work on the code; the author examines the sources and gives his criticisms, points out errors, includes concordances, and appends interpretative notes of great importance. Segovia appears to be one of the few Argentinians familiar with the development of legal science in Germany and his notes have added value through that fact.

In 1883 Manuel Saez, ${ }^{2}$ a severe critic of Velez, published in Mendoza his critical observations on the code. The author died before the publication of a second volume of the work, the first volume consisting of a commentary on the two preliminary titles and the complementary title only. Besides a criticism of the code, the author criticises the courts, lawyers, and the administration of justice in Argentina.

Baldomero Llerena, a jurist of Córdoba, who has devoted practically his entire life to a study of the civil code, published his first studies on the code in $1879,{ }^{3}$ at the time when Congress began the discussions of the errors and corrections ultimately enacted into law in 1882 . These studies of Llerena, in three volumes, contain a draft of the corrections by Senator Paz's Congressional committee, with a report, and a senate report and the debates thereon; besides a commentary on the 170 errors which were to be corrected, with certain amendments proposed by the author. The second volume contains a discussion of his doctrines in connection with Book IV on succession;

\footnotetext{
1 Segovia, Lisandro: Códigorivil de là República Argentina con su esplicación y crítica bajo la forma de notas. Buenos Aires, Pablo e. Coni, r88r. 2 v.

${ }^{2}$ Saez, Manuel A.: Observaciones críticas sobre el código civil. Mendoza, I883. 453 p. (v. I only, published.)

${ }^{3}$ Llerena, Baldomero: Derecho civil. Estudios sobre el codigo civil argentino. Córdoba, Impr. del Eco de Córdoba, 1879. 3 v.
} 
and volume 3 , concordances of the Argentine with the French civil code. Llerena began to issue the results of his further studies on the civil code in 1887 , when the first volumes of his standard work, "concordances and commentaries on the civil code," were published. In 1899 , a second edition ${ }^{1}$ of his concordances and commentaries began publication, the only Argentine commentary on the civil code which has reached a second edition. The work covers ro volumes. At the end of each article the author includes the notes of the codifier and other notes and concordances to foreign codes and authors not cited by Velez Sarsfield. The author's commentaries are considerable. This work is cited perhaps more frequently by the courts and by lawyers than any other commentary on the code.

In I 894, Dr. Lisandro Segovia ${ }^{2}$ published an annotated edition of the civil code which was to serve as a complementary volume to his larger commentary published in $188 \mathrm{I}$. It contains some 3,000 notes and criticisms not included in the original commentary. The scientific spirit of this work of Segovia and of parts of Llerena's commentaries is somewhat marred by the unfortunate recriminations in which these two learned jurists have permitted themselves to indulge.

In 1898 , José Olegario Machado ${ }^{3}$ who had participated as joint author in the Instituta, published in 1872 , began the publication of his extensive commentary on the Argentine civil code. It was completed in II volumes in 1903 and is in fact the only complete commentary on the entire code. The work includes a text of the code and a doctrinal commentary and annotations with a reproduction of the notes of Vélez Sarsfield. The author's original intention to include the decisions of the courts in interpretation of the code was deferred and carried out in another publication to be mentioned presently.

${ }^{1}$ Llerena, Baldomero: Concordancias y comentarios del codigo civil argentino. Second ed. Buenos Aires, 1899-1902. 10 v.

${ }^{2}$ Segovia, Lisandro: Codigo civil argentino anotado. Buenos Aires, F. Lajouane, 1894. $75^{8} \mathrm{p}$.

${ }^{3}$ Machado, José Olegario: Exposición y comentario del código civil argentino conteniendo: la edición oficial y las notas del Dr. Vélez Sarsfield; la aplicación de los fallos de la Suprema corte nacional, los de las cámaras de apelación de la capital y un estudio sobre la ley del registro civil, por el Dr. José Olegario Machado . . Buenos Aires, F. Lajouane, I898-1903. II v. 
In 1898 , Jose M. Guastavino ${ }^{1}$ began the publication of his notes to the civil code which reached four volumes, coming down to article 556 .

Dr. Machado's ${ }^{2}$ edition of the code with extracts from and citations to the interpretative decisions of the courts and notes by the author was published in five volumes in 1903-1905. As already observed, many of the articles of the code, of scientific interest only, have never been judicially interpreted.

Practically all the works already mentioned excepting the Instituta have been analytical commentaries on the various articles of the code. A synthetic treatise by Rodo.fo Rivarola, ${ }^{3}$ a leading jurist of the day, reduces the code to principles, on the order of Laurent, and presents a philosophical and didactic treatment of the code. It is the only work of its kind in Argentina. Volume I deals with the general principles of civil law (the Allgemeiner Teil of the Germans) and volume 2 with family and property rights and obligations, separately and in their reciprocal relations.

Another doctrinal work by Baldomero Llerena, ${ }^{4}$ published in 1898 , deals with a theoretical discussion of certain subjects of the civil law, principally the legal value of the decisions of the superior courts on sale, nullity of wills, prescription, hereditary rights, possessory actions, gifts, guardianship, marriage and partnership.

Among several dictionaries of the civil code, that is, the code arranged in the form of a dictionary with cross references, that of Augusto Carette ${ }^{5}$ is probably the most useful. A collection

${ }^{1}$ Guastavino, José M.: Notas al codigo civil argentino. Buenos Aires, F. Lajouane, $1898-1900$. Arts. $1-556.4 \mathrm{v}$.

2 Machado, José Olegario: El código civil argentino interpretado por los tribunales de la república, con notas originales del Dr. José Olegario Machado. Buenos Aires, F. Lajouane \& Cia, I903-1905. 5 v.

3 Rivarola, Rodolfo: Instituciones del derecho civil argentino; programa de una nueva exposición del derecho civil, por el doctor Rodolfo Rivarola ... Buenos Aires, Impr. de J. Peuser, I9oI. 2 v.

4 Llerena, Baldomero: Estudios juridicos sobre jurisprudencia argentina. Buenos Aires, Coni, r $898.389 \mathrm{p.}$

${ }^{5}$ Diccionario del código civil argentino, ó sea Indice alf: bético de todas las materias, contenidas en los artículos, concordantes entre sí por $\mathrm{el}$ doctor Augusto Carette. Buenos Aires, J. Lajoune y cia, I906. $478 \mathrm{p}$. 
of forms for the customary civil and commercial acts, including procedure, has been edited by $\mathrm{J}$. J. Hall. ${ }^{1}$

Under the head of "Court Reports," reference has been made to the reported decisions in civil matters, which deal principally with the articles of the civil code.

TOPICS INCIDENTAL AND RELATED TO CIVIL CODE PERSONS

Numerous monographs, particularly doctor's theses, have been published on special topics of the civil code. Some of the more important of these may be mentioned. Of the topics in Book I of the code the publishing house of $\mathrm{Kraft}^{2}$ has published a pamphlet containing the law of marriage, with the instructions and forms necessary in the execution and enforcement of the statute. The parliamentary debates on the statute of 1888 were published separately. ${ }^{3}$

A valuable debate on the law of divorce, including an appendix on the history and comparative legislation of divorce and separation, was published officially in 1902. ${ }^{4}$ Professor Rodolfo Moreno, ${ }^{5}$ of the University of La Plata, has published a valuable study on persons, including juristic persons, in comparative civil law, and Nicolás Casarino ${ }^{6}$ a study on juristic persons.

\section{LEGAL LIABILITY - CONTRACTS}

Of the topics in Book II of the code a valuable work on civil liability from the point of view of industrial accidents was

${ }^{1}$ Hall, J. J.: Colección de formularios de escrituras públicas e instrumentos privados. Buenos Aires, Imp. de Mayo, Igro.

${ }^{2}$ Ley de matrimonio. Decreto nombrando visitadores. Instrucciones y formularios de actas. Buenos Aires, G. Kraft, r889. 99 p.

${ }^{3}$ Ley de matrimonio civil. Discusion en el Congreso nacional. Buenos Aires, 1888. $52 \mathrm{I}+408 \mathrm{p}$.

${ }^{4}$ Divorcio. Debates en la Cámara de diputados. Publicación oficial. Buenos Aires, Est. tip. El comercio, I902. 736 p. Apéndice: Antecedentes históricos y legislación comparada sobre divorcio y separación personal, por el doctor Francisco A. Barroetaveña: p. 685-736. [Taken largely from the works of Lehr, Glasson, Carpentier and Laurent.]

${ }^{5}$ Moreno, Rodolfo: Las personas en el derecho civil comparado. Madrid, Libr. de Pueyo, I911. $327 \mathrm{p}$.

${ }^{6}$ Casarino, Nicolás: Estudio sobre las personas jurídicas. Buenos Aires, $188_{3}$. 
published in 1904 by Bialet Masse. ${ }^{1}$ José Guastavino ${ }^{2}$ is the author of a work on the nullity and annulment of legal acts. J. O. Machado ${ }^{3}$ published in 1875 his commentaries on the title of contracts in the civil code. This work has been utilized in his more extensive commentaries on the civil code already mentioned. The lectures of Dr. Hector Lafaille ${ }^{4}$ on contracts in Argentine civil law, delivered in I913, have been published in extenso under the auspices of the Centro estudiantes de derecho.

\section{POSSESSION-REAL PROPERTY}

Of works on the topics in Book III, Pedro Goyena's ${ }^{5}$ treatise on possession, although old, is still highly esteemed. A doctor's dissertation by Luna Olmos ${ }^{6}$ on the transmission of real property under the Torrens system may be mentioned. The regulations and fees governing the registration of real property in the public register have been officially published. ${ }^{7}$ This public-record office was the subject of a work by F. A. Berra, ${ }^{8}$ published in 1904 .

\section{MORTGAGES}

A work on mortgages by Antonio E. Soares ${ }^{9}$ is favorably regarded. E. S. Zeballos ${ }^{10}$ published an extensive article on

1 Bialet Masse, Juan: Tratado de la responsabilidad civil en derecho argentino, bajo el punto de vista de los accidentes del trabajo. Rosario, I904.

${ }^{2}$ Guastavino, José E.: Nulidad de los actos juridicos. Buenos Aires, I897.

${ }^{3}$ Machado, J. O.: Comentarios al titulo de los contratos del código civil. Buenos Aires, Impr. Popular, I875. 487 p.

4 Lafaille, Hector: Los contratos en el derecho civil argentino. Notas tomadas. (Curso de rgr3.) Publicadas bajo la dirección de . . . Arturo Garcia López. Buenos Aires, Impr. "Alsina," 19I4. 656 p.

${ }^{5}$ Goyena, Pedro: Posesión. Buenos Aires, 1869.

${ }^{6}$ Luna Olmos, E.: Transmisión de la propiedad raíz, el sistema Torrens. Buenos Aires, rgoo.

${ }^{7}$ Reglamento e arancel del Registro de la propiedad inmueble de la capital federal. Ed. oficial. Buenos Aires, Penitenciaría nacional, I903. $74 \mathrm{p}$.

${ }^{8}$ Berra, F. A.: El registro de la propiedad de la capital de la República. Buenos Aires, r904.

${ }^{9}$ Soares, Antonio E.: La hipoteca. Buenos Aires, 1903.

${ }^{10}$ Zcballos, E. S.: Le crédit et le régime hypothecaire de la Republique Argentine et dans le nouveau monde. Bruxelles, Imp. F. Van Buggenhoudt, I9ro. ${ }_{59} \mathrm{p}$. 
mortgage rights and obligations in the Revue de l'Institut de droit comparé, of Brussels (v. 2 and 3 ), which has been separately published. The National Mortgage Bank and its operations are discussed in Martinez and Lewandowski's "The Argentine in the 2oth century" (London, I9I I), page 276 et seq., and infra, page $\mathbf{1} 65$.

The agricultural mortgage (prenda agricola) has been regulated by an important statute, No. 9644 of September 30, 1914 .

Of the works on Book IV, a treatise on succession, consisting of the lectures of Professor Eduardo Prayones, ${ }^{1}$ delivered in I 915 at the Faculty of Law, warrants special mention. They deal with many controverted and difficult points of Argentine law. Sanchez Sorondo's ${ }^{2}$ monograph on hereditary possession has been recommended. On July 18, 1912, a new law of succession taxes was enacted in Argentina.

Works on the conflict of laws, which might have been classified in this section, will be mentioned under their appropriate head, infra, page 187 .

\section{LITERARY AND INDUSTRIAL PROPERTY}

COPYRIGHT.-Article 17 of the Argentine constitution provides that every author is the owner of his work for the period provided by law. The statute which now governs the protection of literary and artistic property is law No. 7092 of September 23, 1910, with the regulation of February 4, 1911, carrying the law into effect. The penal code also provides penalties for infringement of copyright.

The customary copyright protection is for life plus ten years. Foreign works are protected for the period of protection in the national state, provided the foreign country has concluded a treaty with Argentina, and the formalities of Argentine law are completed. Argentina signed the Buenos Aires Pan American convention of 19 Io.

The provisions of the law are summarized in 40 Annuaire de législation comparée, 682, and both law and regulation in the Jahrbuch für den internationalen Rechtsverkehr, 1912-13,

\footnotetext{
1 Prayones, Eduardo: Nociones de derecho civil. Notas tomados por

Dr. Américo S. Cacici. Buenos Aires, Centro Estudiantes de Derecho, I9i6.

${ }^{2}$ Sanchez Sorendo, M. G.: Posesión heredịtaria. Buenos Aires, Igoo.
} 
pages 714-715. An excellent history of copyright legislation in Argentina, with a French translation of the law of 1910 is presented in an article by E. S. Zeballos, published in 4 Revue de l'Institut de droit comparé, pages $5^{2-64}$ and issued also as a separate.

On the new law practically no literature except periodical articles has as yet appeared. Several valuable works on copyright, however, were published prior to 1910. The best of these is Ernesto Quesada's ${ }^{1}$ work published in 1904, in connection with an important case coming before the author in his judicial capacity. It consists of a study of 87 pages, with appendices of documents, drafts of laws and critical comments, including court decisions, and an exhaustive bibliography (pp. 127-1 32). Another work well recommended is a treatise of Carlos Baires ${ }^{2}$ published in 1897 , with a draft of a statute. The work exercised a considerable influence. Various compilations in English of copyright laws of foreign countries, such as Singer's ${ }^{3}$ work, deal also with Argentina.

PATENTS.-In execution of Art. 17 of the Constitution there was enacted on October II, I864, law No. II I for the protection of patents of invention, and the decree of November 9, 1866 regulated the application of the law. Various other decrees of 1900, 1901, 1903, and 1905 have modified the application of the original law. In 1910 the Ministry of Agriculture, ${ }^{4}$ within whose jurisdiction is the office for the registration of patents and trade-marks (Oficina de Patentes) published an edition of the law with the regulating decrees and forms to be used in applications for patents. The law and the regulating decrees are published in the Anuario oficial (1912), pages 460-499. The law has been affected by the treaties on private international law concluded at Monte-

${ }^{1}$ Quesada, Ernesto: La propiedad intelectual en el derecho argentino. Buenos Aires, J. Menéndez, I904. 496 p.

${ }^{2}$ Baires, Carlos: La propiedad literaria y artística en la República Argentina, por Carlos Baires . . Buenos Aires, Impr. de J. A. Alsina, 1897. $\quad 318 \mathrm{p}$.

${ }^{3}$ Singer, Berthold: Copyright laws of the world. Chicago, B. Singer, I909. $196 \mathrm{p}$.

4Ley $n^{\circ}$ I II. Ley de patentes de invención, decretos que la reglamentan, y formularios para la presentación de solicitudes . . . Buenos Aires, Oficina meteorológica argentina, rgro. $5 \mathrm{I}$ p. 
video January 16, I889, and approved by the Argentine law No. 3192. Argentina is a signatory, with the United States, to the convention concluded at the Buenos Aires Conference of 19 10. ${ }^{1}$

English translations or summaries of the Argentine patent laws are numerous. These are to be found among other places in the compilation of "Patent and trade-mark laws of the Spanish-American Republics, Brazil and Haiti," issued by the Pan American Union in 1904, and in the compilations of patent laws of the world edited by Abbott (Washington, I886); Greeley (Washington, 1899), Thompson (London, 1905, I3th ed.) and Carpmael (2d ed., London, I889).

A leading work on the law of patents is that of Tomas A. Le Breton, ${ }^{2}$ an authority on the subject, published in 1901 . Another treatise, by N. Mercan, ${ }^{3}$ was published in 1907. Tomas Le Breton began in 1900 the publication of a semimonthly periodical on intellectual and industrial property entitled (translated) "Patents and trade-marks" " which is the official organ of the Patent Office. It is now edited by Dr. M. Baigorri Velar.

A collection of decisions ${ }^{5}$ on patents and trade-marks was issued in two volumes in 1904-5.

TRADE-MARKs.-The Argentine trade-mark law is No. 3975 of November 23, 1900, with its regulation of December 5, 1900, carrying it into effect. There is a further decree of July 30 , I 12 , concerning the registration of trade-marks, which provides that an application for registration must indicate to

1 Convention between the United States and other powers for the protection of inventions, patents, designs, and industrial models. Signed at Buenos Aires, August 20, rgro. Wash., G. P. O., r9r4. Treaty series, no. 595. Ratified by President, March 2I, I9II; proclaimed July 29, I9r4.

${ }^{2}$ Le Breton, Tomas A.: La ley de patentes de invención. Buenos Airès, rgor.

${ }^{3}$ Mercan, N.: Patentes de invención. Buenos Aires, 1907.

${ }^{4}$ Patentes y marcas; revista sud-americana de la propiedad intelectual é industrial, con la publicación oficial del Ministerio de agricultura y Oficina nacional de patentes. Buenos Aires, Impr. de M. Biedma é hijo, etc. r900- I5 v. to I9I5.

${ }^{5}$ Astigueta, F. B.: Sentencias sobre marcas de fábrica y patentes de invención, compiladas por L. Rodriguez de la Torre. Buenos Aires, 1904-I905. $2 \mathrm{~V}$. 
which of the 25 classes mentioned in the decree it belongs, separate registration being required for a mark falling within more than one class. Law No. 3975 with its regulating decrees, except that of 1912, was published officially by the Ministry of Agriculture ${ }^{1}$ in 1909 . The law and regulations are printed in the Anuario Oficial (1912), pages 500-519.

A leading work on the subject is that by Ricardo Bunge ${ }^{2}$ on trade-mark legislation, published in 1900.

A critical discussion of trade-marks, particularly with reference to foreign trade-marks, was published in a little monograph by E. Sarmiento Laspiur and J. L. Duffy ${ }^{3}$ in I9I 2. They present a draft of reforms and explain the reasons for their proposed changes with particular reference to foreign trade-marks.

The law of 1900 with its regulation is translated in the publication of the Pan American Union "Patent and trademark laws of the Spanish American republics," etc. (pp. 20-28) issued by the Government Printing Office in I904. A full description of the Argentine trade-mark law together with a translation of the decree of July 30, I912, establishing the 25 classes for registration, will be found at pages 7-29 of Singer's "Trademark laws of the world" (Chicago, 1913). A summary of the law of 1900 and the procedure in applying for trade-marks is printed at page 99 of the Argentine Year Book for 1913. A preliminary report on the registration of trademarks in Latin America was published by the Bureau of Foreign and Domestic Commerce as Tariff series No. 31 .

Argentina and the United States are parties to the PanAmerican trademark convention ${ }^{4}$ signed at Buenos Aires August 20, 1910, and recently proclaimed by the United States.

${ }^{1}$ Ley $\mathrm{n}^{\circ}$. 3975 de marcas de fábrica, de comercio y de agricultura y decretos que la reglamentan ... Buenos Aires, Talleres de la Ofic. meteor. argentina, 1909. $37 \mathrm{p}$.

${ }^{2}$ Bunge, Ricardo: Marcas. Su legislación. Buenos Aires, I900

${ }^{3}$ Laspiur, E. S. and Duffy, J. L.: Marcas de fabrica y de comercio: Estudio sobre las marcas extranjeras. Buenos Aires, Imp. Grau, 1912. $78 \mathrm{p}$.

4 Trademarks. Convention between the United States and other powers for the protection of trade-marks, signed at Buenos Aires Aug. 20, I910. . proclaimed September 16, I916. Treaty series 626 , $28 \mathrm{p}$. 


\section{COMMERCIAL LAW}

As in practically all the countries of the civil law, so in Argentina commercial law constitutes a special branch of the law with a special code and special courts to administer it. Commercial law is that complex of provisions which govern commercial operations and the capacity, rights, and duties of those who habitually engage in commerce and trade. In the colonial period the principal sources of commercial law were, besides the Spanish compilations and the laws of the Indies, which dealt principally with civil matters, the Consulado del Mar and the so-called Ordenanzas of Burgos, until in 1737 the celebrated Ordenanzas de Bilbao, modeled on the French ordinances of Louis XIV of I68I, were promulgated. This code governed the principal commercial relations throughout Spanish America until the enactment of national codes of commerce. In 1794 a royal decree created the Consulado, a court for the adjudication of commercial cases, also established in Lima and in Mexico. The Tribunal of the Consulado was only suppressed in Argentina when, in I862, the same year that the commercial code was adopted, a new judicial organization was effected.

\section{COMMERCIAL, CODE}

\section{HISTORY AND SOURCES}

The commercial code of Argentina, the first national code adopted, was that drafted by Dr. Velez Sarsfield and Dr. Acevedo for the province of Buenos Aires. It was promulgated as the provincial code in 1859 and as a national code for the entire Republic on September 10, 1862. It was based principally on the Brazilian commercial code of 1850 , although its section on bills of exchange was inspired by the German Wechselordnung of 1849 and the Nurnberg Novels. Dr. Lisandro Segovia has computed the sources of the 1862 code, with the following results: Over 300 articles, constituting the civil part, were copied from the draft of the civil code for the Republic of Uruguay, prepared by Dr. Eduardo Acevedo. Some 500 articles, relating to navigation, were borrowed from the Brazilian, Dutch, and Spanish codes. The articles on bills of exchange were taken from the code of 
Wurtemberg. These codes and a few others were responsible for most of the balance of the code.

The necessity for a revision of the code was soon apparent. In 1870 a congressional committee was appointed to report on proposed amendments necessitated particularly by the enactment of the civil code in 1869 , which required the harmonizing of the two codes. Nearly 400 articles were found by the commission properly to belong in the civil code, and several new titles, such as cheques, produce exchanges, current accounts, and other matters, it was found necessary to add. Numerous bills for the amendment of the code and entire drafts by special commissioners were submitted, ${ }^{1}$ but it was not until 1889 that a code commission of the Chamber of Deputies (consisting of Wenceslao Escalante, Estanislao S. Zeballos, Benjamin Basualdo, and Ernesto Colombres) formulated a draft which, by law of October 9, I 889, became the second Argentine code of commerce. Among the drafts submitted at the Government's request, but not accepted, was one by Lisandro Segovia, ${ }^{2}$ based largely on foreign legislation, which embodies a vast amount of learning, and has been considered a more scientific and better code than the one enacted. It was rejected because it was said to present too great a departure from existing law. The legislative committee used this draft in part and borrowed material from the English law of cheques, from the Portuguese code, on partnerships and carriers, and inserted new matter on maritime mortgages and accounts current. The code came into force on May I, 1890 , and since then many amending statutes on matters treated in and related to the code have been enacted.

The code has been criticised as an incomplete and defective work, and the agitation for its revision has been continuous.

1 Particular mention may be made of an important draft of amendments presented in 1873 by Vicente G. and Sixto Quesada and Villegas, Proyecto de reformas al código de comercio de la República Argentina. Reprinted, Buenos Aires, I908.

${ }^{2}$ Proyecto de código de comercio, redactado por encargo del P. E. de la Nación por el Dr. Lisandro Segrovia. Edition ordered by the Chamber of Deputies. Buenos Aires, "E1 Nacional," 1887. 2 v. French translation, Paris, 1889 . 
Although numerous individual articles have been amended by subsequent laws, the most important and thoroughgoing revision has been that of Book IV on Bankruptcy, which was entirely repealed and replaced by law No. 4156 of December 30, 1902. Even this revision has not satisfied public opinion and the agitation for further revision has been constant. A number of amending statutes on corporations, warrants, and issue of debentures by corporations will be mentioned hereafter.

\section{CONTENTS}

The commercial code of 1889 contains five preliminary articles and I6I I of the text. The preliminary title contains general rules of interpretation, as does the civil code. The commercial code is, however, more liberally construed than the civil code. The latter provides that usage or custom can not create rights unless the law so provides (art. 22) and that anything not explicitly or impliedly mentioned in the code can not have the force of civil law. The commercial code, on the other hand, provides that in all matters in which individual agreement may vary the general law, the judge may ascertain whether custom may give commercial transactions the effect intended by the parties and that commercial customs may serve as rules to determine the meaning of technical words and commercial phrases.

The code itself is divided into four books. The first book covering the persons engaged in commerce deals in Title I with merchants in general and commercial acts, legal capacity to carry on commerce, and the Commercial Register. Title II treats of the obligations of merchants and the keeping of mercantile books and àccounts. Title III relates to exchanges and commercial markets, and Title IV treats of brokers, auctioneers, warehousemen, and commercial employees.

Book II consists of fourteen titles, and deals with commercial contracts and commercial obligations in general; agencies, commissions, and consignments; corporations and partnerships in their various classes, and the mutual rights and obligations of members; commercial sales; guaranties and letters of credit; insurance; loans, debts, and interest; deposit; pledge; 
bills of exchange and promissory notes and other commercial documents; banking and mercantile accounts current; cheques and clearing houses; and the statute of limitations as to debts.

Book III is devoted to maritime law and is divided into sixteen titles. These deal with vessels, their owners, masters, pilots, and officers; supercargoes; rights and duties of officers and seamen; the contract of affreightment and the relation between carrier and shipper, and passenger traffic; bottomry bonds and loans on maritime risks; marine insurance; transportation insurance; collisions; forced entry by stress of weather, etc.; shipwrecks; general and particular average; maritime mortgage and maritime liens, and their order of preference.

Book IV deals with bankruptcy and composition with creditors, and has been replaced by Law 4156 of 1902 . This law has been incorporated in the code as the new Book IV.

\section{TEXTS}

There are numerous editions of the commercial code, new editions being published every year or two. Reference may be made to the editions of collected codes mentioned supra, and to the following: The house of Lajouane has published numerous editions of the commercial code and its supplementary laws. The most recent edition ${ }^{1}$ includes, besides the code, the laws on patents and trade-marks, the recent statute amending the law on warrants (Law No. 9643 of Sept. 30, 1914), the first 24 articles of which were ordered incorporated in the commercial code, various statutes on corporations and the act of 1912 relating to the issuance of debentures by corporations. The house of Lajouane also publishes a pocket edition of the codes, the most recent edition of the commercial code ${ }^{2}$ having been published in 19r3. It likewise

\footnotetext{
${ }^{1}$ Código de comercio de la República Argentina. Nueva edición corregida que contiene la ley de quiebras y un apéndice con las leyes de patentes de invención, marcás de fábrica, comercio y agricultura; warrants, sociedades anónimas; debentures, etc. Buenos Aires, Lajouane, I9I5.

${ }^{2}$ Código de comercio de la República Argentina en vigencia desde el ${ }^{\circ}{ }^{\circ}$ de mayo 1890 y leyes complementarias. Buenos Aires, J. Lajouane y cia, 1913. $429 \mathrm{p}$.
} 
contains the supplementary laws above mentioned, except the law of 1914 on warrants.

An English translation of the commercial code with an introduction by Dr. Guillermo Sanchez Sorondo, ${ }^{1}$ translated by George Wilson-Rae was published in London in 1904. It suffers somewhat from faulty translation. A better English translation is to be found in the edition of the "Commercial laws of the world," the Argentine code being included in volume I of the series for South America. The introduction by Ernesto Quesada ${ }^{2}$ is superior to that found in the volumes for some of the other countries. The translation of the code is supplemented by numerous notes and citations to the decisions of the courts.

\section{LITERATURE}

An extensive bibliography of the literature of Argentine commercial law is printed at pages 36 to 53 of the volume on Argentina in the series "Commercial laws of the world."

In 1887, Amancio Alcorta ${ }^{3}$ published a work giving the sources and concordances of the commercial code. At the end of each article its source is indicated and the article correlated with the other codes. Professor Obarrio's introduction deals with the history of the conmercial code and commercial law in general. On the whole, the work is considered to be inferior to Alcorta's other works.

Various extensive commentaries upon the commercial code have been published. Among the commentators a leading place must be assigned to Manuel Obarrio, at one time dean of the law school and for many years holding the chair of commercial and criminal law. Obarrio began to publish the

${ }^{1}$ Argentine Republic. Code of commerce (Código de comercio). Tr. by George Wilson-Rae ... and Bernardo de Speluzzi ... with introduction by Dr. Guillermo Sanchez Sorondo ... London, Stevens \& Sons, 1904. $354 \mathrm{p}$.

2 The commercial, bills of exchange, bankruptcy, and maritime law of the Argentine Republic, with comments and notes by Ernesto Quesada, with the collaboration of Juan R. Mantilla and Alfredo Persiani. Translated by Wyndham A. Bewes. Boston, Boston Book Co., r908. $318 \mathrm{p}$.

${ }^{3}$ Alcorta, Amancio: Fuentes y concordancias del código de comercio. Buenos Aires, Lajouane, 1887. 576 p. 
result of his studies on the commercial code in 1878 , some years before the enactment of the present commercial code, upon which his work exercised some influence. His commentary of $1878^{1}$ contains but two volumes, the first of which covers the first three titles of Book I (to art. 90) and the second a few titles of Book II, namely, commercial contracts (art. 19I-208), interpretation of agreements (art. 295-298), and agency and commission contracts (art. 335-386). The order of arrangement is as follows: The text of the code, concordances to various foreign codes, and the author's commentary. An interesting account of the history of commercial law incidental to a critical review of Manuel Obarrio's commentary was published by Ernesto Quesada in volume 3 of the Nueva Revista de Buenos Aires, pages 453-4.82. A new edition $^{2}$ of Obarrio's work, arranged rather in the form of a didactic treatise following the topics of the code than a commentary of the various articles, was published in I900. An introduction discusses the relation between commercial and civil law, the interpretation of the code, and the place of usage and custom in the application of the law. The work, which consists of three volumes, comes down to title 8 of Book III on maritime law and does not deal at all with bankruptcy.

Dr. Lisandro Segovia, ${ }^{3}$ to whose learned commentary on the civil code reference has been made, also published an elaborate critical commentary on the commercial code shortly after its promulgation in 1889 . It will be recalled that the author presented a draft code to the government which, while not accepted, has been regarded as more scientific than the code actually adopted. Segovia's commentary is distinguished by its learned treatment of comparative legislation and the author's valuable criticisms of the code in force. Special refer-

1 Obarrio, Manuel: El codigo de comercio argentino concordado y comentado. Buenos Aires, M. Biedma, I878-r882. 2 v.

2 Obarrio, Manuel: Curso de derecho comercial. Nueva ed. Buenos Aires, F. Lajouane, I900-2. $3 \mathrm{v}$.

${ }^{3}$ Argentine Republic. Explicación y crítica del nuevo código de comercio de la Republica Argentina, con el texto íntegro del mismo código, por el Dr. Lisandro Segovia . . B Buenos Aires, F. Lajouane, 1892. $3 \mathrm{v}$.

$71624^{\circ}-17-6$ 
ence may be made to the Introduction. Dr. Segovia appears to take particular delight in pointing out the errors of others. His work covers the entire code, but embodies the old law of bankruptcy which was entirely repealed by the law of 1902 , in the draft of which Segovia's criticisms were carefully studied and utilized.

The most exhaustive commentary, so far as it goes, is the late Dr. Juan B. Siburu's ${ }^{1}$ work, five volumes of which were published between 1905 and 1910. The author led an active life at the bar and on the bench; his commentary, which comes down to article 449 only, enjoys high esteem, although considered somewhat discursive. A biographical sketch of Siburu appears in volume 5I (May, 1915) of the Revista de derecho historia y letras, page I49. Volume I of the commentary contains an exhaustive general discussion of the commercial law and the code, its history and development and the important report of the legislative committee of 1889 which reported out a revised draft of the commercial code, ultimately enacted into law. Under each article the author discusses exhaustively the doctrines, theory, and practical application of the topic.

By reason of the prominence of its author mention may be made of a classic work on the commercial code published by Professor Cárlos Tejedor ${ }^{2}$ in 1863 ; that is, before the adoption of the civil code. His treatise on commercial law covers only the first two books of the code and is designed largely to correlate the commercial code with the civil law; that is, the group of subjects incorporated in the customary civil code. We may also mention a critical work on the old code by Professor Amancio Alcorta, ${ }^{3}$ Part I of which deals with reforms in the code and Part II with the subject of collisions.

${ }^{1}$ Siburu, Juan B.: Comentario del código de comercio argentino precedido de una generalización del derecho comercial.... Buenos Aires, F. Lajouane y cia., I905-Io. 5 v.

2 Tejedor, Cárlos: Curso de derecho mercantil arreglado al codigo de comercio y concordado con el derecho civil. Buenos Aires, Imprenta de "la Tribuna," I863. 2 v.

${ }^{3}$ Alcorta, Amancio: Estudios sobre el código de comercio. Buenos Aires, Casavalle [Impr. de Mayo], I880. 2 II p. 
Professor Nicéforo Castellano's ${ }^{1}$ lectures on the commercial code, published in $\mathrm{r} 88 \mathrm{o}$, were not without merit in their time.

The lectures of Professor Juan Carlos Cruz, of Buenos Aires, on commercial law ${ }^{2}$ have recently been published in a second edition.

A useful edition of the commercial code annotated by the decisions of the Supreme Court, of the Federal Court of Appeals sitting in Buenos Aires, and of the commercial chambers of the Court of Appeals at the Capital, has been published in two volumes by Calatayud and Giustinian. ${ }^{3}$ Under each article of the code brief digests of the relevant decisions are subsumed.

Attention has already been directed to the numerous reports of commercial decisions and to the index by Frías of the decisions of the Court of Appeals of the Capital in commercial cases (supra, p. 34). An alphabetical digest of the commercial decisions of the Capital was published in 1900 by Adolfo Grau. ${ }^{4}$ Various other collections of commercial decisions by individual judges, nearly all judges of first instance, may, however, be mentioned. The decisions of the commercial court of Buenos Aires during the time when Juan Antonio Areco ${ }^{5}$ was judge (1875-1878) were published in 1885 by the clerks of the court, Cedrés and Gonzalez. Each decision indicates its subsequent fate in the Court of Appeals. Judge G. Larsen del Castaño ${ }^{6}$ published his decisions in commercial cases in 1888 .

1 Castellano, Nicéforo: Lecciones sobre el código de comercio argentino. Córdoba, r88o. v. r; 357 p.

${ }^{2}$ Malagarriga, Carlos C. Apuntes de derecho comercial. (Primera parte.) Precedidos por una carta del Dr. Juan Carlos Cruz. $2 \mathrm{~d}$ ed. Buenos Aires, Centro estudiantes de derecho, rgi6. 353 p.

${ }^{3}$ Calatayud, Alfredo P.y Giustinian, Emilio: El código de comercio interpretado por los tribunales de la capital federal comprendiendo los fallos de la Suprema corte nacional de justicia; Cámara federal de apelaciones de la capital y Cámara de apelaciones en lo comercial y criminal de la capital. Buenos Aires, J. Carbone, I909. 2 v.

- Grau, A.: Manual jurídico del comercio. (Libro de consulta.) Buenos Aires, Adolfo Grau, rgoo. 5 II p.

${ }^{5}$ Fallos del tribunal de comercio de Buenos Aires. Juez, Juan Antonio Areco. By Pedro Cedrés y Carlos N. Gonzalez. Buenos Aires, M. Biedma, $1885.326 \mathrm{p}$.

- Larsen del Castaño, G.: Autos y sentencias en materia comercial. Buenos Aires, F. Lajouane, r888. $570 \mathrm{p}$. 
The decisions of Judge $\mathrm{N}$. Amuchastegui ${ }^{1}$ of the commercial court of the Capital during the pariod 1 895-1 902, concorded with the decisions of the Court of Appeals, were published in four volumes with an introduction by Dr. Wilmart and constitute a useful compilation. The decisions of Judge Luis Peyret, ${ }^{2}$ also a commercial judge of the Capital from I890-r 895 were published in three volumes by Carlos González. The decisions of the Board of Trade ${ }^{3}$ through its arbitration and judicial committees were published in 1902 .

A study on the commercial treaties of Argentina and of other countries has recently been published by Ricardo Pillado, ${ }^{4}$ former Minister of Foreign Affairs, who negotiated several of the important Argentine treaties. Another study of Argentine commercial treaties was published in 1898 by Alejandro Guesalaga ${ }^{5}$ of the Argentine diplomatic service.

\section{SUBJECTS INCIDENTAL AND RELATED TO THE COMMER- CIAL, CODE}

Among the subjects in Book I of the code a special study has been made of Title III on stock and produce exchanges and boards of trade by Rafael Llerena ${ }^{6}$ in a doctor's dissertation published in 1903. A useful manual of the stock exchanges of Argentina, with a discussion of their regulations, the public

${ }^{1}$ Amuchastegui, N.: Fallos del Dr. N. Amuchastegui, juez de comercio de la Capital, precedidos de una introducción por el Dr. R. Wilmart, I895-1902. Buenos Aires, F. Lajouane, J. Peuser, Comp. SudAmericana, I896-I903. $4 \mathrm{v}$.

2 Peyret, Luis A.: Colección de fallos dictados por el juez de comercio de la Capital Federal y publicados por Carlos N. González, I89oI895. Buenos Aires, F. Lajouane, I897-1898. 3 v.

${ }^{3}$ Fallos, resoluciones é informes de la Cámara de Comercio, comisión arbitral de cereales y de navegación. Recopilación extractada de las memorias de la Bolsa de Comercio por el doctor Sabas P. Carreras. Buenos Aires, 1902.

${ }^{4}$ Pillado, Ricardo: Comentarios sobre los tratados de comercio argentinos. Buenos Aires, Tall. gráf. del Ministerio de Agricultura, I915. $228 \mathrm{p}$.

${ }^{5}$ Guesalaga, Alejandro: Estudio de los tratados de comercio de la Republica Argentina. Sucre, 1898 .

${ }^{6}$ Llerena, Rafael R.: De las bolsas y mercados de comercio; exposición crítica y comentario del titulo III, libro I del código de comercio ... Buenos Aires, 1903. Ir8 p. 
debts and securities of the provinces of Argentina, and of foreign corporations quoted on the exchange of Buenos Aires, including statistical information of their financial standing, was issued in 1914 by Roberto Ramm Domán." "Gambling on change" is prohibited by article 80 of the Commercial Code and by the stock exchange regulations.

\section{INSURANCE}

Various studies have been made on the subject of insurance in Book II. Francisco Cervini ${ }^{2}$ is the author of a thesis on the contract of insurance, published in 1903 . Enrique L. Huergo ${ }^{3}$ published a small work on the same subject in r 1901 . Vicente F. López ${ }^{4}$ is the author of a work on foreign insurance companies in Argentina. A study on marine insurance has been published by M. Goyena. ${ }^{5}$ The Argentine decisions on the subject of fire insurance have been studied in a thesis published in 1914 by A. G. Llamazares. ${ }^{8}$ Ruiz Guiñazú, ${ }^{7}$ a professor at the law school, has published a small work on farm and agricultural insurance. Among the special statutes which relate to insurance are law No. 3863 of 1899 on agricultural insurance; law No. 3942 of 1900 , providing that insurance is the property of the beneficiary, free from seizure for the debts of the insured; and law No. 3706 providing that insurance companies may keep their guaranteed deposits in the form of internal loan bonds.

\section{COMMERCIAL DOCUMENTS}

Among commercial documents, warrants and warehouse certificates are regulated by a special law, No. 9643 of Septem-

1 Ramm Domán, Roberto A.: Manual de la Bolsa de comercio de Buenos Aires, I914. Santiago de Chile, Soc. imp. y lit. universo, I9r4. $35^{2} \mathrm{p}$. 2 Cervini, Francisco: Caracteres y elementos del contrato de seguros . . . Buenos Aires, Impr. "San Telmo," 1903. 76 p.

${ }^{3}$ Huergo, Enrique L.: El contrato de seguro. Buenos Aires, I90I.

4 López, Vicente F.: Las compañias extranjeras de seguros ante la administración nacional. Buenos Aires, I898.

${ }^{5}$ Goyena, M.: Estudio sobre los seguros marítimos. Buenos Aires, Imp. Americano, 1872 . $122 \mathrm{p}$.

${ }^{6}$ Llamazares, A. G.: El seguro contra incendio ante la jurisprudencia argentina. Buenos Aires, Est. tip. J. Carbone, I9I4. 204 p.

${ }^{7}$ Ruiz Guiñazú, Ėnrique. Seguros agricolas. Buenos Aires, 1902. 
ber 30, 1914. This law altered in material respects law No. 928 of September 5, I878, which, with its regulation, is translated in the volume on Argentina in the "Commercial laws of the world." Law No. 9643 with law 9644 on agricultural pledge or mortgage has been issued separately by Lajouane.

BILLS OF EXCHANGE

Among the topics of Book II on which monographs have been published, the bill of exchange has received much attention and is a favorable subject for doctors' theses. In 1905 Juan Carlos Rébora ${ }^{1}$ published a work on bills of exchange which received a prize from the college of notaries of the province of Buenos Aires. Professor Juan Carlos Cruz, professor of commercial law at the University of Buenos Aires published a criticism and proposed amendments of the sections of the code dealing with bills of exchange in the Revista del Centro de estudiantes de derecho (1914-I5).

Numerous dissertations on bills of exchange are listed in the bibliography printed in the volume on Argentina in the "Commercial laws of the world." A thesis on cheques discussing the obligations of the various parties to a cheque with the comparative legislation of the subject was published by Juan Alberto Roth ${ }^{2}$ in 1907.

\section{CORPORATIONS}

The subject of corporations has received considerable attention in recent years from the Argentine legislature. A valuable work on the relation between government and corporations, the extent of governmental control and a special study on the provision of Argentine law which required corporations up to 1912 to secure governmental authorization before doing business was undertaken by Luis Vicente Varela, ${ }^{3}$ an eminent

${ }^{1}$ Rébora, Juan Carlos: Letras de cambio. Estudio premiado por el colegio de escribanos de la provincia de Buenos Aires. Buenos Aires, 1905.

${ }^{2}$ Roth, Juan Alberto: Cheques ... Buenos Aires, "La Semana médica," I907. $9^{2} \mathrm{p}$.

${ }^{3}$ Varela, Luis Vicente: La intervención de los gobiernos en las sociedades anónimas; el derecho de asociacíon con fines utiles, la legislación de fondo Argentina, la reglamentación del poder ejecutivo. Legislación extranjera comparada. Reformas propuestas á los códigos argentinos civil y de comercio. . . Buenos Aires, J. Lajouane \& cia, r908. $299 \mathrm{p}$. 
jurist and judge. Part I of his work is a study of Argentine legislation on corporations in the civil and commercial codes. Part II, on comparative law, deals with the history of corporations and governmental control. It includes a summary account of the legislation of those countries in which governmental intervention is no longer required and of the few countries where it still exists. Part III proposes reforms and amendments to the civil and commercial codes with respect to corporations. By law No. 8867 of February 6, 1912, foreign corporations were dispensed, under condition of reciprocity, from the obligation imposed on them by article 287 of the Commercial Code of obtaining a preliminary authorization from the Executive in order to do business in Argentina. They need merely show that they are regularly constituted in their home countries, and register their by-laws.

The best commentaries on the titles dealing with corporations are contained in the extensive general commentaries enumerated above. (Supra, p. 80 et seq.) A special commentary and critical discussion of the title "Corporations" was published in 1896 by López Bancalari, ${ }^{1}$ and in 1907 Félix Decurgez, ${ }^{2}$ of the Faculty of Law, published a small critical work on corporations dealing with the constitution of corporations, the issuance of stock, the management and finance of corporations, the general meetings, accounts, the issue of bonds, and dissolution. The notes of the lectures of the course on corporations delivered at La Plata by Professor Ramón S. Castillo ${ }^{3}$ have been published recently.

Many changes and innovations on the power of corporations to issue bonds were introduced by the Argentine law No. 8875

${ }^{1}$ López Bancalari, J.: De las sociedades anónimas, exposición crítica y comentario del código de comercio. Buenos Aires, Juan A. Alsina, I896. $600 \mathrm{p}$.

2 Decurgez, Félix: Las sociedades anónimas, manual teórico-práctico para el fundador de sociedades anónimas y para los accionistas-breve reseña crítica y comparativa, deficiencias, abusos y correctivos . . . Buenos Aires, J. Lajouane \& cia, I907. I5 I p.

${ }^{3}$ Cooke, J. I. y Sommariva, L. H.: Curso de suciedades comerciales, desarrollado a base de las notas tomadas en la cátedra del Dr. Ramón S. Castillo. v. I. La Plata, r916. 318 p. 
of February 23, 1912, known as the law of debentures. The law is appended to most of the recent editions of the commercial code, and has been translated into French (4I Annuaire de législation comparée, pp. 902-911) and German (Blätter für vergleichende Rechtswissenschaft, I912-13, p. 161). Its object is to protect bondholders of corporations, including provincial and municipal governmental bodies, by providing for the election of trustees by the bondholders who shall exercise a certain surveillance over the business of the corporation, and, in certain contingencies, bring about its liquidation.

The former law requiring governmental authorization to do business necessitated an examination of the proposed business by a Bureau of Corporations under the jurisdiction of the Department of Justice. The report ${ }^{1}$ of this Bureau appears to have been published annually after I 894 .

By law No. 5125 of September 19, 1907, as amended by law No. 6788 of October 21, 1909, corporations are obliged to submit their balance sheets at stated intervals to a general inspection bureau in the Department of Justice. The decree of November 17, 1908, ${ }^{2}$ provided the regulations for the functions of this Bureau, which are many, including supervision of corporations and their balance sheets, notaries, registers and archives, justices of the peace, prisons and houses of detention, welfare of released prisoners, and other matters. A useful compilation, ${ }^{3}$ containing the legislative and administrative antecedents leading up to law No. 5I 25 , the administrative decisions of the inspection bureau in corporation cases, and the rules for soliciting governmental authorization, which was necessary up to I912, was published officially in 1909.

${ }^{1}$ Argentine Republic: Cuerpo de inspectores de sociedades anónimas. Memoria . . elevada al Exmo. Señor ministro de justicia, culto é instrucción pública . . . I894-. Buenos Aires, I895-.

${ }^{2}$ Decreto reglamentario de la Inspección general de justicia, Noviembre I 7 de igo8. Buenos Aires, Tall. graf. de la Penitenciaría nacional, I908. $43 \mathrm{p}$.

${ }^{3}$ Digesto de la Inspección general de justicia de la Rep. Argentina. (Sociedades anónimas.) Buenos Aires, Penitenciaría nacional, Ig09. $517 \mathrm{p}$. 
A doctor's thesis recently published by Pedro Baiocco ${ }^{1}$ deals with the relations between corporations and the State, and contends for release from governmental control.

A study ${ }^{2}$ on the amendment of 1912, dispensing with governmental authorization for certain foreign corporations, with a report of the legislative committee, was published in 19II. Several articles on the legal status of foreign corporations are worthy of notice. One, by E. S. Zeballos, was published in 33 Journal du droit international privé (1906), pages 604-618; 1025-1032. Another, by A. Calandrelli, was published in $\mathrm{I}$ Bulletin argentin de droit international privé (1904), pages 342-349. A third, by Wyndham A. Bewes, consisting of a paper read before the International Law Association, has been published in 39 Law Magazine and Review (I9I4), pages 56-69. A work on cooperative societies was published in $\mathrm{I} 887$ by Francisco Medina. ${ }^{3}$

\section{MARITIME LAW.}

Book III of the commercial code, dealing with maritime law, has been the subject of a number of special works. L,uis Goenaga ${ }^{4}$ edited the text of Book III (art. 856-1378), with doctrinal and critical notes, in a work published in 1897 . Recently, the notes of the lectures on maritime law taken by Romulo S. Naon, ${ }^{5}$ in the course of Dr. Manuel Obarrio, have been published in a second edition. An appendix contains international agreements and conventions on maritime law. In I9 I H Horacio H. Dobranich ${ }^{6}$ published a treatise on mari-

${ }^{1}$ Baiocco, Pedro J.: Funciones de la sindicatura y fiscalización de las sociedades anónimas. Buenos Aires, 1917. 200 p.

${ }^{2}$ Sociedades anónimas extranjeras (Reformas al código de comercio). Buenos Aires, rgr r.

${ }^{3}$ Medina, Francisco: Las sociedades cooperativas, with an introduction by Adolfo E. Davila. Buenos Aires, F. Lajouane, I887. 294 p.

4 Goenaga, Luis I: Derecho comercial marítimo. Buenos Aires, Comp. Sud-America de Billetes, I897. 600 p.

${ }^{5}$ Naon, R. S.: Apuntes de derecho comercial marítims, extracto de las conferencias del Dr. Manuel Obarrio, por R. S. Naon, con varios apendices. 2nd ed. Buenos Aires, V. Abeledo, I9r3. 2 v.

- Dobranich, Horacio H.: Derecho mercantil marítimo. Buenos Aires, Igrr. 
time law. The lectures of Professor Leopoldo Melo ${ }^{1}$ have recently been published.

Those sections of the commercial code which deal with general average are translated in the special works on that subject by Lowndes (5th ed., London, 1912) and by Gourlie (Philadelphia, r88I).

Law 7049 of I9ro limited the coastwise trade to Argentine vessels, subject to reciprocity, however, in the case of neighboring states. The law is summarized in 40 Annuaire de de lég. comp., 683.

\section{BANKRUPTCY.}

The subject of bankruptcy has received much attention in the literature, partly by reason of its importance and partly by reason of the deficiencies still found in the law. As already observed, the original sections of the commercial code dealing with bankruptcy, namely Book IV, were entirely repealed by law No. 4156 of December 30, 1902. The text of this law is summarized in 32 Annuaire de lég. comp., 753759, and a French translation of the law by Henri Prudhomme, ${ }^{2}$ with an introduction, was issued in 1904 in the series of foreign codes published in Paris.

Professor Ruiz Guiñazú ${ }^{3}$ published a third edition of his text book on bankruptcy in I9Ir.. It consists of a discussion of the reforms instituted by the statute of 1902 and of the various systems of bankruptcy, and a didactic discussion of the various titles of the statute with references to comparative legislation.

A work hardly less highly regarded is Dr. Armengol's 4 treatise, consisting of a critical discussion of the law. The

${ }^{1}$ Apericio, Néstor J. and Malagarriga, C. C.: Derecho mercantil marítimo. Prólogo del Dr. Leopoldo Melo. Buenos Aires, Centro estudiantes de derecho, rgr6. $336 \mathrm{p}$.

${ }^{2}$ Loi argentine sur la faillite (23 décembre I902) et loi du 23 novembre I897 modifiant l'article $286 \mathrm{du}$ Code de commerce, traduites, annotées et précédées d'une introduction par Henri Prudhomme . . . Paris, A. Pedone, rgo4. $63 \mathrm{p}$.

${ }^{3}$ Ruiz Guiñazú, Enrique: De las quiebras. Concordato preventivo. Buenos Aires, A. González y Cia, rgr r. 368 p.

${ }^{4}$ Armengol, Manuel F.: Fundamentos y critica de la ley de quiebras... 2 ed., aum. notablemente en la parte "critica." Buenos Aires, Impr. de J. Tragant, I9r4. $590 \mathrm{p}$. 
second edition of the work appeared in r9r4. Part I treats of the antecedents of the law with a detailed history of the various drafts of the commercial code with particular reference to the section on bankruptcy. Part II consists of a general criticism of the law with a draft of the Italian law on composition with creditors (concordato preventivo). Part III consists of a commentary, article by article, principally critical, of the various sections of the law of 1902 .

A somewhat smaller work by Bunge Guerrico ${ }^{1}$ consists of a critical discussion of various titles of the law of bankruptcy with reference to theory and doctrine and some citation to court decisions. Ramon S. Castillo, ${ }^{2}$ an authority on bankruptcy and an ardent agitator for revision of the law, published a work on bankruptcy procedure in I9Io.

Two treatises dealing with the repealed law, but worthy of note by reason of their distinguished authors, should be mentioned. José M. Moreno ${ }^{3}$ published his monograph on bankruptcy in $\mathrm{r} 864$. It is a doctrinal discussion of the subject, with a valuable historical introduction. Manuel Obarrio ${ }^{4}$ in I 895 published his study on bankruptcy, designed to facilitate the work of students of the subject. It is a doctrinal treatise which still has considerable value.

Ramon S. Castillo and Leopoldo Melo have each printed drafts for the revision of the law of bankruptcy. They are printed in the Revista juridica $y$ de ciencias sociales for 1914 with a commentary by Dr. Teodoro Becú. An important article by Ramón S. Castillo on the insufficiency of the law in preventing frauds was published in 9 Revista argentina de ciencias politicas, No. 51 (Dec. 12, 1914), page 284 et seq.

The moratorium law of September 30, I9I 4 has been translated into English and commented upon by F. M. Palacios in International Law Notes, April, I9I6, pages 57-58.

1 Bunge Guerrico, Hugo: Interpretación de la ley de quiebras. Buenos Aires, V. Abeledo, r9i5. 242 p.

${ }^{2}$ Castillo, Ramon S.: Ley de quiebras. Su procedimiento. Buenos Aires, rgro.

${ }^{3}$ Moreno, José M.: Estudio sobre las quiebras. I. De las quiebras en general. II. Procedimiento de nuestros tribunales en los juicios de concurso. Disertación leida en la Academia teórico-practica de jurisprudencia. Buenos Aires, Imp. del Comercio del Plata, I864. 268 p.

${ }^{4}$ Obarrio, Manuel: Estudios sobre las quiebras. Buenos Aires, F. Lajouane, $1895.45^{2} \mathrm{p}$. 
CONSUI,S

The relation of consuls to commerce is important. By law No. 4712 of September 29, 1905, the Argentine government reorganized its consular service and issued a new tariff of consular fees with extended provisions governing the functions, duties and obligations of consuls. The law with forms for the various consular acts was published officially ${ }^{1}$ in 1906.

\section{COMMERCIAL TRAVELERS}

Commercial travelers are required to pay fees upon entering the various provinces. The amount of the fee is considerable. An outline of the requirements is given in Tariff Series 35 (October, 1916), issued by the Bureau of Foreign and Domestic Commerce at Washington. The efforts of the International High Commission to bring about uniformity and the payment of one annual fee upon entering the country, with abolition of the provincial fees, appear to give promise of success. ${ }^{2}$

\section{JUDICIAL ORGANIZATION AND CIVIL, PROCEDURE}

\section{JUDICIAL ORGANIZATION}

There is in Argentina, as in the United States and Brazil, a dual judicial hierarchy, namely, the federal courts and the provincial courts. Besides these, there is a special jurisdiction in the capital at Buenos Aires.

\section{FEDERAL COURTS}

The federal courts were oganized by the law of October 16 , 1862. Of these courts there are two instances-first, the district court (juez de seccion) of which there is at least one in each province and two in the more populous provinces (there are now 22 in all) and the Federal Courts of Appeal (Camara federal de A pelaciones) established in 1902, sitting at Buenos Aires, La

1 Ley de arancel consular. Ley no. 47 12 de 29 de septiembre de $1905-$ sobre organización del cuerpo consular argentino, y decreta reglamentario de la misma de enero de rgo6. Buenos Aires, Tip. de la Penitenciaría nacional, 1906. $223 \mathrm{p}$.

${ }^{2}$ Memorandum on proposed treaty governing commercial travelers. [Spanish and English.] Washington, Government Printing Office, IgI6. $6 \mathrm{p}$. 
Plata, Paraná, Córdoba and (since law 7099 of r9ro) at Rosario. The jurisdiction of the federal courts was provided for by the law of September I4, I863, and follows closely the jurisdiction of the United States federal courts. It includes jurisdiction of cases involving the national constitution or federal laws or treaties, cases between citizens of different provinces or between a citizen and a foreigner, admiralty cases, and certain others. (Art. 2 and 3 of law of Sept. 14, 1863.) Article 14 of that law is practically a copy of article 25 of the Judiciary Act of the United States of 1790 , establishing the cases in which the decision of the highest court of a province may be appealed to the federal Supreme Court. Argentina has not yet followed the United States in its important amendment of this article (U. S. Act of Dec. 23, r9r4; 38 Stat. L., 790.)

The federal Courts of Appeal consist each of three judges, and a fiscal, or attorney general, who looks after the interests of the government. They have final jurisdiction of appeals from decisions of the district courts except in the few special cases in which further recourse to the Supreme Court is provided for.

The Supreme Court consists of five judges and a fiscal or attorney general sitting as a judge. The Supreme Court under article IOO-IOI of the constitution has a large jurisdiction of constitutional questions, cases in which the nation is a party, or between two or more provinces, cases involving ambassadors, public ministers, and foreign consuls, and other cases, closely following again the legal system of the United States. The court, furthermore, has a large appellate jurisdiction in cassation for the modification or annulment of the decisions of the federal courts for misapplication of the law.

In the federal territories there are justices of the peace (juez de paz). In all villages and towns having more than 1,000 inhabitants and in the larger towns and cities there are in addition alcaldias deciding cases involving \$20 or less.

\section{THE CAPITAL}

In the capital at Buenos Aires, which was established by law on September 21,1880 , there are two grades of courts, besides the justice of the peace. These are the courts of first instance, 
which have jurisdiction of civil and commercial cases involving above $\$ 200$, and of criminal cases, and the appellate courts divided into three chambers, commercial, civil, and criminal. By law 7055 of August 19, 1910, a second chamber of appeals in civil matters was provided for. The jurisdiction and the organization of the courts in the capital were provided for by the laws of September 21, 1880, November 5, 1881, and November 12, 1886. Considerable changes were made by subsequent laws, notably those effected by law 2860 of November I6, I891, 3670 of January 3, 1898, and 4128 of September 28, 1902.

\section{THE PROVINCES}

There are two grades of superior courts in the provinces, the juez letrado and the Court of Appeal or Supreme Court of the province, which, except for constitutional questions, is the court of last resort in commercial matters under provincial jurisdiction. There are in addition justices of the peace and in many towns alcaldias. Moreover, in the capital and in some of the provinces there is a jurisdiction known as market judges, consisting of merchants who decide on questions involving the receipt of cattle, grain, or fruit, the payment of freight, or weights and measures, when the existence of a contract is not denied. An appeal lies to a board of merchants.

The duties of the fiscal, who sits as a judge in the higher courts, are to look after the interests of the State, to see that penalties are carried out, and to supervise the execution of the laws and judicial orders and the application by the court of the laws of the State. The fiscal's principal function lies in criminal matters in whicil public order is a matter in interest, but fiscals also have jurisdiction in civil cases where the State is concerned, e.g., in succession cases and cases involving public institutions, etc.

\section{CIVIL PROCEDURE}

It has already been observed that each province has its own code of procedure in addition to the special codes of procedure for the federal courts throughout the country and for the courts in the capital at Buenos Aires. Nevertheless, these codes tend to approximate each other in their provisions. The methods of procedure are still those inherited from Spain and are anti- 
quated. The procedure is entirely in writing, even the testimony of witnesses coming before the judge as written depositions. After the formal complaint and answer and the joining of issue a brief period is allowed for the presentation of written evidence and the deposition of witnesses. After complaint, answer, and evidence have been brought together in one file for submission to the judge, the parties have the right to make an oral argument before the decision. It may be accompanied by a written brief (alegato de bien probado) or summary of the evidence. After the decision an appeal may be noted by an expresión de agravios which, after due periods for answer, comes before the appellate court for oral argument. The original record never leaves the hands of the clerk of the court except for the preparation of a case on appeal and then only for a brief period under strict responsibility of the attorneys. The code provides for the usual matters involved in the commencement of a legal action, such as complaint, answer, counterclaim, exceptions, summons and citations, disqualifications of judges, attachment, judgment, execution, and appeals. It is important to note that the code provides for the rules of evidence.

Attention may be called to the so-called execution action (juicio executivo), which may be brought, among other cases, by a plaintiff holding a duly signed commercial document. This procedure is intended quickly to adjudicate the rights of the parties and to enable an acknowledged creditor to secure payment promptly. The idea involved is that the prima facie title produced by the creditor enables him to secure immediate attachment of the debtor's property and places upon the debtor the burden of proving the creditor's claim acknowledged in writing to be unfounded in fact or in law. Extensive provisions covering arbitration of disputes are found in the codes of procedure.

It has already been observed that there are actually sixteen different codes of procedure in force in the Argentine Republic, one for the federal courts, one for the capital at Buenos Aires, and one for each of the fourteen provinces. The organization of the federal courts under the laws of I 862 and I 863 with the rules of civil procedure in these courts are greatly amended by law No. 4055 of January 8, 1902, and by minor laws enacted subsequently. These laws are recounted in the introduction 
to the volume on Argentina in the "Commercial laws of the world" at page 18 . Drafts of codes revising the rules of procedure in the federal courts have been undertaken and submitted at various times without having been enacted by Congress. One of the best known of these drafts is that prepared by Drs. Alcorta and Zeballos ${ }^{1}$ in 1885 .

A collection of laws relating to federal procedure, including the laws on judicial organization, the legislation of the national territories, and the supplementary laws was compiled by José A. Frías ${ }^{2}$ and published in 1905 . There is a joint index to all the codes and laws relating to federal procedure. The laws governing the administration of justice in the federal courts are appended to the rgr 6 edition of the code of civil procedure published by Lajouane. (Infra, p. 99.)

\section{LITERATURE}

A work dealing especially with jurisdiction in its various forms, concurrent, exclusive, appellate, and contentiousadministrative, in the various courts of the Republic, federal, provincial and capital, as well as military and ecclesiastical, and dealing also with the removal of causes, was published in I 908 by J. Honorio Silgueira. ${ }^{3}$ It consists of rewritten lectures delivered before the Notaries School in Mercedes, and is annotated by the decisions of the courts. Professor González Calderón, ${ }^{4}$ of the Faculty of Law at Buenos Aires, published

${ }^{1}$ Proyecto de código de procedimientos en materia civil para los tribunales nacionales y de la capital. Redactado por los Drs. Alcorta y Zeballos. Buenos Aires, J. Klingelfuss, I885. $4 \mathrm{v}$.

${ }^{2}$ Frías, José A.: Recopilación de leyes y codigos de justicia federal. Buenos Aires, Coni Herm., 1905. $55^{8}$ p.

${ }^{3}$ Silgueira, J. Honorio: . . . Procedimientos judiciales; jurisdicción, sus diversas clases, con la jurisprudencia de los tribunales: Suprema corte nacional, Suprema corte de justicia de la provincia, cámaras de apelación en lo civil y en lo comercial de la capital federal. Buenos Aires, J. Lajouane \& cia, I908. $230 \mathrm{p}$.

${ }^{4}$ González Calderón, Juan A.: La función judicial en la constitución argentína; conferencias expuestas en la Facultad de ciencias jurídicas y sociales de la Universidad nacional de La Plata, para optar á la suplencia de la cátedra de derecho constitucional. Buenos Aires, J. Lajouane \& cia, I9II. I74 p. 
a work on the judicial function in the Argentine constitution and its history, both federal and in the province of Buenos Aires. It consists of his initial lectures to obtain an associate professorship in the University of La Plata, and is a work of exposition merely. An excellent external historical account of judicial organization and procedure from colonial times until the present is given in a small work by Dr. Silgueira. ${ }^{1}$

Two works on the jurisdiction of the Supreme Court, by Bernardo de Irigoyen ${ }^{2}$ and by Felipe Espil, ${ }^{3}$ may be noted. The former deals with the general jurisdiction of the court and the latter with its extraordinary jurisdiction. The extraordinary appeal to the federal Supreme Court, under article I 4 of law 48 and article 6 of law 4055, is the subject of an interesting doctor's dissertation, in which court decisions are fully discussed, by Enrique García Mérou (hijo). ${ }^{4}$

Notes of the lectures on civil procedure delivered by various professors at the Faculty of Law at Buenos Aires have been published. Those of particular merit are the lectures of Prof. Casarino ${ }^{5}$ published in 1896 and of Prof. Honorio Pueyrredon, ${ }^{6}$. the latter published in the Revista del centro de estudiantes de derecho in $19 \mathrm{I} 2$.

\section{TREATISES}

Among the treatises on civil procedure several warrant special attention. Probably the most important work on the

I Silgueira, J. H.: Estudios sobre procedimientos y organización judicial. (Reseña histórica). Buenos Aires, F. Lajouane, r904. I33 p.

${ }^{2}$ Irigoyen, Bernardo de: Justicia nacional; apuntes sobre la jurisdicción de la corte suprema. Buenos Aires, Ig03. (ist ed. Buenos Aires, Soc. Tip. Bonaerense, 1867.76 p.)

${ }^{3}$ Espil, Felipe: La suprema corte y su jurisdicción extraordinaria. Buenos Aires, I9r 5.256 p.

${ }^{4}$ García Mérou, Enrique (hijo): El recurso extraordinario ante la corte suprema de justicia de la nación. Buenos Aires, Coni herm., I9r5. $24 \mathrm{I} \mathrm{p}$.

${ }^{5}$ Casarino, N.: Apuntes de procedimientos judiciales . . Buenos Aires, Impr. Europea, I896. $508 \mathrm{p}$.

${ }^{6}$ Pueyrredon, Honorio: Apuntes de procedimiento civil. Buenos Aires, IgI2.

$71624^{\circ}-17-7$ 
subject is that of Salvador de la Colina, ${ }^{1}$ first published in I9ro and in a second edition in 1916 . It is a scientific and critical work on civil procedure and the distribution of judicial power and has become a standard work. Its critical doctrines have exercised influence on the courts and on subsequent codification, particularly in the federal capital and in the province of Buenos Aires. Part I deals with questions of jurisdiction, the exercise of judicial power, judges and minor judicial officers, arbitration, actions, etc. Part II, which covers procedure, deals with the various steps in an action including costs, evidence, appeals, interlocutory proceedings, and execution of judgment. Colina's treatise has taken the place of the classic works of Estevez Sagui, Castro, and Malaver.

A recent work by José $L_{1}$. Canale ${ }^{2}$ deals with various matters of procedure, particularly with the various time periods for notice and notifications and other practical questions. A special work on evidence was published in 1913 by Carlos Malagarriga. ${ }^{3}$ Miguel Angel Garmendia ${ }^{4}$ published in 1901 a work on the administration of justice in the national territories. A pamphlet dealing with proposed reforms in the administration of justice was published in I9I I by Tomas de Veyga, ${ }^{5}$ professor at the University of Buenos Aires. It deals with the revision of the judicial organization and changes in procedure and proposes the suppression of certain courts and the institution of new ones.

It would not be proper to leave the literature of civil procedure in general without mention of the classic treatises of Esteves Sagui, ${ }^{6}$ published in I 850 , of Manuel Castro, first pub-

1 De la Colina, Salvador: Derecho y legislación procesal; materia civil y comercial, por el doctor Salvador de la Colina... Second ed. Buenos Aires, Libreria nacional, J. Lajouane \& cia, r9ı6. 2 v.

${ }^{2}$ Canale, José L.: Cuestiones prácticas del juicio civil. Buenos Aires, Lajouane, I9I5.

${ }^{3}$ Malagarriga, Carlos C.: La prueba judiciaria en materia civil. Buenos Aires, I9I3.

${ }^{4}$ Garmendia, Miguel Angel: La justicia en los territorios nacionales. Posadas, I901.

${ }^{5}$ Veyga, Tomas de: La teforma de la justicia argentina. Buenos Airc Talleres gráficos de la Penitenciaría nacional, I9Ir. $40 \mathrm{p}$.

${ }^{6}$ Esteves Saguí, Migucl: Tratado elemental de los procedimientos civiles en el foro de Buenos Aires. Buenos Aires, Imp. Americana, 1850. $788 \mathrm{p}$. 
lished in 1834 , and in an annotated edition by Dr. Dominguez in $1865,{ }^{1}$ and of Antonio E. Malaver, ${ }^{2}$ published in 1870 in collaboration with his celebrated colleagues Montes de Oca and Moreno. These works, all of which are now antiquated, have exercised an important influence on the development of procedure in Argentina and on the courts and practitioners. Some discussion of them is contained in a book review published by Ernesto Quesada in the Nueva Revista de Buenos Aires, voiume 3 , pages $132-142$.

\section{CODE OF THE CAPITAI}

The code of civil procedure of the Capital at Buenos Aires dates from 1880 , when the code of the province of Buenos Aires was bodily adopted. It has been amended by law No. 1893 of November 12, 1886 and the important law No. 7055 of August 19, 1910 creating a second chamber of appeals in civil matters and establishing a special chamber of appeals in commercial matters. The laws affecting judicial organization and civil procedure in the Capital are listed in the introduction to the volume on Argentina in the "Commercial laws of the world," page 19 et seq.

A draft of a new code by a commission was sanctioned by a decree of September 16, 1909, and its reported draft was officially printed. ${ }^{3}$ Many of the doctrines of Colina were adopted, but the draft has not yet been enacted into law.

New editions of the code are published regularly by the house of Lajouane, ${ }^{4}$ including all recent amendments. The latest was published in 1916 .

${ }^{1}$ Castro, Manuel Antonio de: Prontuario de práctica forense anotado por Dr. Dominguez. 2d ed. Buenos Aires, 1865.

${ }^{2}$ Malaver, Antonio E., et al: Manual de procedimientos civiles y comerciales, adaptado al uso de los practicantes de jurisprudencia por Antonio E. Malaver, Juan José Montes de Oca, José Maria Moreno y Juan S. Fernandez. Buenos Aires, Imp. de la Prensa, 1870. 323 p.

${ }^{3}$ Proyecto de código de procedimientos civiles y comerciales, presentado á S. E. el Señor ministro de justicia é instrucción pública, doctor Rómulo S. Naón por la comisión designada por decreto de r 6 de septiembre de r909. Publicación oficial. Buenos Aires, Tip. de la Prisión nacional I910. I2I p.

4 Codigo de procedimientos en materia civil y comercial de la capital de la República completado con las leyes y decretos sobre justicia tederal. Nueva edición corregida y aumentada. Buenos Aires, J. Lajouane, rgr6. $406 \mathrm{p}$. 
Two commentaries on the code of the Capital warrant special mention. The more important is that of Alberto M. Rodriguez, ${ }^{1}$ published in three volumes between 1908 and 1915, and in a Barcelona edition, 1914-15. It is the most exhaustive commentary on the code of civil procedure published in Argentina. A work of a different type is that of Mariano G. Calvento, ${ }^{2}$ published in 1909 . It is designed for office practice rather than for exhaustive consultation, as is the commentary of Rodriguez. Calvento explains the code not in textual form, but in the form of explanatory notes with references to decisions of the courts of the Capital and some references to the writers on procedure. The code articles are indicated by black faced figures.

A compilation of the principal laws and decrees ${ }^{3}$ affecting the administration of justice in the Capital was published officially in 1904. Eusebio Iñiguez ${ }^{4}$ recently published, in connection with a brief dictionary of civil prozedure, certain critical studies on various practical questions of procedure in the Capital. He points out the defects of the many rules of procedure, discusses doubtful rules, and proposes reforms. An edition of the code as interpreted by the courts in the Capital with brief digests of their decisions subsumed under each article was published in 1904 in three volumes by J. J. Hall. ${ }^{5}$ The first two volumes digest the decisions of the civil chamber, and the third volume, of the commercial chamber. Hall's work entirely replaces an earlier work of the same

${ }^{1}$ Rodriguez, Alberto M.: Comentarios al codigo de procedimientos en materia civil y comercial de la capital de la Republica Argentina. Buenos Aires, 1908-15. 3 v. 2nd ed., Barcelona, S. A. 'I. G. Seix and Barral, I9I4-15. $3 \mathrm{v}$.

2 Calvento, Mariano G.: El codigo de procedimientos civil y comercial explicado y anotado con la jurisprudencia de las Cámaras de Apelaciones. Buenos Aires, Flaiban y Camilloni, rgog. $323 \mathrm{p}$.

${ }^{3}$ Administración de justicia de la capital. Leyes, decretos y reglamentos. Edición oficial. Buenos Aires, Tip. del Asilo de Reforma de Menores Varones, I904. ${ }_{57} \mathrm{p}$.

4 Iñiguez, Eusebio: Estudios sobre el código de procedimientos civiles de la capital federal. Buenos Aires, Lajouane, I9I5. $220 \mathrm{p}$.

${ }^{5}$ Hall, J. J.: El código de procedimientos civil y comercial, interpretado por la jurisprudencia de las Cámaras de apelación de la capital federal en sus 229 tomos de fallos publicados. Buenos Aires, F. Lajouane, I904. $3 \mathrm{v}$. 
character published in 1894 by Carlos Malagarriga. Recently Miguel Garmendia ${ }^{1}$ published the decisions of the first and second chamber of appeals in the Capital sitting as a joint tribunal in accordance with law No. 7055 .

\section{THE PROVINCE OF BUENOS AIRES}

The code of civil procedure of the province of Buenos Aires prior to 1907 was the one of 1878 , adopted in the federal Capital in 1880 . A new code was adopted in the province in 1907. Recent editions of it are published at frequent intervals by the house of Lajouane, ${ }^{2}$ the most recent being of 1914. An edition of the old code, also the code of the Capital, annotated by the decisions of the courts of the Capital has been published by Car.os Malagarriga. ${ }^{3}$ The later (1904) pub.ication of the same nature by $\mathrm{J}$. J. Hall, covering the code of the Capital, has already been mentioned. Professor Tómas Jofré, ${ }^{4}$ a leading jurist, has recently published a small work on the provisions now in force governing the administration of justice in the province.

Proposals for the reorganization of the provincial judiciary have been frequent in recent years. By decree of May I3, r909, Dr. Nicolás A. Avellaneda was commissioned ly the government to draft an organic law of the judiciary. His draft, which was submitted with an interesting explana tory report, ${ }^{5}$ was then submitted, by decree of July 29 , I9IO, to a revisory commission consisting of Professors de la Co.ina, a well-known authority on civil procedure, and Rivarola,

${ }^{1}$ Garmendia, Miguel Angel: Derecho civil y procesal. Buenos Aires, Lajouane, I9r5.

${ }^{2}$ Código de procedimientos en materia civil y comercial de la provinc:a de Buenos Aires. Nueva ed. cor. y aumentada . . . Bucnos Aires, : Lajouane \& Cia., I9I4.

${ }^{3}$ Malagarriga, Carlos: Código de procedimientos vigente en la capital y en la provencia de Buenos Aires. Buenos Aires, Lajouane, I894I897. $2 \mathrm{v}$.

${ }^{4}$ Jofré, Tomás: Administración de justicia de la Provincia de Buenos Aires. Disposiciones vigentes. Buenos Aires, I9ז5. $187 \mathrm{P}$.

${ }^{5}$ Avellaneda, Nicolás A.: Proyecto de ley sobre organización y atribuciones de la administración de justicia. La Plata, Tall. de Impr. Oficiales, rgro. $322 \mathrm{p}$. 
a jurist of note. Their revised draft, ${ }^{1}$ with critical comments upon Avellaneda's draft, was published officially. Some critical comments upon Colina's and Rivarola's draft were incorporated in a work published by Enrique Prack. ${ }^{2}$ Another draft of a law for the organization of the courts of the province was published in 1912 by M. Canedo. ${ }^{3}$

For a long time prior to 1906 a movement had grown for the institution of a jurisdiction by which private individuals might have recourse against the government or administrative officers for violations of the rights of individuals guaranteed them by constitution or law. In cases in which a governmental body or authority acted as a juristic person or in its corporate capacity the right to sue had been preserved in the civil code; and by law of October 6, 1900, an individual was given the right to sue the nation if a complaint had been left unheeded by administrative officers for six months, the decision having merely declaratory effect as to the individual's rights.

The principle of giving individuals this recourse against the provincial administrative authorities, known under the name of contentious-administrative jurisdiction, has been fixed in articles $I_{57}$ and ${ }_{159}$ of the provincial constitution of 1873 , but no code of procedure for carrying it into effect had been provided until Luis V. Varela, a jurist of distinction, drafted a code of contentious-administrative jurisdiction for the province. His draft was published in $1903^{4}$ and in 1905 was enacted into law, to take effect March I, 1906. This code

${ }^{1}$ De la Colina, Salvador, \& Rivarola, Rodolfo: Proyecto de ley sobre organización y atribuciones de la administración de justicia (la provincia de Buenos Aires). La Plata, Tall. de Impr. Oficiales, I9II. I04 p.

${ }^{2}$ Prack, Enrique B.: Observaciones al Proyecto de ley orgánica de los tribunales redactado para la provincia de Buenos Aires por los doctores Rivarola y de la Colina. Buenos Aires, I9I I.

${ }^{3}$ Canedo, Macedonio: Proyecto de la ley orgánica de los tribunales y juzgados de la provincia de Buenos Aires. La Plata, I9I2.

4 Proyecto de codigo de lo contencioso-administrativo para la provincia de Buenos Aires, redactado y comentado con la exposición de motivos de cada artículo ... por Luis V. Varela (typewritten). Buenos Aires, I903. $2 \mathrm{~V}$. 
with the learned report of Varela ${ }^{1}$ and explanatory notes upon its various articles was published by Lajouane in I906.

A collection of forms of pleading and other forms connected with procedure covering the various titles of the code of the Capital and concordances with that of the province of Buenos Aires was published in $\mathrm{r} 9 \mathrm{I}$ I by J. J. Hall, ${ }^{2}$ a compiler of note, whose works have already been mentioned. His collection ${ }^{3}$ of forms of public and private instruments governing various civil and commercial acts, including matters relating to procedure and contentious and voluntary jurisdiction has already been mentioned.

\section{CODES OF OTHER PROVINCES.}

It has already been observed that the codes of the provinces bear a close resemblance to the code of the Capital and of the province of Buenos Aires. The principal differences consist in the time periods for the various steps in procedure. In the introduction to the volume on Argentina in the "Commercial laws of the world" series, page 20 et seq., Ernesto Quesada has presented an outline of these various time periods and at page 29 et seq. a brief account of the legislative history of the codes adopted by the respective provinces. New editions of the provincial codes, at least in the important provinces, are published from time to time. Mention may be made of the code of Entre Rios ${ }^{4}$ of 1904 ; of the code of Salta ${ }^{5}$ of 1905 ; of

${ }^{1}$ Código de procedimientos de lo contencioso-administrativo para la provincia de Buenos Aires. En vigencia desde el $\mathrm{I}^{\circ}$ de marzo de 1906. . . . Dr. Luis V. Varela. Ed. conforme con el texto oficial. Buenos Aires, J. Lajouane \& cia, 1906. $\quad I_{72}$ p.

2 Hall, J. J.: Colección de formularios de escritos forenses en materia civil y comercial. Buenos Aires, Impr. de Mayo, J. E. Hall \& Co., I9Ir. $479 \mathrm{p}$.

${ }^{3}$ Hall, J. J.: Colección de formularios de escrituras públicas é instrumentos privados. . . . Buenos Aires, Imp. de Mayo, Igro.

4 Entre Rios: Código de procedimientos en lo civil y comercial, 1904. Of. ed. Buenos Aires, 1905 .

${ }^{5}$ Salta: Código de procedimientos en materia civil y comercial y ley de organización de los tribunales de justicia, sancionada por el H. L. en 2 de setiembre 1905. Salta, 1905. 
the code of San Juan ${ }^{1}$ of $191 \mathrm{I}$; and of the code of Santa Fé. On this last code an extensive commentary by Alberto Parody, ${ }^{2}$ secretary of the federal court at Rosario, has been recently published. It includes a citation of court decisions and references to the opinions of writers.

\section{NOTARIES PUBLIC}

The notary public or escribano in Argentina is an important official in the legal system of the country. His functions, inherited from Spain and the Roman law, require him to draft legal instruments, to record them officially, and to file them periodically as public records in the Public Registry. Documents drawn by or before a notary and filed in his official register or protocol of sealed instruments have a special evidentiary value not assigned to other documents. The various codes and statutes, both in their substantive provisions and in those relating to the form of legal acts and instruments, are of special importance to the notary. Practically all documents and instruments drawn in the United States by lawyers are, in Argentina, drafted by notaries, who while not admitted attorneys-at-law, have, nevertheless, a good knowledge of law. Notaries are limited in number and their profession is lucrative. A special course for their training has been instituted in various universities.

The history and philosophy of the functions of the notary was the subject of a work published by Carlos Varangot ${ }^{3}$ in 1894. Leandro M. González ${ }^{4}$ has published, in three volumes, a complete course for notaries. This involves, to a great extent, a general course in law. The work deals with the legislation relating to the notary and its history in the provinces, rules for the interpretation of laws, domicil, recog-

${ }^{1}$ Ley orgánica de los tribunales. Código de procedimientos en lo civil, comercial y de minas, y código de procedimientos en lo criminal de la provincia de San Juan, IgIr. San Juan, Igrr.

${ }^{2}$ Parody, Alberto: Comentarios al codigo de procedimientos en lo civil y comercial de la provincia de Santa Fé, por el doctor Alberto Parody (hijo). Buenos Aires, J. Lajouane \& Cia, I9I2-I5. 3 v.

${ }^{3}$ Varangot, Carlos: Historia y filosofia del notariado argentino. Buenos Aires, "La Nacion," I894. I22 p.

${ }^{4}$ González, Leandro M.: El notariado argentino ó auxiliar del escribari ) de registro. 2nd ed. Buenos Aires, F. Lajouane, I893. 3 v. 
nition of children and guardianship; and then follow, in their order, the subjects taken up by the civil code, the commercial code, the penal code, and other codes and special statutes.

Perhaps the best practical work for the notary is that by Juan Baldana, ${ }^{1}$ recently published in four volumes. The first two volumes consist of legal definitions and provisions of law extracted from the various codes, with notes, including some slight references to decisions of the courts. Volumes 3 and 4 contain forms of public instruments in civil, commercial, and procedural matters. Both definitions and forms are arranged alphabetically.

Héctor C. Baudón ${ }^{2}$ has published a text book for the use of notarial students, consisting of a complete outline of a course of law, expository of the codes, with a particular view to the requirements of notaries and to matters of form. The work reached a third edition in 1908 .

A work by J. A. Castillo, ${ }^{3}$ both theoretical and practical, intended for the notary public in Buenos Aires, was published in a new edition in 1893 .

Attention may be called to an index of all the notaries public and other officials authorized to draft and certify public instruments (escrituras publicas) in the Capital and in the province of Buenos Aires from 1584 to $1908,{ }^{4}$ giving also the places in which their records have been filed.

Mention has already been made of the collections of forms published by J. J. Hall. (Supra, p. 103.)

1 Baldana, Juan: El escribano argentino. Teoría y práctica notarial. Buenos Aires, Lajouane, I9r3. $4 \mathrm{v}$.

${ }^{2}$ Baudón, Héctor C.: Estudio teórico para la profesión de escribano público. $3^{\text {rd }}$ ed. Arreglado al programa vigente en la provincia de Buenos Aires. La Plata, Tall. de Sesé, Larrañaga \& Cia., rgo8. $834 \mathrm{p}$.

${ }^{3}$ Castillo, J. A.: Estudio teórico-practico para el oficio de escribano público en la provincia de Buenos Aires y en la Capital Federal de la Republica. Nueva ed. Buenos Aires, 1893.

4 Villalonga, José A.: Indice general. Contiene los nombres de los escribanos y demás funcionarios que autorizaron escrituras públicas en esta capital y en la provincia de Buenos Aires desde el año I584 hasta el r 908 y los puntos donde están los protocolos. Buenos Aires, Irsog. 


\section{CRIMINAL LAW}

Until comparatively recent times the antiquated Spanish legislation and minor statutes on criminal law still governed in Argentina. The constitution of 1853 had authorized the draft of a penal code, among others. Political disturbances, however, prevented this provision from being made effective until $x 863$, on June 9 of which year the Executive was authorized to employ a person to draft the penal code. Accordingly, in I864 Carlos Tejedor, a leading authority on the subject in Argentina and the author of the only treatise published up to that time, was appointed. His draft, based largely on the Bavarian code, was submitted with an explanatory statement in 1868 and a commission was named to report upon it. By reason of changes in the coinmission no report was actually made until $\mathrm{I} 88 \mathrm{I}$, when a draft ${ }^{1}$ by Villegas, Ugarriza, and Juan Garcia was reported out. It was not accepted, although it has been considered a scientific piece of work. The commissioners made a number of important changes in Tejedor's draft, but retained his main principles. In the meantime Tejedor's draft had been accepted by many of the provinces as a penal code. In 1886 a congressional commission, authorized again to examine Tejedor's draft and submit a bill, revised the draft by using as a guide the Spanish code of $185^{\circ}$ as subsequently revised. With very little discussion the draft was adopted as the penal code of Argentina and entered into effect on March I, 1887 .

The deficiencies of the code were so great that the agitation for its amendment began almost immediately. By decree of June 7,1890 , the President named a commission composed of Rivarola, Norberto Piñero, and Matienzo, three of the leading jurists of the day, to prepare a draft of the necessary amendments. In 189 I they presented practically a complete code, ${ }^{2}$

${ }^{1}$ Proyecto de código penal presentado por la comisión nombrada para examinar el proyecto redactado por el Dr. Carlos Tejedor, compuesta de los Doctores S. Villegas, A. Ugarriza y J. A. García. Ed. oficial. Buenos Aires, r88r. $146 \mathrm{p}$.

${ }^{2}$ Proyecto de código penal para la República Argentina, redactado en cumplimiento del decreto de 7 de junio de 1890 y precedido de una exposición de motivos por los Dr. Norberto Piñero, Rodolfo Rivarola y José N. Matienzo. Buenos Aires, r8gr. 494 p. 
with an explanatory report of some 240 pages which is a contribution to criminal law. A congressional committee assisted by Dr. Norberto Piñero advised the adoption of the commission's draft with slight amendments. It was not, however, adopted, and in 1900 a new commission reported against its adoption until additional studies had been made. Finally, on August 22, 1903, a law of reforms (No. 4r89, analyzed in 33 Annuaire de Legislation Comparée, pp. 754760) was enacted, which was designed to bring about the desired results. All but a few of the articles were taken from the draft of $189 \mathrm{r}$ by Rivarola, Piñero, and Matienzo.

In the meantime, the positivist school of Italy had acquired great vogue in Argentina and many reformers who fully accorded with the theory that crime is a pathological phenomenon demanded an entire revision of the code on the basis of the new doctrines. Accordingly, on December 19, 1904, President Quintana issued a decree providing for commissions to draft a new penal code, laws for the organization of the administration of justice in the Capital, and the revision of the code of criminal procedure in the Capital, and other matters. On the penal code commission five jurists and a physician were appointed, namely, Diego Saavedra, Francisco J. Beazley, Rodolfo Rivarola, Cornelio Moyano Gacitúa, Norberto Piñero, and José M. Ramos Mejía. On March 10, 1906, they reported out a revised penal code ${ }^{1}$ of 326 articles with an explanatory statement (exposicion de motivos). The draft of the penal code has recently been published in a French translation. ${ }^{2}$

In 1913 Senator Joaquin V. Gonzalez, one of the eminent jurists of Argentina, moved the adoption of the commission's draft, to take effect on March I, 1913. Up to the present time, however, the draft has not been enacted into law, so that the criminal law in force consists of the code of 1887 , the law of reforms of 1903 , and numerous special statutes. Among these

1 Proyecto de código penal para la Republica Argentina, redactado por la Comisión de reformas legislativas constituida por decreto del poder ejecutivo de fecha ig de diciembre de ig04. Buenos Aires, Tip. de la Cárcel de encausados, igo6. 69+ri4 p.

${ }^{2}$ Harispe, Hippolyte [transl.]. Projet de code pénal pour la Republique Argentina. Laval, E. Barnéoud \& Co., I9r6. I 57 p. 
the principal ones are the law concerning the counterfeiting of money and the important law No. 7029 of 1910 on social security, which covers rules on immigration, the suppression of meetings tending to disturb social order, e. g., anarchist's meetings, rules concerning deportation and expulsion and crimes of the press. An interesting article on the law has been written by Alejandro M. Unsain in the periodical Renacimiento for May, I911. The law has been almost universally criticized and there has been constant agitation for its repeal or amendment.

Congressional committees are still working on a report on the commission's draft. They are at present taking evidence from judges as to the practical operation of certain provisions of criminal law. The new code will probably be adopted during the next few years.

The penal code has been issued in the editions of collected codes already mentioned and in special editions published by the house of Lajouane. The most recent of these text editions ${ }^{1}$ was published in 1915 .

\section{LITERATURE}

A valuable bibliographic work on the literature of criminal law and criminology and its various branches was published in 1912 by Eusebio Gomez ${ }^{2}$ of the Institute of Criminology and a criminologist of authority. The titles are accompanied by brief descriptive notes. The work is preceded by an essay on Argentine criminal problems including the external history of Argentine criminal law and the doctrines of the modern schools in their relation to Argentina.

In 1887 Julian L. Aguirre, ${ }^{3}$ a judge of the criminal chamber of appeals in the Capital, published an edition of the code cor-

${ }^{1}$ Código penal de la Rep. Argentina. Nueva ed. (I915), con las modificaciones introducidas por la Ley de Reformas y con todas las leyes complementarias relativas al mismo. Leyes sobre falsificación y circulación de moneda, juegos de azar, cheques, seguridad social, prostitución, etc. Buenos Aires, Lajouane, I9I5. III p.

${ }^{2}$ Gomez, Eusebio: Criminologia argentina. Reseña bibliografica. Buenos Aires, Imp. Europea, I9I2. 58, 286 p.

${ }^{3}$ Aguirre, Julian L.: Código penal de la República Argentina anotado y concordado con las notas del proyecto primitivo. Buenos Aires, F. Lajouane, I887. $39 \mathrm{r} \mathrm{p}$. 
relating it with Tejedor's draft and explanatory notes from foreign codes and leading writers. It contains various documents, including the report of the parliamentary commission and some of the debates. It is not, however, a commentary.

Perhaps the best commentary on the penal code and one of the ablest critical works on the code is the three volume $E x$ posición y crítica of Rodolfo Rivarola, ${ }^{1}$ one of the foremost of Argentine jurists. His valuable work on civil law has already been mentioned. In his commentary, the code of 1887 is studied title by title in the light of scientific investigations, particularly among the leaders of the Italian schools of criminal law, comparative legislation, the decisions of the courts and practical experience. At the end of the third volume is the text of the code with an indication of the place where the author discusses the various articles.

Another more recent work by Dr. Rivarola, ${ }^{2}$ now professor of criminal law at the University of La Plata, which may be regarded as a supplement to his larger commentary and criticism, was published in rgro. It discusses the general part of the draft submitted by the code commission in 1906, in the light of comparative legislation, particularly that of Spain, Chile, Uruguay, and Peru. The work has a considerable historical and scientific value as it presents the evolution of Argentine criminal law up to 1910 with an expression of views as to the future. Rivarola discusses the origin and history of Argentine criminal law from the earliest times, the basis of criminal law in its various theories, the definition of crimes, criminal law in its relation to philosophy and the sciences and their influence on criminal law, and then presents a study of the topics included in the draft of 1906 , Book I including the sources, application, and interpretation of the law, the punishable act, with its material and psychological elements, penalties and their application, and related matters.

1 Rivarola, Rodolfo: Exxposición y crítica del código penal de la República Argentina, por el doctor Rodolfo Rivarola . . Buenos Aires, F. Lajouane, $1890.3 \mathrm{v}$.

${ }^{2}$ Rivarola, Rodolfo: Derecho penal argentino. Parte General. Tratado general y de la legislación actual comparada con las reformas proyectadas y con legislaciones de lengua española. Buenos Aires, Rivadavia, I9ro. $653 \mathrm{p}$. 
Before proceeding to the critical works it will be well to mention the didactic treatises published by various professors of the subject. The first work on criminal law was that of Carlos Tejedor, ${ }^{1}$ published in 1860 . Volume I deals with the substantive criminal law, with an essay on criminal theories, and Volume II with criminal procedure in its history, principles, and application. The next treatise of importance was that of Manuel Obarrio, ${ }^{2}$ first published in 1884 , and the last edition (third) in 1902. The third edition contains an introduction on the theories of the positivist school of criminal law with relation to penal responsibility and a historical discussion of criminal law in general. Book $\mathrm{I}$, the general part of the code, is then discussed title by title in the form of a treatise for students.

A didactic treatise on criminal law with special relation to its sociological aspects was published in 1899 by Professor Moyana Gacitúa, ${ }^{3}$ formerly of the University of Cordoba and later federal judge and professor at the Faculty of Law at Buenos Aires. He discusses the schools of criminal law; crimes and punishment in history, the relation between general and criminal law, the sociological view of crime, the factors and genesis of crime, the criminal, the degrees of guilt, and preventive measures; and in a second part, punishment, its sociological bases, its kinds, and degrees of responsibility.

Notes of the lectures of various professors have been published by their students, a favorite method of publication of text books. They cover the regular course of criminal law in accordance with the code and in the light of scientific investigation. The notes of Professor Norberto Piñero 4 were published by students in 1892, 1895, and 1901, and those of Pro-

${ }_{1}^{1}$ Tejedor, Carlos: Curso de derecho criminal. Buenos Aires, "Imp. Argentina," I860. 2 v.

2 Obarrio, Manuel: Curso de derecho penal. Nueva ed. (3rd). Buenos Aires, F. Lajouane, 1902. $430 \mathrm{p}$.

${ }^{3}$ Moyano Gacitúa, Cornelio: Curso de ciencia criminal y derecho penal argentino. Buenos Aires, F. Lajouane, I899. 494 p.

${ }^{4}$ Apuntes de derecho penal, de las lecciones del Dr. Norberto Piñero, by Clodomiro Miranda Naon y Antonio Romañach. Buenos Aires, I90I. $3 \mathrm{~d}$ ed. 
fessor Oswaldo M. Piñero were published first in $1902^{1}$ and again in $1909 .^{2}$

Among the critical works, besides the important work of Rivarola mentioned above, special attention may be called to the works of Rodolfo Moreno, José Luis Duffy, and Julio Herrera. Moreno and Duffy examine critically the law of reforms of August 22, 1903, both reaching the conclusion that it was a great legislative mistake. Moreno ${ }^{3}$ has in view the new theories of criminal law of which practically no notice had been taken by the law. It is charged with a lack of unity, exaggeration of penalties and contradiction between the new law and the articles of the code. In a general part he deals with the bases of responsibility, the teachings of the new schools, and a brief history of criminal law. The second part constitutes a special study on the law of reforms of 1903 . Duffy ${ }^{4}$ includes a number of critical essays on various topics of criminal law.

Herrera, ${ }^{5}$ a judge of the Supreme Court of Catamarca, directs his criticism at the draft submitted in 1906 by the codifiers under the decree of December, 1904. He contends that the draft does not reform the old concepts on punishment, nor give them any greater social utility. He studies critically the various penalties proposed and indicates the principles which should guide the codifier and legislature. He fixes the

${ }^{1}$ Piñero, Oswaldo M.: Derecho penal; conferencias tomadas taquigráficamente al profesor de la asignatura doctor Oswaldo Piñero, por Eduardo Catalá (versión taquigráfica sin corrección). Curso de Ig02. Buenos Aires, A. G. Santos, rgo2. 648 p.

2 Piñero, Oswaldo M.: Derecho penal. Apuntes tomados en la Facultad de Derecho al profesor de la materia. Arreglados por C. A. A. Bueños Aires, V. Abeledo, rgog. $5^{\mathrm{r}} 3 \mathrm{p}$.

${ }^{3}$ Moreno, Rodolfo: La ley penal argentina. Estudio critico. 2nd ed. Buenos Aires, V. Abeledo, I908. 345 p.

${ }^{4}$ Duffy, José Luis: Estudios de derecho penal. Buenos Aires, Imp. de la Policía, I904. $439 \mathrm{p}$.

${ }^{5}$ Herrera, Julio: La reforma penal, estudio de la parte general del proyecto de código penal, redactado per los Dres. Saavedra, Beazley, Rivarola, Moyano Gacitúa, Piñero y Ramos Mejía. Principios fundamentales en que debe inspirarse por Julio Herrera . . . con un prólogo del Dr. Osvaldo Magnasco. Buenos Aires, Librería é imprenta de mayo, r9rr. 666 p. 
basis of a penal system and considers the draft, in the light of scientific investigation, new theories, and comparative legislation, as in conflict with modern social conditions. The individual titles of the general part of the draft are each critically considered and an appendix contains an essay on alcoholism.

Among the works on special topics, attention may be called to the study of Antonio Dellepiane ${ }^{1}$ on the causes of crime in their pathological, psychological, and sociological aspects, in the light of modern science. The work includes also the statistics of crime in the capital of Buenos Aires.

Ernesto Quesada, one of the most versatile of Argentine jurists, proposed the establishment of an Archivo criminal, to record the antecedents of criminals. He submitted the draft of a law embracing this reform in a work ${ }^{2}$ published in 19or, which contains an excellent study of comparative legislation on the subject.

Attention has been directed (supra, p. 3o, et seq.) to the reports of decisions of the higher courts in criminal cases and to the indexes by Hall and others. An edition of the code was published in 1896 by Carlos Malagarriga, ${ }^{3}$ annotated by the decisions of the Court of Appeals of the Capital in criminal cases. Under each article a digest of the relevant decisions, with citation and notes from the authorities on the subject, are subsumed.

The decisions of Judge Julian L. Aguirre ${ }^{4}$ from 1875 to 1885 were published in the latter year, subdivided in accordance with the nature of the crime, and including a part on procedure. The scientific value of the publication is not great. A some$\rightarrow$

${ }^{1}$ Dellepiane, Antonio: Derecho penal. Las causas del delito. Buenos Aires, Pablo Coni, 1892 . $318 \mathrm{p}$.

${ }^{2}$ Quesada, Ernesto. Comprobación de la reincidencia. Proyecto de ley. Buenos Aires, Coni herm., 1901. Igo p.

${ }^{3}$ Malagarriga, Carlos: Código penal de la República Argentina comentado por los fallos de la Excma. Cámara de Apelaciones de la Capital. Buenos Aires, F. Lajouane, $1896.320 \mathrm{p}$.

${ }^{4}$ Autos y sentencias del juez del crimen Dr. D. Julian L. Aguirre, precedidos de una introducción por el Dr. D. Luis V. Varela, Departamentos del Sud y Capital de la Provincia de Buenos Aires, 1875 á r88r, Capital de la República, I882 á I885. Buenos Aires, Casavalle, ed. Imp. de Mayo, $1885.653 \mathrm{p}$. 
what similar publication of the decisions of Judge Diez Gómez, ${ }^{1}$ of the province of Buenos Aires, was published in 1907, with annotations to the opinions of writers.

Attention has already been called to the important historical publication of the Faculty of Law, ${ }^{2}$ containing an account of criminal cases in Buenos Aires during the seventeenth and eighteenth centuries.

Cesar Reyes, Attorney General of the Province of La Rioja in criminal cases, has recently begun the publication of his opinions. ${ }^{3}$ :

\section{CRIMINOLOGY}

Criminology, particularly the doctrines of the school of Lombroso and Ferri, has been a favorite subject of study in Argentina. An interesting study in criminal anthropology, particularly the theories of Lombroso and the physical subjective factors in crime, called "Men of prey," and including a critical analysis of the doctrines of the criminal code, was published in $\mathrm{I} 888$ by Luis M. Drago, ${ }^{4}$ who has since achieved fame in other legal fields.

One of the leading criminologists of the day, Director of the Institute of Criminology, and professor at the University, is José Ingegnieros. His important work ${ }^{5}$ on criminology, which has had six editions, is a scientific psychological and pathological study of crime and a criticism of contemporary systems of criminal law. He studies the social aspects of crime and the new theories of criminal law and presents proposals for reform.

${ }^{1}$ Diez Gómez, Diogenes: Sentencias en materia criminal y correccional, con un indice de conclusiones juridicas y comentarios al código penal, de los doctores E. Weigel Muñoz, C. Malagarriga, F. J. Iturburu y J. A. Rojas. Buenos Aires, Lajouane, 1907. 463 p.

${ }^{2}$ Causas instruídas en Buenos Aires durante los siglos xvii y xviii. With an introduction by Dr. Tomás Jofré. Buenos Aires, Facultad de Derecho y Ciencias Sociales, I9I3. 375 p.

${ }^{3}$ Reyes, Cesar: Vistas fiscales en materia criminal. v. I. La Rioja, I916.

4Drago, Luis M.: Antropología criminal. Los hombres de presa. Introduction by Francisco Ramos Mejía. 2d ed. Buenos Aires, F. Lajouane, r888. $265 \mathrm{p}$.

${ }^{5}$ Inge[g]nieros, José: Criminología. Madrid, Daniel Jorro, I9I3. $3^{86}$ p. 6th ed., Buenos. Aires, I916. 405. p.

$71624^{\circ}-17-8$ 
He is an ardent supporter of the positivist school, which recognizes crime as a pathological phenomenon. This particular topic under the title "The bases of criminal law," " was discussed by Ingegnieros in an essay on penal responsibility and its place in scientific doctrine.

Another work following the doctrines of Lombroso was published by Professor Moyano Gacitúa ${ }^{2}$ in 1905 . It is designed to establish the basis of criminal delinquency in Argentina from the ather incomplete data of criminal statistics. The author criticizes the existing theories of punishment from the point of view of the social aspects of crime.

An important periodical on criminology is edited by José Ingegnieros under the title "Archivos de psiquiatria y criminología. It was begun in the nineties. Bernaldo de Quirós, in his work on "Modern theories of criminality" (Boston, I9II) mentions (p. I2I) numerous monographic contributions to criminology in Argentina.

\section{PENOLOGY}

Among other matters which have received much attention is prison reform. José Ingegnieros ${ }^{3}$ has taken a leading part in this movement and published in I $1 \mathrm{I}$ I an interesting pamphlet on the reform of the penal system of Argentina. Two contributions to penology which warrant notice are those of A. Ballvé, ${ }^{4}$ Director of the National Penitentiary, on that institution, and of E. Gomez, ${ }^{5}$ on various problems of penitentiary science. The report of the special commission ${ }^{6}$ on prison reform, appointed by the Minister of Justice, was published

${ }^{1}$ Ingegnieros, José: Las bases del derecho penal. Buenos Aires, Penitenciaría Nacional; rgro. $45 \mathrm{p}$.

${ }^{2}$ Moyano Gacitúa, Cornelio: La delincuencia argentina ante algunas cifras y teorías. ... Precedida de una apreciación del Profesor Lombroso. Córdoba, F. Domenici, 1905. 426 p.

${ }^{3}$ Ingegnieros, José: Sistema penitenciario. Buenos Aires, Penitenciaria Nacional, IgII. $20 \mathrm{p}$.

${ }^{4}$ Ballvé, A.: La penitenciaria nacional de Buenos Aires. Buenos Aires, r907.

${ }^{5}$ Gomez, E.: Estudios penitenciarios. Buenos Aires, rgo6.

${ }^{6}$ Proyecto de reformas carcelarias. Informe de la Comisión especial. Buenos Aires, Talleres gráficos de la Penitenciaria nacional, 1913. I77 $\mathrm{p}$. 
officially in 1913. It is probably the best source of information on prison methods in Argentina, their defects and necessary reforms.

An interesting official publication on the criminal statistics of Argentina, as of December 31, 1906, was published by the Ministry of Justice ${ }^{1}$ in 1909.

\section{LEGAL, MEDICINE}

Two works on legal medicine warrant mention. The one, by Francisco de Veyga, ${ }^{2}$ consists of certain studies in legal medicine in connection with the civil code. Another compendium of legal medicine, by Héctor Taboada, ${ }^{3}$ was published in 1914.

\section{CRIMINAL PROCEDURE}

Each province of Argentina has its own code of criminal procedure. They are more or less alike. Tucumán and Catamarca have, in fact, adopted textually the code in force in the federal courts, the National Capital, and the territories.

On March 6, I 882, the President of Argentina appointed Manuel Obarrio and Emilio R. Coni to draft a code of criminal procedure for the federal courts and the courts of the Capital. As the latter declined the mission, Obarrio undertook the work alone. His draft, ${ }^{4}$ presented in June, 1882, is accompanied by extensive notes explaining the principles introduced. In April, 1883, a revisory commission of three was named by the Executive to examine Obarrio's

${ }^{1}$ Resultados generales del primer censo carcelario de la República Argentina, levantado el 3 I de diciembre de 1906, por A. Ballvé, director de la Penitenciaría nacional [y], M. L. Desplats, director de division del Ministerio de j. é i. p. (Publicación oficial.) Buenos Aires, Talleres gráficos de la Penitenciaría nacional, Igog. $207 \mathrm{p}$.

${ }^{2}$ Veyga, Francisco de: Estudios medico-legales sobre el codigo civil argentino. Buenos Aires, 1900.

3 Taboada, Héctor: Compendio de medicina legal. Buenos Aires, I9I4.

${ }^{4}$ Proyecto de código de proc. en materia penal para los tribunales nacionales de la Rep. Argentina, redactado por el Dr. D. Manuel Obarrio. Buenos Aires, Imp. "La Nacion," I882. 383 p. 
draft. They reported, ${ }^{1}$ in July, I 884 , having made certain changes. A commission of the chamber of deputies made an additional report, introducing certain amendments, on August 18, 1888. By law No. 2372, of October 2, 1888, this draft was enacted into law, coming into force on January $I$, I889, as the code of criminal procedure for the federal courts, the courts of the Capital, and the territories.

Since that time numerous additional statutes have been enacted, among others law No. 2755 , on the substitution of penalties; law No. 3365 , on expert examinations; law No. 3508 , on release from prison on bail or judicial writ; law No. 4055 , revising the administration of federal justice; law No. $4 \mathrm{r} 89$, revising the penal code; and law No. 5 I07, on challenging of judges. The code itself consists of 699 articles, divided into four books, containing ( $\mathrm{I}$ ) the general rules applicable to all actions, including jurisdiction, disqualification of judges, prosecuting attorneys, notifications, costs, and default; (2) the proceedings connected with the preliminary arraignment and examination; (3) trial and sentence; (4) correctional cases, misdemeanors, and special proceedings.

The code has proved very unsatisfaciory and a commission has been appointed to draft a new one. I is report ${ }^{2}$ and a draft of a new code were published official y in 1913. The report of 90 pages is a valuable contributi $n$ to the critical literature of Argentine procedure.

Professor Tomás Jofré, ${ }^{3}$ the author of the draft of the code for the province of Buenos Aires and other provinces, and one of the foremost authorities on the subject, published a

${ }^{1}$ Proyecto de código de proc. en materia penal por la Comision revisoria del formulado por el Dr. D. Manuel Obarrio. Pub. Of. Buenos Aires, Tal. Penitenciaria, 1885. $284 \mathrm{p}$.

${ }^{2}$ Proyecto de código de procedimientos en lo criminal para la justicia federal, la de la capital y de los territorios. Presentado por la comisión compuesta de los doctores Ramón Méndez, M. A. Montes de Oca, Pedro F. Agote y secretario José Luis Duffy. Publicación oficial. Buenos Aires, Talleres gráficos de la Penitenciaría nacional, r913. $90+107 \mathrm{p}$.

3 Jofré, Tomás: Procedimiento criminal argentino. Proyecto de código de procedimientos en materia pénal. Buenos Aires, J. Lajouane, I909. $260 \mathrm{p}$. 
draft of a new code in 1909. In his explanatory report accompanying the draft he criticizes the various features of criminal procedure, among others, the want of oral proceedings, the lack of control of the press, the secrecy of preliminary investigations (sumario), the intervention of the Ministry of Justice, and of the person against whom the crime has been committed, under certain circumstances, the facility of detention, the weakness in the rules of evidence, and the lack of control over negligent judges. His draft, which consists of 522 articles, suppresses the preliminary detention in misdemeanors and lesser crimes, and in the case of certain minors under fifteen. In his draft he has corrected many of the defects mentioned and has introduced new proceedings, aesigned to improve the administration of criminal justice. The articles of the code are accompanied by explanatory notes.

As the draft submitted by the code commission in 1913 has not yet been enacted, the code in force is still that of $\mathrm{r} 888$ with its statutory amendments. Editions of this code are to be found in the collected codes enumerated above and in separate publications issued by the house of Lajouane. The most recent edition ${ }^{1}$ of the code for the federal courts and those of the Capital and territories was published in I9I4.

By all means the most important commentary on this code is that of Malagarriga and Sasso. ${ }^{2}$ Each article has an extensive commentary including theoretical doctrines drawn from the opinions of authorities, concordances, and the decisions of the Supreme Court and those of the Capital. Volume 3 contains the codes of the twelve provinces which have adopted special codes. An appendix in volume 2 contains some essays

${ }^{1}$ Código de procedimientos en lo criminal para la justicia federal y los tribunales de la capital y territorios nacionales. Nueva ed. corregida $\mathrm{y}$ aumentada con todas las leyes complementarias relativas al mismo. Buenos Aires, Lajouane, IgI4.

${ }^{2}$ Malagarriga, Carlos y Sasso, S. A.: . . . Procedimiento penal argentino; código de procedimientos criminales para la justicia federal y los tribunales de la capital y territorios; comentado por la doctrina y la jurisprudencia y completado con el texto de los códigos de todas las provincias. Buenos Aires, Librería nacional, J. Lajouane \& cia, I910. $3 \mathrm{v}$. 
on special topics. Volume 3 includes a critical introduction on criminal procedure.

Tomás Jofré ${ }^{1}$ has also published a manual of criminal procedure in which he discusses the history of procedure, general principles, actions, trial and evidence, sentence and appeals, special proceedings, criminal defenses, jurisdiction and military procedure.

Among the critical works one of the best is that of Rodolfo Rivarola $^{2}$ on the organization and procedure of criminal justice. He discusses the Ministry of Justice, its intervention as accuser in crimes prosecuted by the public, the creation of joint tribunals of accusation and separate tribunals for trial and sentence and appeal or cassation, criticizes the provisions of the code relating to sumario (preliminary examination) and the defective way in which the evidence of witnesses is received in that procedure. He proposes an examination by courts of five judges.

Rivarola's criticism of the jury system is generally supported by Argentine lawyers, judges, and publicists. An important literature has grown up on the subject of the jury, and by reason of its support in several constitutions much controversial literature has appeared. The final conclusion seems to be that the jury system is an instrument inadequate for the solution of Argentine criminal cases except perhaps in certain offenses committed by the press. This is the view taken by Antonio Sagarna, ${ }^{3}$ Chief Justice of the Supreme Court of Paraná and by a host of other writers in periodicals and books whose works are mentioned in the bibliography of Eusebio Gomez. (Supra, p. 17.)

Province of Buenos Aires.-On June i 5, i 88I, a commission was named to draft a code of criminal procedure for the province of Buenos Aires. Nothing appears to have been done by it. In August, I885, another commission was appointed consisting of Juan José Montes de Oca, Manuel

${ }^{1}$ Jofré, Tomás: Manual de procedimiento criminal. Buenos Aires, S. Suarez, I914. $37^{8} \mathrm{p}$.

${ }^{2}$ Rivarola, Rodolfo: La justicia en lo criminal; organización y procedimiento. Buenos Aires, F. Lajouane, I899. 253 p.

${ }^{3}$ Sagarna, Antonio: El jurado en materia criminal. Buenos Aires, Talleres gráficos de la Penitenciaría nacional, I9r r. $3^{2} \mathrm{p}$. 
Obarrio, and Antonio E. Malaver. They presented on August I $6, I_{886^{1}}$ a report which was criticized by Luis M. Drago in certain articles published in "La Nación" and republished under the title El procedimiento criminal en la provincia de Buenos Aires. (P. E. Coni, I887. 38 p.)

New codes have since been enacted twice. The first, promulgated on March I, 1906, was drafted by Lozano, Acevedo and González Roura, ${ }^{2}$ and the most recent one, promulgated by law of January 15, 1915, drafted entirely by Dr. Tomás Jofré. The house of Lajouane has published this code with its supplementary laws and an introduction by Jofré. ${ }^{3}$ The latter has also recently published an exhaustive commentary ${ }^{4}$ upon this code, with the legislative documents preceding its adoption, in two volumes. Very recently Alberto Palomeque ${ }^{5}$ published a commentary and criticism upon the provincia: code.

The code of the province of San Luis, drafted by Jofrc, ${ }^{6}$ ras published officially in $\mathbf{1 9 0 9 .}$

\section{CONSTITUTIONAL LAW}

On May 25, 1810 the Spanish viceroy assembled in the city of Buenos Aires a junta which initiated the Argentine revolution by depriving the viceroy of all his powers. This junta exercised executive power until the convening of the assembly

${ }^{1}$ Proyecto de código de procedimientos en lo criminal para la provincia de Buenos Aires. Buenos Aires, Escuela de Artes y Oficio, I887. $320 \mathrm{p}$.

${ }^{2}$ Código de procedimientos en materia penal de la provincia de Buenos Aires. Sancionado el $2 \mathrm{I}$ de febrero de I906 y promulgado el I. de marzo de igo6. Ed. conforme con el texto oficial. Buenos Aires, J. Lajouane y cia, 1906. $\quad$ I87 p.

${ }^{3}$ Código de procedimiento penal de la provincia de Buenos Aires y leyes complementarios. Precedido de una introducción por el autor del

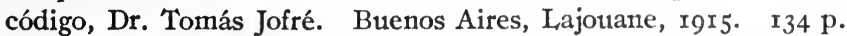

4 Jofré, Tomás: El nuevo código de procedimiento penal de la provincia de Buenos Aires, comentado. Buenos Aires, Lajouane, I9I5. 2 v.

${ }^{5}$ Palomeque, Alberto: Comentarios y crítica al nuevo código de procedimiento penal de la provincia de Buenos Aires. Buenos Aires, I916. ${ }^{8} 8 \mathrm{p}$.

${ }^{6}$ Código de procedimiento criminal de la provincia de San Luis. (Ed. oficial) Buenos Aires, Impr. Nacional de J. Lajouane, I909. 260 p. 
of December 1813. Another assembly met at Tucumán in I 816 and on July 9 of that year Argentine independence was proclaimed. A provisional constitution was promulgated in 1817 with unitarian tendencies, and another in 1819. From 1820 to 1825 the provinces had no common government. In I 825 a constitutional convention agreed upon a form of government loosely uniting the provinces until a constitution, that of 1826 , was adopted. The constitution of 1826 , however, was rejected by the provinces. From 1829 to 1852 the dictator Rosas, ostensible leader of the federalists, governed the country. After numerous attempts to depose him, Urquiza, the governor of Entre Rios, forced him in $185^{2}$ to abdicate and leave the country.

The differences between the unitarians and the federalists then manifested themselves between the province of Buenos Aires, the center of unitarian strength, and the other thirteen provinces. A constitution was adopted by the confederated provinces on May I, I853 and was ratified by all except the province of Buenos Aires, which remained independent until 1859. War between the province of Buenos Aires and the confederated provinces broke out in that year and was terminated by a treaty; as a result of which another constitutional convention was called. It accepted many of the reforms desired by the province of Buenos Aires. On September 25, I 860 the constitution of the Argentine Republic was ratified. Although difficulties again arose between Buenos Aires and the other provinces a national Congress met on May 25, 1862 which elected Bartolome Mitre as President of the Republic.

With two slight amendments the constitution of 1860 has remained in force. It combines the federal principle adopted by the Argentine Confederation with the unitary spirit for which Buenos Aires had contended.

\section{CONSTITUTIONAL HISTORY}

The best constitutional history of Argentina is to be found in the work of Luis Vicente Varela, ${ }^{1}$ published in 1910, on the

1 Varela, Luis Vicente: Historia constitucional de la República Argentina; obra editada por orden del gobierno de la provincia de Buenos Aires en el centenario de la revolución de mayo de $1810 \ldots \mathrm{L}$ a Plata, Taller de Impresiones oficiales, Igro. $4 \mathrm{v}$. 
occasion of the Argentine centenary. Volume I deals with the anteredents of the revolution of May, 18ro, and the first juntas; volume 2, with the first general assembly and the supreme directorate of the united provinces; and volume 3, with the government of General Pueyrredon, the constitution of I8I9, the civil war and national dissolution, and the constitution of 1860 . Volume 4 contains a useful collection of constitutional documents.

Another important work on constitutional history is that of Adolfo Saldias, ${ }^{1}$ published in 1878 . He deals with the early constitutions, particularly those of $1819,1826,1853$, and 1860 to the installation of the federal Congress of 1862 . The work contains a comparative consideration of the constitutions of 1819, I 826 and 1860. Saldias' five volume history of the Argentine Confederation contains important accounts of constitutional movements.

The history of the provincial governors of Argentina from I 81 io to 1880 with an account of the governors and viceroys of the colonial period was published in 1879 by the historian and bibliophile Antonio Zinny. ${ }^{2}$

Constitutional law has been a favorite field for study in Argentina as in other South American countries and the subject has a rich literature. It is the one branch of law in which considerable attention has been paid to legal history. Thus, of the works to be mentioned hereafter, the following are particularly important from the point of view of the historical antecedents of the constitution: the lectures of Professors Aristobulo del Valle and Manuel Agusto Montes de Oca, the important work by Francisco Ramos IMejia on Argentine federalism and the important commentary on the constitution by Perfecto Araya.

${ }^{1}$ Saldías, Adolfo: Ensayo sobre la historia de la constitución argentina . . Buenos Aires, Impr. y librería de mayo, de C. Casavalle, I878. $35^{8} \mathrm{p}$.

${ }^{2}$ Zinny, Antonio: Historia de los gobernadores de las provincias argentinas desde r8 ro hasta la fecha, precedida de la cronología de los adelantados, gobernadores, y vireyes del Rio de la Plata, desde I535 hasta 18 I0 . . B Buenos Aires, C. Casavalle, 1879-1882. 3 v. 


\section{SOURCE BOOKS}

Among the source books of Argentine constitutional law first place must be given to the valuable collection covering the period $1851-1853$ published by the Department of History of the Facultad de Filosofia y Letras. ${ }^{1}$ Volume 3 contains the documents of the convention of 1853 . An index was published in 1914 .

On the occasion of the centenary of the first general convention of 1813 , Congress, by law No. 9044, authorized a reprint, ${ }^{2}$ with an introduction by Jose Luis Cantilo, of the journals and proceedings of the general assembly of 1813 .

An important source book ${ }^{3}$ was published on the occasion of the constitutional convention of 1898 . It brought into one volume the proceedings of the conventions of 1853,1860 , and 1866 , of the Buenos Aires provincial convention of 1859 , which examined the constitution of the Confederation with a view to its acceptance by the province, and the proceedings of the 1898 constitutional convention.

The debates and proceedings of the provincial convention of Buenos Aires with the report and amendment of the examining commission ${ }^{4}$ of the constitution of the Confederation were published in 1860 .

A publication of undoubted interest in the study of the constitutional development of Argentina is the "Messages of the Presidents" $1810-1910,{ }^{5}$ published in six volumes by the centenary commission, and edited by $\mathrm{H}$. Mabragaña.

${ }^{1}$ Documentos relativos á la organización constitutional de la República Argentina ( $\left.185 \mathrm{I}-\mathrm{I} 8_{53}\right)$. Buenos Aires, Compañía sud-americana de billetes de banco, I9II-I2. $3 \mathrm{v}$. Indice alfabético, I9I4. $43 \mathrm{p}$.

${ }^{2}$ E1 Redactor de la Asamblea (I8I3-I8I5). Reimpresión facsimilar ilustrada, dirigida por la Junta de historia y numismática americana, en cumplimiento de la ley 9044. Buenos Aires, Compañía sud-americana de billetes de banco, 19I3. $9^{8} \mathrm{p}$.

3 . . Convención nacional de 1898 . Antecedentes: Congreso constituyente de 1853 y convenciones reformadoras de 1860 y i 866. Buenos Aires, Compañía sud-americana de billetes de banco, r898. II26 p.

${ }^{4}$ Diario de sesiones de la convencion del estado de Buenos Aires encargada del examen de la Constitución federal. Buenos Aires, Imp. del "Comercio del Plata," I860. 33\% p., II, I00, I4, xiii p.

${ }^{5}$ Mabragaña, H. Los mensajes. Historia del desenvolvimiento de la nación argentina redactada cronológicamente por sus gobernantes I8ro-rgro. Buenos Aires, Comp. Gral. de Fósforos, rgro. $6 \mathrm{v}$. 
TEXTS

The text of the constitution of 1860 with its amendments and a brief introduction is printed in Dodd's " "Modern constitutions," pages $1-29$.

Another edition with a more extended historical introduction has been edited, with notes, by Elizabeth Wallace. ${ }^{2}$ The text of the constitution has also been published by the Bureau of American Republics, ${ }^{3}$ now the Pan American Union, and in the compilation of constitutions by Rodriguez. (Washington, 1906. v. I.) It is also printed in English in a compilation ${ }^{4}$ published in 1894 in connection with the New York State Constitutional Convention of 1894 .

The texts of the federal constitution and of the provincial constitutions have been published by Arturo B. Carranza ${ }^{5}$ in a compilation of which the fourth edition appeared in rgro. He includes concordances of the United States Constitution with the Argentine constitution and a list of the dates of the federal and provincial constitutions. The constitution is also to be found in the French compilation of Dareste and in similar collections published in Europe.

\section{LITERATURE}

The father of the federal constitution of Argentina is Juan Bautista Alberdi, the celebrated publicist. His monumental work "Bases and points of departure for the political organi-

${ }^{1}$ Dodd, W. F.: Modern constitutions. Chicago, Univ. of Chicago Press, 1909. 2 v.

${ }^{2}$ Wallace, Elizabeth: The constitution of the Argentine Republic. The constitution of the United States of Brazil, with historical introduction and notes . . . Chicago, The University of Chicago Press, I894. $95 \mathrm{p}$.

${ }^{3}$ Constitution of the Argentine Republic. Washington, I894. Reprinted from Bulletin No. 67 , pp. I $5^{8-182}$.

4... Foreign constitutions, comprising the constitution of Argentine, Belgium, Brazil (empire and republic), Colombia, Ecuador, France, Germany, Honduras, Japan, Mexico, Prussia, Switzerland, and Venezuela. Prepared in pursuance of chapter 8 of Laws of 1893 , and chapter 228 of Laws of 1894 . . by George A. Glynn . . A Albany, The Argus Co., I894. 439 p.

${ }^{5}$ Carranza, Arturo: Digesto constitucional argentino. 4th ed. Buenos Aires, Compañía sud-americana de billetes de banco, I9ı. $072 \mathrm{p}$. 
zation of the Argentine," with a draft of a proposed constitution was the inspiration and fundamental source of the constitution of 1853 . The work, written in 1852 , has been frequently republished.

Domingo F. Sarmiento, another celebrated publicist and later president of Argentina, was an ardent admirer of the United States. In a work entitled "Commentaries on the constitution of the Argentine confederation," published in Santiago, Chile, he advocated a more rigorous conformity with the constitution of the United States, his work being based largely on the doctrines of Story in his commentaries on the constitution of the United States.

Alberdi, who in his previous works had sought to demonstrate the necessity of adjusting the written constitution of the country to the historical and social conditions there prevailing, replied to Sarmiento in his "Estudios sobre la constitucion Argentina de 1853." Alberdi always contended that the origin of the Argentine constitution is to be found primarily in Argentine antecedents and in the work of Argentine jurists, and lastly in the constitution of the United States. While it is true that the wording of the Argentine constitution is in many respects similar to that of the United States, its spirit and development have been much different, largely due to the fact that although the federal form is maintained, the central government in Argentina has much more power than in the United States and the states or prov-: inces much less than in the United States. For example, the civil, commercial, criminal and mining law are national, as are numerous other matters falling under the jurisdiction of the states in the United States.

In his celebrated "Bases" Alberdi studied the early constitutions of South America, the economic and social conditions of Argentina, the degree of federalism which he considered necessary, and comparative constitutions, and presented a draft which was the foundation for the constitution adopted in 1853 . An official publication of the work was authorized by the government. Probably the best edition of Alberdi's constitutional works was published in two volumes in 1913 , with an extensive introduction by Adolfo Posada, the Spanish 
publicist. " Volume I contains Alberdi's "Bases" and his "Elements of provincial public law," written in 1858 , with the constitution of Mendoza and Buenos Aires, and his reply to Sarmiento, the "Studies on the Argentine federal constitution." Volume 2 reprints his work on the economic and fiscal system of Argentina, and another work on Argentine nationality.

Many books on Alberdi have been written. Two of these study particularly his constitutional doctrines. The first, by Martin Garcia Mérou, ${ }^{2}$ is a critical essay and the other, by Santiago Bagué ${ }^{3}$ is an honor doctoral dissertation on the influence of Alberdi on the political organization of Argentina.

Among the commentaries and general treatises on the constitution, the important work of Domingo F. Sarmiento, ${ }^{4}$ just mentioned, has become a classic. The work is not a complete commentary of the 1853 constitution, but is an expository and philosophical discussion, employing the historical and comparative method, of the constitution of Argentina in the light of the institutions of the United States. As already stated, Sarmiento was largely influenced by Story's views.

Among the modern didactic treatises an important place must be assigned to Joaquín V. González's 5 " Manual of the Argentine constitution" designed to serve as a textbook. $\mathrm{He}$ discusses the general principles of constitutional law, historical sources before and after 1810, comparisons with

1 Alberdi, Juan Bautista: Organización de la Confederación Argentina . . . Nueva ed., con un estudio preliminar sobre las ideas políticas de Alberdi por Adolfo Posada . . B Buenos Aires, P. García y cia. [rgr3]. $2 \mathrm{v}$.

${ }^{2}$ Garcia Mérou, Martin: Juan Bautista Alberdi (Ensayo crítico). Buenos Aires, I89o.

${ }^{3}$ Bagué, Santiago: Influencia de Alberdi en la organización política del estado Argentino. Buenos Aires, 1915. I95 p.

${ }^{4}$ Sarmiento, Domingo Faustino: Comentarios de la constitución de la confederación Arjentina, con numerosos documentos ilustrativos del texto . . . Santiago de Chile, Impr. de J. Belin i ca., I853. $236 \mathrm{p}$.

- González, Joaquín V.: Manual de la constitución argentina, escrita para servir de texto de instrucción cívica en los establecimientos de instrucción secundaria . . Buenos Aires, A. Estrada y ca., 1897. 7th ed., I9I5. $795 \mathrm{p}$. 
foreign constitutions, the organization of the Argentine government, and related subjects.

One of the ablest commentaries on the constitution from the point of view of history and political science is that by Perfecto Araya, ${ }^{1}$ published in 1908-1911. His commentary takes up the constitution article by article and, under each, deals with the historical antecedents, the legislative debates, references to authorities, and decisions of the courts. A somewhat similar and very useful work is that published by Agustín de Vedia $^{2}$ in 1907 , based largely on a comparison between the United States and the Argentine constitution, with a history and analysis of each article in comparison with foreign constitutions, including their actual working as well as their written word.

Among the textbooks which are founded upon courses of lectures at the University several should be mentioned. A leading place must be given to the work on constitutional and administrative law of Professor José Manuel Estrada, ${ }^{3}$ consisting of lectures delivered in 1877,1878 , and 1880 . Another edition ${ }^{4}$ of this work with appendices consisting of essays on various constitutional questions published in periodicals was issued as volume 6-8 of Estrada's complete works. In 1914 Dr. Rodolfo Rivarola ${ }^{5}$ published a brief biography of Estrada.

The lectures of Professor Del Valle ${ }^{6}$ were published in 1894 . Only volume $\mathrm{I}$, an exposition of the historical antecedents of

1 Araya, Perfecto: Comentario á 1 a constitución de la nación Argentina ... con un prólogo del Dr. Joaquin Lajarza. Buenos Aires, J. Roldán, Ig08-II. 2 v.

${ }^{2}$ Vedia, Agustín de: Constitución argentina. Buenos Aires, Coni hermanos, I907. $5^{8} 7 \mathrm{p}$.

${ }^{3}$ Estrada, José Manuel: Curso de derecho constitucional, federal y administrativo. . . Buenos Aires, Compañía sud-americana de billetes de banco, $1895 . \quad 56 \mathrm{r}$ p.

${ }^{4}$ Estrada, José Manuel: Curso de derecho constitucional ... Buenos Aires, Compañía sud-americana de billetes de banco, I9oI-2. 3 v.

${ }^{5}$ Rivarola, Rodolfo: El maestro José Manuel Estrada. Buenos Aires, IgI4.

${ }^{6}$ Del Valle, A.: Nociones de derecho constitucional. Notas tomadas de sus conferencias por M. Castro y Alcides V. Calandrelli. Buenos Aires, "La Buenos Aires," I894. v. I and part of vol. 2. 467 p. Reprinted, I9Ir. 
the constitution, and a small part of volume 2 , in which the text of the constitution is taken up, had been published when the distinguished author died.

Professor Manuel A. Montes de Oca's ${ }^{1}$ lectures were published in two volumes in 1902-3. He turns largely to the United States for comparative purposes, following Sarmiento and his school in this respect. Prof. Montes de Oca in I 899 published a brief treatise ${ }^{2}$ on certain questions of constitutional law, namely, the colonial cabildos, the powers of the Minister of Foreign Affairs, the cabinet ministers before Congress, and jurisdiction over rivers and marginal sea. Very recently the lectures of José Nicolás Matienzo ${ }^{3}$ delivered at the University of La Plata have been published."

Apart from these textbooks a number of other general works dealing with Argentine constitutional organization should be mentioned. Among the best of these is Matienzo's ${ }^{4}$ federal representative government in Argentina in which he deals with comparative federal government, the formation of the constitution and its theory, political parties, a discussion of the three powers of government and of the provincial governments, intervention of the federal in the provincial governments under articles 5 and 6 of the constitution, and the administration of justice. It is an excellent account of the actual working of the constitution.

A study in French on the Argentine constitution was published as a Toulouse doctor's thesis by Taussac ${ }^{5}$ in 1904. He discusses the constitution, political organization, the history of the earlier constitutions, the electoral system, and the federal powers outlined in Part II of the constitution. A succinct account of Argentine constitutional and administrative insti-

${ }^{1}$ Montes de Oca, M. A. : Lecciones de derecho constitucional, notas tomadas ... por Alcides Calandrelli. Buenos Aires, "La Buenos Aires," 1902-3. $2 \mathrm{v}$.

${ }^{2}$ Montes de Oca, M. A.: Cuestiones constitucionales . . Buenos Aires, A. Etchepareborda, 1899. $222 \mathrm{p}$.

${ }^{3}$ Matienzo, José Nicolás: Derecho constitucional. Apuntes taquigráficas tomadas en la cátedra del Dr. José $\mathrm{N}$. Maticnzo por Juan Isaac Cooke. La Plata, I9I5-I9I6. 2 v.

${ }^{4}$ Matienzo, José Nicolás: El gobierno representativo federal en la República Argentina. Buenos Aires, Impr. de Coni hermanos, I910. $469 \mathrm{p}$.

"Taussac, Georges: Constitution de la République Argentine ... Toulouse, Impr. Lagarde et Sebille, I904. I87 p. 
tutions has been published in the Bibliothek des offentlichen Rechts by P. Llambi-Campbell. ${ }^{1}$

Several works on the Argentine constitution from the point of view of its federalistic and unitary tendencies have been published. One of the best of these is Francisco Ramos Mejia's ${ }^{2}$ work, first published in 1889 and reprinted in 1915 . Ramos was a leader in the movement toward sociological studies, and the present work was inspired by the views and sociological methods of Buckle, Spencer, and Taine. He combats the view that the Argentine constitution is a copy of that of the United States and seeks by a detailed study of the Spanish colonial origins of federalism to prove its essentially indigenous character. In this connection attention may again be directed to Solórzano's classic work on colonial public law. (Supra, p. 57.) Ramos appears to be the first Argentine writer who has from a strictly historical point of view studied Argentine federal institutions. Practically all the other writers, except Rivarola and one or two others, have turned to comparative law and particularly to the United States.

An able work which emphasizes the unitary factors in the Argentine constitution, as opposed to the federal, was published in 1908 by Rodolfo Rivarola ${ }^{3}$ a jurist whose writings have been mentioned on several occasions. It is a critical work on the political institutions of Argentina with a thesis that the unitarian form is now best suited to its social and economic conditions. He criticizes the electoral system, the absence of proportional representation (toward which some advance has recently been made), the excess of power possessed by the Executive, proposes a greater coherence in the administration of justice, and analyzes the factors making for national unity. It is one of the ablest critical works published in Argentina.

${ }^{1}$ Llambi-Campbell, P.: Abriss des staats- und verwaltungsrechts der Argentinischen Republik, von dr. P. Llambi-Campbell ... übers. von amtsgerichtsrat $R$. Bartolomäus. . . Hannover, M. Jänecke, I9II. $25^{2} \mathrm{p}$.

${ }^{2}$ Ramos Mejia, Francisco (I847-I893): El federalismo argentino. Buenos Aires, F. Lajouane, 1889. 360 p. Reprinted in I915 in "La Cultura Argentina," with an introduction by Nicolás Coronado. 343 p.

${ }^{3}$ Rivarola, Rodolfo: Del régimen federativo al unitario; estudio sobre la organización política de la Argentina. Buenos Aires, J. Peuser, I908. $46 \mathrm{I} \mathrm{p.}$ 
The work of C. O. Bunge ${ }^{1}$ on Argentine federalism published in 1897 is less critical than expository. He seeks to explain the essence of Argentine political institutions and employs largely the historical method.

A criticism of the constitution article by article with the proposed draft of a new constitution was published by Alejaniro Gancedo ${ }^{2}$ in 1909. Its scientific value is questionable.

There are a number of descriptive and philosophical discussions of the Argentine constitution and system of government. Two brief monographs in English warrant special consideration. One by Estanislao S. Zeballos, ${ }^{3}$ former Minister of Foreign Affairs, consists of an address delivered in Buenos Aires, in which the author discusses Argentine governmental institutions and compares them with those of the United States. He finds the origin of the Argentine constitution in the "Federalist" and in Alberdi's "Bases." A somewhat similar monograph by Rómulo S. Naón, ${ }^{4}$ now Argentine Ambassador in Washington, discusses the principles and spirit of the Argentine constitution with an outline of governmental organization and an interesting comparison between Argentine and United States federalism. It is printed as a Senate Document and in 34 Canadian Law Times (1914), pages I095-1 I I 7 .

The spirit and actual operation of the Argentine constitution, largely from the point of view of comparative law, was the subject of a dissertation by Julian Barraquero ${ }^{5}$ first published in 1878 and later republished in a second edition with a criticism by Sarmiento and a reply of the author. Another general work descriptive of Argentine constitutional

${ }^{1}$ Bunge, C. O.: El federalismo argentino. Buenos Aires, 1897.

${ }^{2}$ Gancedo, Alejandro: Reformas á la constitución nacional ... Buenos Aires, Coni hermanos, 1909. $2 \mathrm{v}$.

${ }^{3}$ Zeballos, Estanislao S.: The rise and growth of the Argentine constitution; being a lecture delivered to the St. Andrew's ciebating society by Dr. Estanislao S. Zaballos ... on Saturday, Sept. 29, 1906. Buenos Aires, Albion Printing Press, 1907. 3I p.

${ }^{4}$ Naón, Rómulo S.: Argentine constitutional ideas. Address delivered before the American bar association at the annual meeting held in Wash., D. C., on Oct. 22, I9r4, by the Hon. Rómulo S. Naón ... Wash., G. P. O., 1914. S. Doc. 618, 63rd Cong., 2nd sess. 19 p.

${ }^{5}$ Barraquero, Julian: Espiritu y práctica de la constitución argentina. 2nd ed. Buenos Aires, Colegio Pio IX de Artes y Oficios, r889. 379 p.

$71624^{\circ}-17-9$ 
organization and history and the theory of the State by Rodríguez del Busto ${ }^{1}$ consists of monographs presented by the author at the second and third Latin American Scientific Congress. The material seems to be loosely organized.

MONOGRAPHS.

PARLIAMENTARY GOVERNMENT.

Numerous monographs on particular questions of constitutional law are sufficiently important to warrant special mention. The legislative power, including parliamentary government and the privileges of the legislature and its members, was the subject of the doctoral dissertation of Professor González Calderón, ${ }^{2}$ published in r 909 . He includes a discussion of the electoral system and of the functions of the various organs of the legislative power.

Another valuable work on parliamentary institutions, treated both from the historical and comparative method, was published by Miguel Romero ${ }^{3}$ in two volumes in 1902 . He discusses the principles and rules of Argentine parliamentary law, their history and development compared with the law and practice of foreign countries, and parliamentary precedents, both in Argentina and abroad. The rules of the Senate 4 and of the House ${ }^{5}$ are published officially at frequent intervals.

\section{EXECUTIVE POWER}

A historical work on the executive power as provided for in the various constitutions between r8ro and 1853 was the

1 Rodrísuez del Busto, Antonio: I1 sistema de gobiernó dual de Argentina y su origen, precedido por Cuestiones de política ibero-americana. Buenos Aires, Compañia sud-americana de billetes de banco, I906. $205 \mathrm{p}$.

${ }^{2}$ González Calderón, Juan A.: Poder legislativo en los estatutos, reglamentos y constituciones de la nación y las provincias, organización y funccionamiento. Buenos Aires, V. Abeledo, 1909. 494 p.

${ }^{3}$ Romero, Miguel: El parlamento: derecho-jurisprudencia-historia ... Buenos Aires, F. Lajouane, 1902. 2 v.

${ }^{4}$ Reglamento de la Cámara de senadores de la nación, sancionado en Buenos Aires el 7 de junio de 1862 . Bticnos Aires, El Comercio, I9II. $78 \mathrm{p}$.

${ }^{5}$ Reglamento de la Cámara de diputados de la nación argentina. Publicación oficial. Buenos Aires, rgog. Irg p. 
subject of the doctor's dissertation of Professor Juan P. Ramos, ${ }^{1}$ published in r9i2. A symposium ${ }^{2}$ on the constitutional functions of cabinet officers in Argentina was published by a number of leading publicists in the form of articles in the Revista argentina de ciencias politicas, republished in book form in I9I. Law No. 3727 of October II, r 898 , prescribed the duties and functions of the various executive departments of the government. The law is printed in various constitutional manuals, in the Anuario Oficial (1912) page 57 et seq., and in a special publication of the government. ${ }^{3}$

\section{JUDICIAL POWER}

A small monograph on the judicial function in the Argentine constitution by Professor González Calderón ${ }^{4}$ discusses general principles and the judicial power in the federal government and in the province of Buenos Aires. A critical study of the relation between the judicial and the executive power in connection with a litigation involving the exercise of eminent domain was published in 1872 by José F. López. ${ }^{5}$ It has no special scientific value, however.

\section{GUARANTIES}

A philosophical and critical work on the constitutional guaranties contained in the first part of the Argentine constitution was published in 1897 in a second edition by Professor

${ }^{1}$ Ramos, Juan P.: El poder ejecutivo en los estatutos, reglamentos y constituciones de la nación y las provincias; su reglamentación y funcionamiento (descle r8 ro á 1853). Buenos Aires, G. Mendesky é hijo, 1912. $277 \mathrm{p}$.

${ }^{2}$ Función constitucional de los ministros, por I. Ruiz Moreno, R. Wilmart, N. Piñero, E. de Vedia, J. A. González Calderón, R. A. Orgaz, V. C. Callo y J. N. Matienzo. Prólogo de Rodolfo Rivarola. Buenos Aires, Revista argentina de ciencias políticas, I9I. 196 p.

${ }^{3}$ Ley de organización de los ministros nacionales y decretos reglamentarios. Buenos Aires, Impr. de "La Nacion," rgor. 74 p.

- González Calderón, Juan A.: La función judicial en la constitución argentina. Buenos Aires, J. Lajouane \& Cia, I9II. I74 p.

${ }^{5}$ López, José Francisco: El poder judicial ante el poder ejecutivo en la causa celebre de los terrenos de la Ensenada y su cxpropiacion; defensa ante los tribunales y las camaras, con un estudio sobre el gobierno y la democracia en Sud America, por el Dr. D. José Francisco López. Buenos Aires, Impr. del Porvenir, 1872. 78 p. 
Amancio Alcorta. ${ }^{1}$ He discusses individual rights and their limitations, habeas corpus, martial law and military law and their effects, political parties and constitutional guaranties, the right of resistance, and a number of other topics.

\section{FEDERAL INTERVENTION}

Articles 5 and 6 of the constitution give the federal government the right to intervene in the provinces for the maintenance of public order and the guaranty of constitutional liberty and local institutions. Under this constitutional power the federal government has frequently intervened in the provinces. The documents, decrees, and orders connected with these interventions from 1853 to 1904 were published officially in two volumes by the Ministry of the Interior ${ }^{2}$ and a table of these interventions from 1853 to 1909 was published recently by Jose Giustinian. ${ }^{3}$ These articles of the constitution are discussed in all the commentaries and are the subject of special studies by Luis V. Varela, ${ }^{4}$ published in 1896 , and by Agustín de Vedia, ${ }^{5}$ published in 1904.

\section{UNミONSTITUTIONALITY OF LEGISLATION}

The Argentine courts have a power to declare laws unconstitutional very similar to that vested in the courts of the United States, except that there is no right of appeal to the federal courts from the decision of the highest court of a province declaring a provincial law unconstitutional. The

${ }^{1}$ Alcorta, Amancio: Las garantias constitucionales. 2d.ed.cor. Buenos Aires, F. Lajouane, I897. 488 p.

${ }^{2}$ Intervenciones del gobierno federal en las provincias . . Recopilación de sus antecedentes por Manuel Alberto Urrútia, director de sección . . Buenos Aires, Talleres Sesé y Larrañaga, I904. 2 v. in $\mathrm{I}$.

${ }^{3}$ Giustinian, José: Cuadro sinóptico de las intervenciones del Gobierno Federal en las Provincias, I853-I909. Buenos Aires, I9ro.

4 Varela, Luis Vicente: Estudios sobre la constitución nacional argentina ... Introducción é intervención federal en las provincias; articulos 5 y 6 de la constitución. Buenos Aires, F. Lajouane, I896. 225-3r3 p.

Vedia, Agustín de: La intervención del gobierno federal en las provincias. Buenos Aires, 1904. 
exercise of this power to declare laws unconstitutional was the subject of a small monograph by González Calderón, ${ }^{1}$ published in 1914, which discusses the matter from the point of view of comparative law. The judicial appeal on the ground of unconstitutionality provided in the codes of procedure was the subject of a monograph by Antonio Luis Gil. ${ }^{2}$

\section{EMINENT DOMAIN}

The work of Joaquin V. González as a publicist and statesman has been mentioned on several occasions. He has recently published a work on expropriation ${ }^{3}$ in two volumes which originated in certain speeches before the Argentine Senate. Volume I deals with the theory of the subject and volume 2 with the legislation and the decisions of the courts. A recent pamphlet by Joaquín E. Malarino ${ }^{4}$ on the right and obligations of municipalities in the exercise of eminent domain also warrants mention.

\section{COLLECTED WRITINGS}

Various addresses in Congress, delivered by Joaquin González ${ }^{5}$ between I 898 and 1902 on constitutional questions, particularly the powers of the federal government as opposed to those of the provinces, were published in 1904; and in I9I4 a collection of essays ${ }^{6}$ appeared, the first part of

${ }^{1}$ González Calderón, Juan A.: El poder de declarar la inconstitucionalidad de las leyes. Buenos Aires, S. Suarez, rgr4. $67 \mathrm{p}$.

${ }^{2}$ Gil, Antonio Luis: Recursos de inconstitucionalidad é inaplicabilidad de ley. Buenos Aires, [1878].

${ }^{3}$ González, Joaquin V.: La expropriación ante el derecho público argentino. Discurso en el Senado Nacional, el 30 de julio de 1907. Revisado, ampliado, enriquecido con notas jurídicas, históricas y bibliográficas, hasta I9I4, y seguido de un apéndice, con la legislación y la jurisprudencia federal. v. I Doctrine; v. 2 Legislación y jurisprudencia. Buenos Aires, IgI5. 2 v.

4 Malarino, Joaquín E.: Las municipalidades y el dominio eminente. Buenos Aires, J. Lajouane, I9I4. 28 p.

${ }^{5}$ González, Joaquin V.: Debates constitucionales (1898-1902). La Plata, Talleres gráficos Sesé y Larrañaga, 1904. 2 V. in $\mathrm{I}$.

${ }^{6}$ González, Joaquin V.: Jurisprudencia y politica. Buenos Aires, Juan Roldán, rgr4. 437 p. 
which deal with constitutional questions. Very recently Professor Laurentino Olascoaga ${ }^{1}$ has published two volumes of essays on constitutional law, consisting of critical discussions of particular articles of the constitution and of special topics, such as political parties, the state, elections, nationality, etc.

The collected writings and speeches of Nicolás Avellaneda, ${ }^{2}$ a former president of Argentina, many of which deal with constitutional questions, were published in 12 volumes in I9IO.

\section{CITIZENSHIP}

Citizenship and naturalization have been covered by a special law, No. 346 of October 8,1869 , which is to be found in all the collections of Leyes usuales. The subject is covered in a special work by Ernesto Restelli, ${ }^{3}$ published in 1911 . Various bills and debates on the amendment of the law are reprinted in Carbonell's work Orden y trabajo (infra, p. 158), at page 225 , et seq.

\section{THE PROVINCES}

Since the publication, in 1858 , of Alberdi's "Elements of provincial public law," there have been only a few works devoted to the constitutional law of the provinces, and these have practically all been published in the last few years. Among the best of these books is Professor Juan P. Ramos's ${ }^{4}$ three-volume work, written from a historical point of view. He deals with the historical antecedents of the provincial constitutions, their form and content, and prints the early texts of the provincial constitutions.

${ }^{1}$ Olascoaga, Laurentino: Apuntes sobre derecho politico argentino. Part I. Buenos Aires, "Alsina," I9I4. I64 p. Part 2, Buenos Aires, Impr. A. de Martino, I915. 175 p.

${ }^{2}$ Avellaneda, N.: Escritos y discursos. Buenos Aires, Comp. Sud.America de Billetes, I9ro. I2 v.

${ }^{3}$ Restelli, Ernesto: Adquisición de la nacionalidad en el derecho argentino. Buenos Aires, I9II.

${ }^{4}$ Ramos, Juan P.: El derecho público de las provincias argentinas con el texto de las constituciones sancionadas entre los años I8I9 y I9I3. Buenos Aires, Facultad de Derecho y Ciencias Sociales, I9I4-I9r6. 3 v. v. I, texts, I8I9-I 853 only. 
Professor González Calderón ${ }^{1}$ has published a work on the provincial governments, which deals with the complex of powers residing in the provincial governments, the concurreni powers exercised by the federal and provincial governments, the history of the formation of the provinces, and their institutional and political evolution. A doctor's dissertation, by Mario A. Carranza, ${ }^{2}$ contains a discussion, with the historical development, of the distribution of powers between the federal and provincial governments.

The work of Professor Arturo M. Bas, ${ }^{3}$ of Córdoba, on provincial public law, is used as a text book in the University of Córdoba. It deals with provincial governments, their rights and obligations, their relations with the central government, and with their citizens and each other, a discussion of the three powers of government, and the power over public land, waters, taxation, and other matters, including questions of concurrent jurisdiction between the federal and provincial governments.

Province of Buenos Aires.-The constitution of Buenos Aires was first promulgated in 1854 . New constitutions were adopted in 1868,1873 , and 1889 . A study of the 1868 constitution, as compared with state constitutions of the United States, was published in 1868 by Luis V. Varela. ${ }^{4}$ The debates of the constitutional convention of $1870-1873$, which subsequently adopted the constitution of 1873 , were published officially, under the editorship of Luis V. Varela, ${ }^{5}$ in 1877 . The constitution of 1873 has also been published

${ }^{1}$ González Calderón, Juan A.: Introducción al derecho público provincial. Buenos Aires, J. Lajouane \& $\mathrm{Cia}$, I9I3. 43 r p.

${ }^{2}$ Carranza, Mario A.: Atribuciones nacionales y provinciales. Buenos Aires, Juan A. Alsina, I8g6. 146 p.

${ }^{3}$ Bas, Arturo M.: Derecho público provincial. Conferencias por Arturo M. Bas . . . Córdoba, Impr. de F. Domenici y cía, I909. 496 p.

4 Vareha, Luis Vicente: Estudios sobre la Constitucion de Buenos Aires; por Luis V. Varela . . Buenos Aires, Impr. de la Tribuna, I868. I $59 \mathrm{p}$.

${ }^{5}$ Debates de la convencion constituyente de Buenos Aires, I870-1873; publicacion oficial; hecha bajo la direccion del convencional, Luis V. Varela. Buenos Aires, Impr. de la Tribuna, 1877. 2 v. 
officially. ${ }^{1}$ The debates of the constitutional convention, ${ }^{2}$ sitting between 1882 and 1889 , were published officially, as was the 1889 constitution. ${ }^{3}$ Plans for its revision have been frequent. The leading criticism and draft of a revision of the constitution was published in 1907 by Luis V. Varela. ${ }^{4}$ A recent criticism of the government of the province of Buenos Aires, with a plea for federal intervention under the constitution, was published by Héctor Baudón. ${ }^{5}$

A special place in the literature must be accorded to the important historical work of Adolfo Saldías, ${ }^{6}$ consisting of a history of the province of Buenos Aires from r8 10 to 19ro, published officially on the occasion of the centenary. The important part taken by what is now the province of Buenos Aires in the constitutional evolution of the Argentine Republic makes this an especially valuable work in Argentine constitutional literature.

A study on provincial concessions for railroads and public works in their constitutional aspects was published by Luis V. Varela in 1907 as an expert opinion in a litigation. ${ }^{7}$

Province of Córdoba.-The constitutions of Córdoba bear the dates of $1821,1855,1870,1883$, and 1900 , the last being now in force. A collection of these constitutions was published officially in 1901 ${ }^{8}$ The proceedings of the convention

${ }^{1}$ Constitución de la provincia de Buenos Aires. Edicion oficial. Buenos Aires, Imprenta Americana, 1873. $84 \mathrm{p}$.

${ }^{2}$ Debates de la convención constituyente de la provincia de Buenos Aires, $1882-1889$. Buenos Aires, El Censor, I891-1892. 2 v.

${ }^{3}$ Constitución de la provincia de Buenos Aires. Ed. oficial. Buenos Aires. Estab. tip. “E1 Censor," I889. 64 p.

${ }^{4}$ Varela, Luis V.: Plan de reformas á la constitución de Buenos Aires. La Plata, Imp. Oficiales, 1907.2 v.

${ }^{5}$ Baudón, Héctor Roberto: Politica positiva; la constitución y el gobierno de la provincia de Buenos Aires, necesidad de la intervención nacional. La Plata, Tall. de J. Sese y Ca, I9r4. $290 \mathrm{p}$.

${ }^{6}$ Saldías, Adolfo: Un siglo de instituciones; Buenos Aires en el centenario de la revolución de mayó, escrito por encargo del poder ejecutivo de la provincia de Buenos Aires, r8ro-igro. La Plata, Taller de impresiones oficiales, rgro. $2 \mathrm{v}$.

${ }^{7}$ Varela, Luis V.: Las concesiones provinciales ante el derecho federal argentino. La Plata, Impr. Oficiales, I907. IOI p. $\mathrm{f}^{\circ}$.

${ }^{8}$ Córdoba: Constituciones de 1 a provincia de Córdoba desde I 82 I hasta ıgoo. Córdoba, igor. 
which adopted the constitution of 1855 have been published, ${ }^{1}$ and a discussion of the constitutional reforms adopted in $x 870$ has recently been published in a second edition by Dr. Gerónimo Cortes, ${ }^{2}$ the well-known fiscal of Córdoba.

\section{ELECTION LAW}

The election law, both federal and in the various provinces, has been amended on numerous occasions. Great changes were made by law 4161 of December 29, 1902 on national elections, consisting of 120 articles divided into 5 titles. The law is analyzed in 32 Annuaire de législation comparée (1902), pages $759-763$. This law was considerably amended by law No. 4578 of July 24,1905 , and law No. 4719 of September 26 , 1905. Law No. 81 30 of July I 9, I 9 I I, providing for the drawing of electoral lists under the supervision of federal judges, is printed in the Anuario Oficial (1912), pages 8o-85.

A complete revision of the federal electoral law was effected by law No. 8871 of February I3, I 1912, which consists of 5 or articles divided into io titles. It establishes a measure of proportional representation. The law is printed in Anuario Oficial (1912), pages 86-112, and is briefly described in $4 \mathrm{r}$ Annuaire de législation comparée, pages 896-898.

Law No. 4r6r of 1902 , with its regulating decrees, was published officially ${ }^{3}$ and by the house of Lajouane. ${ }^{4}$ A valuable collection of debates and articles by Joaquín V. González, concerning the electoral laws of 1903 , with various documents, was published in that year.

One of the best, although not recent works on electoral law, is a doctor's dissertation, published in two volumes, by P. E.

${ }^{1}$ Córdoba: Derecho público provincial. Actas de la convención reformadora de la constitución de 1855 , vigente hasta el año 1870 . Córdoba, [1875].

${ }^{2}$ Cortes, Dr. Gerónimo: Exposición de la reforma constitucional sancionada en 1870. 2d ed. Córdoba, 1903.

${ }^{3}$ Ley de elecciones nacionales. Publicación oficial. La Plata, Talleres de publicaciones del museo, 1903. $63 \mathrm{p}$.

${ }^{4}$ Nueva ley electoral, promulgada el 7 de enero de 1903 y decreto estableciendo la división administrativa de la república en I20 circunscripciones electorales. Buenos Aires, F. Lajouane, 1903. 67 p.

${ }^{5}$ González, Joaquín V.: La reforma electoral argentina; discursos del ministro del interior, Dr. Joaquín V. González (I90I-1902) . . Buenos Aires, Impr. "Didot," 1903. 395 p. 
Aguilar. ${ }^{1}$ A brief monograph on popular suffrage published in 1886 by José Nicolás Matienzo ${ }^{2}$ is worthy of attention. Suffrage and elections are the subject of essays in several of the monographs on constitutional law mentioned supra, notably those by Olascoaga, J. V. González, and Matienzo. A recent study on electoral reform by Beccar Varela ${ }^{3}$ deserves special mention.

Each province has its own electoral law for the election of provincial officials. Like the federal law, the laws are frequently amended. A pamphlet by González Calderón ${ }^{4}$ published in 1914 discusses the constitutionality of the present Buenos Aires law of elections. The provinces usually publish their latest election laws officially.

\section{ADMINISTRATIVE LAW}

Under the head of administrative law may be classed all the legislation of a public nature which seeks to regulate the legal relations of individuals with the operation of state functions. We shall discuss first the general works on administrative law and particular topics of administrative law and then proceed to a discussion of individual subjects of legislation coming within the category of administrative laws.

One of the first works on administrative law published in Argentina was a treatise of Ramón Ferreyra, ${ }^{5}$ published in 1865 . As a source of modern law it has little value at the present time. One of the ablest works on the general subject is a treatise by Lucio Vicente López, ${ }^{b}$ consisting of his lectures delivered at

${ }^{1}$ Aguilar, P. E.: Derecho electoral. Tésis. Buenos Aires, "Argos," I893. 2 v.

${ }^{2}$ Matienzo, José Nicolás: La practica del sufragio popular; breve estudio sobre la ley electoral argentina, por José Nicolás Matienzo. Buenos Aires, Impr. de Stiller y Laass, I886. 54 p.

${ }^{3}$ Beccar Varela, Adrián: La reforma electoral; contribución á su estudio. Buenos Aires, Impr. de la Prisión nacional, rgır. 188 p.

${ }^{4}$ González Calderón, J. A.: Constitucionalidad de la nueva ley electoral de la provincia de Buenos Aires. Buenos Aires, I9I4.

${ }^{5}$ Ferreyra, Ramón: Derecho administrativo general y argentino. Buenos Aires, 1865 .

${ }^{6}$ López, Lucio Vicente: Derecho administrativo argentino; lecciones dadas en la Facultad de derecho por el profesor de la materia dr. Lucio V. López. Buenos Aires, Impr. de "La Nación," I902. 473 p. 
the University of Buenos Aires, edited after his death by Beltrán and Romero. After an introduction concerning the work of Lopez and other professors of public law, the lectures themselves discuss the place of administrative law in the legal system, the history of administrative law in America and Argentina since colonial times, the administrative and territorial divisions of Argentina, administrative authorities, their duties, rights, and responsibilities, and the public administration in its various activities for public welfare.

Attention has already been directed to the lectures of Professor José Manuel Estrada delivered at the University in I880 (supra, p. 126), a part of which were devoted to administrative law.

A useful account of the administrative oganization of Argentina and of the operation of the various branches of public administration may be found in the text-book of Ramón Videla, ${ }^{1}$ based upon his lectures at the Faculty of Law.

A recent work consisting of a transcription of the lectures recently delivered at the Faculty of Law by Professor Orma ${ }^{2}$ was published in two volumes in 1914. It is well also to call attention to a descriptive monograph on Argentine constitutional and administrative law by Llambi-Campbell, ${ }^{3}$ published in German in the Bibliothek des offentlichen rechts. In 1915 , J.E. Malarino ${ }^{4}$ commenced the publication of a treatise on administrative law.

\section{ADMINISTRATIVE ORGANIZATION}

The executive and administrative departments of the government were organized by law No. 3727 of 1898 . The law

1 Videla, Ramón: Nociones de derecho administrativo. Buenos Aires, M. Biedma, 1896 . $607 \mathrm{p}$.

${ }^{2}$ Quirós, Herminio J. y Emiliani, Rafael P.: Derecho administrativo. Adaptado al programa vigente en la Facultad de Derecho y Ciencias Sociales de Buenos Aires, teniendo por base las conferencias del catedrático titular de la materia, doctor A. Orma. 2d.ed. Buenos Aires, v. Abeledo, Igr4. 2 v.

${ }^{3}$ Llambi-Campbell, P.: Abriss des staats- und verwaltungsrechts der Argentinischen Republik, von dr. P. Llambi-Campbell . . übers. von amtsgerichtsrat R. Bartolomäus ... Hannover, M. Jänecke, I9II. $252 \mathrm{p}$.

4 Malarino, J. E.: Tratado de derecho administrativo. Buenos Aires, I9I5. v. I, 183 p. 
provides for the jurisdiction and function of the various departments and bureaus of the government. It has been printed officially ${ }^{1}$ with the regulations carrying it into effect. A useful compilation of all the laws whose administration comes within the jurisdiction of the Ministry of Justice, including the administrative laws and the substantive and procedural codes, was published under official auspices in $1899 .{ }^{2}$

On September 10, 1904, law No. 4349, providing for civil pensions of certain employees of the government, was enacted. The Pension Bureau published in r 914 an extensive work containing a census of federal employees and statistics of the pension budget. ${ }^{3}$ It also contains drafts of laws to improve the service.

The province of Buenos Aires in 1888 authorized the official publication of all the provincial laws relating to public administration. The publication was edited by Vicente Villamayor ${ }^{4}$ and contains a vast collection of administrative laws arranged in accordance with the executive department in whose jurisdiction their execution was vested. It includes the laws relating to officers and employees, administrative proceedings in the various departments of the governnent with relevant decisions of the courts, the administration of justice, public education, the law governing municipalities, civil registration, police, militia, inspection, statistics, professional titles, prisons, and finally tax and public land laws of the

${ }^{1}$ Ley de organización de los ministerios nacionales y decretos reglamentarios. Marina-agricultura-obras públicas-guerra-relaciones exteriores y culto-interior-distribución de materias-correos y telégrafos-publicación de memorias. Buenos Aires, Impr. de "La Nación," rgor. $74 \mathrm{p}$.

2 Digesto de justicia. Buenos Aires, Penitenciaría Nacional, I899. I $146 \mathrm{p}$.

${ }^{3} \mathrm{~L}$ a situacion de los funcionarios de la administracion nacional en la actividad y en la pasividad . . Exposición presentada al Señor ministro de hacienda ... por el doctor Hilarion Larguía, presidente de la Caja nacional de jubilaciones y pensiones. Buenos Aires, Imp. A. Moukes e hijos, I9I4. ro35 p.

${ }^{4}$ Leyes, decretos y resoluciones sobre organización y procedimientos administrativos vigentes en la Provincia de Buenos Aires con anotaciones. Publicación oficial. I a Plata, Imp. Buenos Aires, 1888I89o. $4 \mathrm{v}$. in 2. 
province. It does not appear to have been brought down to date since its original publication.

The organic law governing the national territories is No. 1532 of October 16,1884 . It has been amended from time to time. A bill for the revision of the law with a discussion of its antecedents and reasons for revision was presented by the Minister of the Interior, Felipe Yof ré, ${ }^{1}$ in I gor.

\section{MUNICIPALITIES}

It has already been observed that each province has the right of enacting organic laws governing its municipalities. The federal congress in 1882 enacted the organic law of the city of Buenos Aires, the capital of the country and by far the most important city. This organic law of the Capital, No. I260, has been revised and amended on several occasions, particularly by a law of October 25, x 890, and by law No. 5099 of 1904. Law No. 4058 of 1902 concerns municipal taxation in Buenos Aires. The organic law or charter with its amendments is published at frequent intervals. One of its recent issues was in $1907 . .^{2}$ The law itself with its amending statutes and many of the important municipal ordinances are printed in the Anuario Oficial (I9I2), pages I394-I53 I.

A brief account of the public services and administrative bodies operating in the city of Buenos Aires is given in an article printed in the Monthly Bulletin of the Bureau of American Republics, for November, 1908, and published separately.

Attention has already been called (supra, p. 25) to the ordinances enacted by the municipal council and published annually. A valuable work on the legislation and administrative operation of the city of Buenos Aires since r8ro has been published recently by José Saenz Valiente. ${ }^{3}$

1 Territorios Nacionales: Antecedentes y motivos del proyecto de ley orgánica de los territorios nacionales presentados al Hon. Congreso por el señor ministro del interior, D. T'elipe Yofré. Buenos Aires, rgor.

2 Ley organica de la Municipalidad de Buenos Aires. Buenos Aires, I907. $73 \mathrm{p}$.

${ }^{3}$ Saenz Valiente, José M.: Régimen municipal de la ciudad de Buenos Aires. Su organización y funcionamiento desde I8IO. Buenos Aires, Impr. A. Grau, 1911. 575 p. 
A collection of the decisions and rulings of the courts of Buenos Aires in municipal matters was published in two volumes in $1905 .{ }^{1}$ The opinions ${ }^{2}$ of the corporation counsel of Buenos Aires for the period 1878-1882 were published officially in 1883 . The work contains 28 opinions on matters of public works; 48 on economic matters; 29 on matters of public safety and sanitation; and 22 on various topics of municipal administration.

The organic law of municipalities is published officially by the various provinces at frequent intervals. The last issue of the organic law of which information has been obtainable has been in 1909, for Buenos Aires; 1904, for Entre Rios; 1897, for Jujuy; 1902, for Rioja, and I900, for Mendoza. Each province also has its laws on eminent domain. Mention has been made (supra, p. 133) of Malarino's recent treatise on municipalities and the exercise of eminent domain.

\section{CLAIMS}

Mention has been made of law No. 3952 of October 6, 1900, which gives private persons the right to sue the government civilly provided the head of an executive department has made no decision on a claim for six months and three months have passed since a special request for a decision was made. If the state is assessed in damages, however, judgment can not be executed, so that the decision has a declaratory effect only.

Mention has also been made under the head of civil procedure (supra, p. 102) of the code of procedure in contentious-administrative matters enacted by the province of Buenos Aires on the initiative and following the draft of Luis V. Varela. ${ }^{3}$ A

${ }^{1}$ Municipalidad de la Capital. Sentencias y resoluciones judiciales en asúntos de carácter municipal. Buenos Aires, I905. 2 v.

${ }^{2}$ Dictamenes del asesor municipal Dr. D. Luis Beláustegui, I878-1882. Buenos Aires, Biedma, r883. 228 p.

${ }^{3}$ Código de procedimientos de lo contencioso-administrativo para la provincia de Buenos Aires. En vigencia desde el $\mathrm{I}^{\circ}$ de marzo de I906. Precedido del informe ilustrativo de la ley y con notas en cada artículo por el autor del proyecto, Dr. Luis V. Varela. Ed. conforme con el texto oficial. Buenos Aires, J. Lajouane \& cia, I9o6. I $72 \mathrm{p}$. 
work on contentious administrative jurisdiction has been published by Miguel Romero. ${ }^{1}$

\section{IMMIGRATION AND COLONIZATION}

Argentina has always invited immigration, on which its economic future indeed largely depends, and has enacted liberal laws concerning the development of public lands. The original law of immigration of October 19, 1876, and the regulation of March 4, 1880, were published officially in 1907 by the Department of Agriculture, ${ }^{2}$ within whose jurisdiction immigration falls. The immigration laws are also to be found in the Anuario Oficial (1912) pages 138-166. The various statutes affecting the subject are listed at page 34 of the volume on Argentina in the "Commercial laws of the world."

Attention has been called to law No. 7029 of r9ro on the protection of the state against undesirable immigration. The law was discussed in all the periodicals of the year and, among others, attention may be directed to a valuable article by Rodolfo Moreno in the Revista argentina de ciencias politicas (1910), pages 340-376.

Argentina has recently enacted a new law on immigration fixing the conditions of residence and grounds of exclusion and deportation in conformity with articles 14,20 , and 25 of the constitution. Its restrictive provisions resemble closely those of the United States immigration laws. It entered into effect in October, 19r6.

At page 33 of the introduction to the volume on Argentina in the "Commercial laws of the world," Ernesto Quesada gives a list of laws relating to the encouragement of production in various industries of Argentina.

\section{PUBLIC LANDS}

Immigration and the development of public lands are intimately related topics and are often indeed considered together. An important compilation of all the Argentine

1 Romero, Miguel: Lo contencioso administrativo. Buenos Aires, [I908?].

${ }^{2}$ Ley de inmigración y reglamento de desembarco de inmigrantes. Publicación oficial. Buenos Aires, Impr. Arcuri \& cia, 1907. 26 p. 
laws, decrees, and regulations on public lands, immigration, colonization, agriculture, commerce, and industry from 18 ro to 1900 , arranged chronologically, was printed under the auspices of the Ministry of Agriculture ${ }^{1}$ in 1901. There is an alphabetical index, very poorly classified, at the end of the book. The work is of some utility in the investigation of concessions.

An important change in the land laws under federal jurisdiction was effected by law No. 4167 of January 8 , 1903, with its regulating decree of November 8, I906. The law has been published in various languages ${ }^{2}$ for the benefit of foreigners and in an excellent official Spanish edition ${ }^{3}$ and is to be found with its regulating decree in the Anuario. Oficial (I912) pages $36 \mathrm{I}-376$.

The law for the exploitation of forests was enacted on October 4, 1906, and is printed in the Anuario Oficial (1912) at page 377. Proposals for the amendment of the law, with explanatory notes and documents, were submitted by the Executive to Congress in September, $1915,{ }^{4}$ with a view to their enactment.

A compilation of the federal laws and other provisions relating to public lands, colonization, and agriculture was published officially ${ }^{5}$ in 1894 , bringing down to date similar compilations previously issued.

${ }^{1}$ Digesto de leyes, decretos y resoluciones relativos á tierras públicas, colonización, inmigración, agricultura y comercio, 18ro-rgoo. Publicación hecha bajo los auspicios del Ministerio de agricultura. Buenos Aires, Compañía sudamericana de billetes de banco, I9or. $1342 \mathrm{p}$.

${ }^{2}$ Land-law, sanctioned by the Argentine Congress and promulgated on the 8th January I903. Buenos Aires, Argentine meteorological bureau, 1903. $15 \mathrm{p}$.

${ }^{3}$ Ley de tierras no. $4{ }^{167}$, sus decretos reglamentarios y disposiciones generales en vigencia que rigen la venta y el arrendamiento de la tierra pública. Buenos Aires, Tall. de pub. de la Dir. meteorológica, I9r3. I34 p.

4 Ley de bosques y yerbales. Proyecto elevado por el poder ejecutivo al honorable Congreso nacional con fecha 30 de septiembre de r9r5. Notas explicativas y anexos. Buenos Aires, Tall. graf. del Ministerio de agricultura, I9r $5.89 \mathrm{p}$.

5 Tierras, colonias y agricultura. Recopilación de leyes, decretos y otras disposiciones nacionales ordenada por el director general del ramo doctor D. G. de la Fuente. Buenos Aires, r894. 
Numerous studies have been made on the public land legislation of Argentina. A classic on the subject is that by Nicolás Avellaneda, ${ }^{1}$ an ex-President of Argentina, published in 1865. It has recently been reprinted. A pamphlet critically examining the land legislation was published in 1894 by Melitón Gonzalez. ${ }^{2}$ One of the best treatises on the subject is that of Professor Eleodoro Lobos ${ }^{3}$ published in 1900. The law students' association, Centro estudiantes de derecho, in 1912, published notes on the public land legislation of Argentina, taken in the course given by Sanchez Sorondo. ${ }^{4}$

An interesting work of Gómez Langenheim, ${ }^{5}$ published in 1906, deals with colonization and public-land legislation and policy. It includes a history of colonization in many countries, a study of the immigration and colonization problem in Argentina, an analysis of the principal laws and decrees enacted since $18 \mathrm{ro}$ with their practical results and a study of the public-land policy, including agricultural credit and the administrative measures necessary to encourage colonization. A report by Vedia and Zorilla, ${ }^{6}$ appointed to present a draft of a new public-land law in 1894 , is of interest as a study of the public-land problem.

It has been observed that each province has jurisdiction over its own public lands. Compilations of the provincial

'Avellaneda, Nicolás: Estudios sobre las leyes de tierras públicas . . . 2 ed. Buenos Aires, Impr. del Siglo, I865. 308 p. Reprinted, Buenos Aires, La facultad, de J. Roldán, IgI5. $292 \mathrm{p}$.

2 Gonzalez, Melitón: Estudio de la legislación vigente sobre tierras públicas nacionales de la República Argentina, presentado en julio de I89 I al exmo. gobierno nacional por Melitón Gonzalez. Buenos Aires, Impr. del Congreso, r894. 44 p.

${ }^{3}$ Lobos, Eleodoro: Legislación de tierras. Buenos Aires, rgoo.

- Centro estudiantes de derecho. Tierra publica. Legislación Argentina. Notes of course given by Matias G. Sanchez Sorondo (taken by C. C. Malagarriga, Faustino Infante, and Daniel A. Infante). Buenos Aires, La Union, I912. $132 \mathrm{p}$.

- Gómez Langenheim, Antonio: Colonización en la República Argentina ... Buenos Aires, M. Biedma é hijo, rgo6. 462 p.

- Comisión sobre tierras públicas é inmigración: Tierras públicas é inmigración. Informe y proyecto de ley presentados al ministro de justicia, c. é instrucción pública por la Comisión especial nombrada por el poder ejecutivo. Buenos Aires, Impr. de J. A. Berra, I894. $64 \mathrm{p}$.

$71624^{\circ}-17-10$ 
public-land laws and decrees were issued by Córdoba in 1903,1 by Corrientes ${ }^{2}$ in 1905 , and by Mendoza ${ }^{3}$ in 1902 . A compilation of the laws enacted in the province of Buenos Aires from $1810-1835$ was published by J. M. Muzlera ${ }^{4}$ in 1885 . Another compilation of laws and administrative regulations for the period $1811-1865$ was published officially in $1865^{\circ}$

The laws and regulations regarding the use of water in several Latin-American countries, including Argentina, have been discussed in a paper by Rome G. Brown, ${ }^{8}$ to which Phanor J. Eder made valuable contributions.

\section{RURAL CODE}

Each province in Argentina, and the federal government with respect to the national territories, has enacted a rural code which comprises rules for the government of public lands, cattle, boundaries, rural police, municipalities, justices of the peace, irrigation, agriculture, mining, forests, and other matters connected with the land.

In 1892 Juan Goyena, ${ }^{7}$ a compiler of several works; published a rural and agricultural digest, which compiles the laws, decrees, administrative resolutions, and decisions of the federal and provincial courts on the subjects mentioned. It was intended that the compilation should cover 16 or 17 vol-

${ }^{1}$ Córdoba (Prov. of Arg.): Recopilación de leyes y decretos sobre tierras públicas. Córdoba, r903.

${ }^{2}$ Corrientes (Prov. of Arg.): Leyes y decretos reglamentarios para la venta de los centros agricolas. Corrientes, r905.

${ }^{3}$ Mendoza (Prov. of Arg.): Recopilación de leyes sobre tierras públicas, I823 á r902. Mendoza, 1902.

- Muzlera, Joaquin M.: Recopilación de leyes, decretos y resoluciones de la Prov. de Buenos Aires sobre tierras públicas, desde 1810-1835. La Plata, Isidro Sola Sons, I885. $3 \mathrm{v}$.

${ }^{6}$ Buenos Aires (Prov.) Instrucciones á los agrimensores y colección de leyes, decretos y demás disposiciones sobre tierras públicas desde I8I I hasta febrero de 1865 . Buenos Aires, Impr. del Comercio del Plata, 1865. 600, 124 p.

${ }^{6}$ Brown, Rome G.: Laws and regulations regarding the use of water in Pan-American countries . . . New York, Evening post job pr. of., 1916. $54 \mathrm{p}$.

'Goyena, J.: Digesto rural y agrario; recopilación de leyes, decretos, resoluciones, fallos de la corte federal y provinciales, I8ro á I89r. Buenos Aires, Juan A. Alsina, 1892. $3 \mathrm{v}$. 
umes, one for the federal legislation, two or three for the province of Buenos Aires, and one volume for each of the other provinces. The work does not appear to have been carried any further than three volumes, volume I covering the federal legislation on rural andagricultural matters, and volumes 2 and 3 dealing with the province of Buenos Aires. Code provisions and other miscellaneous legislation on the subject have been carefully culled out and brought together.

The rural code for the national territories has been published from time to time by the house of Lajouane. The most recent edition appears to be that of $1912,{ }^{1}$ which includes law No. 707 I of September I3, I910, partially amending article $4 \mathrm{I}$ of the rural code concerning the price or sale of pasture and other land.

An important compilation of articles published under the title "Argentine rural legislation" has been issued in a third edition in 1916." It contains contributions by leading authorities on agricultural insurance, the mortgage system, agricultural warrants, waters, roads, sanitation, and other topics incidental to rural legislation.

Each province, as already observed, has its own rural code. That of the province of Buenos Aires, prepared by Dr. Alsina, dates from I862. It is republished at intervals by Lajouane. ${ }^{8}$ In I9Io, Drs. Sanchez Sorondo and M. A. Avellaneda ${ }^{4}$ were instructed to draft a new code, which they duly completed. It consists of 424 articles dealing with roads and highways, cattle, farming, colonization, agriculture, game, and fishing. The codes of the various provinces are published at frequent intervals.

1 Código rural de los territorios nacionales. Nueva ed. Buenos Aires, Lajouane, Igr2.

${ }^{2}$ Legislación rural argentina. $3^{\text {rd }}$ enl. ed. Buenos Aires, V. Abeledo, I9r6. $337 \mathrm{p}$.

${ }^{3}$ Código rural de la provincia de Buenos Aires. Nueva edición. Seguida de la ley de caminos, cercas y tranqueras; ley sobre marcación de ganado y el reglamento de cerreras. Buenos Aires, Lajouane, Igog. $83 \mathrm{p}$.

4 Sanchez Sorondo, M. H. \& M. A. Avellaneda: Proyecto de código rural para la provincia de Buenos Aires. Buenos Aires, A. de Martino, I9ro. $213 \mathrm{p}$. 
The Ministry of Agriculture in 1903 published a compilation of the laws relating to fishing and game ${ }^{1}$ in the provinces and in the national territories. The same Ministry published in I90I a work on agricultural industries and stock breeding ${ }^{2}$ and certain rules and regulations governing the matter for the particular benefit of immigrants.

\section{MINING LAW}

By virtue of the law of August 26, I875, in execution of the provision of the constitution providing for the draft of a national mining code on the basis that mines are the property of the nation and of the province where located, the executive commissioned Dr. Enrique Rodriguez of Córdoba, a specialist on the subject who had spent many years in the mining center of Copiapo, Chile, to draft a code for Argentina. The work was eight years in preparation and, though inadequate, is a monument to the learning and ability of its author. The draft, in part based upon the Ordenanza de Nueva España, which so greatly influenced mining law in the new world, was published officially in $1885 .^{3}$ The draft is important because of the extensive notes, commentaries and explanations of the author under each of its 4I4 articles and practically all new editions of the code are supplied with Rodriguez's notes. The draft, divided into twenty titles, deals with mines and their ownership, persons who may acquire mines, the relation between owner and miner, special dispositions on minerals of the second and third catagories as classified in the code, questions of discovery and denunciation and other modes of acquiring mines, mining units and demarcation, effect of

' Leyes, decretos y disposiciones sobre el ejercicio de la caza y de la pesca y la destrucción de animales dañinos en las provincias y territorios nacionales. Buenos Aires, Talleres de publicaciones de la Oficina meteorológica argentina, rgo3. $77 \mathrm{p}$.

${ }^{2}$ Miatello, Hugo: Industrias agrícolas y ganaderas en la República Argentina (Datos para los inmigrantes agricultores) por Hugo Miatello . . . Buenos Aires, Tall. tip de la Penitenciaría nacional, rgor. I74 p.

${ }^{8}$ Rodriguez, Enrique: Proyecto de código de minería para la República Argentina redactado por el Dr. D. Enrique Rodriguez. Con notas. Buenos Aires, M. Biedma, I885. 581 p. 
claims, conditions of concessions, mining engineers, contracts and companies, and various civil rights in connection with mining property. The draft was submitted to a code conmission of the chamber of deputies which introduced certain amendments. The code ${ }^{1}$ was finally adopted, in 375 articles divided into 17 titles, on December 8, 1886 , coming into force May I, I887. By decree of September 20, 1889, a commission was appointed for the revision of the code. They reported ${ }^{2}$ in 1890 and drafted a new code which does not appear to have been enacted into law.

New decrees, however, governing particular matters, such as exemption from taxes in certain districts for specific periods, have been enacted from time to time. Editions of the code with its supplementary decrees have been published by the house of Lajouane, ${ }^{3}$ the most recent edition bearing the date I9I4.

A brief sketch of the mining law of Argentina is contained in the descriptive volume on Argentina published in 1903 by the Bureau of American Republics. ${ }^{4}$ In connection with a descriptive report of the mines and mineral resources of the Argentine, Henry D. Hoskold discussed provisions of the mining law. One such report was prepared in $1889^{5}$ for the

1 Código de minería de la República Argentina, sancionado por ley del honorable Congreso de 8 de diciembre de r886. Ed. oficial. Buenos Aires, Imp. lit. y enc. de la Tribuna nacional, 1887. $537 \mathrm{p}$.

${ }_{2}^{2}$ Proyecto de reformas al código de minería presentado por la Comisión nombrada por decreto del poder ejecutivo nacional de setiembre 20 de I889. Buenos Aires, Taller tipográfico de la Penitenciaría, I890. $59 \mathrm{p}$.

${ }^{3}$ Código de minería de la República Argentina, con las notas del doctor Enrique Rodriguez. Neuva edición completada con los decretos relativos a minas. Buenos Aires, Iajouane, rgr4. $294 \mathrm{p}$.

${ }^{4}$ International Bureau of the American Republics, Wash., D. C.: Argentine Republic. A geographical sketch, with special reference to economic conditions, actual development, and prospects of future growth, compiled by the International bureau of the American republics. I903. Washington, G. P. O., I903. 376 p.

${ }^{5}$ Hoskold, Henry Davis: Memoria general y especial sobre las minas, metalurgia, leyes de minas, recursos, ventajas, etc. de la explotación de minas en la República Argentina. Buenos Aires, Impr. del "Courrier de la Plata," x 889.598 p. 
Paris Exposition, in Spanish, and in 1904 in Spanish and English for the St. Louis Exposition ${ }^{1}$.

The literature on mining law is limited. Sanchez Sorondo has published some articles in the Revista de la facultad de derecho and notes of a course of lectures in a small treatise, ${ }^{2}$ published in 1909. Joaquin V. Gonzalez published an article on a special branch of mining law, namely, persons who may acquire mining rights, in the Revista juridica de ciencias sociales for July, I 895. Horacio H. Dobranich ${ }^{3}$, a fifth year law student, published in $\mathrm{r} 9 \mathrm{I}$, under the auspices of the Centro estudiantes de derecho, a small volume containing notes on mining legislation.

A small work dealing particularly with the federal procedure in mining cases was published in 1912 by Joaquin Malarino. ${ }^{4}$ Provincial decrees on the few mining matters within provincial jurisdiction are to be found in the provincial legislation.

\section{RAILROADS}

The railroads of Argentina are in small part government owned, but are principally operated by foreign private interests under government concessions. The fundamental general railroad law is No. 2873 of November 24, 1891. This law, with law No. 2274 creating a Bureau of Railways; the inspection law, No. 961 of 1878 , with its subsequent regulation; the decree providing for receivers of guaranteed railroads; the law for the introduction of material for railroad construction; and law No. 2835, for the payment of guaranties promised to railroads, were published in a compilation issued by the Ministry of the Interior ${ }^{5}$ in 1892. Law No. 5315 of October 1, 1907, with its regulating decree governing railroad concessions, was

${ }^{1}$ Hoskold, Henry Davis: Official report upon the mines, mining, metallurgy and mining laws, etc., etc., of the Argentine Republic. Buenos Aires South American Bank Note Co., I904. 474 p.

${ }^{2}$ Sanchez Sorondo, M. G.: Apuntes. Minas y rural. Buenos Aires, roog.

${ }^{3}$ Dobranich, Horacio H.: Apuntes de legislación de minas. Buenos Aires, Imp. A. Grau, I9Ir. I04 p.

${ }^{4}$ Malarino, Joaquin E.: Legislacion minera, o jurisdicción y procedimiento federal. Buenos Aires, Lajouane, I9r2.

${ }^{5}$ Ferrocarriles nacionales. Leyes y decretos de aplicación general. Buenos Aires, Impr. "La Nueva universidad," I892. II p. 
published officially ${ }^{1}$ in 1908 . The law is analyzed in 2 Revue de l'institut de droit comparé, pages $145-149$, and is also printed in the Anuario Oficial (1912), page 342 et seq.

Law No. 6320, of August 5, 1909, modifies the general railroad law in the part relating to administrative inspection and creates a new division in the Ministry of Public Works of three sections (administration, construction, tariff and statistics), at the head of which is an inspector general. Law No. 6757, of September 30, 1909, creates a general railroad commission of the government charged with the construction and exploitation of lines not granted by concession to private enterprise.

A compilation of the laws, decrees, concessions, and contracts relating to national railroads from $\mathrm{I} 854$ to 1885 was edited by Luis F. Araoz ${ }^{2}$ in 1891. Another collection in seven volumes covering the same subject, including street railways, was published officially ${ }^{3}$ in a second edition in 1904 , with supplementary volumes in 1911 and 1913 . It is arranged by railroad and route, except volumes I and 6 , which contain laws and decrees of a general character.

A compilation of the laws, ordinances, decrees, and concessions for street railways in the municipality of Buenos Aires ${ }^{4}$ with an express indication of those which have expired, was published in 1908 , bringing down to that date and revising similar volumes published previously.

A work by Ernesto Corvalán ${ }^{5}$ on the administrative jurisdiction of Argentine railroads discusses the constitutional

${ }^{1}$ Ley $\mathrm{n}^{\circ} 53 \mathrm{I} 5$ sobre concesiones de ferrocarriles y su decreto reglamentario. Decreto creando la Comisión administradora del fondo de caminos y su decreto reglamentario. Publicación oficial. Buenos Aires, Taller tip. del Ministerio de obras públicas, 1908. 33 p. Also r9ro ed., including laws 5703 and 6369 .

${ }^{2}$ Araoz, Luis F.: Leyes, decretos, contratos, etc., sobre ferrocarriles nacionales desde 1854 á 1885 . Buenos Aires, "Mariano Moreno," I89I-92. $2 \mathrm{v}$.

${ }^{3}$ Leyes, contratos y resoluciones referentes a los ferrocarriles y tranvías a tracción mecánica de la Rep. Argentina. 2nd ed. Buenos Aires, Tip. de Penitenciaria nacional, 1904. v. I-5. v. 6 and 7 , Freites \& Cia, I9II-I9r3.

${ }^{4}$ Recopilación de leyes, ordenanzas, decretos y contratos de concesiones de tranvías. Buenos Aires, Impr. de G. Kraft, i908. I730 p.

${ }^{5}$ Corvalán, Ernesto: Jurisdicción administrativa en los ferrocarriles de la república. 2nd ed. Buenos Aires, Ortega y Redaelli, Igri. $25^{8} \mathrm{p}$. 
questions involved in the administrative control and the concession and exploitation of railroads, jurisdictional conflicts between the province of Buenos Aires and the nation, and a study of the legal position of employees with respect to the public service. A second edition of the work appeared in I9II.

\section{PUBLIC WORKS}

The laws and decrees and regulations concerning public works are to be found in the annual report of the Department of Pablic Works. An interesting account of the public works undertaken from 1898 to 1904 was published in 1904 by the Ministry of Hacienda ${ }^{1}$ (Treasury).

An extensive compilation of the laws relating to public works in the province of Mendoza was published officially ${ }^{2}$ in r910. In recent years many appropriations have been made for public buildings and public works of various kinds, including national monuments.

A building law of 375 articles, the work of Dr. Rodriguez, was sanctioned in 1886 . "There is practically no literature on the law.

\section{MERCHANT MARINE}

An extensive compilation by Goyena ${ }^{3}$ contains the various matters of interest connected with the establishment and operation, and the rights and obligations involved in transportation by water, apart from the provisions of the civil and commercial codes. Goyena's compilation is divided into nine parts. The first deals with the laws and decrees, matters of accounts, employees, navigation and construction of ships, fishing, police, flags, railroad concessions affecting navigation, and judicial decisions governing the matter; the sec-

1 Memorandum al Ministerio de hacienda sobre las obras públicas nacionales, r898-r904. Buenos Aires, Compañía Sud-Americana de billetes de banco, r904. $96 \mathrm{p}$.

${ }^{2}$ Mendoza (Prov. of Arg.): Recopilación de leyes correspondientes al Min. de Industrias y Obras Publicas. Mendoza, rgro. $4 \mathrm{v}$.

${ }^{3}$ Goyena, Juan: Digesto de marina; recopilación de leyes, decretos, ordenanzas, reglamentos, etc., que corresponden á la marina mercante y de guerra, ampliada con otras diversas disposiciones estensivas á toda la administración nacional; toda la documentación es la vigente hasta 1905. 4th ed. corr., anotada y aum. Buenos Aires, Imprenta, calle de México, núm. 1422, 1905. 1315 p. 
ond, with treaties of commerce and navigation; the third, with maritime commercial decisions of the courts and rulings of the stock exchange; the fourth, with regulations and provisions relating to navigation, including ocean and river transportation, tariffs, port dues, and court decisions governing the subject; the fifth, with steam packets, mail steamers, passengers, canals, loading and discharge, fiscal dues, steamboiler inspection; the sixth, with laws and regulations on maritime sanitation, and taxes and judicial decisions on the subject; the seventh, with pilots and lighthouses; the eighth, with Argentine and foreign consuls, and regulations concerning them, including fees, international conventions, etc.; and the ninth, with the navy and special regulations in foreign countries governing warships.

The draft of a law concerning coastwise navigation, with a report by Ricardo Pillado, ${ }_{1}$ Director of the Bureau of Commerce and Industry, was published in 1908 and the law itself, No. 7049, was enacted in $1911 .^{2}$ The administration of the port of Buenos Aires is provided for by law No. 8389 of October 13, I9I I.

\section{IRRIGATION}

The irrigation law of Argentina, No. 6546, was enacted in 1910. It has been published ${ }^{3}$ in Santiago, Chile. Law No. 3646 had invited a study of the question as to how the water of the Republic is to be best distributed and conserved. A number of articles on the subject subsequently appeared in periodicals. Attention may again be called to Rome G. Brown's study on waters and water rights (supra, p. 146.)

\section{POSTS AND TELEGRAPHS}

The postal law dates from October 10, 1876. This with its tariffs is printed in the Anuario Oficial (I9I2), pages

1 Proyecto de ley de cabotaje. Mensaje del poder ejecutivo al honorable congreso nacional é informe elevado á S. E. el Señor ministro de agricultura D. Ezequiel Ramos Mexia, por Ricardo Pillado, director de comercio é industria. Buenos Aires, Talleres de publicaciones de la Oficina meteorológica argentina, 1908. 68 p.

${ }^{2}$ Navegación y comercio de cabotaje. Ley no. 7049. Buenos Aires, Talleres gráficos de L. J. Rosso y cia., IgIr. 2 I p.

s Marin Vicuña, Santiago: La lei de regadio de la Republica Arjentina. Santiago de Chile, Impr. Cervantes, rgro. 27 p. 
305-342. The telegraph law dates from October 7,1875 . The law governs the relations with the state, the relations with individuals, the contract for transmission and questions of legal liability. It is printed in the Anuario Oficial (I912), pages 282-305. A compilation of the postal and telegraph legislation, conventions and regulations, and the organization and administration of the service from 1858 to I 900 was published officially by the Minister of the Interior ${ }^{1}$ in r 901 .

The postal administration of Dr. Carlos Carles was an important one in the development of the postal and telegraph service. A compilation of postal and telegraph $\operatorname{codes}^{2}$ was published in different editions in 1893,1895 , and 1898 . They include the general organization of the service, all forms of postal orders and documents, statistics, regulations of every kind affecting the service, the universal postal union and postal and telegraph conventions. The legislation governing telegraphs with the rates of transmission was published officially ${ }^{3}$ in $x$ 898. A work on the reorganization of the Argentine postal and telegraph service, with the regulations, numerous documents and commentaries, was published in 1909 by Eduardo Olivera, ${ }^{4}$ formerly director of the post and telegraph service.

The parcel-post convention between the United States and the Argentine Republic was signed in Washington ${ }^{5}$ on March 12, 1915 .

${ }^{1}$ I.egislación postal y telegráfica. Convenciones-reglamentos-administración. 1858-1900. Publicación oficial. Buenos Aires, Taller tipográfico de la Penitenciaría nacional, rgor. 664 p.

${ }^{2}$ Códigos postal y telegráfico dictados durante la administración del Dr. C. Carles . . . Buenos Aires, Compañia sud-americana de billetes de banco, 1898 . $1444 \mathrm{p}$.

${ }^{3}$ Legislación y tarifas. Telégrafos nacionales. Publicación oficial, vol. XII. Buenos Aires, Compañia sud-americana de billetes de banco, I898. $243 \mathrm{p}$.

- Olivera, Eduardo: La reorganización del correo Argentino. Buenos Aires, Comp. sud-americana de billetes de banco, 1909. $624 \mathrm{p}$.

5 Parcel-post convention between the United States and the Argentine Republic. Washington, G. P. O., 1915. 13 p. 
The legislation governing a submarine cable to Europe with explanatory documents and reports was published by the Department of Posts and Telegraphs ${ }^{1}$ in 1910.

\section{WEIGHTS AND MEASURES}

The Department of Commerce and Industry is under the jurisdiction of the Minister of Agriculture. A division of the Department of Commerce has jurisdiction of weights and measures. The law on the subject, adopting the metric system, is No. 845 of July 13, I877, printed in the Anuario Oficial (1912), pages 235-238. A discussion of the system of weights and measures by Dr. Valentin Balbin, ${ }^{2}$ was published in $\mathrm{r} 88 \mathrm{I}$. The draft of the law in force with proposed amendments and an extended report on the subject by Carlos Aubone ${ }^{8}$ was published officially in $19 \mathrm{I}$.

\section{SOCIAL LEGISLATION}

\section{LABOR LAWS}

No other country in South America appears to have taken so much interest in social and labor legislation as the Argentine Republic. Although the subject has been debated in Congress for many years and the socialist party has acquired a considerable influence in initiating legislation, the labor legislation in force is confined to practically very few laws. Among these the most important are law No. 466r of August 31, 1905, and its regulation of July 20, I9I I, imposing Sunday rest in certain trades and industries in the Capital and national territories, a law which has been adopted in a number of provinces; law No. 5291 of September 30, 1907, promulgated October 14, 1907 , and its regulation of February 20, 1908, restricting the work of women and children in factories by providing that

${ }^{1}$ Cable argentino a Europa. Via Ascension. Antecedentes, contrato, informes y documentos ilustrativos. Buenos Aires, rgro. $27 \mathrm{I} \mathrm{p.}$

${ }^{2}$ Balbin, Dr. Valentin: Sistema de pesas y medidas. Buenos Aires, r88r.

${ }^{3}$ Proyecto de ley de pesas y medidas é informe á su respecto, por Carlos Aubone. Disposiciones vigentes sobre la materia. (Publicación oficial.) Buenos Aires, Imp. J. H. Kidd \& cía, rgrr. 128 p. 
children under ro and those who have not completed their compulsory education requirement can not be the subject of contract, nor those less than 16 employed in night work; a law of 1907 establishing the National Department of Labor (with its revision by law 8999 of October 8, 1912, and regulation of January 2, 1913) whose quarterly bulletins are of much importance; and the law establishing employment agencies in the provinces and territories, which appears not yet to have been carried into effect.

In 1916, law No. 9688, governing employers' liability in cases of accident, was enacted. The law has been translated into English by F. W. Palacios in the November and December, 19r6, numbers of International Law Notes. The Executive decree of January 25, 1916, printed in the Boletin oficial, regulates the law.

The Sunday law is paraphrased in 35 Annuaire de législation comparée, $72 \mathrm{I}$ and the law regulating the work of women and children in 2 Revue de l'institut de droit comparé pages 143-145.

A compilation of the Sunday law, the women and children labor law, the various regulating decrees and municipal ordinances on employment agencies and industrial establishments and factories in Buenos Aires was published by the Department of Labor ${ }^{1}$ in 1913 .

Very recently, Alejandro M. Unsain, ${ }^{2}$ Chief of Division in the Department of Labor, issued an annotated edition of the Argentine labor laws with their regulating decrees.

The Bulletin ${ }^{3}$ of the National Department of Labor, published quarterly since 1907 , contains matters of interest in labor legislation, including laws, decrees, new bills introduced, debates and many valuable articles, decisions of the courts,

' Leyes de descanso dominical, reglamentaria del trabajo de mujeres y de menores y orgánica del Departamento nacional del trabajo. Decretos reglamentarios. Ordenanzas municipales sobre agencias de colocaciones y establecimientos industriales. Buenos Aires, Impr. "Alsina," r9r3. ro9 p.

${ }^{2}$ Unsain, Alejandro M.: Leyes obreras argentinas. Recopiladas y anotadas con los decretos que las reglamentan. Buenos Aires, I9r6, ${ }^{2} 5^{2} \mathrm{p}$.

${ }^{3}$ Argentine Republic. Departamento nacional del trabajo. Boletin. Buenos Aires, rgo8 -. 4 Bulletins, (I v.) per year. 
recent foreign labor legislation, and labor statistics. The Anuario Oficial (1912) at page 519 et seq. prints a number of laws affecting labor and industries in Argentina and its provinces. The material is extracted largely from official reports and authoritative treatises. Wages in industries constitutes an important part of the report.

The late Juan Bialet Massé, a Spanish physician and lawyer resident in Córdoba, devoted a great part of his life to the study of the condition of the working men in Argentina. His three volume report ${ }^{1}$ to the Minister of the Interior, made after an extensive investigation in the field, became the basis of a bill containing 466 articles drafted largely by him and introduced by Joaquin V. González, ${ }^{2}$ Minister of the Interior, in 1904. This bill, very properly called a national labor code, is a far reaching synthesis of modern labor laws covering indeed more advanced phases of social legislation than are to be found in Germany, Belgium, or other leading countries in this respect. The bill, or code, is preceded by an extended report or message which is regarded as one of the leading contributions to the question of governmental control of social welfare.

An essay on the spirit of the Gonzallez bill was published by Juan Bialet Massé ${ }^{3}$ in 1904 , delivered as a lecture at the University of Córdoba. A critical essay upon the González bill was published by the sociologist José Ingegnieros, ${ }^{4}$ in which he discusses the evolution of socialism, the nature of political socialism, and analyzes critically the González bill with the socialistic program in Argentina.

${ }^{1}$ Bialet Massé, Juan: Informe sobre el estado actual de las clases obreras en el interior de la República, informe presentado al Excmo. Sr. Ministro del Interior. Buenos Aires, I9OI-2. $3 \mathrm{v}$.

${ }^{2}$ González, Joaquin V.: Proyecto de ley nacional del trabajo. Buenos Aires, I904.

${ }^{3}$ Bialet Massé, Juan: El socialismo argentino, el espiritu de la ley nacional del trabajo; conferencia dictada en el salón de la Bibliotéca de la Universidad de Córdoba el miércoles, 27 de julio de r904, por el Dr. Juan Bialet Massé. Buenos Aires, A. Grau, I904. I5 p.

- Ingegnieros, José: La législation du travail dans la République Argen tine; essai critique sur le projet du ministre Gonzalez, tr. de l'espag nol par Charles Barthez. Paris, E. Cornély et cie, I906. I83 p. 
Cayetano Earbonell ${ }^{1}$ has published a compilation in two volumes which deals with the entire social legislation of Argentina. It presents bills and drafts of law, parliamentary discussions, articles, essays and speeches, congressional reports, and the author's notes on such subjects as industrial accidents, the eight-hour day, alcoholism, the civil rights of 'women, González' labor code, Argentina socialism, the right of association and reunion, Sunday rest, workmen's pensions, old-age pensions, anarchism, strikes, conciliation and arbi tration of industrial disputes, citizenship, naturalization and immigration, the law on games of chance and related questions. It includes a number of articles by Bialet Massé on topics of labor legislation.

Among the treatises on labor and social legislation, mention may be made of the following: A manual of labor legislation, by Alejandro M. Unsain, ${ }^{2}$ Chief of Division in the Department of Labor, published in 1915 , discussing systematically the various topics of labor legislation which have engaged the attention of the Argentine legislator; a doctor's dissertation, by Alejandro Russo, ${ }^{3}$ on labor legislation, published in 1906; a treatise by Juan A. Alsina, ${ }^{4}$ on the status and position of the workman in Argentina, which includes the wages paid in various industries; an account of the Argentine Republic, by the Spanish publicist, Adolfo Posada, ${ }^{5}$ a part of which is devoted to a study of social reforms and labor laws in Argentina; an essay by Deputy Lúcas Ayarragaray, ${ }^{6}$ on the social

${ }^{1}$ Carbonell, Cayetano: Orden y trabajo; exposición comentada de las leyes de residencia-ciudadanía argentina, inmigración y desembarco-derecho de reunión-conversión, descanso dominical-juegos de azar, trabajo de las mujeres y niños-anarquismo-huelgas, arbitraje en los conflictos industriales, retiro y seguros obreroscódigo del trabajo, etc. . . Antecedentes, proyectos, trabajos y estudios diversos de carácter económico y social, con juicios críticos del autor . . Buenos Aires, J. Lajouane \& Cia, r9ro. 2 v.

${ }^{2}$ Unsain, Alejandro M.: Manual de la legislación obrera argentina. Buenos Aires, Comp. Sud.-Amer. de Bill. de Bancos, rgr5. 3 rI p.

${ }^{3}$ Russo, Alejandro: Legislación obrera. Buenos Aires, 1906.

- Alsina, Juan A.: El obrero en la Republica Argentina. Buenos Aires, I905. $2 \mathrm{v}$.

5 Posada, Adolfo: Ia República Argentina, impresiones y comentarios . . Madrid, V. Suárez, IgI2. 488 p.

${ }^{6}$ Ayarragaray, Lucas: Socialismo argentino y legislación obrera . . . Buenos Aires, J. Lajouane \& cia, r9r2. [9] 69 p. 
problem, and the development of social legislation and working conditions in the Argentine, with a proposal of reform; and a monograph of Méndez Calzada ${ }^{1}$ on the labor contract, principally a study in comparative law, published in 19I2.

The legal liability for industrial accidents, the subject of the first bill on labor legislation introduced in Argentina (by deputies Avellaneda and Roldán in 1902), has been treated in a notable work by Juan Bialet Massé, ${ }^{2}$ a leader in the movement for labor legislation. The first volume of his treatise, all that appeared before his death, studies the question under the civil law of Argentina, and gives high praise to the draft of Velez Sarsfield in fixing a liability without fault in certain cases. The subject is studied in the light of doctrines of the civil law and the decisions of the courts. A dissertation on the liability of employers and insurance companies for industrial accidents was published by P. L. Manquero $^{3}$ in 1907.

Dr. Alfredo Palacios, a leader of the socialist party and ardent promoter of social legislation in all its forms, took part in nearly all the debates in recent years on social legislation. His parliamentary labors have been recorded and reprinted ${ }^{4}$ in a three-volume work published in 1907 . His socialist speeches ${ }^{5}$ and work during the years $1912-13$, including the laws initiated by him, were printed in a volume published in 1914 in Valencia. Recently, he published a defense of the socialist party and of socialism and the labor laws of Argentina. ${ }^{b}$

' Méndez Calzada, Luis: El contrato de trabajo: su naturaleza jurídica; doctrina y legislación. Buenos Aires, Coni herm., I9I2. 23 I p.

${ }^{2}$ Bialet Massé, Dr. Juan: Tratado de la responsabilidad civil en derecho argentino, bajo el punto de vista de los accidentes de trabajo. Rosario, "La Argentina," Ig04. 507 p.

${ }^{3}$ Manquero, P. L.: Responsabilidad del patron y seguros en los accidentes del trabajo. Buenos Aires, r907.

* Palacios, Alfredo I.: Actuación parlamentaria como diputado del partido socialista argentino, I904-I906. Buenos Aires, 1907. 3 v.

${ }^{5}$ Palacios, Alfredo L.: Dos años de acción socialista en el parlamento argentino (I9r2-rgr3). Valencia, Prometeo, r9r4. 445 p. See also his Acción parlamentaria, May, I912-April, r9r3. Buenos Aires "La Vanguardia, Igr3.

- Palacios, Alfredo L.: En defensa de los trabajadores, el Partido socialista argentino. Valencia, Prometeo [19r6]. $464 \mathrm{p}$. 
Another collection of parliamentary speeches by Deputy (now Senator) Enrique del Valle Iberlucea, ${ }^{1}$ socialist and professor at the University of La Plata and the faculty of philosophy at Buenos Aires, was published in 1914. They deal, among other matters, with socialism and the budget, the legal working day, pensions for railroad workmen, the right to strike, work in the home, and with the socialistic disturbances in Buenos Aires in 1909.

A study on the sociological and economic conditions in Argentina, particularly the effect of European immigration on social conditions in Argentina, was published in 1910 by José Ingegnieros. ${ }^{2}$

Belisario J. Montero, ${ }^{3}$ Argentine consul general in Belgium published in two series his social studies made up of reports submitted to the Minister of Foreign Affairs of Argentina. They deal largely with social conditions in Belgium and other European countries in their application to Argentine conditions. A few topics dealing particularly with Argentina are also included. Among other matters they discuss public welfare and charitable organization in Argentina, public morality, esthetic instruction in primary schools, the education of orphans, the struggle against tuberculosis, Argentina as a country for immigration, mendicancy, expropriation for public utility and similar matters.

Two laws of 1906, Nos. 5034 and 5036, for the welfare of children, making appropriations for the benefit of poor children, are paraphrased in 36 Annuaire de législation comparée, 744.

\section{CIVIL, PENSIONS}

The law of civil pensions and retirement funds, No. 4349 of September 10, 1904, is administered by the National Pension Bureau. The laws and decrees governing this Bureau have been published at intervals, the last edition ${ }^{4}$ bearing

${ }^{1}$ Valle Iberlucea, Enrique del: Discursos parlamentarios. Valencia, F. Sempere y compañía, [rgr4]. 263 p.

${ }^{2}$ Ingegnieros, José: La evolución sociologica argentina. Buenos Aires, J. Menendez, 19ro. $187 \mathrm{p}$.

${ }^{3}$ Montero, Belisario J.: Estudios sociales. Brussels, Weissenbruch, 1904. Barcelona, rgro. 2 series.

- Caja nacional de jubilaciones y pensiones civiles. Ley No. 4349, modificada por las leyes números $4870,5143,6007$, y 7497. Decretos reglamentario de la misma. Buenos Aires, Monkes, r9r3. 29 p. 
date of 1913. Some of the provinces, for provincial employees, also have enacted pension laws during the last ro years.

\section{SANITATION AND PUBLIC HYGIENE}

A compilation of the sanitation laws of Argentina with the regulations governing the practice of medicine, directories of physicians, pharmacists, and veterinarians, and the organization of the National Department of Hygiene, was published by the Department of Hygiene ${ }^{1}$ in r9r3. A law of r 900 regulated the sanitary police and inspection of cattle. This law, with the amendments introduced by law of July 26, I904, was published by the Department of Agriculture ${ }^{2}$ in 1904 .

Law No. 4475 of September 26, I 904 approved the sanitary convention signed at Rio Janeiro on June I2, I904, by Argentina, Brazil, Paraguay, and Uruguay, embracing measures to prevent the propagation of the oriental pest, Asiatic cholera, and yellow fever. The law is summarized in 34 Annuaire de législation comparée, 580-582. The convention, with the maritime sanitary regulations and the law governing cattle inspection and police are printed in the Anuario Oficial (I912), pages I9I-229, 384-459.

The administration of sanitary regulations and measures of public welfare in the city of Buenos Aires was the subject of a compilation $^{3}$ published in Buenos Aires in two volumes in r 9ro. The result of the regulations for social hygiene was the subject of a two-volume work published by Augusto Bunge ${ }^{4}$ in 1908 .

Law 4687 of September I I, 1905, paraphrased in 35 Annuaire de législation comparée, I719, governs the exercise of the profession of pharmacy, requiring graduated pharmacists for all

${ }^{1}$ Guía oficial datos para la historia-organización actual-división y funcionamiento-legislación sanitaria argentina-nóminas de profesionales y establecimientos de toda la nación . . . Redacción y compilación: Luis J. Maisonnave. Buenos Aires, Imp. de G. Kraft, r9i3. r105 p.

${ }^{2}$ Ley y reglamento general de policía sanitaria de los animales, con las modificaciones introducidas hasta el 26 de julio de r904. Buenos Aires, Talleres de publicaciones de la Oficina meteorológica argentina, r904. rig p.

${ }^{3}$ Administración sanitaria y asistencia pública de la ciudad de Buenos Aires. Buenos Aires, Igro. 2 v.

${ }^{4}$ Bunge, Augusto: Las conquistas de la higiene social. Buenos Aires, 1908. $2 \mathrm{v}$.

$71624^{\circ}-17-11$ 
druggists preparing prescriptions. Law 6350 of September 1o, 1909, abrogates article 3 of law No. 4687.

\section{EDUCATIONAL LAW}

A so-called code of primary instruction, comprising a collection of the laws, decrees, rules, and orders relating to primary instruction, was edited by Martín and Vedia ${ }^{1}$ in 1890 . A history of primary education in Argentina from 1810 to 1910 as projected by the late Dr. José María Ramos Mejía, the well known publicist and historian, then president of the National Board of Education, was compiled by his son Professor Juan P. Ramos in $1910 .{ }^{2}$ A code of primary and normal instruction in the province of Buenos Aires was published officially ${ }^{3}$ by the province in 1898 .

A compilation of the laws, decrees, and resolutions on secondary, normal, higher, and special education was compiled by Juan Garcia Merou ${ }^{4}$ in two volumes in 1900-1901. They cover the period $1810-1900$.

A collection of the parliamentary debates concerning common and higher education was compiled by Ernesto L. O’Dena ${ }^{5}$ in 1904 .

${ }^{1}$ Código de instrucción primaria. Colección de leyes, decretos, acuerdos, reglamentos y disposiciones vigentes, por F. Martín y Herrera and J. M. de Vedia. Buenos Aires, I8go.

${ }^{2}$ Ramos, Juan P.: Historia de la instrucción primaria en la República Argentina, r8ro-rgro (atlas escolar). Proyectada por el presidente del Consejo nacional de educación, Dr. José María Ramos Mejía, comp. y redactada por Juan P. Ramos. . . . Buenos Aires, J. Peuser, rgio. $2 \mathrm{v}$.

${ }^{3}$ Código de enseñanza primaria y normal de la provincia de Buenos Aires, proyecto redactado por F. A.Berra. Ed. oficial. La Plata, Talleresde publicaciones del Museo, 1898. $224 \mathrm{p}$.

4 Leyes, decretos y resoluciones sobre instrucción superior, secundaria, normal y especial. . . . Recopiladas por Juan Garcia Merou, ex-empleado del Ministerio de justicia é instrucción pública. Buenos Aires, Taller tipográfico de la Penitenciaría nacional, rgoo-rgor. 2 v.

5 Debates parlamentarios sobre instrucción pública. Recopilación de debates del $\mathrm{H}$. Congreso nacional sobre leyes y proyectos de organización de la instrucción general y universitaria. Publicación ordenada por S. E. el Señor ministro de justicia é instruccion pública Dr. D. Juan R. Fernández. Trabajo realizado por Ernesto L. O'Dena. Buenos Aires, Taller tipográfico de la Penitenciaría nacional, rg04. $\times 696 \mathrm{p}$. 
The addresses of Joaquín V. González ${ }^{1}$-a publicist fre quently mentioned in the course of this Guide-while Minister of Justice and Public Education (1902-1905), were published in a volume issued by Lajouane in 1905. They cover such matters as the University of Córdoba in Argentine cuiture, questions of university reform, intellectual life in the interior, the scientific spirit in instruction, professorships, secondary studies, and the primary school. The latter part of the book is devoted to lectures on government.

Projects and reports on university reform were published officially ${ }^{2}$ in 1904 .

Special education has been an important field of study for educators in Argentina. The basis and precedents for the institution of commercial education in the Republic were the subject of an official publication by the Ministry of Justice and Education ${ }^{3}$ issued in 1906.

A reorganization of agricultural education in the country was the subject of a draft of a law and of certain reports prepared in the agricultural division of the Ministry of Agriculture. $^{4}$ Law 7477 of September 30 , 1910, relates to the erection of a school for backward children.

The provinces have independent educational laws for schools falling within their jurisdiction. An extensive report on public education in the province of Entre Rios ${ }^{5}$ was recently published. The national schools located in the provinces were described in an official publication issued in $1910 .^{6}$

${ }^{1}$ González, Joaquín V.: Educación y gobierno; discursos del ministro de justicia é instrucción pública y ex ministro del interior, Dr. Joaquin V. González (1902-1905). Buenos Aires, Impr. "Didot" de F. Lajouane \& cia, r905. 285 p.

${ }^{2}$ La reforma universitaria; proyectos é informes. Buenos Aires, Taller de tip. de la Penitenciaría nacional, r904. 50 p.

${ }^{8}$ Antecedentes sobre enseñanza comercial en la República Argentina. Publicación oficial. Buenos Aires, Talleres gráficos de la Penitenciaría nacional, r906. $184 \mathrm{p}$.

- Reorganización de la enseñanza agrícola. El proyecto de ley y los resultados de su aplicación. Trabajos realizados por la División de enseñanza agricola (enero-junio-I908). Buenos Aires, I908. 286 p.

${ }^{5}$ Entre Rios: Legislación de la educación comı́n de la provincia de Entre Rios. Publicación oficial, Paraná-19r3. Santa Fé, Est. tip. “P. D. Languasco," I9I3. 397 p.

- Escuelas nacionales de las provincias. Ley 4874. Buenos Aires, Tall. de la casa J. Peuser, r9ro. I38 p. 


\section{PUBLIC LIBRARIES}

Public libraries throughout the Republic are fostered by means of a Public Library Commission, which supervises their administration, selects appropriate books for purchase, and centralizes many features of library work in one board. The laws and decrees governing the commission ${ }^{1}$ have been published officially.

\section{FINANCIAI LEGISLATION}

\section{BANKING LAW}

The law of negotiable instruments was discussed under the head of "Commercial code." At this point we shall take up the laws and relevant literature concerning the various organs for the administration of the financial system of the country. Attention should again be called to the classic work of Alberdi on the economic and financial system of the country, first published in the fifties and reprinted in his collected political writings. (Supra p. 44.)

The Banco Nacional, which was in existence until I891, was established by law No. $58 \mathrm{r}$ of October 3,1872 . During the eighties, various banking laws were enacted. The political and financial crisis under President Juarez Celman which culminated in 1890 induced the administration of President Pellegrini to establish the Banco de la nacion by law No. 284I of October 5, 1891. This organic law was greatly amended by law No. 4507 of September 29, 1904, and the corresponding regulations of December 9, 1904, and September 26, 1905.

A historical account of the national bank from 18 I I to 1854 is given in a work by Agustín de Vedia. ${ }^{2}$ A collection of the laws and decrees governing banking and money from 1854 to $1890,{ }^{3}$ was published officially in 1890 . Another extensive

${ }^{1}$ Leyes y decretos relativos á la Comision protectora de bibliotecas populares. Buenos Aires, Tall. de la Oficina meteorológica argentina, I9Ir. $35 \mathrm{p}$.

${ }^{2}$ Vedia, Agustín de: El banco nacional. Historia financiera de la Republica Argentina. Buenos Aires, F. Irajouane, I8go. v. I, I8I I-I854. 5I3 p.

${ }^{3}$ Bancos y moneda. Recopilación de leyes y decretos, 1854 á r89o. (Publicación oficial.) Buenos Aires, Impr. la Tribuna nacional, I89o. $444 \mathrm{p}$. 
collection of federal laws and decrees regarding banks of issue and public finance beginning with 1872 was published by the Ministry of Hacienda ${ }^{1}$ in 1889 . The volume explains the ecomomic and legislative origin of the various laws and decrees, being supplied throughout with historical notes and commentaries, probably the work of Agustín de Vedia.

The organic law of the national bank, with its amending statutes and regulations, ${ }^{2}$ has been published separately. Law 4507 of 1904 which amended the organic charter is discussed in 34 Annuaire de législation comparée, pages 584-585. An account of the origin and development of the Banco de la nacion from $\mathrm{r} 89 \mathrm{I}$ to $19 \mathrm{IO}$ is given in a work published by J. J. Solveyra. ${ }^{3}$ The annual report of the bank is published in Spanish, French, and English.

The national mortgage bank was established by law 1804 of September 14, 1886, with regulations of December 18, 1886. Various laws have amended the original act, among the most recent being law 8172 of September 2, 191 I. The bank issues an annual report in Spanish and in French. A work dealing with the rights and privileges of this bank was published by Julio R. Salas. ${ }^{4}$

A work on mortgage and savings banks was published by Sixto J. Quesada ${ }^{5}$ in 1887 . The organic law of guaranteed banks is No. 226 of November 3, 1887. A bill for the establishment of a national agricultural bank was introduced in the Argentine Congress by Deputy Frers in I9I3. It has been published with an explanatory report. ${ }^{6}$

${ }^{1}$ Bancos de emision y hacienda pública. Buenos Aires, Impr. de la Tribuna Nacional, 1889. 399 p.

${ }^{2}$ Banco de la Nación Argentina. Ley orgánica y reglamento, I904. Buenos Aires, rgo8.

${ }^{3}$ Solveyra, J. J.: Banco de la Nación Argentina. Origen y desarrollo, r89r-rgro. Buenos Aires, rgro.

- Salas, Julio R.: Derechos y privilegios del banco hipotecario. Buenos Aires, 1908.

${ }^{5}$ Quesada, Sixto J.: Bancos hipotecarios y cajas de ahorros. Buenos Aires, Impr. de P. E. Coni é hijos, r887. 192 p.

"Frers, Emilio: El banco agricola. Proyecto de ley presentado á la Camara de diputados de la nación en la sesion de agosto 8 de rgr3. Buenos Aires, Impr. P. Gadola, I9r5. 92 p. 
The mortgage bank ${ }^{1}$ of the province of Buenos Aires goes back to 1872 . A work on this bank with a discussion of banking systems and agricultural credit with particular reference to the difficulties of the bank during the financial crisis of the nineties has been published by Sixto J. Quesada ${ }^{2}$.

A postal savings bank (Caja Nacional de Ahorro Postal) was established by law 9527 of September 29, 1914.

An interesting work on the banks of the country with some account of its financial system is that of Martínez and Lewandowski, ${ }^{3}$ published first in French and translated into English in I9Ir. Some account of the banking system and practice of Argentina is also given in a report by Edward N. Hurley ("Banking and credit in Argentina, Brazil, Chile and Peru") published in 1914 by the Department of Commerce, Special Agents series 9o, and reprinted as Senate Document 659 (63d Cong., $3 \mathrm{~d}$ sess.).

The banking system of the country is described in a work published in 1893 by the statesman and economist José A. Terry, ${ }^{4}$ with special reference to the financial crisis of $1885^{-}$ I 892. His lectures on public finance including the financial history of Argentina have been published by his students in a book regarded as a standard work. ${ }^{5}$ A work on public

${ }^{1}$ Banco hipotecario, Buenos Aires: Ley orgánica y otras disposiciones sobre el Banco hipotecario de la provincia de Buenos Aires. Buenos Aires, Impr. del Siglo, 1872. 26 [I8] p.

${ }^{2}$ Quesada, Sixto J.: E1 Banco hipotecario de la provincia de Buenos Aires; sistemas bancarios, el crédito agrícola y el crédito territorial, el Banco hipotecario de la provincia y las causas que han motivado su derrumbe. Buenos Aires, M. Biedma, I894. 407 p.

${ }^{3}$ Martínez, Alberto B.: The Argentine in the twentieth century, by Albert B. Martínez ... and Maurice Lewandowski ... with a preface by M. Émile Levasseur . . . and an introduction by the late Ch. Pellegrini ... tr. by Bernard Miall, from the French of the 3 d ed., rev. and brought up to date. With a map. London, [etc.] T. F. Unwin, I9II. 55-376 p.

4 Terry, José A.: La crisis, $188_{5^{-18}}^{-12}$, Sistema bancario. Buenos Aires, M. Biedma, 1893. $353 \mathrm{p}$.

- Terry, José A.: Finanzas; conferencias dictadas por el catedrático de la inateria. Apuntes taquigráficos tomados por los alumnos Iuis A. Folle y Carlos M. Biedma ( 1898 ). 2. ed. ampliada por el autor. Buenos Aires, V. Abeledo, I912. 54I p. 
finance by Sixto J. Quesada ${ }^{1}$ is also well regarded. His history of economic evolution and public finance ${ }^{2}$ is especially useful for its account of Spanish colonial and Argentine economic development. The general part is equally accessible in works in English.

One of the ablest Argentine works on public finance is that of Tristán Avellaneda ${ }^{3}$ published in three volumes in Córdoba. He deals in the first two volumes with public finance, methods of taxation and the budget, and in the third volume with public credit. It is valuable also as a work on Argentine financial history.

Two works recently published also warrant mention. They are both economic and financial studies, in which legislation is only incidental. The first, by José Bianco, ${ }^{4}$ is a critical study of the recent financial crisis, the instruments of credit and exchange, the banking institutions of the country, the public debt, and the economic effect of the introduction of foreign capital. The other, by Carlos F. Soares, ${ }^{5}$ is an economic and financial history of the last thirteen years.

\section{DEBT AND TAXATION}

A valuable compilation of laws, decrees and resolutions governing the national debt was published in 1907 by J. B. Peña ${ }^{6}$ in four volumes. One of the most extensive reports made on the public debt, banking institutions, mint, and the national and provincial taxation laws was prepared in the eighties by Pedro Agote, the Chief of the Bureau of Public Credit, upon a request made by the government of the United States for

'Quesada, Sixto J.: Las finanzas de la República Argentina. Buenos Aires, M. Biedma, 1892. 434 p.

${ }^{2}$ Quesada, Sixto J.: Lecciones de economia politica y de finanzas. Buenos Aires, Impr. de M. Biedma, r905. $62 \mathrm{I} \mathrm{p.}$

${ }^{3}$ Avellaneda, Tristán: Finanzas. Córdoba, A. Aveta and F. Domenici, I904-rgo9. $3 \mathrm{v}$.

* Bianco, José: La crisis. Nacionalización del capital extranjero. Buenos Aires, Mendesky, I9I6. 348 p.

'Soares, Carlos F.: Economía y finanzas de la Nación Argentịna, 1903Igr6. Buenos Aires, 1916. 229 p.

' Peña, José.: Deuda argentina; compilación de leyes, decretos y resoluciones, notas y contratos sobre la deuda pública nacional. Buenos Aires, Impr. de J. A. Alsina, 1907. 4 v. in 2. 
information regarding the coining of money, the emission of paper currency, and the public debt of Argentina. This extensive report, ${ }^{1}$ published in five volumes, has been translated into English ${ }^{2}$ and French. ${ }^{3}$

Reports of the House and Senate of the Argentine Congress frequently contain valuable accounts of the public debt legislation and the wealth and taxation of the country. For this purpose, the annual reports of the Ministry of Hacienda are also important.

The law provides for the publication of an annual budget. ${ }^{4}$ A useful treatise on the budget with an introduction by Wenceslao Escalante, was published in 1890 by Alberto B. Martinez. ${ }^{5}$ The fiscal laws and provisions ${ }^{8}$ relating to the budget appear to have been published annually since 1885 . A collection of the laws, decrees and regulations governing internal revenue, with voluminous statistical reports, was published officially ${ }^{7}$ in five volumes in 1905.

An important compilation of fiscal laws was published officially by the chief clerk $^{8}$ of the Ministry of Hacienda in 1904. It reprints the laws on almost every subject in which the

${ }^{1}$ Informe del presidente del crédito público nacional, Pedro Agote, sobre la deuda pública, bancos, [etc.]. Buenos Aires, r881-88. $5 \mathrm{v}$.

${ }^{2}$ Report on the public debt, banking institutions, and mint of the Argentine Republic, and on the national and provincial estimates and taxation laws, presented by Pedro Agote, chairman of the Public Credit Department. Tr. from the Spanish original by L. B. Trant ... Buenos Aires, Stiller \& Laass, r882-r889. 5 v.

3 Rapport du président du Crédit public national, Pierre Agote, sur la dette publique, les banques, les budgets, les lois d'impôts et la frappe des monnaies de la nation et des provinces. Tr. de l'espagnol par Henri Menjou. Buénos Aires, 1882-r889. 5 v.

${ }^{4}$ Ley de presupuesto general de la República Argentina. Buenos Aires, annual.

${ }^{5}$ Martinez, Alberto B. El presupuesto nacional, con un prólogo del Dr. Wenceslao Escalante. Buenos Aires, 1890 .

${ }^{6}$ Leyes y disposiciones fiscales. Buenos Aires, ${ }^{8} 88_{5}$-.

7 Impuestos internos . . Publicación ordenada por la administración general de impuestos internos. Buenos Aires, Talleres gráficos de la Penitenciaría nacional, 1905. $5 \mathrm{v}$.

${ }^{8}$ Digesto de hacienda, compilación hecha por J. Hiram Pozzo, oficial mayor del Ministerio de hacienda y Federico Rodríguez Anido . . . Buenos Aires, Coni hermanos, r904. 
state has a financial interest. It includes the customs legislation, duties, imposts and dues, regulations governing navigation, commerce and industry, accounts, pensions, public works and all forms of federal tax law including territorial taxes, licenses and stamped paper, and salaries and fees in all departments of the government.

A valuable statistical report ${ }^{1}$ which prints the laws governing taxation and appropriations was published by the Department of Statistics from 1886 to 1888 , when it appears to have been suspended. It includes the budget receipts and expenditures of the federal government and of all the provincial governments and the principal municipalities in tabular form and constitutes for the years published an important source of comparative financial statistics.

Each province publishes annually its tax law entitled usually "ley de impuestos;" its license law, "ley de patentes fiscales;" and its stamped paper law, "ley de papel sellado." There is also in the federal government and in the provinces a law relating to the Bureau of Public Accounts (ley de contabii$i d a d)$ which governs the system of public accounting.

The leading works on taxation are the standard work of Professor José Terry ${ }^{2}$ and a valuable study on the wealth, debt and taxation of Argentina as compared with other countries, written for the purpose of showing the high credit which Argentina deserves, its vast resources and favorable trade balances, published by the Uruguayan publicist Gonzalo Ramírez ${ }^{3}$ in rgor.

\section{CUSTOMS LAWS}

The rules and regulations governing the administration of the customs and the organization of the customs inspection service are to be found in an official publication of the Ministry

${ }^{1}$ Los presupuestos, los recursos y las leyes de impuestos de la nacion, las 14 provincias y las principales municipalidades. Año I886-I888. Buenos Aires, Stiller and Laass, $1887-1889$.

${ }_{2}$ Terry, José A.: Finanzas; conferencias dictadas por el catedrático de la materia. Apuntes taquigráficos tomadas por los alumnos Luis A. Folle y Carlos M. Biedma (1898). 2d ed. Buenos Aires, V. Abeledo, rgr2. $54 \mathrm{I}$.

${ }^{3}$ Ramírez, Gonzalo: La tasa del impuesto en la Argentina y pueblos de Europa. Montevideo, Impr. y lit. “La Razón," rgor. 324 p. 
of Hacienda. ${ }^{1}$ The character of the tariff system, the customs duties and charges and customs procedure are discussed at pages $47-92$ of an important monograph by Dr. Frank R. Rutter " "Tariff systems of South American countries" published officially by the United States Department of Commerce. An excellent report on Trade and tariffs in Brazil, Uruguay, Argentina, Chile, Bolivia, and Peru has recently been published by the Federal Trade Commission (Washington, G. P. O., I9I6, 246 p.). At pages 106 to 146 of that publication there is a discussion of the characteristics of the Argentine tariff and of matters connected with trade and commerce, such as ships' manifests, bills of lading, consular invoices, and customhouse procedure.

The leading Argentine work on the customs legislation of the country with concordances, references to court decisions, and commentaries was published in a second edition in 1900 by Eduardo de Ezcurra. ${ }^{3}$

The customs tariff (tarifa de avaluos) of the Argentine Republic has been altered frequently. - The tariff in force in $\mathrm{I} 893$, in I 899, in I902, and the present law, No. 4933 of December 20, 1905, including the import and export taxes, have been published officially. ${ }^{4}$ The tariff now in force is that under law No. 4933 with its amendments. ${ }^{5}$

The draft ${ }^{6}$ submitted by a tariff commission appointed to prepare a revision of the tariff was published in rgro. The

1 Ley de aduana y decreto reglamentario. Reorganización de la Inspección de aduanas y resguardos. Buenos Aires, Talleres gráficos de la Penitenciaría nacional, rgro.

2 Tariff systems of South American countries, by Frank R. Rutter. Tariff series, No. 34. Washington, G. P. O., I916. 308 p.

${ }^{3}$ Ezcurra, Eduardo de: Legislación aduanera, concordancias, jurisprudencia y comentarios. 2nd ed. Buenos Aires, 1900. $378 \mathrm{p}$.

4 Tarifa de avalúos. Ley de la nación desde el $1^{\circ}$. de enero de rgo6 (Art. I4-ley n. ${ }^{\circ}$ 4933). Publicación oficial. Reimpresa para el año Igr I . . Buenos Aires, Compañia sud-americana de billetes de banco, I9II. $280 \mathrm{p}$.

- Reformas á la tarifa de avalúos. Mensaje enviado por el poder ejecutivo al h. Congreso é informe de la comisión designada por el Ministerio de hacienda. Agosto de rgro. Buenos Aires, Impr. de G. Kraft, Igro. $[5]-26 \mathrm{p}$.

6. Planillas de reformas á la tarifa de avalúos. Proyecto de la comisión designada por el Ministerio de hacienda. Publicación oficial. Buenos Aires, Est. gráfico M. Rodriguez Giles, rgro. 303 p. 
law has recently (1911) been published in English by the Pan American Union. ${ }^{1}$ The tariff laws are published also in many compilations such as the Anuario Oficial of 1912 and Digesto de Hacienda already mentioned, with the supplementary warchousing laws, port dues, drayage law of the Capital, and fees for discharging, cranes, etc.

The import duties on textiles in Argentina have recently been published in a separate pamphlet by the United States Department of Commerce. ${ }^{2}$

An important study on the commercial policy and tar.ff system of the Argentine Republic was published in 1906 by Ricardo Pillado, ${ }^{3}$ Chief of the Bureau of Commerce and Industry.

\section{MILITARY LAW}

The Argentine Republic has actively promoted its military organization, and new laws relating to the army and navy are enacted almost annually. Among the principal laws are law 403r of December 6, I901, establishing obligatory military service; law 4707 of September 25, 1905, governing recruiting; and law 3679 of December 8,1898 , as amended by law 4708 of September 21, 1905, which is the code of military justice and closely follows the draft of Dr. Bustillo. In addition, there is law 3239 on military retirement, as amended by law 4707; law 3995 of I90I, on naval officers; law 5043 of December 21, 1906, amending certain provisions of law 4707; law 8r29 of July I4, r9ri, for the general enrollment of all Argentine citizens, native or naturalized; law 8823 of November 27, 191 I, conferring Argentine nationality upon foreign officers in the army or navy who are enrolled in accordance with law No. 8129 .

I aw 4707 is analyzed in 35 Annuaire de législation comparée, pages $722-724$, and the amending law, 5043, in 36

${ }^{1}$ Argentine tariff law. Washingtou, rgrr. $33 \mathrm{p}$.

2 Import duties on textiles in South America. Part I: Argentina. February, I9I6. L. Domeratzky, chief of Division of foreign tariffs. Washington, G. P. O., Igr6. 34 p. (U. S. Dept. of Conmerce, Tariff Series, No. 32.)

${ }^{3}$ Pillado, Ricardo: Política comercial argentina; contribución á su estudio... Buenos Aires, Talleres de publicaciones de la Oficina meteorológica argentina, I906. $367 \mathrm{p}$. 
Annuaire de législation comparée, page 744. Law 8129 and 8823 are summarized in 4I Annuaire de législation comparée, 900. The law on obligatory military service and its regulation have been published officially. ${ }^{1}$ The law governing military enrollment, 8129 , of $19 \mathrm{II}$, with the amendment of article 15 as set out in law 8185 , with the regulations for carrying the law into effect, have been translated into English and issued in a British parliamentary paper ${ }^{2}$ and officially by the Ministry of War. ${ }^{3}$

The best collection of the laws, decrees, and departmental orders governing the army and navy from 18 ro to 1913 , with annotations, is a seven-volume compilation edited by Emilio Dominguez. ${ }^{4}$

A legislative war manual, ${ }^{5}$ which was published officially in a second edition in 1909 , with a supplementary volume in I9I I, contains a complete collection of the laws, regulations, decrees, etc., in force in I9II, relating to the army. Goyena's "Maritime Digest," ${ }^{8}$ already mentioned (supra, p. I52), also covers the laws and decrees, ordinances, and rules affecting the navy.

${ }^{1}$ Ley sobre servicio militar obligatorio y su reglamentación. Buenos Aires, I902.

${ }^{2}$ Laws and regulations respecting general enrclment in the Argentine Republic, enacted in Igr I . . . London, Pub. by H. M. Stationery off., printed by Harrison and sons, x9r3. 9 p. (Gt. Brit. Foreign Office, Misc. No. 4, r9r3.) Cd. 6640.

${ }^{3}$ Ley de enrolamiento general $n^{0} 8129$ y su reglamentación. Buenos Aires, Arsenal principal de guerra, talleres gráficos, rgir. 2 I p.

4 Dominguez, Emilio: Colección de leyes y decretos militares concernientes al ejercito y armada de la Rep. Argentina, r8ro-rgr3. Buenos Aires, Comp. Sud-Americana de Billetes and Arsenal principal de guerra, 1898-rgr3. $7 \mathrm{v}$.

5 Digesto de Guerra. Leyes, reglamentos, decretos y disposiciones militares vigentes y leyes y disposiciones generales civiles cuyo conocimiento es necesario en el ejército, dictados hasta el $\mathrm{I}^{\circ}$ de octubre de $1909.2^{\text {nd }}$ ed. Buenos Aires, Arsenal principal de guerra, I909. I325 p. Supplement, r9ri. $222 \mathrm{p}$.

'Goyena, Juan: Digesto de marina; recopilación de leyes, decretos, ordenanzas, reglamentos, etc., que corresponden á la marina mercante y de guerra, ampliada con otras diversas disposiciones estensivas á toda la administración nacional: toda la documentacion es la vigente hasta 1905,4 . ed. corr., anotada y aum. ... Buenos Aires, Imprenta, calle de México, núm. 1422, 1905. I315 p. 
A compilation of the laws for the administration of justice in the army and navy ${ }^{1}$ was published in a fourth edition in 1906. It contains the code of military justice, the army and navy regulations, and their penalties, and the general penal code.

In 1914 Deputies Gonnet, Palacios, and Gallo, ${ }^{2}$ members of a House committee designated to revise the code of military justice, submitted their revised draft, with an extensive report, in I9I3. The administration of military justice in Argentina was the subject of a treatise by Horacio H. Dobranich, ${ }^{3}$ published in 1913 , in which he presents a proposal of reforms of the code, with discussions and criticisms, including an interesting historical introduction.

A manual ${ }^{4}$ for the national guard of Argentina, consisting of a compilation of the laws, decrees, ordinances, and rules of military science, was published in 1895 .

\section{ECCLESIASTICAL LAW}

Undoubtedly the principal Argentine work on ecclesiastical law is that of Dr. Dalmacio Velez Sarsfield, ${ }^{5}$ the celebrated jurist and codifier. His work deals with the relations between church and state in colonial Spanish America, and constitutes a history of ecclesiastical law in America as well as a treatise on positive ecclesiastical law. The work was first published in 1854 and republished in new editions in $187 \mathrm{I}$ and in 1889.

The patronato, or the right of the state to make appointments in the church and to administer charitable establish-

${ }^{1}$ Leyes de justicia para el servicio del ejercito y armada. I. Codigo de justicia militar; II. Reglamento de disciplina y sus penas; III. Codigo penal ordinario. 4th ed. Buenos Aires, rgo6. $3 \mathrm{v}$.

${ }^{2}$ Gonnet, Manuel B.; Palacios, Alfredo L.; Gallo, Vicente C.: Justicia militar argentina. Proyecto de código. Buenos Aires, L. J. Rosso y Cía, rgr4. $229 \mathrm{p}$.

${ }^{8}$ Dobranich, Horacio H.: Justicia militar argentina. Buenos Aires, J. Bonmati, I9r3. 243 p.

- Manual del guardia nacional argentino: compilación de leyes, decretos, ordenanzas y nociones de instrucción militar, por un oficial del ejercito . . . La Plata El Dia, I895. 264 p.

s Velez Sarsfield, Dalmacio: Derecho público eclesiastico. Relaciones del estado con la iglesia en la antigua América Española. Buenos Aires [ 1854$][\mathrm{I} 87 \mathrm{I}], \mathrm{I} 88 \mathrm{~g}$. I $56 \mathrm{p}$. 
ments, has been the subject of several works. One by $\mathrm{C}$. Chacaltana ${ }^{1}$ was published in 1885 , and a more extensive work, by M. Navarro Viola, ${ }^{2}$ dealing with the history, law, and procedure of the patronato, was published in $x 887$. A more recent study of the patronato, as a public legal relation between church and state, was published by Vicente G. Quesada ${ }^{3}$ of the faculty of philosophy.

Juan Goyena, ${ }^{4}$ the well-known compiler, has also compiled an ecclesiastical digest containing a compilation of the laws and decrees, bulls, constitutions, etc., referring to the church from 1810 to 1880 . It is divided into eight books, dealing with general administrative provisions, churches, convents, religious persons, church property, marriage, cemeteries, and benefit societies.

The legal nature of the concordat is the subject of a treatise published in 1909 by F. Martin y Herrera. ${ }^{5}$

\section{INTERNATIONAL LAW}

The contributions of Argentina to international law, while not many, have nevertheless been important. The renowned treatise of Calvo, the much discussed Drago doctrine, and the important writings of Zeballos are products of Argentina.

General treatments of public international law, except for Calvo's treatise, are very few. A work of some interest is the recent translation into Spanish of the work of Ciriaco Morelli, ${ }^{B}$ professor at the University of Córdoba at the end of the eighteenth century, whose work on the elements of natural law and the law of nations was published in Latin in Venice in

1 Chacaltana, C.: Patronato nacional argentino. Buenos Aires, 1885.

${ }^{2}$ Navarro Viola, M.: Patronato, recursos de fuerza y escomuniones, su historia y derecho. Buenos Aires, M. Biedma, I887. 306 p.

${ }^{3}$ Quesada, Vicente G.: Derecho de patronato. Buenos Aires, Facultad de Filosofia y Letras, r9ro. $499 \mathrm{p}$.

` Goyena, Juan: Digesto eclesiástico argentino; recopilación de leyes, decretos, bulas, pastorales, constituciones, etc. (I8ro-r88o.) Buenos Aires, Impr. Esp. de Obras, 1880. 287 p.

${ }^{5}$ Martin y Herrera, F.: De la naturaleza juridica del concordato. Buenos Aires, I909.

- Morelli, Ciriaco: Elementos de derecho natural y de gentes, traducción del Dr. Luciano Abeille. Buenos Aires, Coni Herm, rgr I. 440 p. 
1791. The book was translated into Spanish by Dr. Ltciano Abeille, under the auspices of the University of La Plata. The work deals less with the law of nations than with natural law, civil law, and public law from a theoretical and philosophical point of view.

The first modern treatise on international law published in Argentina was the elementary book of Ramón Ferreira, ${ }^{1}$ fiscal of the Supreme Court. He published in book form the lectures he delivered in 1854 at the college of Tacna, then in Peru. The work covers the usual elementary topics of a general treatise on international law.

The next work is the celebrated treatise of Carlos Calvo, ${ }^{2}$ Argentine diplomat, whose extensive work was first published in $\mathrm{I} 868$, in two volumes, in Spanish. In 1870 a second edition in French appeared, and in 1896 the fifth edition, in six volumes, was published in Paris. Mention should also be made of Calvo's well-known dictionary ${ }^{3}$ of international law, published in 1885 .

Professor Amancio Alcorta, one of the leading jurists of Argentina, published the first and only volume of his general treatise on public international law in $1886,{ }^{4}$ although in 1878 he had published an elementary book on international law. The volume published in 1886 , which deals with social groups and their laws, the character and elements of international law, the basis and manifestation of international law, social sciences and their relation to international law,the historical development of international relations and law, and includes an important chapter on the literature of international law, was translated into French with an introduction by Ernest Lehr ${ }^{5}$ in 1887.

'Ferreira, Ramón: Lecciones de derecho internacional. Paraná, Imp. Nacional, r86r. r40 p.

${ }^{2}$ Calvo, Carlos (r824-r906): Derecho internacional teórico y práctico de Europa y América. Paris, Ist ed. 2 v. (I868); $5^{\text {th }}$ ed. 6 v. (I896).

${ }^{3}$ Calvo, Carlos: Dictionnaire de droit international public et privé. Berlin, Puttkammer \& Mühlbrecht, 1885. 2 v.

- Alcorta, Amancio: Curso de derecho internacional público. Buenos Aires, Lajouane, $x 886$.

'Alcorta, Amancio: Cours de droit international public ... Ed. française, avec une introduction par Ernest Lehr. Paris, Larose \& Forcel, r887. $492 \mathrm{p}$. 
The notes of the lectures on international law of Professor E. L. Bidau, ${ }^{1}$ now Dean of the Faculty of Law at Buenos Aires, were published by students in book form in 1906 . They likewise include a chapter on the literature of international law on the order of the corresponding sections in Nys and Rivier, but include also a discussion of the monograph literature in Argentina. More recent editions of these lectures have also been published.

\section{TREATIES}

The treaties of Argentina have been published in several editions. Those of the Confederation ${ }^{2}$ were published in Paraná in 1859 . In 1863 a collection ${ }^{3}$ was issued which included the agreements, capitulations, armistices, and other documents connected with foregn relations concluded from the time of the first juntas to the date of publication.

Carlos Calvo ${ }^{4}$ was also the compiler of a celebrated collection of treaties relating to Latin America from the Papal Bull of 1493 to I 819 . The first i i volumes embrace the colonial epoch, the last few volumes dealing with the question of boundaries between Spain and Portugal, and an index volume. The second period, covering 5 volumes, dates from the revolutions of the early part of the nineteenth century to the recognition of independence of the Latin American states by Europe. This collection, in 16 volumes, made more valuable by the notes and extensive commentaries of the editor, Calvo, were all that were published.

In 1884 a three-volume collection of treaties was prepared by officials of the Foreign Office ${ }^{5}$ which included a number of

1 Bidau, E. L.: Apuntes de derecho internacional publico (por A. H. y A. P. C.). 2nd ed. Buenos Aires, Antonio Garcia, 1906. 2 v.

2 Tratados públicos de la Confederación Argentina con las potencias extranjeras. Paraná, 1859 .

${ }^{3}$ Colección de tratados celebrados por la Republica Argentina con las naciones estrangeras. Publicación oficial. Buenos Aires, Impr. y litog. de Bernheim y Boneo, I863. 475 p.

- Calvo, Charles: Recueil complet des traités, conventions, capitulations, armistices et autres actes diplomatiques de tous les états de l'Amerique Latine, depuis l'année I493 jusqu'à nos jours. Paris, A. Durand, 1862-69. 2nd ser., 1864-1867.

5 Colección de tratados celebrados por la República Argentina con las naciones extrangeras. Publicación oficial . . Buenos Aires, Impr. de J. A. Alsina, r884. 3 v. 
documents not printed in former compilations. It is chronological only, an appendix containing the earliest international agreements of the colonial period relating to the Argentine.

Another three-volume collection ${ }^{1}$ was authorized in 1901 , volume I covering the treaties from i 82 I to r 900 concluded between two powers, and volume 2 the conventions concluded in general congresses to which Argentina has been a party. There is both a chronological and an alphabetical index. Volume 3 covers the period r $901-1905$.

By all means the most exhaustive collection of the treaties, conventions, capitulations, agreements, and other international documents concluded by Argentina, including the interprovincial agreements from $\mathrm{I} 8 \mathrm{I}$ I to $\mathrm{I} 86 \mathrm{I}$, and arbitral awards and the documents of the colonial period prior to 1810 , is the I I-volume compilation authorized during the presidency of Figueroa Alcorta in 1910 and prepared by Francisco Centeno, ${ }^{2}$ librarian of the Foreign Office. The collection, fortified by many incidental documents, is arranged by country and by the nature of the agreement and constitutes the most valuable repository of international documents published in Argentina.

Two studies on the commercial treaties of Argentina should be mentioned. The first, by Alejandro Guesalaga, ${ }^{3}$ sometime Argentine Minister in Bolivia, is a brief discussion of the mostfavored-nation clause and of the individual treaties concluded with various powers, the commercial relations of Argentina with different countries, and the necessity of revising the treaties, especially of establishing closer relations with Bolivia. A more scientific and valuable study is that of Ricardo Pillado, ${ }^{4}$ Director General of the Department of Commerce in the Min-

1 Tratados, convenciones, protocolos y demás actos internacionales vigentes celebrados por la República Argentina. Publicación oficial. Buenos Aires, Impr. de "La Nación," I90I-5. 3 v.

2 Tratados, convenciones, protocolos, actos y acuerdos internacionales. Publicación oficial. Buenos Aires, J. A. Alsina, I9II-I2. II v.

${ }^{3}$ Guesalaga, Alejandro: Estudio de los tratados de comercio de la República Argentina . . Sucre; en Buenos Aires, F. Lajouane [etc.], I8g8. I $20 \mathrm{p}$.

4 Pillado, Ricardo: Comentarios sobre los tratados de comercio argentinos, ... con una carta-prólogo del doctor Eleodoro Lobos... Buenos Aires, Talleres gráficos del Ministerio de agricultura 19r5. $228 \mathrm{p}$.

$71624^{\circ}-17-12$ 
istry of Agriculture, who has studied the economics of commercial treaties and the necessity, from the point of view of the economic development of Argentina, of continuing or amending certain treaties and of terminating others. It includes a detailed discussion of the commercial treaty relations of the last ten years with various powers and contains a valuable criticism of tariff questions.

\section{ALIENS}

The position of the alien in Argentina is exceedingly favorable. In his civil rights he is on a footing of equality with natives, and in political rights his freedom from military service for ten years after residence in Argentina more than compensates for any political disadvantages under which he labors. Naturalization was made very easy by the law of 1869 . In spite of this favorable condition Argentina has had to defend itself against numerous claims of aliens, beginning at an ear:y period. The difficulties between France and the Argentine Confederation in 1838 arose out of al'eged violations of the rights of French citizens. The ultimatum ${ }^{1}$ of the French consul to the government of Buenos Aires, with the documents in support, constitutes a valuable study of the rights of aliens. On the occasion of certain Italian claims in the eighties Adolfo Saldias, ${ }^{2}$ the well-known publicist, published an interesting study, translated into French, on the position of aliens in international law. In addition, the rights of aliens are discussed in a work in German by B. Lehmann, ${ }^{3}$ and in an article in French by Emilio Daireaux, published in 13 Clunet's Journal (1886), 296-298; 414-424.

Besides the law of citizenship, aliens are affected largely by law 4144 of 1902, which defines the conditions of their resi-

${ }^{1}$ Ultimatum adressé par M. Aimé Roger, consul de France, au gouvernement de Buenos Aires, chargé des relations extérieures de la Confédération Argentine, avec la réponse de ce dernier, et d'autres pièces à l'appui. Buenos-Ayres, Imprimerie de l'état, 1838 . 189 p.

${ }^{2}$ Saldias, Adolphe: La politique italienne au Rio de la Plata. Les étrangers residents devant le droit international. Paris, L. Sauvaitre, 1889 . I08 $\mathrm{p}$.

${ }^{3}$ Lehmann, B.: Die Rechtsverhältnisse der fremden in Argentinien. Buenos Aires, I889. 
dence and the conditions on which they may be expelled. The bills, debates, and speeches on this law have been collected in the work of Carbonell (supra, p. 158), and the various laws affecting aliens including the constitutional provisions, the law on immigration and colonization of 1876 , the citizenship law of 1869 , the law of 1900 governing claims against the state, the law of 1885 on extradition in the absence of treaties, and the expulsion of aliens, now law 4144 of 1902, are all printed in the Anuario Oficial (1912), page I35 et seq.

An interesting study on the naturalization of aliens from the point of view of comparative law and a criticism of the law of 1902 on expulsion and of the law of rgro governing social security, which law delegated large powers of deportation of undesirable aliens to the Executive is the work of Francisco Durá, ${ }^{1}$ published in I9II. It is largely influenced by the theories of Zeballos.

Undoubtedly one of the ablest treatises on nationality in its philosophical and theoretical aspects as well as from the point of view of comparative positive law was published in two volumes by Professor Zeballos ${ }^{2}$ in 1914. It deals with nationality not only in the light of municipal law and comparative law, but particularly in its international relations and the conflicts arising therefrom. Volume 2 includes the best study available of citizenship and naturalization under Argentine law.

Two small works on the expulsion of aliens may be mentioned. One, by Miguel Cané, ${ }^{3}$ the author of one of the bills which was ultimately enacted into law, was published in 1899 , prior to the enactment of law 4I44. The other, by Carlos Groussac, ${ }^{4}$ is a doctor's dissertation which, besides a comparative law treatment, includes a discussion of law 4144 of 1902.

'Durá, Francisco: Naturalización de extranjeros. Actos é intentos legislativos sobre esta materia en la Republica Argentina. Buenos Aires, Coni, I9II. $4 \mathrm{I} 6 \mathrm{p}$.

${ }^{2}$ Zeballos, E. S.: La nationalité au point de vue de la législation comparée et du droit privé humain. Paris, Rec. Sirey, r914. 2 v.

${ }^{3}$ Cané, Miguel: Expulsión de extranjeros. Buenos Aires, J. Sarrailh, I899. I26 p.

4 Groussac, Carlos: Expulsión de extranjeros. Buenos Aires, Coni hermanos, 1903. $68 \mathrm{p}$. 


\section{CIVIL WAR CLAIMS}

South America has produced a number of works on the responsibility of the State and the rights of aliens in cases of civil war, for injuries arising out of which many South American countries have had to pay heavy indemnities. One of the best works on the subject was published in 1913 by Luis A. Podestá Costa. ${ }^{1}$ He deals with the effects of civil war on the person and property of foreigners and the responsibility of the State for injuries thereto both in theory and in practice, using Argentine and foreign precedents. An interesting study on the civil wars of South America in the light of international law has been published recently as a doctor's dissertation by Roberto Domenech, ${ }^{2}$ with an introduction by Prof. José Léon Suarez.

\section{EXTRADITION}

Argentina has concluded numerous extradition treaties, including a convention signed by certain South American republics at the Montevideo Congress of 1889 . Law 1672 of August $25,1885,{ }^{3}$ governs extradition in the absence of treaty.

\section{INTERNATIONAL CONFERENCES}

Alberdi was an earnest advocate of Pan American congresses. Argentina has participated in nearly all the Latin American congresses and took an important part in the Second Hague Conference. The report of the Argentine delegation to the Second Pan American Congress at Mexico in 1901 has been published in Spanish ${ }^{4}$ and in English, ${ }^{5}$ as has the

${ }^{1}$ Podestá Costa, Luis A.: E1 extranjero en la guerra civil. Buenos Aires, Impr. de Coni hermanos, I913. $272 \mathrm{p}$.

${ }^{2}$ Domenech, Roberto: Las guerras civiles americanas ante el derecho internacional; prólogo del Dr. José Léon Suarez. Buenos Aires, "La Semana Medica," r9r5. 402 p.

${ }^{3}$ Ley de extradicion . . B Buenos Aires, Impr. de J. A. Alina, I885. I 3 p.

${ }^{4}$ Informe que la Delegación de la Republica Argentina presenta á la segunda Conferencia pan-americana. México, Tip. de la Oficina impresora de estampillas, I9or. $45 \mathrm{p}$.

${ }^{5}$ Report which the Delegation of the Argentine Republic submits to the second Pan-American conference. Mexico, r90r. 49-93 p. 
Memoria ${ }^{1}$ of the Argentine Delegation to the Third Congress at Rio de Janeiro in 1906.

A valuable study of the results of the various Pan American congresses, with particular reference to those of Washington (1889), Mexico (I 901), Rio de Janeiro (I906), and Buenos Aires (I9IO), and a special study of the history of the agreements on the subject of trade-marks, patents, literary and artistic property, and sanitary inspection, was published in 1914, with many valuable tables, by Dr. Zeballos. ${ }^{2}$ Dr. Enrique Gil, in an address delivered at the Pan American Scientific Congress in December, 1914-since reprinted by the American Association for International Conciliation-has presented an interesting summary of the various Latin and Pan American congresses.

The report ${ }^{3}$ of the Argentine delegation of their labors at the Second Hague Conference, including the conventions subscribed by Argentina, was published in 1908 .

\section{ARBITRATION}

Numerous monographs on topics in international law have been published in Argentina and constitute contributions to the literature. Joaquin V. Gonzalez, whose ability is matched by his versatility, delivered in 1909 an important address on international arbitration and Argentine policy in connection with the general treaty of arbitration entered into between Italy and Argentina. The address has been translated into English. ${ }^{4}$

${ }^{1}$ Memoria de la Delegación de la Republica Argentina, presentada a la tercera Conferencia internacional americana reunida en Rio de Janeiro julio y agosto de I906. Rio de Janeiro, Imprensa nacional, I906. I $53 \mathrm{p}$.

${ }^{2}$ Zeballos, E. S.: Conferencias internacionales americanas (I797-I9ro). Valencia, ז9r4. 29I p.

${ }^{3}$ La República Argentina en la Segunda conferencia internacional de la paz. Haya, 1907. Buenos Aires, Impr. A. Pech, 1908. 207 p.

- González, Joaquín V.: International arbitration and Argentine policy; speech delivered by the informing member and president of the Committee of constitutional and foreign affairs of the national senate, during the session of the 26th August, I909, in connection with the Italian-Argentine treaty of general arbitration of the 18 th September, 1907, by Dr. Joaquín V. González . . . tr. by Mr. Willam J. Shilton. Buenos Aires, J. Lajouane \& cia., 1910. 127 p. 
The miscellaneous addresses and writings on topics of public and private international law and foreign relations of Roque Saenz Peña, ${ }^{1}$ twice president of Argentina and a jurist of distinction, were published in 1905. Various addresses on international topics by Joaquin V. González ${ }^{2}$ were collected in a volume published in 1910.

\section{DRAGO DOCTRINE}

The principle advocated by Luis M. Drago, Minister of Foreign Affairs in 1902, to the effect that the nonpayment of a public debt can not justify the seizure or occupation of the territory of a debtor state, expressed on the occasion of the joint action of the Powers against Venezuela in 1902, has received the name of the "Drago doctrine" and has been the subject of international discussion ever since. A collection of the views of foreign publicists and statesmen on the effect of this doctrine was published by Dr. Drago ${ }^{3}$ in 1903 in a work entitled (translated) "The Argentine Republic and the case of Venezuela."

Further studies and opinions on the subject of the collection of public debts by armed force were included by Dr. Drago in a work published in 1906 on the occasion of the Rio Janeiro Conference. ${ }^{4}$ A part of this work was published in the Revue générale de droit international public for March, 1907.

Among the many important works on the Drago doctrine, of which the French work by Moulin occupies a prominent place, that of Alfredo N. Vivot, ${ }^{5}$ pub.ished in I 911 , deserves special mention. It deals with the doctrine in all its aspects and in its evolution into the Porter proposition at The Hague, and

${ }^{1}$ Saenz Peña, Roque: Derecho publico americano. Escritos y discursos. Con una introducción del Dr. Miguel Cané. Buenos Aires, Penitenciaría nacional, r905. $408 \mathrm{p}$.

${ }^{2}$ González, Joaquín V.: La Argentina y sus amigos; discursos sobre política internacional por el Dr. Joaquín V. González . . Buenos Aires, J. Lajouane \& cia., I910. 320 p.

${ }^{3}$ Drago, Luis M.: La república argentina y el caso de Venezuela. Buenos Aires, Coni Hermanos, 1903. 326 p.

- Drago, Luis M.: Cobro coercitivo de deudas públicas. Buenos Aires, Coni Hermanos, xgo6. x69 p.

- Vivot, Alfredo N.: La doctrina Drago. Buenos Aires, Coni Hermanos, IgI. $395 \mathrm{p}$. 
among other matters discusses the somewhat misunderstood Calvo doctrine, mentioned in various American and English works on international law.

\section{SPECIAL TOPICS}

Dr. Drago was one of the arbitrators in the North Atlantic Coast Fisheries Arbitration at The Hague in r gro between the United States and Great Britain. He published many of the documents in connection with that case and the award, ${ }^{1}$ on Question 5 of which he wrote a brilliant dissenting opinion.

A brief study on neutrality, according to The Hague Conventions, was published by Carlos A. Becú ${ }^{2}$ in 1908 .

The important boundary dispute between Chile and Argentina, which was happily settled without war in 1900 , gave rise during the course of its long negotiation to many valuab'e legal works, both in Argentina and Chile. Among the Argentine works on the question, mention may be made particular:y of one by Antonio Bermejo, ${ }^{3}$ formerly professor of internation. law and justice of the Supreme Court, published in 1879; on by Vicente G. Quesada, ${ }^{4}$ on the doctrine of uti possidetis, i connection with the dispute; and two by Ernesto Quesada, $O^{*}$ on the Chilean policy, ${ }^{5}$ published in 1895 , and one on the Arge: tine policy, ${ }^{6}$ published in 1898 .

The historical antecedents of the Monroe doctrine and the right of intervention were the subject of a monograph by Carlos M. Urien, ${ }^{7}$ published in 1898.

${ }^{1}$ Drago, Luis M.: El arbitraje de las pesquerías del Atlantico norte entre la Gran Bretaña y los Estados Unidos de America. Buenos Aires, Coni Hermanos, I9I r. $232 \mathrm{p}$.

2 Becú, Carlos A.: La neutralidad segun las convenciones de la Haya. Buenos Aires, rgo8.

${ }^{3}$ Bermejo, Antonio: La cuestion chilena y el arbitraje. Buenos Aires, I879. $228 \mathrm{p}$.

${ }^{4}$ Quesada, Vicente G.: Derecho internacional latino-americano. Il uti possidetis del año ıo. Buenos Aires, I88I. $400 \mathrm{p}$.

${ }^{5}$ Quesada, Ernesto: La politica chilena en el Plata. Buenos Aires, 1895. $384 \mathrm{p}$.

${ }^{6}$ Quesada, Ernesto: La politica argentina respecto de Chile. Buenos Aires, 1898 .

${ }^{7}$ Urien, Carlos M.: El derecho de intervención y la doctrina de Monroe (antecedentes historicos). Buenos Aires, Imp. J. Peuser, I898. I74 $\mathrm{p}$. 
A succinct, although not specially noteworthy, account of the laws of war was published by Alejandro Guesalaga, ${ }^{1}$ a diplomat and writer on various topics of diplomacy and international law.

\section{DIPLOMATIC AND CONSULAR SERVICE.}

The most recent organic law of the diplomatic service is No. 47 II of 1905 . This, with its regulations, has been published officially by the Foreign Office. ${ }^{2}$ The consular service was reorganized by law 4712 of 1905 . This law, with its regulations of January, 1906, and law No. 4280 of 1904 on consular fees with related decrees, was published in a compilation ${ }^{3}$ issued in 1906. The law governing consular fees is also published in the Anuario Oficial (1912), page 187. The decrees governing diplomatic ceremonial were issued in a pamphlet by the Foreign Office ${ }^{4}$ in I 19 . 2 .

Two compilations are of special interest to the diplomatic and consular service. One, called the Anuario of the Ministry of Foreign Affairs, published only during the year 1908 and edited by Daniel Antokolet $z,{ }^{5}$ includes a collection of the laws and decrees of interest to the diplomatic and consular service, including lists of treaties, directories of diplomatic and consular officers, and statistical, economic, and legal information concerning the Argentine Republic which might be of use to the foreign representatives of Argentina.

Another compilation of laws and decrees affecting the conduct of foreign relations and the diplomatic and consular

${ }^{1}$ Guesalaga, Alejandro: Estudio de las leyes de la guerra. Berlin, I896. I64 p.

${ }^{2}$ Ley de organización diplomática No. 47 II, de septiembre 29, r905, y decretos que la reglamentan. Buenos Aires, Impr. del Hospicio de las mercedes, IgI2. $30 \mathrm{p}$.

${ }^{3}$ Ley de arancel consular. Ley No. 47 I2, de 29 septiembre de r905sobre organización del cuerpo consular argentino, y decreta reglamentario de la misma de enero de I906. Buenos Aires, Tip. de la Penitenciaría nacional, Igo6. 223 p.

4 Ceremonial diplomático. Buenos Aires, Impr. del Hospicio de 1as mercedes, I9I2. $26 \mathrm{p}$.

${ }^{5}$ Anuario del Ministerio de relaciones exteriores y culto de la Republica Argentina. Por Daniel Antokoletz. Buenos Aires, Comp. SudAmericana de Billetes, $1908.65^{2} \mathrm{p}$. 
service, with directories, was compiled, under the title "Digest of Foreign Relations, 1810-1913," by Francisco Centeno, ${ }^{1}$ librarian of the Foreign Office.

The original source of the history of the foreign relations of Argentina is to be found in the Memoria, or Annual Report of the Minister of Foreign Affairs, ${ }^{2}$ which has been issued regularly since I 86o. Besides this, the Foreign Office has published a Boletin ${ }^{3}$ containing reports of consular and diplomatic officers.

\section{DIPLOMATIC HISTORY}

Several treatises on the diplomatic history of Argentina have been published. A work which promises to be the most extensive on the subject has been begun by Daniel Antokoletz, ${ }^{4}$ Chief of Division in the Ministry of Foreign Affairs and adjunct professor of diplomatic law, a course given at the University of Buenos Aires. The first volume deals with the diplomacy of the Provisional Junta from May 25, I 810 to September 3, I 8 I I, and of the Triumvirate from September 23, I 8I I to January 22, 1814, including Spanish antecedents.

A course of diplomatic law which embraces the rules governing the conduct of foreign relations. both in foreign offices and through the diplomatic service is given at the University by Dr. José León Suarez, an able and versatile jurist. A work based on his course, dealing with the history of diplomacy and the functions of diplomatic agents and the organization of ministries of foreign affairs, diplomatic privileges and business, and with the rules of diplomatic negotiation, was published in 1914 by Ernesto $T$. Rayneli ${ }^{5}$ with an important introduction by Dr. Suarez.

${ }^{1}$ Centeno, Francisco: Digesto de relaciones exteriores, r8ro-rgr3, comp. por Francisco Centeno, director de la Biblioteca de la administración nacional. Buenos Aires, Est. grafico "Centenario," r9r3. 385 p.

${ }^{2}$ Argentine Republic. Ministerio de relaciones exteriones y culto. Memoria ... Buenos Aires, I860- .

${ }^{3}$ Boletin del Ministerio de Relaciones exteriores. Buenos Aires, Tall. Graficas H. A. Storm. 40 v. to I9I5.

4 Antokoletz, Daniel: Histoire de la diplomatie argentine. Paris, A. Pedone, etc., r9I4- . v. I, $5^{28}$ p.

5 Rayneli, Ernesto T.: Derecho diplomático moderno. Buenos Aires, F. Lajouane, I9I4. $349 \mathrm{p}$. 
Two works on diplomatic agents have been published by Alejandro Guesalaga, one published in $1893,{ }^{1}$ and the other, a continuation of that work, published in $1900 .^{2}$ The first is in no way noteworthy, but the second contains an account of a number of international controversies, which makes it of interest.

The diplomatic history of the United States was written by Martin Garcia Mérou, ${ }^{3}$ formerly Argentine minister at Washington, in a work of two volumes published in 1904. It is based on the best American literature and is undoubtedly the best account in Spanish on the subject.

A diplomatic and consular periodical, edited by Daniel Antokoletz, ${ }^{4}$ has recently (I 915 ) begun issue.

Among the diplomatic incidents and questions which are of particular importance in the foreign relations of Argentina, the question of the respective jurisdiction of Uruguay and Argentina over the La Plata River and Martín Garcia Island is one of the most vital. It involves also important international questions affecting other countries, inasmuch as the river is nearly Ioo miles broad at its mouth and continues broader than 6 miles to an inland penetration of many miles. The best work on the controversy between Argentina and Uruguay is that of Agustin de Vedia, ${ }^{5}$ who deals with it historically. It has been an active question both prior to and since the independence of these Republics. Another work on the subject, consisting of the lectures delivered by Alberto Palomeque ${ }^{6}$ in the light of the historical antecedents, was published in Montevideo in 1909.

${ }^{1}$ Guesalaga, Alejandro: Agentes diplomáticos: la exterritorialidad-de los privilejios é inmunidades-de sus funciones $\mathrm{y}$ de sus deberes. Berlin, r893. $238 \mathrm{p}$.

${ }^{2}$ Guesalaga, Alejandro: Derecho diplomático y consular, con los últimos casos de controversias entre los estados. Buenos Aires, J. Peuser, I900. $393 \mathrm{p}$.

${ }^{3}$ Garcia Mérou, Martin: Historía de la diplomacía americana. Politica internacional de los Estados Unidos. Buenos Aires, F. Lajouane, I904. 2 v.

4 Revista diplomatica y consular argentina. Director: Daniel Antokoletz. Buenos Aires, Aven. de Mayo Ir20, I9r5-.

${ }^{5}$ Vedia, Agustin de: Martín Garcia y la jurisdicción del Plata. Buenos Aires, Coni Hermanos, 1908. 472 p.

6 Palomeque, Alberto: La jurisdicción del Plata; Martín Garcia, la Laguna Merin. Montevideo, L. F. Guimaraens, I909. 286 p. 
An important diplomatic incident has been initiated through the recent seizure by the British cruiser Orama of the Argentine steamer Presidente Mitre in the La Plata. The official documents ${ }^{1}$ connected with the case have been published by the Foreign Office. Another collection of documents, with opinions and studies by various persons on the questions involved, has been published by Delfine and Brother, claimants, the representatives of the charterers. ${ }^{2}$

\section{CONFLICT OF LAWS}

Among the most important international conferences which have been held is the South American Congress on private international law which met at Montevideo in 1889 , participated in by Argentina, Bolivia, Brazil, Chile, Paraguay, Peru, and Uruguay. Treaties were signed among these states on the subjects of international civil procedure, literary and artistic property, patents, trade-marks, extradition, the exercise of the liberal professions, and on the rules governing the conflict of laws in civil relations. The conventions concluded have been published by Argentina, ${ }^{3}$ together with the proceedings at each of the 35 sessions, with the speeches and texts. ${ }^{4}$ A similar publication has recently been issued by the government of Uruguay. ${ }^{5}$ A discussion of private international law in connection with the Montevideo congress was published by Lisandro Segovia ${ }^{6}$ in 1889 .

1 El apresamiento del vapor Presidente Mitre. Documentos oficiales. Buenos Aires [Talleres Peuser] rgr6. 63 p.

${ }^{2}$ Delfino y Hermano, A. M.: El apresamiento del vapor "Presidente Mitre." Buenos Aires, Tailhade \& Rosselli, I9r6. I59 p.

${ }^{3}$ Tratados sancionados por el Congreso sud-americano de derecho internacional privado, instalado en Montevideo el 25 de agosto de 1888 y clausurado el 18 de febrero de 1889 . Publicación ordenada por el gobierno de la República Argentina. Buenos Aires, Impr. de J. A. Alsina, 1889. 72 p.

4 Actas de las sesiones del congreso sud-americano de derecho internacional privado. Instalado en Montevideo el 25 de agosto de 1888 y clausurado el r8 de febrero de r889. Publicación ordenada por el gobierno de la República Argentina. Buenos Aires, Impr. de J. A. Alsina, r889. $650 \mathrm{p}$.

${ }^{5}$ Actas y tratados celebrados en el Congreso internacional sud-americano de Montevideo. Montevideo, El Siglo Ilustrado, I9II. 857 p.

${ }^{6}$ Segovia, Lisandro: El derecho internacional privado y el Congreso sudamericano de Montevideo. Buenos Aires, Imp. Mariano Moreno, 1889. $277 \mathrm{p}$. 
Instruction in private international law began at the University of Buenos Aires in 1863 under Professor Federico Pinedo. Bello's work served as a text. For his course, Pinedo prepared certain notes called "Cuadros sinopticos," which have at present no serious importance. The first important treatise on the subject was published by Professor Amancio Alcorta ${ }^{1}$ in three volumes, I 887-1 892. He deals with the history, the basis, the sources, the extension and application of private international law; with the status of aliens in history and particularly in Argentina, and with nationality and citizenship; and then in volumes 2 and 3 takes up seriatim the subjects of the civil code and commercial code in the light of the rules of private international law. The rules on the conflict of laws adopted in the Argentine civil code were discussed by Victor M. Molina ${ }^{2}$ in a work published in I 882 .

A summary of the subject for students was published by Vargas Videla in 1905..$^{3}$ It follows somewhat the order of the continental treatises dealing first with general principles and then with domicil, capacity and status, protection and representation of incompetents, limitations on the personality of law, the form of acts, marriage, succession, juristic persons, obligations arising out of contracts, merchants, transportation, bills of exchange, bankruptcy, intellectual property, maritime law, marine insurance, and international criminal law and procedure.

An important work on the subject published by Dr.Zeballos ${ }^{4}$ under the title "Positive international justice" appeared in I9I I. It is a philosophical and legal discussion of the rules of human society in their interstate relations from antiquity to

${ }^{1}$ Alcorta, Amancio: Curso de derecho internacional privado. Buenos Aires, F. Lajouane, $1887-\mathrm{r} 892.3 \mathrm{v}$.

${ }^{2}$ Molina, Victor M.: E1 derecho internacional privado y el Código civil argentino. Buenos Aires, I882. 238 p.

${ }^{3}$ Vargas Videla, R.: Resumen de derecho internacional privado. Buenos Aires, F. Lajouane, I905. 306 p.

- Zeballos, Estanislao S.: Justicia internacional positiva. Conferencias dadas en la Facultad de Derecho y Ciencias Sociales de la Universidad de Buenos Aires, en el curso intensivo de Derecho internacional privado (Derecho privado humano). Valencia, IgrI. 
the present time. It includes important chapters on the codification of private international law. Dr. Zeballos ${ }^{1}$ has also translated and annotated the French manual of Professor Weiss of the University of Paris.

Dr. Alcides Calandrelli, ${ }^{2}$ now professor of privateinternational law at the Universities of Buenos Aires and of La Plata, has published three volumes entitled "Questions of private international law" which include many of the articles he had previously published. Volume $\mathrm{I}$ deals with the codification of international private law and its development in various congresses, property and the capacity to acquire it, international maritime law, capacity to contract marriage, the intervention of consuls in the administration of the estates of their deceased nationals, and the resolutions of the Institute of International Law and of other international associations. Volume 2 deals with the definitions of private international law, the effect of obligations, the rule locus regit actum and the rules of South American congresses on private international law. Volume 3 constitutes a valuable discussion of domicil and nationality. Dr. Calandrelli ${ }^{3}$ has also published a brief monograph on the codification of private international law.

In I 898, Sylla Monsegur ( ${ }^{3 a}$ ) published a small descriptive bibliography of the Argentine contributions to the conflict of laws.

The international legal status of corporations was the subject of a work published in I91 3 by Raúl A. Orgaz. ${ }^{4}$

${ }^{1}$ Weiss, A.: Compendio de derecho internacional privado. Traducido y anotado por el Dr. E. S. Zeballos. Paris, Larose and Tenin, [rgo2]. $2 \mathrm{v}$.

2 Calandrelli, Alcides: Cuestiones de derecho internacional privado. $v$. I, Buenos Aires, La Buenos Aires, IgIr; v. 2, Madrid, V. Suarez, I9r3; v. 3, Buenos Aires, V. Abeledo, I9r 5 .

${ }^{3}$ Calandrelli, Alcides: La codificación del derecho internacional privado. Buenos Aires, I9r3.

3a Monsegur, Sylla T.: El derecho internacional privado en la Republica Argentina. Apuntaciones bibliográficas. Buenos Aires, M. Biedma, I.898, I $36 \mathrm{p}$.

4 Orgaz, Raúl A.: Condición juridica internacional de las sociedades anónimas. Córdoba, Imp. Arg. Belbian y Rosi, I9r3. II p. 
Among dissertations published on the subject of bankruptcy in private international law mention may be made of one by Aristóbulo Rodriguez ${ }^{1}$ published in 1907.

For a brief period between 1903 and 1909 Dr. Zeballos ${ }^{2}$ published an Argentine "Journal of private international law" which contained numerous articles of importance.

${ }^{1}$ Rodriguez, Aristóbulo: Quiebras en derecho internacional privado. Buenos Aires, V. Abeledo, 1907. 9r p.

${ }^{2}$ Bulletin argentin de droit international privé. v. I (July, Igo3-Oct., r905). v. 2, No. I-5 (rg06-r909); no. 6-7. Index. Buenos Aires, [rg03-rgog]. 


\section{BRAZIL}

\section{INTRODUCTION}

Brazil, the last of the countries of Latin America to adopt a republican form of government, became, by the Papal Bull of Alexander VI of 1493 and the treaty of Tordesillas of the following year, the possession of the King of Portugal. By reason of that fact, its history has differed greatly from that of the Spanish American colonies. Although there were no Conquistadores in Brazil, it was the victim of a backward colonial policy until $\mathrm{I} 808$, when the modern era may be said to have begun. In that year the Prince Regent of Portugal, Dom João, fleeing before Napoleon's troops, landed in Brazil, bringing in his train several thousand Portuguese emigrants. One of his earliest acts was to repeal the laws prohibiting industries and to establish economic instruments and machinery of progress, such as opening the ports to commerce, the institution of banks and printing presses, and other measures.

In 1815 the country was proclaimed as the Kingdom of Brazil. Three years after, Dom João was proclaimed King of Portugal, and left Brazil under the control of his son Dom Pedro. From this time on political instability prevailed in Brazil. On September 7,1822 , dissatisfaction with the Portuguese domination led to a political uprising, which resulted, on October 12,1822 , in the proclamation of a constitutional monarchy, at the head of which Dom Pedro, who had espoused the Brazilian cause, placed himself. A popular assembly, called in May, 1823, adopted a constitution on March 25, 1824, which is notable for the frequency with which it was violated. The Emperor proved so unpopular that political opposition compelled him, on April 7, i 831, to abdicate in favor of his son, Dom Pedro II, whose long reign until I 889 marks the gradual development of modern Brazil.

The constitution of I 824 was based on the political doctrines of Benjamin Constant. The provinces, which were granted legislative assemblies by a constitutional change in 1834 , were controlled by presidents appointed by the imperial govern- 
ment and had authority to legislate on certain matters concerning provincial administration.

After a period of a Regency, Dom Pedro assumed the throne, with a powerful Council of State holding the reins of government. The bloodless revolution of 1889 , which compelled the. abdication of Dom Pedro II on November 15 of that year, was followed by a provisional government of some fifteen months. On February 24, I891, the federal constitution of the Republic of the United States of Brazil was adopted, the twenty provinces being erected into states with far more power than they possessed before, and the city of Rio Janeiro being set aside as a Federal District for the location of the federal capital. The states are: Alagôas, Amazonas, Bahia, Ceará, Espirito Santo, Goyaz, Maranhão, Matto Grosso, Minas Geraes, Pará, Parahyba, Paraná, Pernambuco, Piauhy, Rio de Janeiro, Rio Grande do Norte, Rio Grande do Sul, Santa Catharina, São Paulo and Sergipe; besides the Federal District and the territory of Acre, obtained by cession from Bolivia.

The constitution of $r 891$ is modeled upon that of the United States, the provinces, now states, possessing all legislative power not expressly delegated to the federal union. The revenues of the state and the union derived by taxation are carefully delimited in the constitution. Thus, the federal government has exclusive power to levy (I) import duties on merchandise from abroad; (2) ship dues; (3) stamp fees of a federal nature; (4) postage and telegraph fees. The states levy taxes (I) on state products exported; (2) on real estate; (3) on the transfer of property; (4) on industries and professions. The federal government furthermore has full jurisdiction over coinage and banks of issue and has control of customhouses and interstate commerce. The states own mines and vaste lands located in their territory, reserving to the union merely those lands necessary for military defense and federal railroads.

The federal government has exclusive jurisdiction to enact civil and commercial codes and laws, to govern throughout the country, and to enact the penal law for the Federal District. The states have jurisdiction over adjective or procedural law in application of the civil and commercial codes. There is a dual judicial hierarchy-state and federal-closely resembling that of the United States. 


\section{BIBLIOGRAPHY}

Bibliographic information in Brazil is rather more complete than in Argentina. One of the most important works is the bibliographical dictionary of Dr. Sacramento Blake ${ }^{1}$ published in seven volumes from 1883 to 1902 . It includes biographies of the principal writers of books relating to Brazil, with some description of the contents of their principal works. A feature of the work which impairs its utility to some extent is the fact that the authors are listed by their first Christian name, so that there are several hundred Joãos. This habit of listing and cataloguing authors by their Christian names is a practice followed by various catalogues and a considerable part of the general public. In the present monograph the practice will not be followed and the difficulty occasioned by the multiplicity of surnames with which most Brazilians are endowed will be relieved, so far as possible, by cross references in the index.

The most useful catalogue of law books is that of the faculty of law at Recife (Pernambuco) ${ }^{2}$, one of the eight leading law faculties of Brazil. The catalogue was originally published in 1896 under the supervision of the librarian, Dr. Manoel Cicero Peregrino da Silva, a well-known scholar, and now Director of the National Library at Rio de Janeiro. It was arranged by subject. A supplement, alphabetically arranged, appeared in 19r3. A less useful law catalogue, both by reason of its early date and poverty of material, is that of the library of the faculty of law at São Paulo ${ }^{3}$, published in 1887 .

In connection with the celebration of the fiftieth anniversary in 1894 of the founding of the Instituto da ordem dos advogados brazileiros in Rio de Janeiro, an exposition of the legal literature of Brazil was held, for which a catalogue was issued. ${ }^{4}$

${ }^{1}$ Sacramento Blake, Augusto Victorino Alves do: Diccionario bibliographico brazileiro pelo doutor Augusto Victorino Alves Sacramento Blake . . . Rio de Janeiro, Typographia nacional, 1883-1902. 7 v.

${ }^{2}$ Faculdade de direito do Recife. Catalogo geral da Bibliotheca da . . . Recife, Empr.d'A. Provincia, I896. 4I7 p. Primeiro Supplemento. Recife, Impr. Industrial, I9I3. $439 \mathrm{p}$.

- Catalogo da bibliotheca da faculdade de direito de São Paulo em I887. São Paulo, 1887 .

- Catalogo da exposicão de trabalhos juridicos, realizada pelo Instituto da ordem dos advogados brazileiros á 7 de septembro de 1894. Rio de Janeiro, 1894.

$71624^{\circ}-17-18$ 
Useful catalogues of law books are published by two of the leading publishers of Brazil, Francisco Alves and J. Ribeiro dos Santos. The catalogue of Alves, ${ }^{1}$ published in 1910, is the more complete and is of interest also because of its subject index. A I9I7 edition is said to have been just issued. The catalogue of Ribeiro dos Santos ${ }^{2}$ is rather meager. It was published in 1914, with a supplement in 1915.

An excellent bibliography of the history of Brazil was prepared in I 88I under the supervision of Dr. B.F. Ramiz Galvão ${ }^{3}$ with a supplement by João de Saldanha da Gama, as the catalogue of the exposition of Brazilian history at the National Library. It is divided into broad subject divisions. For the material relating to Brazil published prior to $188 \mathrm{o}$ it is unsurpassed for completeness, although Trübners Bibliotheca Brazilica, 1 500-1879 (London, I 879); deserves mention. The historical catalogue published in I88I contains sections on the various branches of hist ory and economics, including under the topic constitutional history, the literature on law and legislation. The work appears also as volume nine of the Annaes of the National Library.

One section (class 2) of the catalogue of the municipal library of Rio de Janeiro ${ }^{4}$ published in 1878 is devoted to legal literature. It is not exhaustive.

For historical material the catalogue of the library of the National Archives, ${ }^{5}$ published in 1901 , will be found useful. A note on the historical bibliography of Brazil will be found in volume 8 of Winsor's "Narrative and critical history of America," published in. Boston in I889. It is appended to

${ }^{1}$ Alves, Francisco: Extracto do catalogo de direito, politica e sciencias sociaes. Apontamentos para o Catalogo 3. Rio de Janeiro, I9ro. I02 p. A I9I7 catalogue is reported as just issued.

2 Livraria Cruz Coutinho. " Catalogo de obras de direito. Rio de Janeiro, J. Ribeiro dos Santos, I9I4. Supplement, I9r5. 39 p.

${ }^{3}$ Catalogo da exposiçao de historia do Brazil realizada pelo Bibliotheca nacional do Rij de Janeiro a 2 de dezembro de $188 x$. Rio de Janeiro, Typ. de G. Leuzinger \& filhos, I88r. 2 v. 'Supplemento . . . Rio de Janeiro, Typ. de G. Leuzinger \& fllhos, ì883.

- Catalogo da Bibliotheca municipal (Publicação official) Rio de Janeiro, Typ. central de Brown \& Evaristo, 1878 . 8r 5 p.

5 Catalogo da bibliotheca do Archivo publico nacional. Rio de Janeiro, Imprensa nacional, x901. $9 \circ \mathrm{p}$. 
Markham's 1 "Colonial history of South America" included in the former work.

A valuable catalogue of literature relating to colonial Brazil from 1492 to 1822 has been published recently by José Carlos Rodrigues, ${ }^{2}$ the owner of one of the most complete collections of manuscripts in Brazil. The work is to be continued to include the literature covering the period of the Empire and the Republic.

A catalogue of French and Latin works relating to Brazil, published between 1500 and 1898 , was issued by Anatole L. Garraux, ${ }^{3}$ formerly. librarian at São Paulo. This work, like the critical survey of German literature relating to Brazil published by Oskar Canstatt, ${ }^{4}$ contains but few references to legal literature.

Two works on the history of the national printing office, with some account of its productions, warrant mention. The first, by Valle Cabral, ${ }^{5}$ consists of a bibliography of government publications issued during the period 1808 to 1822 , chronologically arranged. The other, by Oliveira Bello, ${ }^{6}$ consists of a history. of the government printing office from 1808 , the

1 Markham, Sir Clements Robert: Colonial history of South America, and the wars of independence . . . [With a critical essay on the sources of information and editorial notes, including a note on the bibliography of Brazil.] (In Winsor, Justin, ed.) Narrative and critical history of America. Boston and New York, 1884-89. v. 8 (r889) p. [295]-368. Bibliography, p. 349-358.

${ }^{2}$ Rodrigues, José Carlos: Bibliotheca brasiliense. Catalogo annotado dos libros sobre o Brasil e de alguns autographos e manuscriptos pertencentes a J. C. Rodrigues . . . Rio de Janeiro, Typ. do "Jornal do commercio," rgo7-. $680 \mathrm{p}$.

${ }^{3}$ Garraux, Anatole Louis: Bibliographie brésilienne: catalogue des ouvrages français \& latins relatifs au Brésil (1500-1898). Paris, Chadenat [etc.], r898. $400 \mathrm{p}$.

- Canstatt, Oskar: Kritisches repertorium der deutsch-brasilianischen literatur. Berlin, D. Reimer (E. Vohsen), r902. I24 p. Nachtrag zum Kritischen repertorium . . Berlin, D. Reimer, rgo6. 64 p.

5 Valle Cabral, Alfredo de: Annaes da Imprensa nacional do Rio de Janeiro de 1808 a 1822 . Rio de Janeiro, Typographia nacional, I88I. $339 \mathrm{p}$.

6 Bello, Oliveira: Imprensa nacional (officina official) r 808-r908; apontamentos historicos, por Oliveira Bello, redactor do "Diario official." Rio de Janeiro, Imprensa nacional, I908. $\mathrm{r}_{52}^{2} \mathrm{p}$. 
date of its establishment, until 1908, and contains but little bibliographical information.

A valuable history of printing in Brazil, with a descriptive account of the periodical literature published in various states of Brazil, was issued in 1908 as a volume of the Revista do instituto historica e geographico brazileiro.

Passsing mention may be made of the bibliography of periodical literature published in Pernambuco ${ }^{1}$ and Pará, ${ }^{2}$ two of the most important states of Brazil, up to 1908 .

Among the less important bibliographies for legal purposes mention may be made of the recent bibliography of general works relating to Latin America, published by Peter H. Goldsmith, ${ }^{3}$ and the unclassified list of books, magazine articles, and maps relating to Brazil, published in 1901 by P. Lee Phillips.4.

The National Library at Rio de Janeiro has, since 1876 , published Annaes, ${ }^{5}$ which had reached 32 volumes up to 1910. In these volumes are to be found valuable historical contributions, consisting principally of catalogues of various special collections and of manuscripts in the Library, of philological and ethnological studies of native tongues and customs, of biographical studies, incunabula, histories of coins, medals, drawings, etc., in the Library, scholarly editions of many historical documents and reports of the director of the Library, including the history of the Library. Although

1 Carvalho, Alfredo de: Annaes da imprensa periodica pernambucana de I82I-I908; dados historicos e bibliographicos collecciónados por Alfredo de Carvalho. Recife, Typographia do "Jornal do Recife," Ig08. $640 \mathrm{p}$.

2 Bellido, Remijio de: Catalogo dos jornaes paraenses 1822-I908. Pará, Imprensa official, I908. I63 p. I pte. Catalogo alphabetico et descriptivo; 2 pte. Catalogo chronologico; 3 pte. Catalogo segundo as localidades.

${ }^{3}$ Goldsmith, Peter H.: A brief bibliography of books in English, Spanish, and Portuguese, relating to the republics commonly called Latin American, with comments. New York, The Macmillan Co., I9I5. I07 $\mathrm{p}$.

- Phillips, Philip Lee: A list of books, magazine articles, and maps relating to Brazil. I800-I900. Prepared by P. Lee Phillips ... A supplement to the Handbook of Brazil (rgor) comp. by the Bureau of the American Republics. Washington, G. P. O., Igor. I45 p.

5 Annaes da Bibliotheca nacional do Rio de Janeiro . . . vol. I-32. r876-rgro. Rio de Janeiro, I876-rgri. 
the decree governing the administration of the Library, No. 8835 of July II, I9I I, provides in article 9, section 27 , for the publication of a bibliographical bulletin, no such publication appears as yet to have been issued. The decree referred to, together with the copyright law of August I, 1898, with its regulation and the law providing for the deposit of one copy of each printed book in the National Library, were published together in one pamphlet in $1911 .^{1}$

In 1895 it appears that an effort was made by the section on Brazilian bibliography of the Historical and Geographical Institute to cooperate with the Bibliographic Institute at Brussels for the regular publication of Brazilian bibliography, principally historical and geographical. No record has been found of the publication of the bibliographies planned.

Casual interest may attach to a three-volume biography ${ }^{2}$ of prominent Brazilians, published in 1876 in connection with the Centennial Exhibition at Philadelphia. Curiously, it consists of brief biographies of 365 persons, one for each day of the year, arranged according to the date of birth or the date of some prominent event in the history of Brazil with which the subject of the biography was connected

\section{LEGISLATION}

The legislation of Brazil in civil matters is based upon the old Portuguese law, which passed from Portugal to the Empire of Brazil and later to the Republic. By a law of October 20, 1823, and article 85 of the Constitution of $189 \mathrm{I}$, the ordinances of Phillip I (II of Spain), compiled in 1603 , were declared in force in Brazil; and much of this law continued in force until the newly enacted civil code took effect on January I, 1917. More special reference to the Portuguese ordinances, known as the Codigo Philippino, will be made in the discussion of legal history.

\footnotetext{
1 Regulamento, decreto n. 8835, de II de julho de I9II. Direitos autoraes: lei n. 496, de I de agosto de 1898 , e instrucções de II de junho de rgor. Remessa de obras impressas: decreto legislativo n. 1825 , de 20 de dezembro de 1907 , e instrucções de I de junho de 1908 . Rio de Janeiro, Imprensa nacional, I9Ir. $3^{8}$ p.

${ }^{2}$ Macedo, Joaquim Manuel de: Brazilian biographical annual . . . Rio de Janeiro, Typ. e lith. do Imperial instituto aristico, $1876.3 \mathrm{v}$.
} 
The legislation of Brazil proper commenced with the issuance of the royal decrees of Dom João in 1808 and, with brief omissions, has continued steadily since then.

Official Gazettes.-Like the other countries of Latin America, Brazil has published since 1808 an official gazette under various titles, with intermissions and variation of content. The Gazette of the present time, known as Diario Official, contains, besides the laws, decrees and ministerial orders, circulars and notices, a judicial section devoted to court calendars, public notices, judicial citations, publication of trade-marks and patents, governmental authorizations for corporations and publications of statistical reports, such as balance sheets, and other documents and notices of public interest. For some time it also included the decisions of the Supreme Court.

The first Gazette published in Brazil, the Gazeta do Rio de Janeiro, ${ }^{1}$ commenced on September I0, 1808, and was edited by Tiburcio José da Rocha. After November 14, 1822, it bore the Brazilian arms, and after December 3I, I822, it was replaced by the Diario do Governo. The Diario do Governo, printed at the Imprensa Nacional, commenced publication on January 2, 1823 , and continued publication until June 30 , I833, having, however, changed its name on May 20, I824, to Diario Fluminense. ${ }^{2}$ It appeared in two volumes a year. This publication was succeeded by the Correio Official, ${ }^{3}$ which continued in existence from 1833 until I841. Two to three volumes were published annually.

There then seems to be a gap of several years until, on September I, I846, the Gazeta Official do Imperio do Brazil ${ }^{4}$ made its appearance; five volumes were published up to 1848 . Again there appears to be a hiatus until October I, 1862, when

${ }^{1}$ Gazeta do Rio de Janeiro. Rio de Janeiro, Impr. Regia, I808-r822. I $5 \mathrm{v}$.

2 Diario do governo [after May 20, I824, Diario fluminense]. Rio de Janeiro, Impr. Nacional, I823-33. $22 \mathrm{v}$.

${ }^{3}$ Correio Official, I833-I84x. Rio de Janeiro, Typ. de Dh. Hunt e Typ. Nacional, I833-4I. 2 to 3 v. per year.

${ }^{4}$ Gazeta Official do Imperio do Brazil. Rio de Janeiro, Typ. Naciōnal, r846-r848. 5 v. f $^{\circ}$. 
the Diario Official, ${ }^{1}$ still in course of publication, was first issued. "At the creation of the Republic it merely altered its subtitle from an Imperial to a Republican Gazette. Three to four volumes appear annually.

While not an official gazette, attention should be called to the Diario do Rio de Janeiro ${ }^{2}$ which began publication on June I, I82I, under the editorship of Zephyrino Vieto de Meirelles and ceased on October $3 \mathrm{I}, \mathrm{I} 878$. It is a respository for many of thr official documents, notices, and publications usually found only in official gazettes and is especially important for the periods during which no official gazette appears to have been issued.

LAWS AND DECREES.-As already observed, the indigenous legislation of Brazil began in the form of royal decrees in 1808 . Numerous collections of the laws and decrees issued since I 808 were compiled between 1830 and 1880 in more or less long series. It seems unnecessary, however, to enumerate these various collections, inasnuch as the government has in recent years undertaken to reprint the statutes from the beginning. This series, which will be enumerated in detail presently, is obtainable at a low price at the Imprensa Nacional in Rio de Janeiro.

The first official collection (incomplete) of the laws and imperial orders and decrees was published in a four-volume folio edition ${ }^{3}$ covering the years 1808 to 1827 .

The official collection, including the reprint, consists of two parts. The first part called the Colleç̧ão das leis consists of two sections; the first containing acts (decretos) of the legislative power, and the second, acts (decretos) of the executive power, signed by the President in execution of an authority vested in him by Congress. The second part consists of orders (decisões) of the various executive departments or

${ }^{1}$ Diario Official do Imperio do Brasil, I862-I9I4. Rio de Janeiro, Typ. Nacional, r862-rgr 5 . 3 to $4 \mathrm{v}$. per year. In progress.

${ }^{2}$ Diario do Rio de Janeiro, I82 I-I878. Rio de Janeiro, Typ. Real e Typ. do Diario, $182 \mathrm{I}-78$. $170 \mathrm{~V}$.

${ }^{3}$ Codigo brasiliense, ou Collecção das leis, alvarás, decretos, cartas regias, etc., promulgadas no Brasil desde a cheguda do Principe Regente a estas estados, 1808-1827. Rio de Janeiro, Impr. Regia, I811-1827. 4 v. $f^{\circ}$. 
ministries which have the force of law. It seems merely necessary to enumerate the imprints of the session laws from I 808 to $1889 .^{1}$

${ }^{1}$ Collecção das leis do Brazil. Rio de Janeiro, Imprensa Nacional. 1808-1810 (Impr. Nacional, I89I). I8I I-I8I7 (Impr. Nacional, I89o). 1818-1821 (Impr. Nacional, 1889). Also reprinted in $7 \mathrm{v}$.

Collecção das leis do Imperio do Brazil. Rio de Janeiro. 1822 (Imprensa Nacional, I887). 1823 (Imprensa Nacional, 1887 ). I824-25 (Imprensa Nacional, I887).

Colleç̧ão de decretos, cartas imperiaes e alvarás do Imperio do Brazil. 1825. Rio de Janeiro, Imp. Nacional, 1885.

Colleç̧ão das leis do Imperio do Brazil. Rio de Janeiro. I826 (Typ. Nacional, 1880). 1827-28 (Typ. Nacional, 1878). 1829 (Typ. Nacional, 1877 ). 1830-3I (Typ. Nacional, 1876). 1832 (Typ. Nacional, 1874). Same, 3rd ed. (Impr. nacional, 1906.) 1833 (Typ. Nacional, 1872 ). 1834 ('Typ. Nacional, 1866). I835 ('Typ. Nacional, 1864). 1836-37 (Typ. Nacional, r86r). I838, v. I ('Typ. Nacional, I863). I839, v. 2 (Typ. Nacional, I864). I840-4I, v. 3-4 (Reimpresso na typ. nacional, I863-64). 1842 , v. 5 , pt. 2 (Reimpresso na typ. nacional, 1865 ). $\mathrm{r} 843$, v. 5 , pt. I (Reimpresso na typ. nacional, 1865 ). 1843 , v. 6, pt. 2 (Reimpresso na typ. nacional, I868). $\mathrm{I} 844$, v. 6 , pt. I (Reimpresso na typ. naciónal, I865). 1844 , v. 7 , pt. 2 (Reimpresso na typ. nacional, I865). 1845 , v. 7 , pt. I (Reimpresso na typ. nacional, I866). $\mathrm{I} 845$, v. 8, pt. 2 (Reimpresso na typ. nacional, I866). I846-48, pt. I, v. 8-Io, pt. 2, v. 9-II (Typ. nacional, I847-49). 1849 , v. 12 , pt. 2 (Typ. nacional, 1850 ). 1850, v. II, pt. I (Impresna nacional, I885). 1850 , v. 13, pt. 2 (Imprensa nacional, 1885 ). I85I, v. I2, pt. I (Imprensa nacional, [I884]). I85I, v. I4, pt. 2 (Imprensa nacional, [1884]). I ${ }_{52}$, v. I3, pt. I (Typ. nacional, I853). $185^{2}$, v. 15 , pt. 2 (Typ. nacional, 1853 ). I853, v. I4, pt. I (Imprensa nacional, I887). 1853 , v. I5, pt. 2 (Imprensa nacional, 1887 ). 1854-1889, pt. $x$, v. $x_{5}-36$ (1854-1874, vol. I5-33). (Typ. Nacional, I854-89.) (1875-1889, vol. 24-36). I854-I889, pt. 2, v. $17-52$ (Typ. Nacional, I854-I889). 
Section $\mathrm{x}$ of each year comprises the "Actos do poder legislativo." From 1838 to 1889 these are numbered "Tomo $1-33,24-36$ " $(34-46$ ?); none were published for the years I $842, \mathrm{I} 849, \mathrm{I} 863, \mathrm{I} 872, \mathrm{I} 876$, and $\mathrm{I} 878$.

Section 2 comprises the "Actos do poder executivo," which from 1838 to 1889 are numbered "Tomo $x-52$."

Prior to 1889 , the decretos of the Executive are also to be found in an Annexo to the annual report (Relatorio) of the Minister of Justice.

During the period of the provisional government from November 15, 1889, to February I3, I891, numerous laws ${ }^{1}$ were enacted, among others a law on the naturalization of aliens, a mortgage law, a law doing away with the necessity of an offer of conciliation before beginning civil action (an institution, curiously, which is now advocated by a committee of law reform in New York), a Torrens system of land registration, a law on civil marriage and divorce (i. e., legal separation), a law organizing the federal judiciary, a penal code, changes in the bankruptcy law (since completely revised), the separation of church and state, and the nationalization of cemeteries.

The laws since February 24, 1891, have been published regularly, ${ }^{2}$ except that it must be noted that they are published with delays as great as four years, making it almost necessary for current legislation to resort to the Diario Official.

The Ministerial orders (decisões), having been published in a separate series, will be separately enumerated. ${ }^{3}$

${ }^{1}$ Decretos do governo provisorio da Republica dos Estadus Unidos do Brazil. Rio de Janeiro, Imprensa nacional, I890-I89I.

Nov. I5, I889-Dec. 31 , I889 (I fasc.).

Jan., I890-Dec., I89o (I2 fasc.),

Jan., I89r-Feb., I8gr (2 fasc.).

2 Colleç̧ão das leis da Republica dos Estados Unidos do Brazil. Feb. 24, I89I-I9r4. Rio de Janeiro, Imprensa Nacional, I892-I9I7. [Annual] 1894, I898, I899, I903-1906, I908-1909 in 2 v. each; I907 and 1910 in $3 \mathrm{v}$. each; I9II-IgI. 3 in $4 \mathrm{v}$. each. IgI in $5 \mathrm{v}$.

8 Colleç̧ão das decisões do governo do Brazil . . . 1808-1820. (With Collecção das leis ....)

Collecção das decis̃̃es do governo do Imperio do Brazil. Rio de Janeiro. I82 I (Imprensa nacionai 1889 ). I822 (Imprensa nacional |-888]). 
Partly on account of the tardiness in the publication of the session laws, Dr. Candido Mendes de Almeida began, in October, I913, the publication of a periodical Legislasão e jurisprudencia do Brasil, ${ }^{1}$ which reports monthly the legislation of

Footnote ${ }^{3}$-Continued.

Callecção das decisões do governo do Imperio do Brazil. Rio de Janeiro.

I823 (Imprensa nacional, I887).

I824 (Imprensa nacional, I886).

I825 (Imprensa nacional, I885).

I826 (Typ. nacional, I88I).

1827-1828 (Typ. nacional, 1878 ).

I829-1830 (Typ. nacional, I877, I876).

183I (Typ. nacional, 1876).

I832 (Typ. nacional, I875). Reprint, Imp. nacional, I906.

1833 (Typ. nacional, 1873).

I834 (Typ. nacional, r866).

I835 (Typ. nacional, 1864).

I836-1837 (Typ. nacional, I86I).

I838, v. I (Typ. nacional, $186_{3}$ ).

I839, v. 2 (Typ. nacional, I864).

I840-4I, v. 3-4 (Reimpresso na typ. nacional, 1863-I864).

$\mathrm{I} 842$, v. 5 (Reimpresso na typ. nacional, I865).

1843 , v. 6 (Reimpresso na typ. nacional, 1868 ).

I844, v. 7 (Reimpresso na typ. nacional, 1865).

I845 [v. 8] (Reimpresso na typ. nacional, 1866).

I846-r849, v. 9-12 (Typ. nacional, I847-I850).

I850 [v. I3] (Imprensa nacional, I885).

$185^{2}$, v. I 5 (Typ. nacional, $185^{2}$ ).

1853 [v. I6] (Imprensa nacional, I887).

I854-1875, v. I7-38 (Typ. nacional, $1854-1876$ ).

1876-r889, Nov. 8 (Typ. nacional, $1877-1889$ ).

Additamento á collecção das decisões do governo do Imperio do Brasil, expedidas pelo Ministerio dos negocios da fazenda no anno de 1864 . . . Rio de Janeiro, Typ. Nacional, 2866.

Decisões do governo provisorio da Republica dos Estados Unidos do Brazil. Rio de Janeiro, Imprensa Nacicnal, I892-1893.

Fasc. I (Nov. 15, 1889-Mar. 31, I89o).

Fasc. 2 (Apr.-June, I89I (for 1890$)$ ).

Fasc. 3 (July, 189o-Feb. 23 , I891).

Decisões do governo da Republica dos Estados Unidos do Brazil. I89II9ri. Rio de Janeiro, Imprensa Nacional, 1894-1915. [Annual.] In progress.

${ }^{1}$ Legislação e jurisprudencia do Brasil, publicação mensal sob a direç̧ão do Dr. Candido Mendes de Almeida . . . Rio de Janeiro, Officinas graphicas do Jornal do Brasil, I9I3-. $4 \mathrm{v}$. per year. In progress. 
the federal government, printing in full the more important acts and summarizing the less important, with references in all cases to the Diario Official. The same jurist had planned to publish an Annuario ${ }^{1}$ cumulating and continuing the monthly publication bound in quarterly volumes. This does not, however, seem as yet to have made its appearance.

Various indexes to the national legislation have been published. One of the most important is the five-volume index of the legislation from 1808 to 1850 , published by Souza Furtado de Mendonça ${ }^{2}$ between 1847 and 1862 . It is a continuation of an earlier classic index by Manoel Fernandez Thomaz (infra, p. 235).

A chronological index-digest covering the years 1822 to 1848 was issued by Antonio Manoel Fernandes ${ }^{3}$ in Nictheroy, the capital of the state of Rio de Janeiro, in 1849 , with a supplement covering the year $185^{\circ}$. The continuation of this work covering the years 1850 to 1870 was published in two volumes by Joaquim Candido de Azevedo Marques, ${ }^{4}$ with continuations covering the years 1871 to 1873 and 1874 to 1878 .

Very recently an index of the legislative acts from November I5, 1889, to December 31, 1899, has been published officially. ${ }^{5}$

A brief but useful index to the legislation in force in 1903, including the municipal ordinances of the Federal District,

1 Annuario da legislação e da jurisprudencia do Brasil.

${ }^{2}$ Repertorio geral ou Indice alphabetico das leis do Imperio do Brazil . . . desde 1808 até o presente, em seguimento ao Repertorio geral do Manoel Fernandez Thomaz . . . Ordenado por Francisco Maria de Souza Furtado de Mendonça. Rio de Janeiro, E. \& H. Laemmert, I847-62. $5 \mathrm{v}$.

${ }^{3}$ Indice chronologico, explicativo e remissivo da legislação brasileira desde $x 822$ até 1848 . . pelo Antonio Manoel Fernandes, Jr. Nictheroy, Typ. Nictheroy de M. S. Rego, 1849. For 1850, Rio de Janeiro, Typ. M. A. da Silva Lima, I850. 204 p.

${ }^{4}$ Legislação geral. Indice alphabetico explicativo das disposicões dos annos de r850 á r870. Organisado por Joaquim Candido de Azevedo Marques. Rio de Janeiro, Typ. Nacional, I872-74. 2 v.

Same. I871-73. Rio de Janeiro, Typ. Nacional, I876. $x$ v.

Same. 1874-78. Rio de Janeiro, Typ. Nacional, I880. I v.

${ }^{5}$ Silvera Reis, Eugenio Adolpho da: Repertorio dos actos emanados dos poderes legislativos no periodo de 15 noviembro de 1889 a 3 I de dezembro de 1899 . Rio de Janeiro, Impr. nacional; I9I6. 
was published in that year by a lawyer with the initials "A. C." 1

As a source of interpretation of statutory law, the proceedings and debates of the Chamber of Deputies ${ }^{2}$ and of the Senate $^{3}$ are of much importance. Regular sessions of both houses began in 1826 and continued until 1889 . The proceedings and debates were published regularly. A separate publication of the Senate ${ }^{4}$ proceedings for the years $185^{-}$ I 879 was also issued.

An excellent work, containing a record of the various Ministries from 1822 to 1889 , with a summary of the decrees enacted in each year, together with lists of the senators and deputies during the period mentioned, the governors of the provinces, the members of the Council of State (abolished in i 889), and other information of value in the administration of the country from 1822 to 1889 , was published in $I 889$ by the Secretary of the Chamber of Deputies. ${ }^{5}$

At the conclusion of the provisional government in February, i 891, the regular sessions of the legislature, commencing on May 3 of each year, began and their proceedings have been published under the title Diario do Congresso nacional. ${ }^{\circ}$

\section{STA'TE LEGISLATION}

Legislative assemblies in the states began to sit in 1835 in consequence of the constitutional amendment of 1834 . In

'A. C.: Synopse da legislação brazileira, contendo a indicação das principaes leis, decretos, regulamentos, instrucções, avisos e outros actos concernentes não só aos serviços federaes em toda a republica, mas tembem aos municipaes do Districto Federal, por C. A. Rio de Janeiro, Typ. Leuzinger, 1903. $\quad$ I6 p.

${ }^{2}$ Actas das sessões da Camara dos Senadores do Imperic do Brazil; 1826r889. Rio de Janeiro, Impr. Imp. e Nacional, r826-1889. 2 to 3 v. per year.

a Actas das sessões da Camara dos Deputados do Imperio do Brazil, 1826-1889. Rio de Janeiro, Imp. Imperial e Nacional, I826-1889. 2 to $3 \mathrm{v}$. per year.

4 Annaes do Parlamento Brasileiro. Senado. I858-1879. Rio de Janeiro, Empreza do Diario, Typ. do Correio Mercantil e Typ. Nacional, I858-r88o. 52 v.

5 Camara dos deputados. Organisações e programmas ministeriaes desde I822 á r889. Rio de Janeiro, Impr. Nacional, I889. 469 p.

6 Diario do Congresso nacional, I89I and following. Rio de Janeiro, Impr. Nacional, 189I-. 3 to $4 \mathrm{v}$. per year. 
I 89 I the provinces were, by the constitution of that year, erected into states with considerable autonomy and exclusive jurisdiction over numerous matters theretofore controlled by the central government at Rio de Janeiro. The state legislation since $189 \mathrm{I}$, therefore, is of more importance than that preceding.

Bibliographic information concerning the source books in which the legislation of the erstwhile provinces, now states, is to be found has been difficult to obtain. Practically no library in Brazil possesses the complete legislation of the provinces and states, and probably no library elsewhere possesses any considerable collection. Nevertheless, from the files of the Library of Congress and such information as has been obtainable from the National Library at Rio de Janeiro and from bibliographies and catalogues, the following information is presented in the hope that it is approximately correct. The titles are self-explanatory and require no discussion. Compilations of laws covering considerable periods have also been included. The states are listed alphabetically.

Alagôas:

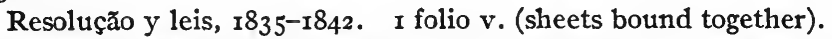

Collecção das leis provinciaes, 1842. Pernambuco, Santos \& Co., I842.

Colleç̧ão de leis da assembléa legislativa, 1843-1887. Maceió, João Vasco Cabral [etc., etc.], 1843-1888. $45 \mathrm{v}$.

Compilação das leis provinciaes das Alagôas de 1853 a 1872 por Olympio Eusebio de Arroxellas Galvão e Tiburcio Valeriano de Araujo. Comprehendendo os actos administrativos e legislação subsidiaria; e seguida de um repertorio alphabetico das materias contidas na compilacão. Maceió, Typ. Commercial de A. J. da Costa, 1870-72. $6 \mathrm{v}$. and Appendice (v. VII), I874.

Collecção de leis e decretos do Estado de Alagoas r892-rgir [annual]. Maceio, Liv. Commercial, etc., I894-1913.

Indice das leis da provincia das Alagoas de 1835 a 1858 que por ordem do presidente da provincia, Angelo Thomaz do Amaral, organizou José Francisco Soares. Maceio, Typ. do Tempo, 1859. $9^{6}$ p. $f^{\circ}$. Amazonas:

Collecção de leis da Assemblea legislativa da provincia do Amazonas: 1852-1888. Barro do Rio Negro, 1852-55; Manáos, Francisco J. da Silva Ramos, etc., 1856-r902. 37 v. (Publisher varies; each v. in 2 parts.)

Compilação das leis da provincia do Amazonas. 1852-1883. By Gentel Rodrigues de Souza. Manaos, Comercio, i883. I32 p. (Index to the laws by subject.) 
Amazonas-Continued.

Decretos, leis e regulamentos, colleccionadas na administração do Ex. Sr. Dr. Fileto Pires Ferreira, 1889-[1896]. Manaos, Imp. Official, r897. v. I, I889-90; v. II, I89I; v. III, I89r; v. IV, I892.

Collecção das leis de 1892, 1893 and r894. Manaos, Luio Agaisor \& Co., rgor.

Collecção das leis de $189^{2-1899 . ~ M a n a ́ o s, ~ L i v r a r i a ~ e ~ t y p . ~ " P a l a i s ~}$ Royal," etc., I90I-[1905]. $8 \mathrm{v}$.

Leis, decretos y regulamentos colleccionadas na administração do Exmo. Sr. Dr. Silverio José Nery, I900; I90I (2 v.); I902; I903. Rio de Janeiro, Jornal do Commercio, IgoI-[Igr2]. 5 v.

Leis, decretos y regulamentos colleccionadas na administração do Exmo. Sr. Dr., Antonio Constantino Nery [and others]. I904-rgrr. Manaos, Amazonas, rgo6-[1913]. I3 v. (From Jan.-June, rgo6, Bahia: there is no publication of laws.)

Leis e resoluções da assembléa legislativa da Bahia, sanccionadas e publ. nos annos de . . . 1835-1889. Bahia, Diario da Bahia, etc., I836-189o. $55 \mathrm{v}$.

Colleç̧ão das leis e resoluções da assemblea legislativa da Bahia, de 1835-r86o. Bahia, Typ. de Antonio Olavo da França Guerra, I862-1866. I3 v.

Collecção das leis . . . do Estado da Bahia, r891-1913. Bahia, I893Ceará: r914. [Annual].

Collecção das leis, decretos, resoluções e regulamentos, I835-1843.

Ceará, Typ. Fidelissima, etc., I836-1844. 9 v.

Collecção das leis, decretos, resolucões, etc., I844-r87r. (v. r-37.) Ceará, Typ. Fidelissima, Brasiliense, etc., etc., I845-1872. $37 \mathrm{v}$.

Compilação das leis provinciaes do Ceará comprehendendo os annos de I835 a I86I, pelo Dr. José Liberato Barroso, seguida de um indice alphabetico pelo mesmo autor. Rio de Janeiro, Typ. Universal de Laemmert, $1863.3 \mathrm{v}$.

Collecção dos actos legislativos . . . I873-1889. Fortaleza, Typ. constitucional, etc., I873-1889. I7 v.

Decretos e leis do estado. . . compiladas pelo . . . C. d'Albuquerque M. Pereira, I889-1892 [and probably continued annually]. Fortaleza, r889-.

Espirito Santo:

Livro das leis da provincia do Espirito Santo contendo as leis e resoluções da assembléa legislativa nas sessões ordinarias de 1835-

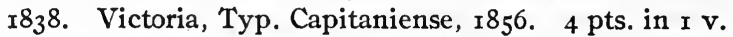

Livro das leis da provincia, $1839-1887$ (v. I-52). Nictheroy, Rio de Janeiro, and Victoria (after v. II). [Imprint varies], I839-1887. $52 \mathrm{v}$.

Compilação das leis provinciaes ( $1835^{-188}$ I) por Miguel B. Vieira de Amorim. Victoria, 1882 .

Leis do estado, 1892 and cont. (probably annual). Victoria, 1892-. 
Goyaz:

Livro da lei goyana e collecção das leis e resoluções da provincia de Goyaz nos annos de 1840-1888. Goyaz, Typ. Provincial e Typ. Goyazense, 1840-1888. $45 \mathrm{v}$.

Collecção das leis: 1835-88, I892-93, 1896-1902. Goyaz, I835-1902. Gram-Pará: I5 v. [1903 et seq. probably annual volumes].

Collecção das leis da provincia de Gram-Pará.

v. 1-23, 1838-1861 (Pará, Typ. da Aurora Paraense, 1854-1861).

v. 24-33, I862-I87I (Pará, I862-I87I).

Collecção das leis e dos actos do governo. v. $34-43$, I872-1881. (Pará, Typ. do Diario do Gram-Pará, $1872-1883$ ).

Collecção das leis . . . I882-1889. Pará, 1882-1889. 8 v.

Decretos e actos do governo . . . Pará, 1890-93. I v.

Collecção das leis do estado I89I [and continuation], Pará, I89I[probably annual].

Indice ... das leis da asemblea legislativa provincial: $183^{8}-1853$. Pará, 1854 .

Maranhão:

Collecção das leis, decretos [regulamentos] e resoluções da provincia . . .

I835-I84I. Maranhão, I847-[1850]. 2. v.

1843-1888. Maranhão, J. J. Ferreira [etc., etc.], I843-1889. $46 \mathrm{v}$.

Collecção das leis e decretos do Estado . . . I889 [and continuation]. Maranhạ̃o, 1889-[probably annual].

Matto Grosso:

Collecção das leis provinciaes: I835-54, I857-66, I868-86, I888. Cuyabá, 1850-89. II v.

Colleç̧ão das leis do estado, decretadas ... em I89r [and continuation] e decretos do presidente [poder executivo] do mesmo estado. Cuyabá, Typ. da Gazeta Official, I892- [probably annual].

Minas Geraes:

Livro da lei mineira e collecção de leis da assembléa legislativa de Minas-Geraes de $1835-1889$. Ouro Preto, Typ. Social, Actualidade [etc., etc.], 1835-1889. 55 v. (Title and publisher vary; 1869 , publ. in Rio de Janeiro, Typ. Dezeseis de Julho, 1870.)

Collecção dos decretos do governo provisorio do estado de Minas Geraes Dec. 3, 1889-Dec. 13, 1890. Ouro Preto, 1890.

Collecção das leis do estado, I89r [and continuation]. Ouro Preto, I892-I897; Belle Horizonte, I898- [probably annual].

Pará:

Indice alphabetico da legislação provincial, de I854-1880. Compren[den]dendo os actos e decisões do governo da provincia até 1879. inclusive. Publicão official. Belém, Typ. "Commercial" de Francisco da Costa Junior, 1880. $217 \mathrm{p}$.

Actos e decisões do Governo da Provincia Estado I889. Belém, Diario Official, 1894 . 
Pará-Continued.

Collecção das leis ... r891-1900. Belem, r900 [continuation, probably annual].

Indice alphabetico da legislação do Estado de Pará. Nov. 15, 1889-1893. By Manuel Buena. Belém, Diario Official, 1894.

Parahyba do Norte:

Legislação parahybana ou collecção de leis, decretos e resolucões da Assemblea legislativa ... [etc.], 1835-1877; 1879-1888. Pernambuco, 1844-46. Parahyba [1847-1889]. 54 v. (Title and publisher vary.)

Indice alphabetico das leis da provincia da Parahyba, publicadas de 1835 a 1874 , pelo bacharel Antonio de Souza Martins. Parahyba, Typ. do Jornal da Parahyba, 1875 .

Colleç̧ão das leis e decretos, 1892, 1893. Parahyba, 1893.

Collecção dos actos do poder executivo, I894-95 to 1899 . Parahyba, 1895-I899.

Collecção dos actos do poder legislativo: 1895-98. Parahyba [189699].

Collecção dos actos do poder legislativo e executivo, r899 [and cont.]. Paraná: Parahyba, Igor-.

Leis e decretos, regulamentos e deliberações do governo da provincia . . . Curityba, Typ. Paranaerse de C. M. Lopes, 1855-1857. v. I-4. 1854-1857.

Collecções das leis, decretos, regulamentos e deliberações do governo da provincia. Rio de Janeiro, Typ. Nacional, 1858. v. 5 (1858).

Leis e decretos da provincia. Curityba, Typ. Paranaense de C. M. Lopes, I859-1884. v. 6-3I, 1859-I884. (Title and publisher vary.)

Leis, decretos e regulamentos ... . 1885-1888. Curityba, Typ. da Gazeta Paranaense, $1885^{-1888 .}$

Indice alphabetico das leis, actos e regulamentos da provincia do Paraná até o anno de 1874 , por Agostinho Ermelino de Leão. - Rio de Janeiro, Typ. Americana, 1875.

Leis, decretos e regulamentos do Estado . . I 890 [and cont.]. Curityba, I89r- [annual].

Pernambuco:

Colleç̧ão de leis, decretos e resoluções da provincia, $1835-1859$. (v. I-20.) Recife, M. F. de Faria, 1836-1859. $20 \mathrm{v}$.

Same. I860-1888. Recife, M. F. de Faria e Filhos [etc.], 1860I888. $29 \mathrm{v}$.

Piauhy:

Decretos e leis, 1890 [and cont.]. Recife, I89o- [annual].

Codigo das leis piauhyenses.

v. I-4 (1840-1843). Oeiras do Piauhy, Typ. Nacional, $1840-43$.

v. 5-16 (1844-56). Oeiras, etc., $1844-56$.

v. 17 (1857). Maranhão, Typ. de Temperança, 1857 .

v. $18-23$ (1858-1865). Maranhão, etc., $185^{8-65}$. 
Piauhy-Continued.

Codigo das leis piauhyenses-Continued.

v. 24-39 (1866-1884). Theresina, Typ. de J. S. Leite, I867I884.

1885-86. [Therésina, 1885-86.]

(Imprint varies.)

Indice alphabetico das leis provinciaes . . I 1835-1878. By Gabriel Luiz Ferreira. Maranhão, Typ. do Paiz, 1878.

Decretos e resoluções do governo . . . I889-9r. Therezina, I89r. I v.

Leis e decretos do estado, I892 [and cont.]. Therezina, 1894[annual, but, frequently 2 years in I v.].

Moraes Corrêa, Francisco de. Collectanea de leis, decretos, resoluções e regulamentos do Estado do Piauhy [Nov. 15, 1889-Dec. 31, Ig08]. Therezina, rgro.

Rio de Janeiro:

Collecção de leis, decretos e regulamentos da provincia . . . 1835r888. Nictheroy (to 1860 ) and Rio de Janeiro (after 1860 ). Typ.do Correio mercantil [etc.], r839-r888. $54 \mathrm{v}$.

Legislação do Rio de Janeiro de 1835 a I 850 , seguida de um repertorio da mesma legislação, organisado por Luiz Honorio Vieira Souto. Nictheroy, Typ. Fluminense de Lopes \& Co., 1850-51. 2 v.

Same. $1851-53$. Nictheroy [ibid.], 1854. 2 v.

Classificação das leis, decretos, regulamentos e deliberações da provincia do Rio de Janeiro desde o anno de 1835 até o de 1859 inclusive. Pelo ... Caetano José de Andrade Pinto. Rio de Janeiro, E. \& H. Laemmert, r860.

Colleç̧ão de leis decretos, 1890 [and cont.], Rio de Janeiro, 1891[annual].

Rio Grande do Norte:

Collecção de leis provinciaes do Rio Grande do Norte.

v. I-3 (I835-4I), Pernambuco, 1844 .

v. 4-I2 (1842-50), Pernambuco, Typ. de Santos [etc.], 1842-1851. I85I-1887 [Pernambuco, Natal, Maranhão, Rio de Janeiro, Rio Grande do Norte], 1852-1888. 37 v. (Imprint varies.)

Decretos do governo, Dec. 7, I889-Dec. 3, 1891. Natal, I891. I v.

Leis do congresso, I892-1895. Natal, 1896 .

Actos legislativos e decretos do governo . . r 896 [and cont.]. Natal, r897- [annual].

Rio Grande do Sul:

Colleç̧ão das leis e resoluções ... 1835-1888. Porto Alegre and Pelotas, 1835-1888. v. 5-22 (1849-1867). About 35 v.

Colleç̧ão das leis e resoluções, 1892, [and cont.]. Porto Alegre, Typ. de Porto Alegrense [etc.], 1893- [probably annual].

Santa Catharina:

Collecção das leis da provincia ... dos annos de r835 a r840. Cidade do Desterro, Typ. Catharinense de Germano Antonio Maria, 1856 . I v.

$71624^{\circ}-17-14$ 
Santa Catharina-Continued.

Same. $184 \mathrm{I}-1847$. Cidade do Desterro, Typ. Catharinense de Germano Antonio Maria, I857. I v.

Same. I848-1859. Rio de Janeiro [1856-59].

Same. v. Io, 1860 (Santa Catharina, Typ. Desterrense de J. J. Lopes, 1860).

Same. v. II, I86I (Desterro, Typ. Catharinense de Germano Antonio Maria Avelim, r86r).

Same. v. 12, 1862 (Santa Catharina, Typ. Desterrense de J. J. Lopes, I862).

Same. $1863-1886$ (Cidade do Desterro, Typ. de J. A. do livramento, I864-1886). (Publishers vary.)

Same. 1887. Desterro, 1887.

Collecção das leis do estado, I892 [and cont.]. Desterro, 1893[annual].

São Paulo:

Collecção de leis da provincia . . . 1835-1887. São Paulo, 1835I888. 54 v. (Imprint varies.)

Legislação provincial. I844-I849. (in I vol.) (No title-page.)

Indice alphabetico (Legislação geral) explicativo das disposições dos annos de 1835 a 1873 . . . São Paulo, 1875-1879. 3 v.

Repertorio das leis promulgadas pela assembléa legislativa de Provincia de São Paulo desde 1835 até 1875 . . . . Por João Carlos da Silva Telles. São Paulo, Typ. do Correio Paulistano, 1877. 979 p.

Repertorio das leis promulgadas pela Assembléa legislativa provincia de São Paulo desde 1876 a 1889 , em continuação do ordenado pelo Dr. João Carlos da Silva Telles . . . Por Alberto Souza e José Jacintho Ribeiro . . São Paulo, Typ. do "Diario Official," 1898. $365 \mathrm{p}$.

Decretos e resoluções do governo provisorio do Esstado, Nov. 18, 1889, to Oct. I7, 189o.

Same. Oct. I8, I89o, to June 30, I891. São Paulo, 1891-92. I v.

Collecção das leis e decretos do Estado de São Paulo . . . São Paulo, Typ. do "Diario official," I89I-I9I5. v. I-25 (I89I-I9I5). In progress.

Indice das leis ... de São Paulo, desde a adhesão do estado á Sergipe: republica brasileiro até . . . I895. São Paulo, I896. I v.

Collecção de leis e resoluçoes da assembléa, 1848-1849. Sergipe, I848-49.

Collecção de leis, decretos e resoluções da provincia. Sergipè, Typ. Provincial de Sergipe, I850-59. I850-1859.

Collecção de leis e resoluçoes da assembléa. I860-I884, I886. [Sergipe I860-86.]

Compilação das leis provinciaes de Sergipe r835 a r880, pelo Juiz de Direito Candido Augusto Pereira Franco. Aracajú, Typ. de F. das Chagas Lima [ $[88 \mathrm{r}]$. $2 \mathrm{v}$.

Colleç̧ão de leis e decretos, r8gr [and cont.]. Aracaja, r8gr[probably annual]. 
The states of Brazil all publish official gazettes, usually known as the Diario Official, in which is to be found the current state legislation.

The laws governing the municipal organization of the Federal District have been compiled at various times in pamphlet form. The most recent issue is of 1912.1

Reports of recent legislation in Brazil are contained in various publications on comparative law such as the Jahrbuch für vergleichende Rechtswissenschaft and the Annuaire de législation comparée. Translations of statutes appear occasionally in the Revue de l'institut de droit comparé, which, since the beginning of the war, has ceased publication, and meager and incomplete references are to be found in the $A \mathrm{n}$ nual Bulletin of the Comparative Law Bureau now published as a part of the American Bar Association Journal.

\section{COURT REPORTS}

As already observed, there is a dual judicial hierarchy in Brazil analogous to that of the United States. The federal courts consist of one lower judge of first instance in each state and two in the Federal District called district judges (juizes de seç̧ão) and the federal Supreme Court of fifteen justices with its seat in the Federal District. In the smaller judicial districts of the state (comarcas) there are only representatives or deputies of the respective district judges.

In the Federal District there are first, praetors or local officials (fifteen in number) having administrative functions and jurisdiction of cases up to 5,000 milreis (about $\$ 1,250$ ) with appeal as of right to the ordinary law judge (juiz de direito). The juiz de direito, of which there are six in civil and commercial cases, has original and appellate jurisdiction. This will be described at greater length in the section on "Judicial organization." (Infra, p. 286.)

Above the juiz de direito is a court of appeal (Corte de Appelacão) of two chambers, with provision for a joint session of the two chambers as a court of revision on petitions for annulment of the decisions of either one of them.

In practically all the states there are two instances, judges of first instance sitting in various districts of the state, with an

1 Consolidação das leis sobre organização municipal do Districto Federal. Rio de Janeiro [1912]. 
appellate tribunal, usually called the tribunal superior or tribunal de relaşa o, having its seat at the state capital.

Only in recent years has there been any systematic attempt to publish the decisions of the highest courts. Before 1892 the decisions are found scattered in various sources, official and unofficial, the decisions of the lower courts being generally unreported. Naturally, the decisions of the federal Supreme Court are reported with greater frequency and system than those of the other courts.

One of the first systematic compilations of the decisions of the Supreme Court was published in 1885 by Candido Mendes de Almeida and Fernando Mendes de Almeida, ${ }^{1}$ covering the decisions of the Supreme Court for the period 1829 to 1883 . Between 1875 and 1890 selected decisions were published in one of the numerous Annexos to the annual Relatorio or report of the Minister of Justice. For the years 1893 and 1894 these decisions are reported in full in an Annexo to that Relatorio.

For the period 1895 to 1901 a seven-volume collection of decisions taken from the Annexo to the annual report of the court has been compiled. ${ }^{2}$ It is published at the government printing office in Rio de Janeiro and received official recognition by legislative decree no. 1466 of January 8, 1906, article 2 . Subsequent to 190 r the decisions of the court are published regularly in the Diario Official. Since April, 1914, a more convenient arrangement of the decisions is to be found in the Revista do Supremo Tribunal, ${ }^{3}$ a monthly quasi-official publication authorized by contract between the editors and the court on February 3, 1914. This publication is divided into two parts, of which Part I contains, in section I, the proceedings of the court in its various sessions and its rules and orders on administrative matters and on motions and, in section 2, the decisions in full. The decisions are poorly arranged, but indexed

${ }_{1}$ Arestos do supremo tribunal de justiça colligidos em ordem chronologica até hoje (1829-1883) pelos advogados Candido Mendes de Almeida e Fernando Mendes de Almeida. Rio de Janeiro, I885. I v.

2 Jurisprudencia. Accordãos annexos ao relatorio apresentado do tribunal e proferidas em I895-190r. Rio de Janeiro, Imp. Nacional, I897-1905. $7 \mathrm{v}$.

${ }^{3}$ Revista do Supremo Tribunal. Director: Dr. Astolpho Rezende; Secretary, Dr. Attila de Carvalho. Rio de Janeiro, Sete de Setembro, I09, I914-. $3 \mathrm{v}$. per year. 
chronologically and by subject. Part II consists of four sections. The first, or doctrinal section, contains brief articles on practical questions of law. The second consists of the report of decisions of the courts of the Federal District and of the important states, with an occasional decision of a foreign court. Section 3 is devoted to legislation and reprints the more important legislative and executive decrees. Section four deals with notices of interest to the bench and the bar. It is a valuable publication.

Among the unofficial repositories of the reported decisions, attention should be called to the periodical $O$ Direito, ${ }^{1}$ the oldest of the current periodicals, first published in 1873 . One of its sections is devoted to the report of decisions of the highest courts.

Since July, 1906, Antonio Bento de Faria ${ }^{2}$ has edited a periodical, Revista de direito civil, commercial e criminal, one section of which is devoted to the decisions of national courts and another to the decisions of foreign courts. Four volumes have been published annually. A separate index covering volumes $I$ to 25 was published in I 913 , which includes subject indexes to the sections on national and foreign court decisions.

Further compilations of decisions have been published at various times. A three-volume compilation of the decisions from I 84 I to 1868 was published by Manoel da Silva Mafra. ${ }^{3}$

Tavares Bastos ${ }^{4}$ has recently published a compilation of the decisions of the Supreme Court. In $1908^{5}$ he had published, in three volumes, a compilation of the decisions of the courts of Brazil from 1892 on, accompanied by numerous

${ }^{1} \mathrm{O}$ Direito. Revista de legislação, doutrina e jurisprudencia, founded by João José de Monte. Rio de Janeiro, 1873-. I20 v. to I9I2.

${ }^{2}$ Revista de direito civil, commercial e criminal, publ. mensal de dou. trina, jurisprudencia e legislação dirigida pelo Dr. Antonio Bento de Faria. Rio de Janeiro, J. Ribeiro dos Santos. Index to v. I-25, $37^{8}$ p. $38 \mathrm{v}$. 1906 to $19 \mathrm{r} 5$.

${ }^{3}$ Mafra, Manoel da Silva: Jurisprudencia dos tribunaes, compilada dos accordãos dos tribunaes superiores desde I84I. Rio de Janeiro, r868. $3 \mathrm{v}$.

4 Tavares Bastos, José: Jurisprudencia do Supremo Tribunal. Rio de Janeiro [1908?] 2 v.

${ }_{5}^{5}$ Tavares Bastos, José: Jurisprudencia dos tribunaes e juizes da Republica. Rio, de Janeiro, Gamier, Ig08. 3 v. 
opinions of jurists and various decisions of the highest state court of Rio de Janeiro. The decisions are divided by courts beginning with the Supreme Court and supreme military court, the Camara civil and the Camara commercial, the Tribunal civil e criminal, the joint session of the two chambers of the court of appeals (Camaras reunidas), the decisions of each chamber, and the decisions of the court of Relacanos of Rio de Janeiro, São Paulo, and Minas Geraes. Volume 2 comprises the judgments of minor courts and contains a brief subject index. Volume 3 , an appendix, includes private and expert opinions and decisions of lower courts, with a special subject index.

In October, 1913, Dr. Candido Mendes de Almeida, ${ }^{1}$ a jurist of eminence, began to edit a monthly periodical bound in quarterly volumes, entitled Legislaşão e jurisprudencia do Brasil, which, besides legislation, includes the decisions of the Supreme Court, the Court of Accounts, the Court of Appeals of the Federal District, and the Supreme Military Court, with trimonthly indexes and an alphabetical index of the names of parties.

An index-digest of the decisions of the federal Supreme Court from I9Io to 191 3 as published in the Diario Official was prepared by Octavio Kelly, ${ }^{2}$ federal district judge in the state of Rio de Janeiro. It is the editor's intention to continue the publication. An index-digest of the decisions of the courts was begun by João de Morrison Faria in 1907, but does not appear to have extended beyond the first numbers.

Among numerous special compilations of decisions, attention may be called to a collection of commercial decisions of Marques Pinheiro, ${ }^{3}$ rendered from 1850 to 1869 , and to a twovolume collection of decisions by Justice Montenegro, ${ }^{4}$ judge of

${ }_{1}^{1}$ Legislação e jurisprudencia do Brasil, publicação mensal sob a direcção do Dr. Candido Mendes de Almeida . . . Rio de Janeiro, Officinas graphicas do Jornal do Brasil, I9r3. 4 v. per year.

${ }^{2}$ Kelly, Octavio: Manual de jurisprudencia federal. Rio de Janeiro, J. Ribeiro dos Santos, I9I4. $367 \mathrm{p}$.

${ }^{3}$ Pinheiro, F. B. Marques: Jurisprudencia commercial, I850-I869. Rio de Janeiro, 1870.

4 Montenegro, Caetano Pinto de Miranda: Trabalhos judiciarios do Dr. Caetano Pinto de Miranda Montenegro, juiz do Tribunal civil e criminal do Districto federal. Rio de Janeiro, Typographia Mont'Alverne, $1895^{-1902.2} \mathrm{v}$. 
the Commercial Chamber of the Tribunal Civil in the Federal District, rendered between 1892 and 1899 . The majority of the decisions relate to corporations, bankruptcy, liens, and other questions of commercial law. The decisions of Augusto Ribeiro Mendes, ${ }^{1}$ judge of first instance in Rio de Janeiro, have been published in two volumes. Many of his opinions are contributions of value.

In 1900 Viveiros de Castro, ${ }^{2}$ a judge of the criminal court, published a collection of decisions in criminal cases. A collection of the opinions of M. A. Duarte de Azevedo, ${ }^{3}$ an eminent jurist and former councillor, handed down in important cases coming before him, was published in 1907. They deal primarily with civil, commercial, and procedural law.

The opinions of the so-called "Corporation Counsel," Consultor Geral, of the Republic are important as interpretations of administrative and constitutional law. The opinions of Dr. T. A. Araripe, jr., ${ }^{4}$ who occupied the position from January; 1903, to October, $191 \mathrm{I}$, were published officially in three volumes. The present Consultor Geral is Dr. Rodrigo Octavio, an eminent jurist of national and international reputation, whose opinions are printed occasionally in the Revista do Supremo Tribunal.

The Council of State, which was organized in 1842 and abolished only at the fall of the Empire in I889, was divided into various committees. The judicial committee of the Council passed upon many important matters of conflicts of jurisdiction and administrative and procedural questions referred to them by the courts and by government departments. A collection of their resolutions going back to 1842 was begun in 1877 , but only volume one, covering the period 1842 to $I 846,{ }^{5}$ appears to have been published. After $\mathrm{I} 845$

${ }^{1}$ Ribeiro Mendes, Augusto: Sentenças e despachos. Rio de Janeiro, J. Ribeiro dos Santos [19r5?]. 2 v.

${ }^{2}$ Viveiros de Castro, F. J.: Jurisprudencia criminal. Rio de Janeiro, Igoo.

${ }^{3}$ Duarte de Azevedo, M. A.: Controversias juridicas. Rio de Janeiro. 1907. $500 \mathrm{p}$.

'Araripe, Dr. T. de A., jr.: Paraceres do consultor geral. Rio de Janeiro, Imp. Nacional, IgrI-Igr4. $3 \mathrm{v}$.

${ }^{5}$ Imperiaes resoluções tomadas sobre consultas da Secção de Justiça do Conselho de Estado desde o anno em que começou a funccionar o mesmo Conselho . . . por Bellarmino Braziliense Pessoa de Mello. Rio de Janeiro, Typ. Nacional, $x 877$. I v., $1842-x 846$. 
the resolutions of the judicial committee appear as one of the Annexos of the Relatorio of the Minister of Justice.

The opinions, orders, and decrees of the Minister of Justice are of importance as interpretations of procedural questions and as rulings binding upon the courts in various matters connected with the administration of justice. An alphabetical and chronological index of these opinions, covering the years I 822 to I 88 I, was published officially ${ }^{1}$ in 1883 .

The reports of the highest courts of the states are published in the official gazette or Diario Official of the state, and occasionally in special publications, official and unofficial. They are often found in the Relatorio of the president of the Tribunal de Relação.

The decisions of the highest court of the state of Maranhão are reported in semiannual volumes ${ }^{2}$ begun in 1894 by Judge F. da Cunha Machado, and continued after volume i9 (1904) by Judge José Marianno da Costa. An index ${ }^{3}$ to the first i 8 volumes, covering the decisions from January, 1893 , to December, 1902 , was published in 1903 .

In the state of Minas Geraes the Revista forense, ${ }^{4}$ one of the best legal periodicals published in Brazil, reports the decisions of the highest court and some of the lower courts of the state. They are of importance because of the mining interests of the state of Minas Geraes. The decisions of the Tribunal da Relação ${ }^{5}$ are also published separately.

In the state of Paraná a monthly periodical edited by Dr.

${ }^{1}$ Repertorio ou indice alphabetico e chronologico dos avisos, alvarás e portarias do ministerio da justiça desde 1822 até $188 \mathrm{r}$. Rio de Janeiro [1883].

${ }^{2}$ Jurisprudencia do supremo tribunal de justiça do Estado do Maranhão. Publ. semestral. Maranhão, I894-. 24 v. to 1906.

${ }^{3}$ Maranhão: Indice dos accordãos (Superior tribunal de justiça do Maranhão) proferidos desde Jan. 1893 até Dec. 1902. Maranhão, 1903.

4 Revista forense, de doutrina, legislação e jurisprudencia, dirigida pelo . . . Drs. Estevao L. de Magalhães Pinto e Francisco Mendes Pimentel. Bello Horizonte, Impr. Official do Estado de Minas Geraes, I904-. 2 v. per year. $22 \mathrm{v}$. to r9r4.

${ }^{5}$ Decisões do Tribunal da Relação do Estado de Minas Geraes. Bello Horizonte, IgI0-. 
Alencar Piedade, entitled Gazeta dos tribunaes, ${ }^{1}$ publishes the decisions of the highest court.

In Rio Grande do Norte two volumes of the decisions of the highest court ${ }^{2}$ covering the period 1892 to 1899 have been published. A similar publication for Rio Grande do $\mathrm{Sul}^{3}$ in four volumes covers the period 1897 to 1905 . In that state there is also published an Archivo judiciario.

In the state of São Paulo several publications report judicial decisions. Besides the decisions reported in the Gazeta juridica (infra, p. 222) begun in I 893, Judge José Machado Pinheiro Lima, of the Supreme Court of São Paulo, began in 1895 to publish the decisions of the court in the Revista mensal das decisões, ${ }^{4}$ of which eight volumes appeared, with an index. To continue this publication, O São Paulo judiciario, edited by Dr. Carlos Augusto de Freitas Villalva," was issued; it has appeared monthly since I 903 .

Many ephemeral publications reporting decisions of state courts have appeared from time to time. Among those worthy of mention is the Revista dos tribunaes for the state of Bahia, which began in 1894 and ceased in 1903, after 23 volumes had been published.

In the state of Amazonas, the Julgados e decisões do Supremo Tribunal, edited officially by Judge Manoel Agapito Pereira, commenced to appear in 1892 , but it has not been possible to ascertain when it ceased publication. A similar publication for the state of Ceará, called Revista annual, began to appear in 1899 , the first volume reporting the decisions since 1892 .

${ }^{1}$ Gazeta dos tribunaes. Corityba, Estado de Paraná. Revista mensal de doutrina, jurisprudencia e legislação, de que é redactor o adv. Dr. Alencar Piedade.

${ }^{2}$ Rio Grande do Norte. Jurisprudencia do Superior Tribunal de justiça do ... I892-95; 1896-1899. Natal, I897-Igor. 2 v.

${ }^{3}$ Rio Grande do Sul. Decisões do Superior tribunal de justiça, I8951905. Porto Alegre, I896-1906. II v. to 1906 (probably continued).

- Revista mensal das decisões proferidas pelo Tribunal de justiça de São Paulo, coordenadas pelo Ministro ... Dr. José Machado Pinheiro Lima, 1895 á r 898 . $8 \mathrm{v}$. Index published in 1903 .

s O São Paulo judiciario. Editor: Dr. Carlos Augusto de Freitas Villalva. São Paulo, 1903-. 23 v. to I9ro; 3 v. per year. 
Parahyba has its Revista do fôro, begun in 1907; Pernambuco its Archivo de jurisprudencia; Sergipe its Revista forense; and Rio Janeiro its $O$ archivo juridico, all of which appeared for various periods after $\mathrm{r} 89 \mathrm{r}$.

\section{GENERAI，WORKS}

Among the general works, attention should be called to the important work, edited by Reginald Lloyd," "Twentieth century impressions of Brazil," of which a small section (pp. $157-164$ ), by Souza Bandeira, gives an outline of the constitution and of the legal system of Brazil.

Another general work which warrants mention is the Brazilian Year Book, edited by J. P. Wileman. ${ }^{2}$ It appeared during the years 1908 and 1909 only. Besides its economic statistics, it contains a useful history of Brazil, reprints the constitution, and translates numerous laws of interest to corporations. As a statistical work on the corporations of Brazil it is of first importance.

Undoubtedly one of the most useful works on Brazilian law is the collection of codes and laws of frequent application, edited under the title Leis usuaes, ${ }^{3}$ by Tarquinio de Souza and Caetano Pinto de Miranda Montenegro, published under official authorization. The work is divided into five parts, as follows: First, political law, under which is included the constitution, laws relating to the trial of public officials, organization of the federal administration, citizenship and naturalization, tribunal of accounts and ecclesiastical matters; and second, criminal law, in which is included the general penal code, the penal code governing the navy and the army, extradition, and related statutes. Part 3, entitled

${ }^{1}$ Lloyd, Reginald: Twentieth century impressions of Brazil. Its history, people, commerce, industries, and resources. Director in chief: Reginald Lloyd ... Editors: W. Feldwick . . . L. T. Delaney ... Historian: Arnold Wright . . L London, Etc. Lloyd's greater Britain publishing Co., Itd., I913. I064 p.

${ }^{2}$ The Brazilian year book; issued under the patronage of the Brazilian government. Rio de Janeiro, The offices of the Brazilian year book; New York, G. R. Fairbanks; etc., etc., I908 and 1909. 2 v.

- Leis usuaes da republica dos Estados Unidos do Brazil publicadas por ordem do exm. Sr. Dr. J. J. Seabra ministro da justiça e negocios interiores pelos Dr. Tarquinio de Souza . . . e Dr. Caetano Montenegro . . . Rio de Janeiro, Imprensa nacional, 1903. $992 \mathrm{p}$. 
"Civil-law," includes the various statutes on subjects relating to the civil law enactcd in Brazil and supplementary to the civil law to be found in the Codigo Philippino. Some of the provisions of these laws have found their way into the civil code, which was enacted on January $I, 1916$, and came into force on January I, 1917. Among the laws printed in part 3 are those on marriage, registration of civil status, registration of titles of indebtedness and bonds, mortgages, patents, and trade-marks, literary property, and expropriation. Part 4, on commercial law, includes the commercial code, the law of stock companies, the registration of firms, the law of debentures and bonds, coastwise navigation, bankruptcy, chattel mortgages, warrants, consular invoices, and insurance in its various branches. Part 5, procedural law, includes the regulation No. 737 of 1850 and various statutes relating to judicial organization, procedural costs, taxation, etc.

A practical dictionary or encyclopedia of law, including in alphabetical order the statutory provisions relating to civil, criminal, commercial, and probate law, including the law in the Federal District, with citations to authoritative sources, was published in 1910 by João de Sá Albuquerque, ${ }^{1}$ a prolific commentator of many laws of practical utility. A somewhat similar dictionary of law, by Teixeira de Freitas, ${ }^{2}$ first published in 1883 , was edited in a 1915 edition by Vicente Ferrer.

An earlier dictionary or encyclopedia of law, published in a second edition in 1875 by João José Rodrigues, ${ }^{3}$ of Minas Garaes, consists of an alphabetical digest of the decisions of the courts, the decrees and orders of the executive and the doctrinal interpretation of Brazilian statutes, rules and principles of law by jurists.

'Sá Albuquerque, João de: Repertorio juridico. Rio de Janeiro, rgro. 68I $\mathrm{p}$.

2 Teixeira de Freitas: Vocabulario juridico, accommodado ao fôro brazileiro, pelo Dr. Vicente Ferrer. Rio de Janeiro, J. Ribeiro dos Santos, I9r 5. $1300 \mathrm{p}$.

${ }^{3}$ Rodrigues, João Jose: Miscellanea juridica, ou grande peculio de decisões do tribunal da relação da corte, supremo tribunal de justiça e tribunal do commercio sobre questões de direito civil, commercial e criminal; decretos e avisos do poder executivo; interpretaçăo doutrinal de nossas leis pelos jurisconsultos antigos e modernos . . . Rio de Janeiro, x868. and ed. Rio de Janeiro, 1875 . 
Among works or collected essays of a general nature several warrant mention. Among the most important of these is Professor João Monteiro's ${ }^{1}$ work on "Applications of the law," containing $\mathrm{I}_{52}$ of his most interesting opinions on various questions of law, civil, criminal, constitutional, and administrative. A second edition of the work, which first appeared in 1904, was published in 1909. Mention may also be made here of Professor Monteiro's celebrated work on the "Universalization of law," " published in a second edition in 1906. Monteiro, who was professor at São Paulo, was regarded as one of the most eminent of Brazilian jurists, and all his works enjoy high repute.

Dr. João Continentino's ${ }^{3}$ collection of studies and decisions, published in 1907 , include some excellent contributions to various topics of criminal law and habeas corpus, an extraordinary remedy frequently resorted to in Brazil.

Pedro I,essa, ${ }^{4}$ also one of the most eminent jurists of Brazil, and now a justice of the Supreme Court, has published a collection of his essays and articles in book form. They include essays on constitutional law (interpretation of articles I I and 22 of the federal constitution), civil law (mortgages and wills), criminal law (defenses), public law (taxation of corporations and naturalization and its effects), the history of law in the nineteenth century, Roman law, and procedure. Any work of Pedro Lessa is regarded as important in Brazil.

In 1908, under the auspices of the Institute of Advocates, there was held a Lawyers' Congress, at which reports and papers were read on various branches of law. The report of its proceedings ${ }^{5}$ includes excellent contributions on legal

${ }^{1}$ Monteiro, João: Applicações de direito (Pareceres e promoções). 2nd ed. Rio de Janeiro, 1909. (Ist ed., São Paulo, 1904.)

2 Monteiro, João: Universalisação do direito. Cosmopolis do direito. Unidade do direito. 2nd ed. São Paulo, Duprat, 1906 (first ed., 1892 ).

${ }^{3}$ Continentino, João Pereira da Silva: Estudos, doutrinas e julgados. Rio de Janeiro, 1907.

${ }^{4}$ Lessa, Pedro: Dissertações e polemicas (estudos juridicos). Rio de Janeiro, Jornal do Commercio, Igog. $360 \mathrm{p}$.

s Relatorio geral dos trabalhos do $\mathrm{I}^{\circ}$ Congresso juridico brasileiro, 1908. Rio de Janeiro, rgog. 
education (by Pedro Lessa), constitutional law (Viveiros de Castro), civil law (Coelho Rodrigues), commercial law (Ouro Preto), criminal law (Lima Drummond), administrative law (Souza Bandeira), international law (Didimo da Veiga), and procedure (Eugenio de Barros).

Lucio de Mendonça, ${ }^{1}$ a former justice of the Supreme Court, published in 1903 a collection of essays under the title Paginas juridicas, consisting of opinions, studies, and essays on various topics of law.

João José Rodrigues, ${ }^{2}$ a lawyer of Minas Geraes, who died in 1877 , edited a collection of opinions on various branches of Brazilian law given by the leading jurists of Brazil. The work was published in two volumes in 1873 .

Franklin Doria, former Councillor of State, has published two volumes of collected essays and studies on various topics of public and private law. One was published in $188 \mathrm{I}^{3}$ and the other in $1909,{ }^{4}$ with an introduction by Clovis Bevilaqua.

José Gonçalves Maia, ${ }^{5}$ an attorney and fiscal of Amazonas, has collected numerous briefs and opinions on various questions, e. g., assignment, nullity of wills, jurisdiction, civil responsibility of the state, slander, and questions of procedure, in a volume published in Paris in 1913.

\section{LEGAL, PERIODICALS}

A great number of legal periodicals have appeared in Brazil. Among those still in existence the oldest and one of the best

${ }^{1}$ Mendonça, Lucio de: Paginas juridicas: estudos, pareceres e decisões. Rio de Janeiro, I903.

${ }^{2}$ Rodrigues, João José: Consultas juridicas ou collecção de propostas, questões de direito civil, commercial, criminal, administrativo e ecclesiastico, respondedas pelos mais notaveis jurisconsultos brazilciros. Rio de Janeiro, $1873.2 \mathrm{v}$.

${ }^{3}$ Doria, Franklin A. Menezes: Questões juridicas. Rio de Janeiro, I88r.

4 Doria, Franklin A. Menezes: Arrazoades e estudos de direito, com un prefacio de Dr. Clovis Bevilaqua. Rio de Janeiro, I909. 34I p.

${ }^{5}$ Gonçalves Maia, José: Questões forenses: cessão de credito, nullidade de testamento, executivo fiscal, competencia, terrenos de marinha, responsabilidade civil do estado, calumnia e injuria; com pareceres e opiniões de Clovis Bevilaqua, Bento de Faria, Carvalho de Mendonça (processo de calumnia) . . Paris, M. Giard \& E. Brière, rgi3. Ir6 p. 
is $O$ Direito, ${ }^{1}$ begun in 1873 , three volumes appearing annually. It contains legislation, the decisions of the courts and doctrinal articles, and critical book reviews. Indexes appear frequently. The last cumulative indices include volumes. $I$ to 60 and 61 to 100 , each in one volume.

In 1873 there was also begun the Gazeta juridica, ${ }^{2}$ edited by Carlos Perdigão. In $188 \mathrm{I}$ it was suspended, being revived in I 886, although it ceased publication the next year. A monthly periodical under the same name was begun in São Paulo ${ }^{3}$ in 1893; three volumes are published annually. An index ${ }^{4}$ to volumes I to 45 was published in 1909 by João Mendes.

An excellent periodical, Revista de jurisprudencia, ${ }^{5}$ was begun in 1897 , but unfortunately was definitely suspended in 1903 , after I9 volumes had been published.

Some of the best contributions to legal literature consist of papers read before the Institute of Lawyers (BarAssociation). Most of them, with additional articles, were published in the Revista do Instituto da ordem dos advogados brazileiros ${ }^{6}$, of which the first series, 1862-1903, consists of fifteen volumes, and the second series, begun in 1906, of two annual volumes. The Revista de direito civil, commercial e criminal, ${ }^{7}$ edited

10 Direito. Revista de legislação, doutrina e jurisprudencia. First Editor, J. J. do Monte. Rio de Janeiro, 1873-. I20 v. to I912. In progress.

${ }^{2}$ Gazeta juridica. Orgão de legislação, doutrina e jurisprudencia do Imperio do Brasil. Edited by Carlos Fred. Marques Perdigão. Rio de Janeiro, $1873-188 \mathrm{r}$; r886-r887. 40 v., including 3 indices.

${ }^{3}$ Gazeta juridica. Revista mensal de legislação, doutrina e jurisprudencia do Estado de São Paulo. Founded by Manoel Augusto de Alvarenga. Saõ Paolo, I893-. 52 v. to I9Io. 3 v. annually. In progress.

- Mendes, João: Indice da Gazeta juridica. v. I-45. São Paulo, I909.

${ }^{6}$ Revista de jurisprudencia. Doutrina, legislação e jurisprudencia da União, Estados e Districto Federal. Editors, Raja Gabaglia, B. Portella and Torres Camara. Rio de Janeiro, 1897-1903. I9 v.

${ }^{6}$ Revista do Instituto da ordem dos advogados brazileiros. Rio Janeiro, I862-I893, first series, 15 v. Second- series, 1906-. 2 v. annually.

${ }^{7}$ Revista de direito civil, commercial e criminal, publ. mensal de doutrina, jurisprudencia e legislação dirigida pelo Dr. Antonio Bento de Faria. Rio de Janeiro, J. Ribeiro dos Santos, Ig06-. 4 v. per year. $38 \mathrm{v}$. to I9I5. Index to v. I-25. $37^{8} \mathrm{p}$. I9I3. 
by Antonio Bento de Faria, has been published monthly since July, 1906, four volumes appearing annually. It includes, particularly, selected decisions of the courts, both federal, state, and foreign, doctrinal articles and legislation, with a brief section of book reviews. An index covering volumes I to 25 has been published.

The last of the general periodicals which warrant serious consideration is the Revista forense, ${ }^{1}$ edited by Dr. Estevão Pinto and Francisco Pimentel and published at Belle Horizonte, the seat of one of the best law schools of Brazil. It was begun in 1904 and two volumes are published annually. Its principal contents are doctrinal articles, state legislation, and decisions of the courts of Minas Geraes.

The faculties of law at Recife, the seat of what is often considered the best law school, Bahia, Rio de Janeiro, and Sĩo Paulo publish reviews (Revista da Faculdade de Direito) which frequently contain legal articles of considerable value.

The periodicals on special subjects will be mentioned in their appropriate places.

\section{LEGAL EDUCATION}

Faculties of law were created in 1827 , mode'led after that of Coimbra, Portugal. Various laws were subsequently enacted until by law of October 30, I 895, with its regulating decree of February I, I8g6, a complete reform in legal education was effected. The former course, which had been divided into social science, law, and notarial law, was unified. Attendance on lectures, which by the decree of April 19, '1879, had been optional, was made obligatory and examinations, instead of including several years at one time, could not be taken for more than the work of one year. Private law schools required the authorization of the government, with provision for governmental supervision. The law course lasts five years, but includes such subjects as political economy, sociology, and finance.

1 Revista forense, doutrina, legislação e jurisprudencia. Dr. Estevão L. de Magalhães Pinto and Dr. Francisco Mendes Pimentel. Belle Horizonte, Impr. Official do Estado de Minas Geraes, r9o4-rgr4. 2 v. per year. 
There are eight prominent law schools in Brazil, of which the leading ones are those of Recife, São Paulo, Bahia, Rio de Janeiro, and Belle Horizonte. Those at Bahia, Rio de Janeiro, São Paulo, and Recife were resanctioned by decree in 1891 and those of Pará, Ceará, Porto Alegre, and Belle Horizonte by decrees of 1903 .

The Institute of Advocates at Rio de Janeiro (Instituto da ordem dos advogados Brazileiros) and a similar Institute in São Paulo exercise an important influence in the maintenance of high standards of education and ethics, although until recent times cases of corruption in the courts, particularly the minor courts, have not been infrequent.

Numerous articles on legal education have appeared in the periodicals. Attention may be directed to the paper of Pedro Lessa published in the report of the proceedings of the first congress of lawyers in 1908. (Supra, p.220.) Practically the only book on the subject is that of Professor Aurelino Leal, ${ }^{1}$ apropos of the project for the reform of legal education presented to the Chamber of Deputies in 1904 by Dr. Juvenal Lamartine. Professor Leal criticizes the existing system as sterile and archaic and submits proposals for reform.

\section{GENERAL JURISPRUDENCE}

Brazil numbers among its jurists many able thinkers, several of them of international renown. The contributions of Brazilian writers to the philosophy of law are, comparatively speaking, more numerous than those of the other countries of South America. Although few of them make original contributions to the history of legal thought, many of them have thoroughly digested and expounded the principles and ideas of the European thinkers and have presented them in works which may be considered contributions to legal literature. The works on the theory of law are very few and an examination of some of the books on the philosophy of law would indicate the absence of any clear line of demarcation between the philosophy and the theory of law.

Among the leading jurists who have made the philosophy of law their field of study Tobias Barreto (1839-1889), formerly professor of the subject at Recife, occupies a prominent

'Leal, Aurelino de Araujo: A reforma do ensino do direito no Brasil. Recife, r905. $201 \mathrm{p}$. 
place. He was a German scholar and was the acknowledged head of the scientific school in Brazil. Among his numerous works special importance attaches to his "Studies on law," 1 edited posthumously by Sylvio Roméro, and his "German studies " ${ }^{2}$ on philosophy, law, and literature..

Among the most eminent scholars of Brazil was Dr. José Soriano de Souza (1833-1895), physician, philosopher, jurist, and statesman, and for many years professor at Recife. Among his many contributions, his "Elements of legal philosophy" 3 warrants special notice.

Leão Laurindo, ${ }^{4}$ now professor at Recife, published in 1904 his studies on the philosophy of law. He draws largely on Kant, Lange, Comte, Helmholtz, Spencer, Wundt, and Jhering, but presents many original ideas. The work was to have been the first of a series, which does not appear to have been continued.

Perhaps none among the legal philosophers of Brazil enjoys greater repute than Sylvio Roméro, ${ }^{5}$ whose essays on the nature of law, according to the different schools of philosophy, have recently been published in a second edition. His monumental report on the Civil Code, as Secretary of the Chamber of Deputies Committee of 2I (infra) is a permanent contribution to legal literature. Lafayette Rodrigues Pereira, himself one of the classical jurists of Brazil, has published an appreciation of Sylvio Roméro as a critic and philosopher. ${ }^{8}$

Izidoro Martins, jr., ${ }^{7}$ practically the only writer on Brazilian legal history and professor at Recife, published in r89r a num-

${ }^{1}$ Barreto de Menezes, Tobias: Estudos de direito: publicação posthunı por Sylvio Roméro. Rio de Janeiro, I898. 560 p. (Ist ed., I892).

${ }^{2}$ Barreto de Menezes, Tobias: Estudos allemães: philosophia, direito, litteratura e critica. Escada, 1880-8I. Reprinted in Recife, I882. Posthumous edition of $189_{2}$ by Sylvio Roméro. $710 \mathrm{p}$.

${ }^{8}$ Soriano de Souza, José: Elementos de philosophia do direito. Pernambuco, 1880. $474 \mathrm{p}$.

4 Laurindo, Leão: Estudos de philosophia de direito. Recife, I904.

${ }^{6}$ Roméro, Sylvio: Ensaios de philosophia do direito. 2 d ed. Rio de Janeiro, I9I4. 307 p. (Ist ed., I895; Appendix by Gumersindo Bessa).

- [Lafayette Rodrigues Pereira]: Vindiciae, O Sr. Sylvio Roméro, critico e philosopho, por Labienus. Rio de Janeiro [n. d.].

${ }^{7}$ Martins Junior, J. Izidoro: Fragmentos juridico-philosophicos. Recife, I89r. $180 \mathrm{p}$.

$71624^{\circ}-17-15$ 
ber of essays on legal philosophy. The book is cited frequently by other writers.

A philosopher who has turned his attention to law and its interpretation and theory is Arthur Orlando, ${ }^{1}$ of Recife, a scholar of considerable reputation.

Professor Clovis Bevilaqua, ${ }^{2}$ of Recife and Rio de Janeiro, who will be frequently mentioned in the course of this monograph, is probably the most versatile of modern Brazilian jurists. His contributions to positive law, both public and private, and especially to the present civil code, justly accord him a place as one of the leading jurists of the day. While professor at Bahia in 1897 he published a series of studies on the legal philosophers, who up to the present time have come principally from Germany, Italy, and France.

The present incumbent of the chair of legal philosophy at Bahia is Almachio Diniz, ${ }^{3}$ who promises to become one of the most eminent legal philosophers of Brazil. He is a disciple and great admirer of the German philosopher Hegel and much of his work is a consideration of legal theory rather than philosophy. He is well acquainted with the doctrines of the sociological school. One of his leading works, on "Current questions of philosophy and law" was published in 1909. A work published in 1906 entitled "Philosophical essays on the mechanism of law" "was designed to be the first volume of a series on legal philosophy. He reviews the history of legal philosophy and the contributions of the leading philosophers from the period of classic antiquity through the various schools of thought and of method down to the sociological school of the present day. His comments and criticisms are important. His inaugural lecture ${ }^{5}$ to the course given in 1906 on "the science of law and the spiritual productions of man" has been favorably reviewed.

${ }^{1}$ Orlando, Arthur. Philocritica. Pernambuco, I886. See also his Propedeutica politico-juridica. Recife, 1904.

${ }^{2}$ Bevilaqua, Clovis: Juristas philosophos. Bahia, Frota \& Co., 1897. I $43 \mathrm{p}$.

${ }^{3}$ Diniz Gonçalves, Almachio: Questões actuaes de philosophia e direito, com uma introducção do Dr. Clovis Bevilaqua. Bahia, I909.

4 Diniz Gonçalves, Almachio: Ensaios philosophicos sobre o mecanismo do direito. Bahia, r9o6.

${ }^{5}$ Diniz Gonçalves, Almachio: A sciencia do direito e as producçóes espirituaes do homem. Bahia, I906. 
Professor José Mendes, ${ }^{1}$ of São Paulo, is another jurist whose contributions to legal philosophy have given him distinction. In 1905 he published a work entitled "Essays," in fact an exhaustive treatise on legal philosophy.

Professor Farias Brito ${ }^{2}$ of the Faculty of Belem (Pará) published in 1905 a philosophicai work on "Truth as a guide to human transactions," which was designed as an introduction to the study of law. The author has written a number of philosophical treatises, the principal one of which is the important work Finalidade do mundo. (Para, 1903. 3 v.)

Pedro Lessa, ${ }^{3}$ the well-known justice of the Supreme Court, published, in I $9 \mathrm{I}$, a number of the articles on legal philosophy which he had written while professor of law at São Paulo; they had been previously published in the Revista of that faculty.

Laudelino Freire ${ }^{4}$ recently published in a second edition his "Studies on philosophy and ethics" which reviews the philosophical doctrines from Greek antiquity to the present time and emphasizes liberty, obligations, and justice as fundamental principles.

An interesting work by $\mathrm{F}$. Alves Lima ${ }^{5}$ on the psychology of law was published in 1909. It discusses the antecedents of moral law, the synthetic method and the postulates of moral law, the historical evolution of the idea of law, and its philosophic and scientific bases, with a criticism of the institutions of Brazil.

Numerous works of European legal philosophers have been translated into Portuguese by Brazilian scholars. One of the recent works thus translated is Professor Stricker's ${ }^{6}$ "Physiology of law" which was translated by Adherbal de Carvalho with a preface by Clovis Bevilaqua. It is an analysis of the concept and theory of law and deals to a large extent with its application to criminal offenses.

'Mendes, José: Ensaios de philosophia do dire1to. Rio de Janeiro, 1905. $2 \mathrm{v}$.

2 Farias Brito, R. de: A verdade como regra das acções. Belem, rgo5.

${ }^{3}$ Lessa, Pedro: Estudos de philosophia do direito. Rio de Janeiro, rgrr. $392 \mathrm{p}$.

4 Freire, Iaudelino: Estudos de philosophia e moral. 2 d ed. Rio de Janeiro, rgra.

${ }^{5}$ Lima, F. Alves: A psychologia do direito. Rio de Janeiro, rgog. 2 rg p.

- Stricker, S.: Physiologia do direito. 2d ed. Rio de Janeiro, I909. 
The work of Professor Antonio J. Ribas, an introduction to Brazilian civil law (infra, p. 25I) is in fact an exposition of the general principles and concepts of law, such as is to be found in English works on general jurisprudence like that of Holland.

\section{LEGAL HISTORY}

Brazilian law, as is natural, finds its origin in that of Portugal. When Portugal became a separate state in 1153 , its law entered upon a distinct growth, independent of that of the Peninsula in general. Within the limits of the space at our disposal, it will not be possible to do more than undertake a brief survey of the external history of Brazilian law and to mention the important codes and compilations of law, which at various periods represent the source books of the legal history of the country.

The sources of Portuguese law are the Visigothic code and the decretals of the councils, the customary law, the foraes or municipal charters and statutes, the Roman law, as found in the Breviary of Alaric and its subsidiary sources, the Siete partidas, the canon law with its later concordias, and the general legislation which commenced in $12 \mathrm{I}$. The best study that has been made of the influence exercised upon Portuguese law by the early races inhabiting the Peninsula is in a work by Julio Vilhena, ${ }^{1}$ published in 1873 .

The work of codification began under João I. It was actually first undertaken by João das Regras, the chancellor, and was continued by João Mendes, whose Livro das leis e posturas, also called Livro das leis antiguas, published at the end of the fourteenth and beginning of the fifteenth centuries, is a landmark in Portuguese law. This work, with the Ordenações de Don Duarte (1436), completed largely by Ruy Fernandez, constituted the principal sources of the Ordenasões Affonsinas (r447), the first important compilation of laws published in modern Western Europe.

In the Portugaliae Monumenta historica, leges e consuetudines, whose publication was undertaken by the Academica Real das

1 Vilhena, Julio Marques de: As raças historicas da peninsula iberica e a sua influencia no direito portuguez. Coimbra, Impr. da Universidade, I873. I4I p. 
Sciencias, under the direction of the historian, Alexandre Herculano, there are collected all the general laws until the reign of Don Diniz, which are found principally in the Livro das leis and the Ordenações de Don Duarte. The Ordenaşões de Don Duarte were republished at Coimbra in $\mathrm{I} 792$ by the Imprensa da Universidade, under the direction of Professor Luiz Joaquim Correia da Silva, who wrote a preface to the work in which he describes its history and manuscripts. A chronological list of the earliest Portuguese laws in continuation of these compilations are to be found in the chronological digest (Synopsis chronologica) by José Anastacio de Figueiredo Ribeiro, ${ }^{1}$ and in the Additamentos e retoques a synopsis chronologica by João Pedro Ribeiro, ${ }^{2}$ the former published in 1790 and the latter in 1829 . The latter publication is supplemented by the Indice chronologico of Portuguese legislation subsequent to the Codigo Philippino, published by João Pedro Ribeiro in a second edition in $1805-1830$.

The Ordenações Affonsinas, prepared largely from the Livro das leis of João Mendes and the Ordenações de Don Duarte, with extracts from the foraes and customary law, were published in 1447 and contained the concordats concluded with the Papacy since the reign of King Diniz and decisions and resolutions promulgated since the reign of Affonso IV. They reduced to one body of law all the old legislation in force, depriving of practical utility all the earlier collections. In I792, under royal authority, the University of Coimbra undertook the republication of these Ordenações of Affonso V. ${ }^{3}$

This was the first of three important compilations which received the name Ordenaçose do Reino. The Affonsina collection was a loose compilation, but many of its institutions were

${ }^{1}$ Figuieredo Ribeiro, José Anastasio de: Synopsis chronologica de subsidios, ainda os mais raros, para a historia e estudo critico da legislação portugueza, mandada publicar pela Acad. R. das Sciencias, Lisboa, Typ. da mesma Acad., r790. 2 v., 4I3, 37 I p. v. I (II43-I549); v. 2 ( $1550-1603)$.

${ }^{2}$ Ribeiro, João Pedro: Additamentos e retoques á Synopsis chronologica. Lisboa, Typ. da Academia, I829. 328 p.

3 Ordenações do Senhor rey D. Affonso v. . . . Coimbra, Real Imprensa da Universidade, I792. 5 v. (Half-title: Collecção da legislação antiga e moderna do reino de Portugal. Parte I. Da legislação antiga.) 
naintained in the Ordenaşões Manuelinas published more than fifty years later, by which the law of the Kingdom was consolidated and unified. The Manuelinas were prepared by a number of jurists designated by King Manuel in 1505 to revise the Ordenações Affonsinas and include the new laws enacted subsequently. Their work was completed in $15 \mathrm{I} 2$ and was published in 1514, although the official edition was the third, published in 1521 . The right to appeal from the opinion of Bartolus on questions of civil law to the opinions of other jurists was maintained in the Ordenasões of Manuel and of Philip, to be mentioned presently. The Imprensa da Universidade of Coimbra republished the Ordenaşoes of Manuel in 1583 and again in 1797.1 There is an index, published in 1820 , to the five books of the Ordenações de Manuel and the additional leis extravagantes, published by Duarte Nunez. ${ }^{2}$ These supplementary laws were prepared at the direction of the prime minister of King Sebastian in 1569.

Soon after the Crowns of Spain and Portugal were united in the person of Philip I in 1580 , Philip ordered the revision of the Ordenafões of Manuel, namely, by decree of June 5, I 595 . The resulting compilation, in whose preparation several of the leading jurists of the time, notably Jorge de Cabedo, took part, has received the name Ordenaçoes Philippinas, or, as it is more commonly known, Codigo Philippino, promulgated by Philip II on January II, I603. It was confirmed by King João IV by law of January 29, 1643 . It constitutes the great landmark in the civil law of Brazil, for by the Brazilian law of October 20, 1823, and article 85 of the Constitution of 1891 , the Codigo Philippino has been given the force of law in Brazil, except for such parts as have been repealed; only with the coming into effect of the civil code on January I, 1917, has it gone out of force.

${ }^{1}$ Ordenações do Senhor rey D. Manuel . . . Coimbra, Real imprensa da Universidade, r797. 5 v. (Half-title: Collecção da legislação antiga e moderna do reino de Portugal. Pt. I. Da legislação antiga.) Repertorio dos cinquo livros das Ordenações do Senhor rey D. Manuel, com addições das leyes extravagantes. Dirigido . . . per o licenciado Duarte Nunez do Leão, procurador da casa soppricação. Coimbra, Real Imprensa da Universidade, 1820. $344 \mathrm{p}$.

${ }^{2}$ Leis extravagantes collegidas e relatadas pelo lic. Duarte Nunez de Leão per mandado do rei D. Sebastião. Lisboa, Antonio Gonçalvez, ז69. 
The Codigo Philippino contains practically the same material as the Ordenaşões Affonsinas and Manuelinas, with the inclusion of subsequent laws, principally those contained in the collection of Duarte Nunez. It is divided into five books, as follows-first, judges and judicial officers; second, relations between church and state, the treasury and nobility; third, civil procedure; fourth, right of persons and things, contracts, wills, guardianship, land, etc.; and fifth, criminal law. Many of its provisions have, of course, been repealed since the independence of Brazil.

Several editions of the Codigo Philippino were published in the year of its promulgation ${ }^{1}$ and others were published in I636, 1695, 1708, 1727, 1747-1749 and subsequently, embracing twenty-four editions in all. One of the best known is the so-called Vicente edition of $1747,{ }^{2}$ which includes the leis extravagantes, the decrees and royal orders, and the decisions of the Casa de supplicação. An appendix was published in I 860 .

Another notable edition, the ninth, was published by the Imprensa da Universidade of Coimbra ${ }^{3}$ in 1824 ; but the best edition, for purposes of Brazilian law, is that edited in 1870 , with notes and a valuable introduction by Candido Mendes de Almeida, ${ }^{4}$ an eminent jurist of Brazil. A supplement was also

${ }^{1}$ Ordenações e leis do reino de Portugal, recopiladas per mandado do moito alto catholico \& poderoso rei Dom Philippe o Pri. Iisboa, Impresas no mostr. de S. Vicente, Camara real de Su Mag. I603. 298, I00, I69, I22, I80 p.

${ }^{2}$ Ordenações e leys do reyno de Portugal, confirmadas, e establecidas pelo Senhor rey D. João IV. Novamente impressas, e accrescentadas com tres collecções a primeira, de leys extravagantes; a segunda de decretos, e cartas; a terceira, de assentos da Casa da supplicação e relação do Porto. Por mandado do muito alto e poderoso rey $\mathrm{D}$. João $\mathrm{V}$. . . L Lisboa, Mosteiro de S. Vicente de Fóra, I 747-49. $5 \mathrm{v}$. in 3. Appendix, 1860.

${ }^{3}$ Ordenações e leis do reino de Portugal, recopiladas per mandado del rei D. Filippe o Primeiro. 9 ed., feita sobre a primeira de Coimbra de 1789 , confrontada e expurgada pelo original de $1603 . .$. Coimbra, Real imprensa da Universidade, I824. $3 \mathrm{v}$.

- Codigo Philippino, ou Ordenações e leis do reino de Portugal, recopiladas por mandado d'EI Rey D. Philippe I. 24th ed., segundo a $\mathrm{I}^{\circ}$ de 1603 , e a $9^{\circ}$ de Coimbra de 1824 . Com diversas notas ... por Candido Mendes de Almeida. Rio de Janeiro, Typ. do Instituto Philomathico, 1870 . $1487,24 \mathrm{p}$. in $2 \mathrm{v}$. 
published. ${ }^{1}$ Mendes de Almeida's noteworthy edition contains philological, historical, and exegetic notes, showing the differences between the various editions, with particular reference to the Vicentina of 1747 ; the origin and development of each legal institution, particularly whether it has fallen into disuse or been repealed; and a clear indication of the source of each paragraph, as revealed in the works of Joaquim José Ferreira Gordo, Gabriel Pereira de Castro, and João Pedro Ribeiro. In an appendix to each book there is given the Brazilian legislation on the material codified in the book, besides valuable bibliographical information concerning the jurists who have written on the Ordinances from I603 to 1870 .

After the Codigo Philippino come the leis extravagantes, which include laws, alvaras, royal decrees and orders, resolutions, and decisions of the courts and of the council, several of which related to Brazil. Among the most important of these laws is the lei da boa razao or law of interpretation of August 18, I769, enacted by the prime minister Pombal, which reduced greatly the influence of the canon law as a source of law, coming as it did with the extinction of the power of the Jesuits. There is, further, a complementary law of August 28, I772, revising the statutes of the University of Coimbra.

The collections of leis extravagantes are all unofficial. Those collected from 1569 , the date of the Duarte Nunez collection, to 1663 were not collected in any authentic edition. There were two minor private collections, one by Correa, published in 1570 , containing twenty-two laws, and another by Antonio Ribeiro, published in 1583 and containing four laws. The other laws of the period are to be found in the Appendice das leis printed in the 1747 Vicente edition of the Ordenaşoes of Philip, in the Systema dos regimentos reaes, and in the Provas da historia genealogica da casa real. A list of them is also presented in the Synopsis chronologica of José Anastacio de Figueiredo Ribeiro. Several collections of the laws subsequent to

${ }^{1}$ Mendes de Almeida, Candido: Auxiliar juridico. Servindo de appendice a decima quarta edição do codigo Philippino ou ordenações do Reino de Portugal. Rio de Janeiro, r869. 
the Codigo Philippino have been published. One of the best of these is the ten volume collection compiled and annotated by J. J. Andrade e Silva, ${ }^{1}$ covering the period I603 to 1700 and printed in Lisbon in $1854-1859$.

For the period 1750 to 1820 the only important collection is that of Antonio Delgado da Silva ${ }^{2}$ published in nine volumes, the first six volumes, $1825-1830$, and the three supplementary volumes, $1842-1847$.

The Imprensa da Universidade of Coimbra published in I8I9 a six-volume collection of the leis extravagantes from 1603 to $\mathrm{I} 76 \mathrm{I},{ }^{3}$ including those published in the supplement of the Vicente edition (I747) of the Codigo Philippino. It includes a chronological index for the period covered. The first four volumes include leis and alvarás and the last two decretos, cartas, etc. The Imprensa da Universidade also published in I 806 a five-volume collection of the early and modern legislation of Portugal.4

The legislation governing Brazil from $\mathrm{I} 808$ to $\mathrm{I} 82 \mathrm{O}$, including the years I 82 I and I 822 which was lacking in the collection

${ }^{1}$ Collecção chronologica da legislação portugueza, comp. e annotada por José Justino de Andrade e Silva .. I I603-1700. Lisboa, Impr. de J. J. A. Silva, I854-59. ro v.

${ }^{2}$ Collecção da legislação portugueza desde a ultima compilação das ordenações redegida pelo dezembargador Antonio Delgado da Silva . . . I750-I820. Lisboa, Typ. Maigrense, I825-1830. 6 v. 3 v. Supp., $1842-1847$.

${ }^{3}$ Collecção chronologica de leis extravagantes, posteriores a' Nova compilação das ordenações do reino, publicadas em r603. Desde este anno até o de 176 c conforme ás collecções, que daquellas se fizerão e inserirão na edição Vicentina destas do anno de $I_{747}$, e seu appendix do de $1_{7} 60$. A's quaes accrescêrão nesta edição as compiladas por $\mathrm{F}$. da C. França em suas addições e appendix. Recenseadas todas, accuradamente rev. e frequentemente emendadas de muitos errores e faltas daquellas e outras edições por J. I. de F. . . Coimbra, Real Imprensa da Universidade, 1819. $6 \mathrm{v}$. in 5 . Index chronologico das Leis extravagantes desde 1603 até $176 \mathrm{x}$, comprehendidas na Collecção chronologica de 6 vol. $4^{\circ}$, impressa na Real imprensa da Universidade, em r8r9. Coimbra, Real imprensa da Universidade, r833. $140 \mathrm{p}$.

4 Collecção da legislação antiga e moderna do Reino de Portugal. Pt. I. Da legislação antiga. Pt. II. Da legislação moderna. Coimbra, Impr. da Universidade, I806. 5 v. 
of Delgado, was published in 1835 by Joze Vieira ${ }^{1}$ in a pamphlet. Attention may also be called to a digest of Brazilian law consisting of extracts from the Codigo Philippino and the laws subsequent thereto relating to Brazil. This work by Azambuja Susano ${ }^{2}$ was published in a third edition in three volumes in 1866 .

Numerous digests of the Codigo Philippino, including extracts and notes and concordances, have been published at various times. The first of these, concorded with the Partidas of Spain, was published by Manuel Mendes de Castro ${ }^{3}$ in 1604 .

An index to the Vicente edition was compiled by Silva Pereira ${ }^{4}$ in 1749 , and an important annotated index was published by the Imprensa da Universidade of Coimbra ${ }^{5}$ in 1795 .

Attention has already been called to the chronological index-digest of Portuguese legislation subsequent to the Codigo Philippino compiled by João Pedro Ribeiro ${ }^{6}$ and pub-

${ }^{1}$ Legislação, que falta na collecção de Delgado, desde I808 até I820, seguida da dos annos de 182 I e 1822 até 7 de setiembre, entermedia entre a de Delgado, e a posterior á Independencia de Joze Ignacio Vaz Vieira, 1835 . Rio de Janeiro, 1835 . 65 p. folio.

2 Azambuja Susano, Luiz da Silva Alves de: Digesto brasileiro ou extracto e commentario das ordenações e leis posteriores até as presente. Rio de Janeiro, E. and H. Laemmert, 1866. 3rd ed. $3 \mathrm{v}$.

${ }^{3}$ Mendes de Castro, Manuel: Repertorio das ordenaçoes do reyno de Portugal novamente recopiladas. Com as remissões dos doutores do reyno que as declarão \& concordia das leis de partida de Castella. Composto pelo licenciado Manuel Mendez de Castro . . . Lisboa, Impresso por I. Rodriguez, $\mathrm{I}_{604}$. $\mathrm{I}_{3} 6 \mathrm{p}$.

${ }^{4}$ Silva Pereira, Jeronymo da: Repertorio das ordenaçóes e leyes do reyno de Portugal, novamente correcto: accrescentado com muitas conclusões tiradas das mesmas ordenações, e com hum novo index no fim delle das materias das collecções, que se ajuntarão aos livros da ordenação novamenta impressa: illustrado com copiosas remissões dos doutores; concordia das ordenações, leys extravagantes, decretos reaes, e assentos das relações que se tem expedido, e feito desde a nova compilação das ordenações; e com muitas notas de casos prati$\cos$ e arestos, que deixárão apontados nas suas ordenações alguns grandes ministros deste reyno . . . Lisboa No mosteiro de S. Vicente de Fóra, Camara real de Sua Magestade, r749. 2 v.

${ }^{5}$ Repertorio das ordenações e leis do reino de Portugal. Coimbra, Impr. Universidade, I795. $4 \mathrm{v}$.

"Indice chronologico remissivo da legislação Portugueza posterior a publicação do codigo filippino pelo João Pedro Ribeiro. Lisboa, T yp. de Academia R. das Sciencias de Lisboa, $1805-1830$. 2nd ed. $6 \mathrm{v}$. 
lished in a second edition in six volumes, $1805-1830$. This is the continuation of the Synopsis chronologica and Additamentos. (Supra, p. 229) Another alphabetical index of the leis extravagantes of Portugal promulgated since the Codigo Philippino, so far as they were in force in 1815 , was published in that year by Manoel Fernandes Thomaz ${ }^{1}$ with a second volume in I825.

Brazilian law, like that of Argentina, contains no indigenous element. Until the date of independence its sources are entirely European. During the colonial period the country was divided into captaincies. It was endowed with a general government in 1549 and divided into two states in 1624 . The state of Maranhão was, moreover, during the colonial epoch administratively and politically independent of the state of Brazil. Bahia was the center of the government until 1773 . After 1640 the governor of Brazil had the title of viceroy.

In the administration of justice, the colonization companies which were formed during the period of colonial expansion enjoyed almost unlimited power. The judicial power was separated from the administrative only at the end of the eighteenth century. The separation was manifested by the creation of the council of the fisc, the council of conscience and orders, and the ultramarine council, which succeeded the Council of the Indies created in 1604 . This ultramarine council exercised the function of a supreme court for all the non-European Portuguese countries. Judges had a large measure of police jurisdiction. Colonial justice was administered by captains general in a summary fashion, by corregedores, by provedores, ouvidores geraes, ouvidores, and by other judges, as well as by two courts of second instance known as Relação, and by a court of appeal at Lisbon known as the Casa da Supplicasão. A court of appeal was established at Bahia in 1652 .

After the establishment of the Empire, the court of appeal at Rio de Janeiro became the court of revision for all Brazil.

${ }^{1}$ Repertorio geral, ou Indice alphabetico das leis extravagantes do reino de Portugal, publicadas depois das Ordenações, comprehendendo tambem algunas anteriores, que se achão em observancia ... pelo Dr. Manoel Fe.nandes Thomaz. v. I Coimbra, Impr. Universidade, 1815. v. 2 Lisboa, Imp. Regia, 1825. 2 v. 
A supreme court of justice, police, and administration was created (Casa da Supplicasaão), as weil as a supreme military council, and in addition a Council of State and of the Treasury, a tribunal of commerce, and a court of appeal of the palace (Dezembargo do Paço), similar to the high court in Portugal, whose jurisdiction was exclusively civil. By the constitution of 1824 a moderating (equitable) jurisdiction exercised by the emperor and later by the Council of State was established. The collections of the opinions and orders of the Council of State, which required imperial confirmation, are an important source of administrative interpretation on questions of public law.

In order to secure a proper insight into Brazilian legal history, it is necessary to have recourse first to the important works on Portuguese legal history. The two classic Portuguese treatises are Mello Freire's ${ }^{1}$ " History of Portuguese law," published in Lisbon in 1794, and Professor Coelho da Rocha's treatise on "The history of the government and legislation of Portugal." " Mello Freire is a Portuguese jurist of international renown, all of whose works are of primary importance. He published the first systematic treatise of Portuguese civil and criminal law. Coelho da Rocha was professor of law at Coimbra in the first part of the nineteenth century. His works on civil law are regarded as classics in Brazil. His work on legal history, above mentioned, has had six editions and is regarded as indispensable in the study of Brazilian legal history.

Another important Portuguese work on foral law is that of Braga, ${ }^{3}$ published in 1868 and cited as authoritative in practically all the subsequent works on legal history. Professor Pedro Martins ${ }^{4}$ has recently published his lectures on the

${ }^{1}$ Mello Freire, Pascoal José de: Historiae juris civilis Lusitani. Olisipone, I794. I3 chap. Also edition of Coimbra, $18_{53}$.

${ }^{2}$ Coelho da Rocha, M. A.: Ensaio sobre a historia do governo e da legislação de Portugal para servir de introducção ao estudo do direito patrio. 6th ed. Coimbra, 1887. 247 p. (First ed., r84r.)

${ }^{3}$ Braga, Theopilo: Historia do direito portuguez: Os foraes. Coimbra, r868.

${ }^{4}$ Martins, Pedro: Historia geral do direito romano, peninsular e portugués. Coimbra, Impr. da Universidade, I9ro. $\quad 582 \mathrm{p}$. 
"History of Roman, Peninsular, and Portuguese law" as delivered in the University of Coimbra. The last portion of the book gives an excellent account of the external history of Portuguese law.

A history of the institutions of Roman, Peninsular, and Portuguese law, particularly the institutions of civil law, systematically arranged, has been published by Professor Marnoco e Souza, ${ }^{1}$ likewise based upon lectures delivered at the University of Coimbra.

Mention should also be made of the history of Portugal by the noted scholar, Alexandre Herculano, ${ }^{2}$ in which the history of law and legislation occupies an important place. The work has appeared in several editions.

Brazilian writers on legal history are very few in number. Practically the only extensive work on the history of Brazilian law is that of Professor J. Isidoro Martins, jr., ${ }^{3}$ published in 1895 . The first part of the book deals with the Portuguese elements of Brazilian law and the second part with Brazilian law, coming, however, down to I 822 only. It is to be followed by another work dealing with the history of law during the Empire and Republic. For the period covered it constitutes a valuable contribution to legal literature.

A brief survey of the evolution of law in Brazil, published under the title "Survey of historical sources of Brazilian law," was published in French by A. Velloso-Rebello, ${ }^{4}$ of the Brazilian diplomatic service. It is a useful outline of the development of Portuguese law in the colonial epoch and of the movement of codification and the administration of justice during the Empire.

${ }^{1}$ Marnoco e Souza, José Ferreira: Historia das instituções do direito romano peninsular e português; prelecções feitas ao curso do $2^{\circ}$ anno juridico do anno de 1904 a 1905 . 3rd ed. Coimbra, França Amado, I91o. $574 \mathrm{p}$.

${ }^{2}$ Herculano de Carvalho e Araujo, Alexandre: Historia de Portugal. Lisboa, En casa de viuva Bertrand e filhos, 1846-53. 4 v. Another ed. $1875-88.4 \mathrm{v}$.

${ }^{3}$ Martins Junior, J. Isidoro: Historia do direito nacional. Rio de Janeiro, Typ. de Empreza democratica edit., r895. 290 p.

${ }^{4}$ Velloso-Rebello, A.: Aperçu des sources historiques du droit brésilien. Bruxelles, Impr. F, van Buggenhoudt, rgri. $71 \mathrm{p}$. 
Sylvio Romero, the legal philosopher, published various excellent studies on Brazilian legal history in the Revista braziliense between 1885 and 1895 . Professor J. Isidoro Martins, jr., is also the author of a general history of law, ${ }^{1}$ designed as a text book for his course in the faculty of law at Recife.

\section{CIVIL, CODE}

Brazil may justly lay claim to two distinctions-first, in having produced Augusto Teixeira de Freitas, generally admitted to have been the most eminent constructive jurist of Latin America, and, secondly, in possessing the most scientific and practical code of Latin America. This code was enacted on January $1, x 916$, more than fifty years after the first draft had been submitted by Teixeira de Freitas.

\section{HISTORY}

The civil law which Brazil had inherited from Portugal was a heterogeneous collection of rules and laws scattered in the Ordenafões Philippinas and in the leis extravagantes, with a subsiduary source in Roman and canon law, often contradictory. In 1783 the eminent Portuguese jurist Mello Freire undertook to redraft and systematize, with additions, Books 2 and 3 of the Ordenações Philippinas, a work which he executed, but which did not become law.

The constitution of the Brazilian Empire of 1824 recognized the urgency of a civil code in article 179 , section 18 , but no action appears to have been taken until the decree of December 22, 1858 , No. 2318. Before that, in 1855 , the government had concluded a contract with Teixeira de Freitas to consolidate the civil laws into a systematic work. This he produced in 1857 in a classic compilation, Consolidação das leis civis, with excellent annotations. ${ }^{2}$ Of this work there were

${ }^{1}$ Martins, Jr., J. Isidoro: Ensaio de historia geral do direito, compendio segundo o programma da Fac. de Direito do Recife. Rio de Janeiro, [1897]. $237 \mathrm{p}$.

${ }^{2}$ Teixeira de Freitas, A.: Consolidação das leis civis. Ist ed., Rio de Janeiro, $1857 ; 237,5^{27}$ p. 2nd ed., Rio de Janeiro, I865; I87,680 p. $3^{\text {rd }}$ ed., Rio de Janeiro, 1876 . 4th ed., Rio de Janeiro, Igr4. $5^{\text {th }}$ ed., Rio de Janeiro, I9r5. 
three editions published during the author's life-time, each of them, particularly the third, of 1876 , profiting by the latest legislation, decisions of the courts, and doctrinal writings. In 1914 and 1915 a fourth and fifth edition were published, the latter edited by Martinho Garcez, ${ }^{1}$ reediting the third edition with additional annotations and appendices containing statutes in modification and amplification of the consolidation.

In 1857 , a committee appointed by the Minister of Justice, Nabuco de Araujo, reported so favorably upon the consolidation that by decree No. 2318 of December 22, 1858, Teixeira's consolidation was officially approved and the Minister of Justice was anthorized to appoint an eminent jurist to prepare a draft of the civil code, a task which was assigned to Teixeira de Freitas by decree of January II, 1859. This he fulfilled by the submission of his Esboso de codigo civil, ${ }^{2}$ not a complete draft but only a sketch which was designed to open the discussion. The Esboço is a long and exhaustive work of 4,908 articles, but incomplete, since all of Book III of the special part on succession is lacking. The classification, however, is excellent and has served as a model for subsequent codifiers. Many of the legal rules, also, have stood the test of time. Teixeira de Freitas was convinced of the necessity of combining the civil and the commercial codes, a project which has recently been again attempted by a draft code of Inglez de Souza under authorization from the Minister of Justice, Rivadavia Correia.

A commission of eminent jurists was appointed to examine Teixeira's draft by decree No. 3293 of July 23, 1864. ${ }^{3}$

${ }^{1}$ Garcez, Martinho: Consolidação das leis civis, publicação autorisada pelo governo, por Augusto Teixeira de Freitas, annotada por Martinho Garcez. 5th enl. ed., Rio de Janeiro, J. Ribeiro dos Santos, r915. $775 \mathrm{p}$. and appendix $363 \mathrm{p}$.

2 Teixeira de Freitas, A.: Esboço de codigo civil. Rio de Janeiro, I860-r864. $2 \mathrm{v}$. in 3. $\mathrm{r}, 688 \mathrm{p}$.

${ }^{3}$ Instrucções . . . pelas quae se ha de regular a Commissão, creada . . . 29 de Decembrero [I863] . . para examinar o Projecto de codigo civil, redigido pelo Bacharel Augusto Teixeira de Freitas. Rio de Janeiro, Typ. Nac., 8865 . 5 pp. Dated 23 de Julha, 1864. "Zacarias de Góes e Vasconcellos." 
They submitted a detailed report ${ }^{1}$ in 1865 . Although Teixeira's work was at once recognized as monumental and served, indeed, as a model for the Argentine and Uruguayan civil codes, it was not acted upon in Brazil.

Three other important attempts at the production of a civil code warrant mention. By decree No. 5I64 of December II, I 872, the draft of a code was entrusted to Nabuco de Araujo, former Minister of Justice. He died soon thereafter, leaving r 82 completed articles, following the original plan of Teixeira de Freitas, with notes. He did, however, prepare the entire code which was found in manuscript, but with notes that apparently only the author could understand.

The next attempt was due to Felicio dos Santos, who in I 88I offered to the government his $A$ pontamentos para o projecto do codigo civil Brasileiro. In July of that year the Minister of Justice, Souza Dantes, an eminent jurist, named a commission composed of some of the leading jurists of Brazil, namely, Lafayette Rodrigues Pereira, Antonio Joaquim Ribas, Francisco Justino Gonçalves de Andrade, Antonio Coelho Rodrigues, and Antonio Ferreira Vianna to report upon the plan submitted. The commission found much merit in the work, but criticized its method. Felicio dos Santos was requested to prepare a complete code, and in 1882 he offered to the Minister of Justice and to the Chamber of Deputies an elaborate draft of a code, with commentaries. The code contained 2,692 articles, and although bills for its approval were introduced in the Chamber of Deputies it was not adopted. Felicio dos Santos then published a long defense of his code, with excellent commentaries. ${ }^{2}$ The Minister of Justice, Candido Oliveira, named a commission in 1889 to undertake the work of codification, but the overthrow of the monarchy in that year prevented its execution.

The provisional government, however, on July 15,1890 , through the initiative of the Minister of Justice and later President, Campos Salles, assigned the work to Coelho Rodri-

${ }^{1}$ Relatorios e pareceres dos membros da Commissão encarregada de examinar o projecto do codigo civil do Imperio redigido pelo Bacharel Augusto Teixeira de Freitas. Rio de Janeiro, Typ. Nacional, 1865. I66 p.

${ }^{2}$ Felicio dos Santos, Joaquim: Projecto de codigo civil brazileiro e commentario. Rio de Janeiro, Typ. Nacional, $1884-87.5 \mathrm{v}$. 
gues, a jurist of prominence, who was to report in three years. He was given the general plan on which to work, but was requested to consolidate the existing law and propose new reforms in accordance with the experience of the most civilized nations and the necessities of Brazil. His draft, ${ }^{1}$ presented in I893, was not accepted by the government of Floriano Peixoto. An examining commission reported unfavorably upon it, although the charge made by Coelho Rodrigues that they were actuated by personal animus may not be without foundation. The author published, in French, ${ }^{2}$ an explanatory statement of the history, execution, and the contents of his draft, with the report ${ }^{3}$ of the examining commission and his reply thereto. Coelho's draft had much merit, but instead of being discussed for purposes of amendment, its acceptance or rejection as a whole became something of a political question in Congress, where it was finally rejected.

When Campos Salles assumed the presidency he again turned his attention, assisted by his able Minister of Justice, Epitacio Pessoa, to the preparation of a civil code. By a decree of 1899 the Government commissioned for this task Clovis Bevilaqua, perhaps the most versatile jurist of Brazil, a profound scholar and a practical jurist of proven achievement. His legal gifts and his personal moderation and tolerance secured for his appointment practically universal approval. In November, I899, Bevilaqua submitted his draft ${ }^{4}$ with an explanatory report. The draft was submitted by the Executive to Congress with a message on November 17, 1900. It was also sent out to the various judges, to faculties of law, and to leading jurists and prominent public men throughout the Republic for criticisms, comments, opinions, and suggestions.

1 Coelho Rodrigues, Dr. A.: Projecto de codigo civil brasileiro, precedido da historia documentada do mesmo e dos anteriores. Rio de Janeiro, I893. $342 \mathrm{p}$.

2 Coelho Rodrigues, A.: Exposé des motifs du projet de code civil brésilien. Rédigé en vertu du décret du I $_{5}$ juillet I $_{90}$ par le Dr. A. Coelho Rodrigues . . . Rapport de la Commission de révision du même projet et réponse de 1'auteur. Genève, Imprimerie suisse, I894. $78 \mathrm{p}$.

${ }^{3}$ Parecer da commissão revisora do projecto do codigo civil do Dr. A. Coelho Rodrigues. Rio de Janeiro, 1893 .

- Bevilaqua, Clovis: Projecto do codigo civil. Rio de Janeiro, Imp. Nacional, I899. $8 \mathrm{v}$. in 4 .

$71624^{\circ}-17-10$ 
The Chamber of Deputies appointed a committee of twentyone, which began its sessions on July 27 , r 901 . They divided into subcommittees and called to their aid leading lawyers of the country, including the author of the draft code, and Andrade Figueira, one of the leading jurists of the Empire, whose constructive criticism helped greatly in the formation of the final code. The proceedings ${ }^{1}$ of the committee of twenty-one have been published officially. On January 26, 1902, the Chamber of Deputies received the draft from its committee of twenty-one, accompanied by an exhaustive report of Sylvio Romero, its secretary. The reports of the subcommittees are to be found in the Diario do Congresso Nacional for 1901, together with many of the criticisms, comments, opinions, and suggestions which were received by the committee in response to its invitation.

The Chamber of Deputies also published separately in eight volumes the proceedings of the committee of twenty-one, ${ }^{2}$ the various drafts and revisions, the opinions and suggestions received from judges, lawyers, and others, and the reports of its subcommittees and general committee. Clovis Bevilaqua ${ }^{3}$ replied to various criticisms submitted, in a work published in 1906. An account of the discussion of the code in the Chamber of Deputies was published in 1903 by Juvenal Pacheco. ${ }^{4}$ On April 8, 1902, the code as approved by the Chamber of Deputies was sent to the Senate, and there it experienced a minute examination and discussion which ultimately delayed its final enactment for some fourteen years.

It is here that Ruy Barbosa, one of the most gifted of contemporary Brazilians, enters upon the scene. As a member of the Senate committee which was appointed to examine the code he published an exhaustive criticism directed principally

1 Actos dos trabalhos da Commissão . . E Elaborado pelo Clovis Bevilaqua (Publicação official). Rio de Janeiro, Impr. Nacional, rgor. $427 \mathrm{p}$.

${ }^{2}$ Projecto do codigo civil brazileiro. Trabalhos da Commissão especial da camara dos deputados. Rio de Janeiro, Imp. Nacional, 1902. 8 v. in 4 .

${ }^{3}$ Bevilaqua, Clovis: Em defesa do projecto de codigo civil brasileiro. Rio de Janeiro, Alves, rgo6. $538 \mathrm{p}$.

* Pacheco, Juvenal: O codigo civil na Camara dos Deputados. Rio de Janeiro, 1903. $200 \mathrm{p}$. 
to matters of form and language. As a recognized philologist and scientific student of grammar and one of the foremost jurists of the Republic his criticisms received serious attention and actually exercised a great influence upon the code as finally drafted and accepted. Ruy Barbosa's criticisms aroused many objections and polemics in reply, among the most noteworthy of which was one by Eirnesto Carneiro Ribeiro ${ }^{1}$ of Bahia, one by Clovis Bevilaqua, and one by José $\mathrm{J}$. de Oliveira Fonseca of Recife. To these defenses of the original draft and criticisms of Senator Barbosa's objections, the distinguished senator replied in 1904 . His original criticism, with his reply to the polemics directed against it, were published officially in two volumes by the Senate. ${ }^{2}$ In answer to Ruy Barbosa's final defense of his criticisms, Ernesto Carneiro Ribeiro $^{3}$ rejoined with another voluminous reply. These works are mentioned because they contribute so greatly to the historical evolution of the present civil code and because of their contribution to legal literature.

For several years no further action was taken in the Senate, until in 1908 and again in 1909 and in I9I I new commissions were named to undertake to report upon the draft. A commission finally reported out an amended airaft which was adopted on December 3I, I9I2, with I,757 amendments of the original draft accepted by the Chamber of Deputies. The draft code thereupon experienced a number of transmittals from one house to the other, each time with a reduction in the number of amendments upon which agreement could not be reached. Finally in $1_{91} 4^{-I} 5$ special conference committees were appointed to act upon the nine final amendments which remained in dispute. All the committee reports and debates are to be found in the Diario do Congresso Nacional between I9I2 and 1915. The draft having finally been approved by

1 Carneiro Ribeiro, Ernesto: Ligeiras observações. Bahia, I903.

${ }^{2}$ Projecto de Codigo civil brazileiro; Trabalhos da Commissão especial do Senado. v. I. Parecer do Senador Ruy Barbosa sobre a redacção do projecto da Camara dos deputados. v. 2. Replica do Senador Ruy Barbosa ás defesas da Redacção do projecto da Camara dos deputados. Rio de Janeiro, Imp. Nacional, I902-1904. $2 \mathrm{v}$.

${ }^{3}$ Carneiro Ribeiro, Ernesto: A redacção do projecto do codigo civil e a replica do Senador Ruy Barbosa. Bahia, r905. 889 p. 
the conference committees, it was adopted in both houses and approved and promulgated by the President on January $I$, I916, to come into effect on January I, I9I7.

In its long preparation, in the fact that the leading jurists of the country took part in its discussion and elaboration, in the minuteness with which every provision was examined, may be found the explanation for the excellence of the code. While not so monumental in the evolution of law as the enactment of the French, Italian, or German civil codes, it is, nevertheless, a remarkable work of codification. One is reminded by its prolonged consideration and the innumerable conferences, discussions, and debates, legislative and private, of the preparation of the German civil code; and, indeed, it may be said that the influence of German legal science appears to be greater in Brazil than in any other country of Latin America.

\section{CONTENTS}

The code consists of 1,806 articles with an introduction of $2 \mathrm{I}$ articles. The introduction deals with general principles not properly to be included in the body of the code, but which are recognized as necessary to its effective execution. Rules are presented on the obligatory character of the law, its application in time and in space, the revocation and interpretation of the law, its extraterritorial effects, the recognition of foreign juristic persons, public and private, the execution of foreign judgments, and security for costs. In this introduction important changes of the former law were effected, due largely to the work of the committee of 21 and the initiative of Andrade Figueira, who redrafted most of the articles. The constitutional principle of the nonretroactivity of laws was defined in matters of civil law, and the principles of the conflict of laws, previously uncertain, were carefully specified.

The body of the code consists of a general part and a special part. The general part is divided into three books, which deal with persons, property, and legal acts. Book I on persons is divided into two chapters; the first deals with natural persons, recognizing in all men legal capacity, declaring civil equality between Brazilians and foreigners (art. 72 of the constitution), enumerating the cases of incapacity de facto 
absolute and relative, abrogating the benefit of restitution, fixing the age of majority and the cases of emancipation regardless of sex, fixing the rules as to survivorship in common disasters, amplifying the registration of civil status to include not merely births, marriages, and deaths, but also emancipation and legal declaration of absence and incompetency.

Chapter II deals with juristic persons, bringing order into a subject which had theretofore been most confused. The chapter is divided into four sections. In the first it defines the legal persons of public and of private law; in the second it creates civil registration for juristic persons of private law (corporations) and presents the rules for their inscription in the Register; in the third, it treats of civil associations, prescribing the rules as to their existence, constitution, operation, term, and disposition of property after liquidation; and the fourth fixes the method of creating and establishing a foundation with the rules for its administrative supervision and term of existence. Title II deals with civil domicil, both of natural and juristic persons.

Book II deals with property, retaining in general the prior law. It includes the general rules relating to movable and immovable property, confusion of goods, divisibility and indivisibility of things, single and collective property, public and private property, noncommercial property, and family property or homestead. This last is an important new institution (arts. 70-73), by which a person free of debt may set aside a homestead for his family which shall thereafter, when properly registered, be exempt from execution.

Book III, on juristic acts, has three titles, besides a preliminary title concerning the rules relating to the acquisition of rights and their guaranty by legal action. The three titles deal with juristic or legal acts, illicit acts, and prescription. The two former are merely a systematic restatement of the earlier law, which was greatly confused, especially the section on the nullity of legal acts. The first title on juristic acts covers mistake, fraud, duress, deceit, fraud against creditors, the various kinds of juristic acts, their form and proof and their nullity. The title on prescription, which altered the former law, deals with general provisions, the cases which impede, suspend, or interrupt prescription, and the time periods. 
Then comes the special part of the code which is by far the longest. It is divided into four books, covering, respectively, rights of family, things, obligations, and succession.

Book I, on family rights, is divided into six titles. Title I, dealing with marriage, preserves the existing law under decree I 8 I of January 24,1890 , with a number of additional provisions concerning the proof and annulment of marriage and remarriage. It deals with the formalities, the impediments, celebration, proof, void and voidable marriages, and penal provisions. Title II, on the legal effects of marriage, does not greatly alter the prior law, but organizes the material better and gives a greater equality of rights to women. It deals with general provisions and the right and duties of husband and wife. Title III governs the property relations between husband and wife, fixing rules which theretofore had been vague and uncertain and had given rise to much difficulty. There are certain new provisions on the dotal régime and antenuptial gifts. Title IV deals with the dissolution of marriage and the protection of the children. Marriage remains indissoluble, except by death, which must be proved. The so-called divorce merely involves legal separation. Title $\mathrm{V}$ deals with the relations of parent and child and contains important provisions concerning legitimacy and the recognition of children, adoption, and the patria potestas. The former law is greatly changed in certain matters. The recognition of natural children may be made at any time, and the action for the establishment of paternity is admitted in certain cases. Title VI deals with trustees of persons, guardians, and absent persons, and their legal relations with respect to the ward or cestui que trust and third persons.

Book II deals with property rights and contains three titles dealing with possession, property or ownership, and real rights over the property of others. In Title I, which concerns possession, the code rejects both the elements of Savigny, the corpus and the animus, and adopts the theory of Jhering, thereby going beyond the German civil code and the Swiss civil code, which, while abandoning animus, retain the corpus. Title II is divided into six chapters, containing numerous amendments of the prior law. It deals with the acquisition and loss of ownership in movable and immovable 
property, the various kinds of property, the various forms of ownership, including co-ownership, and with literary, scientific, and artistic property. It confirms the transfer of real property by registration, which is extended to the distribution of decedents' estates and public auction. Title III, on real rights in the property of others, deals with emphyteusis, servitudes, usufruct, use and occupation, a new section on annuities derived from immovable property (art. 749-754), pledge, including the pledge of securities, anticresis, and mortgage, with a new section on mortgages upon railroads. The rules as to mortgage rights are systematized and revised, and the provisions for the registration of mortgages and other real rights are improved.

Book III deals with obligations. It is the longest part of the code and the part which most required codification. The book contains 9 titles. Title I deals with the kinds of obligations: to give and to do, alternative, divisible and indivisible, joint and several, active and passive, and a new provision governing liquidated penalties. Title II, on the effects or performance of obligations, concerns payment in its various forms, novation, compensation, compromise, confusion, remission of debts, the results of nonfulfillment of obligations, and damages, etc. Title III relates to assignment. Title IV deals with the general rules of contracts, their form, bilateral contracts, marriage settlement contracts, contracts in favor of third persons, causes of nullity, etc. Title $\mathrm{V}$, the longest in the book, deals with the different kinds of contracts, which heretofore had been governed by the provisions of the Codigo Philippino, the commercial code, and subsidiary Roman law. It deals with purchase and sale, exchange and barter, gifts, letting and hiring, loan, deposit, agency, negotiorum gestio, publication and dramatic representation, partnership, association in agricultural and pastoral enterprises, trusts created in favor of third persons, insurance, including a section on life insurance, gambling and wagering contracts, and bail or security. Title VI deals with obligations by unilateral declaration of will, and particularly bonds or instruments to bearer and reward. Title VII deals with the obligations arising out of unlawful acts, specifying those who are responsible for a violation, by 
agents, of the rights of others, establishing among them joint liability, cstablishing the principle of reciprocal independence of civil and criminal responsibility, etc. Title VIII deals with liquidation of obligations and the making of compensation for violation of rights. Title IX deals with insolvency and regulates the order of preference of privileged creditors.

Book IV deals with succession and is divided into four titles. The first concerns succession in general, the transfer and acceptance of the inheritance, and the persons who may and may not be heirs. Title II concerns legitimate succession, and deals with the order of distribution and the right of representation. Title III deals with testamentary succession and concerns wills in general, capacity, including capacity of testators, and of heirs to take, the form of wills, codicils, special wills, legacies, defect of heirs or legatees, substitution, revocation, disinheritance, rejection of legacies, etc. Title IV deals with the inventory, partition, and distribution of decedents' estates.

\section{LITERATURE}

As already mentioned, the civil code of Brazil was finally promulgated on January $\mathrm{I}, 1916$, to take effect on January I, 1917. (Impr. Nacional, I916. 308 p.) Up to this time only a few text editions of the new code have appeared. The best of these seems to be an edition by Paulo de Lacerda ${ }^{1}$ with an interesting historical and descriptive introduction and an index digest of its contents. Joseph Wheless of the Comparative Law Bureau of the American Bar Association is engaged in making a translation of the code. A few of its first sections were translated by him in the April, r916, number of the American Bar Association Journal.

The publishing house of J. Ribeiro dos Santos has undertaken to publish an exhaustive commentary on the new code in 20 volumes, under the general editorship of Paulo de Lacerda. The leading jurists of Brazil will contribute to the work. It will consist of a series of scientific treatises on the various topics of the code, rather than an exegetic commentary. The first volumes of a commentary by Clovis Bevilaqua has just appeared.

${ }^{1}$ Lacerda, Paulo de: Codigo civil brasileiro. Rio de Janeiro, J. Ribeiro dos Santos r9r6. 376, 294 p. 
Inasmuch as the civil code is a scientific consolidation of existing law, the earlier treatises and commentaries upon civil law are not without considerable value in its interpretation and elucidation. In the following pages attention will, therefore, be called to the more important contributions to the subjects which have been incorporated in the civil code. Several of them, indeed, were written during the long period between 1902 and 1915 that the draft reposed in the Senate and were written with that draft in mind. As in former cases, reference will be made first to the general works dealing with the civil law as a whole and then to the special contributions to individual parts of the code and its incidental topics.

Before mentioning the Brazilian literature, it is proper to call attention to the three classic works of Portugal which have exercised a potent influence upon the development of Brazilian civil law. Reference is made ( $\mathrm{I}$ ) to Mello Freire's " "Institutes of Portuguese civil law," the first Portuguese treatise on civil law, published at the end of the eighteenth century; and (2) to Coelho da Rocha's " "Institutes of Portuguese civil law, " whose work furnished the basis for the Portuguese civil code adopted in 1867. His work covers particularly the history of the sources and principles of the civil law and its institutions. A recent edition published in Rio de Janeiro contains a valuable biographical account of the author's influence and service; and finally (3) to the treatise of Homen Corrêa Telles ${ }^{3}$ called a "Portuguese digest, or treatise of civil rights anci obligations." This work, which has been republished a number of times, was last issued in Lisbon in 1909. Its four volumes deal (I) with rights and obligations; (2) rights and obligations relating to persons and family relations; (3) the modes of acquiring

${ }^{1}$ Mello Freire, Pascoal José de: Institutionum juris civilis Lusitani cum publici tum private. Olisipone, $\mathrm{x} 789^{-1} 793.4 \mathrm{v}$. in 2.

${ }^{2}$ Coelho da Rocha, Manuel Antonio: Instituções de direito civil portuguez por M. A. Coelho da Rocha . . . para uso dos seus discipulos. Nova ed. augm. com o elogio historico do auctor . . . Rio de Janeiro, etc., H. Garnier [1902]. 2 v.

${ }^{3}$ Homen Corrêa Telles, J.: Digesto portuguez, ou Tratado dos direitos e obrigações civis accommodado ás leis e costumes da nação portugıeza para servir de subsidio ao "novo codigo civil." Nova edição revista. Lisboa, A. M. Teixeira, rgo9. $4 \mathrm{v}$. 
property and transferring it by deed or will; and (4), with a manual of civil procedure, consisting of a supplement to the earlier volumes.

It has already been observed that the first systematic treatment of Brazilian civil law was Teixeira de Freitas's "Consolidation of the civil laws of Brazil," " which was so excellent that it was officially approved by decree in $185^{8}$. Since then four further editions have appeared, in 1865,1876, I914, and 1915 , the last, edited by Martinho Garcez, ${ }^{2}$ containing an extensive appendix of all the acts supplementary to the original consolidation. The last edition revised by Teixeira de Freitas himself was the third, in 1876 . In 1877 Teixeira de Freitas made certain additions ${ }^{3}$ to his consolidation. About the same time he also published a compendium ${ }^{4}$ of his work in the form of an alphabetical digest. It is proper here to call attention to a biographical sketch of Teixeira de Freitas published in 1905 by Professor Sá Vianna. ${ }^{5}$

A work cited with almost as great frequency as that of Teixeira de Freitas is the consolidation of Brazilian law as in force in 1899 , by Carlos Augusto de Carvalho. ${ }^{8}$ Until the enactment of the code this work was of primary importance.

General treatments of the civil law are but few in number. Professor Lourenço Trigo de Loureiro ${ }^{7}$ published in $185 \mathrm{I}$ a

1 Teixeira de Freitas, A. (1817-1888): Consolidação das leis civis. Ist ed., Rio de Janeiro, $1857 ; 237,527$ p. 2d ed., Rio de Janeiro, 1865; 187680 p. 3 d ed., Rio de Janeiro, I876. 4th ed., Rio de Janeiro, I9r4. $5^{\text {th }}$ ed., Rio de Janeiro, I9I 5 .

${ }^{2}$ Garcez, Martinho: Consolidação das leis civis. 5th enl. ed. Rio de Janeiro, J. Ribeiro dos Santos, I9r 5.775 p. and Appendix 363 p.

3 'Teixeira de Freitas, A.: Legislação do Brazil. Additamentos á consolidação das leis civis. Revista annual, anno $x^{\circ}$. Rio de Janeiro, I877. $953 \mathrm{p}$.

4 Teixeira de Freitas, A.: Promptuario das leis civis. Rio de Janeiro, I876. $607 \mathrm{p}$.

${ }^{5}$ Sá Vianna, M. A. de S.: Augusto Teixeira de Freitas . . Traços biographicos. Rio de Janeiro, I905.

${ }^{6}$ Carvalho, Carlos Augusto de: Direito civil brazileiro recopilado, ou nova consolidação das leis civis, vigentes em Ir de Agosto de I899. Rio de Janeiro, Francisco Alves, 1899. 77 I p.

${ }^{7}$ Loureiro, Lourenço Trigo de: Institucões de direito civil brasileiro, extrah. das Inst. de dir. civil lusitano de . . Paschoal José de Mello Freire ... e augmentadas. Pernambuco, Typ. Roma e filhos e Recife, Meira Henrique, I85I. 5th ed. Rio de Janeiro, B. L. Garnier, $1884.2 \mathrm{v}$. 
collection of extracts from Mello Freire's work on Portuguese civil law which he entitled "Institutions of Brazilian civil law." Having been the first general treatise published in Brazil it was accepted as a textbook and up to r 884 had had five editions. It is merely a compendium of excerpts, without much system.

Antonio Joaquim Ribas, ${ }^{1}$ formerly professor at São Paulo, has published what is perhaps the best elementary introduction to the study of Brazilian civil law. Its introductory part is divided into five main titles, as follows-first, the science and history of law, the divisions of law and the auxiliary sciences; second, sources of law; third, the definition and classification of civil law, dealing with the general part or introduction to the civil code, including the promulgation, the obligatory force, the nonretroactivity, the effects, and the rules of interpretation of law; fourth, codification in the various foreign systems; fifth, legal literature of the civilians during the middle ages, and the Portuguese jurists prior and subsequent to the Codigo Philippino, with mention of a few of the Brazilian jurists. The general part deals, first, with rights and their elements in general; second, with persons; third, with things; and fourth, with legal acts. The first edition was published in 1875 and the fourth in $19 \times 5$.

A treatise on Brazilian civil law arranged on the order of Teixeira de Freitas's work is a compilation by Alencar Araripe, ${ }^{2}$ former Councillor of State, who in 1885 compiled the original ordinances on civil law of the Codigo Philippino and the subsequent laws on topics relating to civil law. It has no great value at the present day except as a reprint of the old texts.

A treatment in French by Raoul de La Grasserie ${ }^{3}$ of the civil laws of Brazil was published by that well-known student of comparative law in the compilation of civil codes of foreign

${ }^{1}$ Ribas, Antonio Joaquim: Curso de direito civil brasileiro . . . Pelo conselheiro Dr. Antonio Joaquim Ribas. 4. ed. Rio de Janeiro, J. Ribeiro dos Santos, I9r $5.582 \mathrm{p}$.

${ }^{2}$ Araripe, Tristão de Alencar: Codigo civil brazileiro, ou Leis civis do Brazil, dispostas por ordem do materias em seu estado actual, pelo conselheiro Tristão de Alencar Araripe . . Rio de Janeiro, $H$. Laemmert \& Co., 1885.799 p.

${ }^{3}$ La Grasserie, Raoul de: Code civil du Vénézuéla . . Los civiles du Brésil, . . Paris, V. Giard \& E. Brière, 1897. 328 p. 
countries published in Paris. It consists of a résumé of Teixeira de Freitas's consolidation.

A work of Professor Eduardo Espinola ${ }^{1}$ of the Faculty of Law at Bahia proposes to deal systematically with the Brazilian civil law in five volumes. Up to the present time only two volumes have appeared-the first, published in 1908 , dealing with the introduction and the general part of the civil code, and the second, published in 1912 , dealing with obligations in general. The work so far as published appears to be scientific and in vast footnotes, reference is made to foreign codes and jurists and the development of the subject comparatively considered. It is undoubtedly a work of erudition.

Two works dealing with the general principles of civil law from the comparative point of view are worthy of serious attention. They are both contributions of note. The first, by Clovis Bevilaqua, ${ }^{2}$ consists of lectures on private law, historically treated from the point of view of comparative legislation. The author deals with the methods of comparative law, classification of civil law and a review of the various institutions of private and especially civil law. The other, by former Councillor of State Candido de Oliveira, ${ }^{2}$ likewise based upon lectures on comparative law, deals with the general part of the civil law with a treatment of the sources.

\section{INCIDENTAL AND RELA'TED TOPICS}

GENERAL PART OF THE CODE

The works of Clovis Bevilaqua constitute probably the best scientific discussions of the various parts of the civil code. His method throughout is the historical and comparative, with the result that his contributions are a valuable synthesis of comparative law, including the best opinions of jurists, past and present, with the historical development of the subject and the author's critical judgment of the whole. This method

${ }^{1}$ Espinola, Eduardo: Systema do direito civil brasileiro. Bahia, r9o8 (v. I); Rio de Janeiro, F. Alves, rgr2 (v. 2).

${ }^{2}$ Bevilaqua, Clovis: Resumo das liç̧ões de legislação comparada sobre o direito privado. 2. ed. rev. e augm. Bahia, Magalhães, I897. $295 \mathrm{p}$.

${ }^{3}$ Oliveira, Candido L. M. de: Curso de legislação comparada. Rio de Janeiro, rgo3. 
pursued in his book on the general part of the code ${ }^{1}$ has produced a work of scholarship which is a credit to Brazil. In this work he deals with law, objective and subjective; laws, and their kinds and nature; the application of law in time and in space; the sources of law, custom, Roman law, canon law, and that of modern nations; the general principles of law; interpretation of laws; their revocation; the analysis of subjective law; the subject and object of law; and legal relations, followed by specific treatment of the topics contained in the general part of the code, namely, persons, property, and legal acts.

A work bearing the same title but differing greatly in content was published by Professor Martinho Garcez, ${ }^{2}$ with an interesting introductory criticism of Brazilian legal conditions and the judiciary. The work deals with the general part of the civil code showing the history and development of each article, the opinions thereon of the committee of $2 \mathrm{I}$ of the Chamber of Deputies, the relevant amendments of Ruy Barbosa, and the opinions and the amendments of the special committee of the Senate and of the Second Commission of the Chamber of Deputies on the first 201 sections of the civil code, of which part the work constitutes a valuable commentary. Among the appendices are the report of Sylvio Romero as secretary of the committee of 2I, a contribution of great merit; the amendments of Ruy Barbosa; and the reports of the special committee of the Senate and of the Second Commission of the Chamber of Deputies upon the general part of the code.

Professor Almachio Diniz ${ }^{3}$ has recently published a commentary on the Introduction and General Part of the civil code.

\section{LEGAL INTERPRETATION}

Among the works dealing especially with the topics considered in the introduction to the code is a classic work on

Bevilaqua, Clovis: Theoria geral do direito civil. Rio de Janeiro, etc. F. Alves, r9o8. $433 \mathrm{p}$.

${ }^{2}$ Garcez, Martinho: Da theoria geral do direito segundo o projecto de codigo civil brazileiro. Rio de Janeiro, J. Ribeiro dos Santos, rgr4. $569 \mathrm{p}$.

${ }^{3}$ Diniz, Almachio: Introducção é parte geral segundo o codigo civil de I9r6. Rio de Janeiro, F. Alves, rgr6. 
legal interpretation by Paula Baptista, ${ }^{1}$ published in 1860. It is appended to nearly all the later editions of his wellknown Compendio de theoria e practica do processo civil. (Infra, p. 293.) A work entitled "The rules of law" was prepared in $\mathrm{r} 882$ by Teixeira de Freitas, ${ }^{2}$ selected from the works of four celebrated jurists, Simão Vaz Barboza Luzitano, Felippe José Nogueira Coelho, João Homen Correa Telles, and the well-known Dupin. An important monograph by Porchat $^{3}$ deals with the retroactivity of civil laws. Attention should also be called to a recent article by Rodrigo Octavio ${ }^{4}$ on capacity in Brazilian private international law.

\section{LEGAL PERSONS}

One of the best monographs on the title "Legal persons" has been published by Lacerda de Almeida, professor at Rio de Janeiro and a legal scholar of the first rank. Practically all of his works are notable contributions. His work on juristic persons, ${ }^{5}$ based largely on Gierke's theory of association, contains a general part dealing with the theory of personality and a special part studying analytically the various corporations, associations, and institutions with a critical analysis of the law of September 10, 1893, on the acquisition and loss of legal personality of corporations. His discussion of the various kinds of legal persons in public and in private law is one of the best to be found in Brazil.

\section{LEGAL ACTS}

A work on legal acts, dealt with in Book III of the general part of the code, has been published by Professor Espinola. ${ }^{6}$

${ }^{1}$ Paula Baptista, F. de: Compendio de hermeneutica juridica. Recife, I860.

2 Teixeira de Freitas, A.: Regras de direito; selecção classica em quatro partes, revocada para o imperio de Brazil até hoje. Rio de Janeiro, 1882.

${ }^{3}$ Porchat, Reynaldo: Retroactividade de leis civis. Rio de Janeiro, I909. $162 \mathrm{p}$.

* La capacité et son exercice dans le droit international privé brésilien. By Rodrigo Octavio. 9 Rev. de Dr. Int. Privé (r9r3), pp. 78I-792.

${ }^{5}$ Lacerda de Almeida, Francisco de Paula: Das pessoas juridicas. Ensaio de uma theoria pelo Dr. Francisco de Paula Lacerda de Almeida . . . Rio de Janeiro, Typ. da Revista dos tribunaes, r905. 264 p.

${ }^{6}$ Espinola, Eduardo: Practicas dos actos juridicos. Bahia [1902]. 700 p. 
It does not appear to be especially distinguished. A noteworthy contribution by Professor Martinho Garcez ${ }^{1}$ deals with the nullity of juristic acts in accordance with the draft of the civil code. A second edition of the work was published in 1910-1912 in two volumes. In its general part it deals with the genesis of the nullity of legal acts, the causes thereof, the rescission and cancellation of written instruments, and the judicial means of bringing about the annulment of legal acts; and in its special part it deals specifically with the different kinds of legal acts, their proof, interpretation, and character, with the grounds of nullity of each, and the methods of having them so declared. It includes not merely civil but also commercial contracts, bankruptcy, and wills. At the end of each section the decisions of the courts are included.

\section{PRESCRIPTION}

Prescription is dealt with in a work of Eduardo Espinola, of Bahia, and in a recent work of Almeida Oliveira, ${ }^{3}$ a new Brazilian edition of a well-known Portuguese treatise.

The special part of the code is, as already observed, divided into four books-family law, things, obligations, and succession.

\section{BOOK I. FAMILY LAW}

The leading work on the subject of family law at the present time is that of Clovis Bevilaqua, ${ }^{4}$ a third edition having been published in 1908. His method is the historical-comparative, as in all his works; he includes a survey of the concept of family, betrothal, and marriage in their original form, the impediments of marriage, matrimonial property, the dowery system, the relations between parents and children, including illegitimacy, adoption, maintenance, and guardianship. A

${ }^{1}$ Garcez, Martinho: Nullidades dos actos juridicos. 2nd ed. Rie do Janeiro, J. Ribeiro dos Santos, rgro-I2. 2 v.

${ }^{2}$ Espinola, Eduardo: Theoria e pratica da prescripção. Bahia [rgoo]. $700 \mathrm{p}$.

${ }^{8}$ Almeida Oliveira, Antonio de: A prescripção em direito commercial e civil. Rio de Janeiro, J. Ribeiro dos Santos, I9r5. 339 p.

- Bevilaqua, Clovis: Direito da familia. 3rd ed. Recife, Ramiro M. Costa, 1908. 654 p. 
work by Martinho Garcez, ${ }^{1}$ published in 1914, follows the method of his book on the general part of the code, and is valuable for the legislative history and commentary of the articles in Book I of the special part of the code.

A somewhat older but a classic treatise is that of Lafayette Rodrigues Pereira, ${ }^{2}$ Councillor of State, and one of the most eminent jurists of Brazil. The first edition of the work was published in 1869 and the second in 1898 .

The greatest change was effected in the law of domestic relations by one of the first decrees of the provisional government, namely, 181 of January 24,1890 , on civil marriage, with a strict definition of the rights and duties of the parties with reference to person and property. Until that time the canon law had governed with the Portuguese legislation. The new law in its doctrinal and practical aspects, as compared with foreign law concerning divorce, has been discussed in a work by Almachio Diniz. ${ }^{3}$ The older law, which may be of interest for historical purposes, is set forth in a monograph of Romualdo Seixas. ${ }^{4}$

Divorce is still limited to legal separation. Bills introduced at various times giving divorced persons permission to remarry have been defeated. Various commentaries on the law of civil marriage have been published. Among these two are selected as of special interest. The first is by Ludgero Coelho, ${ }^{5}$ and the second by Macedo Soares. ${ }^{6}$ The law, brought into

${ }^{1}$ Garcez, Martinho: Direito da familia. Rio de Janeiro, J. Ribeiro dos Santos, I9I4.

${ }^{2}$ Lafayette Rodrigues Pereira: Direitos da familia. 2nd ed. Rio de Janeiro, I898. $422 \mathrm{p}$.

- Diniz, Almachio: Tratado de theoria e praxe do divorcio no direito brazileiro. Rio de Janeiro, J. Ribeiro dos Santos [IgII?].

- Seixas, Romualdo Antonio de: Ensaio d'um tratado regular e pratico sobre o divorcio, segundo o dereito sinodal, canonico e civil brasileiro, contendo o formulario das acções respectivas e notas proveitosas ao assumpto, pelo advogado Romualdo Antonio de Seixas. . . B Bahia; Typ. da Constituição de F. A. de Freitas, 1867. 248 p.

${ }^{5}$ Coelho, Ludgero Antonio: Da casamento civil brasileiro. Commentario ethico-juridico ao decreto n. 18 I de 24 de Janeiro de 1890 . Rio de Janeiro, 1899. $396 \mathrm{p}$.

- Macedo Soares, Oscar de: Casamento civil. Decreto n. I8I de 24 de Janeiro de 1890 , commentado e annotado. 2nd ed. Rio de Janeiro [n. d.]. 
correlation with the new civil code, has been commentated, with forms annexed, in a recent edition by Sá Albuquerque. ${ }^{1}$ The law of marriage and divorce in Brazil from the point of view of the conflict of laws was discussed in an article by Rodrigo Octavio, ${ }^{2}$ published in volume 3 of the Revne de l'Institut de droit comparé (1910), pages 41 2-428.

A discussion of the law governing the nullity of marriages and divorce was included in a report submitted to the International Law Association in I9I 3 by A. Velloso-Rebello.

The Public Register of births, marriages, and deaths as at present in force was created by decree No. 9886 of March 7 , $1888,{ }^{3}$ as revised by certain sections of decree No. 181 of January $24, x 890$. These laws, with forms and supplementary decrees, administrative regulations, opinions; and orders, including the state laws on civil registration, are arranged in a useful manual edited in 1909 by José Tavares Bastos, ${ }^{4}$ a prolific writer, and are discussed in a more scientific work by Galdino Siqueira. ${ }^{5}$

\section{BOOK II. THINGS}

Two or three important works dealing with the topics included in Book II of the special part of the code should be mentioned. The best of these is a systematic exposition of the Brazilian law of property by Lacerda de Almeida, ${ }^{6}$ pub-

'Sá Albuquerque, João de: Casamento civil, lei do: Decreto n. I8r de 24 de Janeiro de 1890 , commentado . . . já de accôrdo com o codigo civil brazileiro. Rio de Janeiro; J. Ribeiro dos Santos, I $_{9} \mathrm{r}_{5}$.

${ }^{2}$ Octavio, Rodrigo: Le mariage au Brésil (célébration, annulation et divorce au point de vue du droit international privé) par Rodrigo Octavio. . . . Bruxelles, Impr. F. van Buggenhoudt, Igro. I9 p.

${ }^{3}$ Regulamento do registro civil dos nascimentos, casamentos e obitos approvado pelo decreto n. 9886 de 7 de março de $r 888$. Rio de Janeiro, Imprensa nacional, I888. $29 \mathrm{p}$.

4 Tavares Bastos, José: O registro civil na republica, nascimentos, casamentos e obitos, contendo tudo quanto diz respeito á instituição com todas as leis, decretos e avisos do regimen imperial e da republica, referentes ao registro civil . . . a Lei do casamento civil annotada e seu formulario. . . . Rio de Janeiro, H. Garnier, r9o9. 459 p.

'Siqueira, Galdino: O estado civil, nascimento, casamento e obitos. São Paulo, I912.

${ }^{6}$ Lacerda de Almeida, Francisco de Paula: Direito das cousas. Rio de Janeiro, 1908-IC. $2 \mathrm{v}$.

$71624^{\circ}-17-17$ 
lished in 1908-1910, valuable also for its discussion of servitudes and mortgages. As is usual in the best works on Brazilian law, the author draws largely on comparative law. A recent commentary on this part of the code by Martinho Garcez, ${ }^{1}$ following the method of his work on the general part of the code, has recently appeared. Professor Almachio Diniz $^{2}$ has recently published a commentary on Book II of the code. The classic treatise of Lafayette Rodrigues, ${ }^{3}$ published in 1877 , also warrants mention.

\section{POSSESSION}

One of the best works on possession in Brazilian law, compared with Roman and canon law, is that of Antonio Joaquim Ribas, ${ }^{4}$ published in a new edition in 1901. It deals first with possession as such, its nature, the classification of the different kinds of possession and their titles, and the acquisition and loss of possession, and in a second part with the possessory actions, the Roman and canon law interdicts, and the actions under Brazilian law. Another well regarded work on possession was published in 1902 by $\mathrm{J}$. Nogueira Itagyba. ${ }^{5}$ A recent work on possessory actions, which includes a commentary on the articles of the draft of the civil code relating to possession, with the decisions of the courts, has been published by Astolpho de Rezende. ${ }^{\circ}$

A work on the right of retention or liens by Professor Pacheco, ${ }^{7}$ of Coimbra, was published in Rio de Janeiro in 1912. It is a doctrinal study dealing with cases in which

${ }^{1}$ Garcez, Martinho: Do direito das cousas. Rio de Janeıro, I915.

${ }^{2}$ Diniz, Almachio: Direito das cousas segundo o codigo civil de 1916. Rio de Janeiro, Alves, r916.

${ }^{3}$ Lafayette Rodrigues Perelra: Direito das cousas. Rio de Janeiro, 1877 . $2 \mathrm{v}$.

${ }^{4}$ Rihas, Antonio Joaquim: Da posse e das acções possessorias segundo o direito patrio comparado com o direito romano e canonico . . . Nova ed. cuidadosamente annotada. São Paulo, M. Melillo \& Cia. [pref. 1901]. $340 \mathrm{p}$.

5 Nogueira Itagyba, J.: A posse: manutenção de dıreitos. Rio de Janeiro, 1902.

${ }^{6}$ Astolpho de Rezende, Dr.: As acções possessorias e a jurisprudencia dos tribunaes. Rio de Janeiro, Alves, 1914. $300 \mathrm{p}$.

${ }^{7}$ Pacheco, Antonio Faria Carneiro: Do direito de retenção. Rio de Janeiro, J. Ribeiro dos Santos, I912. 
retention may be employed and the manner of its exercise, accompanied by a synthesis of comparative legislation.

WATERS

A valuable work on rivers and running waters in their legal relations was published in 1909 by Manuel Ignacio Carvalho de Mendonça, ${ }^{1}$ undoubtedly one of the most eminent jurists of South America. The work deals with the subject both in private and in public law, and is a valuable contribution to the study of the relation of the state to the control of water power and the grant of concessions to its use. A work by Almeida Lobão ${ }^{2}$ on water law also warrants mention.

PARTITION

Actions for partition, division and enclosure of land are governed by decree 720 of September 5, 1890, and certain supplementary acts and state statutes. There has been a considerable literature of the subject. The classic treatise, written prior to the enactment of the decree of 1890 is that of Antonio J. Macedo Soares, a third edition of which was published in $1887 . .^{3}$ Among the commentaries, the best are those of Rodrigo Octavio ${ }^{4}$ and Levindo Lopes, ${ }^{5}$ each of which includes some state legislation and forms. Each has recently appeared in a third edition.

\section{MORTGAGES}

The mortgage system of Brazil has been highly developed and has furnished an abundant literature. Before 1834 Brazil had no special legislation on mortgages. In that year, when the draft of the commercial code was considered, a Mortgage

${ }^{1}$ Carvalho de Mendonça, Manuel Ignacio: Rios e aguas correntes em suas relações jurıdicas; monographia... Coritiba, A. Rocha \& Cia., 1909. 38 I p.

${ }^{2}$ Lobão, Almeida: Aguas. Rio de Janeiro, J. Ribeiro dos Santos [rgro?].

${ }^{3}$ Macedo Soares, Antonio Joaquim de: Tratado juridico e pratico das medições e demarcações de terras tanto particulares como publicas. Rio de Janeiro, Typ. Polytechnica, 1887. $3^{\text {rd ed. }}$

- Octavio, Rodrigo: Divisão e demarcação de terras particulares. Commentario do Dec. 720 de 5 de setembro de 1890 . $3^{\text {rd }}$ ed. Rio de Janeiro, Alves, r9r3. I70 p.

${ }^{5}$ Lopes, Levindo Ferreira: Divisões, demarcações e tapumes. $3^{\text {rd }}$ ed. Rio de Janeiro, r9r5. 
Register was provided for without compulsory registration. Although the commercial code was adopted only in 1850 the register had been established by administrative decree in 1843 and regulated in 1846 . In 1854 the Minister of Justice, Nabuco de Araujo, proposed to establish an agricultural credit and mortgage system. The early drafts and speeches on that subject may be of interest. ${ }^{1}$ The final legislation of the Empire on the mortgage system and on building and loan associations was enacted by law 1237 of September 24, 1864, and regulated by decree of April 26, 1865. ${ }^{2}$ Supplementary decree No. 3272 of January 23,1886 , completed the imperial legislation.

The provisional government, however, by decree No: $169 \mathrm{~A}$ of January 19, 1890, with its regulation of May 2, effected a great change in the Brazilian system. The law is not merely one of procedure for registraticn, but is a rule for application in the decision of complicated questions of title.

The mortgage system of Brazil is described in an article by E. S. Zeballos, the Argentine jurist, in an article published in 3 Revue de l'institut de droit comparé (1910), pages 432-447.

One of the leading works on the mortgage law is that of Didimo da Veiga, ${ }^{3}$ the well-known publicist and scholar, published in 1899 . It is a special study of the decree of January 19, 1890. Another good work is that of José Mendes, ${ }^{4}$ of São Paulo, published in 1901. A work of Alcides Lima, ${ }^{5}$ published in a second edition in Pelotas, also warrants mention. The decisions on mortgage law were published in 1903 by $T$. Fulgencio, ${ }^{8}$ of Minas Geraes.

${ }^{1}$ Reforma hypothecaria. Projecto n. 124 de $\mathrm{r} 854$, e parecer da commissão especial da Camara dos Srs. deputados. Projecto substitutivo ao decreto n. 124 de 1854 . Projecto de reforma hypothecaria. Redacçạao approvada na Camara dos deputados na sessão de 23 de agosto de 1856 . Rio de Janeiro, Typ. de J. Villeneuve e comp., i856. I I2 p.

${ }^{2}$ Lei e regulamento da reforma hypothecaria estabelecendo as bases das sociedades de credito real. Rio de Janeiro, Typ. Nacional, I86.5. $64 \mathrm{p}$.

${ }^{3}$ Veiga, Didimo Agapito da: Direito hypothecario. Rio de Janeiro, I899. 66r p.

${ }^{4}$ Mendes, José: Direito hypothecario do Brasil. São Paulo [rgor].

${ }^{5}$ Lima, Alcides: Hypothecas. 2nd ed. Pelotas, 1897.

${ }^{6}$ Fulgencio Alves Pereira, Tito: Jurisprudencia hypothecario e formularios. Minas Geraes, Typ. de Gazeta de Leopoldina, x903. 549 p. 
A useful manual for the mortgage registrar, whose functions are largely judicial in character, was published in $\mathrm{I} 888$ by Oliveira Machado. ${ }^{1}$ Besides a history of the institution and forms, he gives a list of the ministerial decrees, orders, and opinions affecting the subject and includes the statutory provisions governing it.

The Torrens system for the registration of transfers of title to real estate was established in Brazil by law of May 3r, I 890 . A compilation of the transfer taxes for the transmission of property inter vivos and causa mortis, with the rules of registration, was published in 1912 by Tavares Bastos. ${ }^{2}$

The law arising out of the construction, ownership, and leasing of houses has been discussed in a classic work by Antonio Moura, ${ }^{3}$ recently brought up to date by Sá Albuquerque. He deals particularly with the law of landlord and tenant, the administrative law, and judicial interpretations relating to restrictions upon the freedom to build, and the different kinds of easements and servitudes. It includes a section on legal actions, and is supplemented by interesting historical notes.

A periodical ${ }^{4}$ dealing with property rights has recently been established under the editorship of Carvalho de Mendonça, Candido de Oliveira, and Lacerda de Almeida, three jurists of eminence. It includes doctrinal articles, statistics, decisions of the courts, and legislation on matters relating to real property.

Although Book II of the code contains a chapter on literary, scientific and artistic property, and Book III deals with

1 Oliveira Machado, Joaquim de: Manual do official de registro geral e "das hypothecas, tratado completo sobre e definição, criação, con'curso ... etc. por Joaquim de Oliveira Machado auxiliado por seu filho Joaquim de Oliveira Machado Junior . . . Rio de Janeiro, B. L. Garnier, r888. 568 p.

2 Tavares Bastos, José: Repertorio da transmissão de propriedade. Rio $\therefore$ de Janeiro, Igr2. 736 p.

${ }^{3}$ Moura, Antonio Ribeiro de: Manual do edificante, do proprietario e do inquilino. . . . Modificado e adoptado á legislação actual, pelo Dr. João de Sá Albuquerque. Rio de Janciro, J. Ribeiro dos Santos, I9I5. $400 \mathrm{p}$.

- Revista predial, edited by Dr. Carvalho de Mendonça, Candido de Oliveira Filho e Lacerda de Almeida. Rio de Janeiro, r9r3- 
the contract of publication and dramatic representation, we shall follow the order established in the other parts of this monograph and treat in a separate section, to follow presently, the rights of literary and industrial property.

\section{BOOK III. OBLIGATIONS}

Several notable contributions to the law of obligations have been made. Among the best of these is Professor Bevilaqua's ${ }^{1}$ work, published in a second edition in 1910. He systematizes the theory of obligations in the light of the new doctrines of the science of law, philosophy, history, economics, and comparative law. Part I deals with the history of obligations, Part II with the moving causes or consideration of obligations, and Part III with the particular kinds of contracts enumerated in the civil code, treated historically and comparatively.

A work of equal value is the excellent treatise of Manuel I. Carvalho de Mendonça. ${ }^{2}$ While Bevilaqua's book is a manual and a synthetic treatment of a great many subjects, many questions are left unsettled. Carvalho de Mendonça's work in two volumes deals with the modern concepts and the historical evolution of obligations, the kinds and variations of obligations, the effects and performance of obligations, the consequences of nonperformance and the question of damages, the transmission of obligations, and the sources of obligations, contractual and noncontractual. The dearth of reported decisions and the excellent theoretical work done by the Italians and the Germans on the subject has compelled the Brazilian writers to resort to comparative law in elucidation of their material. Carvalho de Mendonça's treatise is one of the ablest produced in Brazil.

Another valuable work, more theoretical and perhaps more profound than that of Bevilaqua's, is Lacerda de Almeida's ${ }^{3}$

'Bevilaqua, Clovis: Direito das obrigações ... 2. ed. rev. e accrescentada. Bahia, Magalhães, I9ro. 531 p.

${ }^{2}$ Carvalho de Mendonça, Manuel Ignacio: Doutrina e pratica dasobrigações ou Tratado geral dos direitos de credito . . . 2nd ed. augm. Rio de Janeiro, F. Alves \& Cia.,.1912. 2 v.

${ }^{3}$ Lacerda de Almeida, F. de P.: Obrigações. 2d. ed. Rio de Janeiro, Typ. "Revista dos tribunaes," 1916. 440 p. Ist ed., I897. 
treatise published in a new edition in 1916 . It is a systematic treatment of the subject, following the method of Lafayette Rodrigues, but correlated to the civil code. In notes, the author examines the theories he presents in comparison with those of others and the texts of positive law. He deals with the legal nature, the foundation, and the cancellation of obligations. Attention has already been called to Eduardo Espinola's extensive treatise on the civil code, of which the second volume deals with obligations (supra, p. 252).

\section{CONTRACTS}

Carvalho de Mendonça reserved for another work his treatment of the special kinds of obligations and contracts. This he published in $19 \mathrm{II}^{1}$ in two volumes, and it constitutes the most exhaustive treatment of contracts published in Brazil.

An edition of the work of Professor Pacheco, ${ }^{2}$ the Portuguese jurist, on privileged creditors, discussed in title 9 of Book III, was published in a new edition in Rio de Janeiro in 1914. He deals with the institution of guaranty and privilege, its history, the nature and character of privilege, its application in the different classes under Portuguese law, its extinction, and its special application in cases of bankruptcy.

A work on non-contractual damages published in 1878 by Silva $\operatorname{Costa}^{3}$ is still regarded as useful.

Title 6 of Book III deals with obligations created by unilateral declaration of will and includes bonds and instruments of indebtedness to bearer. This subject has been treated in an exhaustive work published in 1898 by Inglez de Souza, ${ }^{4}$ which will be more fully described under the head of commercial law.

1 Carvalho de Mendonça, Manuel Ignacio: Contractos no direito civil brazileiro, . . . Rio de Janeiro, F. Alves \& Cia., Igrr. 2 v.

2 Pacheco, Antonio Faria Carneiro: Dos privilegios creditorios. 2d ed. Rio de Janeiro, J. Ribeiro dos Santos, r9r4. 300 p.

${ }^{3}$ Silva Costa, José de: Estudo theorico e pratico sobre a satisfacção do damno causado pelo delicto. $2 \mathrm{~d}$ ed. Rio de Janeiro, Typ. Perseverança, 1878 . $104 \mathrm{p}$.

4 Inglez de Souza, H.: Titulos ao portador no direito brazileiro. Rio de Janeiro, F. Alves, 1898 . $540 \mathrm{p}$. 
The law of succession, which to a large extent follows the Portuguese law, was sor.1ewhat amended by decree of December 31,1907 , regulating the devolution of property in case of succession $a b$ intestato, modifying the old Portuguese system. A surviving husband and wife can now inherit directly; formerly they could only inherit in default of descendants and ascendants, or collateral heirs to the tenth degree. Now there need only be default of descendants or ascendants. In the absence of a surviving spouse the collateral heirs are called to the sixth degree.

Two of the best works on the subject of succession are those by Clovis Bevilaqua ${ }^{1}$ and Lacerda de Almeida. The former has rearranged the classical Portuguese work of Gouvea Pinto. He deals first with the general theory of testamentary law; the transmission of inheritance and the principles of succession in private international law, and then in a special part deals with the particular institutions of succession-first, legitimate succession and the various classes of heirs; second, testamentary succession, including the whole subject of wills; and third, the division and distribution of the decedent's estate.

The other standard work, by Lacerda de Almeida, ${ }^{2}$ published in 1915 , deals principally with testamentary succession and constitutes a treatise on Book IV of the code.

The standard Portuguese work on succession was that of Gouvea Pinto, ${ }^{3}$ which was adapted to Brazilian conditions in an edition by Teixeira de Freitas in I88r." Another edition of the work by Macedo Soares is not so good. A work on corporate succession by Samuel Martins will be referred to under the head of corporations.

A classic Portuguese work on the distribution, inventory, and partition of estates by Alberto Menezes was published in

${ }^{1}$ Bevilaqua, Clovis: Direito das successões. Bahia, Magalhães, I899. $463 \mathrm{p}$.

${ }^{2}$ Lacerda de Almeida, Francisco de Paula: Successões; exposição doutrinaria desta parte do direito civil . . . Rio de Janeiro, Typ. "R. dos tribunaes," I915. 525 p.

${ }^{3}$ Gouvea Pinto, Antonio J. de: Tratado dos testamentos e successões, accommodado ao foro do Brazil até o anno de 1880 por Augusto Teixeira de Freitas. Rio de Janeiro, Garnier, I88ז. 534 p. 
a seventh edition in 1914 by Tavares Bastos. ${ }^{1}$ A complete manual and form book relating to the distribution and inventory of estates, including the procedure in the various states of the Republic, and doctrinal discussions, judicial decisions, and administrative circulars and orders has been edited by Tavares Bastos ${ }^{2}$ in four volumes.

Decree $2800^{3}$ of January 19,1898 , fixed the inheritance and transfer tax in Brazil.

\section{LITERARY AND INDUSTRIAL PROPERTY}

COPYRIGHT.-Brazil has been backward in its copyright legislation, particularly in the protection of the works of nonresident foreigners. The constitution had extended protection to Brazilian and foreign authors in Brazil and this provision was carried into effect by law 496 of August I, I 898 . The protection of foreigners was subject to diplomatic reciprocity. By law 2577 of January 17, I912, protection was extended to scientific, literary, and artistic works published in foreign countries, provided the nation of the foreign author had concluded an international treaty with Brazil, or had adhered to a general international convention with Brazil. Treaties were concluded with Portugal and with France (Dec. 15, 1913), the two countries whose works most needed protection in Brazil. On January 7, 1913, the legislature gave its authorization for Brazilian adherence to the Berne Convention as revised at Berlin. The Pan American Convention was approved by decree 2393 of December 31, 1910, and promulgated and ratified by decree 9190 of September 6, I9II. Sections $1346-1362$ of the newly enacted civil code contain numerous rules on the rights and duties of authors and publishers of literary and dramatic works. The penal code of r 830 as well as the new code of 1890 (art. 342-350) provide for punishment of infringement of copyright.

1 Menezes, Alberto Carlos de: Practica dos inventarios, partilhas e contas. 7th ed. by Jose Tavares Bastos. Rio de Janeiro, J. Ribeiro doș Santos, rgr4. $742 \mathrm{p}$.

3 Tavares Bastos, José: Tratado formulario e pratico dos inventarios na Republica. Rio de Janeiro, J. Ribeiro dos Santos [rgI2?]. 4 v.

- Regulamento do imposto de transmissão de propriedade a que se refere o decreto n. 2800 desta data. Rio de Janeiro, Imprensa nacional, I898. $16 \mathrm{p}$. 
Law 496 of August I, 1898 , and the instructions of June I , I 901 , together with the legislative decree of December 20, I907; and its instructions of June $\mathrm{I}, \mathrm{1908}$, providing for the deposit of a copy of every Brazilian work in the National Library was published in a pamphlet by the National Library in I9I.$^{1}$

An account of the copyright legislation and situation in Brazil is given by Rodrigo Octavio in a note published in 9 Revue de droit international privé (1913), pages 663-667.

The copyright literature is negligible. The only books of importance are a monograph by Professor Samuel Martins, ${ }^{2}$ of Recife, presenting the theory of copyright protection, its history and the Brazilian legislation, and a recent work by Armando Vidal, ${ }^{3}$ discussing the subject in the light of the treaty with France of December, 1913, and the provisions of the new civil code.

PATENTS. - The protection of inventions by patent in Brazil is governed by law No. 3129 of October 14, 1882, and decree No. 8820 of December 30, 1882 . Decree No. 8136 of August 4 , 1910, repealed article 57 of decree No. 8820 of 1882 , providing that once an action for annulment has been brought in certain cases the protection afforded by the patent is suspended until the decision in the case. By decree No. I 483 of February 10, 1915, in execution of article 79, section to of law No. 2924 of January 5 , 1915, the terms for filing are provisionally extended by reason of the interruption of com: munication incidental to the European War.

Law 3129 of October 14, 1882, is translated into English at pages $27 \mathrm{I}-292$ of the compilation of "Patent and trade-mark laws of the Spanish American Republics, Brazil and the Republic of Haiti," "4 published in 1904 by the Pan American

1 Regulamento, decreto $n .8,835$, de Ir de julho de rgri. Direitos autoraes: lei n. 496 , de I de agosto de 1898 , e instrucções de I I de junho de rgor. Remissa de obras impressas: decreto legislativo ñ. I825, de 20 de dezembro de 1907 , e instrucçóes de I de junho de 1908 . Rio de Janeiro, Imprensa Nacional, IgrI. $3^{8} \mathrm{p}$.

${ }^{2}$ Martins, Samuel: Direito autoral; seu conceito, sua historia e sua legislação entre nos. Recife, Lib. Franceza, I906. I2I p.

3 Vidal, Armando: Propriedade litteraria, a convenção litterarià com a Franca de accordo com o projecto do codigo civil. Rio de Janeiro, J. Ribeiro dos Santos, I9I5. $200 \mathrm{p}$.

- Patent and trade-mark laws of the Spanish-American Republics, Brazil and the Republic of Haiti. Translated into English. Washington, G. P. O., I904. 343 p. 
Union. Decree 8820 of December 30 , 1882 , in regulation of the law, is paraphrased in the Brazilian Year Book for 1909 , pages $7-8$.

The patent laws of Brazil are discussed in the compilations of patent laws of the world edited by Carpmael, ${ }^{1}$ Thompson, ${ }^{2}$ Greeley, ${ }^{3}$ and Abbott. ${ }^{4}$

Brazil has adhered to the international patent conventions of 1883 and its subsequent amendments, and by decree of September 23, 1914, approved the several acts of the international convention for the protection of industrial property held at Washington in May, I9II. It is also a party to the Pan American Convention ${ }^{5}$ concluded at Buenos Aires in 1910, which has been ratified by the United States.

A recent work in French by G. A. Bailly ${ }^{6}$ deals with the protection of inventions in Brazil. The Brazilian literature on patents is very scarce. A recent work by Nogueira and Fischer, ${ }^{7}$ who have also collaborated in an excellent work on trade-marks, appears to be one of the best on the subject.

${ }^{1}$ Carpmael, Alfred: Patent laws of the world, collected, edited, and indexed. By Alfred Carpmael ... a and Edward Carpmael . . . 2d ed. rev. London, W. Clowes \& Sons, I889. 64I p.

2 Thompson, William Phillips: Handbook of patent law of all countries. r $3^{\text {th }}$ ed. completely rev. March, 1905. Iondon, Stevens and Sons, 1905. 2 I I p.

${ }^{3}$ Greeley, Arthur Philip: Foreign patent and trade-mark laws; a comparative study with tabular statements of essential features of such laws, together with the text of the International convention for the protection of industrial property, concluded at Paris, March 20, $188_{3}$, as amended, with notes thereon, and other conventions and treaties of the United States relating to patents and trade-marks. . . Washington, D. C., J. Byrne \& Co., I899. 3 I9 p.

4 Abbott, Benjamin Vaughan: The patent laws of all nations. Compiled and annotated by Benjamin Vaughan Abbott. Washington, C. R. Brodix, x886. 2 v.

${ }^{5}$ Convention between the United States and other powers for the protection of inventions, patents, designs, and industrial models, signed at Buenos Aires, Aug. 20, I910. Washington, G. P. O., I914. Treaty series No. 595. Ratified by the President, Mar. 2I, I9II; proclaimed July 29, 19I4.

- Bailly, G. A.: Protection des inventions au Brésil. Paris, Tours, Imp. Deslis frères \& Cie; Paris, edité por Escriptorio de informações do Brasil, I9r5. 304 p. 2d ed., Giard \& Brière, I9I5.

' Nogueira Almeida, J. L. de e Fischer, Jr., Guilherme: Privilegios e patentes de invencão. São Paulo, I9I5. 
TRADE-MARKs.-Trade-mark protection in Brazil dates from 1875 . The law now in force is to be found in decree No, 3346 of October 14, 1887, and law No. 1236 of September 24, 1904, with its regulating decree No. 5424 of January 10, 1905. Decree No. 2747 of December 19, 1897, as amended by decree $5_{\text {I I } 4}$ of January I2, I904, approved the regulation concerning the international registration of trade-marks adopted at Madrid, April 14, I891. By law No. 2085 of August 6, I 909, international trade-marks registered at the International Bureau at Berne by citizens of countries which adhered to the Madrid arrangement of $189 \mathrm{I}$ were relieved from the necessity of publication in the Diario Official, although appeal was possible from a decision admitting such mark to registration in Brazil. By decree No. 984 of January 9, 1903, Brazil approved and ratified the additional act of Brussels of December I4, 1900, and the additional act of Madrid also signed at Brussels concerning the international registration of trademarks. Persons entitled to the benefits of the convention enjoy priority of twelve months from the date of first foreign application for filing an application for patents in Brazil and a priority of four months for filing an application for the registration of trade-marks.

The law of October 14, 1887, with the regulation of December 31,1887 , is translated in the compilation of "Patent and trade-mark laws of the Spanish-American republics," etc., published by the Pan American Union. The law of September 24, 1904, which amended the law of October 14, 1887 and the important decree No. 5424 of January 10, 1905, are translated into English in the Brazilian Year Book (1908), pages 8-1o. The provisions of these laws and regulations are also summarized in Singer's work on the "Trade-mark laws of the world" (Chicago, 1913, pp. 87-93). The law of 1904 is also translated into English in the Bulletin of the International Bureau of American Republics, February, 1905, page 230, and in the Patent and Trade-mark Review, volume 3 (1905), page I I 43. The law of 1904 was also translated into French in 35 Annuaire de legislation comparée, pages $728-735$.

An excellent article on "The basis of the property right in trade-marks in Brazil" consisting of an analysis of the law 
of 1904 and its regulation was published by Layton B. Register in 63 University of Pennsylvania Law Review (1915), pages 876-892.

The best work on the law of 1887 is that of Visconde Ouro Preto, ${ }^{1}$ (Affonso Celso) but as this law has been greatly amended by the law of 1904, the practically useful books are those written subsequently to the new law. Among these the best is the work of Almeida Nogueira and G. Fischer, Jr.; ${ }^{2}$ it is a theoretical and practical treatise on trade-mark and tradename legislation, including the international treaties, with forms.

Another work of some importance is that of Antonio Bento de Faria, ${ }^{3}$ which was published in 1906 . Part I deals with the history of trade-marks and trade names, and Part II with national legislation. Comparative law is treated at some length. An appendix contains the international conventions to which Brazil is a party.

\section{COMMERCIAL LAW}

The ports of Brazil were opened to foreign commerce by royal decree of the Prince Regent on January 28, 1808, an act directly brought about by José da Silva Lisboa, later Visconde Cayrú. By decree of August 23 of that same year a commercial court was established in Rio de Janeiro and in the following year the court charged Lisboa, one of its members, with the mission of drafting a commercial code. With this the first step was taken toward the adoption of a com-

1 Ouro Preto, Affonso Celso de Assis Figueiredo, Visconde de: . . . Marcas industriaes e nome commercial; lei n. 3346 de 14 de outubro de 1887 e regulamento n. 9828 de $3 \mathrm{I}$ de dezembro de $\mathrm{I} 887 \ldots$. Rio de Janeiro, Imprensa nacional, B. L. Garnier, I888. $420 \mathrm{p}$.

${ }^{2}$ Nogueira Almeida, J. I. de e Fischer, Jr., G.: Marcas industriaes c nome commercial. Tratado thcorico e pratico segundo a jurisprudencia dos tribunaes, legislação patria e convenções diplomaticas referentes ao assumpto, e de formularios e modelos. São Paulo, Hermies e Irmãos, Igro. $2 \mathrm{v}$.

${ }^{3}$ Bento de Faria, Antonio: Das marcas de fabrica e de commercio e do nome commercial (decreto n. 3,346 de 14 de outubro de 1887 e lei n. I, 236 de 24 de setembro de I904) . . . Rio de Janeiro, J. Ribeiro dos Santos, 1906. $476 \mathrm{p}$. 
mercial code, which was not accomplished until 1850 . Silva Lisboa, one of the classic jurists of Brazil, prepared his Regras da Praşa or bases of commercial rules in conformity with the new codes of commerce and the legislation of the country, which was printed in 1832 and has been republished in various editions since then.

\section{COMMERCIAL CODE}

By law of October 20,1823 , it was provided that the Portuguese law of August 18, 1769, which provided for the observance of commercial and maritime customs as subsidiary law, the laws of the civilized nations of Europe and the French code of commerce, should be observed in Brazil. As this collection of law was eminently unsatisfactory, the permanent ${ }^{*}$ regency established during the minority of Pedro II took the first effective step in 1833 for the codification of the commercial law. It is unnecessary to dwell upon the various commissions which were appointed to bring the code to fruition. Suffice it to recall that José Clemente Pereira, the chairman of the commission and one of the principal draftsmen of the code, is to be regarded as the moving spirit in the work. Numerous sessions were held in both Senate and House until in 1850 agreement upon all amendments was obtained and the code published and promulgated as law 556 of June 25, 1850. This code, although still in force, has been amended on numerous occasions, and movements for its entire revision have received inspiration from the excellent work done on the codification of the civil law and from the valuable drafts submitted recently by Professor Inglez de Souza. It is considered certain that a new code will be adopted within the next few years.

The Brazilian code of 1850 was the first original codification in America, for the Haitian code of 1826 and the San Domingo code of 1845 were reproductions of the French code, and the Bolivian and Paraguayan codes of 1834 and the Costa Rican code of 1850 were reproductions of the Spanish code.

The Brazilian commercial code of 1850 has as its principal sources the French code of 1810 , the Spanish code of 1829 , the Portuguese code of 1833 , and the Dutch code of 1838 with notable changes induced by local conditions. 
Regulation No. 737 of November 25, 1850, published in execution of article 27 of the final single title of the commercial code, providing for procedure, is another monument to Brazilian codification. This code of commercial procedure was by decree No. 763 of September 18, 1890, ordered to be observed in civil causes in general, and decree No. 848 of October II, I890, organizing the federal judiciary and procedure, reproduced most of its provisions. It still governs civil and commercial procedure in the Federal District and in many states, with slight modifications.

The code of commerce of 1850 was adopted while the civil law was still in a confused and disorganized state. As early as I 867 Teixeira de Freitas, the pioneer draftsman of the civil code, had proposed the unification of civil and commercial law into a code of private law for, as is well known, the provisions of the civil code and commercial code supplement each other in many rules governing contractual relations. The Italian Vivanti is also a proponent of this project. In recent years, when the adoption of the civil code was assured, attention has again been directed to this subject and particularly because the commercial law, although codified in 1850 , had been so frequently amended and responded so little to the needs of the time that a revision seemed essential.

Congress, therefore, by law No. 2379 of January 4, I9II, authorized the government to prepare a new code. This work was entrusted to Professor Inglez de Souza, of Rio de Janeiro, one of the country's eminent specialists on commercial law. In three volumes which he submitted in response to his commission, ${ }^{1}$ he publishes, in the first, a long explanatory report on the work of codification and on the amendments which he submitted. In volume 2 he submits a revised commercial code of 1,644 articles, divided into six books, namely, persons, things, obligations and contracts, navigation, bankruptcy, and registration. Volume 3 of the work consists of a draft of amendments designed to convert the commercial code into a code of private law. Up to the present time, Congressional action does not appear to have been taken upon the drafts submitted.

${ }^{1}$ Inglez de Souza, Herculano Marcos: Projecto de codigo commercial. Rio de Janeiro, Impr. Nacional, I9I3. $3 \mathrm{v}$. 


\section{CONTENTS}

The commercial code is divided into three parts. Part I, dealing with commerce in general, is divided into 18 titles dealing, first, with merchants; second, exchanges; third, auxiliary persons engaged in commerce, such as brokers, agents, factors, warehousemen, and commission men; fourth, brokers; fifth, contracts and commercial obligations; sixth, commercial agency; seventh, commission merchants; eighth, commercial purchase and sale; ninth, commercial barter; tenth, commercial hiring and letting; eleventh, loan and interest; twelfth, guaranty and suretyship and letters of credit; thirteenth, mercantile mortgage and pledge; fourteenth, mercantile deposit; fifteenth, corporations and commercial associations, a title which has been greatly revised by subsequent laws; sixteenth, promissory notes, negotiable instruments and bills of exchange, a title which has been entirely replaced; seventeenth, the extinction of commercial obligations; and eighteenth, prescription.

\section{SUPPLEMENTARY LEGISLATION}

These sactions have been amended or supplemented by the following acts, among others:

Decree 857 of August 9, 1902, and article 188 of the bankruptcy law of 1908 on execution or bankruptcy sales by auctioneers;

Decree IIO2 of November 21, 1903, on warehouses, which repealed laws of $1869,1870,1897,1898$, I90r;

Decree $165 \mathrm{~A}$ of January 17,1890 , on bills to order payable in merchandise;

Law 2044 of December 31, 1908 on bills of exchange, which repealed the entire title 16 of the code with parts of title 7 of regulation 737 of 1850 , namely, articles $370-389$ and decree 2591 of August 7, 1912, on cheques;

Decree 5122 of February 26, 1904, regulating the junta commercial in the Federal District, reorganized by decree 8247 of September 22, 1910;

Decree 3259 of April II, 1899, on consuls; and decree I103 of November 21, 1903, on consular invoices;

Law 354 of December 16, r895, on government bond brokers in the Federal District as amended by law 556 of January 9, 1899, with its important regulation, decree 2475 of March I3, 
1899. Ship brokers and commercial brokers are governed by decree 806 of July 26,1851 , which governed in Rio de Janeiro and was extended to other provinces by later decrees. Decree 2813 of February 7,1898 , organized the board (junta) of brokers in the Federal Capital, created by article 34 of decree 806, above mentioned;

The register of commercial names and firms is governed by decree 916 of October 24, I890;

Law 1425 B of November 28 , I 905 , providing for rules governing the seizure of merchandise with a false indication of origin;

Decree 5072 of December 12, 1903, on insurance companies;

Decree Í 4 of January I 7,1890 , which, by article 43 , repealed law 3 I 50 of November 4,1882 , on stock corporations, the whole subject being now governed by decree 434 of July 4 , I 891 , with its regulating decree 603 of October 20,1891 , as amended by decree 698 of December 22, 1891;

Decree $177 \mathrm{~A}$ of September 15,1893 , on the issuance of debentures by corporations;

Law 1637 of January 5, 1907, on cooperative societies and professional unions and organizations;

Law $149 \mathrm{~B}$ of July 20,1893 , on bonds and instruments to bearer.

Part II of the Commercial Code deals with maritime commerce and hereunder particularly of ships, their owners, masters of vessels, pilots, the rights and obligations of the crew, freight, charter parties and bills of lading, bottomry loans, marine insurance, shipwreck and salvage, forced entrance by stress of weather, collisions, abandonment, and average, general and particular.

Part III of the code deals with bankruptcy which, with certain other laws enacted thereafter, was entirely replaced by law 2024 of December 17, 1908. Appended to Part III of the code is a single title dealing with the administration of justice in commercial matters, in execution of article 27 of which the important decree 737 of 1850 was enacted.

\section{LITERATURE}

The text of the code, with most of the supplementary and amending statutes up to 1903 , are to be found in the leis usuaes $71624^{\circ}-17-18$ 
of Tarquino and Montenegro. (Supra, p. 218.). Anothèr edition of the code with some of its amending statutes is contained in the collection of "Commercial laws of the world". in Portuguese and in German, ${ }^{1}$ the English edition for Brazil not yet having been published. An English translation by Spence (infra, p. 312) was published in 1866.

One of the classic editions of the code is that of Augusto Teixeira de Freitas, ${ }^{2}$ published in two volumes in $1878-79$. After printing the code he appends notes on legislation, doctrine, and decisions under each article, giving in an appendix various laws and regulations affecting commerce and commercial procedure.

Among the commentaries on the commercial code, the best is generally believed to be that of Salustiano Orlando, ${ }^{3}$ first published in 1863. The important notes and annotations of the author have been commented upon in a work written in I 87 I by Annibal Ribeiro. ${ }^{4}$ A seventh edition of Orlando's commentary, in two very large volumes, was published in I912, with some additional annotations by Alencaștro Autran. It includes concordances to foreign codes and notes on comparative legislation and the decisions of Brazilian courts. Volume 2 is an annotated edition of the code of commercial procedure included in decree 737 of November 25,1850 , with

${ }^{1} \mathrm{O}$ Direito commercial, cambial, maritimo e as leis de fallenciá do Brazil, tratado pelo Dr. Jur. Rodrigo Octavio de Langgaard Menezes . . . tr. por Richard Bartolomäus ... Das handelsrecht, wechselrecht, seerecht und konkursrecht Brasiliens ... Separatausgabe der deutschen ausgabe, signatur D. Berlin, R. v. Decker, 1908. 287 p.

${ }^{2}$ Additamentos ao codigo do commercio .... Rio de Janeiro, Typographia Perseverança, 1878-79. $2 \mathrm{v}$.

${ }^{3}$ Codigo commercial do Brazil annotado com toda a legislação do paiz que lhe é referente ... pelo conselheiro desembargador aposentado Salustiano Orlando de Araujo Costa . . . 7.ed. cuidadosamente rev., mais cor. e. consideravelmente augm. e contendo em supplemento a Lei de fallencia ( 7 de dezembro de I908) a letra de cambio e nota promissoria (3I de dezembro de I908); annotadas por M. G. de Alencastro Autran ... Rio de Janeiro, etc., F. Alves, rgr2. $2 \mathrm{v}$.

4 Ribeiro, Annibal André: Bréves observações sobre as annotações do desembargador Salustiano Orlando de Araujo Costa ao codigo commercial do Imperio do Brazil ... precedido de um prefacio do cons $^{\circ}$. Zacarias de Góes e Vasconcellos. Rio de Janeiro, I871. 
a reprint practically unannotated of all the subsequent laws and decrees affecting commercial law. The voluminous seventh edition is not so highly regarded as the sixth edition of 1906 .

Another very extensive commentary on the commercial code and the other commercial laws in force is that of Antonio Bento de Faria, ${ }^{1}$ published in a second edition in 1912 . It contains voluminous notes to the original code of $185^{\circ}$ and to the code of procedure of the same year, with notes on comparative law, citations to the opinions of foreign jurists and texts of codes, and some annotations of court decisions. The appendix containing the code of procedure with supplementary laws is not nearly so thoroughly annotated as the original code.

An important commentary on the code was published in 1898 in a second edition by Didimo da Veiga. ${ }^{2}$ A dictionary of Brazilian commercial law, reproducing the text of the code and related laws, was published in Lisbon in two volumes in 1892 by A. de Souza Pinto. ${ }^{3}$

Undoubtedly the best treatise on Brazilian commercial law is that of José X. Carvalho de Mendonça, which is not yet completed. Two volumes were published in 19ro-I I. In his introduction he deals with the concept of commercial law, primary and subsidiary sources of the code, the operation of commercial law in time and space, the interpretation of commercial law, the influence of comparative law, the commercial register and junta commercial, and a brief bibli-

' Codigo commercial brazileiro annotado de accordo com a doutrina, a legislação e a jurisprudencia nacional e estrangeira, e os principios e regras do direito civil, seguido de um appendice contendo o regulamento n. 737 de 1850 , e todas as leis commerciaes em vigor, igualmente annotadas por Antonio Bento de Faria . . . 2. ed. Rio de Janeiro, J. Ribeiro dos Santos, I912. 1704 p.

2 Veiga, Didimo A. da: Codigo commercial commentado e posto ao par da doutrina, da legislação e jurisprudencia modernas. and ed. Rio de Janeiro, 1898-190r. $2 \mathrm{v}$.

${ }^{3}$ Souza Pinto, A. de: Diccionario da legislação commercial brazileira. Lisboa, I892. $2 \mathrm{~V}$.

- Carvalho de Mendonça, José Xavier: Tratado de direito commercial brazileiro . . . São Paulo, Cardozo filho \& Comp., rg10-r1. 2 v. 
ography. Book I deals with acts of commerce, and Book II with merchants in general and the persons engaged in commerce. The whole is treated from the point of view of doctrine and comparative law. It is expected that other volumes will be published.

Another excellent treatise is that of Professor Inglez de Souza, ${ }^{1}$ consisting of a revision of lectures delivered at the faculty of law at Rio de Janeiro, transcribed by Alberto Biolchini. It is a doctrinal treatise on the topics of the commercial code, with a historical introduction.

A useful work was published in 1909 by Judge Vieira Ferreira. ${ }^{2}$ It is a draft of a commercial code coordinated with the draft of the civil code as approved by the Chamber of Deputies. It revises the commercial code with respect to the rules of the civil code and differentiates and coordinates the rules of the two codes.

The general works on commercial law should not be left without mention of the classic treatise of Silva Lisboa ${ }^{3}$ on the principles of commercial law, edited and exhaustively annotated in a sixth edition by the learned Candido Mendes de Almeida. It includes various monographs of Silva Lisboa on the rules of trade, commerce, and insurance.

A collection of decisions in commercial cases from 1850 to 1869 was published in 1870 by Francisco Pinheiro. ${ }^{4}$ Subsequent decisions are to be found in the periodicals and other works mentioned in the section on court reports.

${ }^{1}$ Inglez de Souza, Herculano Marcos: Direito commercial. 2nd ed. Rio de Janeiro, F. Alves, 1910. $348 \mathrm{p}$.

${ }^{2}$ Vieira Ferreira: Esboço de um codigo commercial brasileiro coordenado ao projecto de codigo civil approvado pela Camara dos Deputados. Rio de Janeiro, I909.

${ }^{3}$ Silva Lisboa, José da: Principios de direito mercantil e leis de marinha por José da Silva Lisboa (Visconde de Cayrú). 6th ed., accrescentada com os opusculos do mesmo auctor intitulados Regras da Praça e reflexões sobre o commercio dos seguros, além da legislação portugueza anterior á Independencia do Imperio.e brazileira até á época presente addicionadas cada um dos tratados, por Candido Mendes de Almeida. Rio de Janeiro, I874. 2 v.

4 Pinheiro, Francisco Baptista Marques: Jurisprudencia commercial. Collecção de todas as sentenças proferidas em gráu de revista pelo Supremo Tribunal de Justiça e accordams revisores dos tribunaes de commercio. Rio de Janeiro, I870. $300 \mathrm{p}$. 


\section{REGISTRATION OF FIRMS}

The registration of firms was provided for by decree 916 of October 24 , 1890, a valuable study of which has been published in a monograph by José X. Carvalho de Mendonça. ${ }^{1}$ Under the auspices of the Commercial Department of the British Board of Trade a report was prepared in I9ro containing particulars of the laws on the registration of firms in foreign countries (Cd. 4420). It includes a brief report on Brazil.

The necessary mercantile books which a merchant must keep are covered by articles 10-25 of the code. A special commentary on these articles was published in 1906 by Carvalho de Mendonça. ${ }^{2}$

\section{ACTS OF COMMERCE}

An excellent work on the classification of acts of commerce has recently been published in Bahia by Descartes de Magalhães, ${ }^{3}$ a work presented to the faculty of law to obtain the title of professor of commercial law. The study is divided into three chapters, first, the economic and legal concepts of commerce, with a discussion of the theories concerning acts of commerce; second, the character of commerce and its legal difficulties; and third, the general principles relating to acts of commerce and their systematic classification in Brazilian law.

\section{CONTRACTS}

A classic work cn contracts and commercial obligations was published in $187 \mathrm{I}$ by Liberato Baruoso, ${ }^{4}$ and another equally famous work was published in $\mathrm{I} 86 \mathrm{I}$ by Silva Ramos. ${ }^{5}$

1 Carvalho de Mendonça, José Xavier: Das firmas ou razões commerciaes. Decr. n. 9 I6 de 24 de outubro de 1890 . Estudo theorico-pratico. São Paulo, I909.

2 Carvalho de Mendonça, José Xavier: Dos livros dos commerciantes. (C. Com., art. 10-20; 23-25.) Estudo theorico-pratico. São Paulo, Igo6.

${ }^{3}$ Descartes de Magalhães: Noção economico-juridica da commercio. Clássificação dos actos de commercio. Bahia, I9I5.

4 Baruoso, Liberato: Contractos e obrigações mercantis. Rio de Janciro, I 87 I.

${ }^{5}$ Silva Ramos, J. J.: Apontamentos juridicos sobre o contractos. Rio de Janeiro, ז86r. 383 p. 
The contract of account current, which is barely mentioned in the Brazilian commercial code has, nevertheless, come before the courts on numerous occasions. Two important studies on this contract have been published, one by Paulo de Lacerda, ${ }^{1}$ who deals with the commercial books, a historical sketch of the account current, the nature and proof of the contract and its analysis, its exercise and effects, and its liquidition and termination, with important references to comparative legislation; and a somewhat earlier study on the same subject by Silva Costa. ${ }^{2}$

The contract of opening credit with a bank by its depositors and customers, which is not well considered in any code of South America, has been treated by Paulo de Lacerda ${ }^{3}$ in a monograph published in 1904. He resorts principally to the important studies on the subject by French, Belgian, Italian, and German jurists, and the decisions of the courts.

\section{WARRANTS}

Warrants or warehouse receipts are now governed by legislative decree 1102 of November 21, 1903,.which is translated in the appendix of the edition of the code published in the "Commercial laws of the world" (German translation). Agricultural warrants are still very limited in Brazil. The French legislation on the nature of the warrant and its legal effects as compared with the Brazilian legislation, with the draft of a law for Brazil, has been dealt with in a recent work published by Armando Vidal. ${ }^{4}$

The law governing the pledge of movables, including cattle, trees cut, and other agricultural personal property, with the negotiable paper issued on the deposit of merchandise, was covered by a special statute, decree $165 \mathrm{~A}$ of January $17, \mathrm{i} 890$, printed in the appendix to the German translation of the "Commercial laws of the world." The subject has been dis-

${ }^{1}$ I acerda, Paulo de: Estudos sobre o contracto de conta-corrente. . . . . Sāo Paulo, Typ. Hennies Irmãos, 1901. 321 p.

${ }^{2}$ Silva Costa, José da: Contracto de conta-corrente. Rio de Janeiro [1883].

${ }^{3}$ Lacerda, Paulo de: . . Do contracto de abertura de credito. São Paulo, N. Falcone \& Cia. [pref. I904]. 463 p.

4 Vidal, Armando: Warrants agricolas. Rio de Janeiro, 1915. 
cussed in an excellent work of Visconde de Ouro Preto ${ }^{1}$ (Affonso Celso), published in 1898 .

\section{BILLS OF EXCHANGE}

Decree 2044 of December 30, 1908, has completely revised the Brazilian law on bills of exchange and promissory notes. It resembles closely the modern German law, originally the work of the Zollverein, which, with the "Numberg Novels," and as consolidated in $\mathrm{r} 869$, has commended itself to the scientific and commercial world and to the modern legislator as the bést of modern codes. It in turn furnished the basis for the draft of an international code on bills of exchange adopted at the Hague Conferences in rgro and r9r2. The Brazilian law of 1908 has given obligatory force to the bill of exchange as a contract requiring no proof of consideration, making it an authentic title of indebtedness of the persons signatory, notwithstanding the forgery of others, and it has provided a summary action for its enforcement. It has suppressed the signed invoice contas assignadas and the letra de terra, the bill drawn and accepted in the same place. It has eliminated the question of the provision of funds. It has extended endorsement to all commercial bills, even those which do not contain the clause "to order."

The law of 1908 is translated into French in 38 Annuaire de législation comparée, pages 823-837 and in 2 Revue de l'institut de droit comparé, pages 195-210. It is summarized also by Rodrigo Octavio in the Nouvelle Revue de droit international privé (1910), page 4.

Practically, the draftsman of the Brazilian bills of exchange act is Judge José A. Saraiva of the Supreme Court of Minas Geraes and professor of commercial law at Bello Horizonte. He published in 1905-1908 two volumes of a standard treatise on the Brazilian law of bills of exchange, ${ }^{2}$ dealing with the subject historically, comparatively, and from the point of view of the doctrines of foreign writers. Throughout he recommends

1 Ouro Preto, Visconde de: Credito movel pelo penhor e o bilhete de mercadorias. Rio de Janeiro, $\mathrm{I} 898.4 \mathrm{r} 3 \mathrm{p}$.

${ }^{2}$ Saraiva, José A.: Direito cambial brasileiro; estudo theorico-pratico ... Bello Horizonte; Impr. official do estado de Minas Geraes, 1905-8. $2 \mathrm{v}$. 
reforms in the Brazilian law. Volume II is a commentary of articles 354-39r of the commercial code, which have now been entirely replaced by the law he advocated. In I912 Dr. Saraiva ${ }^{1}$ published his extensive commentary on the new law of 1908 , in which he presents the origin and evolution of bills of exchange, the legal concept of the contract, and an exhaustive commentary on the Brazilian law elucidated throughout by comparative law. An appendix contains the Hague convention.

The law of 1908 was not altogether clear. Paulo de Lacerda, ${ }^{2}$ therefore, published a monograph explaining and applying the doctrines of the law and abstaining from all theoretical discussion. His work was first published in 1912, but became so rapidly exhausted that a second edition was issued in I913. Professor João Arruda, ${ }^{3}$ of São Paulo, has also recently published an excellent commentary in two volumes on the act of 1908 .

The Brazilian representative at the bills of exchange conference at The Hague in rgro was Dr. Rodrigo Octavio, a versatile and able jurist. He published his report ${ }^{4}$ to the Brazilian government in I9II. It contains an excellent study on the uniformity of bills of exchange legislation and the history of the efforts to that end, the work of the Hague Conference of I9ro, a study of the draft code adopted by the Conference, a report on the Brazilian law, and a comparison of the Brazilian law with the draft of the Conference.

On August 7, 191 2, by decree 2591, a new statute on cheques was enacted, modifying the law of August 22, I 860, the first Brazilian law on cheques. The law of 1912 is described and translated by Rodrigo Octavio in 5 Revue de l'institut de

'Saraiva, José A.: A cambial. Rio de Janeiro, Typ. do "Jornal do commercio" de Rodrigues, I9I2. $772 \mathrm{p}$.

${ }^{2}$ Lacerda, Paulo de: A cambial no direito brasileiro. 2nd ed. Rio de Janeiro, J. Ribeiro dos Santos, rgr3. 49r p.

${ }^{3}$ Arruda, João: Decreto No. 2044 de $3^{1}$ de dezembro de 1908 annotado. São Paulo, I9I4-I5. $2 \mathrm{~V}$.

- Octavio, Rodrigo: Letra de cambio e nota promissoria. Relatorio apresentado ao Ministro das relações exteriores pelo . . . Dr. Rodrigo Octavio de Langgaard Menezes. Rio de Janeiro, Impr. Nacional, I9II. $185 \mathrm{p}$. 
droit comparé (1912), pages 549-553, and is discussed by that jurist in a commentary on the law published in $1913 .^{1}$

\section{CORPORATIONS}

Stock corporations are governed by decree 434 of July 4 , I 89I, consolidating the legislative acts and regulations enacted theretofore, particularly law 3I50 of November 4, I882, as amended by decree 164 of January 17, 1890. Decree 434 with certain amendments is translated in the Brazilian Year Book for 1909, pages 568-681. The regulations concerning debentures issued by corporations are provided for by decree I 77 A of September 15, r 893, which, with its amendment, is translated in the Brazilian Year Book for 1909 , pages $68 \mathrm{r}-683$.

An extensive commentary on limited partnerships and limited liability companies, as dealt with in articles $31 \mathrm{I}-314$ of the commercial code, was published in 1884 by Francisco da Rocha. ${ }^{2}$ It includes a historical sketch of companies and partnerships, especially limited partnerships, a resume of the provisions of the code on partnerships and companies, with their differences, extensive commentaries on the code sections, and excerpts from foreign legislation.

The same author published in 1885 a work on limited partnerships with share capital ${ }^{3}$ and particularly a commentary on those articles of law 3 150 of November 4,1882 and the regulating decree 8821 of December 30,1882 , which relate to limited companies. A learned commentary on the law of I 882 was that of Didimo de Veiga, ${ }^{4}$ published in 1888 .

Among the modern works the best is the commentary of

${ }^{1}$ Octavio, Rodrigo: Do cheque; sua crigem, funcção economica e regulamentação. Rio de Janeiro, Alves, 1913. 216 p.

${ }^{2}$ Rocha, Francisco José da: Sociedades em commandita segundo o codigo commercial do imperio do Brazil . . Rio de Janeiro, B. L. Garnier, 1884. $576 \mathrm{p}$.

${ }^{3}$ Rocha, Francisco José da: Commandita por acções; commentario aos artigos da lei n. 3150 de 4 de novembro de 1882 e aos artigos do decreto $\mathrm{n} .882$ I de 30 dezembro de 1882 relativos ás sociedades em commandita . . . Rio de Janeiro, B. L. Garnier, r885. 680 p.

- Veiga, Didimo A. da: As sociedades anonimas. Rio de Janeiro, Impr. Nacional, 1888 . 
Spencer Vampré, ${ }^{1}$ published in São Paulo in 1914. It is an exhaustive commentary, with references to comparative law and the application of the statutes on stock companies by the courts.

A recent work by Salvador Moniz ${ }^{2}$ is also of interest. It deals with the constitution of companies, their nullity, founders, combination and incorporation of companies, foreign corporations, capital stock and its legal effects, bonds and their issue, managers, meetings of stockholders, and the liquidation of companies.

A study on stock corporations, particularly the defects in their organization, was published in $\mathrm{I} 893$ by Ruy Barbosa and Garça Aranha. ${ }^{3}$ An article on foreign corporations in Brazilian law was published by Rodrigo Octavio in I Questions pratiques de droit international privé, pages 353-360.

The succession of corporations and business associations was discussed in a monograph by Samuel Martins, ${ }^{4}$ judge and professor at Recife, published in I9I4.

\section{BONDS}

Bonds and commercial documents to bearer were the subject of a standard work published by Professor Inglez de Souza ${ }^{-5}$ in I 898. Part I deals with bonds and instruments of indebtedness to bearer, their issue and emission, their legal nature and revindication. Part II deals with the different kinds of such instruments-first, public bonds, and, second, private bills, orders, and documents, including debentures, mortgages and pledge certificates, bank books, cheques and unliquidated certificates, such as shares of stock, warrants, bills of lading, invoices, theater and passage tickets, etc.

The reclaiming of documents to bearer was the subject of a notable article by A. J. Macedo Soares ${ }^{\circ}$ published in $O$ Direito, volume 55 .

1 Spencer Vampré: Das sociedades anonymas (Decr. 434 de jullho de I89r). São Paulo, Pocai-Weiss, I914. 675 p.

${ }^{2}$ Moniz, Salvador: Sociedades anonymas, prefaciado pelo $\mathrm{Dr}$. Clovis Bevilaqua. "Rio de Janeiro, Francisco Alves \& Co., I9I4. 387 p.

3 Barbosa, Ruy \& Garça Aranha: Sociedades anonymas. Vicios na sua organisação. Rio de Janeiro, 1893 .

4 Martins, Samuel: Successões commerciaes. Recife, I914.

5 Inglez de Souza, H.: Titulos ao portador no direito brazileiro. Rio de Janeiro, F. Alves, I8g8. $540 \mathrm{p}$.

${ }^{6}$ Macedo Soares, A. J.: Reivindicações dos titulos ao portador. 
The conversion of registered stock into stock to bearer was the subject of a monograph by Samuel Martins ${ }^{1}$ published in r9o9.

\section{INSURANCE}

Life insurance companies, governed by law 294 of September 5,1895 , and foreign insurance companies under decree 2153 of November I, 1895, with decree 2769 of December 28 , 1897 , on the taxation of policies, was the subject of an interesting monograph published in 1900 by Nogueira Itagyba. ${ }^{2}$ Silva Costa discussed marine and land insurance in his book published in 1883 (infra). The decree of $x 895$ proved so severe for foreign insurance companies that a number, including the New York Life and Equitable, left the country. The law regulating insurance companies is now governed by decree 5072 of December 12, 1903. Marine insurance will be considered under the head of maritime law in Part II of the code:

Prescription in commercial and civil law was the subject of a well-known Portuguese work by Almeida Oliveira, ${ }^{3}$ a posthumous work, published in a new edition, with particular reference to Brazilian legislation, in 19r4. It is regarded as a standard work.

A form book of commercial actions was published in 1909 by Cunha Salas. ${ }^{4}$ Some of the many published works of this kind will be mentioned in the section on civil procedure.

\section{MARITIME LAW}

Book II on maritime commerce has been treated in two works. The leading work on the subject is that of José da Silva Costa, ${ }^{5}$ professor at Rio de Janeiro. It is valuable also for its references to the comparative law of the countries

'Martins, Samuel: Conversão das acções nominativas em acções ao portador no direito commercial. Recife, Medeiros, I909. $117 \mathrm{p}$.

${ }^{2}$ Nogueira Itagyba, J.: Tratado sobre seguros de vida. . . . Rio de Janeiro, Companhia typ. do Brazil, I900. ${ }^{4} 8 \mathrm{p}$.

${ }^{3}$ Almeida Oliveira, Antonio de: A prescripção em direito commercial e civil. Lisboa, A. M. Teixeira, 1914. 339 p.

- Cunha Salas, José Roberto da: Formalario das acções commerciaes, contendo as formulas de todos os processos commerciaes, e annotadas. Buenos Aires, 1909 .

' Silva Costa, José da: Direito commercial maritimo. . . . 2. ed. Paris, Société générale d'impression, 1912. $2 \mathrm{v}$. 
of Western Europe. It is a systematic treatise dealing with commerce in general, the history of commerce, maritime law, its definition and relation to other branches of the law, the desirability of international agreement on its rules, ships, their nature and the legal relations arising out of them, their registration, their ownership, and the liability of owners, personnel, the transportation contract, freight and passenger, general and particular average, marine insurance, bottomry loans and maritime liens, with an appendix containing the rules of York, and model forms for general average. The work was first published in 1899 , with a second edition in 1912.

Professor João Candido Martins ${ }^{1}$ has recently published a text-book on maritime law dealing with the general topics discussed in the code.

A monograph on salvage from the point of view of comparative law was published in I910 by Professor Samuel Martins ${ }^{2}$ of Recife.

Marine insurance, including land insurance, has been discussed in a well-known work of Silva Costa, ${ }^{3}$ published in 1883 .

The rules concerning general average (arts. $76 \mathrm{I}-794$ of the code of 1850 ) are translated into English at pages 478-483 of Lowndes "The law of general average" (5th ed., London, Stevens and Sons, 1912) and in Gourlie's work on "General average," published in Philadelphia in $188 \mathrm{I}$.

The law governing coastwise navigation was completely revised by decree 10524 of October 23 , 1913, in execution of law 2543A of January 5, 1912. The law contains 204 articles. A useful work on the merchant marine of Brazil, ${ }^{4}$ with projects for its reform, was prepared in I gro in behalf of a special

1 Candido Martins, João: Direito commercial maritimo. Rio de Janeiro, I9r5.

${ }^{2}$ Martins, Samuel: Assistencia maritima. Recife, Imp. Industrial, r9ro. 1 r8 p.

${ }^{3}$ Silva Costa, José da: Seguros maritimos e terrestres. Rio de Janeiro, 1883 .

4 Costa, Affonso: A marinha mercante no Brasil; estudos, projectos e reforma. Rio de Janeiro, Officinas graphicas da Liga maritima brazileira, r9ro. $230 \mathrm{p}$. 
committee appointed by the chamber of deputies to form a plan for the reorganization of the Brazilian merchant marine.

\section{BANKRUPTCY}

Book III deals with bankruptcy. The original sections of the code were greatly amended by the law of October 24, I 89o, based on the French and Italian legislation and by law 859 of August I6, I902, as amended by decree 4855 of June 2, 1903 . The law of 1902 , which was based largely on the Argentine code, itself inspired by the Italian and the Portuguese code, gave such bad results that demands for its revision were constant. These were finally heeded by the enactment of law 2024 of December 17, 1908, which now governs the law of bankruptcy and entirely replaces the original sections of the code and prior laws. The act of 1908 is translated into French in 2 Revue de l'institut de droit comparé, pages $753-838$, and into German in the respective volume of the series "Commercial laws of the world."

The law of 1908 has been published officially. ${ }^{1}$ While it may seem unnecessary to refer to any of the books dealing with the bankruptcy law prior to the act of 1908 , it is well, nevertheless, to mention the important treatise of $\mathrm{J}$. X. Carvalho de Mendonça, ${ }^{2}$ published in São Paulo in 1899. As a scientific treatise it has still some value, and a new edition is said to be in course of preparation. A useful work was also published by Professor Sá Vianna ${ }^{3}$ in 1907 , giving a historical summary of bankruptcy in Roman, Portuguese, and Brazilian law, the characteristics of bankruptcy, a discussion of the persons who may become bankrupt, the effects of bankruptcy, jurisdiction, the administration of the bankrupt's estate, and the means by which bankruptcy is terminated or suspended.

${ }^{1}$ Lei sobre fallencias. (17 Dec., r908.) Of. ed. Rio de Janeiro, r909. $64 \mathrm{p}$.

${ }^{2}$ Mendonça, J. X. Carvalho de: Das fallencias e dos meios preventivos de sua declaração, Decree 917 of Oct. 24, 189o. Estudo theoricopratico. São Paulo, Typ. Brazil de Carlos Gerke, r89g. 2 v.

${ }^{3}$ Sá Vianna, Manoel Alvaro de Souza: Das fallencias. . . . Rio de Janeiro, L. Figueiredo, 1907. 566 p. 
Two commentaries on the law of 1908 warrant consideration. One by Manoel Autran ${ }^{1}$ deals with the nature of the declaration of bankruptcy, its legal effects, the personnel involved in the administration of the bankrupt's estate, the preservation of the assets, the proof of claims and classification of creditors, the meeting of creditors, composition, the realization of the assets, and liquidation of the debts and revindication (reclaiming specific goods from the estate), discharge in bankruptcy; composition in anticipation of bankruptcy, effects of bankruptcy, the criminal aspects of bankruptcy, and forms.

An extensive commentary by Antonio Bento de Faria ${ }^{2}$ is merely a separate taken from his exhaustive commentary on the commercial code.

\section{COMMERCIAL, TREATIES}

The Brazilian treaties of commerce and navigation are discussed in a small monograph by Abranches, ${ }^{3}$ published in 1909. He discusses the treaties with England and France, commercial relations with the United States, and other treaties, and then deals with the treaties concluded during the various forms of government through which Brazil has passed in the last century.

\section{JUDICIAL, ORGANIZATION AND CIVIL, PROCEDURE}

\section{JUDICIAL ORGANIZATION}

The constitution of the Republic created a dual judicial hierarchy similar to that of the United States. The federal courts have jurisdiction of all matters assigned to the federal government by the Constitution or federal laws, particularly cases in which either party bases his action or defense on some provision of the federal constitution; cases in which

${ }^{1}$ Das fallencias segundo a lei n. 2024 de 17 de dezembro de 1908 accompanhada de seu formulario, annotada e seguida de um indice alphabetico por Manoel Godofredo de Alencastro Autran ... Rio de Janeiro, F. Alves, rgr2.

${ }^{2}$ Bento de Faria, Antonio: Das fallencias. 5th ed. Rio de Janeiro, J. Ribeiro dos Santos, r9r3. 222 p.

${ }^{3}$ Abranches, Dunshee de: Tratados de commercio e navegação do Brazil; memoria apresentada á Commissão de diplomacia da Camara dos deputados. Rio de Janeiro, Imprensa nacional, r9o9. $70 \mathrm{p}$. 
the federal government is a party; claims of individuals against the federal government for compensation or indemnity, or of suits of the government against individuals; between one state and the citizens of another (contraby to the eleventh amendment of our Constitution), or between the citizens of different states, when the respective state laws are different; suits between foreign states and Brazilians; suits of aliens based upon contracts with the federal government or upon treaties; all questions of maritime law and navigation; questions of international law, criminal and civil, arising out of the Constitution or federal laws; and political offenses.

The state courts have jurisdiction of all matters not expressly assigned to the federal courts. It has already been observed that each state has an autonomous power to legislate on matters of procedure. As a matter of fact, however, the state codes of civil procedure do not differ greatly from one another, practically all the states having, with slight modifications, adopted decree 848 of October II, I890, concerning the regulation of procedure before the federal courts, which in turn adopted the principles of regulation 737 of November 25,1850 , concerning procedure in commercial cases. This regulation of 1850 simplified the rules of procedure in commercial cases and facilitated the administration of justice. By the decree of 1890 civil and commercial cases were brought under one procedure, the object being to secure a more speedy administration of justice in all cases. The federal government has also published a special code of procedure for the Federal District of Rio de Janeiro, the capital of the country.

According to the federal law of November 14, r89o, organizing the federal judiciary, there is one lower judge of first instance in each state and two in the Federal District called district judges (juizes de seção), and a Federal Supreme Court of fifteen judges with its seat in the Federal District. In the smaller districts of the state (comarcas) there are only representatives or deputies of the respective district judges.

- A similar organization prevails in the states. There is a judge of first instance in each judicial district, with a court of second instance having its seat in the capital of the state. Justices of the peace have jurisdiction of smaller cases. 
The judicial organization of the Federal District, which now consists of a million inhabitants, was reorganized by law I338 of January 9, 1905, with its regulating decree, as amended by decree 9263 of December 28, I9II. There are, first, praetors or local officials, who, besides having administrative functions, are competent to pass upon litigated cases up to 5,000 milreis (about $\$ 1,250$ ), with a right of appeal to the ordinary judge (juiz de direito). There are fifteen praetors, assisted by three vice praetors, having their offices in the respective wards of the Federal District, and fifteen law judges (juizes de direito), three civil, three commercial, two judges for minors and absent persons, one probate, one administrative, and five criminal judges. There are also two jury courts. The law judges have jurisdiction on appeal from judgments of the praetors up to 5,000 milreis and an original jurisdiction in cases above 5,000 milreis. They also have jurisdiction in the liquidation and bankruptcy of commercial partnerships and corporations.

From the decisions of the law judges in cases over which they have original jurisdiction appeal lies to a court of appeals (Corte de Appellação). The court of appeals, which has fifteen members, is divided into two chambers, either of which may pass upon the decisions of the juiz de direito or upon decisions of the junta commercial relating to trademarks. The two chambers united sit as a court of cassation on petitions for the annulment of the decisions of either chamber.

Provision is also made for a superior council which has jurisdiction of cases of challenge against the law judges for disqualification, corruption, etc., and of conflicts of jurisdiction between the various judicial authorities of the Federal District and between them and administrative authorities not federal.

The judges of the Supreme Court are nominated by the President subject to ratification and approval of the Senate. The judges of the federal courts of first instance are nominated by the President from a list of three names presented to him by the Supreme Court, a system inherited from the Peninsula. Appointments of all federal judges are for life, revocable only upon a judicial conviction. 
The Supreme Court besides its appellate jurisdiction has original jurisdiction of cases between one state and another, between the federal government and one of the states, or between foreign countries and the federal government or the states, conflicts of jurisdiction between the federal courts, or between federal and states courts, as well as between the courts of different states, and jurisdiction in certain criminal cases over the President and diplomatic officers.

The Supreme Court has been given original jurisdiction of petitions for the enforcement of the judgments of foreign courts. Besides the jurisdiction of the state courts already referred to, there is a right of appeal to the Federal Supreme Court in cases of doubt as to the validity or application of the constitution, or of the federal laws, or as to the validity or the application of state acts or laws alleged to be contrary to the constitution or federal laws; in certain criminal cases when the judgment is reversed at the instance of the person convicted; in matters of habeas corpus; or succession of a deceased foreigner when not provided for by treaty. The federal courts have power to declare legislation unconstitutional very similar to that prevailing in the United States.

The federal judiciary was organized by law of November i 4 , I 890 , but so many decrees were passed subsequently, and so much confusion prevailed, that the laws on judicial organization and procedure were consolidated by decree 3084 of November 5,1898 , enacted under authority granted to the Executive by article 87 of law 22: of November 20, 1894 . Part I includes the organization and functions of the federal judiciary; Part II, criminal procedure; and Part III, civil procedure, $\mathrm{I}, 963$ sections in all.

A good edition of the consolidated act has been published by José Tavares Bastos, ${ }^{1}$ with annotations and an appendix of supplementary acts relating to procedure in the federal courts. The federal judicial organization was the subject of another work by Tavares Bastos. ${ }^{2}$

1 Tavares Bastos, José: Decreto No. 3084 de 5 de novembro de 1898 ou consolidação das leis referentes á justiça federal. Rio de Janeiro, J. Ribeiro dos Santos, 1914-15. 2 v.

. Tavares Bastos, José: Organisação judiciaria federal. Rio de Janeiro [rgo6?]. $71624^{\circ}-17-19$ 
An excellent article on the federal judiciary in Brazil as compared with that of the United States has been published by Amaro Cavalcanti, an eminent jurist of Brazil, and justice of the Brazilian Supreme Court, in 6o University of Pennsylvania Law Review (1913), pages 103-I 22.

Many important functions of the Supreme Court and rules of procedure are to be found in the rules of the court (Regimento interno), which were revised on June 24, 1908, and completed by the amendment of November 30, 1914. They consist of 279 articles, and give the Chief Justice or president of the court a very considerable administrative power not possessed by the courts of the United States.

The jurisdiction and operation of the courts in Brazil were the subject of two valuable works-one by Pedro Lessa, ${ }^{1}$ the eminent justice of the Supreme Court, containing an exhaustive commentary on articles $55^{-62}$ of the Constitution, relating to the judicial power, published in 1915 ; and the other by Carvalho de Mendonça, ${ }^{2}$ published in 1899.

\section{FEDERAL DISTRICT}

The judicial organization in the Federal District was reorganized by decree 9263 of December 28, I91 I, amending a law of January 9, 1905. Civil procedure had been regulated by decree 8332 of November $3,1910 .^{3}$ It consists of a general part dealing with jurisdiction and general rules of procedure, special proceedings, provisional remedies, administrative procedure, noncontentious jurisdiction, execution, appeal, and general provisions.

The cucree of I9II, as compared with the reform of 1905 showi ig lie amendments, with a detailed index, was the subjest of a commentary published in I9I 2 by Sá Albuquerque. ${ }^{4}$ A consolidation of all the provisions relating to civil

${ }^{1}$ Less?, Pedrs: O poder judicial. Rio de Janeiro, F. Alves, I9I5. $435 \mathrm{p}$.

${ }^{2}$ Carra'ho de X.'endonça, Manuel Ignacio: O poder judicial no Brazil. Curityba, r339. $490 \mathrm{p}$.

${ }^{3} \mathrm{Coc}$, $\mathrm{x}$ Ce proce sso civil e commercial do Districto Federal, approvado D:? Decreto n. $833^{2}$ de 3 de novembro de rgro. Rio de Janeiro. Impr. Z..cionnt, I910. $168 \mathrm{p}$.

4 Sá … à Ferieral. D : $: 9263$ de 28 de Dezembro de rgrr. Rio de Janeiro, j. Ribeiro dus Santos, IgI2. 
procedure in the Federal District (2083 articles) was published by Professor Armando Vidal ${ }^{1}$ in 1913.

By decree 10902 of May 10, 1914, carrying out the provisions of article 76 of law 284I of December 31,1913 , and decree 9957 of December 31, 1912, the district attorney's office (procuradoria) of the Republic in the Federal District was reorganized. It consists of 158 articles.

The judicial organization of the state of São Paulo was the subject of a work published in 1907 by Cardozo de Almeida. ${ }^{2}$

\section{CIVIL PROCEDURE}

Procedure in Brazil is entirely in writing-complaint, answer, and even evidence being all reduced to written form before presentation to the judge. It is the duty of the clerk of the court to receive and arrange, in chronological order, the various pleadings and documents, such as the written instruments and depositions of witnesses used as evidence, the arguments of the attorneys, the exceptions, and every interlocutory decree and step in the procedure incidental to the joining of issue and the support of the respcctive contentions of the parties. Only at the end of the case may this record be handed to the respective attorneys for the preparation of an appeal. The record constitutes the sole basis for the decision of the court of first instance and of the appellate tribunal, subject to oral arguments which either court may request for its enlightenment.

One of the best consolidations of the laws of civil procedure, annotated, has been published by Antonio Ribas, ${ }^{3}$ first issued in 1875 and given official authority by resolution of December $28, \mathbf{1} 876$. A third edition of this work, recently edited by his son, Julio A. Ribas, deals with judicial organization, including the jurisdiction and powers of the various judges,

1 Vidal, Armando: Consolidação das disposições referentes ao processo civil e commercial da justiça local do Districto Federal, vigentes em 3 I de julho de igi3. Rio de Janeiro, S. a. Progresso, r9i3. $501 \mathrm{p}$.

${ }^{2}$ Cardozo de Almeida: Organisação judiciaria de S. Paulo. $3^{\text {rd }}$ ed. São Paulo, 1907. 276 p.

${ }^{3}$ Ribas, Autonio: Consolidação do processo civil, commentada pelo . . . com a collaboração de seu filho, Dr. Julio A. Ribas. $3^{\text {rd ed. Rio }}$ de Janeiro, J. Ribeiro dos Santos, 1915. 798 p. 
the forms of procedure, the tariff of costs, and the different kinds of actions.

Some exceptionally good works on civil procedure have been published in Brazil. To mention first the classics, attention should be called to a treatise by the Portuguese jurist Pereira e Souza, ${ }^{1}$ which was annotated and revised to conform with Brazilian conditions by Teixeira de Freitas in I 877 , using as a basis the fifth Portuguese edition of 1849 . A new edition of this work, published in 1907 , contains additional annotations with an appendix showing the reform of 1905 for the administration of justice in the Federal District. This revision of 1905 has itself been amended by decree 9263 of December 28, 191 I, above mentioned.

Another classic work is that of Souza Pinto, ${ }^{2}$ first published in 1849 , with a second edition in 1875 in three volumes. Another valuable work on precedure was published by Moraes Carvalho, ${ }^{3}$ which in a third revised edition by Levindo Ferreira Lopes was published in 1910. A new edition appeared in 1915 .

Commentaries on the code of civil and commercial procedure are included in the commentaries on commercial law by Orlando and Bento de Faria. (Supra, p. 274.)

Among the best treatises on civil procedure is Professor João Monteiro's 4 "Theory of civil and commercial procedure," published in a third edition in three volumes in I9r3. It is a scientific work based upon lectures delivered at the University of São Paulo. He deals (I) with the theory of actions, the

1 Pereira e Souza, Joaquim José Caetano: Primeiras linhas sobre o processo civil ... Accommodadas ao fóro do Brasil até o anno de I877 por Augusto Teixeira de Freitas ... Nova ed. seguida da reforma judiciaria da justiça local do Districto federal. Rio de Janeiro [etc.], H. Garnier, r907. 63I p.

${ }^{2}$ Souza Pinto, José Maria Frederico de: Primeiras linhas sobre o processo civil brasileiro. 2nd ed. Rio de Janeiro, 1875. $3 \mathrm{v}$.

${ }^{3}$ Moraes Carvalho, Alberto Antonio: Praxe forense. Direito pratico do processo civil brazileiro. 3 rd ed. by Levindo Ferreira Lopes. Rio de Janeiro, J. Ribeiro dos Santos, rgro. $43^{8}$ p. New edition by L. F. Lopes, I9I5.

${ }^{4}$ Monteiro, João: Theoria do processo civil e commercial. (Programma do curso de processo civil.) 3rd ed. São Paulo, Duprat \& Cia., I9I3. $3 \mathrm{v}$. 
general organization of procedure, judicial organization, jurisdiction, parties, attorneys, and forms of procedure; (2) with the steps in the ordinary action, the rules of evidence, the summary action which may be brought upon certain documents which prima facie acknowledge a debt; and (3) with judgment, appeals, writs of error, execution, and the incidental steps in procedure.

A classic treatise on civil procedure is the compendium of the theory and practice of procedure of Paula Baptista, ${ }^{1}$ one of the foremost jurists of Brazil and at one time Professor at Recife. A seventh edition of this celebrated work was edited in 1910 by Dr. Vicente Ferrer. The author deals in a general part with jurisdiction, parties, process and nullity of process, and in a special part with civil procedure in comparison with commercial, the procedure for conciliation, which has now been abolished in Brazil as a condition precedent for the bringing of an action, the various steps in procedure beginning with the summons, answer, counterclaim, exceptions, opening the case to proof, the submission of evidence and its various kinds, presumptions, documentary evidence, witnesses, admissions, oaths, etc., execution and its incidents and appeals and petitions for review. It also includes the author's valuable essay on the rules of legal interpretation, hermeneutica juridica, written in 1860 .

A work which enjoys an equal reputation is the Praxe Brasileira of Joaquim Ramalho ${ }^{2}$ first published in 1869 and published in a second edition in 1904 with annotations by Dr. Pamphilo d'Assumpção. Part I deals with judicial organiza tion in civil cases and discusses jurisdiction, judges and courts, the steps in the litigation and parties, and the various judicial officers. Part II deals with ordinary procedure including provisional remedies, process, beginning with the summons, and

1 Paula Baptista, Francisco de: Compendio de theoria e practica do processo civil comparado com o commercial e de hermeneutica juridica.

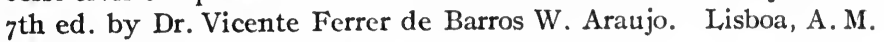
Teixeira \& Co., Igro. 482 p.

2 Ramalho, Joaquim Ignacio: Praxe brasileira. 2. ed. augm. com annotações pelo Dr. Pamphilo d'Assumpção, devidamente autorisado em vida, pelo autor o ex. ${ }^{\circ}$ Snr. Cons. ${ }^{\circ}$ Dr. barão de Ramallo. S. Paulo, Duprat \& Comp., r904. 668 p. 
the rules of pleading and evidence. Part III deals with summary procedure, including the procedure known as ten-day notice, Part IV with appeals and writs of error, and Part V with execution of judgment.

\section{ACTIONS}

A classic work on actions by the Portuguese jurist Corrêa Telles was accommodated to Brazilian legal conditions by Teixeira de Freitas ${ }^{1}$ in 1879 . Legal actions were discussed in a well-known work by Professor João Monteiro ${ }^{2}$ published in 1905 .

The grounds of nullity of actions were discussed in a scientific work by Pimenta Bueno, ${ }^{3}$ an eminent jurist of the last century, whose work was edited in a third edition in $191 \mathrm{I}$ by Sá Albuquerque. The nullity of legal actions has also been treated in the work on the nullity of legal acts by Martinho Garcez. (Supra, p. 255.)

A consolidation of the laws of civil procedure in the state of Rio de Janeiro was published in 1895 by Marcellino da Gama Coelho. ${ }^{4}$

Among the special actions is the so-called ten-day notice procedure (assignação de dez dias), called in the new consolidation ação decendial, by which, upon the exhibition of unpaid. negotiable instruments duly signed, the debtor is summoned to

1 Teixeira de Freitas: Doutrina das acções, por João Homem Corrêa Telles, accommodada ao fôro do Brazil, até o anno de 1877 . Rio de Janeiro, 1879 . Nova edicão melhorada, Rio de Janeiro, H. Garnier, [1909]. $320 \mathrm{p}$.

${ }^{2}$ Monteiro, João Pereira: Direito das acções. São Paulo, Typ. Duprat \& Co., 1905. 206 p.

${ }^{3}$ Pimenta Bueno, José Antonio: Apontamentos sobre as formalidades do processo civil . . . 3. ed. cor. e augm. pelo advogado Dr. João de Sá e Albuquerque. Rio de Janeiro, J. Ribeiro dos Santos, I9II. 263 p.

${ }^{4}$ Consolidação das leis do processo civil do estado do Rio de Janeiro de ordem de seu presidente o Exm. Sr. Dr. José Thomaz da Porciuncula, por Marcellino da Gama Coelho . . . Rio de Janeiro, Typ. Guimarães, 1895. 2 v. Additamentos á Consolidação das leis do processo civil e criminal do estado do Rio de Janeiro pelo Dr. Marcellino da Gama Coelho . . Rio de Janeiro, Companhia impressora, $1897.48 \mathrm{p}$. 
pay within ten days or give security, in the absence of rhich execution is made at once. For bills of exchan rc, $1 .$. s procedure has now been replaced by the summary a:tis.s. The best book on this special procedure is the standarc work of Almeida Oliveira, ${ }^{1}$ published in a new edition in Rio c J J aneiro in 1915 .

Procedure in the surrogate's court, covering tie ratters usually coming before such a court, is the subject of a classic work by José Pereira de Carvalho. ${ }^{2}$ In a new edition by Dr. Levindo Ferreira Lopes, with annotations and amendments showing the rules observed in the Federal District and in the states of Rio de Janeiro, São Paulo, and Minas Geraes, this work has recently been republished.

The jurisdiction of provedoria is a creation of the old Portuguese law of procedure. It formerly extended to guardianship, the supervision of religious corporations and mortmain, trustees for absent persons, etc. It now is confined to the validity and execution of testamentary dispositions and the decision of questions arising therefrom. A standard work on this subject is that of Ferreira Alves, ${ }^{3}$ which had its fifth edition in rgr2. Besides its practical it has a considerable scientific value. After a historical survey of the development of the institution, it describes the various kinds of wills, their form and execution, and then deals with legal succession.

Two works on justices of the peace by J. X. Carvalho de Mendonça ${ }^{4}$ and by Levindo $F$. Lopes ${ }^{5}$ should be mentioned. The former is the more scientific.

1 Almeida Oliveira, A. de: A assignação de dez dias no fôro commercial e civil. Rio de Janeiro, I9r5.

${ }^{2}$ Pereira de Carvalho, José: Primeiras linhas sobre o processo orphanologico. New ed. by Dr. Levindo Ferreira Lopes. Rio de Janeiro, J. Ribeiro dos Santos, I9r 5.464 p.

${ }^{3}$ Ferreira Alves, Joaquim Augusto: Consolidação das leis relativas ao juizo da provedoria. 5th ed. in $2 \mathrm{v}$. Rio de Janeiro, I9r2. $600 \mathrm{p}$.

* Carvalho de Mendonça, J. X.: Tratado de justiça de paz. São Paulo, [rgoo?]

${ }^{5}$ Lopes, Levindo Ferreira: Manual dos juizes de paz. 2d ed. Rio de Janeiro, J. Ribeiro dos Santos [19II?] 373 p. 
FORM BOOKS

Probably the most useful form book is the Assessor forense, ${ }^{2}$ published in four volumes in I9I2. The first volume deals with civil actions and is a ninth edition of the classic work of Carlos Antonio Cordeiro. The second volume, on criminal actions, is likewise a ninth edition of the work of Cordeiro. The third volume on commercial actions is the sixth edition of the standard work of J. J. Pereira da Silva Ramos, and the fourth volume, on actions in the orphan's court, is the fourth edition of a work by the editor of all the volumes, Dr. M. G. de Alencastro Autran.

The various Consultores of Cordeiro, civil, criminal, commercial, and orphan's court, have also been annotated and revised by Oscar de Macedo Soares in modern editions published by the firm of $\mathrm{H}$. Garnier. New editions have also been issued from time to time of the collection of forms of Dr. Nabuco de Araujo.

A collection of decisions on procedure was published in 1908 by Professor Galdino de Siqueira, ${ }^{2}$ of São Paulo.

\section{POWERS OF ATTORNEY}

Suit is usually begun, especially by foreigners, by the sending of a power of attorney to a Brazilian lawyer. The questions involved are not always simple by reason of the special forms of powers needed in certain casés. The leading work on the subject of powers of attorney is that of Affonso Gama, ${ }^{3}$ a second edition of which was published in 1913, employing doctrine and theory, national and foreign legislation, and the

${ }^{1}$ Assessor forense, comprehendendo todas as acções conhecidas no foro brazileiro em materia civil, criminal, commercial e orphanologico, dividido em quatro partes, a saber: I. Acções civeis, por Carlos Antonio Cordeiro gth ed. by M. G. de A. Autran. II. Acções criminaes, por Carlos Antonio Cordeiro. gth ed. by M. G. de A. Autran. III. Acções commerciaes, pelo Dr. J. J. Pereira da Silva Ramos. 6th ed. by M. G. de A. Autran. IV. Acções orphanalogicas. 4th ed. by M. G. de A. Autran. Rio de Janeiro, Alves, rgr 2.

2 Siqueira, Dr. Galdino de: Practica forense, ou repositorio completo dé jurisprudencia patria. São Paulo, I908. 829 p.

${ }^{3}$ Gama, Affonso Dionysio: Das procurações . . . 2. ed. cor. e muito augm. Rio de Janeiro, F. Alves \& Cia. [etc., etc.] 19r3. 367 p. 
decisions of the courts. He discusses, first, agency in general and agents; secondly, forms and powers of attorney; and thirdly, the tariff of judicial costs in the Federal District and in the various states of the country in the matter of agents and powers of attorney, including costs for the registration of title. Part IV consists of the provisions of the Brazilian, Portuguese, French, Italian, and German codes on agency and powers of attorney, and Part $\mathrm{V}$ of a useful index digest. A less useful book is that of Gonçalves Maia, ${ }^{1}$ district attorney in the state of Amazonas, published in riro. It is largely a book of forms.

\section{SECURITY FOR COSTS}

By decree 564 of July Io, I 850 , nonresidents, whether citizens or aliens, have to give security for costs, a provision contained in article 12 of part 3 of decree 3084 of 1898 consolidating the laws of federal justice. While the matter is treated in the works on procedure, it is the subject of a special work by Nogueira Almeida, ${ }^{2}$ published in 1909. It is also discussed in an article by Rodrigo Octavio in 40 Clunet (19r3), page 783 , and in a recent work of the same author, Le droit international privé dans la législation Brésilienne (Paris, I9I5, p. I83).

\section{JUDICIAL, COSTS}

Decree 3422 of September 30, 1899 , governs the tariff of costs in the federal courts. This has recently been amended by decree 11842 of December 29, $1915 .^{3}$

For the Federal District a new regulation was enacted by decree ro291 of June 25, 1913. A table of judicial costs is included in many of the works on procedure. A special work on the subject was published by Tavares Bastos. ${ }^{4}$ A guide

${ }^{1}$ Gonçalves Maia: Theoria e pratica das procurações. Amazonas, I9ro, $140 \mathrm{p}$.

${ }^{2}$ Nogueira Almeida, J. L.: Estudo theorico e pratico sobre fiança ás custas no direito processual brasileiro. São Paulo, 1909. 7 I p.

${ }^{3}$ Decreto n. 11842 de 29 de dezembro de I $_{15} 5$, e decreto $n .3422$, de 30 de setembro de I899: Regimento de custas. Rio de Janeiro, J. Ribeiro dos Santos, I9I6.

- Tavares Bastos, José: Custas judiciarias na Republica. Rio de Janeiro, [1903?]. 
to the costs of procedure and notarial fees by the well-known authority on procedure, Oliveira Machado, ${ }^{1}$ was published in a third edition in r9r2.

\section{EXCEPTIONS}

Minor objections or exceptions taken in the course of the proceedings are called aggravos, which may be appealed immediately in an interlocutory proceeding to a higher court. Cases in which aggravos may be brought are set forth in article 715 of Part III of the consolidation of 1898 . This recourse, which was first codified by decree 143 of March 15,1842 , and by the subsequent code of procedure of 1850 , and again in 1890 , has been discussed in the standard work of Oliveira Machado, ${ }^{2}$ issued in a second edition by Sá Albuquerque in 1914. This procedure has been amended in the Federal District by decree 9263 of December 28, I9II. The new edition also includes the provisions of state codes of civil procedure on the subject. A work on this special topic in procedure has also been published recently by Martinho Garcez. ${ }^{3}$

\section{EXECUTION}

Execution of judgment has been discussed in numerous special works. The best of these is that of Almeida Oliveira, ${ }^{4}$ published in a new edition in I915. As early as I 896 bills for homestead exemption had been introduced in the Brazilian Congress. It has been observed that a provision for homestead is included in the new civil code.

${ }^{1}$ Oliveira Machado, Joaquim de: Novissima guia dos tabelliães ou o notariado no Brasil e a necessidade de sua reforma. 3d ed. Rio de Janeiro, [rgr2 ?]. 479 p.

${ }^{2}$ Oliveira Machado, Joaquim de: Pratica dos aggravos no juizo civil e commercial, segundo o ultimo estado da legislação no Brasil; comprehende largos e minuciosos commentarios a cada um dos artigos dos decretos $\mathrm{n}$. 143 de 15 de março de $1842, \mathrm{n} .737$ de 25 de novembro de 1850, e n. 5467 de $\mathrm{x} 2$ de novembro de 1873 , e 370 de may 2 , 1890 . . . 2. ed. alterada e modificada por João de Sá e Albuquerque . . . Rio de Janeiro, F. Alves \& cia., I9ז4. 536 p.

${ }^{3}$ Garcez, Martinho: Theoria e pratica dos aggravos. Rio de Janeiro, J. Ribeiro dos Santos, I9r4. $580 \mathrm{p}$.

4 Almeida Oliveira, A. de: A lei das execuções. Rio de Janeiro, J. Ribeiro dos Santos, I9r 5 . 
Foreign judgments are executed by order of the Federal Supreme Court in Brazil, which must give them validity by a certificate of legalization (homologaşa o), a procedure governed by articles 7-19 of Part V of decree 3084 of 1898 . The subject is discussed in a special work of Professor Samuel Martins, ${ }^{1}$ of Recife, and by Rodrigo Octavio in his work already cited, Le droit international privé dans la législation Brésilienne.

\section{ATTORNEY GENERAL.}

The Attorney General's office is an important factor in procedure in Brazil. As in the case of Argentina, a representative of the Attorney General's office (fiscal) sits as a member of the Supreme Court to safeguard the interests of the Government; although without right to vote. He also represents the State in many proceedings in which public institutions are parties and in numerous civil, criminal, and surrogate's actions in which the Treasury or State is interested. Naturally, the office acts as public prosecutor in criminal actions. The most important modern work on the functions of the district attorney's office is that of Tavares Bastos. ${ }^{2}$ He includes complete forms in civil, criminal, and surrogate's actions in behalf of absent persons, and for the protection of the property of deceased persons, with extensive annotations.

\section{CRIMINAL LAW}

\section{PENAL CODE}

The penal code was first adopted in 1830 . It was praised by Chauveau and Hélie in their "Theory of criminal law" as one of the best of modern codes. With the overthrow of the monarchy, and in accordance with authority vested in the federal government by the Constitution, a new code was enacted by decree 847 of October I I, I 890 . This decree with certain supplementary statutes, particularly decree 2 I IO of September 30, 1909, on the falsification of national currency and public and private instruments (repealing law 1785 of 1907 and also arts. $239^{-2} 50$ of the penal code), is now in force.

\footnotetext{
1 Martins, Samuel: Execuções das sentenças estrangeiras no Brazil. Recife, J. B. Edelbrock, 1906. I35 p.

2 Tavares Bastos, José: As attribuções do promotor publico na Republica. Rio de Janeiro, H. Garnier, 1907. 629 p.
} 
The code of 1890 follows largely the Italian code of 1889 , which is based upon the classical schools of criminal law. Capital punishment is abolished, except under military law in time of war. Banishment, which was found in the old code, was abrogated by the Constitution. Punishment restricting individual liberty is limited to thirty years. A warrant of arrest issuing from a judicial authority is always necessary, except when the offender is caught in the flagrant commission of an offense.

\section{HABEAS CORPUS}

An important institution of criminal and constitutional law is the writ of habeas corpus which may be demanded in case of unlawful detention of any kind. It may be demanded by any citizen in behalf of a person detained. It is also used freely to raise constitutional questions. Appeal both from state and federal courts lies to the federal Supreme Court, whose decision is final. An examination of the decisions of the Supreme Court shows a remarkable number of decisicns on habeas corpus. The measures of restraint permissible during martial law, when constitutional guaranties are suspended, are limited to imprisonment in places not occupied by common criminals and to banishment to some other part of the national territory.

\section{EXTRADITION}

Extradition is now governed by a statute which limits the extradition of natives to cases where the foreign demanding country grants a similar remedy by reciprocity. The order can only be granted after examination by the federal Supreme Court, without right of appeal. Extradition is not granted for political crimes, military offenses, offenses against religion or the press, or crimes for which under Brazilian law the punishment is less than twelve months, or when the statute of limitations by the law of the demanding country has applied. An interesting mon ograph on extradition in the law of Brazil was published in a second edition in I9 I by Sylvio Roméro; Jr. ${ }^{1}$

${ }^{1}$ Roméro, Sylvio, jr.: O instituto da extradicão no direito brasileiro 2. ed. Melhorada. Rio de Janeiro, Impr. nacional, IgIr. 53 p. 
The code of I 890 having proved unsatisfactory, a new code was drafted, the bill for its adoption having reposed in Congress for a number of years. Its principal draftsman was Vieira de Araujo. ${ }^{1}$

While the code of 1830 is no longer in force, it may not be without interest to mention a few of the prominent commentaries upon it or works discussing its theories. The code itself has been translated into French by Foucher, ${ }^{2}$ with an interesting introduction comparing it with the French penal code.

\section{LITERATURE}

One of the best commentaries on the old code was that of Thomaz Alvez. ${ }^{3} \quad$ A scientific and critical commentary upon the topics covered in the code was published by the celebrated legal philosopher, Tobias Barreto, ${ }^{4}$ in I 888 . A practical work in explanation of the institutions of the criminal code was published in 1882 in two volumes by Carlos Perdigão. ${ }^{5}$

Shortly before the overthrow of the monarchy the draft of a new code had been entrusted to Vieira de Araujo, ${ }^{6}$ professor of law, judge, and representative in congress and the leader among modern Brazilian criminalists. The manuscript of this draft, with extensive explanatory notes, the opinion of a special commission upon the draft, and a refutation of that opinion were not published until I 910 , when the learned author

1 Codigo criminal Brazileiro, Ante-projecto. Rio de Janeiro, Imprensa nacionel, [Igor ?].

${ }^{2}$ Code criminel de l'empire du Brésil, adopté par les chambres législatives dans la session de 1830 . Tr. par M. Victor Foucher . . . et précédé d'observations comparatives avec le code pénal français. Paris, Imprimerie royale, 1834 . $137 \mathrm{p}$.

${ }^{3}$ Alvez, Thomaz: Annotações théoricas e practicas ao codigo criminal. Rio de Janeiro, $1864.648 \mathrm{p}$.

${ }^{4}$ Barreto, Tobias: Commentario theorico e critico do codigo criminal brasileiro. Recife, I888.

${ }^{5}$ Perdigão, Carlos Frederico Marques: Manual do codigo penal brazileiro, estudos syntheticos e praticos. Rio de Janeiro, $1882.2 \mathrm{v}$.

${ }^{6}$ Vieira de Araujo, João: Nova edição official do codigo criminal brasileiro de 1830 . Ante-projecto. Rio de Janeiro, Impr. nacional, I910. I53 p. 
permitted its publication. For historical purposes it is an excellent presentation of the state of criminal law several months before the institution of the Republic.

\section{CONTENTS.}

The code of 1890 is divided into four books, containing $4^{12}$ articles. Book I, the general part, deals with crimes and punishment, the application and effects of criminal law, crimes and criminals, criminal responsibility and causes of crime, aggravating and exteruating circumstances, penalties and their effects, the application and method of execution, and the extinction or suspension of penal actions and of sentence.

Book II, covering special crimes, is divided into thirteen titles, dealing with crimes against (I) the political existence of the Republic; (2) the safety of the state; (3) public tranquillity; (4) the free exercise of individual rights; (5) good order and public administration; (6) public faith (national currency and securities and the integrity of instruments); (7) the treasury; (8) the honor and moral relations of the family; (9) security of civil status (marriage and protection of minors); (Io) security of person and life; (II) reputation and honor; (12) public and private property; (I3) persons and property, particularly extortion.

Book III deals with special misdemeanors and Book IV contains general provisions.

\section{LITERATURE}

The ablest work upon the penal code of 1890 is that of Vieira de Araujo." His "theoretical and practical commentary" upon the penal code is a new edition of another commentary published in 1889 , based upon the code of 1830 . It discusses philosophically and scientifically the principles and doctrines of the general part of the code, with extensive recourse to comparative law. It is not a commentary by articles.

1 Vieira de Araujo, João: Codigo penal commentado teorica e praticamente, pelo advogado Dr. João Vieira de Araujo . . . Rio de Janeiro, e S. Paulo, Laemmert \& Co., 1896-97. 2 v. 
A supplement to this work under the title "The penal code interpreted according to its sources, doctrine, and jurisprudence, with references to the projects for its revision," 1 is an exhaustive commentary in two volumes of the subjects treated in the special part of the code, namely, the individual crimes covered by Book II (art. 87 et seq.). It is a scientific treatise on the different crimes covered by the code, employing comparative legislation, the decisions of courts, and the doctrines of the author, written partly in the light of a proposed new penal code. These two works constitute the most scientific works of the modern Brazilian literature on criminal law.

Dr. Vieira, who is a representative of the Italian school of criminal law, also furnished the report on Brazilian criminal law, which is found in the monumental German work Die Strafgesetzgebung der Gegenwart in rechtsvergleichender Darstellung, Vo'ume II. (Berlin, Otto Liebmann, I898.)

The best practical commentaries on the articles of the code have been published by Macedo Soares ${ }^{2}$ (5th ed., 19ro) and by Bento de Faria ${ }^{3}$ (2d ed., I913). The former work is perhaps the more reliable of the two and is more prolific in its references to theory and practical literature. In the latter, comparative law is laid under contribution to a greater extent and under each article the decisions of the courts are systematically subsumed. Both contain extensive appendices printing verbatim the various laws and decrees which contain penal provisions.

An edition of the penal code, containing the supplementary laws, decrees, opinions, and orders of the Department of Justice,

${ }^{1}$ Vieira de Araujo, João: O codigo penal interpretado segundo as fontes, a doutrina e a jurisprudencia e com referencias aos projectos de sua revisão. Parte especial pelo Dr. João Vieira de Araujo. . . . Rio de Janeiro, Imprensa nacional, rgor-2. $2 \mathrm{v}$.

2 Codigo penal da republica dos Estados Unidos do Brasil, commentado por Oscar de Macedo Soares . . . 5. ed. cor. e consideravelmente augm., contendo em appendice a legislação criminal publicada até á presente data. Rio de Janeiro, etc., Garnier [19ro]. 860 p.

${ }^{3}$ Bento de Faria, Antonio: Annotações theorico-praticas ao codigo penal do Brazil de accordo com a doutrina, a legislação e a jurisprudencia, nacionaes e estrangeiras, seguido de um appendice contendo as leis em vigor e que the são referentes... 2nd ed. Rio de Janeiro, F. Alves [etc., etc.], rgr3. 2 v. 
the decisions of the courts, with some citation to foreign décisions, has been published by Manoel Escorel. ${ }^{1}$ A dictionary of criminal law by João Romeiro ${ }^{2}$ also warrants notice.

\section{MONOGRAPHS}

Numerous monographs on criminal law have been published which warrant passing attention. The classic work of Tobias Barreto ${ }^{3}$ on minors and incompetents in criminal law; a study on article ro of the old code, was published in a second edition in I 886. Pedro Lessa, ${ }^{4}$ the well-known Supreme Court justice and scholar, published an important psychological study on criminal responsibility in 1905 .

A collection of studies on criminal law was published in I 898 by Dr. Lima Drummond, ${ }^{5}$ the well-known criminologist and student of penology and prison administration.

Viveiros de Castro, a judge and criminalist, has published numerous monographs on criminal law. A collection of essays on various topics of criminal law ${ }^{B}$ was published by him in 190I. A study ${ }^{7}$ on crimes against the honor of women was published in 1897 .

A criticism of the Brazilian law on the duel and infanticide in the light of modern schools of criminal law was published in 1903 by Phaelante da Camara. ${ }^{8}$ A well recommended work on criminal law was published by the former Councilor of State, now professor, Filinto Bastos, of Bahia. ${ }^{9}$

${ }^{1}$ Escorel, Manoel Clementino de Oliveira: Codigo penal brasileiro, contendo: leis, decretos, avisos de governo, calculos de penas figurados todos os casos, jurisprudencia brasileira e estrangeira e um indice alphabetico. São Paulo, Duprat, I905. 267 p.

${ }^{2}$ Romeiro, João Marques de Moura: Diccionario de direito penal. Rio de Janeiro [rgor?]. $422 \mathrm{p}$.

${ }^{3}$ Barreto, Tobias: Menores e loucos em direito criminal: estudos sobre o Art. Io do codigo criminal brasileiro. 2nd ed. Rio de Janeiro, I886.

${ }^{4}$ Lessa, Pedro: O determinismo psychico e a imputabilidade e responsabilidade criminaes. Rio de Janeiro, I905. $130 \mathrm{p}$.

${ }^{5}$ Drummond, J. da Costa Lima: Estudos de direito criminal. Rio de Janeiro, $\mathrm{I} 898$.

${ }^{6}$ Viveiros de Castro, F. J.: Questões de direito penal. Rio de Janeiro, I90I. $4 \mathrm{I} 7 \mathrm{p}$.

7 Viveiros de Castro, F. J.: Delictos contra a honra de mulher. Rio de Janeiro, I897. $323 \mathrm{p}$.

${ }^{8}$ Phaelante da Camara: O duello e o infanticidio. Bahia, 1903.

${ }^{9}$ Bastos, Filinto J. Ferreira: Estudos de direito penal. Bahia, Typ. Almeida, Ig06. $220 \mathrm{p}$. 


\section{CRIMINOLOGY}

A collection of studies on criminology and legal history was published in 1906 by Clovis Bevilaqua ${ }^{1}$. Among the studies on criminal law are the following: a new theory of responsibility, notes on crime in the State of Ceará, crime in relation to time and population, geographical distribution of crime, and suicide in the federal Capital.

Viveiros de Castro ${ }^{2}$ has published a study on the new school of criminal law, in which he examines the theories of Lombroso, Ferri, Garofalo, Tarde, and others. A second edition was published in I9I3. The three different schools of criminal law were the subject of an interesting study by Moniz Sodré, ${ }^{3}$ published in 1907.

An important study on the penitentiary system according to the notes and doctrines of Dr. Lima Drummond was published, with a preface by Count Affonso Celso (Ouro Preto), by Paulo Domingues Vianna. ${ }^{4}$ Part I discusses the historical evolution of the penitentiary question and outlines the known systems. It discusses conditional liberty, patronage, and supervision of released persons, penal disciplines whose employment is permitted in penitentiaries, penal transportation, and similar questions. Part II contains legislation, the regulation of the Casa de Detenção and de Correç̧ão, the Escola Correccional, and other correctional institutions.

The probation system and the supervision of released criminals was the subject of a study by Lima Drummond ${ }^{5}$ as chairman of the commission appointed by the government to elaborate a draft of a law on the subject.

1 Bevilaqua, Clovis: Criminologia e direito. Bahia, rgo6. 247 p.

${ }^{2}$ Viveiros de Castro, F. J.: A nova escola penal. $2 \mathrm{~d}$ ed. Rio de Janeiro, J. Ribeiro dos Santos, rgr3.

${ }^{3}$ Moniz Sodré, Dr.: As tres escolas penaes. Bahia, Ribeiro, Gouvea \& Co., Liv. dos Dous Mundos, r907.

- Domingues Vianna, Paulo: Regimen penitenciario. Rio de Janeiro, J. Ribeiro dos Santos, I9I4.

- Ministerio da justiça e negocios interiores: Patronato official dos liberados ou egressos definitivos da prisão. Trabalhos que precederam o decreto e a expedição do regulamento, sendo ministro o Sr. Dr. Esmeraldino Olympio de Torres Bandeira, Igro-Janeiro a outubro. Rio de Janeiro, Imprensa nacional, r9ro. ro5 p.

$71624^{\circ}-17-20$ 
The police service in the Federal District was reorganized by decree 947 of December 29, 1902, to which there are occasional supplementary decrees. The report of the chief of police $^{1}$ on crimes and criminals in the Federal District for 1904 is of interest. The house of detention in the Federal Capital was established by decree 10873 of April 29, 1914, by virtue of article ro of law 2842 of January 3, igr4. The decree contains 132 articles. Attention may be called to the annual reports of the Minister of Justice, which, in appendices, contain criminal statistics, reports from the various courts of the Republic, reports on police and prison administration, pardons, etc.

Two collections of decisions on criminal law have been published by Judge Viveiros de Castro. ${ }^{2}$ They include decisions of foreign courts as well as Brazilian.

In I 913 a journal of criminal law and procedure was begun under the editorship of Evaristo de Moraes ${ }^{3}$ and others. It consists of doctrinal articles, decisions of the courts, and legislation, national and foreign, including legal medicine, criminal statistics, and criminology.

\section{LEGAL MEDICINE}

Two modern works on legal medicine warrant special attention: the one by Souza Lima, ${ }^{4}$ a standard work published in a third edition in 1900; the other by Professor Afranio Peixoto, ${ }^{5}$ of the faculty of medicine at Rio de Janeiro, an elementary book for students dealing with criminal responsibility and the sexual and pathological factors of crime.

${ }^{1}$ Relatorio apresentado ao exmo. Snr. Dr. J. J. Seabra, ministro da justiça e dos negocios interiores pelo chefe de policia do Districto federal A. A. Cardoso de Castro. Rio de Janeiro, Typ. Rebello Braga, Ig04. $39 \mathrm{I}$.

${ }^{2}$ Viveiros de Castro, Francisco José: Sentenças e decisões em materia criminal. Rio de Janeiro, 1896.

Jurisprudencia criminal. Paris [Rio de Janeiro], x900. 346 p.

${ }^{3}$ Revista de direito e processo penal. Editors, Evaristo de Moraes, Gregorio Garcia Seabra, Jr., and Januario da Assumpção Osorio. Rio de Janeiro, I9r3.

4 Souza Lima, Agostinho J. de: Medicina legal. 3rd ed. Rio de Janeiro, 1909. $928 \mathrm{p}$.

' Afranio Peixoto: Elementas de medicina legal. Rio de Janeiro, Alves, r9o9. $523 \mathrm{p}$. 
A note by C. Bell on the progress made in Brazil in the study of psychiatry, neurology, and legal medicine was published in 28 Medico-Legal Journal (September, I910), pages 87-89.

\section{MILITARY CRIMINAL LAW}

The military and naval penal code is distinct from the ordinary penal code. An excellent study upon the military code by Vieira de Araujo ${ }^{1}$ was published in I898. A good commentary upon it has been published by Oscar de Macedo Soares. ${ }^{2}$

One of the best studies on military criminal law has very recently been published by Chrysolito de Gusmão. ${ }^{3}$ It deals with military discipline and sociology, the military legislation of Brazil, its history and present development and status, and military crimes and their differentiation from ordinary crimes, including questions of jurisdiction and procedure. In an appendix he includes the penal code of the army and navy and the regulations for military criminal procedure.

\section{CRIMINAL PROCEDURE}

It has been observed that criminal procedure is within the jurisdiction of the various states, although there has been much dispute by authorities as to the extent to which the states may depart from the basic principles of Brazilian criminal procedure. It may be said, however, that in the majority of the states the code of criminal procedure closely resembles that adopted in the Federal District.

The Brazilian code of criminal procedure, first adopted in I832, grants ample rights of defense and secures the accused against an abuse of authority or violation of his rights. He must be furnished with a statement of the charge, signed by a competent authority, with the names of his accusers or witnesses, within twenty-four hours of his arrest. He may resort to habeas corpus against any violations of law or abuse

1 Vieira de Araujo, João: Direito penal do exercito e armada. Rio de Janeiro, I898.

${ }^{2}$ Macedo Soares, Oscar de: Codigo penal militar da Republica das Estados Unidos do Brasil, commentado. Paris, 1903. $5^{\text {I } 2} \mathrm{p}$.

${ }^{3}$ Gusmão, Chrysolito Chaves de: Direito penal militar. Rio de Janeiro, J. Ribeiro dos Santos, I9r5. 400 p. 
of authority in his detention. He may, throughout, be accompanied by a lawyer and may present any evidence, may examine the documents of the prosecution, and examine and cross-examine witnesses. The secret interrogatory has been abolished.

It is interesting to observe that the jury system has been preserved in Brazil, although in Argentina it has been found not adaptable to the institutions of the country. The formal rules for the operation of the jury system resemble those of the United States, although in practice it is said not to work well. The tendency is to restrict the jury system to its most narrow limits.

The code of criminal procedure of 1832 has been amended by numerous laws, notably law $26 \mathrm{I}$ of December 3, I84I, with its regulation 120 of January 31, 1842, and law 2033 of September 20, 1871 , with its regulation by decree 4824 of November 22, 1871. The decree 848 of October II, 189o, on federal procedure, contains various provisions on criminal procedure. This, with decree 1030 of November I4, I890, together with decree 2464 of February 17,1897 , and decree 2579 of August 16, 1897, governed criminal procedure in the Federal District until, by decree 8259 of September 29, I910, a code of criminal procedure in the Federal District was approved. Numerous special acts for particular matters, such as law 628 of October 28,1899 , on the public prosecution of offenses by the Ministry of Justice and other acts, to be found in recent editions of works on criminal procedure, have also been passed. The consolidation of the laws of procedure of the State of Rio de Janeiro was published by Marcellino da Gama Coelho ${ }^{1}$ in 1895 .

\section{LITERATURE}

A classic work on the older law, by Josino do Nascimento Silva, ${ }^{2}$ may warrant brief mention. A sixth edition was pub-

1 Consolidação das leis do processo criminal do estado do Rio de Janeiro de ordem de seu presidente o Exm. Sr. Dr. José Thomaz da Porciuncula, por Marcellino da Gama Coelho . . . Rio de Janeiro, Typ. Guimarães, I895. 272 p. Additamentos, 1897.48 p.

${ }^{2}$ Silva, Josino do Nascimento: Codigo de processo criminal . . . até o fim do anno de 1869 . 6th ed. Rio de Janeiro, Laemmert, 1870. $2 \mathrm{v}$. in $\mathrm{I}$. 
lished in 1870 . The classic work of Pimenta Bueno, ${ }^{1}$ consisting of a scientific commentary on criminal procedure discussing Brazilian and foreign legislation, and the philosophical principles of criminal science and criminology, has been published in several editions. The fourth was edited in rgro by Dr. Vicente Ferrer.

An excellent work on the code of criminal procedure in courts of first instance was published by Paula Pessoa ${ }^{2}$ in I899.

One of the most valuable works published in Brazil is the treatise on criminal procedure by João Mendes de Almeida, Jr., of São Paulo, ${ }^{3}$ first published in I90r, with a second edition in I9Ir. It is particularly important for its historical development of the various institutions of criminal procedure. It is divided into nine books as follows: first, Brazilian criminal procedure, a historical survey of judicial institutions and forms of procedure, the various systems, accusatory, iniquisitorial and mixed, the system of Brazilian legislation, and the police jurisdiction of criminal offenses; second, detention, preventive and other, and bail; third, formation of the corpus delicti; fourth, jurisdiction, the initiation of the criminal action and its course; fifth, motions and remedies, including habeas corpus; sixth, ordinary and special procedure; seventh, criminal defenses; eighth, dismissal of actions and conviction; execution of sentence.

An excellent textbook on criminal procedure has been published by Professor Galdino de Siqueira, ${ }^{4}$ of São Paulo. A work by Alfredo Pujol ${ }^{5}$ also deserves notice.

${ }^{1}$ Pimenta Bueno, José: Apontamentos do processo criminal brasileiro.

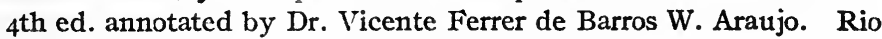
de Janeiro, J. Ribeiro dos Santos, r910. $636 \mathrm{p}$.

${ }^{2}$ Paula Pessoa, Vicente Alves de: Codigo de processo criminal de $\mathrm{I}^{\mathrm{a}}$ instancia, no Brasil, com a Lei n. 26I de 3 de Dezembro de $184 \mathrm{I}$ e Regulamento n. I20, de 3 I de Janeiro de 1842 . Disposição provisoria e decreto de $I_{5}$ de Março de $I_{842}$, com todas as reformas que se lhes seguiram, explicando, revogando e alterando muitas de suas disposições. Rio de Janeiro, J. Ribciro dos Santos, 1899. 654 p.

${ }^{3}$ Mendes de Almeida, Jr., João: O processo criminal Brasileiro. $2 d$ ed. Rio de Janeiro, F. Alves, I9ı. 2 v.

"Siqueira, Galdino de: Curso de processo criminal. São Paulo, ıوro. $390 \mathrm{p}$.

${ }^{5}$ Pujol, Alfredo: Processos criminaes. Rio de Janeiro; 1908. 3 II p. 
Probably the best form book on criminal actions is that of Carlos Antonio Cordeiro, which has been published in several subsequent editions by various editors. The fifth edition was edited in I9ro by Oscar de Macedo Soares, ${ }^{1}$ and in I9I 2 by Dr. Adherbal de Carvalho. ${ }^{2}$ In Macedo's edition, the editor appends all the recent statutes relating to criminal actions, including the decree reorganizing the administration of justice in the Federal District No. 1338 of January 9, 1905, with a regulating decree, No. 556I of June 19, 1905 (amended in 19II, supra, p. 288), and the rules of the court of appeals in criminal cases.

Various special studies have been made on topics of criminal procedure, some of which warrant mention. The revision of penal actions was the subject of a well-known study by Vieira de Araujo, ${ }^{3}$ published in 1900.

\section{DISTRICT ATTORNEYS}

The functions of the district attorney were discussed in a work published in 1907 by Tavares Bastos. ${ }^{4}$ In Part I he prints extracts from the constitutions of all the states relating to the district attorney (promotor publico). In Part II he discussss the functions of the district attorney in the State of Rio de Janeiro; in Part III, the organization of the district attorney's office and the preparation of criminal actions; and in Part IV, forms.

${ }^{1}$ Cordeiro, Carlos Antonio: Consultor criminal acerca de todas as acções seguidas no foro criminal. 5 ed. completamente refundida de accordo com a legislação promulgada depois de $\mathrm{I}_{5}$ de novembro de r889, contendo ainda os formularios dos processos criminaes intentados perante a justiça local do Districto federal e bem assim os formularios dos habeas corpus processados no juizo local e no Supremo tribunal federal por Oscar de Macedo Soares ... Rio de Janeiro [etc.], H. Garnier, [rgro]. $56 \mathrm{r}$ p.

${ }^{2}$ Cordeiro, Carlos Antonio: Formulario de todos as acções criminaes. New ed. by Dr. Adherbal de Carvalho. Rio de Janeiro, Alves, rgr2. $600 \mathrm{p}$.

${ }^{3}$ Vieira de Araujo, João: A revisão das processos penaes, segundo a doutrina, a jurisprudencia e a legislação comparada. Rio de Janeiro, 1900.

4 Tavares Bastos, José: As attribuições do promotor publico na republica contendo tudo quando diz respeito ao promotor publico . . . Rio de Janeiro [etc.], H. Garnier, 1907. 629 p. 


\section{HABEAS CORPUS}

It has already been observed that the writ of habeas corpus is of very frequent application in Brazil and that the decisions of the Supreme Court are largely concerned with questions arising under habeas corpus. Probably the best works on the subject are a monograph by Oliveira Machado, ${ }^{1}$ and one by Mendes de Moraes. ${ }^{2}$

\section{JURY SYSTEM}

A report on the operation of the jury system in Brazil, which has been preserved in the federal courts by article 40 of decree 848 of October II, I89o, incorporated as article 83 of the consolidation decree 3084 of November 5,1898 , and in the Federal District in articles 108 et seq. of decree I03o of November 14, I 890, and articles 19-22 of the law of January 9 , 1905, is contained in a note by A. Velloso-Rebello, Secretary of the Brazilian Legation in Lisbon, published in 6 Revue de l'institut de droit comparé (1913), pages 38-45. In the main, it is a translation of the relevant provisions of the abovenamed decrees. An extensive study of the jury system, with forms, has been published by José Tavares Bastos. ${ }^{3}$

A study on the procedure in the petition for pardon was published in 1878 by Souza Bandeira. ${ }^{4}$

\section{CONSTITUTIONAL LAW}

A brief outline of the important historical events in the constitutional development of Brazil has already been presented in the introductory paragraphs of the section on Brazil in this monograph. It will be recalled that on October I2, I822, Pedro I was proclaimed constitutional Emperor of Brazil. On May 23, 1823, he called a popular assembly to form a constitution. ${ }^{5}$ Its efforts were unsuccessful. The proceedings of this

${ }^{1}$ Oliveira Machado, Joaquim de: O Habeas-Corpus no Brasil. Rio de Janeiro [1908?].

${ }^{2}$ Moraes, Justo Mendes de: Recurso de "habeas-corpus." Rio de Janeiro, rgr4.

${ }^{3}$ Tavares Bastos, José: O jury na republica. 2nd ed. Rio de Janeiro, Igro. $2 \mathrm{v}$.

4 Souza Bandeira Filho, A. H.: O recurso de graça segundo a legislação brazileira. Rio de Janeiro, Typographia do imperial instituto artistico, 1878 . I2I $\mathrm{p}$.

${ }^{3}$ Actas das sessões da Assembléa geral, constituente e legislativa do imperio do Brazil. Rio de Janeiro, Typ. nacional, 1823. $2 \mathrm{v}$, 
constituent assembly were republished officially in $1876-1884 .^{1}$ The body having been dissolved, a committee of ten was appointed to draft a constitution. The resulting constitution, based on the doctrines of the French political writer Benjamin Constant and pervaded with the liberal ideas then prevailing, was accepted and promulgated on March 25, 1824. Important constitutional changes were effected, particularly by the acto addicional of $1834,{ }^{2}$ which altered the form of government of the provinces by granting them legislative assemblies. The constitution of 1824 has been translated into English. ${ }^{3}$

\section{CONSTITUTIONAL HISTORY}

An interesting work was published in $\mathrm{I} 876$ by Machado Portella, ${ }^{4}$ director of the public archives. He presents in parallel columns the provisions of the constitutions of Brazil (1824), Portugal (1826), Belgium (I831), Spain (1845), Italy (I848), and France (1830). In addition, he presents the constitutional amendments with an important section on the sources of the Brazilian constitution, article by article. Useful notes are appended.

A constitutional history of Brazil (beginning with the incipient revolutions which broke out in the provinces as early as 1789 ) down to 1834 , with an account of the various ministries and the Houses of Congress and the Council of State down to I87o has been published in two volumes by Mello Moraes. ${ }^{5}$

1 Annaes do parlamento brazileiro: Assemblea constituente, r823. Rio de Janeiro, Typ. do Imp. Instituto Aristicto, 1876-84. 6 v. in 2.

${ }^{2}$ Constituição politica seguida da lei das reformas constitucionaes, r834. São Paulo [Garraux \& Ca., 1834]. 35 p.

3 The commercial and constitutional laws of Brazil (Now first translated from the Portuguese) by $T$. Spence ... Commercial code of Brazil [promulgated under Peter II]. Constitution of Brazil [promulgated under Peter I]. London, Salford, 1866.

${ }^{4}$ Machado Portella, Joaquim Pires: Constituição politica do imperio do Brazil confrontada com outras constıtuições e annotada. . . Rio de Janeiro, Typographia nacional, $\mathrm{x} 876.424 \mathrm{p}$.

${ }^{5}$ Mello Moraes, Alexandre José de: Historia do Brasil-reino e Brasil- imperio comprehendendo: A historia circumstanciada dos ministerios, pela ordem chronologica dos gabinetes ministeriaes, seus programmas, revoluções politicas que se derão, e cores com que apparecerão, desde o dia 10 março de 1808 até $x 87$ x. Rio de Janeiro, Typ. de Pinheiro \& Cia., $187 \mathrm{I}-73.2 \mathrm{v}$. 
A classic commentary upon the constitution of 1824 , important for its discussion of its practical operation, is that of Pimenta Bueno. ${ }^{1}$ An extensive commentary upon the constitution of 1824 , a standard work in its time, was published by Rodrigues de Sousa ${ }^{2}$ in 1867-1870. Judge Lopes de Leão ${ }^{3}$ published, in 1872 , a brief study on three phases of Brazilian constitutional law. It deals with the moderating power of the Emperor and the Council of State, the executive power and parliamentary government.

An important constitutional study on the provinces was published in 1870 by A. C. Tavares Bastos. ${ }^{4}$ His work is divided into three parts, as follows: (I) The work of centralization, the government of modern states, centralization and reforms, and a comparative study on federation in the United States and the autonomy of the English colonies; (2) provincial institutions, under which he discusses the acto addicional of $\mathrm{r} 834$, the legislative assemblies, president, municipalities, police, national guard, and the administration of justice; and (3) provincial interests, under which he discusses public education, associations, immigration, public works, debt and taxation, general business of the provinces, and new provinces and territories.

Valuable information on the form of government and institutions of the Empire may be found in the published lectures of Oliveira Lima, ${ }^{5}$ an eminent scholar of Brazil, delivered at Leland Stanford University in I912.

${ }^{1}$ Pimenta Bueno, José Antonio: Direito publico brazileiro e analyse da constitução do imperio. Rio de Janeiro, J. Villeneuve, I857. 586 p.

${ }^{2}$ Rodrigues de Sousa, Joaquim: Analyse e commentario da constitução politica do Imperio do Brazil, ou theoria e pratica do governo constitucional brazileiro. S. Luiz de Maranhão, Typ. de B. de Mattos, I867-70. $2 \mathrm{v}$.

${ }^{3}$ Lopes de Leão, Polycarpo: Considerações sobre a constitução brasileira; pelo Dr. Polycarpo Lopes de Leão. . . . Rio de Janeiro, Typographia Perseverança, 1872 . $46 \mathrm{p}$.

4 Tavares Bastos, Aureliano Candido: A provincia; estudo sobre a descentralisação no Brazil. Rio de Janeiro, B. L. Garnier, I87o. $418 \mathrm{p}$.

${ }^{5}$ Oliveira Lima, Manuel de: The evolution of Brazil, compared with that of Spanish and Anglo-Saxon America . . . ed. with introduction and notes by Percy Alvin Martin ... Stanford University, Cal., The University, I9r4. $159 \mathrm{p}$. 
Two interesting official publications warrant mention. The first, ${ }^{1}$ on the organization and ministerial programs of the government from 1822 to 1889 is an account of the legislative activity of each Congress during the Empire divided by the ministry to which the legislation related. It contains notes on parliamentary discussions of important measures and particularly a valuable account of the discussion of the acto addicional of 1834 and other important laws. It includes lists of the cabinet members and members of the Chamber of Deputies and Senate in the various congresses during the Empire, together with the members of the Council of State.

The other is a compilation of the addresses of the Emperor on the opening of the various sessions of Congress from 1823 to $1889,{ }^{2}$ with a record of votes on numerous measures of importance and useful historical notes. An earlier edition had been published in 1872 .

The literature on constitutional law during the Empire, up to $\mathrm{I} 88 \mathrm{I}$, is to be found listed in Volume I, pages $85 \mathrm{I}-855$, of the Catalogue of History, issued by the National Library in I88I. (Supru, p. I94.)

\section{THE REPUBLIC}

A new epoch in the constitutional development of Brazil began in 1889. With the bloodless revolution of November I5 of that year, the Republic was proclaimed. A provisional government soon after began its activities, and in 1890 various attempts were made by the constituent assembly to secure the adoption of a constitution. The proceedings of the constituent assembly are published in the Annaes of the

${ }^{1}$ Organisações e programmas ministeriaes desde 1822 a $1889 \ldots$ trabalho organisado na Secretaria da Camara dos deputados. Rio de Janeiro, Imprensa nacional, I889. 469 p.

${ }^{2}$ Fallos do throno desde o anno de 1823 até o anno de 1889 , acompanhadas dos respectivos votos de graças da camara temporaria e de differentes informações e esclarecimentos sobre todas as sessões extraordinarias, adiamentos, dissoluções, sessões secretas extraordinarias, adiamentos, dissoluções, sessões secretas e fusões com um quadro das epochas e motivos que deram lugar a reunião das duas camaras e competente historico. Colligidas na Secretaria de Camara dos deputados. Rio de Janeiro, Imprensa nacional, I889. $923 \mathrm{p}$. 
National Congress. The senate proceedings of the preparatory sessions and of the constituent assembly have been published separately. ${ }^{1}$

A constitution was finally adopted on February 24, I891, based largely upon that of the United States. Some of the various drafts proposed during 1890 are published in some of the works on constitutional law to be mentioned hereafter. The draft of June 22, I890 was published by the Government Printing Office, ${ }^{2}$ and either this or the one of October 23,1890 , is apparently the one printed in the monograph of Elizabeth Wallace, ${ }^{3}$ published in 1894.

\section{TEXTS OF CONSTITUTION}

The actually adopted constitution of February 24, I891, is to be found translated into English in Volume I of Dodd's "Modern constitutions" (Chicago, 1909), and in Volume I of Rodriguez's "American constitutions" (Washington, 1906). It is also printed in the Brazilian Year Book edited by J. P. Wileman for 1908 and 1909, pages 25-32. An outline of the constitution is given in the handbook on Brazil issued by the Pan American Union in r9or, in the Bulletin for 1914 of the Comparative Law Bureau, and in the section on "Constitution and law," by Souza Bandeira, published in Lloyd's "Twentieth century impressions of Brazil," pages I 57-I 59 .

The constitution has been published officially. ${ }^{4}$ It erected the provinces of the Empire into Federal states with extensive autonomous powers of government. Indeed, the Brazilian constitution adopted the American theory of nonenumerated powers, by which the states possess all powers not del-

1 Annaes da Camara dos senadores, sessões preparatorias de 4 á 14 de nov. de 1890 , constituinte de 15 de nov. a 3 I de dez. de 1890 . Rio de Janeiro, $189 \mathrm{r}$.

${ }^{2}$ Constitution of the Republic of the United States of Brazil, I89o. Washington, Government Printing Office, I89I. 23 p.

${ }^{3}$ Wallace, Elizabeth: The constitution of the Argentine Republic. The constitution of the United States of Brazil, with historical introduction and notes ... Chicago, The University of Chicago Press, 1894. $95 \mathrm{p}$.

* Constituição da Republica dos Estados Unidos do Brazil. Rio de Janeiro, Imprensa nacional, r891. 39 p. 
egated to the Federal government. Summaries of the state constitutions are to be found in the Brazilian Year Book for 1908 and 1909 edited by J. P. Wileman.

Two important compilations of texts of federal and state constitutions have been published. One by Felisbello Freire ${ }^{1}$ deals in Part I with the provisions of the constitution by subject and subsumes under each topic the appropriate articles of the state constitutions with a commentary. In Part II the editor prints the constitutions of the states. $\mathrm{He}$ includes also a comparative study of the constitutions of the states among themselves and compared with the federal constitution. The volume constitutes the fourth volume of a series of works published by the author under the general title "Constitutional history of the Republic," ${ }^{2}$ in which he deals, first, with the Republican revolution of 1889 , secondly, with the provisional government, and thirdly, with the constituent assembly which drafted and adopted the constitution. Another compilation of texts of state constitutions has been edited by Domingues Vianna. ${ }^{3}$

A presentation of the provisions of the Brazilian constitution, compared with those of Argentina, the United States, and Switzerland, from which it was largely drawn, was published in 1897 by Rodrigo Octavio, ${ }^{4}$ the well-known jurist.

\section{IITERATURE}

Two important commentaries on the constitution have been published. Undoubtedly the best one is that of João Barbalho, ${ }^{5}$ published in 1902. A new edition by Aurelino Leal is in course of preparation and is expected to be published

${ }^{1}$ Freire, Felisbello de Oliveira: As constituições dos estados e a constituição federal. Rio de Janeiro, Imprensa nacional, x898. $637 \mathrm{p}$.

${ }^{2}$ Freire, Felisbello: Historia constitucional da Republica dos Estados Unidos do Brasil. Rio de Janeiro, Impr. nacional, I894. $3 \mathrm{v}$.

${ }^{3}$ Domingues Vianna, Paulo: Constituição federal e constituições dos estados . . Rio de Janeiro, F. Briguiet \& Cie., rgri. 2 v.

4 Octavio Langgaard de Menezes, Rodriga: Constituições federaes. Confronto entre a constitução federal dos Estados Unidos do Brazil com as constituções da Republica Argentina e dos Estados Unidos da America do Norte e da Suissa. Rio de Janeiro, Alves; 1897.

${ }^{5}$ Barbalho, U. C. João: Constituição federal brasileira. Rio de Janeiro, Comp. Litho.-Typ. en Sopopenha, r902. 
shortly. The other commentary is the work of Aristides Milton, ${ }^{1}$ and was published in a second edition in 1898 . Both commentaries include valuable notes on comparative law and an exhaustive commentary under each article of the constitution.

Various treatises warrant mention. Professor Filinto Ferreira Bastos ${ }^{2}$ has published a manual of constitutional law for his classes in the Faculty of Law at Bahia. He deals with the science of law, its divisions and classification and particularly public law, the theory of the state and its functions, the constitution, sovereignty, centralization and decentralization, representative constitutional government, a sketch of Brazilian constitutional history, the organs of government in Brazil and their operation, the tribunal of accounts, the political organization of the states and municipalities of Brazil, citizenship, constitutional guaranties and the bill of rights, and the procedure for the amendment of the constitution.

A work by the celebrated publicist, Soriano de Souza, ${ }^{3}$ published in 1893 , dealing with somewhat the same subjects, is highly regarded.

Dr. Rodrigo Octavio and Dr. Domingues Vianna ${ }^{4}$ have recently published an elementary treatise on the constitutional and public law of Brazil.

A treatise on constitutional law was published by Alfredo Varela $^{5}$ in a second edition in 1902 . His work includes many valuable notes, with decisions of the courts. He advocates

1 Milton, Aristides Augusto: A constituição do Brazil; noticia historica, texto e commentario ... 2. ed. cor. e augm. Rio de Janeiro, Imprensa naciorial, 1898 . $526 \mathrm{p}$.

${ }^{2}$ Bastos, Filinto Justiniano Ferreira: Manual de direito publico e de direito constitucional brasileiro de conformidade com o programma da Faculdade de direito da Bahia . . Bahia, J. Ribeiro \& Co., I9r4. $469 \mathrm{p}$.

- Soriano de Souza, José: Principios geraes de direito publico e constitucional. Recife, 1893 .

- Octavio, Rodrigo, and Domingues Vianna, Paulo: Elementos de direito publico e constitucional brasileiro. Rio de Janeiro, F. Briguiet \& Cia., r9r3. $277 \mathrm{p}$.

$\checkmark$ Varela, Alfredo: Direito constitucional brazileiro, reformas das instituções nacionaes . . 2. ed. Rio de Janeiro, H. Garnier, Ig02. $539 \mathrm{p}$. 
many reforms in the Brazilian constitution and seeks to combat. the idea that the constitution is of English or American origin.

\author{
MONOGRAPHS \\ EXECUTIVE POWER
}

Several excellent studies have been published on the powers of government. The legislative and the executive power were critically discussed in a monograph by Henrique Coelho, ${ }^{1}$ published in 1905. The author analyzes the provisions of the constitution and their actual operation in practice. Annibal Freire de Fonseca has recently published a monograph on the executive power. ${ }^{2}$

\title{
JUDICIAL POWER
}

The judicial power has been the subject of two important works-one by Pedro Lessa, ${ }^{3}$ the celebrated justice of the Supreme Court, who published in I9r 5 an exhaustive commentary on articles $55^{-62}$ of the constitution, which deal with the judicial power. He turns largely for comparative legislation to the United States and Argentina. A similar work was published in 1899 by Carvalho de Mendonça, ${ }^{4}$ another distinguished jurist.

A notable address by Ruy Barbosa on "The Federal Supreme Court in the Brazilian Constitution," delivered on assuming the presidency of the Bar Association (Instituto dos Advogados) in 1914 , is printed in volume 2 of the Revista do supremo tribunal (doutrina), pages 393-4I4.

\section{UNCONSTITUTIONALITY OF LEGISLATION}

By article 59, paragraph $\mathrm{I}$ and $60(a)$ and $(b)$ of the federal constitution, as well as article 13 of law 22I of November 20, I894, and article 6 of law 1939 of August 28, 1908 (see also consolidation decree 3084 of Nov. 5, I898, Part III, arts.

' Coelho, Henrique: O poder legislativo e o poder executivo no direito publico brazileiro. São Paulo, Typ. do Diario Official, 1905. 305 p.

${ }^{2}$ Fonseca, Annibal Freire de: Do poder executivo na republica brasileira. Rio de Janeiro, I9r6.

${ }^{3}$ Lessa, Pedro: O poder judicial. Rio de Janeiro, F. Alves, I915. 435 p.

- Carvalho de Mendonça, Manuel Ignacio: O poder judicial no Brazil. Curityba, I899. $490 \mathrm{p}$. 
744-752), the Federal Supreme Court in Brazil has the power to declare inapplicable laws which they find unconstitutional, including the annual acts of the government which are found violative of individual rights. This power extends to legislative and executive acts of the government, or of the states or municipalities. State courts possess the power over the legislation of the states, if in conflict with the state constitution. If it is alleged that the state law is in conflict with the federal laws or treaties or constitution, the case may, by an extraordinary appeal, be removed to the jurisdiction of the federal courts. The question is fully discussed in a work by Ruy Barbosa, ${ }^{1}$ published as an argument in a litigated case in 1893 , and by Pedro Lessa, in his work on the judicial power.

\section{FEDERAL SYSTEM}

Several other monographs, by reason of their importance, warrant special mention. Among these a prominent place must be assigned to the Regimen federativo of Amaro Cavalcanti, ${ }^{2}$ Justice of the Supreme Court, and one of the foremost jurists of Brazil. His work is divided into two parts, general and special. The first deals with preliminary notes on state sovereignty and unitary and federal government, a historical survey of the government of other countries, confederations of states, federations of states, and incidental questions. The special part deals with the federal union of Brazil, its formation and difficulties, federal power and the legal status of the Brazilian government compared with other federations, state power and its legal status, and state sovereignty; the operation of the various powers of government, the duality of the system of the administration of justice, including procedure, the division of taxation and revenue, the relations between federal and state governments, and the defects of the system, abuses of federal powerand state power, and political parties. An appendix prints the draft constitution under decree 914A of October

\footnotetext{
${ }^{1}$ Barbosa, Ruy: Os actos inconstitucionaes do congresso e do executivo ante a justiça federal. Capital federal [Rio de Janeiro] Companhia impressora, 1893. $249 \mathrm{p}$.

${ }^{2}$ Cavalcanti, Amaro: Regimen federativo e a Republica Brazileira. Rio de Janeiro, Imprensa nacional, 1900. 448 p.
} 
23,1890 , in substitution of the draft proposed by decree 510 of June, 1890, with the opinion of the commission of 21 appointed to consider it.

\section{MISCELLANEOUS STUDIES}

A valuable collection of studies on constitutional law was published in I9I 4 by A. O. Viveiros de Castro, ${ }^{1}$ Director of the Tribunal of Accounts and professor at the Faculty of Iaw at Rio de Janeiro. He includes essays on state sovereignty, the organs of government, the classification of states, federalism, an important study on the power of municipalities and states to issue bonds without federal consent (a proposition long debated in Congress), the parliamentary system and the functions of the president, and numerous constitutional questions such as governmental intervention, parliamentary immunities, initiative in taxation, municipal organization of the Federal District, the state of siege (martial law), the necessity of reestablishing a Council of State, the legal status of public officers, and a few other topics.

The respective property and rights of the federal government and the states was the subject of an important monograph published by Rodrigo Octavio ${ }^{2}$ in 1887 ; it received a gold medal from the Brazilian Bar Association.

Alberto Torres has recently published two interesting works. One is a study of Brazilian nationality and civilization from the point of view of political science. ${ }^{3}$ The other, on national organization, ${ }^{4}$ is a study of the land and people of Brazil and of national institutions and their interpretation. He deals with government and politics, the powers of government and their operation, and the economic status of the population. He includes in Part III a proposal of constitutional

1 Viveiros de Castro, Auguste-Olympio: Estudos de direito publico. Rio de Janeiro, J. Ribeiro dos Santos, 1914. 709 p.

${ }^{2}$ Octavio, Rodrigo: Do dominio da união e dos estados segundo a constituição federal. . . Rio de Janeiro, Imprensa nacional, 1897. $108 \mathrm{p}$.

3 Torres, Alberto: O problema nacional brasileiro, introducção a um programma de organização nacional. Rio de Janeiro, Imprensa nacional, I9I4. I50 p.

- Torres, Alberto: A organização nacional. Rio de Janeiro, Imprensa nacional, 1914. $384 \mathrm{p}$. 
revision dealing with the union and the provinces, the organs of national sovereignty, political powers, and the provinces and municipalities. At the end of the work he prints the existing constitution with his proposed draft of a revised constitution.

A brief monograph on the operation of the Brazilian constitution was published in 1914 by Aurelino Leal.1

\section{FEDERAL INTERVENTION}

The federal government has the right to intervene in matters relating to the states, first, to repel foreign invasion or the invasion of one state by another; secondly, to maintain a Republican form of government; thirdly, to reestablish order in a state, at its request; and fourthly, to assure the execution of federal laws and decrees. This right has been exercised on numerous occasions. A collection of the historical data relating to the matter was published officially ${ }^{2}$ by the Brazilian Congress in 1913 .

In cases of extraordinary emergency Congress has the power by section 2I of article 34 to declare a state of [siege (martial law) in case of attack by foreign forces, or of internal disturbance and to approve or suspend a state of siege declared by the executive power during a recess of Congress. Owing to the many local revolutions to which Brazil has been subject this power has often been invoked. A collection of the cases was published officially ${ }^{3}$ by Congress in I9I 3 .

Congress may also grant amnesty. After the revolt of the Navy in I 893 amnesty was extended to some of the leaders, while many of them were condemned to death. An argument in defense of those condemned, consisting of an exhaustive study of the right of amnesty under the decree of 1895 was published by Ruy Barbosa. ${ }^{4}$

Under Brazilian law "terrenos de marinha" is a strip of land thirty meters wide along the coast of the sea or of rivers flow-

${ }^{1}$ Leal, Aurelino: Technica constitucional brazileira. Rio de Janeiro, Typ. do Jornal do commercio, Igr4. 8I p.

${ }^{2}$ Intervenção nos estados. Rio de Janeiro, Impr. nacional, I9I3. 5 v.

${ }^{3}$ Estado de sitio: Rio de Janeiro, Impr. nacional, I9I3. $5 \mathrm{v}$.

- Barbosa, Ruy: Amnistia inversa. Caso de teratologia juridica. Segunda edição. Rio de Janeiro, "Jornal do Comercio," I896. I27 p. $71624^{\circ}-17-21$ 
ing into it. The question has been raised under article 64 of the constitution whether this strip is the private property of the federal government, or of the municipality or local community. The subject is discussed by Epitacio Pessôa ${ }^{1}$ in a small book published in 1904 .

\section{PARLIAMENTARY LAW}

The last edition of the Senate manual ${ }^{2}$ appears to be that of 1905 . Besides the rules of the Senate and of the two Houses united, it contains the constitution, the electoral law of 1904 , the law of 1892 concerning offenses by the President and his trial, the law of October 30 , r89r, organizing the federal departments, and law 5160 of March 8, I904, consolidating the laws on the organization of the Federal District. The House manual, containing much the same material, was published in 1912. ${ }^{3}$ The Presidential messages ${ }^{4}$ from $189 \mathrm{I}$ to 1910 were published officially in I 912 .

A small work for civic instruction, explaining the history and reasons for the various national holidays of Brazil, has been published by Rodrigo Octavio. ${ }^{5}$

\section{ELECTIONS}

Numerous works on election legislation have been published. Those of the Empire are now merely of historical interest. An alphabetical compilation of the laws, decrees, and rules on elections from I 823 to 1865 was published by Manuel Ferreira. ${ }^{6}$

1 Pessôa, Epitacio: Terrenos de marinha. Rio de Janeiro, I904.

2 Manual do senador. Rio de Janeiro, Typ. do "Jornal do commercio" de Rodrigues, etc., I905. 249 p.

${ }^{3}$ Manual do deputado. Rio de Janeiro, Imprensa nacional, rgr2. 335 p.

4 Documentos parlamentares. Mensagens presidenciaes (r89I-I9ro). Rio de Janeiro, Impr. nacional, I9I2. $737 \mathrm{p}$.

${ }^{5}$ Octavio, Rodrigo: Festas nacionaes; livro approvado pelo Conselho superior de instrucção publica do Districto federal e de varios estados da união. 3. ed. Rio de Janeiro, F. Alves, 1905. $\quad$ I75 p.

${ }^{6}$ Ferreira, Manuel Jesuino: Promptuario eleitoral. Compilação alphabetica e chronologica das leis, decretos, e avisos sobre materia de eleições comprehendendo as disposições desde a constituição politica do imperio até o presente. Organisada pelo bacharel Manoel Jesuino Ferreira. . . . Rio de Janeiro, E. \& H. Laemmert, 1866. $520 \mathrm{p}$. 
A work on election law by Teixeira de Freitas, jr., ${ }^{1}$ published in $188 \mathrm{r}$, was of some importance in its day. The literature on election law during the Empire, including both federal and provincial governments, is assembled in the Catalogue of History of Brazil, prepared by the National Library in I88I (vol. I, p. 81 3 et seq.).

The federal election law was entirely revised by law 1269 of November 15, 1904. It was supplemented by instructions under decrees 5391 of December I2, 1904, and 5453 of February 6,1905 . An exhaustive commentary on the new law, including the congressional debates and preceded by a historical sketch of the election law was published by Oscar de Macedo Soares ${ }^{2}$ in 1909 .

\section{SLAVERY}

Slavery in Brazil was not abolished until $\mathrm{r} 888$. Its abolition had considerable influence in persuading the land-owning class to support the Republican revolution of I889. An excellent study upon slavery in Brazil, historical, legal, and social, was published by Perdigão Malheiro ${ }^{3}$ in I 866-67.

By the law of September $28,187 \mathrm{I}$, sons of slave women born after that date were declared free, and other provisions made for the gradual liberation of slaves. The work of Luiz Francisco da Veiga ${ }^{4}$ published in 1876 contains this law of $187 \mathrm{I}$, with the decrees and orders issued by the various ministries of the government from that date up to December 31 , r 875 , including a list of all the legislative and executive acts on behalf of slaves beginning with the law of November 7 , 183r. It may be of interest to cite the report of the special

1 'Teixeira de Freitas, Jr.: Legislação eleitoral. Rio de Janeiro, I88ז.

${ }^{2}$ Macedo Soares, Oscar de: Consultor eleitoral, lei n. I269, de $_{5}$ de Novembro de I904, reforma a legislação eleitoral e da outras providencias commentada por Oscar de Macedo Soares. I. ed. contendo as instrucções expedidas pelos decretos ns. 539I de I2 de dezembro de r 904 , e. n. 5453 de 6 de fevereiro de 1905 e o formulario dos processos do alistamento dos eleitores, dos recursos e das eleições federaes. Rio de Janeiro [etc.], H. Garnier, r9o9. 6 r6 p.

${ }^{3}$ Perdigão Malheiro, Agostinho Marques: Da escravidão no Brazil. Ensaio historico, juridico e social. Rio de Janeiro, I866-67. $3 \mathrm{v}$. in $\mathrm{r}$. $586 \mathrm{p}$.

4 Veiga, Luiz Francisco da: Livro do estado servil e respectiva libertação. Rio de Janeiro, Typographia nacional, 1876. 
committee of the Chamber of Deputies ${ }^{1}$ which reported upon the law of $187 \mathrm{I}$. An interesting analysis and criticism ${ }^{2}$ of the law was also published in that year.

The legislative history of the law of 1888 abolishing slavery is to be found at page 233 et seq. of the work "Organization and ministerial programs from 1822 to I889," published officially in 1889 . (Supra, p. 314.)

\section{CITIZENSHIP AND NATURALIZATION}

The law governing the naturalization of aliens has been revised by decree 6948 of May 14, 1908. It reproduces some of the provisions of the constitution of $189 \mathrm{r}$ and makes certain changes in the law of 1902 concerning the effects of marriage on citizenship and on the citizenship of the wife and minor children of an alien. The law of November 26, r889, which had provided that all aliens in Brazil should $i p s o$ facto become citizens unless they expressly declared before their national consuls an intention to remain aliens, evoked strong protests from foreign governments and was not strictly enforced. The law of 1908 is translated in 38 Annuaire de législation comparée, pages $816-821$.

Citizenship and naturalization in Brazil were discussed in an article by $\mathrm{A}$. de Busschère in I Revue de l'institut de droit comparé (1908), pages 230-239, and by Rodrigo Octavio in volume 6 of the same periodical (I913), pages 299-3r8. The decree relating to the expulsion of aliens will be discussed under the head of "International law."

\section{ADMINISTRATIVE LAW}

Numerous works on administrative law were written during the Empire. While they are of no great practical value at the present time, they do present the theory of administrative law and are important for the history of public administration in Brazil. The leading works are the treatises published during

${ }^{1}$ Elemento servil. Parecer da Commissão especial apresentado á Camara dos Srs. deputados na sessão de 30 de junho de 187 I sobre a proposta governo de 12 de maio de mesmo anno. Rio de Janeiro, Typographia nacional, $\mathrm{r} 87$ r. $58 \mathrm{p}$.

${ }^{2}$ Analyse e commentario critico da proposta do governo imperial ás legislativas sobre o elemento servil, por um magistrado. Rio de Janeiro, Typographia nacional, 187 I. $67 \mathrm{p}$. 
the Empire by Cabral, ${ }^{1}$ Rego, ${ }^{2}$ Visconde Uruguay (one on the central government, ${ }^{3}$ and one on provinces $\left.{ }^{4}\right)$, Ribas, ${ }^{5}$ and an important work on Brazilian public law by Pimenta Bueno, ${ }^{\circ}$ part of which deals with administrative law.

Two works of importance on administrative law have been published in recent years. The one, by $A$. O. Viveiros de Castro, ${ }^{7}$ first published in 1906 , reached its third edition in 1914. In its first part it deals with administrative science, and in the second part with Brazilian administrative law as compared with that of the United States, Argentina, Chile, Switzerland, Austria, Germany, and Italy. It includes the texts of various Brazilian statutes dealing with public law.

The other work, in the form of a textbook by Professor Alcides $\mathrm{Cruz}^{8}$ of the Faculty of Law at Porto Alegre deals in Part I ( $\mathrm{I}$ ) with the organization of public administration, the President, the Departments, Congress, and the Tribunal of Accounts; (2) with the states, territories, and municipalities, and (3) with the civil responsibility of the state; and in Part II with administrative action, including thereunder public finance and taxation, police, army and navy, public property and expropriation for public use, postal, telegraph and railroad service, public education and welfare assistance, and the administrative jurisdiction of the courts.

A "compendium of administrative law," by Professor Filinto Bastos, of Bahia, is now in course of preparation.

${ }^{1}$ Cabral, P. G. T. Veiga: Direito administrativo brasileiro. Rio de Janeiro, 1859 .

${ }^{2}$ Rego, Vicente Pereira do: Elementos de direito administrativo brasileiro. Recife, $1857.2 \mathrm{v}$. in I. 436 p.

${ }^{3}$ Uruguay, Visconde de: Ensaio sobre o direito administrativo. Rio de Janeiro, $1862.2 \mathrm{v}$.

${ }^{4}$ Uruguay, Visconde de: Estudos practicos sobre a administração das provincias do Brasil. Rio de Janeiro, $1865.2 \mathrm{v}$.

${ }^{5}$ Ribas, Antonio J.: Direito administrativo brasileiro. Rio de Janeiro, I866.

${ }^{6}$ Pimenta Bueno, J. A.: Direito publico brasileiro. Rio de Janeiro, 1867. 2 v.

7 Viveiros de Castro, Augusto Olympio: Tratado de sciencia da administração e direito administrativo . . 3. ed. Rio de Janeiro, J. Ribeiro dos Santos, I9I4. $864 \mathrm{p}$.

${ }^{\star}$ Cruz, Alcides: Direito administrativo brasileiro, exposição summaria e abreviada . . . 2. ed. cor. e ampliada. Rio de Janeiro, F. Alves \& Cia., I914. 264 p. 


\section{JUDICIAL, CONTROL, OF ADMINISTRATION}

During the Empire there was a considerable judicial control of the administration by administrative tribunals and bodies. This was not exercised by separate courts, but was a power incidental to the judicial functions exercised by the Ministers of State, by the Comptroller of the Treasury, by the governors of the provinces, and by the ctstoms inspectors. The subject of judicial control of the administration occupied the attention of all the earlier writers on administrative law and was the subject of a special work by Rego Barros ${ }^{1}$ published in 1874 . The subject has recently been discussed in its history during the Empire and since the establishment of the Republic in a small monograph by Pinheiro de Andrade. ${ }^{2}$ The work contains an excellent summary of control of administrative acts from the beginning of the Empire.

The Council of State which was created by law of November 23, I84I, while not acting in a judicial capacity, nevertheless, by its advisory opinions, exercised much influence upon the development of administrative law during the Empire. Its resolutions during the period $1842-1876$ were published in seven volumes by Sobreira de Mello. ${ }^{3}$ An interesting study on the Council of State was recently published by Fernando Machado. ${ }^{4}$

\section{PUBLIC OFFICERS}

The statute governing public officers has recently been published in an edition with a preface by Dr. Guimarães Natal. ${ }^{5}$ Among several works on public officers one of the best is the monograph of Paulo Domingues Vianna, ${ }^{6}$ a separate of an

${ }^{1}$ Rego Barros: Apontamentos sobre o contencioso administrativo. Rio de Janeiro, 1874.

2 Pinheiro de Andrade, Nuno: O contencioso administrativo no Imperio e o julgamente dos actos administrativos na Republica. Rio de Janeiro, Jornal do Commercio, Rodrigues, I915. $90 \mathrm{p}$.

${ }^{3}$ Sobreira de Mello, E. X.: Imperiaes resoluções do conselho de estado $(1842-1876)$. Rio de Janeiro, $1867-76.7 \mathrm{v}$.

4 Machado, Fernando: O conselho de estado. São Paulo, Igra.

5 Estatutos dos funccionarios publicos, com um prefacio do Dr. Guimarães Natal. Rio de Janeiro, J. Ribeiro dos Santos [I9r 5 ?].

${ }^{6}$ Domingues Vianna, Paulo: Do estatuto dos funccionarios publicos. Rio de Janeiro, r915. 
opinion presented by a committee of the Instituto dos Advogados upon the draft presented to the Chamber of Deputies providing for the adoption of an administrative code (codigo administrativo). It is a valuable contribution on the rights and duties of public officers, including all the legislation in force relating to the subject.

\section{RESPONSIBILITY OF THE STATE}

The Government in Brazil is under far greater liability to suit at the hands of individuals injured by acts of the government or its officers than is the United States. The Supreme Court has jurisdiction of all cases arising out of an injury to private rights committed by officers under color of authority, extending even to cases sounding in tort. Indeed, the individual appears to be protected against acts of the state acting as a corporation to an extent even greater than that granted by the decisions of the Conseil d'Etat in France. This protection of individuals and liability to suit of the government is provided for in the Constitution and has been expressly renewed in articles $I_{4}$ and $I_{5}$ of the new civil code. It was discussed by Amaro Cavalcanti at page II6 et seq. of his article on "The federal judiciary in Brazil" in 6o University of Pennsylvania Law Review and was the subject of a special work $^{1}$ on the civil responsibility of the state, published in 1905. This work, the ablest and practically the only one of its kind published in South America, contains an excellent analysis of the theory of state liability to suit at the hands of injured individuals, and a valuable discussion of the coinparative law of the subject.

\section{EXECUTIVE DEPARTMENTS}

The executive departments of the Republic were organized in 1891 and reorganized in part by executive decree 11436 of January 13, I915. An important source of administrative law is to be found in the opinions of the executive departments. The annual report of the Minister of Justice and Interior is of particular value.

${ }^{1}$ Cavalcanti, Amaro: Responsabilidade civil do Estado. Rio de Janeiro. 1905. $634 \mathrm{p}$. 
When Amaro Cavalcanti was Minister of Justice in 1898 he directed the preparation of a historical account ${ }^{1}$ of the various bureaus, functions and powers within the jurisdiction of his Ministry. This work, published in 1898 , contains a legislative and statistical history of the following subjects: The secretaries of state, elections, naturalization, the registration of civil status, public health, the national guard, judicial and police organization, the House of Correction, the fire department, insane asylums, primary and secondary education, the Faculties of Medicine at Rio de Janeiro and Bahia, the Faculties of Law at São Paulo and Recife, the Polytechnic School at Rio de Janeiro, the School of Mines at Ouro Preto, the National Archives, the National Museum and the National Library, the School of Fine Arts, the Institute of Music, and various other educational and scientific institutions and academies.

\section{MUNICIPALITIES}

Municipal organizations during the Empire were governed by a law of October I, I 828 , as subsequently amended. A useful work by Cortines Laxe ${ }^{2}$ published in 1868 annotated this law and its amendments, and presented a good account of the functions of municipal officers and a review of the history of municipalities and their organization, especially of the municipalities in the Province of Rio de Janeiro.

The organization of municipalities is now within the jurisdiction of the states.

The administration of the Federal District was reorganized by decree 5160 of March 8, 1904. A compilation of the legis-

${ }^{1}$ Noticia historica dos serviços, instituções e estabelecimentos pertencentes a esta repartição, elaborada por ordem do respectivo ministro Dr. Amaro Cavalcanti. Publicação official. Rio de Janeiro, Imprensa nacional, $1898.626 \mathrm{p}$.

${ }^{2}$ Cortines Laxe, João Baptista: Regimento das camaras municipaes, ou, Lei de $I^{\circ}$ de outubro de 1828 ; annotada com as leis, decretos, regulamentos e avisos que revogão ou alterão suas disposições e explicão sua doutrina; precedida de uma introducção historica, e seguida de sete appensos, contendo o ultimo uma breve noticia da formação dos municipios da provincia do Rio de Janeiro. Rio de Janeiro, E. \& H. Laemmert, r 868 . $290 \mathrm{p}$. 
lative provisions relating to the municipal organization of the Federal District with an introduction on their sources was published in I 914 in a pamphlet by Alexandre Soares de Mello. ${ }^{1}$

\section{PUBLIC WORKS}

A chronological index of the laws, decrees, and departmental orders and decisions relating to public works from I 808 to 1895 has been published officially. ${ }^{2}$ The best source of information for the development of public works and the legislation affecting the subject, including concessions, is the annual report (Relatorio $)^{3}$ of the Minister of Industry and Public Works.

\section{RAILROADS}

An appendix of this volume contains railroad statistics." After many years of discussion Congress provided by law 268I of December 7, 1912, for the civil responsibility of railroads, under certain circumstances, in the transportation of freight and passengers. The law contains 26 articles.

\section{PORTS}

The laws relating to the development of the ports of the Republic, including all contracts and official acts and concessions relating to docks, port works, dredging, and similar matters covering the years $1831-1891$ were collected in a volume by Antonio José Caetano, jr., ${ }^{3}$ published officially. A continuation of this work covering the years rgor to rgr I was

${ }^{1}$ Soares de Mello, Alexandre: Compilação das leis federaes sobre a organisação municipal do Districto Federal. Rio de Janeiro, Impr. nacional, 1914. $55 \mathrm{p}$.

${ }^{2}$ Indice chronologico das leis, decretos e decisões concernientes . . . a obras publicas . . . (1808-r895). Rio de Janeiro, Impr. nacional, r 896 .

${ }^{3}$ Ministerio da industria, viação e obras publicas. . . . Relatorio . . . Rio de Janeiro, Imprensa Nacional r893-1915 and cont.

4 Directoria geral de obras e viação. Estatistica das estradas de ferro da União e das fiscalisadas pela união. Rio de Janeiro, I89r-.

${ }^{3}$ Caetano, Antonio José, jr.: Repertorio da legislação sobre docas, portos maritimos e terrenos de marinha $(183 r-189 r)$. Rio de Janeiro, Impr. nacional, rgot. 
published officially in 1912. ${ }^{1}$ In a general part it deals with the acts and legislation of general interest and in a special part it is divided by states. For the principal ports there is a historical review followed by all the legislation relating to them.

\section{WATERS}

The Brazilian legislation on waters and the control of water power during the Empire was exceedingly deficient. It increased rapidly in quantity after the establishment of the Republic.

In 1904 Alfredo Valladão ${ }^{2}$ published a treatise on public and private streams and rivers, which was designed to help the legislator in preparing a modern law for Brazil. By article 35 of law 1617 of December 30, I906, Valladão was authorized by the government to prepare the draft of a code of water law, which he published with a valuable explanatory report ${ }^{3}$ in 1907 .

One of the ablest treatises on the legal status of waters, both public and private, the rights of riparian owners, the use of public waters, the control of the state in the concession of their use to private persons and the control of water power was published by Manuel Ignacio Carvalho de Mendonça, ${ }^{4}$ one of the foremost jurists of Brazil.

The law of waters is summarized in the appendix (by P. J. Eder) of the paper on "Laws and regulations regarding the use of water in Pan-American countries" read by Rome G. Brown before the Pan-American Scientific Congress in Washington in 1916.

${ }^{1}$ Portos do Brazil. Leis, decretos, contractos e mais actos officiaes sobre os portos do Brazil, com ennotações e noticia resumida dos estudos, projectos, concessões e obras de melhoramento nelles executados de Igor a I9II. Supplemento ao relatorio do ministro de estado da viação e obras publicas, Dr. José Barboza Gonçalves. Rio de Janeiro, Imprensa nacional, I9I2. $592 \mathrm{p}$.

${ }^{2}$ Valladão, Alfredo: Dos rios publicos e particulares. Bello-Horizonte, I904. II2 p.

${ }^{3}$ Valladão, Alfredo: Bases para o codigo das aguas da republica. Rio de Janeiro, Imprensa nacional, r907. $84 \mathrm{p}$.

${ }^{4}$ Carvalho de Mendonça, Manuel Ignacio: Rios e aguas correntes em suas relações juridicas; monographia . . . Coritiba, A. Rocha \& Cia., r909. $3^{8 I} \mathrm{p}$. 
The taxation of water consumption is a matter of municipal regulation: In the Federal District it is governed by decree 5I4I of February 27, I904.

\section{EMINENT DOMAIN}

The procedure for expropriation was regulated by law I02I of August 26, I903, which applied law 810 of July ro, I855. The laws governing expropriation for public use in connection with public works under the jurisdiction of the federal government and the Federal District were consolidated and revised by decree 4596 of September 9, 1903, in which year the great improvements were effected in the city of Rio de Janeiro.

An excellent commentary upon the regulation of September 9, 1903, was published in that year by A. Leite Solidonio. ${ }^{1}$ A work on the same subject has been published by Sá Albuquerque. $^{2}$

\section{POSTAL LEGISLATION}

Except for the Postal Guide, the only work of importance on postal legislation which need be cited is that of Paulo Orosimbo, ${ }^{3}$ a compilation of the postal legislation in force in 1898 .

\section{MINING LAW}

The constitution of $189 \mathrm{I}$, article 72 , provided that all mines shall belong to the owners of the soil, with the limitations that may be established by law to encourage the development of mining. This settled a long disputed question as to whether ownership in the soil included that of the subsoil, or whether the state owned the mines, as well as the relationship between the discoverer and the owner of a mine. The constitution also provided that mines and vacant lands situated in the

\footnotetext{
${ }^{1}$ Solidonio, A. Leite: Desapropriação por utilidade publica. Commentario ao regulamento de 1903 que modificou e consolidou as leis em vigor; seguido do texto das mesmas leis. Rio de Janeiro [1903]. I60 p.

${ }^{2}$ Sá Albuquerque, João de: Desapropriação por utilidade publica. Varias disposições de leis, colleccionadas e adaptades á legislação actual. Rio de Janeiro, J. Ribeiro dos Santos [I9ro?].

${ }^{3}$ Orosimbo, Paulo: Repertorio synthetico da legislação postal brasileira. São Paulo, 1898. $240 \mathrm{p}$.
} 
states shall belong to them, with the union having a right to that portion of the territory which may be necessary for the defense of the frontier, for fortifications, military constructions, and federal railways. There has been a great deal of legislation, particularly administrative, on the part of the states in mining matters.

An excellent work on the mines of Brazil was published in three volumes in 1904 by Pandiá Calogeras. ${ }^{1}$ The first two volumes deal with the history of mining and mining methods and statistics. They turn then to the various classes of mines-diamonds, precious stones, rare metals, iron, manganese, copper, silver, and other substances, including under each the history of the development of the industry, the methods of mining, the geology, and an extensive bibliography. Volume three is devoted to mining legislation, including the original Portuguese law, the development in Brazil, property in mines under the constitution, the jurisdiction of the federal government, the limitations on property in mines, the attempts at codification, state legislation, and an appendix containing the drafts of laws.

A valuable alphabetical and chronological compilation of the laws relating to mining was published in $\mathrm{r} 88_{4}$ by Francisco Ignacio Ferreira, ${ }^{2}$ Chief of the Division of Mines. It contains an interesting introduction on the comparative law of mining, with an alphabetical reprint of the principal legislation and a chronological list of the provincial concessions for mining.

An important federal mining law relating to property owned within the jurisdiction of the federal government was enacted on January 6, ig15 (law 2933). In Title I it regulates the property in mines, dealing with mines in general, servitudes, and the police of mining, and in Title II with mines in the ownership of the union, concessions, police, supervision, taxation, and general provisions. It provides for the terms upon

${ }^{1}$ Pandiá Calogeras, João: As minas do Brasil e sua legislação. Rio de Janeiro, Impr. nacional. I904-5. $3 \mathrm{v}$.

${ }^{2}$ Ferreira, Francisco Ignacio: Repertorio juridico no mineiro. Consolidação alphabetica e chronologica de todas as disposições sobre minas, comprehendendo a legislação antiga e moderna de Portugal e do Brasil. Rio de Janeiro, Typ. Nacional, 1884.356 p. 
which mines belonging to the union may be granted for exploitation to private persons or corporations.

Walmesley's " "Guide to the mining laws of the world" is not of much value for Brazil.

\section{IMMIGRATION AND COLONIZATION}

The latest governmental regulation on immigration and colonization is decree $908 \mathrm{I}$ of November 3 , I 911 , consisting of 277 articles. The decree has been published officially in an English translation ${ }^{2}$ by the Brazilian Department of Agriculture and contains detailed provisions for the development of vacant land and colonization in the Republic.

In connection with the reports of the United States Immigration Commission, a report on Brazil was prepared, dealing with colonization and immigration. ${ }^{3}$ While the information is of some interest, the report is guided by the former decree 6455 of April 19, 1907, which is translated at pages 81 8-838 of the October, 1907, Bulletin of the Pan American Union.

\section{PUBLIC LANDS}

The law on public lands was enacted on September 18,1850 (law 601). A brief history of the act is to be found at pages 107-108 of the work Organisaçoes e programmas ministeriaes desde $1822 \quad a$ I889, published officially by the Chamber of Deputies in 1889. A report on the land law was published by A. Velloso-Rebello in 2 Revue de l'institut de droit comparé (1909), pages 839-846. Decree 908I of November 3, I91 I, on immigration and colonization contains the principal provisions of law relating to public lands.

One of the classic works on the land law is that of J. M. de P. Vasconcellos. ${ }^{4}$

'Walmesley, Oswald: Guide to the mining laws of the world. London, Eyre \& Spottiswoode [etc.], I894. $33^{\mathrm{I}} \mathrm{p}$.

2 Decree n. 908I of Nov. 3, I9Ir, regulating the service of immigration and colonization. Rio de Janeiro, Typ. do Servico de estatistica, 19r3. $23 \mathrm{p}$.

${ }^{8}$ Immigration Commission: The immigration situation in other countries: Canada, Australia, New Zealand, Argentina, Brazil ... Washington, G. P. O., Igrr. 229 p.

4 Vasconcellos, J. M. de P.: Lei das terras. Rio de Janeiro [I $87 \mathrm{I}$ ?]. 


\section{AGRICULTURE}

For many years attempts were made to enact laws governing contractual relations between the landowners and agricultural laborers. The President in 1896 vetoed a bill on this subject which had passed both Houses. Decree 979 of January 6,1903 , finally regulated the organization of agricultural and industrial cooperative organizations. Law 1637 of January 5, I907, governed trade unions and cooperative syndicates, or guilds, and cooperative societies.

Decree 9213 of December I5, I9I I, provided for the regulation of agricultural inspection and protection. It was intended for the development of agriculture and related industries. Brazil has enacted numerous laws for the development of agriculture and forestry. The subject is discussed in 6 Revue de l'institut de droit comparé (1913), page 492.

The executive decree I 1460 of January 27 , I91 5 , provides for the organization of a "service of pastoral industry" to be attached to the Department of Agriculture, Industry, and Commerce.

The International Institute of Agriculture at Rome publishes annually an Annuaire internationale de législation agricole, in which Brazilian and other South American legislation on agricultural matters is to be found.

\section{EDUCATIONAL LAW}

Public instruction, primary and secondary, is within the jurisdiction of the state and municipal authorities. Higher education is for the most part in the control of the federal government. The federal government maintains two agricultural schools, four law schools, four military schools, two medical schools, one naval school, and one school of mines. It also maintains the Gymnasio Nacional, a secondary school. The states render no reports on education to the federal government and only São Paulo appears to have made a serious effort to solve the problem of public education. But little heed appears to have been paid to primary education. It will be of some interest to mention a report on secondary and higher education presented in 1882 to the Chamber of Depu- 
ties by a Commission on Public Instruction under the chairmanship of Ruy Barbosa. ${ }^{1}$

A new law on higher education, which comes within the jurisdiction of the Minister of Justice and Interior was approved by decree 8659 of April 5, I9I I. This decree, with an explanatory report, has been published officially. ${ }^{2}$

It may be of interest to cite the regulations governing some of the educational institutions under the jurisdiction of the federal government. The School of Mines ${ }^{3}$ at Ouro Preto is governed by a decree of 1875 . The Instituto Benjamin Constant, ${ }^{4}$ the National Institute of Deaf-Mutes, ${ }^{5}$ the National Institute of Music, ${ }^{6}$ the Faculties of Medicine, ${ }^{7}$ and the Collegio Pedro $\mathrm{II}^{8}$ are all governed by decrees of I9I I and the Gymnasio Nacional ${ }^{9}$ by a decree of 1898 .

1 Commissão de instrucção publica: Reforma do ensino secundario y superior. Parecer e projecto (relativo ao decreto n. 7247 de Ig de abril de I879) apresentado em sessão de I3 de abril de I882 pela Commissão de instrucção publica, composta dos Srs. Ruy Barbosa (relator), Thomaz do Bomfim Spindola e Ulysses Machado Pereira Vianna, seguido de um additamento organizado na secretaria da Camara dos deputados contendo os projectos relativos ao assumpto, e respectivo andamento, apresentados no decennio de $1870-\mathrm{r} 880$. Kio de Janeiro, Typ. nacional, r882. 74, $25 \mathrm{p}$.

${ }^{2}$ Lei organica do ensino superior e do fundamental da republica, approvada pelo decreto n. 8.659, de 5 de abril de rar I (precedida da exposição de motivos). Rio de Janeiro, Imprensa nacional, IgIr. 29 p.

${ }^{3}$ Regulamento da Escola de minas creada por decreto n ${ }^{\circ} .6026$ de 6 de novembro de 1875 . Rio de Janeiro, Typographia nacional, I875. $24 \mathrm{p}$.

${ }^{4}$ Regulamento do Instituto Benjamin Constant, approvado pelo decreto no. 9.026, de 16 de novembro de rgrr. Rio de Janeiro, Imprensa nacional, I9I2. $32 \mathrm{p}$.

${ }^{5}$ Regulamento do Instituto nacional de surdos-mudos, approvado pelo decreto n. 9:198 de r2 de dezembro de r9rI. Rio de Janeiro, Imprensa nacional, 1912. $23 \mathrm{p}$.

- Regulamento do Instituto nacional de musica, approvado pelo decreto n. 9.056, de 18 de outubro de I9II. Rio de Janeiro, Imprensa nacional, I9r. $20 \mathrm{p}$.

'Regulamento das faculdades de medicina, approvado pelo decreto $\mathrm{n}$. 8.66r, de 5 de abril de rgIr. Rio de Janeiro, Imprensa nacional, I9II. I7 p.

${ }^{8}$ Regulamento do Collegio Pedro II, approvado pelo decreto n. 8.660, de 5 de abril de rوır. Rio de Janeiro, Imprensa nacional, I9II. I8 p.

${ }^{9}$ Regulamento para o Gymnasio nacional e ensino secundario nos estados, approvado pelo decreto $n .2857$ de 30 de março de 1898 . Rio de Janeiro, Imprensa nacional, I898. $54 \mathrm{p}$. 


\section{PUBLIC HEALTH}

Brazil has had to contend with serious problems of public health, for certain virulent diseases, such as yellow fever, have been endemic in some of the principal parts of the Republic. Excellent administration of the Public Health Service has assisted greatly in eliminating the more dangerous diseases. Various decrees in 1904 reorganized the Public Health Service, for example, law $115 \mathrm{I}$ of January 5,1904 , with the important decree 5122 of February 26, 1904. Attention should also be called to decree $5 \mathrm{I} 57$ of March 8, 1904, against yellow fever; decree $5^{\text {I }} 5^{8}$ of March 8, 1904, placing the Public Health administration at the expense of the federal department; and decree 5224 of March 8, I904, governing the judicial procedure in matters of public health, hygiene, and sanitation. A law of October 3 I, 1904, deals with compulsory vaccination.

The Public Health Service was reorganized by executive decree 10821 of March 18, 1914, an important regulation of 357 articles, which in part revokes the organic law of superior education, decree 8659 of April 5, I9II. Important information concerning public health legislation and sanitary affairs is contained in the annual report of the Directoria geral de saude publica, ${ }^{1}$ which is under the jurisdiction of the Ministry of Justice and Interior.

A historical survey of the public health service and legislation on hygiene and sanitation from 1808 to 1907 was published officially in 1909 by Drs. Placido Barbosa and Cassio Barbosa de Rezende. ${ }^{2}$

Attention may be called to the sanitary convention ${ }^{3}$ concluded by Argentina, Brazil, Paraguay, and Uruguay in 1904 , covering public hygiene, health, and quarantine.

The Presidential message of 1896 , submitting to congress reports made by the director of medico-legal assistance to

${ }^{1}$ Directoria geral de saúde publica. Relatorio . . Rio de Janeiro, r905-.

${ }^{2}$ Directoria geral de saúde publica. Os serviços de saúde publica no Brasil especialmente na cidade do Rio de Janeiro de 1808 a 1907 (esboço historico e legislação). Trabalho organisado pelos Drs. Placido Barbosa e Cassio Barbosa de Rezende por ordem do Dr. Oswaldo Gonçalves Cruz . . . Rio de Janeiro, Imprensa nacional, rgog. 2 v.

${ }^{3}$ Convención sanitaria celebrada entre las repúblicas Argentina, Estados Unidos del Brasil, Paraguay y Oriental del Uruguay. Año I904. Montevideo, Talleres tipográficos de "La Prensa," I906. I9 p. 
insane persons, including the administrative legislation on the subject has been published separately. ${ }^{1}$

\section{LABOR LEGISLATION}

Labor legislation in a general sense is still in its earliest stages in Brazil. The most progress appears to have been made in the State of São Paulo-perhaps the most important industrial State of the Republic-where a Department of Labor was established some years ago. An important study on the indemnification of injuries sustained by workmen through accidents and the legislation on the subject was published in 1914 in the Boletim of the São Paulo Department of Labor (anno IIi, no. II, pp. 28I-462).

Decree 8072 of 1910 , providing for protection and assistance for the Indians, has been translated in 40 Annuaire de legislation comparée, pages 688-689.

\section{FINANCIAL, LEGISLATION}

\section{BANKING}

BANKING Laws.-Banks of issue were established by law of January 17,1890 , and the country divided into banking districts by subsequent laws of that year. In the banking reform of the early nineties, Ruy Barbosa, the first Minister of Finance, had a prominent part. The decree of March 8, 189o, gave the Banco do Brazil and the Banco Nacional the right to issue bank notes. By a subsequent decree these two banks were amalgamated into the Banco da Republica, with a capital of $200,000,000$ milreis and the right to issue notes. These decrees were confirmed and amended by subsequent decrees of 1892 and 1893 by which the government guaranteed the notes. These were issued against cash funds or public bonds.

By decree 233 of 1896 the government undertook the guaranty of all outstanding bank notes. A funding loan was arranged in 1898 in London with the holders of bonds. By law of December 31, 1898, the government was authorized to take the necessary steps to consolidate the internal debt and pay the interest in bonds, an arrangement adopted in the funding loan.

1 Mensagens ao Congresso nacional sobre os serviços da Assistencia medicolegal dos alienados. Rio de Janeiro, Imprensa nacional, I896. $33 \mathrm{p}$. $71624^{\circ}-17-22$ 
A conversion fund was established by law of December 22, 1906, based upon the gold received from import duties. Bank notes have now been abolished, and the conversion fund provided for by decree of December 31, 1910, raised to an exchange rate of 16 pence, is to redeem all outstanding notes. Paper money is issued by the Bureau of Conversion (Caixa de Conversão), established by law of December 29, 1906. By law $58 \mathrm{I}$ of June $20, \mathrm{r} 899$, guaranty and exemption funds were established; they were subsequently abolished, but have recently been restored.

A law of November 28, 1907, authorized the establishment of a central agricultural bank designed to assist agriculture with capital and credit. The Postal Savings Bank regulation became effective on January I, 1909. It is published in the Diario Official of November 24, 1909.

One of the best works on the monetary system of Brazil is that of Amaro Cavalcanti ${ }^{1}$ published in 1891. J. P. Wileman, ${ }^{2}$ the editor of the Brazilian Year Book, has published a study on the Brazilian currency question, which became of primary importance during the nineties.

The law governing the establishment of banks is to be found in articles $65-80$ of the decree 434 of July 4, 1891, governing the legal status of stock corporations. The decree in question is translated in the Brazilian Year Book for 1908 and 1909. Banks, like other corporations, must submit their by-laws to the government, the whole of their capital must be subscribed, and one-tenth actually deposited in cash. A similar deposit for increases of capital is required. They must deposit in the Junta Commercial (Board of Trade) or in the Register of Mortgages, their by-laws, a list of their shareholders, with the number of shares held and amounts paid in, the certificate showing a deposit of ro per cent of the subscribed capital, and the minutes of the first general meeting, and show the appointment of managers. Foreign banks must appoint a representative in Brazil with the necessary

1 Cavalcanti, Amaro: O meio circulante' nacional. Rio de Janeiro, I893. 2 v. in I. 328 p.

${ }^{2}$ Wileman, J. P.: Brazilian exchange; the study of an inconvertible currency. Dedicated to Dr. Fernando Abbott . . Buenos Aires, printed by Galli Bros., r896. 267 p. 
powers to represent the institution, and they must publish a monthly balance sheet.

As in other countries, banks are heavily taxed. The decree of authorization bears a small fixed tax of about $\$ 5$. There is an additional stamp tax of I.100 milreis (now about \$0.28) for each conto (now about $\$ 250$ ) of paid-up capital employed in Brazil. In addition there is an annual industrial tax of 80 milreis $(\$ 20)$, and a proportional tax of 20 per cent on the rent paid for the bank building.

There is an income tax of $2 \mathrm{x} / 2$ per cent on dividends distributed on the capital invested in Brazil. In addition to these taxes the Treasury Department and the Finance Department levy taxes. The Treasury Department taxes the managers 300 milreis (about $\$ 75$ ), the accountant 40 milreis (about $\$ 10$ ), besides a water tax varying according to consumption. The Finance Department taxes the bank annually about 2,500 milreis $(\$ 625)$, the manager I conto $(\$ 250)$, the accountant 20 milreis $(\$ 5)$, besides small taxes on flagstaffs, dust bins (sanitary tax), and a tax on the bank building, if owned by the bank, of 12 per cent semiannually of its rental value.

Mortgage banks also exist.

\section{PUBLIC DEBT AND TAXATION}

The annual budget of Brazil, presenting the receipts and expenditures, is published in various forms. The estimates ${ }^{1}$ are first submitted and then the law published, leis de orçamento, with a detailed account and explanation of the items, elaboração das orfamentos. In addition the Directoria de contabilidade, under the Ministry of Finance, publishes annually a provisional balance ${ }^{2}$ of receipts and expenditures and an annual synopsis. ${ }^{3}$ The Ministry of Finance, moreover, publishes at various periods the statistics of the returns of various individual taxes.

${ }^{1}$ Directoria de contabilidade: Proposta de orçamento da receita e despeza . . . Rio de Janeiro, I8-.

${ }^{2}$ Directoria de contabilidade: Balanço da receita e despeza da Republica ... e estado das dividas activa e passiva. Rio de Janeiro, 18-.

${ }^{3}$ Directoria de contabilidade: Synopse da receita e despeza. Rio de Janeiro, I8-. 


\section{LITERATURE}

One of the most valuable compilations of laws relating to all branches of fiscal legislation, including receipts, expenditures, taxation, pubiic debt, and accounting, and the administrative law of the various operations of the government relating to fiscal matters, was recently compiled and published by Carlos Olympio Barretto, ${ }^{1}$ an officer of the Department of Finance. His work is divided into two parts-first, legislation, including laws, decrees, and regulations in force on December 31, 1915, and, second, jurisprudence, including decisions, opinions. orders, departmental circulars, etc., up to June 30, 1915. Each part is arranged alphabetically. One supplement has been published, and it is proposed to keep the work up to date by the publication of further supplements.

Numerous early works on the financial system, particularly on the taxation and public debt of the Empire have been published. They are described at some length at pages $32-38$ of Amaro Cavalcanti's important work on "The elements of finance." (Infra, p. 34I.)

A classic treatise was published in 1855 by Pereira de Barros. ${ }^{2}$ An important work on the financial history, particularly the budget of the Empire from its beginning, was published in I 889 by Castro Carreira. ${ }^{3}$ An important work on the financial history of the Empire was also published by Amaro Cavalcanti, ${ }^{4}$ the well-known jurist and statesman. It was awarded a medal at the International Exposition of Legal Works held in 1894 at Rio de Janeiro. An account of the finances of the royal family from $\mathrm{r} 808$ until the downfall of the Monarchy on November 15, I889, with important documents, was published in 1890 by A. J. S. Botafogo. ${ }^{5}$

${ }^{1}$ Barretto, Carlos Olympio: Repositorio alphabetico da legislação de fazenda. Rio de Janeiro, J. Ribeiro dos Santos, I9r6. ${ }^{2} 36$ p.

2 Barros, José M. F. Pereira de: Apontamentos de direito financeiro brazileiro. Rio de Janeiro, $1855.43 \mathrm{I}$ p.

${ }^{3}$ Castro Carreira, Liberato de: Historia financeira e orçamentaria do imperio do Brazil desde a sua fundação, precedida de alguns apontamentos acerca da sua independencia, pelo senador Dr. Liberato de Castro Carreira. Rio de Janeiro, Imprensa nacional, 1889. 796 p.

${ }^{4}$ Cavalcanti, Amaro: Resenha financiera do ex-Imperio. Rio de Janeiro, $1890.336 \mathrm{p}$.

${ }^{5}$ Botafogo, A. J. S.: O balanço da dynastia . . . Offerecido ao governo provisorio dos Estados Unidos do Brazil .. R Ro de Janeiro, Imprensa nacional, $\mathrm{r} 890$. $\mathrm{I}_{5} \mathrm{I} \mathrm{p}$. 
Ruy Barbosa, the first Minister of Finance, and Amaro Cavalcanti, Minister of Finance and Minister of Justice, have had an important part in the development of the modern financial system of Brazil. Both men are masters of the subject, scientifically and practically. Numerous essays, articles, and speeches by Ruy Barbosa ${ }^{1}$ on currency questions and finance published during the early years of the Republic were issued in collected form in I892. An important work by Amaro Cavalcanti ${ }^{2}$ entitled "The elements of finance," but indeed a scientific work on the history and administration of finance in Brazil, was published in 1896 . He deals with the principles of financial administration, public expenditure, public receipts, the domain of the state, public and private, taxation, public credit and public debts, the history of financial administration and public accounting. A manual of the science of finance by Veiga Filho ${ }^{3}$ is also of value.

The presidency of Campos Salles (1898--1902) was an important period in the financial history of Brazil. The events of that period in their relation to finance were discussed in a volume by Alcindo Guanabara. ${ }^{4}$

The annual reports of the Ministry of Finance are of great importance in matters of financial legislation and administration. The department, in its various branches, was reorganized by decree $2807^{5}$ of January 31,1898 , and in important matters by law 2083 of July 30 , I9II.

The resolutions of the committees on finance of the Council of State, established by law of $184 \mathrm{I}$, are of much importance. The government, in 1867 , began the compilation of the important resolutions of this committee, which reached nine volumes up to $1879 .^{\circ}$ The opinions are arranged

${ }^{1}$ Barbosa, Ruy: Finanças e politica da republica. Discursos e escriptos. Capital federal, Companhia impressora, 1892. $475 \mathrm{p}$.

${ }^{2}$ Cavalcanti, Amaro: Elementos de finanças (estudo theorico-practico). Rio de Janeiro, Imprensa nacional, $1896 . \quad 5^{82} \mathrm{p}$.

${ }^{3}$ Veiga Filho, J. P. da: Manual da sciencia das finanças. 2nd ed. São Paulo," rgo6. $508 \mathrm{p}$.

${ }^{4}$ Guanabara, Alcindo: A presidencia Campos Salles; politica e finanç̧as,

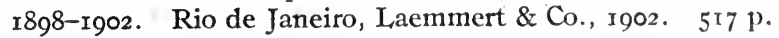

${ }^{5}$ Decreto n. 2807 de 31 de janeiro de 1898 . Reorganiza as repartições de fazenda. Rio de Janeiro, I898. 28 p.

${ }^{6}$ Imperiaes resoluções do Conselho de Estado na secção de fazenda desde o anno em que começou a funcionnar, I842-r879. Rio de Janeiro, Typ. nacional, 1867-r879. $9 \mathrm{v}$. 
chronologically but are indexed. The first editor was Emilio $\mathrm{X}$. Sobreria de Mello, followed by Joaquim Isidoro Simões.

The leading work on taxation in Brazil is that of Augusto O. Viveiros de Castro, ${ }^{1}$ first published in 1901 , with a second edition in 1910. He deals with the theory of taxation, drawing on comparative law, and covers all the regulations of Brazilian law relating to taxation, including circulars, decisions of the courts, and administrative orders. His work is divided as follows: the definition of the budget, public expenditure and receipts, a historical survey of taxation, the principal direct taxes, other direct taxes, indirect taxes, taxes on articles of consumption, stamp taxes, transfer taxes, judicial costs, taxation of corporations, lottery taxes, fees for the industrial services of the union, e. g., posts, telegraph, railroad, water, and in the Federal District the printing office and the mint, and finally a review of the financial situation of the principal states of Europe and the federal government of the United States.

An interesting account of the division of the taxing power between federal and state governments in Brazil is presented in Lloyd's "Twentieth century impressions of Brazil," pages r62-163.

Interstate taxes is the subject of a work published in 1913 by Augusto Meira, ${ }^{2}$ of the Faculty of Law at Pará. It constitutes a valuable interpretation of article II of the federal constitution.

The federal stamp tax created by decree 3564 of January 22 , 1900, and revised by law 2919 of December 31, 1914, with its related decrees, was annotated with the decisions of the Treasury Department, the Supreme Court, and the tribunal of accounts, by Carlos Olympio Barretto, ${ }^{3}$ of the Department

Viveiros de Castro, Augusto Olympio: Tratado dos impostos (estudo theorico e pratico) pelo dr. Augusto Olympio Viveiros de Castro . . . 2. ed. Rio de Janeiro, Imprensa nacional, I9ro. $828 \mathrm{p}$.

${ }^{2}$ Meira, Augusto: Impostos inter-estadoaés. Pará, I913. Io5 p.

${ }^{3}$ Ministerio da fazenda: Regulamento do imposto do sello federal a que se refere o decreto n. 3564 de 22 de janeiro de I900, organisado de accôrdo com a lei n. 2919 de 3 I Dec. I914, e anteriores que o modificaram, annotado com toda a jurisprudencia do Thesouro nacional, accordãos do Supremo tribunal federal e Tribunal de contas, seguido do regul. das facturas commerciaes e de um indice alphabetico das tabellas, por Carlos Olympio Barretto (funccionario da Fazenda). Rio de Janeiro, J. Ribeiro dos Santos, I915. 124 p. 
of Finance. An alphabetical compendium of the stamp taxes, annotating the regulamento of 1900 , has also been published by Julio Ferreira, ${ }^{1}$ Judge in Christina.

An annotated edition of the decree II5II, of March 4, 1915, providing for the taxation of articles of consumption, has recently been published by Carlos O. Barretto. ${ }^{2}$

The power of states and municipalities to contract external loans was the subject of a monograph by Nogueira Almeida, ${ }^{3}$ published in 1904 . It will be recalled that the relation of the federal government to state and municipal loans was the subject of a bill introduced in Congress and discussed at length in the work of Viveiros de Castro, "Studies in public law." (Supra, p. 320.)

The right of the union and of the states and municipalities independent of the agreement of their creditors to convert or redeem in advance their outstanding debts, was treated in a monograph published in 1912 by Nogueira Almeida, ${ }^{4}$ professor at São Paulo.

Here it may be observed that the works on political economy discuss to some extent questions of finance.

Brokers of public funds were governed by decree 1359 of April 20, I 893 and law 354 of December I6, I 895, with its regulation under decree 2475 of March 13,1897 .

\section{COURT OF ACCOUNTS}

A Tribunal of Accounts was provided for by article 89 of the constitution to audit the accounts of receipts and expenditures, and to pass upon their legality before their presentation to Congress. The court is composed of four members, and acts as a Comptroller of the Treasury. It was

${ }^{1}$ Ferreira, Julio Octaviano: Promptuario do sello do papel. Rio de Janeiro [1905?]. II 8 p.

${ }^{2}$ Ministerio da fazenda: Regulamento para a arrecadação e fiscalisaçāo do imposto de consumo, approvado pelo decreto n. II 5 II de 4 de março de I9I5, annotado e augmentado de uma synopse alphabetica, por Carlos Olympio Barretto (funccionario de Fazenda). Rio de Janeiro, J. Ribeiro dos Santos, I9I5. I35, I53-I69, I9I$201 \mathrm{p}$.

${ }^{3}$ Nogueira Almeida, J. L. de: Podem os estados e os municipios contrahir emprestitos externos? São Paulo, 1904.

4 Nogueira, Almeida J. L. de: E'direito da União, dos Estados e dos municipios, independente do accordo dos credores, a conversão ou a resgate antecipado das suas dividas. São Paulo, Ig̣ı. 
organized during the Republic by decree of December 17, I 892, as amended by law of October 8,1896 , and its regulation of December 23, 1896 . The court has been described in a note by Busschère in 4 Revue de l'institut de droit comparé (I9II), pages $352-358$, a résumé of an account given by Viveiros de Castro.

\section{CUSTOMS LAWS}

The customs tariff of Brazil has frequently been changed. Even during the time of the Empire customs tariffs were enacted in $1857,1869,1874,1879$, and 1887 . The tariff now in force was established by executive decree 3617 of March 19, 1900. The legislative authority for this tariff and for the subsequent changes which are made almost annually are to be found in the annual budget law passed by Congress. Numerous editions have been published of the customs tariff in force. One of the best of these is the publication of the house of J. Ribeiro dos Santos ${ }^{1}$ in 1913 , which contains all the annual amendments enacted subsequent to the draft of 1900. This compilation was revised and brought down to date in 1915. The same house has published the consolidation of the customs laws by Sa Albuquerque, ${ }^{2}$ consisting of 672 articles, and including in an appendix the law 2524 of December 3I, I9I I, on customs administration.

A new proposed tariff which had been in course of preparation for some years was published on August 2, 1913; an English translation of it was published officially by Great Britain. ${ }^{3}$

1 Tarifa das alfandegas, revista e annotada de accordo com todas as

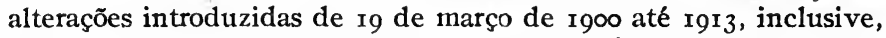
por leis e actos officiaes posteriores, contendo em appendice o regulamento de facturas consulares, o de isenções de direitos, o de serviço relativo á exportação de artigos de producção nacional para portos brasileiros em transito por territorio extrangeiro . . . por um empregado de Fazenda. Rio de Janeiro; J. Ribeiro dos Santos, I9I3. $240 \mathrm{p}$.

${ }^{2}$ Sá e Albuquerque, João de: Nova consolidação das leis das alfandegas e mesas de rendas da Republica. Rio de Janeiro, J. Ribeiro dos Santos, I9I5. 3 I $2 \mathrm{p}$.

${ }^{3} \mathrm{New}$ draft customs tariff for Brazil. Translation of the new draft customs tariff for Brazil, with comparison of the proposed and existing rates of duty. London, H. M. Stationery Off., by Darling \& Son, 1913. I $5^{2}$ p. (Gt. Brit. Parliament. Papers by command. Cd. 7094.) 
While containing numerous changes, it was largely a consolidation of the existing law. It was not enacted by Congress, and a new tariff commissiom is now in session for the purpose of revising all the tariff schedules. It may be observed that the Brazilian tariff is probably higher than that of any other country of the world.

An excellent account of the customs tariff of Brazil, its form, the method of paying duties, its principal features, the various charges incidental to importation into the country, and customs procedure is to be found at pages II $5^{-I} 4_{2}$ of the work of Frank R. Rutter," "Tariff systems of South American countries," published as a bulletin of the Department of Commerce. A discussion of the characteristics of the Brazilian tariff and of the customhouse procedure and administration and related matters is to be found at pages $30-78$ of the Report on trade and tariffs in Brazil, Uruguay, Argentina, Chile, Bolivia, and Peru recently published (June 30, 1916) by the Federal Trade Commission.

Export taxes by the federated states of Brazil, which are authorized by the constitution, are levied on numerous products of the states, the tax varying from year-to year. It is levied on such state products as rubber and other staples of the country.

By a reciprocity agreement of 1891 certain American articles were admitted free into the country and others granted a considerable reduction in duty. While it was soon allowed to lapse, it was renewed in 1904 in favor of certain articles and subsequently extended to others. The preferential tariff on American products as it existed in 1908 has been published officially. ${ }^{2}$ The reduction was 20 per cent for most articles and 30 per cent in the case of wheat flour, a reduction granted in return for concessions made to Brazilian products. An account of this preferential tariff to American articles is given

1 Tariff systems of South American countries, by Frank R. Rutter. Tariff series 34. (Bureau of Foreign and Domestic Commerce, Department of Commerce), Washington, Government Printing Office, rgr6. $308 \mathrm{p}$.

2 Brazil. Preferential tariff on American products. Washington, Government Printing Office, Ig08. 4 p. (U. S. Bureau of Manufactures. Tariff series, No. 16.) 
in Dr. Rutter's report, page I 21. The Department of Finance ${ }^{1}$ publishes annually an analysis of the customs and internal revenue duties.

\section{MILITARY AND NAVAL LAW}

A digest of the military legislation in force in the army of Brazil in 1870 has been published by Antonio José do Amaral. ${ }^{2}$ A synopsis of Brazilian legislation enacted up to 1878 , which was of interest to the Ministry of War, was published by Nascimento e Silva ${ }^{3}$ in a second edition, $1879-80$. A supplement ${ }^{4}$ to this work covering the years $1879-1884$ was also published. These works were compiled from the legislation in print, from the orders of the different Ministries, from the orders of the day of the army, and from different works published in Brazil and in Portugal.

A collection of the opinions of the Council of State in matters relating to the Ministry of War from 1842 , the date of its creation, until 1872 was edited by Nascimento e Silva ${ }^{5}$ in 1884. A collection ${ }^{6}$ of the orders of the supreme military council and the military court from 1823 to 1856 was published in $\mathrm{r} 86 \mathrm{r}$.

A textbook on law for the use of students in the Military College has been published in two volumes by Espirito Santo. ${ }^{7}$

${ }^{1}$ Directoria das rendas publicas. Analyse das rendas aduaneiras e internas . . . Rio de Janeiro, 18-.

${ }^{2}$ Amaral, Antonio José do: Indicador da legislação militar em vigor no exercito do imperio do Brasil. 2. ed. Rio de Janeiro, Typographia nacional, 1870-72. $3 \mathrm{v}$. in 4 .

${ }^{3}$ Nascimento e Silva, Manoel Joaquim: Synopsis de legislação brazileira até 1878 cujo conhecimento mais interessa aos empregados do ministerio da guerra. Rio de Janeiro, Oliveira \& Laemmert, I879-80. 2d ed. 3 v.

${ }^{4}$ Nascimento e Silva, Manoel Joaquim do: Synopsis da legislação Brazileira cujo conhecimento mais interessa aos empregados do ministerio da guerra, I879-1884. . . . Rio de Janeiro, 1885. 434 p.

${ }^{5}$ Nascimento e Silva, M. J. do: Consultas do conselho de estado . . . relativas ao ministerio da guerra ... I842-66, 1867-72. Rio de Janeiro, I884-85. 2 v.

${ }^{6}$ Collecção de provisões do conselho supremo militar e de justiça de I823 a 1856. Rio de Janeiro, F. \& H. Laemmert, I861. 334 p.

${ }^{7}$ Espirito Santo, V. A. do: Compendio para a cadeira de direito da escola militar. Rio de Janeiro, rgoz. 2 v. 
It is divided into five parts: Natural law, including the principles of legal science; public law; constitutional law; international law, public and private; and military law. It is a useful résumé of the subjects covered.

An officer's handbook, consisting of the provisions relating to the National Guard, was published by direction of Amaro Cavalcanti, Minister of Justice, by Benevenuto Magalhães ${ }^{1}$ in 1898 .

A compilation in six volumes of the laws relating to the navy of Brazil was published in $188 \mathrm{I}-82$ by Leal Sobrinho. ${ }^{2}$

\section{ECCLESIASTICAL LAW}

During the Empire, ecclesiastical law was of much importance by reason of the close association between church and state and of the many matters, even affecting civil life, which came within the jurisdiction of the church. Catholism was the state religion. Shortly after the proclamation of the Republic in 1889 , however, church and state were separated (decree of Jan. 7, I 890); cemeteries were nationalized (decree of Sept. 27, 1890); and only civil marriages were recognized. These reforms, with the establishment of the freedom of religious worship, were incorporated in article 72 of the constitution of $\mathrm{r} 89 \mathrm{r}$.

The works on ecclesiastical law are of importance in the: historical development of Brazilian law, and practically all of them were written during the Empire. An index of the ecclesiastical legislation from 1500 to 1874 was published by Campos Porto, ${ }^{3}$ and an alphabetical digest of the provisions

${ }^{1}$ Magalhães, Benevenuto: Guia pratico para o official da Guarda nacional; organisado por determinação do Dr. Amaro Cavalcanti, ministro da justiça e negocios interiores, pelo Ten. Cor. Benevenuto Magalhães. (Disposições principaes em vigor na Guarda nacional, consolidadas as da lei n. 602 , de $185^{\circ}$ e seus regulamentos e as dos decretos n. I I 21 de 1890 e n. $43 \mathrm{I}$, de 1896 . . . . Rio de Janeiro, Imprensa nacional, I898. 2 I9 $\mathrm{p}$.

2 Leal Sobrinho, Felippe José Pereira: Promptuario da legislação de marinha, compilado da legislação impressa, do expediente dos diversos ministerios e das ordens do dia do quartel general. Rio de Janeiro, $188 \mathrm{r}-82.6 \mathrm{v}$.

${ }^{3}$ Campos Porto, M. J. de: Repertorio de legislação ecclesiastica desde I500 até 1874 . Rio de Janeiro, 1875 . 
of Brazilian laws relating to ecclesiastical matters was published by Rocha Vianna ${ }^{1}$ in Bahia in 1867 . The opinions of the Council of State ${ }^{2}$ in ecclesiastical matters were published in three volumes in $1869-70$.

The leading treatises on ecclesiastical law in Brazil are the three-volume work of Monte Rodrigues ${ }^{3}$ published in 1857 and the important work on Brazilian civil and ecclesiastical law by Candido Mendes de Almeida. ${ }^{4}$ It consists of a chronological compilation of the ecclesiastical laws in force in Brazil, with historical notes. It is the leading work of its kind published in Brazil.

\section{INTERNATIONAL LAW}

The best original sources for the international relations of Brazil and Brazilian contributions to international law are the annual reports (Relatorio) 5 of the Ministry of Foreign Affairs, which began with the Empire. Those published since 1896 contain an alphabetical index of the matters coming within the jurisdiction of the Ministry of Foreign Affairs. Numerous years contain appendices or annexos, which include particular documents and correspondence in special cases.

The Council of State organized in $184 \mathrm{I}$ was a consultative body sitting as an adviser of the Executive. Among its vari-

1 Rocha Vianna, Antonio da: Compilação em indice alfabetico das disposições das leis civis Brazileiras que regem materia canonico. Bahia, I867. II 5 p.

2 Consultas do Conselho de estado sobre negocios ecclesiasticos. Comp. por ordem de S. Ex. o Sr. ministro do imperio. . . . Rio de Janeiro, Typographia nacional, 1869-70. $3 \mathrm{v}$.

${ }^{8}$ Monte Rodrigues d'Araujo, Manoel do: Elementos de direito ecclesiastico em relação á disciplina geral da igreja e com applicação aos usos da igreja do Brasil. Rio de Janeiro, 1857-1859. $3 \mathrm{v}$.

4 Direito civil ecclesiastico Brazileiro antigo e moderno em suas relações com o direito canonico ou colleç̧ão completa chronologicamente disposta desde a primeira dynastia até o presente, comprehendendo além do Sacrosanto Concilio de Trento, Concordatas, Bullas e Breves; leis, Alvarás, e Decretos . . . a que se addicionão notas historicas e explicativas indicando a legislação actualmente em vigor, e que hoje constitue a jurisprudencia civil ecclesiastica do Brazil por Candido Mendes de Almeida. Rio de Janeiro, H. Garnier, I8661873. $2 \mathrm{v}$. in 4 .

'Ministerio das relações exteriores: Relatorio. Rio de Janeiro, r8-. 
ous committees was one on Foreign Affairs. Their opinions are important sources of information for the international relations of the Empire. These opinions were collected in I 895 under the direction of the Minister of Foreign Affairs, Carlos Augusto de Carvalho, a noted jurist, by Cardoso de Oliveira, ${ }^{1}$ but still appear to be in manuscript unpublished. An index ${ }^{2}$ to the opinions of the Foreign Affairs committee of the Council of State and of the legal adviser of the Ministry of Foreign Affairs was published in the Annexo to the Relatorio of the Ministry of Foreign Affairs for 1896.

\section{TREATIES}

One of the best collections of early treaties of Brazil, or relating to Brazil, down to $182 \mathrm{I}$ is the important collection of Carlos Calvo ${ }^{3}$ covering the diplomatic history, with documents, of the Spanish and Portuguese colonies in America.

A collection of treaties concluded by Brazil with different nations from 1808 to 1864 was published in four volumes with valuable historical notes and other related documents by Antonio Pereira Pinto, ${ }^{4}$ Director of Public Archives of the Empire. The next collection of treaties appears to be the

1 Cardoso de Oliveira, José Manuel: Collecção das consultas do conselho de estado, e dos pareceres do consultor do ministerio dos negocios exteriores (I842 á I889). Rio de Janeiro, I895. 2 I v. MSS.

${ }^{2}$ Indice . . . das consultas do conselho de estado (I842 a I889) e dos pareceres do consultor do ministerio dos negocios extrangeiros, Annexo to the Relatorio das relações exteriores for 1896 .

${ }^{3}$ Calvo, Carlos: Recueil complet des traités, conventions, capitulations, armistices et autres actes diplomatiques de tous les états de 1'Amérique latine comprisentre le golfe du Mexique et le cap de Horn, depuis 1 'année I493 jusqu'à nos jours, précédé d'un mémoire sur 1'état actuel de l'Amérique, de tableaux statistiques, d'un dictionnaire diplomatique avec une notice historique sur chaque traité important ... Paris, A. Durand [etc., etc.], I862-. 7 v. 2 période. Depuis la révolution jusqu'à la reconnaissance de l'independence. Paris, A. Durand [etc., etc.], I864-67. $5 \mathrm{v}$.

${ }^{4}$ Apontamentos para o direito internacional, ou, collecção completa dos tratados celebrados pelo Brasil com differentes nações estrangeiras; accompanhada de uma noticia historica, e documentada sobre as convençũes mais importantes por Antonio Pereira Pinto . . . Rio de Janeiro, F. L. Pinto \& Co., I864-69. 4 v. 
Codigo das relações exteriores ${ }^{1}$ of Brazil, prepared by Feliciano José da Costa under direction of the Minister of Foreign Affairs, Dr. Olyntho de Magalhães. The collection is published in two volumes as an Annexo to the report of the Minister of Foreign Affairs for r 900 . Volume I contains the general international conventions to which Brazil is a party and Volume II the list of treaties with particular countries. It appears that Cardoso de Oliveira ${ }^{2}$ of the Ministry of Foreign Affairs made a collection of various treaties, agreements, and protocols, concluded by Brazil from 1808 to 1908 , but they have thus far remained unpublished.

A calendar of the diplomatic documents of Brazil, including treaties, agreements, protocols, and numerous other documents from 1493 to 1912 , has been published in two volumes by Cardoso de Oliveira. ${ }^{3}$ The various documents which are merely calendared and not printed textually are annotated at some length. The work contains analytical indices and indices by country, and lists of the presidents, members of the Council of State, and of the Ministers of Foreign Affairs.

The treaties of commerce and navigation concluded by Brazil were the subject of a report by the chairman of the committee on diplomacy of the Chamber of Deputies, Dunshee de Abranches, ${ }^{4}$ published in 1909 . He deals with the treaties and commercial relations of Brazil with various foreign countries and then discusses the treaties concluded during the various forms of government which Brazil has had since 1808 .

${ }^{1}$ Codigo das relações exteriores do Brazil. Publicação anexa ao Relatorio do Ministro das Relações Exteriores de 1900 (Elaborado por Feliciano José da Costa, por incumbencia do respectivo Ministro Dr. Olyntho de Magalhães. Rio de Janeiro, Impr. nacional, rgoo. 2 v.

${ }^{2}$ Cardoso de Oliveira, José Manuel: Pactos internacionaes do Brasil ou Collecção de tratados, convenções, accordos, ajustes e protocollos desde 1808 até os nossos dias, composto de ordem do mesmo Ministro. Rio de Janeiro, rgo8-ri. MSS.

${ }^{3}$ Cardoso de Oliveira, José Manuel: Actos diplomaticos do Brasil, tratados do periodo colonial e varios documentos desde 1493. Coordenados e annotados por José Manoel Cardoso de Oliveira . . . Rio de Janeiro, Typ. do Jornal do commercio, de Rodrigues \& Co., rgr2. 2 v.

${ }^{4}$ Abranches, Dunshee de: Tratados de commercio e navegação do Brazil; memoria apresentada á Commissão de diplomacia da Camara dos deputados. Rio de Janeiro, Imprensa nacional, r909. $70 \mathrm{p}$. 
The Third International American Conference was held at Rio de Janeiro in 1906. A convention on the status of naturalized citizens ${ }^{1}$ and a convention on pecuniary claims, ${ }^{2}$ concluded between the United States and various countries of Latin America, including Brazil, was ratified by the United States and proclaimed on January 28, 1913. The United States and Brazil concluded a naturalization treaty (Treaty Series 547$)^{3}$ on April 27, 1908; it was proclaimed on April 2, 19ro. An arbitration convention was concluded by the United States and Brazil (Treaty Series 562 ), ${ }^{4}$ on January 27 1909, proclaimed August 2, I9II. The parcel-post convention between the United States and Brazil ${ }^{5}$ was concluded on March 26, I910.

By law 2881 of November 9, 1914, the Brazilian Congress approved and the President ratified the fifteen conventions and resolutions adopted at the Fourth International American Conference held in Buenos Aires in 1910.

A list of the thirty-one arbitration treaties to which Brazil is a party was presented in the course of a report on arbitration by Dunshee de Abranches, ${ }^{6}$ chairman of the Brazilian House Committee on Diplomacy. The report includes inter-

1 Internationa! American conference. 3d, Rio de Janeiro, 1906. Convention between the United States and other powers. Status of naturalized citizens. Signed at Rio de Janeiro, August 13, 1906 ... Washington, Govt. Print. Off., I9r3. 7 p. (U. S. Treaties, etc. Treaty series, No. 575.)

2 International American Conference. 3d, Rio de Janeiro, I906. Convention between the United States and other powers. Pecuniary claims. Signed at Rio de Janeiro, August I3, Igo6. Washington, Govt. Print. Off., I9r3. 7 p. (U. S. Treaties, etc. Treaty series, No. 574.)

${ }^{3}$ Convention between the United States and Brazil. Naturalization ... Washington, Govt. Print. Off., rgro. 6 p. (Treaty series, No. 547.)

4 Convention between the United States and Brazil. Arbitration. Signed at Washington, January 23, 1909 . . Washington (Govt. Print. Off.), rgrr. 5 p. (Treaty series, No. 562.)

${ }^{5}$ Parcel-post convention between the United States of America and the United States of Brazil. Signed in Rio de Janeiro, March 26, I9ro. Washington, Govt. Print. Off., rgr I. 15 p.

${ }^{6}$ Abranches, Dunshee de: O Brazil e o arbitramento, tratados e convenções; memoria historica . . . Rio de Janeiro, Typographia Leuzinge, I9II. $52 \mathrm{p}$. 
esting historical notes and asserts the claim that Brazil up to I9I I was a party to more international arbitration treaties than any other country. Whether this remains true since the conclusion by the United States of the Bryan peace treaties may be doubtful.

The wars and treaties of Brazil were the subjects of a historical paper prepared for the book on the Fourth Centenary in 1900 by. Clovis Bevilaqua and Gregorio Azevedo. ${ }^{1}$

\section{GENERAL，WORKS}

A few general treatises on international law have been published in Brazil. Of these the best appears to be that of Clovis Bevilaqua, ${ }^{2}$ published in I9I I. The work is a synthetic treatment of the principles of international law as expounded by the leading authorities, with emphasis upon the contributions made by Brazil to the development of the topics discussed. The work is divided into seven parts, as follows: (I) The society of states, the medium in which it operates, and the basis of public international law; (2) the state as an international legal person, with its rights and duties; (3) the physical basis of the state, the population and territory; (4) the organs by which the state enters into relations with other states; (5) legal international relations during peace; (6) pacific solution of international conflicts; and (7) their solution by force and by war.

Another important treatise on international law has been written by Lafayette Rodrigues Pereira, ${ }^{3}$ the eminent jurist and former Councillor of State. This work, in two volumes, was published in 1902 .

Among the more elementary works are the lectures on international law by Antonio Drummond ${ }^{4}$ published in 1867 , with special reference to Brazilian law, and the elements of

${ }^{1}$ Bevilaqua, Clovis, and Azevedo, Dr. Gregorio Thaumaturgo de: Guerras e tractados do Brazil. Rio de Janeiro, rgoo.

${ }^{2}$ Bevilaqua, Clovis: Direito publico internacional; a synthese dos principios e a contribuição do Brazil. Rio de Janeiro, F. Alves, IgIr. $2 \mathrm{v}$.

${ }^{3}$ Lafayette Rodrigues Pereira: Principios de direito internacional. Rio de Janeiro, J. Ribeiro dos Santos, r902. 2 v. 972 p.

4 Drummond, Antonio de Vasconcellos Menezes de: Preleções de direito internacional. Pernambuco, Tip. do Correio do Recife, 1867. 2 I9 p. 
international law published by Sá Vianna, ${ }^{1}$ a well-known publicist, in 1908 . João Cabral ${ }^{2}$ is the author of a historicalphilosophical monograph on international law published in 1908 under the title "Evolution of international law." It contains in an appendix the acts of the Third International American Conference of 1908 and of the Second Hague Conference of 1907 .

Epitacio Pessoa, ${ }^{3}$ the noted jurist and statesman, presented for the consideration of the International Commission of Jurists, which assembled in 1912 , the draft of a code of public international law proposed by the Third International Conference which had convened at Rio de Janeiro in 1906. Similar attempts at codification had been made at the Congresses at Lima in 1878 , and at Montevideo in 1889 . . The code, which consists of $72 \mathrm{I}$ articles, is divided into seven books-(I) states as persons, (2) sovereignty of states, (3) pacific relations of states, (4) regulation and administration of social and economic interests of states, (5) pacific solution of international conflicts, (6) war, and (7) civil war.

An elementary work on international maritime law for the use of students in the Naval School was published in 1884 by Oliveira Freitas. ${ }^{4}$

\section{NEUTRALITY.}

Two excellent monographs on neutrality, with particular reference to Brazil, have recently appeared. At the beginning of the war Helio Lobo, a specialist on international law, discussed the principles of neutrality as applied by Brazil. ${ }^{5}$ More recently Amaro Cavalcanti, a jurist whose contributions

'Sá Vianna, M. A. de S.: Elementos de direito internacional. Rio de Janeiro, I908. 3 I8 p.

${ }^{2}$ Cabral, João: Evolução do direito internacional. Essboço historicophilosophico seguida das actas geraes de terceira conferencia intercional americana do Rio de Janeiro e da segunda conferencia internacional da paz, da Haya. Rio de Janeiro, 1908. $307 \mathrm{p}$.

3 Pessoa, Epitacio: Projecto de codigo de direito internacional publico. Rio de Janeiro, Impr. nacional, I9II. 335 p.

- Oliveira Freitas, Carlos Vidal de: Elementos de direito it.t rnacional maritimo. Rio de Janeiro, Lombaerts \& Co., I884. 4I3 p.

- Lobo, Helio: O Brazil e scus principios de neutralidede. Rio de Janeiro, Impr. nacional, 1914. $140 \mathrm{p}$.

$71624^{\circ}-17-23$ 
are all noteworthy, discussed neutrality ${ }^{1}$ in the light of the restrictions, open and insidious, imposed by Great Britain and by Germany upon neutral commerce in the present world war.

\section{DRAGO DOCTRINE}

The Drago doctrine was the subject of two monographs published in 1907; one by Coelho Rodrigues, ${ }^{2}$ and the cther by Souza Pinto. ${ }^{3}$

\section{EXTRADITION}

Extradition treaties concluded by Brazil with foreign countries have been edited in a volume by Arthur Briggs 4 published in 1909. By law 2416 of June 28 , 191 I, the jurisdiction and procedure in Brazil on a request for extradition for crimes committed abroad were provided for. The law is described and its translated text printed by Rodrigo Octavio in 6 Revue de l'Institut de droit comparé (1913), pages 488492, and 9 Revue de droit int. privé, pages 982-987. The law is also translated in $4 \mathrm{r}$ Annuaire de legislation comparée, pages 912-915.

\section{ALIENS}

By all means the best work on the rights of aliens is that of Rodrigo Octavio ${ }^{5}$ published in 1909. In five titles he deals, first, with the history of the law of aliens; second, with conventional law, discussing the early agreements, the rights of succession of aliens, consular conventions and those on industrial and artistic property; third, positive international law relating to aliens, including nationality, naturalization, expulsion, capacity, marriage and divorce, corporations, elections, letters rogatory, and foreign judgments; fourth,

1 Cavalcanti, Amaro: A neutralidade e las restricçoes do commercio internacional na presente guerra européa. Rio de Janeiro, Impr. nacional, I9r6. $67 \mathrm{p}$.

${ }^{2}$ Coelho Rodrigues, Manoel: Cobrança militar de dividas dos estados. Rio de Janeiro, 1907.

${ }^{3}$ Souza Pinto: A doutrina Drago: Recife, I907.

4 Briggs, Arthur: Extradição; tratados vigentes entre o Brasil e outros . paizes . . . com um parecer do Dr. Clovis Bevilaqua. Rio de Janeiro, Imprensa nacional, rgog. $376 \mathrm{p}$.

- Octavio de Langgaard de Menezes, Rodrigo: Direito do estrangeiro no Brazil. Rio de Janeiro, Libr. de Francisco Alves, 1909. 366 p. 
international criminal law, including crimes committed abroad and extradition, and fifth, a brief history of the codification of the civil law in Brazil with special reference to its provisions on private international law. An appendix contains the draft of the civil code in its sections on the conflicts of law, the law of expulsion of 1907 , and the law of naturalization of 1908 . An older work on the rights and duties of aliens was published in 1868 by Gama Lobo. ${ }^{1}$

Interesting articles on the rights of aliens were published by Rodrigo Octavio in 40 Clunet (1913), pages 783-795, and by Vladimir Pappafava in 3 Jahrbuch der int. Vereinigung $f$. vergl. Rechtswissenschaft (1 897), pages 187-198.

\section{EXPULSION}

The expulsion of aliens is now governed by law 1641 of January 7, 1907, with the instructions of May 23, 1907, to carry it out. The law is explained and translated in 38 Annuaire de législation comparée, pages 1066-1072, and in 4 Revue de droit international privé (1908), page 855. The law restrains the arbitrary power of the government in expelling aliens by enumerating the grounds of expulsion and specifying the persons who may not be expelled. The best commentary on the law is that of the well-known jurist, Lacerda de Almeida. ${ }^{2}$ He deals, first, with general principles; second, with the constitutionality of the law; third, with its conformity with foreign law; fourth, with the practice of expulsion in Brazil; fifth, with the decisions of the courts; and sixth, with the antecedents of law I64I and a commentary, article by article.

\section{NATURALIZATION}

The law governing the naturalization of aliens was amended by decree 6948 of May 14, 1908, and law 2004 of November 26,

1 Gama Lobo, Ovidio da: Direitos e deveres dos estrangeiros no Brazil. Maranhão, Ed. Antonio P. R. de Almeida, 1868.

${ }^{2}$ Lacerda de Almeida, Francisco de Paula: O decreto n. r64r de 7 de janeiro de 1907 sobre expulsão de extrançeiros do territorio nacional, ligeiramente commentado e precedido de alguns capitulos doutrinarios sobre o fundamento juridico e applicação practica do direito de expulsão e com referercias aos autores nacionaes e á jurisprudencia patria. . . Rio de Janeiro, Typ. de Revista dos tribunaes, 1907. r $30 \mathrm{p}$. 
1908. Law 2 I 5 approved the conventions concluded August 23, 1906 at the Third International American Conference between Brazil and various other countries. Law 2116 approved the naturalization convention of April 27, 1908, between the United States and Brazil.

\section{INTERNATIONAL CONFERENCES}

Brazil has participated in practically all the American international conferences. The Latin American Scientific Congress met at Buenos Aires in I898, in Montevideo in 1901, in Rio de Janeiro in 1905, and in Santiago de Chile in 1908. The latter was called "Pan American" by reason of the participation of the United States. At the 1905 Congress Alejandro Alvarez, of Chile, presented a memorial advocating a recognition of an American international law, that is, a body of rules which the Latin American states observe in their relations among themselves and the other states of America and Europe. Dr. Alvarez's book on the subject is mentioned under the literature of Chile. The proposal was slightly changed in form in 1908. Professor Sá Vianna combats the proposition of Alvarez by stating that there are no rules of American international law which are not a part of universal international law, but that certain special rules have had an American origin and have thence found their way into international law. He presented his thesis in a monograph presented to the Latin American Scientific Congress at Santiago in r908. It was published separately in I912. ${ }^{1}$

The proceedings of the Third International American Conference at Rio de Janeiro on the codification of international law, with a draft code, were edited by Amaro Cavalcanti ${ }^{2}$ in 1906. Pursuant to the resolutions of that Congress, the International Commission of Jurists ultimately met in Rio de Janeiro in 1912. Their acts, resolutions, and documents during their sessions from June 26 to July I 9, I 91 2, have been published in

' Vianna, Sá: De la nonexistence d'un droit international américain. Rio de Janeiro, I. Figueredo, rgr2. 290 p.

${ }^{2}$ Cavalcanti, Amaro: Trabalhos na $3 \mathrm{~d}$ Conferencia internacional americana. Exposição sobre codificação do direito internacional e projecto de codigo. Rio de Janeiro, Impr. nacional, 1906. 
Portuguese and in English. ${ }^{1}$ The report of the United States delegates, John Bassett Moore and the late Frederick Van Dyne, appear in House Document I343, Sixty-second Congress, third session (83 p.).

Sá Vianna has published an article in I Jahrbuch des Völkerrechts, pages $1047-\mathrm{IO}_{2}$, which indicates the various Pan American conventions which have been ratified by each of the countries of Latin America and gives an account of the conference of the commission of jurists in 1912 .

The important contributions of Ruy Barbosa to the Second Peace Conference at The Hague have been preserved in book form by William $T$. Stead. ${ }^{2}$ His work has been published in English and in French and has been translated into Portuguese.

By law I I037 of August 4, 1914, Brazil adopted general rules of neutrality in case of war between two foreign powers.

\section{DIPLOMATIC AND CONSULAR SERVICE}

The reports of the diplomatic and consular officers of Brazil so far as they relate to commerce and navigation and other matters generally published are issued in two series, one an annual series of consular reports, ${ }^{3}$ issued since 1900 , and the other a special series of diplomatic reports, ${ }^{4}$ published at irregular intervals, beginning in 19or. A compilation of the reports of diplomatic and consular officers during the years 1868 to 1873 on commerce and navigation was published officially ${ }^{5}$ in 1873 .

${ }^{1}$ International commission of jurists. Rio de Janeiro Congress, I9I2. Acts, resolutions, and documents. First assembly in Rio de Janeiro. (From June 26 to July I9, r9r2.) Rio de Janeiro, I9r4. I59 p.

${ }^{2}$ Stead, William Thomas: O Brazil em Haya . . . Notas sobre a conferencia seguidas dos discursos . . . do conselheiro Ruy Barbosa. . . . Tr. do francez e do inglez por Arthur Bomilcar . . . Rio de Janeiro, Typ. de M. Piedade \& Cia., I908. 184 p.

${ }^{3}$ Ministerio das relações exteriores: Relatorios consulares. Série annual. Rio de Janeiro, I900-.

${ }^{4}$ Ministerio das relações exteriores: Relatorios diplomaticos. Série especial. Rio de Janeiro, Imprensa nacional, I90I-.

${ }^{5}$ Ministerio das relações exteriores: Informações dos agentes diplomaticos e consulares do imperio publicadas em execução do decreto no. $425^{8}$ de 30 de setembro de 1868 . . . Annos de 1868-1873. Rio de Janeiro, Typographia nacional, 1873. 2 v. 
A list of the members of the diplomatic service of Brazil in foreign countries from 1808 to 1912 and of the diplomatic corps in Rio de Janeiro was published by the chief clerk of the Ministry of Foreign Affairs, Raul Campos, ${ }^{1}$ in 1913.

A well-known monograph on diplomatic functions in time of peace was published by the Brazilian Minister to Chile, Henrique Lisboa, ${ }^{2}$ in 1908.

\section{DIPLOMATIC HISTORY}

One of the ablest works on the diplomatic history of Brazil, dealing principally with the recognition of the Empire, has been published by the well-known scholar, Oliveira Lima. ${ }^{3}$ An appendix contains documents. The lectures on Brazilian diplomacy of Professor Antonio Drummond ${ }^{4}$ were published in 1867 .

The diplomatic history of the Repubiic from 1889 to 1902 was discussed in a monograph by Araujo Jorge. ${ }^{5}$ He deals with the recognition of the Republic, the provisional government, the military presidents, Fonseca and Peixoto, and with the diplomatic relations during the presidency of Prudente de Moraes and Campos Salles.

A collection of three essays on the diplomatic history of Brazil was published in 1913 by Helio Lobo. ${ }^{B}$ They deal with the Pan American movement, the attempts at the codification

${ }^{1}$ Ministerio das relações exteriores: Relações diplomaticos do Brasil, contendo os nomes dos representantes diplomaticos do Brasil no estrangeiro e os dos representantes diplomaticos dos diversos paizes no Rio de Janeiro, de 1808 a rgr2. Publicação organisada pelo primeiro official da Secretaria de estado das relações exteriores, Rau! Adalberto de Campos, com um prefacio do professor Dr. Sá Vianna. Rio de Janeiro, Typ. do "Jornal do commercio," de Rod. rigues \& Co., rgr3. $223 \mathrm{p}$.

${ }^{2}$ Lisboa, Henrique C. R.: Les fonctions diplomatiques en temps de paix. Santiago de Chile, rgo8.

${ }^{3}$ Oliveira Lima, Manuel de: Historia diplomatica do Brazil; o reconhecimento do imperio. 2. ed. Rio de Janeiro [etc.], H. Garnier, rgo2. $\quad 376 \mathrm{p}$.

${ }^{4}$ Drummond, Antonio de V. M. de: Preleções da diplomacia. Pernambuco, Tip. do Correio do Recife, I867.

${ }^{5}$ Araujo Jorge, Arthur Guimarães de: Ensaios de historia diplomatica do Brasil no regimen republicano. r. serie. (r889-rg02.) Rio de Janeiro, rgr2. r8 $\mathrm{r}$.

${ }^{B}$ Lobo, Helio: Brasil, terra chara. Rio de Janeiro, Imprensa ingleza, I9r3. $87 \mathrm{p}$. 
of international law, and the international relations of Brazil. The relations of Brazil with the United States were the subject of a monograph by Oliveira Lima, ${ }^{1}$ published in a Bulletin of the American Association for International Conciliation.

Vicente G. Quesada, ${ }^{2}$ the father of Dr. Ernesto Quesada, was for years in the diplomatic service of the Argentine Republic. He was Argentine Minister to Brazil during the eighties. He has published the diplomatic memoirs of his mission in Brazil in two volumes, published in Buenos Aires in $1907-8$.

Among the diplomatic incidents which have played a prominent part in the international relations of Brazil, several warrant mention. Perhaps the most important international event in the history of Brazil has been the devastating war of five years cariied on with Paraguay between 1865 and 1870 . The difficulties leading up to that war are described in several works. The mission of the Argentine Minister to Uruguay, José Antonio Saraiva, had much to do with the beginning of the struggle. His purpose was to obtain redress for the violation of the rights of Brazilian citizens in the Republic of Uruguay. The diplomatic documents relating to this mission were published by the Uruguayan Ministry of Foreign Affairs, ${ }^{3}$ and his mission is the subject of an important monograph by Helio Lobo, ${ }^{4}$ recently published. The work contains numerous footnotes. The Argentine Republic has also published numerous documents relating to the difficulties of Brazil with Uruguay and Paraguay. ${ }^{5}$

${ }^{1}$ Oliveira Lima, Manuel de: The relations of Brazil with the United States,... New York City, American association for international conciliation, I9r3. r4 p. (Int. Conciliation, pub. monthly by the American Asso. for Int. Conciliation ... no. 69.)

${ }^{2}$ Quesada, Vicente Gaspar: Mis memorias diplomaticas, misión ante el gobierno del Brasil . . . Buenos Aires, Impr. de Coni hermanos, 1907-8. $2 \mathrm{v}$.

${ }^{3}$ Uruguay. Ministerio de relaciones exteriores: Documentos diplomaticos. Mision Saraiva. Montevideo, Impr. de la "Reforma pacifica," I864. $75 \mathrm{p}$.

"Lobo, Helio: Antes da guerra (a missão Saraiva ou os preliminares do conflicto com o Paraguay). Rio de Janeiro, Imprensa ingleza, IgI4. $260 \mathrm{p}$.

${ }^{5}$ Missão especial cerca da Republica Argentina: Documents officicls relatifs au conflit existant entre le Bresil et les gouvernements de Montevideo et de 1'Assomption. Buenos Aires, Impr. de "La Tribuna," I865. I8 p. 
The diplomacy of Brazil in the River Plate region was the subject of a monograph by Oneto y Viana, ${ }^{1}$ published in Montevideo in 1903. The relations between Uruguay and Paraguay were the subject of a monograph by Luis Alberto Herrera ${ }^{2}$ of Uruguay.

The war with Paraguay was ended in 1870 by the death of Lopez, the dictator of Paraguay. It had been understood that the allies, Argentina, Uruguay, and Brazil, were to unite in a treaty of peace with Paraguay. For various reasons this attempt was frustrated, so that Brazil concluded a separate treaty. The Argentine Republic protested against this, and feeling against Brazil ran high in Argentina. Brazil also maintained a small body of troops in Paraguay to maintain order. These difficulties were the subject of a long correspondence between Brazil and Argentina, ${ }^{3}$ and laid the foundation for the important questions concerning the Misiones Territory, which were arbitrated many years later.

A boundary treaty which had been concluded between Brazil and Paraguay by the Paraguayan Minister at Rio de Janeiro, Sosa Escalada, was rejected at Paraguay and the negotiator branded as a traitor. A work on his mission, published in $1875,{ }^{4}$ was designed as a defense against this charge.

The diplomatic difficulties with Great Britain arising out of the seizure by Brazilian citizens in 1861 of the wrecked ship Prince of Wales and the arrest of the officers of the Forte in Rio de Janeiro were the subject of long correspondence. This has been published in English from the papers laid before

${ }^{1}$ Oneto y Viana, Carlos: La diplomacia del Brasil en el Rio de la Plata . . Montevideo, Libreria de la Universidad [etc.], r903. $387 \mathrm{p}$.

${ }^{2}$ Herrera, Luis Alberto de: La diplomacia oriental en el Paraguay. . . . comentada . . Montevideo, Talleres A. Barreiro y ramos, I908-.

${ }^{3}$ Ministerio das relações exteriores: Correspondence between the Brazilian and Argentine governments respecting the treaties concluded between Brazil and the republic of Paraguay and the withdrawal of troops from the island of Atajo.' London, printed by C. W. Reynell, I872. 84 p.

${ }^{4}$ Sosa Escalada, Jaime: Negociaciones diplomáticas entre el Brasil, la República Argentina y el Paraguay; mision del ciudadano paraguayo Jaime Sosa á Rio de Janeiro. Buenos Aires, Impr. de la Tribuna, 1875 . $108 \mathrm{p}$. 
Parliament. ${ }^{1}$ The British government took steps to resort to reprisals, and seized five Brazilian vessels. The Prince of Wales claim was paid under protest and the Forte claim, submitted to the arbitration of the King of Belgium, was decided in favor of Brazil (Moore's Arbitrations, 4925-4928.)

In 1893 part of the Brazilian navy revolted against the military government of Peixoto and bombarded the city of Rio de Janeiro. For a long time they controlled the situation, but were ultimately beaten. Saldanha da Gama, one of the commanders of the revolting ships and admiral in command, received asylum with some of his men on a Portuguese man-of-war. The government of Brazil raised the incident into a diplomatic conflict, which assumed for a time alarming proportions. The correspondence has been published in English $^{2}$ and in French ${ }^{3}$ and is discussed historically in a monograph by Augusto Forjaz, published in Lisbon. The Portuguese commander, Augusto de Castilho, ${ }^{5}$ was tried by a courtmartial, and has published his defense and documents in support in a work of four volumes.

Brazil has had more boundary disputes with its neighboring countries than any other republic of Latin-America. Some were settled diplomatically and some by arbitration. They include differences with Great Britain over British Guiana, with France over French Guiana, with the Netherlands over

1 The Brazil correspondence in the cases of the Prince of Wales and officers of the Forte. (Reprinted from the papers laid before Parliament.) With an introduction, telling some truth about Brazil. London, W. Ridgway, I863. 339 p.

${ }^{2}$ Ministerio das relações exteriores: Correspondence exchanged with the legation of Portugal and the legation of Brasil at Lisbon in regard to the surrender of the insurgent refugees on board the Portuguese corvettes "Mindello" and "Affonso de Albuquerque." Rio de Janeiro, Typ. Leuzinger, r894. $3^{8} \mathrm{p}$.

${ }^{3}$ Ministerio das relações exteriores: Correspondance échangée avec la légation de Portugal et la légation du Brésil à Lisbonne, au sujet de la remise des rebelles réfugiés à bord descorvettes portugaises. Rio de Janeiro, Impr. Leuzinger, r894. $36 \mathrm{p}$.

4 Forjaz, Augusto: Portugal e Brazii; apontamentos para a historia do nosso conflicto com a republica dos Estados Unidos do Brazil . . Lisboa, Typographia C. Irmão, I894. $105 \mathrm{p}$.

${ }^{5}$ Castilho Barreto e Noronha, Augusto de: Portugal e Brazil; conflicto diplomatico . . . Lisboa, M. Gomes, $1894.4 \mathrm{v}$. 
Surinam, with Uruguay over the Yaguaron River and Lake Merín, with Argentina over the Misiones territory, with Bolivia over the Acre territory, with Colombia over the Ica (or Putamayo) river, and with Peru. There is a vast literature on these cases, but limitations of space and the paucity of their contribution to law preclude its presentation in this monograph.

\section{CONFLICT OF LAWS}

Several valuable works on the conflict of laws have been published in Brazil. One of the best is that of Clovis Bevilaqua, ${ }^{1}$ published in 1906 . In a general part he deals with the general principles of international private law, the various systems of the older and the modern writers, and discusses the reasons for the application of foreign law, the sources, application, interpretation, and object of the conflict of laws, and the question of renvoi. In a special part he deals, in Title I, with the legal status of aliens in history and in modern legislation and of foreign corporations. In Title II he deals with the conflicts of civil law relating to persons, property, legal acts, domestic relations, things, obligations, and succession, and in commercial law, bills of exchange and maritime law, procedural law, and bankruptcy. The last title deals with vested rights.

The lectures of Rodrigo Octavio at Rio de Janeiro were transcribed and published by two of his students ${ }^{2}$ in 1908 . They deal with the general part only. That same jurist has also published in French a valuable work on the conflict of laws in Brazilian legislation, ${ }^{3}$ composed of lectures delivered by him at the Faculty of Law in Paris.

A bibliography of Brazilian contributions to international law is printed at pages $357-360$ of Rodrigo Octavio's work on aliens (supra, p. 354).

\footnotetext{
${ }^{1}$ Bevilaqua, Clovis: Principios elementaes de direito internacional privado. Bahia, Magalhães, I906. $368 \mathrm{p}$.

2 Joppert da Silva, O. e Teixeira de Freitas, M. A.: Direito internacional privado. Parte geral. Niteroy, Tip. Americano, I908.

${ }^{8}$ Octavio, Rodrigo: Le droit international privé dans la législation brésilienne; cours professé à la Faculté de droit de 1'Université dc Paris. . . Paris, L. Tenin, I915. $248 \mathrm{p}$.
} 
The draft of a code of private international law by Epitacio Pessoa ${ }^{1}$ was submitted to the international commission of jurists which met at Rio de Janeiro in I912. An important work on the codification of private international law was published by Rodrigo Octavio ${ }^{2}$ in 1910 , as was an address on the subject delivered by him before the Brussels Congress of international associations. ${ }^{3}$

A classic work on private international law, with special reference to Brazil, is that of Pimenta Bueno, ${ }^{4}$ published in I 863 .

Among the special topics of private international law several works warrant mention. Reference has already been made to the work of Rodrigo Octavio on aliens, which is principally concerned with the conflict of laws. Dual nationality and loss of nationality in Brazilian law was the subject of an article by Rodrigo Octavio published in the Journal du droit international privé (1913), pages 4I2-434.

An interesting work by Arthur Briggs, ${ }^{5}$ of the Ministry of Foreign Affairs, on letters rogatory was published in I9I 3 Book I deals with the compliance in Brazil with letters rogatory issued by courts of other countries. He discusses the character of letters rogatory, their transmission, authentication, translation, exequatur, letters rogatory in criminal matters, and circulars and orders. In Book II he deals with the compliance by foreign courts with Brazilian letters rogatory. He discusses the mere request in criminal matters, and the legal provisions and the practice in the various foreign countries. Book III deals with conventional law, and includes the negotiations and attempts at negotiation of agreements

${ }^{1}$ Pessoa, Epitacio: Projecto do codigo de direito internacional privado. Rio de Janciro, Impr. Nacional, Igrr.

${ }^{2}$ Octavio, Rodrigo: A codificação do direito internacional privado. Porto, Magalhães and Moniz [1910]. $212 \mathrm{p}$.

${ }^{3}$ Octavio, Rodrigo: L'union juridique des nations au point de vue du droit privé. Bruxelles, Impr. F. de Buggenhoudt, r9ro. 25 p.

" Pimenta Bueno, José Antonio: Direito internacional privado, e aplicação de seus principios com referencia ás leis particulares do Brazil. Rio de Janeiro, Tip. Imp. de Const. de J. Villeneuve \& Co., I863.

5 Briggs, Arthur: Cartas rogatorias internacionaes. Rio de Janeiro, Imprensa nacional, r9r3. $393 \mathrm{p}$. 
with foreign countries, the agreements concluded with Argentina, Bolivia, Paraguay, Peru, and Uruguay, and the clauses on the subject inserted in treaties of extradition.

The execution of foreign judgments in Brazil was the subject of a monograph by Samuel Martins, ${ }^{1}$ of Recife, published in 1906. Divorce in its international legal aspects was the subject of a monograph by the noted jurist Carlos de Carvalho, ${ }^{2}$ published in $\mathrm{I} 894$. It has been translated into other languages. An important contribution to the conflict of laws may also be found in his work on the consolidation of Brazilian civil law as in force in $\mathrm{r} 899$. (Supra, p. 250.)

A classic work on the Brazilian law relating to the property of deceased and absent persons, which has some importance for its contribution to the conflict of laws, was published in a second edition in 1878 by Sobreira de Mello. ${ }^{3}$

${ }^{1}$ Martins, Samuel: Execução das sentenças estrangeiras no Brazil. Recife, Tip. J. B. Edelbrock, I906. I35 p.

${ }^{2}$ Carvalho, Carlos de: A questão do divorcio no Brazil; solução pelo direito internacional. Rio de Janeiro, Typ. do Jornal do Comercio, I894.

${ }^{3}$ Sobreira de Mello, Eduardo Xavier: Comentario á legislação brazileira sobre bens de defuntos e ausentes, vagos e do evento. $2 \mathrm{~d}$ ed. Rio de Janeiro, Laemmert, I878. $3 \mathrm{v}$. 


\section{CHILE}

\section{INTRODUCTION}

Chile differs in several respects from Argentina and Brazil. The greatest difference lies in the fact that it is a unitary and not a federal government, with a resulting simplicity and coherence of administration. It is the only one of the three Republics under discussion in this monograph which now possesses a Council of State and an Executive Commission (Comisión conservadora). Being a smaller country than Argentina or Brazil, and having only recently reached a considerable diversity of economic and industrial development, its legal literature is less numerous than that of Argentina or Brazil, although among the jurists of Chile there are several of renown.

The movement for Chilean independence began in 1810. Several constitutions were adopted between 18 I 2 and 1828 , and the constitution now in force, dating from May 25, 1833, is one of the oldest in Latin America. Like Argentina during much of the same period, the Chilean government from 1833 to I 86 I was republican in name only, the president being practically a dictator. Since $187 \mathrm{I}$ the constitution has been amended on numerous occasions.

The private law and procedure are uniform throughout the Republic. An organic law of municipalities prescribes the powers and functions, very wide in scope, of these local bodies.

\section{BIBLIOGRAPHY}

Bibliographies of a strictly legal character are very few in number. The best known Chilean legal bibliographer is Anibal Echeverría i Reyes. In 1890 he published a bibliography by title of the literature on the Chilean codes, ${ }^{1}$ listing the various editions of the codes and their commentaries. This bibliog-

\footnotetext{
'Echeverría i Reyes, Anibal: Bibliografía de los códigos chilenos. Santiago, Imprenta Cervantes, I89o. $3 \mathbf{I}$ p.
} 
raphy was published in fifty copies only. It first appeared as an article in Volume VI, No. 4 of the Revista forense Chilena. Its errors were pointed out by Dr. Miguel Luis Amunátegui in the following number of the Revista. New and revised editions of this bibliography were prefaced to the 1891,1896 , and 1903 editions of the Chilean collected codes publiched by the house of Miranda. In 1891 Dr. Echeverría, at the request of the University of Chile, published a fairly complete bibliography of 923 items, with notes, of the Chilean legal literature published up to that time. ${ }^{1}$ The report was reprinted in the Anales de la Universidad de Chile, volume 79 (I891), pages 33-180.

A select biliography of Chilean legal literature, divided in accordance with the plan of the guides to foreign law issued by the Library of Congress, was published by title only in the Revista de bibliografía Chilena y extranjera, Año 2 (1914), No. I-2, pages $42-49$, a publication of the National Library of Chile, to be mentioned more fully hereafter.

Chile is rich in general bibliographies of the products of the Chilean press and of foreign works relating to Chile. It will be of interest, therefore, to mention those general bibliographies which bear a relation to, or contain material on, law. Taking up these bibliographies for the period they cover in a chronological order, attention should first be called to the remarkable bibliographic works of the celebrated bibliophile, José Toribio Medina. Among numerous works of this scholar his bibliography of the early Spanish books relating to Chile, or which were used in Chile, is of some importance for early law books. This publication, entitled Biblioteca hispanochilena ( $1523-1817)^{2}$ covers works published in Spain, but not those printed in Chile, the latter having been listed in another bibliography of Medina to be mentioned presently. The work covers 876 titles, arranged chronologically and transscribed line for line with references to authorities and to libraries where copies are to be found. It is supplied with numerous quotations and critical bibliographical notes.

\footnotetext{
' Echeverria i Reyes, Anibal: Ensayo de una biblioteca chilena de lejislación y jurisprudencia. Santiago, Imprenta nacional, I891. I $55 \mathrm{p}$.

${ }^{2}$ Madina, José Toribio: Biblioteca hispano-chilena ( $1_{52} 3^{-18} 87$ )... Santiago, Impreso y grabado en casa del autor, 1897-99. $3 \mathrm{v}$.
} 
The productions of the Chilean press up to 1817 have been listed by Medina in a separate work published in $189 \mathrm{I}$ and issued in three hundred copies only. ${ }^{1}$ Stress is laid by the compiler on factors of importance in the history of printing in Chile. Luis Montt some years later began the publication of a bibliography of the Chilean press which was intended to come down to 1823 and to cover four volumes. ${ }^{2}$ Only one volume, however, covering the period $\mathrm{I} 8 \mathrm{I} 2 \mathrm{I}-\mathrm{I} / \mathrm{I}$, was published and to a considerable extent, therefore, the work duplicates the material mentioned by Medina. Montt's work, however, contains an historical, descriptive, and critical account of the early publications of the Chilean press, both official and unofficial, and reports the contents of the books more fully than Medina.

At various times up to i 860 partial bibliographies and catalogues had been published; for example, Lindsay's catalogue of books on sale, published in 1858 in the Anuario of the Statistical Office, which contains I,240 publications. About 1860 , however, the Council of the University of Chile saw the necessity for a complete catalogue of Chilean literature and entrusted the work to Ramón Briseño, who was then professor of philosophy at the National Institute of Chile and subsequently became the Director of the National Library. In 1862 the first of two volumes entitled Estadistica bibliográfica de la literatura chilena ${ }^{3}$ was published, listing 4,594 publications, covering the publications of the first forty-eight years of the Chilean press, namely, I812-1859. In 1879 a second volume appeared comprising $5, \mathrm{r} 43$ titles and bringing the bibliography down to 1876. The works are listed alphabetically by author as well as chronologically by year. It includes also the newspaper literature of Chile and volume 2, covering $1860-1876$, includes the literature published abroad relating to Chile.

${ }^{1}$ Medina, José Toribio: Bibliografía de la imprenta en Santiago de Chile desde sus orígenes hasta febrero de $\mathrm{r}_{8 \mathrm{r}} 7$, por $\mathrm{J}$. T. Medina . . Santiago, Impreso en casa del autor, I89r. I79 p.

${ }^{2}$ Montt, Luis: Bibliografía chilena, precedida de un bosquejo histórico sobre los primeros años de la prensa en el pais. Tomo II. I8I2-I8I7. Santiago de Chile, Imprenta Barcelona Ig04. 499 p. Without the historical sketch.

${ }^{3}$ Briseño, Ramón: Estadística bibliográfica de la literatura chilena. Obra compuesta, en virtud de encargo especial del consejo de la Universidad de Chile. Santiago de Chile, Imprenta Chilena, I862-I879. $2 \mathrm{v}$. 
In 1886 , when I fuis Montt became Director of the National Library, he began the publication of the Anuario de la prensa chilena, ${ }^{1}$ which records the publications of the Chilean press and of the foreign press relating to Chile, or by Chilean authors. Under the copyright law of Chile two copies of each Chilean book must be deposited in the National Library, so that the Anuario also performs the function of a register of copyright entries. The Anuario is issued by the National Library and is a most useful repository of bibliographic information of Chile.

The gap between 1876 , when Briseño's bibliography terminated, and I 886 , when the Anuario began, was covered by a catalogue prepared by Luis Montt, of which unfortunately the entire edition, with the exception of five or six copies, was consumed in a fire.

An eminently valuable publication covering Chilean and foreign bibliography is the Revista de bibliografía chilena y extranjera ${ }^{2}$ published monthly or in bimonthly numbers by the National Library. It contains, among other features, select bibliographies on various subjects and reports, by subject, all new works.

In 1915 there was published in this Revista a monograph by Ramón A. Laval, which consists of a bibliography of Chilean bibliographies. It was also issued separately. ${ }^{3}$

Among the catalogues of miscellaneous works which have bibliographic value for law, attention may be called to a catalogue of the library of Ramón Briseño ${ }^{4}$ published by the owner in 1874 , which consists of a miscellaneous collection of Chilean material including a list, by administration, of the official publications of the various ministries. It is not well arranged.

${ }^{1}$ Anuario de la prensa chilena, pub. por la Biblioteca nacional. Santiago, I887-. I v. per year.

${ }^{2}$ Revista de bibliogafía chilena y extranjera. Publicada mensualmente por la Sección de informaciones de la Biblioteca nacional. Santiago, Imprenta Universitaria, I913-.

${ }^{8}$ Laval, Ramón A.: Bibliografía de bibliografía chilenas. Santiago, Impr. Universitaria, 19r5. 7 I $\mathrm{p}$.

- Briseño, Ramón: Catalogo razonado de la biblioteca chileno-americana de Don Ramon Briseño. Santiago, Impr. de "La Estrella de Chile," 1874. $105 \mathrm{p}$. 
An important catalogue of the library of Gregorio Beéche was prepared by the celebrated historian, Vicuña Mackenna, ${ }^{1}$ in 1879; this contains a valuable collection of briefs, drafts of laws, official documents, and periodicals. It may be added that other countries besides Chile are covered in the bibliography.

A biographical dictionary of Chile, prepared by the late Pedro Figueroa, ${ }^{2}$ an enthusiastic bibliographer, includes biographies of many Chilean jurists and is useful bibliographically as well.

A little work of Figueroa on Chilean books was prepared in the report of a journey of Roberto Miranda throughout Europe and America for the propagation of Chilean literature. It contains useful bibliographical information. ${ }^{3}$

For maritime law, it is of interest to add a bibliography prepared by Anrique, covering publications on maritime matters from 1840 to $1894 .^{4}$

\section{LEGISLATION}

The legislation of Chile is contained in the official gazettes and in separate publications both official and unofficial. Beginning with the official gazettes, the first repository of the decrees of the governing authorities was La Aurora, ${ }^{5}$ begun on February 12,1812 , and ending on February 12,1817 , when the

1 Beéche, Gregorio M. P. de: Bibliografía americana. Estudios i catálogo completo $\mathrm{i}$ razonado de la biblioteca americana coleccionada por el Sr. Gregorio Beéche ... por B. Vicuña Mackenna. Valparaiso, Impr. del Mercurio, $1879.802 \mathrm{p}$.

2 Figueroa, Pedro Pablo: Diccionario biográfico de Chile ... 4. ed. ilus. con retratos. Santiago de Chile, Imprenta y encuadernacion Barcelona, $1897-1902.3 \mathrm{v}$.

${ }^{3}$ Figueroa, Pedro Pablo: La librería en Chile. Estudio histórico y bibliográfico del canje de obras nacionales establecido y propagado en Europa y América, por el editor y librero Don Roberto Miranda 18841894 . . . 2. ed. Paris, Garnier hermanos, 1896. 136 p.

- Anrique, R. Nicolas: Bibliografía marítima Chilena (r840-r894). Santiago, Imprenta Cervantes, 1894. $201 \mathrm{p}$.

- La Aurora de Chile. First official gazette began Feb. 12, 1812, founded by Padre Camilo Henriquez. 58 numbers bound in 2 vols. In addition: La Aurora de Chile, periodico ministerial i politico began Feb. 12, 1812. E1 Monitor Araucano ed. by Padre Camilo Henriquez, 1813.

$71624^{\circ}-17-24$ 
government of the King of Spain was ended. On November 14,1814 , the Spanish régime began the publication of the Gaceta del Gobierno de Chile ${ }^{1}$ which continued in existence until I 817 .

In 1817 the first Chilean official gazette, known as the Gaceta de Santiago de Chile, whose title soon changed to Gaceta Ministerial de Chile, ${ }^{2}$ began issue. Two hundred and sixty-eight regular numbers, in three volumes, and I 9 extraordinary numbers, some with and some without numbering, were published. It was edited by Dr. Bernardo Vera, with the collaboration of others. Between 1817 and 1830 various ephemeral gazettes were issued, but they lived for such a short time that it is not considered necessary to mention them in detail. Briseño's bibliography (supra) lists them all.

In 1830 began the publication of the important official gazette, El Araucano, ${ }^{3}$ which was issued from September 17 , 1830, to February 26,1877 . It was issued bi- or tri-weekly and contained the laws, decrees, ministerial orders, and other official documents until I86r, when it was reduced to a repository of the laws and decrees, and reports of debates of congress, with but few other official documents. During its 46 years of existence 34 completed volumes were issued, although the numbering of the volumes is not printed in the periodical. It was founded by Supreme Court Justice Manuel $\mathrm{J}$. Gandarillas, and among its editors in chief were Andres Bello, Ambrosio Montt, and other celebrated Chileans. In 1877 it was replaced by the Diario Oficial, ${ }^{4}$ a daily official gazette, of which some 85 volumes had appeared up to I9I 5 . It includes laws, decrees, official notices, ministerial orders, and other official material of importance.

1 Gaceta del Gobierno de Chile (español) began Nov. 14, I814, edition by José María Torres and José María Pozo. Santiago, Imprenta Gobierno. I73 numbers.

${ }^{2}$ Gaceta ministerial de Chile, r8I7-r823. Santiago, Imp. del Estado, I8I 7-r823. $3 \mathrm{v}$.

${ }^{3} \mathrm{E} 1$ Araucano, Sept. $\mathrm{I} 7,1830$, to Feb. 26, I877, 4,842 numbers, usually bound in $34 \mathrm{v}$. Santiago, Impr. nacional, $1830-1877$.

- Diario Oficial de Chile, I 877 and cont. Santiago de Chile, Imprenta nacional, $1877^{-}$. 
The official repository of the laws and decrees is known as the Boletin de las leyes $i$ decretos del Gobierno de Chile. It was begun in February, 1823. The period from 1810 to 1822 was not covered by any official publication, except the various Gacetas, until r896, when the government published the laws and decrees for that period in four volumes. ${ }^{1}$ In 1846 , however, an unofficial publication, by Cristóbal Valdés, ${ }^{2}$ reprinted the laws and decrees in chronological order as extracted from the Gaceta Ministerial and earlier gazettes. The work has become very scarce.

The Boletin itself is issued under the direction of the Ministry of Justice, the laws and decrees being published by Ministries rather than in chronological order. It seems that the Chilean method is to place the execution or administration of various laws under appropriate Ministries, the Ministry of Justice being considered the residuary authority for laws which can not be placed under any other Ministry-for example, laws amending the civil code, or relating to criminal law and to procedure. The ordinance power of the Chilean Executive is also great, so that many ministerial decrees, having the force of law, are issued annually. In 1893 the laws began to be numbered serially. Up to the present time the Boletin has appeared in some 84 volumes, of which various years contain two or three parts, so that the actual number of volumes is now about $1400^{3}$

In 1900 the Council of State ordered the separate publication of the laws enacted since 1893 , when the serial numbering of the laws began. This publication omits all executive decrees and ministerial orders, following merely the numer-

1 Boletin de las leyes i decretos del Gobierno, I8Io-1822. Santiago de Chile, Impr. Nacional, $1896,1898,1900$, I901. (V. 1, 1810-1814; v. 2 , I8r 7-r818; v. 3, r819-1820; v. 4, 182 I-1822.)

2 Coleccion de las leyes $\mathrm{i}$ decretos del gobierno desde r8ro hasta 1823 . Publicada con la autorizacion i revision competente. Santiago, Imprenta chilena, $1846.392 \mathrm{p}$.

Boletin de las leyes i de las ordenes i decretos del gobierno. Santiago de Chile, Imprenta de la Independencia, 1823-. $84 \mathrm{v}$. to I915. v. $1-8$ (1823-1842). 2nd ed. v. 68 omitted in numbering. Years $1823-1846$ published also in 1848 by Imprenta Mercurio, Valparaiso, in $14 \mathrm{v}$. 
ical order of the laws, which, as has been noted above, is not the case in the Boletin de las leyes. Seven volumes had been issued to 1914, including the laws to Number 2888. It is indexed by number, by ministry, and by subject. ${ }^{1}$

In 1902 the government authorized Messrs. Ricardo Anguita and Valerio Quesney ${ }^{2}$ to reprint the laws chronologically, omitting the decrees. The compilation was published in two volumes. In I913 a new edition of this work was undertaken by Dr. Anguita, ${ }^{3}$ which appeared in four volumes, with an additional volume of consolidated index covering the individual indexes of the other volumes. The order of the Boletin de las leyes is not strictly followed, but it is, without question, the handiest edition of the Chilean laws.

As will be observed hereafter, corporations require governmental authority to begin business. This authorization, with the charter of the company, is published in the Boletin de las leyes. In view of the great number of corporations which have received this authorization, the Boletin de las leyes, in 1890 , began the annual publication of a supplementary volume which contains a compilation of all the governmental authorizations and charters for corporations doing business in Chile, whether national or foreign. This publication was continued until 1897.4

It will be of interest to mention the important compilations of laws in force at various periods. The first of these, chronologically, was the work of Ignacio Zenteno, ${ }^{5}$ which compiles the laws in force on December $31, x 859$. The mate-

${ }^{1}$ Recopilacion de leyes por orden numerico arreglada por la secretaría del Consejo de estado. Santiago de Chile, Imprenta litografía i encuadernacion Barcelona, r900 and cont. 7 v. to r9r 4 .

${ }^{2}$ Leyes promulgadas en Chile desde 18 Io hasta rgor inclusive. Santiago de Chile, Imprenta nacional, 1902-[5]. 2 v. (At head of title Ricardo Anguita i Valerio Quesney M.)

${ }^{3}$ Anguita, Ricardo, comp.: Leyes promulgadas en Chile desde 1810 hasta el I. $^{\circ}$ de junio de I9r2. Santiago de Chile, Imprenta Barcelona, IgI2-I3. 4 V. V. 4 has title: desde r8ro hasta el $I^{\circ}$ de Junio I9r3. (v. 5, Indice general; consolidated index.)

4 Boletin de las leyes y decretos del gobierno. Sociedades anónimas. Published separately from 1890 to 1897 in $8 \mathrm{v}$. (v. $59^{-66 .)}$

${ }^{5}$ Zenteno, Ignacio: El boletin de las leyes reducido á las disposiciones vigentes $\mathbf{i}$ de interes jeneral. Santiago, Imprenta nacional, I86I. $562 \mathrm{p}$. 
rial is taken not merely from the Boletin de las leyes, but covers, in addition, material found in the Araucano and the various official gazettes. It is divided into four books, in accordance with the four ministries within whose jurisdiction the various laws were brought, namely, (I) Interior and Foreign Relations; (2) Justice and Education; (3) Finance; (4) War and Navy. Zenteno excluded laws which had been completely abrogated, but the work does not show which laws were in part repealed. The classification of the material into ministries at times results also in an artificial division. Under each subject of the compilation a chronological order is followed.

The next compilation of importance was prepared by the brothers Larrain Zañartu, ${ }^{1}$ and includes a compilation of the laws enacted and decrees issued from 1860 to 1871 . It was designed to afford a supplement to Zenteno's compilation. It prints complete texts of the laws, including charters of corporations. It is likewise divided according to ministries and is supplied with a copious alphabetical subject-index.

The next compilation of importance is that prepared by the celebrated jurist, José Bernardo Lira, ${ }^{2}$ entitled (in translation) "The uncodified Chilean legislation." It was published in four volumes from 1879 to 1884 , each volume including the legislation coming under the respective jurisdiction of the four ministries then in existence. The compilation follows substantially Zenteno's plan and includes an alphabetical subject-index. It also shows laws which have been abrogated in part. It includes treaties and amendments to the various codes and in certain exceptional cases reprints, with a special notice, important laws which have been abrogated. It excludes the budget, the army bills, and similar annual laws. In its time it had great value.

' Larrain y Zañartu, José Ignacio: Boletin de las principales leyes y decretos vijentes dictados desde enero $I^{\circ}$ de $\mathrm{r} 860$ hasta enero $\mathrm{I}^{\circ}$ de $187 \mathrm{x}$ y recopilados por orden de materias por $\mathrm{J}$. Ignacio y $\mathrm{J}$. Joaquin Larrain $Z$. Valparaiso, Imprenta del Mercurio de Tornero y Letelier, $187 \mathrm{r}$. r,024 p.

2 Lira, José Bernardo: La lejislacion chilena no codificada, o sea colección de leyes $\mathrm{i}$ decretos vijentes i de interes jeneral ordenada por . . . Santiago de Chile, Impr. de "El Correo" de R. Varela, r879-84. $4 \mathrm{v}$. in 2 . 
A few other compilations warrant mention. In 1886 Ramón Chaverría ${ }^{1}$ published a compilation of the constitutional and administrative laws in force. In r888 Anibal Echeverría and Del Rio ${ }^{2}$ prepared a compilation of administrative laws in force in 1888 , including the laws on the constitution, elections, posts and telegraph, public health, railroads, statistics, and similar matters. In 1893 a compilation covering much the same ground was prepared by Ovalle and Anguita. ${ }^{3}$

In 1898 a compilation of the legislation and decrees in force in two very large folio volumes was prepared by Boza and Anguita ${ }^{4}$ under governmental authority. The laws and decrees are again divided by ministry, following the new division of the ministries under the law of 1887 . The material under each ministry is separately indexed and there is also a chronological index.

A compilation of all the laws, decrees, and other provisions of general interest relating to the Ministry of the Interior ${ }^{5}$ was published officially in 1903.

\section{INDICES}

The first important index was prepared in 1837 by Diego Arriarán ${ }^{6}$ and covered in alphabetical order the laws and

1 Chaverría, Ramón Contardo: Recopilacion de leyes. Constitución política, leyes constitucionales, políticas y algunas administrativas y civiles ... I I886. Santiago, I886. 4II p.

${ }^{2}$ Echeverría y Reyes, Anibal and Del Rio, Abraham: Recopilación de leyes y decretos de interés general vigentes en $2 \mathrm{I}$ de mayo de $\mathrm{r} 888$. Santiago, Imprenta nacional, 1888. 806 p.

3 Orrego Ovalle, Eduardo y Anguita Acuña, Ricardo: Recopilación de leyes constitucionales y administrativas vigentes en 18 de setiembre 1893. Santiago, Imprenta nacional, r893. $889 \mathrm{p}$.

4 Boza y Lillo, Agustín and Anguita, Ricardo: Lejislacion política, administrativa $\mathrm{i}$ judicial, o sea colección completa de las leyes $\mathrm{i}$ decretos dictados en Chile $i$ vijentes en 30 de junio de 1898 , ordenada por Agustin Boza I. . . . y Ricardo Anguita . . . Santiago de Chile, Est. poligrafico Roma, I898. 2 v.

${ }^{5}$ Recopilación de todas las leyes, decretos i demas disposiciones de interes jeneral del Ministerio del interior. Santiago de Chile, Imprenta nacional, I903. I279 p.

${ }^{6}$ Arriarán, Diego: Indice de las leyes y decretos que se contienen en los tres tomos de la Gaceta ministerial. Santiago, Imprenta de la Independencia, I837. $18 \mathrm{p}$. 
decrees contained in the three volumes of the Gaceta Ministerial. In 1848 the Imprenta Mercurio, which had republished the Boletin de las leyes from 1823 to $\mathrm{I} 846$, also published an alphabetical index to the Boletin covering these years. It was prepared by Juan Bautista Alberdi, ${ }^{1}$ although his name does not appear on the title page.

The next important index of the laws was prepared by Dr. Manuel B. Ballesteros, ${ }^{2}$ who subsequently became a justice of the Chilean Supreme Court and enjoys a high reputation among Chilean jurists. His index covered the years r8roI 88I and was published in Lima during the Chilean occupation of that city. A supplement to this index was prepared by an unnamed attorney ${ }^{3}$ in 1892 covering the laws and decrees promulgated in the period $188 \mathrm{I}-\mathrm{I} 890$. It includes a brief digest of the laws, the material itself being divided by ministries in accordance with the governmental reorganization of June $2 \mathrm{I}, \mathrm{x} 887$.

The most useful index at the present time is the three-volume index covering the years $1810-1905$ prepared by Messrs. Lazo and Márquez. ${ }^{4}$ The work is based on Ballesteros's earlier index and includes a brief digest of the laws.

\section{COURT REPORTS}

The most important and only official court report is the periodical entitled Gaceta de los tribunales, ${ }^{5}$ which was begun as a weekly publication on November 6, I $84 \mathrm{I}$. It includes the decisions of the Supreme Court and of the courts of appeal.

1 [Alberdi, Juan Bautista]: Indice alfabetico del Boletin de las leyes y de las órdenes y decretos del gobierno de Chile, $1823-1846$. Valpariso, Imprenta del Mercurio, I848. 2 II $\mathrm{p}$.

2 Ballesteros, Manuel E.: Indice jeneral del Boletin de las leyes que comprende todas las leyes i disposiciones supremas . . . I810 hasta I88I. Lima, "La Patria," r882. $5^{17}$ p.

${ }^{3}$ Indice jeneral del Boletín de las leyes y decretos del Gobierno que comprende todas las leyes y disposiciones supremas dictadas . . E Enero de $188 \mathrm{I}$-Diciembre de 1890 . [Por un Abogado.] Santiago de Chile, Imprenta de la Librería Colón, I892. 363 p.

- Lazo, Santiago y Márquez, Narciso N: Indice general del Boletín de las leyes y decretos del gobierno de Chile . . 1810-1905. Santiago, Cervantes, I905. $3 \mathrm{v}$.

${ }^{6}$ Gaceta de los Tribunales, I84I-I9I5, and cont. Santiago, Imprenta del Estado, 184r et seq. 
From numbers 62 to $4 \mathrm{r} 6$ it included the added title " $i$ de $l a$ instrucción púbiica" and included not merely decisions but interlocutory decrees and articles on legal subjects. From I 850 on, however, it has been confined to decisions of the courts. Its contents have increased in bulk with the progress of time, so that at present several thousand pages are included in the year, the publication being issued monthly. At one time it appeared daily. It is now in its seventy-seventh year and includes over eight thousand numbers. It is divided by classes of cases, civil or criminal, of the Supreme Court, and in accordance with the seven courts of appeals now sitting in Chile. It also includes the reports of the quinquennial visits of inspection of the judges of the courts of appeal to the courts of first instance, which will be described hereafter. (Infra, p. 404.)

More detailed reference will be made hereafter (infra, p. 379) to the unofficial collection of decisions printed in the Revista de los Tribunales and the Revista de Derecho, Jurisprudencia $y$ Ciencias Sociales.

In 1902 the Supreme Court was given authority to act as a court of cassation for errors in substantive law in addition to its previous jurisdiction of reversing decisions for errors in form. The innovation induced the publication of a number of law reports which, however, expired after brief periods of existence. One by Juan José Molina Ramos, ${ }^{1}$ the chief clerk in the office of the secretary of the Supreme Court, reprinted the decisions in matters of cassation. Its existence was limited to one year. A similar collection of decisions covering the years 1903-1909 has been published with a detailed index. ${ }^{2}$

The court of appeals at Valpariso passes upon important commercial cases. In 1902 two attorneys, Messrs. Escobar and Muñoz, ${ }^{3}$ prepared an index digest with annotations of the reports of the Valparaiso Court of Appeals for the period I 892-

${ }^{1}$ Molina Ramos, Juan José: Recursos de casación i revisión de la Corte Suprema. Santiago de Chile, Imprenta Cervantes, I903. 377 p.

${ }^{2}$ Corte Suprema. Dictamenes de los señores ministros emitados en los recursos de casación en el fondo, 1903-r909. Santiago de Chile, Imprenta del Debate, I903-r909. 5 v.

${ }^{3}$ Escobar, Ricardo Cerda y Muñoz, Fidel Rodriguez: Jurisprudencia civil y commercial de la Corte de apelaciones de Valpariso. (v. I, I892-I90I; v. 2, I901-x902.) Valparaiso, Imprenta Gillet, I902-. 
1901, a supplementary volume bringing the work down to 1902 . It includes a table of statutory citations.

\section{INDICES AND DIGESTS.}

Between 1865 and 187 r Severo Vidal ${ }^{1}$ prepared an alphabetical index in three volumes of decisions rendered by the Chilean courts. Volume $\mathrm{x}$ indexes the decisions between 1857 and 1864 in which the civil code was applied. Volume 2, which covers the period r 865-r 867, deals with the civil code and commercial code. Volume 3 deals with the decisions under both codes during I 868-I869.

Among various indexes to the court reports several warrant mention. In 1873 Valentín Gormaz ${ }^{2}$ prepared an index of the decisions for the period $1843-1873$ in alphabetical order.

The decisions of the courts between 1857 and 1892 which have interpreted the sections of the civil code have been listed by section in a work by Eulojio Piñera ${ }^{3}$ in two volumes, the first published in 1879 and the second in 1894 . Notes are occasionally inserted. An important work in the form of a dictionary of the decisions of the courts published in the Gaceta de los Tribunales between 1878 and i 887 , with critical comments and doctrinal discussion, was published in 1892 by José Ravest. ${ }^{*}$ This is an important work for the period covered.

By far the most useful index at the present time is the five volume work by Juan de Dios Plaza, ${ }^{5}$ which indexes the Gaceta

1 Vidal, Severo: Indice alfabético de cuestiones resueltas por nuestros tribunales. Valparaíso, Imprenta Chile (v. I), Albion (2), and La Patria (3), $1865-187$ r. $3 \mathrm{v}$.

${ }^{2}$ Gormaz, Valentín: Repertorio de jurisprudencia técnica y práctica chilena, durante los últimos treinta años. Santiago, Imprenta Chilena, 1873 . $307 \mathrm{p}$.

${ }^{3}$ Piñera, Eulojio: La jurisprudencia civil; repertorio de las sentencias en que se ha aplicado el código civil chileno desde que comenzó a rejir en $I^{\circ}$ de enero de 1857 hasta el año $r 892$ inclusive. Santiago, Imprenta de R. Varela, $1879-1894.2 \mathrm{v}$.

4 Ravest y Campaña, J. R.: Diccionario de jurisprudencia de las cortes de justicia de la Republica de Chile. Santiago, Imprenta Barcelona. I892-93. 2 v.

- Plaza, Juan de Dios: Indice jeneral de la Gaceta de los tribunales que comprende el resumen de las sentencias interesantes publicadas en este periódico, desde su fundación el 6 de nov. $x 8_{4}$ I, hasta el . . . 19r5. Santiago, Imprenta chilena de N. Ezquerra, r89o-rgr5. 5 v. 
de los Tribunales from $184 \mathrm{I}$ to 1910 . It includes, however, only the important decisions with a brief digest. Volume I, published in 1890 , covers the period $184 \mathrm{I}-1890$. Volume 2 , published in 1899 , includes the material in the first volume and brings the work down to I899. Volume 3, published in 1905 , volume 4 , published in 1910, and volume 5, published in 1915 , are supplements carrying the work down to December, 1915.

\section{GENERAL WORKS}

\section{COLLECTED CODES}

Collections of the various codes of Chile, to which more detailed reference will be made hereafter, have been published in handy volumes by the publishing house of Miranda. The last of these text editions of the codes was published in $1912^{1}$ and contains the constitution, the civil code, code of civil procedure, the commercial code, the penal code, the code of criminal procedure, the mining code, the judiciary code or law organizing the courts, with the various supplementary laws which have amended these codes. The last of these editions to incorporate the valuable bibliography of Echeverría, mentioned above, appears to have been the 1903 edition.

\section{LEGAL ENCYCLOPEDIAS}

Recent dictionaries or encyclopedias of law do not exist. In 1874 Vitalicio A. López ${ }^{2}$ published a dictionary of Chilean legislation which is of historical value inasmuch as it contains practically all the old Spanish and Chilean codes and laws in force in Chile in 1874 , the provisions of the civil code, the autos concordados of the Cortes, the ecclesiastical laws, and the decisions which have applied the civil code since 1857 .

${ }^{1}$ Coleccion de códigos de la república de Chile. Constitucion politica. Código civil. Código de procedimiento civil. Código de comercio. Código penal. Código de mineria. Lei de organizacion i atribuciones de los tribunales. Apéndice a la misma lei. Santiago, Librería Miranda, IgI2. [I,218 p.] Also ed. Valparaiso, Impr. Universo, I9I2. 48,44 , I919 $\mathrm{p}$.

${ }^{2}$ López, Vitalicio A.: Diccionario razonado de legislación y jurisprudencia civil. Valparaiso, Imp. del Mercurio, 1874.695 p. folio. 
In 1883 Carlos V. Risopatron ${ }^{1}$ published a dictionary of legislation and court decisions which contains under alpha. betical arrangement the text of all the codes and laws in force in Chile in 1883 , with explanatory notes and the citation of the decisions in which the laws and the codes have been applied.

\section{LEGAL, PERIODICALS}

Among the modern legal periodicals, the most important while it existed was the Revista forense Chilena, ${ }^{2}$ edited by Enrique C. Latorre. It was first issued in June, 1885 , and ceased publication in 1902 after $I_{5}$ volumes had been ptiblished.

In October, 1903, the publication of what is now the only important legal periodical, Revista de derecho y jurisprudencia, ${ }^{3}$ began. Its chief editors have been Eliodoro Yáñez, a practicing lawyer of Santiago; Luis Claro Solar, professor of civil law at the University; Alejandro Valdés Riesco, professor of commercial law at the University; and Antonio Huneeus, professor of philosophy of law. The editor in chief is now Oscar Davila Izquierdo. It is published bimonthly. It contains a few articles, exhaustive reports of the decisions of the highest courts, namely, the Supreme Court and the Courts of Appeals, criticisms of the decisions, bibliographical notes, principally of foreign works, and a brief summary of the contents of foreign legal periodicals. In rgro the title of the work was amended to read Revista de derecho, jurisprudencia y ciencias sociales, and it became the organ of the bar and of the faculty of law and political science. The scope of its contents, however, was not changed.

Attention should also be called to the periodical Revista de tribunales, ${ }^{4}$ founded in March, I898, by David Toro Melo, its

${ }^{1}$ Risopatron, Carlos V.: Diccionario razonado de lejislación y jurisprudencia chilenas . . Santiago, Imp. de H. Izquierdo i cia., I883. 2 v. folio.

${ }^{2}$ Revista forense Chilena. Santiago, Cervantes, r885-rgo2. I5 v. + index v.

${ }^{8}$ Revista de derecho y jurisprudencia, v. I, issued 1903 . Title changed in Igro (v. 7) to Revista de derecho, jurisprudencia y ciencias sociales. Santiago, 1903-.

- Revista de tribunales. Publicación mensual de lejislación i jurisprudencia. Santiago, Imprenta Universitaria, I898-1906. $9 \mathrm{v}$. 
editor. It constitutes a repository of court decisions, doctrinal articles, and critical discussion of decisions. It ceased publication in 1906, after nine volumes had been published.

Among the periodical publications which contain contributions of value for law mention should be made of the university periodical Anales de la Universidad de Chile, which commenced publication in 1843 . For a long time each volume consisted of two parts, the first, called official, containing a record of the important events of the year, including laws, decrees, governmental orders, and other matters of public interest, and the second, containing articles, lectures, and other papers contributed by members of the Faculty and others connected with the university.

\section{COLLECTED WORKS}

It has become a custom in Chile to publish the collected works of its celebrated public men. Among these men various lawyers occupy a prominent place, and either at government expense or with governmental aid the collected works of several jurists have been published which, by reason of their wide range, may be included among the general works on Chilean law. The first of these men to warrant mention is the famous jurist, Andrés Bello, ${ }^{1}$ who, while of Venezuelan origin, dedicated his life to the elaboration and codification of much of the present law of Chile. His collected works have been published in 15 volumes. Their main interest lies in the discussion of questions of civil law, and in our discussion of the civil code occasion will be taken to refer at some length to the work and publications of Bello.

Another scholar to whom tribute has been paid by the publication of his collected works is José V. Lastarria, ${ }^{2}$ whose principal contributions were made in the field of public law and the civil code. Up to 1914,13 volumes of his collected works had been published.

Another prominent jurist whose name is closely identified with law reform and codification in Chile is José Clemente

${ }^{1}$ Bello, Andrés: Obras completas. Santiago, Imp. de Pedro G. Ramirez, I885-. I5 v.

${ }^{2}$ Lastarria, José V. (r81 7-1888): Obras completas. Ed.oficial. Santiago, Imp. Barcelona, Igo6-. I3 v. to I9I4 published. 
Fabres. ${ }^{1}$ He was the first dean and professor of civil law at the Catholic University of Santiago de Chile, and the University has undertaken the publication of his collected works. He was an important contributor to the codification movement during the seventies and took a prominent part in the preparation of the mining code, the penal code, and the judicial code. He was exceedingly versatile, so that while he is primarily known as one of the most learned Chilean jurists on civil law, he has made valuable contributions to canon law, the conflict of laws, and other branches of the law. A brief sketch of his life, by G. Lira Palma, is printed in 5 Revista de derecho y jurisprudencia (1907), pages I09-II4.

The works of the celebrated jurist Miguel Luis Amunátegui ${ }^{2}$ were begun to be published in 1906 .

A few volumes of collected essays by other lawyers may be mentioned. Among the best of these is the volume of legal studies of Correa Bravo, ${ }^{3}$ the learned commentator of the law of municipalities. This work was published in 1890 , with an introduction by Vicente Aguirre Vargas.

Robustiano Vera, ${ }^{4}$ a prolific, although not very eminent writer, whose literary productions cover practically the entire field of law, is the author of two general works of collected articles which warrant mention by reason of their informative character. The author seems to have been particularly desirous of cultivating a reputation abroad and does not appear to enjoy the high reputation in Chile for which many of his foreign colleagues gave him credit. In his work entitled "Practical jurisprudence," a collection of various articles, attention may be directed to articles dealing with the history of the judiciary, his sketch of the principal old Spanish codes,

${ }^{1}$ Fabres, José Clemente: Obras completas . . . recopiladas, anotadas y publicadas de cuenta de la Universidad Católica, por don Santiago Lazo. Santiago, Impr. Cervantes and La Ilustración, Igo8-rgI4. I $5 \mathrm{v}$. to I9I4.

${ }^{2}$ Amunátegui, Miguel Luis: Obras completas. Santiago, Impr. Barcelona, r9o6 and cont.

${ }^{8}$ Correa Bravo, Agustin: Estudios legales y de jurisprudencia práctica. Santiago, La Epoca, I8go. 248 p. $4^{\circ}$.

- Vera, Robustiano: La jurisprudencia práctica de nuestros tribunales de justicia . . Santiago, Impr. de los Debates, I888. 500 p. 
his article on the codification movement in Chile, and various studies on criminal law. In his volume entitled "Estudios juridicos," or "Legal studies," there is an interesting article on extradition, various essays on criminal law, and an article on paper money which has been recommended.

In connection with the First Pan American Scientific Congress held at Santiago, Chile, in 1908, numerous papers were published, among which those devoted to law were published separately as volume 7 of the collected series. In this volume, edited by Tomás A. Ramirez, ${ }^{2}$ there are several articles by the learned Chilean jurist, Marcial Martínez, Chilean minister to the United States during the eighties.

\section{PHILOSOPHY OF LAW}

It can not be said that Chileans have made any important contributions to the philosophy of law. In this field they have been followers of Spanish, French, and Italian schools of thought, and such works as do exist can hardly be called original contributions. The best of these works, however, is that of Fernández Concha, ${ }^{3}$ first published in 1881 , with a second edition in two volumes in $1887-88$.

Somewhat earlier works which served as text books in the university course on the subject was that by Ramón Briseño, ${ }^{4}$ first published in 1856 , of which a fourth edition appeared in 1870, and José Antonio Lira's ${ }^{5}$ work, published in 1877 .

\section{LEGAL HISTORY}

Chile was a part of the old vice-royalty of Peru. The viceroyalty and its subdivisions, the captaincies general and audiencias, were not colonies of Spain, but dependencies of the Crown of Castile. The system in force in Chile at the time

1 Vera, Robustiano: Estudios juridicos. Santiago, "E1 Correo," I890.

${ }^{2}$ Ramirez, Tomás A.: Ciencias juridicas. (Pan American scientific cong. Santiago de Chile, rgo8, vol. 7.) Santiago, Lit. y Enc. "Barcelona," rgro. I v.

${ }^{3}$ Fernández Concha, Rafael: Filosofía del derecho 6 derecho natural. 2d ed. Barcelona, Tip. Católica, r887-88. 2 v.

4 Briseño, Ramón: Derecho natural ó filosofía del derecho. 4th ed. Valparaiso, Mercurio, $1870.285 \mathrm{p}$.

- Lira, José Antonio: Filosofía del derecho 6 sea derecho natural. Santiago, Imp. de El Correo, $1877.582 \mathrm{p}$. 
of the declaration of independence in 1810 was that which had been established by Spain for the Indies in general, and for the Reino de Chile in particular. This legislation was in the form of books of codes and other legislation and was scattered in the archives of the Consejo de Indias in Madrid, or in the various administrative departments in America. The Spanish monarchs had, since the conquest of America, concentrated in their hands the entire sovereign power; nevertheless, a consultative body with the title Consejo de Castilla had been created in Madrid charged with the duty of communicating to the authorities of the Peninsula the royal orders and decrees. In imitation of this Council there were created those of Aragon and others in subsequent periods, and in like manner, for the administration and well-being of the oversea dominions there was created the Consejo de las Indias, whose functions and responsibilities became as important as those of the Consejo de Castilla. There were enforced in America, therefore, only such royal cedulas and decrees and orders as were communicated by the Council of the Indies to the viceroyalties, captaincies general, and audiencias, as provided by law 40 , Title I, Book II of the Recopilación de las Indias, to be described presently. By reason of the number of these provisions and the distance of the localities in which they were to be enforced, it became exceedingly difficult either to know or to find them. This fact induced Philip II in 1560 to order that the rules be codified. This work was completed and promulgated by Charles II on May I8, r68o, with the title Recopilacion de las leyes de las regiones de las Indias in imitation of the Spanish compilation Recopilacion de las leyes de España, which was begun in the reign of Charles I and finished in the reign of Philip II.

The Spanish sovereigns, however, continued to govern their colonial territories, issuing royal cédulas, decrees, and general and local ordinances, whose complexities and unsystematic character produced numerous errors and difficulties in application. The royal cédulas after I680 are not officially compiled in any book or code; the important ones may be found in the wori of Matraya. In 1776 a new and complete recodification of the "Recopilacion" and subsequent orders and decrees was provided for, but of this compilation, which was 
to bear the title Codigo Carolino, only the first book was written and duly authenticated, although it was never apparently communicated to the Audiencia of Chile. The legislation which was of special concern to Chile after r68o was to be found in the old archives of the Gobierno or Real Audiencia of Santiago and even in the archives in Spain of the Consejo Real de Indias. Among the most important of the special regulations in force in Chile was the Ordenanzas de Mineria de Nueva España, with the Chilean and Peruvian declarations (infra, p. 428); the Ordenanza de Intendentes, sanctioned in 1786 ; the Reglamento, called the libre comercio of 1778 ; and the Ordenanza de Bilbao, communicated by cédula of February 26, 1795, in force until replaced by national codes of commerce.

The laws of the Indies, compiled and uncompiled, referred principally to military, political, and economic matters of the new empire, and when they contained any provision relating to the organization of the courts, to civil, criminal, or commercial law, it was only in particular cases when it was desired to introduce some exception to the common law in force in Spain.

The civil law in force in Spain was applied, in so far as not abrogated or modified by the laws of the Indies or special decrees. In Chile, although there were doubts as to the relevant application of the laws of the Indies and Spanish law, the Spanish laws were applied in the determination of cases when not capable of decision by express laws or decrees of the Indies, a rule which was expressly recognized by the senatus consultum of June 7,1820 . It was uniformly admitted, however, that later provisions of law or regulations took precedence over prior provisions, and a definite order of preference in the application of conflicting or doubtful laws and codes was enforced by courts and administrative officials. The order of preference in which the laws were applied in Chile was as follows:

I. The decrees, ordinances, orders, and royal cédulas issued for America and communicated by the Council of the Indies from May 18,1680 to the period of independence;

2. The Recopilacion of the laws of the Indies;

3. The Novisima Recopilacion of the laws of Spain; 
4. Leyes de Estilo (see Decreto Supremo of April 28, 1838);

5. Fuero real;

6. Fuero juzgo;

7. The Siete Partidas.

On September 18, 1810, independence was declared, and in the period between 1810 and 1855 , when the civil code was adopted, numerous laws were enacted on various branches of civil and commercial law reforming prior rules of the colonial period. The heterogeneous character of the laws, and the difficulty of reconciling the new and the old legislation, particularly distinguishing laws which had been tacitly repealed, rendered codification necessary. Some reference to the preparation of the various codes of Chile will be made at more appropriate places.

Several collections have been made of the various Spanish codes and laws which for historical purposes are valuable in the study of Chilean law. These editions have been referred to in the "Guide to the law and legal literature of Spain" issued in 1915 by the Library of Congress, pages $30 \mathrm{et} \mathrm{seq.}$ One of the most useful editions is the 12 volume collection published by the house of La Publicidad in Madrid in 18471851,1 and another 2 volume edition in 1885 , edited by Martinez Alcubilla. ${ }^{2}$ These contain the Liber Judicum, Fuero Juzgo, Fuero Viejo, Estilo, Fuero Real, Ordenamiento de Alcalá, Las Partidas, Indices y Glosas de Gregorio López, Espéculo, Leyes de los Adelantados, Leyes Nuevas, Ordenamiento de las Tafurerias, Ordenanzas Reales, Leyes de Toro, Novisima Recopilación, Suplementos é Indices, Nueva Recopilación, Autos acordados and Ordenanzas de Bilbao.

Of the Recopilacion de las Indias ${ }^{3}$ there are numerous editions. As already observed, it was first published in 1680 . Later editions appeared in $1756,1774,1791$, and 1841 . The

${ }^{1}$ Los códigos españoles concordados y anotados. Madrid, Imp. de la Publicidad, $1847-51$. I2 folio v.

${ }^{2}$ Martinez Alcubilla, Marcelo: Códigos antiguos de España . . . desde el Fuero juzgo hasta la Novísima Recopilación. Madrid, Administración, $1885 . \quad 2,05^{\circ} \mathrm{p}$.

${ }^{3}$ Recopilación de las leyes de los reinos de los Indias mandados imprimir y publicar por la Magestad Católica del Rey Don Carlos II. Madrid, r680. 2 v.; 2 nd ed., I $75^{6}$; $3^{\text {rd }}$ ed., I774, 4 v.; $4^{\text {th }}$ ed., I79r; $5^{\text {th }}$ ed., $184 \mathrm{I}$.

$71624^{\circ}-17-25$ 
legislation governing the colonies subsequent to $168 \mathrm{o}$ has been collected unofficially by Eusebio Ventura Beleña, ${ }^{1}$ who published his work in two volumes in Mexico in 1787 . It relates principally to matters affecting the northern intendencies and captaincies general, particularly that of Mexico. $\mathrm{He}$ also republished the cédulas and decrees issued between I 528 and 1677 , which had previously been collected by Montemayor, and added those from 1677 to 1680 .

A chronological index ${ }^{2}$ of the Spanish colonial legislation, covering the years 1680 to 1847 , was published in 1848 . Walton in his "Civil law in Spain and Spanish-America" (pp. 5 $18-526$ ) gives a brief account of the administration and laws of the Indies. The laws of the Indies, with the legislation subsequent to 1680 so far as in force about 1885 , were collected under the auspices of the Government of Spain by Miguel de la Guardia ${ }^{3}$ and published in $1888-1890$ in 13 volumes.

There is no general work dealing with the history of Chilean law. The well-known manual of Juan Sala, ${ }^{4}$ was published in a Chilean edition in 1845 . It is a presentation of Spanish law as affected by Chilean legislation, and includes in volume I a historical sketch of Chilean law. A brief article by Valentin Letelier on the evolution of codification in Chile was published in volume I of the Revista de.derecho y jurisprudencia, pages $277-287$. Enrique C. Latorre ${ }^{5}$ published a historical sketch of the formation of the civil code, which also covers the early history of Chilean law, in the first volume of his work Explicaciones de codigo civil. It is also published separately. In a collection of papers reprinted from the Anales de la Universidad, edited by Enrique C. Latorre, under the title Memorias y discursos universitarios sobre el código

${ }^{1}$ Ventura Beleña, Eusebio: Recopilación sumaria de todos los autos acordados de la Real Audiencia y sala del crimen de esta Nueva España. Mexico, I787. 2 v. folio.

${ }^{2}$ Indice cronológico de la serie de leyes, etc. . . . de las provincias de Indias desde 1680 hasta 1847 . Madrid, 1848 .

${ }^{3}$ Guardia, Miguel de la: Las leyes de Indias con las posteriores á esta código, vigentes hoy ... Madrid, Nuñez, 1888-1890. I3 v.

4 Sala, Juan: Sala Hispano-Chileno ó Ilustración del derecho español. Paris, Librería de D. Vicente Salva, I845. 3 v.

${ }^{3}$ Latorre, Enrique C.: Reseña historica de la formación del codigo civil. Santiago, Imp. Cervantes, $x 882.56 \mathrm{p}$. 
civil chileno (infra, p. 394), a historical introduction by J. B. Lira is of considerable importance for the history of early Chilean law and the history of the civil code. In the same volume Toro Melo has contributed an essay on the history of civil procedure in Chile. The two-volume work by Luis Claro Solar (infra, p. 393) of "Explicaciones" of Chilean civil law contains in its introduction a valuable account of the external history of the early Spanish codes and of the later Chilean codification.

Enrique Cood, a learned jurist and for many years professor of civil law at the university, in his compilation of legislative and preparatory antecedents of the civil code (infra, p. 389) has included a useful historical introduction to Chilean law. In 1913 a brief account of the legislative history of procedure in Chile was published by Rigoberto Chávez. ${ }^{1}$

In public law only a few historical contributions have been made. A valuable work is the historical sketch of the Chilean constitution during the period $1810-1814$, by José Victorino Lastarria, ${ }^{2}$ published in 1847 and reprinted in his collected works. Attention should also be called to the historical introduction to Lastarria's work on the constitution of Chile, published in 1856 , considered the best commentary on the theory of the constitution (infra, p. 417).

In I 849 Ramon Briseño (infra, p. 416) published a historical and critical essay on Chilean public law since i 810 , which is useful principally because it contains the text of all the constitutions and drafts which were prepared in Chile up to 1849 .

It may be well to mention that the presidential messages which submit the draft codes to Congress for adoption are of historical value in explaining the origin and purposes of many of the provisions of the codes.

\section{CIVIL CODE}

\section{HISTORY}

The period of codification in Chile began with the promulgation of the civil code on December 14,1855 . It came into

${ }^{1}$ Chávez F., Rigoberto: Antecedentes de la legislación procesal Chilena. Concepción, José V. Soulodre, I9r3. 64 p.

${ }^{2}$ Lastarria, José Victorino: Bosquejo histórico de la Constitución del Gobierno de Chile durante el primer período de la revolución desde I8ro hasta 1814. Santiago, Impr. Chilena, 1847. $212 \mathrm{p}$. 
force January 1, 1857. Various plans of reform and codification were advanced after independence had been achicved. Some proposed the revision of the French codes, others a revision of the partidas, and others the appointment of commissions of jurists to draft a code. The latter plan was adopted, and the government prevailed upon Andrés Bello, the celebrated Venezuelan jurist, to assist in the work. Having spent a number of years in London and made a profound study of comparative civil law, he settled in Chile and dedicated his service to that country. Practically alone he drafted the present civil code, and he is justly regarded as the father of the Chilean civil code. The original draft was subjected to much revision by Bello himself before its final transmission by the Executive to Congress.

The sources of the code of Bello were the Roman law, the Partidas, the Novisima Recopilacion, the Code Napoleon, the Code of Louisiana, the Austrian Allgemeines bürgerliches Gesetzbuch, and the draft of García Goyena, and there is abundant evidence that he studied with profound care the writings of the leading jurists of the day, especially Savigny.

Bello's first draft, published in the Araucano in I 846-1 847, and the draft of 1853 with Bello's notes, are historically of great importance. The former is reprinted in volume II of Bello's collected works, with an introduction by Miguel Luis Amunátegui Reyes. ${ }^{1}$ Volume 12 of Bello's works contains the 1853 draft with notes indicating the sources of each article. This likewise contains an introduction by Professor Amunátegui. An official edition of the civil code published in 1858 by Rodriguez ${ }^{2}$ also contains Bello's notes to the draft of 1853 . The appendix of a small volume by Professor Amunátegui, ${ }^{3}$ entitled "Andrés Bello and the civil code," gives an account of the notes to this draft of 1853 .

There are several publications in which the legislative history of the civil code may be found. One of these is

${ }^{1}$ Bello, Andrés: Obras completas. v. XI. Proyectos de código civil. Santiago, Imp. de Pedro G. Ramírez, I887. 622 p.

${ }^{2}$ Rodriguez, Abraham: Código civil de la Republica de Chile. and authorized ed. Santiago, Imp. Chilena, 1858. $426 \mathrm{p}$.

${ }^{3}$ Amunátegui Reyes, Miguel Luis: Don Andrés Bello y el código civil. Santiago, Imp. Cervantes, I885. I45 p. 
Enrique C. Latorre's ${ }^{1}$ historical sketch of the formation of the civil code included in the first volume of his "Explicaciones" on the civil code and also published separately. Professor Amunátegui's ${ }^{2}$ introduction to volume 13 of Bello's collected works, also published separately, is entitled "The codification of the civil laws." It is of value in the study of the history of the civil code.

One of the best source books for the history of the code is the collection of various projects and drafts and decrees providing for the codification of the civil laws of Chile, containing committee reports, congressional discussions, opinions, and communications exchanged on various topics of the code, published by Professor Enrique Cood, ${ }^{3}$ under the title (translated) of "Legislative antecedents and preparatory labors of the Chilean civil code." Besides these documents it contains a table showing differences between the drafts and the code as promulgated. Only one volume of the work was published. A biographical essay of Enrique Cood and his work was published in 1888 by Miguel Amunátegui ; ${ }^{4}$ it contains a valuable account of the influence of Professor Cood on the civil code and the law of Chile.

The Chilean civil code, while following to a considerable degree the French code and other continental codes, was in many respects original and more complete than any other of its time. In its original provision concerning the equality of nationals and aliens, it preceded by ten years the Italian civil code, in which Fiore has claimed this provision to have been for the first time embodied. In whole or in part it has been adopted by the majority of the Latin American republics, and it has been almost textually adopted in Ecuador, Colombia, and some of the Central American republics, notably Nicaragua.

${ }^{1}$ Latorre, Enrique C.: Reseña histórica de la formación del código civil. Santiago, Imp. Cervantes, I882. 56 p.

${ }^{2}$ Amunátegui Reyes, M. L.: La codificación de las leyes civiles. Santiago, P. Ramírez, i89o. 4I p.

2 Cood, Enrique: Antecedentes lejislativos, trabajos preparatorios del codigo civil de Chile recopilados. Santiago, Impr. de H. Izquierdo i ca., I883. $25^{2}$ p. (Only I vol. published.)

Amunategui Reyes, Miguel Luis: Enrique Cood. Santiago, Imp. Cervantes, 1888 . $15^{2} \mathrm{p}$. 


\section{CONTENTS}

The civil code contains 2,524 articles, divided into four books, including a preliminary title dealing with its promulgation, the effects of the law, interpretation of the law, and various definitions.

Book I deals with persons, Book II with property, Book III with succession, and Book IV with obligations. The code has been amended by the enactment of various important laws, particularly the law concerning the registration of real property of June 24,1857 ; the law of October 7,1861 , concerning the retroactive effect of laws, and especially laying down, rules by which conflicts between the old and the new legislation were to be adjusted; the law of August 13, I859, requesting institution in the rights of majority (habilacion de edad) by which persons of twenty-one years could request a judicial declaration of the privileges of an adult (the civil code providing that twenty-five was the age of majority); and the important law of January 10,1884 , which separated religious from civil marriage and provided that only the latter had legal force. This reform was completed by the law of civil registration (Ley de registro civil) of July I7, I884, with the reglamento of October 24, I884, relating to both laws. Moreover, the code of civil procedure has modified various provisions of the civil code. After lengthy deliberation the law of December $3 \mathrm{I}, 1907$ was promulgated, which permitted and regulated the use of water as a motive power.

Book I of the code deals with persons, their status and capacity, marriage, legal relations of husband and wife, parent and child, and guardianship. Property relations between husband and wife are treated apart from personal relations. Book II deals with the various classes of property, ownership, the methods of acquiring and losing ownership and possession, usufructs and servitudes, and contains special titles relating to transfer and delivery, possessory actions, right of vindication, and other topics omitted from the French civil code.

Book III deals with succession by will and $a b$ intestato, executors and administrators, wills, and rules relating to legacies and gifts inter vivos. 
Book IV deals with the various forms of contracts and obligations, purchase and sale, exchange, assignment, bailments, partnerships, agency, guaranty, mortgages, quasicontracts and noncontractual obligations, and prescription.

\section{TEXTS}

The text of the civil code may be found in the various editions of the collected codes above mentioned. An official edition ${ }^{1}$ was published in $185^{8}$, with an appendix containing references and concordances to the various European civil codes. A French translation with annotations and a valuable introduction of 56 pages by Henri Prudhomme ${ }^{2}$ was published in 1904 as volume 2 of the Collection de codes étrangers published in Paris.

An analytical and doctrinal treatise on the Chilean civil code was published by Raoul de La Grasserie ${ }^{3}$ in 1896 . This contains a valuable discussion of the code, pointing out its differences from other codes and particularly drawing comparisons with the French civil code. An alphabetical index to the code was published in 1857 by Manuel Gormaz. ${ }^{4}$

In 1894 Professor Miguel Amunátegui ${ }^{5}$ issued a work, originally published in the Anales de la Universidad, entitled (translated) "The imperfections and errors manifested in the official edition of the Chilean civil code." Only volume I was published. The author takes up the notes of Bello and the criticisms of J. B. Lira and adds others of his own.

1 Codigo civil de la Republica de Chile. Ed. Oficial. Santiago, Imp. Chilena, $185^{8} .426 \mathrm{p}$.

2 Code civil chilien, promulgué le ${ }^{4} 4$ décembre ${ }^{2} 855$, entré en vigueur le rer janvier 1857 ; tr. annoté et précédé d'une introduction par Henri Prudhomme. Paris, A. Pedone, I904. 536 p.

${ }^{3}$ La Grasserie, Raoul de: Code civil chilien, précédé d'une introduction, par Raoul de La Grasserie. Paris, V. Giard and E. Brière, I896. $400 \mathrm{p}$.

4 Indice del código civil. Puesto en órden alfabético por Don Manuel Gormaz. Santiago, Imp. nacional, 1857. I55 p.

- Amunátegui y Reyes, Miguel Luis: Imperfecciones i erratas manifiestas de la edicion auténtica del código civil chileno. Santiago, Impr. Cervantes, I894. $287 \mathrm{p}$. 
Miguel Elizalde ${ }^{1}$ published in I 87 I a handy reference book of concordances of the articles of the Chilean and of the French civil code with an appendix of notes on the various titles of the code.

A useful reference book; designed to facilitate the knowledge of the codes and showing the relation of one code to the others, was published by Anibal Echeverria, ${ }^{2}$ the well-known bibliographer, under the title (translated) "Analogies and differences among the articles of the Chilean codes." Each article of the code is annotated with references to the other codes, and in addition there is a table of cross references.

\section{LITERATURE}

There are several commentaries on the Chilean civil code, but it is believed that none of them is particularly valuable. Jacinto Chacón ${ }^{3}$ is the author of a well-known work embodying the exposition and a comparative study of the Chilean civil code. The work was first published in I 868 and a third edition in three volumes appeared in 1890 . The code is studied in relation to Roman, Spanish, and French law, notes referring to other codes. The code is taken up by book and title, followed by a critical and didactic discussion and an exposition of the sources of the code. The work unfortunately covers only Books I and II of the code, ending with article 950. Volume 3 of the work merely contains the text of the code.

The nine-volume commentary of the Colombian jurist, Velez, ${ }^{4}$ is of considerable value for the Chilean code.

The seven-volume edition of the civil code by Robustiano Vera ${ }^{5}$ contains the articles of the code followed by commen-

${ }^{1}$ Elizalde, Miguel: Concordancias de los artículos del código civil Chileno entre si i con los artículos del código Frances. Santiago, La Libertad, I87 r. $584,72 \mathrm{p}$.

${ }^{2}$ Echeverría y Reyes, Anibal: Analogias y diferencias entre los artículos de los códigos Chilenos. Santiago, Miranda, r893. I45 p.

${ }^{3}$ Chacón y Barrios, Jacinto: Esposición razonada i estudio comparativo del código civil chileno. 3. ed. Santiago, Impr. nacional, r8go-9r. $3 \mathrm{v}$.

${ }^{4}$ Velez, Fernando: Estudio sobre el derecho civil colombiano. Medellin, C. A. Molina, r898-rgrr. 9 v.

${ }^{5}$ Vera, Robustiano: Código civil de la república de Chile, comentado $\mathrm{i}$ esplicado . . . Santiago, Impr. Gutenberg, El Correo y La Gaceta, I892-97. $7 \mathrm{v}$. 
taries. The discussion is based largely on theories of foreign writers on the various subjects discussed. The work appears not to be highly regarded in Chile.

Professor Claro Solar's " "Explicaciones" of Chilean and comparative civil law is, in fact, a scientific discussion by way of commentary on Book I of the code, which, in two volumes, is the only part published. The work, in fact, does not quite complete the law of persons in Book I of the code.

Besides the works mentioned, several valuable treatises exist. The best of these is the "Instituciones" of José Clemente Fabres, ${ }^{2}$ first published in 1863 , with a second edition in I893-1902. This is a standard treatise and covers as well the laws complementary to the code. The work in its discussion of subjects follows the order of the code. There are many learned explanatory notes.

Luis F. Borja, ${ }^{3}$ a lawyer of Ecuador, where the Chilean code was adopted, is the author of a seven-volume work of "Studies on the Chilean civil code," published in Paris in I90I-I 908. It consists of a comparative treatment of the articles of the Chilean code, by concordances to the Roman law, the Code Napoleon, and the civil codes of a number of other South American countries, with references to the writings of the leading jurists, including appropriate translations and a brief commentary by the author. The work was inspired by the success of St. Joseph's celebrated "Concordances," and as a reference book has a decided value. A discussion of the doctrines of the Chilean civil code is contained in José Lastarria's ${ }^{4}$

1 Claro Solar, Luis: Explicaciones de derecho civil chileno y comparado . . Santiago, Estab. poligrafico Roma, I898-rgo2. 2 v.

${ }^{2}$ Fabres y Fernandez, José Clemente: . . I Instituciones de derecho civil chileno. 2. ed. corr. y notablemente aumentada con varias notas y con el comentario á la ley de efecto retroactivo y al reglamento del registro del conservador de bienes raices y con la inserción de todas las leyes complementarias . . . Santiago, Impr. y lib. Ercilla $1893-\mathrm{rgO2} .2 \mathrm{v}$.

${ }^{3}$ Borja, Iuis F.: Estudios sobre el código civil chileno. Paris, A. Roger and $F$. Chernoviz, I90r-rgo8. 7 v. (Covers the code to art. 563 only.)

4 Lastarria, José Victorino: Instituta de derecho civil chileno. Lima, Tip. del Comercio, r863. 454 p.

Same: Estudios juridicos. $\mathrm{x}^{\mathrm{a}}$ serie; Instituto de derecho civil chileno. Santiago, Impr. Barcelona, rgr4. $437 \mathrm{p}$. 
work on the "Institutes of Chilean civil law," published in Lima in 1863 and included in volume 13 of Lastarria's collected works.

A volume of students' notes taken in the class of Professor Urrutia, dealing with articles $1437-2524$ on obligations in general and contracts, was published by Davila and Cañas ${ }^{1}$ in 1907.

A collection of articles published in the Anales of the University of Chile by leading lawyers ${ }^{2}$ on various topics of the civil code was issued in $187 \mathrm{I}$. This volume was reprinted in 1887 in Bogota, with an introduction by Ramón Rómez. . A new and more extensive edition of this work, reprinting the papers published in the Anales of the University up to 1887 , was published under the editorship of Enrique C Latorre ${ }^{3}$ in 1888-89. Volume I deals with the first three books of the code and volume 2 with Book IV. The articles follow the order of the code by books and topics.

A collection of articles on the civil law by Professor Aguirre Vargas ${ }^{4}$ was published in 1891 , shortly after the death of the author. The volume is edited by Enrique Latorre.

\section{INCIDENTAL AND RELATED TOPICS}

A scholarly work which enjoyed a high reputation in its day is Villalón's ${ }^{5}$ treatise on the relation between Chilean law and moral theology. Among various works dealing with special topics of the civil code special mention may be made of Latorre's ${ }^{6}$ essay on the law of civil marriage of January io, I 884 .

${ }^{1}$ Davila J., Oscar i Cañas O'R., Rafael: Explicaciones del código civil. Santiago, Impr. Cervantes, 1907. $423 \mathrm{p}$.

${ }^{2}$ El codigo civil ante la Universidad .. . (vol. I all published). Santiago, Imprenta Chilena, I87r. 70 r p.

${ }^{3}$ Latorre, Enrique Camilo: Memorias y discursos universitarios sobre el código civil chileno. Santiago, Impr. de La Union, r888-9. 2 v.

${ }^{4}$ Aguirre Vargas, Carlos: Obras jurídicas. Santiago, Impr. Gutenberg, I89r. $464 \mathrm{p}$.

${ }^{5}$ Villalón, Zoilo: Tratado teológico-legal de la justicia. Santiago, Imprenta del Correo, 187 I. $73^{6} \mathrm{p}$.

${ }^{6}$ Latorre, Enrique C.: Estudio sobre la ley de matrimonio civil de ro de enero de I884. Santiago, Imprenta de La Union, I887. I82 p. 
An English translation of a work in English by Enrique $\mathrm{Cood}^{1}$ on the law of marriage by non-Catholics was useful prior to the enactment of the law of civil marriage, and is still of historical value for its documentation.

Grain ${ }^{2}$ has published a work in English dealing with testamentary and intestate succession in Chile. It is not a translation of the code but an analytical account of the rules of Chilean law, which, in this respect, differ considerably from those familiar in common law countries.

\section{MARITAL PORTION}

One of the most interesting institutions of Chilean law is the law on marital portion embodied in articles $1172-1178$ and 1185 and II 190 of the code. 'This "marital quarter" of the old Spanish law was changed in the Chilean code, where the proportion may differ and it may also be given to the husband and not merely to the deceased wife. This was a distinction which Bello introduced for which he has not indicated his source. This institution and the articles dealing therewith were treated at length by José Clemente Fabres ${ }^{3}$ in an extensive essay reprinted in volume 2 of his collected works.

\section{MORTGAGES}

A valuable work on mortgages in comparative law and in Chilean legislation was published by Eubique Tocornal in Volume II of the Memorias y discursos universitarios sobre el codigo civil (supra, p. 394), pages 333-404. There is also in that volume at pages $413-426$ a further article on the Chilean mortgage law by Alejo Palma. In an article by Estanislas Zeballos, the Argentine jurist, in volume 3 of the Revue de l'Institut de droit comparé on mortgages in comparative law, one section (pp. 447-456) is devoted to the law of Chile.

1 Cood, Enrique: The law of Chile as to the marriage of non-Catholics. Valparaiso, Imp. del Universo, i888. $70 \mathrm{p}$.

${ }^{2}$ Grain, William: The testamentary and succession laws of the Republic of Chile. London, H. Sweet, I880. I29 p.

${ }^{3}$ Fabres y Fernandez, José Clemente: La porción conyugal según el código civil chileno. v. 2 of his Qbras. 


\section{INDUSTRIAL PROPERTY}

The patent legislation of Chile originates in article 152 of the Chilean constitution and in the law of September 9, 1840, as subsequently amended, particularly in 1872 and 1874. An English translation or discussion of the Chilean patent laws is to be found in the compilation of patent and trade-mark laws of the South American republics, published by the International Bureau of American Republics (Washington, 1904), and in the compilations of patent laws of the various countries of the world edited by Benjamin V. Abbott (Washington, I 886, 2 v.), Alfred Carpmael (London, I889, 2 ed.), and Arthur P. Greeley (Washington, I 899).

Trade-marks in Chile are governed by the laws of November 12, 1874 and August 12, 1905. A translation or summary of the trade-mark legislation is to be found in the compilations of the International Bureau of American Republics and of Greeley above mentioned, and in B. Singer's compilation of trade-mark laws of the world (Chicago, 1913).

The legislation concerning both patents and trade-marks is included in the compilation published by the International Bureau for the protection of industrial property at Berne. (Berne, 1896-1912, 7 v. French translation) and in the compilation of German translations edited by Bruno AlexanderKatz (Berlin, I912, 2 v.).

Chile is a party to the Pan American conventions for the protection of patents and trade-marks signed at Buenos Aires August 20, 1910, and ratified by the United States February 8, I9II. (Treaties, conventions, etc., III, Washington, I913, pp. 354,362 .)

\section{COMMERCIAL, LAW}

\section{HISTORY}

By the royal cédula of February 26, I795, the Ordenanza de Bilbao, which embodied a considerable portion of the commercial law of Spain, was introduced into Chile and remained in force there with various amendments until the enactment of the present commercial code in I 865. After a beginning had been made upon a draft of the civil code, committees were entrusted with the task of drafting a commercial code based 
on that of Spain. After two such committees, appointed in $\mathrm{r} 846$ and in $\mathrm{r} 85 \mathrm{I}$, respectively, had failed to produce practical results, the work was entrusted to Dr. José Gabriel Ocampo, whose draft was approved by the Executive and by Congress and adopted on November 23, 1865. The codecameinto force on January I, I 867. It draws principally upon French and Spanish sources. In the Presidential message, drafted by Ocampo, which accompanied the draft code as transmitted to Congress, the plan of the code and the reforms which it proposed to introduce were briefly outlined. Among these reforms was the acceptance of the testimony of witnesses in purely commercial matters, without fixing a limit, as was done in the civil code; requiring the registration in a commercial register of powers of attorney and agreements for representation; the publication in extract of the by-laws of corporations to give them validity among the members; and establishing three kinds of commercial association, the collective or partnership, the joint stock, and the limited.

Commercial cases were tried during the end of the colonial period before the Tribunal del Consulado, ${ }^{1}$ created by the law of February 26, I795. By various Chilean decrees this Tribunal of the Consulado was reorganized and in 1839 there were instituted the commercial courts of Santiago and Valparaiso with the denomination of Tribunales del Consulado, which were definitely organized by the law of September 29, 1855, and were incorporated with their new jurisdiction in the judiciary code of 1875 .

An account by Valentin Letelier of the life and work of Dr. Ocampo, the author of the code, is contained in volume 5 of the Revista de derecho y jurisprudencia (1907), pages I77196.

\section{CONTENTS}

The commercial code contains 1534 articles divided into four books. Book I deals with merchants and commercial agents, the obligations of merchants, brokers, and auctioneers, and has been amended by the regulation of August I, I866, for the keeping of the Commercial Register, and the regulation of September I, r 866, on professional brokers.

${ }^{1}$ Real cédula de erección del Consulado de Chile, expedido de Aranjuez. á 26 de febrero de r795. Madrid, Imp. de Cano, r795. 53 p. 
Book II relates to mercantile contracts and obligations in general and deals among other matters with purchase and sale, barter, assignment of mercantile credits, carriage by land and water, factors and commission agents, managers and clerks, associations, partnerships and corporations with their various classes, insurance in its various forms, contract of current account, bills of exchange and promissory notes, letters of credit, various bailments, such as loan, deposit and pledge, and guaranty and prescription, which follows the provisions of the civil code. This book has been amended by the enactment of various supplementary statutes such as the law of June 23, I868, practically abolishing imprisonment for debt except in certain cases of fraudulent bankruptcy and default in certain trust relations, by the law of September 6,1878 , on the obligations of transferor and transferee in the transfer of shares or promises of shares of limited companies; by the law of September 12, 1877, on the appointment of inspectors of limited companies and by the important law of November 17 , 1904, and the regulation of December 14, 1904, on foreign insurance companies.

Book III, entitled "maritime commerce," deals with merchant vessels and their owners, with persons who may take part in maritime commerce, with the rights and obligations of the various officers engaged in the management of vessels, agreements with seamen, the rights and obligations of the parties to a contract of affreightment, including the contract of the charter party and bills of lading and passengers, the rules governing the risks and losses connected with carriage by sea, including general and particular average, collision, stranding, shipwreck, etc., bottomry loans, marine insurance, and prescription in maritime cases. Among other laws which have been passed affecting the subjects of this book are the consular regulation of April 9, 1897, which in Chapter VII sets forth the powers and duties of consuls in relation to the Chilean merchant marine. Mention may also be made of the navigation law of June 24,1878 , supplemented by various regulations governing the survey and equipment and management of vessels.

Book IV deals with bankruptcy, but has been considerably amended by the law of January $I 1,1879$, and by the code of 
civil procedure of 1902 . The code of civil procedure covers insolvency of persons not merchants as well as of merchants. Inasmuch as article 897 of the code of civil procedure provided that the provisions of Title III relating to insolvency and the meeting of creditors in noncommercial cases shall remain in force, except as otherwise repealed, it has proven difficult in practice to determine just to what extent the code of civil procedure has altered and amended the commercial code.

In connection with bankruptcy, the provisions of the civil code, particularly articles $2465^{-249}$ r relating to the priority of creditors, are also of importance.

\section{TEXTS}

The commercial code is contained in the collected codes above mentioned (supra, p. 378) and in independent editions. It is well here again to mention that the presidential message of October 5, I 865, which accompanied the submission of the draft by the President to Congress and is usually printed as a preface to the code is valuable in explaining its history and purpose and many of its provisions. A recent text edition of the code published by the house of Miranda ${ }^{1}$ has been recommended as accurate.

A French translation, with annotations by Henri Prudhomme, ${ }^{2}$ was published in 1892 as a volume in the Collection de codes étrangers. In a useful introduction of 42 pages, there is a historical discussion of Chilean commercial law, with special attention to those matters of Chilean law which are of interest in comparison with European codes.

Perhaps the most useful edition of the commercial code to Anglo-American lawyers is contained in the American edition of the "Commercial laws of the world," " Volume VI. Besides

${ }^{1}$ Código de comercio de la República de Chile. Santiago, R. Miranda y Cia, Ig09. $280 \mathrm{p}$.

${ }^{2}$ Code de commerce chilien promulgué le 23 novembre 1865 mis en vigueur le $I^{\text {er }}$ janvier $I 867$, tr. et annoté sur la dernière édition officielle du 20 septembre 1889, par Henri Prudhomme. Paris, G. PedoneLauriel, I892. $425 \mathrm{p}$.

${ }^{3}$ The Commercial laws of the world. The commercial, bills of exchange, bankruptcy and maritime law of Chile by Arturo Fernandez Pradel and Dr. Julio Philippi. Translated by W. A. Bewes. Boston, The Boston Book Co. [r9o9]. 
its translation of the commercial code, it contains a translation of various supplementary laws which amend or modif $v$ the code.

\section{LITERATURE}

An important edition of the commercial code is the commentary by Pinto Izarra and Bordali, ${ }^{1}$ which, besides the text of the code, contains under each article a citation or extract of all the decisions in which the code has been applied from 1867 to March I, I 89o. It does for the commercial code what Eulogio Piñera's book does for the civil code.

José Alfonso, ${ }^{2}$ a former judge of the Supreme Court, has published a useful commentary to the preliminary title and Title I of Book I of the code. It is an extensive commentary on the first 25 articles of the code. It was originally published in the Revista forensechilena, and is important for its determination as to the acts which are commercial and those which are civil.

COMMERCIAL ACTS

An extensive study of article 3 of the commercial code dealing with commercial acts in relation to jurisdictional questions, but not considered so good a work as Alfonso's, was published by Francisco Ugarte ${ }^{3}$ in 1869 . Since the enactment of the judiciary code it has lost some of its importance. A recent treatise by Aníbal Bravo ${ }^{4}$ on the provisions of the code relating to commercial documents may be mentioned.

\section{CORPORATIONS}

A commentary on section 8 of Title VII of Book II of the commercial code dealing with joint-stock companies was pub-

${ }^{1}$ Pinto Izarra, F. y Bordalí Huméres, Emiliano. El código de comercio y la jurisprudencia comercial. . . . por Federico Pinto Izarra y Emiliano Bordalí H. . . Valparaiso, F. T. Lathrop, I890. 574. p.

${ }^{2}$ Alfonso, José: Comentario del título preliminar y del título primero del libro primero del código de comercio . . . Santiago, Impr. Cervantes, 1886. $3^{86} \mathrm{p}$.

${ }^{3}$ Ugarte Zenteno, Francisco: De los actos de comercio en su relación con la competencia de jurisdicción. Santiago, Imprenta de "El Independiente," r869. $289 \mathrm{p}$.

4 Bravo, Aníbal: Tratado de las disposiciones del código de comercio relativas a los documentos comerciales. Santiago, Imp. Universitaria, I9I4. $242 \mathrm{p}$. 
lished in 1882 by Miguel Cruchaga, ${ }^{1}$ and there have been numerous dissertations on this subject submitted to obtain the degree of licenciado (attorney at law). Some of them are mentioned in the bibliography which is printed at the head of the volume dealing with Chile in the series known as the "Commercial laws of the world." Ibáñez ${ }^{2}$ has published an interesting dissertation on the revision of the commercial code, which has been accorded a certain value. An interesting article discussing the necessity for the revision of the provisions of the code relating to stock companies was published by Alejandro Valdes in volume 2 of the Revista de derecho $y$ jurisprudencia (1904), pages $182-186$ and pages 265-270.

New regulations concerning foreign corporations are enacted from time to time. A recent act of July I3, I9I6, holds agents of foreign corporations personally responsible for payment of taxes, if they fail to make formal declaration of all particulars concerning their principal.

On January I, I9I 7 , a new law concerning fees to be paid by commercial travelers went into effect.

\section{NAVIGATION}

The law of navigation of 1878 , with various regulations relating to it, has been published in an official edition. ${ }^{3}$ An annotated English translation of this law was published in New York in $1894 .{ }^{4}$ The best commentary on the law is that by Ramón Guerrero, ${ }^{5}$ which includes a brief history of the Chilean merchant marine. The provisions of Chilean law relating to general average (arts. 1084-1 I23 of the commercial code) have

1 Cruchaga, Miguel: De la reglamentación de las sociedades anónimas en Chile. Santiago, Gutenberg, I882. 286 p.

${ }^{2}$ Ibáñez, Maximiliano: Revisıón del código de comercio. Paris, Imprimerie Paul Dupont, 189o. 280 p.

${ }^{3}$ Lei de navegación de la Republica de Chile, promulgada el 24 de junio de $x 878$. Official ed. Santiago, Imp. nacional, I879. I63 p.

${ }^{4}$ Navigation laws of the Republic of Chile, with comments by R. G. Vergara. Pt. 2. Text of the law preceded by the various ordinances to which it refers. New York, C. G. Burgoyne, I889.

${ }^{8}$ Guerrero V., Ramon: Ley de navegación de la República de Chile, promulgada en 24 de junio de 1878 . Santiago, Mercurio, 1878. 220 p. $71624^{\circ}-17-26$ 
been translated in the work of John $\mathrm{H}$. Gourlie, ${ }^{1}$ in which the laws of some thirty countries have been treated, and are summarized in Lowndes' work on general average (5th ed., London, Stevens, 1912), pages 484-494.

Questions of maritime law, particularly maritime mortgages, have been discussed in a number of dissertations presented to obtain the title of licenciado.

\section{BANKRCPTCY}

Probably the most useful work on the bankruptcy law as in force after the enactment of the code of civil procedure is the manual published by Luis Barceló ${ }^{2}$ in 1904. Another work by Aureliano Quijada ${ }^{3}$ covers somewhat the same ground, but not so well. A commentary on the bankruptcy law, as it existed before the enactment of the code of civil procedure in 1902, is that by Alejandro Valdes Riesco, ${ }^{4}$ in which the provisions of the bankruptcy law are compared with those of foreign codes and citations to the decisions of the courts since the enactment of the commercial code are included.

Banking law will be discussed under the head of financial legislation.

\section{JUDICIAL, ORGANIZATION AND CIVIL, PROCEDURE}

\section{JUDICIARY ACT}

\section{HISTORY}

One of the most important codes in force in Chile is the lei de organización $i$ atribuciones de los tribunales or judiciary act or code of 1875 . The first Chilean organization of the courts

1 Gourlie, John H.: General average. The laws and customs of the United States, Argentina, Austria, Belgium, Brazil, Canada, Chili, Cuba, Denmark, Ecuador, Egypt, England, Finland, France, Germany, Greece, Hayti, Holland, Italy, Mexico, Norway, Peru, Portugal, Russia, Spain, Sweden, Turkey, U. S. Colombia, Uruguay, Venezuela, Wallachia. Philadelphia, Sherrerd's printing house, r88r. $820 \mathrm{p}$.

${ }^{2}$ Barceló, Luis: Prontuario del juicio de quiebra. Santiago de Chile, Impr. Cervantes, I904. r76 p.

3 Quijada B., Aureliano: . . . Quiebras. El libro iv del código de comercio complementado con lo pertinente del código de procedimiento civil. Santiago, G. E. Miranda, r903. ${ }_{5}^{8} \mathrm{p}$.

4 Valdes Riesco, Alejandro: Quiebras. Comentarios al libro IV del código de comercio . . Tomo I. Santiago, 1897. 
was provided for in the Reglamento de administracion de justicia of 1823 , which was amended and amplified by numerous subsequent laws and executive decrees. The first efforts at codification were made in a draft by Várgas Fontecilla, ${ }^{1}$ who was commissioned for this purpose in 1863 and made a report in the following year which was designed to serve as a basis for a judiciary act and for a code of civil procedure. An introduction of 32 pages to this work is historically of much value.

A commission was appointed to examine the draft, José Bernardo Lira being one of the most active. The revisory commission sat for two different periods between 1864 and 1874 , but only the reports of the second period were preserved and their proceedings were not edited, so what is in civil law an important source of interpretation is here lacking. There was some debate in Congress when the law was submitted for its approval, but on October 15,1875 , it was adopted in 408 articles divided into 22 titles. Its contents are far greater than its title would indicate, and it is in effect a code defining not merely the jurisdiction of the courts but the functions of all officers connected, even remotely, with judicial proceedings, including notaries, attorneys, sheriffs, clerks, public defenders, and other officers. The code has been amended by a variety of subsequent laws and decrees which are usually printed in the recent editions of the act and in the collected codes already mentioned. (Supra, p. 378.)

The judicial organization in Chile is composed of five courts. The district judge (juez de distrito), the circuit judge (juez de subdelegacion), the judge of first instance (juez de letras $y$ alcaldes), which is the lowest court of record, the court of appeals (corte de apelacion) in the various departments, and the Corte Suprema, or the Supreme Court sitting at Santiago. The juez de distrito has jurisdiction in cases not exceeding 50 pesos; the juez de subdelegacion, from 50 to 100 pesos; the juez de letras, of whom there is at least one in each department, has jurisdiction in civil and commercial cases exceeding 200 pesos and in all cases of noncontentious jurisdiction. There are now seven cousts of appeal-one each at Tacna, Serena, Valparaiso, Santiago, Talca, Concepción, and Valdivia. The court

1 Várgas Fontecilla ${ }_{2}$ F.: Proyecto de lei de organización i atribuciones de los tribunales. Santiago, Imp. nacionar, I864. I26 p. 
at Santiago consists of 12 judges, divided into two chambers. The Supreme Court is composed of II judges and has jurisdiction in cassation, and in second instance of cases initiated in the courts of appeal, and original jurisdiction in prize cases, extradition, and certain other cases.

A Council of State, modeled after the French Council of State, has a limited jurisdiction in certain matters involving church property and in questions of conflicting jurisdiction of administrative bodies and the courts, and of certain actions against higher administrative officials of the government, such as the governors of departments. Officials known as "fiscals" are attached to the courts of appeal and to the Supreme Court. They are representatives of the Department of Justice sitting as judges of the court, and look after the interests of the government and the proper execution of the laws.

The judiciary code, besides providing for the jurisdiction of the various classes of judges, the method of the appointment of judges, their rights and duties, their fees and prerogatives, discusses also the jurisdiction of arbitral judges, various questions of procedure, the functions and jurisdiction of the Department of Justice and of public defenders and the rights and powers of relators (officers who read to appellate courts a summary of the case on appeal), secretaries and clerks of courts, notaries, conservators and depositaries, procurators, solicitors, and attorneys at law.

The judiciary code provides a method by which the higher courts exercise supervision over the work of the courts immediately below them in the judicial hierarchy by means of periodical visits of inspection. In the case of the juzgados de letras, for example, the Court of Appeals in the respective department makes quinquennial inspections and issues a report, showing the number of cases still awaiting decision, the status of the calendar, the work of the court since the last inspection, and other matters connected with the functions of the court. Up to the early nineties these reports were issued separately by the Imprenta Nacional, under the title, Informes or Memorias $i$ Actas de las visitas quinquenales, but more recently they have published in the Gaceta de los Tribunales.

The fees of the various judicial officers were laid down in a 
law of December 21, I865, when the peso was worth $\$ 0.96$ gold, as compared with its present value of \$0.18 to \$0.20. Probably taking into account the fall in the rate of exchange, the tariff of judicial costs was doubled by law in I9I I, but it may be said that, in first instance, fees and costs double or triple the amount fixed in the tariff must be paid to secure prompt action by judicial officers.

By all means the ablest work on the judiciary code and in fact one of the most notable works published in South America, is the two-volume treatise and commentary by Manuel $\mathrm{E}$. Ballesteros, ${ }^{1}$ a member of a number of the important revisory commissions of various codes, later a member of the Supreme Court and professor at the University of Chile. In this work, published in 1890 , the author has brought together the legislative antecedents of the code, with a comparative study of the provisions of the law and those of other countries and the decisions of the courts which have applied the law, all accompanied by the author's learned comments. The work is arranged by articles, the history of each article being given, its relation to the draft, and the discussion in the special commission and in Congress, its comparison with similar provisions of other countries, a critical discussion of the doctrines relating to it, and the decisions of the courts which have applied the article.

A student's work, with comments and explanations of the law, but entire omission of decisions, is that by Professor Cárlos Risopatrón, ${ }^{2}$ published in 1900 . The arrangement and discussion are by title and not by article. Another student's work, consisting principally of concordances, by Coo Tagle, ${ }^{3}$ is taken largely from notes of the lectures of Professor Miguel Luis Valdés. Numerous laws on procedure embodied in the appendix, which is perhaps the most important part of the book, were included later in part in the code of civil procedure of 1902 .

${ }^{1}$ Ballesteros, Manuel E.: La lei de organización i atribuciones de los tribunales. Santiago, Imprenta nacional, 189o. $2 \mathrm{v}$.

${ }^{2}$ Risopatrón, Cárlos: Ley de organización y atribuciones de los tribunales, y comentarios . . Santiago, Barcelona, I900. $424 \mathrm{p}$.

${ }^{3}$ Coo Tagle, Alberto: Concordancias de la lei de organización i atribuciones de los tribunales con la lejislación chilena. Santiago, Impr. Roma, I896. $573 \mathrm{p}$. 
For historical purposes, mention may be made of a collection of biographies of the early colonial judges of the Audiencia of Santiago during the seventeenth century. ${ }^{1}$ The monograph first appeared as an article in volume 13 of the Anales de la Universidad.

The code of civil procedure of 1902 affected so considerably the older judiciary act that plans for its revision have been frequently proposed. At the time of the enactment of the code of civil procedure, a commission was appointed to prepare a new draft of a judiciary code. The draft was published in $1902,{ }^{2}$ but no subsequent action appears to have been taken. It may be said that the changes advocated in the older law were inconsiderable.

\section{CIVIL, PROCEDURE}

\section{HISTORY}

The rules governing civil procedure prior to the enactment of the code in 1902 were scattered through various Spanish codes commencing with the Fuero juzgo and terminating with the Novisima Recopilación promulgated in 1805 . In addition, numerous amendments had been introduced by Chilean statutes and decrees. Of the Spanish collections, the Siete Partidas, sanctioned in 1348 , the Recopilacion de las Indias and the Novisima Recopilacion were the principal sources of the law of procedure. Law 12, Title XV, Book II of the Recopilación de las Indias provided for the courts and judicial organization of Santiago. Until 1875 , when the courts were organized into a coherent system, numerous special courts had been created for various classes of cases. For example, commercial cases were tried before the tribunal del consulado, created in 1795 , whose jurisdiction was later assigned to the lower courts of Santiago and Valparaiso. Mining cases were tried before the junta de mineria, and exchequer cases, accounts, military, and ecclesiastical cases were tried by special courts. In 1837 the Executive, availing himself of the large ordinance power vested in him

${ }^{1}$ Silva y Molina, A. de: Oidores de la Real audiencia de Santiago de Chile durante el siglo XVII. Santiago, Impr. Barcelona, 1903. 75 p.

${ }^{2}$ Proyecto de código orgánico de tribunales revisado por la comisión mista de senadores $\mathrm{i}$ diputados. Santiago, Imp. Cervantes, 1902. $234 \mathrm{p}$. 
by the law of January 31,1837 , issued a series of decrees establishing new rules of procedure in many matters. These decrees are known as Leyes Marianas because they were practically all the work of the fiscal of the Supreme Court Mariano Egania, one of the foremost jurists of his day.

Only in I 86I did a serious movement begin for a codification of the rules of procedure. A draft was in that year prepared by Florentino Gonzalez, a distinguished Colombian resident in Chile. The draft was submitted to various advisory commissions named by the Executive, but was barren of practical results. In 1874 a new draft was begun by José Bernardo Lira, sitting with a drafting commission which was occupied with the work until r884. Their final draft, published in 1885 , while not adopted in Chile, was nevertheless accepted completely in Honduras, where it is believed to be still in force. A new draft was published in I 893; upon this a good critical work exists by Augustin Bravo Zisternos. ${ }^{1}$ A new revisory commission ${ }^{2}$ began to sit in 1900 and held thirty-nine sessions, amending considerably the draft of 1893 . They published a volume of their proceedings, arranged by code articles, and in I 902 published a draft of a code showing the amendments they had made. ${ }^{3}$ This draft became the official code, ${ }^{4}$ adopted by Congress on August 28, I902. It came into force on March I, 1903.

\section{CONTENTS}

The code consists of four books. The first contains general rules relating to all lawsuits from the first summons to appeals from final judgments and includes among other matters the pleadings, their requirements, the various forms of dilatory and peremptory pleas, the grounds of incompetency of judges

1 Bravo Zisternos, Augustin: Proyecto de código de enjuiciamiento civil. Valparaiso, 1898 .

${ }^{2}$ Actas de la comision mista de senadores 1 diputados encargada de informar sobre los proyectos de codigos de procedimiento civil i criminal. Santiago, Imprenta nacional, I9or. $376 \mathrm{p}$.

${ }^{3}$ Proyecto de código de procedimiento civil, revisado por la comision mista de senadores $\mathrm{i}$ disputados. Santiago, Imprenta Barcelona, I902. $470 \mathrm{p}$.

4 Código de procedimiento civil. Ed. oficial. Santiago, Barcelona, rgo2. $353 \mathrm{p}$. 
and other judicial officers, matters of jurisdiction, suits in forma pauperis, matters of costs, abandonment of the suit, interlocutory decrees and final judgments, appeals, execution of judgments, both domestic and foreign, and fines.

Book II. is entitled "Ordinary actions" and includes all those which are not submitted to a special procedure. This book includes the rules relating to the complaint or declaration, provisional remedies, principally attachment, certain dilatory pleas, rules relating to the answer and the counterclaim, the rules of evidence, the proceedings following the taking of the evidence and its submission to the judge (for there is no jury trial and evidence is taken in a separate proceeding before the judge or clerk of the court), and the rules for the taking of an appeal.

Book III deals with special actions, among which the most important is the summary" execution" action (juicio executivo) of which there are two kinds, one involving an obligation to give or pay money, the other an obligation to specifically perform a certain work. The essential feature of this action is that a prima facie title of credit such as a signed negotiable instrument enables the plaintiff immediately to secure his judgment and order of execution, placing on the defendant the burden of proving its illegality. The time period for adducing this proof is exceedingly short. The code specifies the documents, particularly publicly acknowledged instruments, which may serve as a foundation for the summary procedure. It involves prima facie proof of an instrument of indebtedness duly acknowledged, and provisional attachment of the debtor's property. This book also includes rules relating to the meeting of creditors in cases of insolvency which have largely modified the provisions of Book IV of the commercial code. Herein are also discussed the various interdicts, the various special actions in cases of rents, water rights, accounts, fees, actions below 300 pesos (\$60), annulment of marriage, etc. Among its two most important sections are those dealing with arbitral procedure and with the appeal for cassation or reversal of judgment, a jurisdiction of the Supreme Court to reverse judgments of the lower courts both for errors in form and for errors in substantive law. 
Book IV deals with matters of noncontentious jursdiction, particularly with legitimation, matters of guardianship, and matters of succession.

\section{LITERATURE}

The code is one of the most complete of South America. One of the leading commentaries on it is the official edition of Toro Melo and Echeverría. ${ }^{1}$ This work, published in 1902, with an introduction by Luis Vergara, contains numerous annotations and concordances of the code, besides a history of the various articles and of the work of the various commissions employed in the draft of the code, the contributions of the various members, a bibliography of the various drafts, and the works relating to procedure and various parts of the codes.

Another annotated edition of the code, particularly important in the fact that each article is annotated with a summary of and occasionally lengthy quotations from the decision of the courts, is that by Franklin Otero Espinosa, ${ }^{2}$ the second edition of which appeared in I9ro with a reprint edition in 1913. The decisions are taken from the Gaceta de los Tribunales. It is to be noted that not all the courts have given the same interpretation to the various articles of the code. It may be observed that court decisions are cited with great frequency in Chilean briefs. The code is brought into concordance with the other codes and with modifying laws and includes also the decisions of minor courts reported in the newspapers "El Mercurio" and "Ultimas Noticias." A recent work of concordances of the articles of the code of civil procedure and the other Chilean codes and laws was published by Ruiz de la Barra. ${ }^{3}$

The majority of the treatises on civil procedure were published prior to the enactment of the code in ig02. A work

1 Toro Melo, David and Echeverría, Anibal: Código de procedimiento civil anotado. (Ed. oficial.) Santiago, Impr. Barcelona, r9o2. $874 \mathrm{p}$.

2 Otero Espinosa, Franklin: Concordancias i jurisprudencia del código de procedimiento civil de la República de Chıle . . . 2. ed. . . . Santiago, Impr. Barcelona, I9Io. 874 p.

${ }^{3}$ Ruiz de la Barra, Eleazar: Concordancias indicadas de los artículos del código de procedimiento civil chileno. Santiago, I9r3. 432 p. 
published in 1904 by Professor Cárlos Risopatrón ${ }^{1}$ consists of a commentary with didactic notes explanatory of the text of the code, designed to make it clear to students. Very recently a student's notes of the course on civil procedure were published in Santiago. ${ }^{2}$

José Bernardo Lira's contributions to the code have already been noted. He is the author of a manual of civil procedure which was held in high repute. The fourth edition of this work was published in 1886 by José Antonio Lira. ${ }^{3}$ It was originally a text book for the Instituto Nacional and includes a valuable history of civil procedure as evolved from its sources in the various Spanish codes and laws, the Fuero Juzgo (69670I), the fueros municipales, Fuero Real (1254-1255), Leyes del Estilo, Siete Partidas (1256-1263), the Recopilacion of Philip II (I 527) and the Novisima Recopilacion (I 806) which incorporated almost all the Ordenamiento de Alcalí of 1348 and the 83 leyes de Toro of 1505 , besides the important procedural laws of the Recopilacion de las Indias of 1680 . The work is copiously supplied with forms.

In I9I2 Francisco Pinto ${ }^{4}$ published a manual of civil procedure in contentious and noncontentious cases which consists principally of a form book for notaries and a number of essays on the duties of notaries and other officials. It includes a useful study on the law of stamped paper and the forms in cases of voluntary jurisdiction before administrative authorities. The author had previously published a work on public instruments (1897-1906).

Attention may also be called to a manual for notaries public, clerks of courts and sheriffs, which was published in

${ }^{1}$ Risopatrón, Cárlos: Estudios sobre el código de procedimiento civil. Santiago, Imp. Cervantes, I904. $890 \mathrm{p}$.

${ }^{2}$ Freeman O., Pedro: Explicaciones del codigo de procedimiento civil, r. y 2. curso, correspondientes al 4. Y5. años de derecho. I. Edición. Santiago, 19r5.

${ }^{3}$ Lira, José Bernardo: Prontuario de los juicios o tratado de procedi. mientos judiciales $\mathrm{i}$ administrativos con arreglo a la lejislación chilena . . . 4th ed. Santiago, Impr. de "El Correo," 1886. 2 v.

"Pinto S., Francisco: Prontuario de los juicios civiles y de jurisdicción voluntaria. Santiago, Sociedad Imp. y Lit. "Universo," I912. 720 p. 
I 884 by Robustiano Vera. ${ }^{1}$ This work includes a brief history of the office of Escribano or notary, whose functions are of considerable importance in Chile and other SpanishAmerican countries. The notary, whose number is determined in each department by the President with the consent of the Corte de A pelaciones, constitutes a public registry office and keeps the originals of every document subscribed by him. The importance of public instruments in the law of evidence and as a title for the executive or summary action is great. The discussion by Vera on the question of fees has become antiquated since the amending law of I9II.

An important innovation established by the code of 1902 consists in giving the Supreme Court jurisdiction on appeal for the reversal of judgments for errors in substantive law called "recurso de casacion en fondo," the purpose of which was to maintain uniformity in the interpretation of the law and consistency in its application. Prior to 1902 this recourse had been limited to appeals for errors in form. Probably the best work on this particular form of appeal is that by Agustín Rodríguez, ${ }^{2}$ published in 1897 , with a view to the adoption of this reform. The work is historical and comparative and based on the proposal of this reform in the draft submitted by the drafting commission. A useful article on the subject, particularly in relation to questions of fact, was published by Tomás A. Ramírez in volumes I and 2 of the Revista de derecho y jurisprudencia (1904).

Attention has already been called to the abortive work of Molina $\operatorname{Ramos}^{3}$ (supra, p. 376), which was designed to report the decisions of the Supreme Court in matters of cassation.

A constructive discussion of recently proposed amendments to the code of civil procedure and to the Judiciary Act was

1 Vera, Robustiano: Manual del notario publico, del receptor i del procurado de numero, o sea Cartilla para el desempeño de estos cargos . . . Santiago, Impr. de la Libreria americana, I884. 336 p.

${ }^{2}$ Rodríguez, Agustín: . . . Estudio sobre el recurso de casación (Memoria premiada en el último certámen de la Facultad de leyes í ciencias políticas). Santiago, Impr. Cervantes, I897. $120 \mathrm{p}$.

${ }^{3}$ Molina Ramos, Juan José: Recursos de casación i revision de la Corte suprema. Santiago, Impr. Cervantes, I903. I v. only published. 
conducted in 1915 before the Santiago Bar Association by Carlos Aldunate Solar and Luis Barriga. ${ }^{1}$ The report was subsequently published.

\section{CRIMINAL LAW}

\section{PENAL, CODE}

Prior to the enactment of the penal code on November I2, 1874, Spanish legislation as amended by various Chilean laws and decrees was in force in Chile. In 1846 , with the object of drafting a criminal code, a commission of lawyers was named, whose labors, however, proved fruitless. In $185^{2}$ the jurist, Antonio Garcia Reyes, was appointed for the same purpose, with an injunction to take as a basis the Spanish code, with the modifications introduced in New Granada. He died, however, in 1855 , without having completed the work. The work was later entrusted to Manuel Carvallo, Chilean Minister to Belgium. He died in 1867 , having, however, finished a draft code which did not become law. By decree of January I7, I870, Joaquin Blest, Minister of Justice, named a commission of lawyers to draft a code which was to be founded on the Belgian code. The majority of the commission, however, favored the Spanish code as a basis. After three and one-half years they completed the draft, issuing a report of their proceedings. They held 175 sessions from March 8 , 1870 , to October 22, 1873 . The report ${ }^{2}$ of their proceedings is a valuable source book for the interpretation of many articles susceptible of ambiguous construction. Among members of the drafting commission were Alejandro Reyes, José Clementé Fábres, and Manuel Rengifo. The draft was not accepted as a whole by Congress as had been done in the case of various

${ }^{1}$ Aldunate Solar, Carlos, and Barriga, Luis: Conferencia dada el 12 de noviembre de I9I5, acerca del proyecto de ley aprobada por la Camara de Senadores, sobre organización y funcionamiento de la Corte Suprema ... y reforma del recurso de casación y de varios preceptos del codigo de procedimiento civil y de la ley de organización y atribuciones de los tribunales. Santiago, 1915.

${ }^{2}$ Actos de las sesiones de la Comisión redactora por el codigo penal chileno. Santiago, Imp. de la Republica, 1873. 314 p. 
other codes, but was subjected to considerable amendment. The code came into force March 1,1875 .

Editions of the code are to be found in various forms. An official edition was published in 1874 , and it is to be found in the volume of collected codes published by the house of Miranda. A German translation by Alfredo Hartwig ${ }^{1}$ was published in the collection issued by the Zeitschrift jür die gesamte Strafrechtswissenschaft.

The best commentary on the code is now somewhat antiquated. This is the work of Fuenzalida, ${ }^{2}$ which was a standard work in its day and has still a considerable importance. It was published in Lima in I883, during the Chilean occupation. It is particularly good in the study of the theories of criminal law, besides its citations and abstracts of the decisions affecting the various articles of the code.

A more recent commentary by Fernández, ${ }^{3}$ published in a second edition in 1899 , is also important. In an introduction of 50 pages he presents the legislative history of the code and the discussions which took place in the Chamber of Deputies and the Senate. There are extensive annotations, including court decisions, and an appendix prints various laws related to the code.

Robustiano Vera ${ }^{4}$ is the author of a commentary on the code, published in 1883 , which contains a historical sketch of the criminal law in general and the history of the penal code in Chile, with a lengthy discussion of various articles. There is also a useful table of concordances with European codes and the Brazilian code. The work includes a valuable essay by Professor Alejandro Reyes, professor of criminal law in the University of Chile.

\footnotetext{
${ }^{1}$ Strafgesetzbuch der republik Chile. Amtliche ausg. Ubers. von Alrredo Hartwig. Berlin, J. Guttentag, I900. I09 p.

${ }^{2}$ Fuenzalida, Alejandro: Concordancias i comentarios del código penal chileno, seguida de un apéndice sobre la jurisprudencia de los tribunales. Lima, Imp. Comercial, I883. $2 \mathrm{v}$.

${ }^{3}$ Fernández, Pedro Javier: Código penal de la república de Chile, esplicado i concordado. 2. ed., notablemente aum. i corr. Santiago, Impr. Barcelona, I899. $2 \mathrm{v}$.

${ }^{4}$ Vera, Robustiano: Código penal de la República de Chile comentado ... Santiago, Cadot, I883. $840 \mathrm{p}$.
} 
Very recently Santiago Lazo has published an annotated edition of the code, ${ }^{1}$ with concordances and notes of court decisions.

A text book, based upon the University lectures, was published in a fourth edition in 1898 by Rueda. ${ }^{2}$

Several monographs warrant mention. One, on the death penalty, was published in 1896 by Newmann, ${ }^{3}$ and two studies on criminology have been published by Galdames ${ }^{4}$ and Brandau. ${ }^{5}$

The best Chilean work on legal medicine is that of Puga Borne, ${ }^{6}$ published in 1896 . It is largely devoted to criminal law, the last 200 pages consisting of opinions and briefs in cases involving legal medicine.

\section{CRIMINAL PROCEDURE}

The draft of a code of criminal procedure was entrusted to Carvalho and afterwards to Professor Alejandro Reyes. As neither finished the work it was subsequently entrusted to José Bernardo Lira, who died before its completion. The government then abandoned the idea of special commissioners and on November 29, I889, issued a decree offering a prize for a competitive submission of the best draft of a code of criminal procedure. The prize was awarded to Manuel E. Ballesteros, one of the ablest Chilean jurists. This draft was submitted for approval to Congress, which named a joint commission of the House and Senate to examine and revise it. The commission was presided over by the President

${ }^{1}$ Lazo, Santiago: Origines, concordancia y jurisprudencia del codigo penal. Santiago, rgr6.

${ }^{2}$ Rueda y Neira, Ramón Ramiro: Elementos de derecho penal, con arreglo al programa de esta asignatura en la Universidad de Santiago . . . 4. ed. corr. y aum. Santiago, Impr. de J. M. Paredes, I898. 2 v.

${ }^{3}$ Newmann, Q.: Notas sueltas sobre la pena de muerte. Santiago, Barzelona, 1896 . $228 \mathrm{p}$.

${ }^{4}$ Galdames, Iuis: La lucha contra el crimen. Santiago, BlanchardChessi, r9o3. r30 p.

${ }^{5}$ Brandau, V.: Politica criminal represiva. Santiago, Cervantes, I909. 20r $\mathrm{p}$.

${ }^{6}$ Puga Borne, F.: Compendio de medicina legal, adaptada á la lejislación chilena. Santiago, Impr. Cervantes, r896. 895 p. 
of Chile. The commissioners' report, ${ }^{1}$ showing by articles the drafts and amendments and the session in which they were made, was officially published, as were also the proceedings of the 33 sessions of the commission, with their discussions by articles. ${ }^{2}$

The code was approved by Congress on February 13, 1906, promulgated on June 12,1906 , and came into force on March 1, 1907. The code consists of 738 articles, divided into three books, of which the first deals with provisions of a general character applicable to all criminal cases. The second establishes rules for the prosecution of ordinary cases of crimes and felonies, and the third deals with special proceedings. The code made numerous changes in the law of judicial organization. To aid the judges it instituted the judicial police and provided various rules for police officials.

An official edition ${ }^{3}$ of the code was published in 1906 and it is to be found in all recent editions of the collected codes. Two annotated editions of the code may be recommended. One by Carlos E. Ibañez ${ }^{4}$ contains all the legislative antecedents for the study of the code, the discussions upon it in the Senate and Chamber of Deputies, the laws relating to it, and the notes made by the Mixed Commission on the revision of the code interpretating the scope and meaning of its various articles. It includes the report of the Mixed Commission of August 25, I9O2, and the presidential message of I894, first submitting Ballesteros' code to Congress. The other is an annotated edition by Robustiano Vera, ${ }^{5}$ which includes the first draft, the revisions by congressional commissions, and various commentaries from foreign codes and

${ }^{1}$ Proyecto de código de procedimiento penal revisado por la Comisión mista de senadores i diputados. Santiago, Impr. Cervantes, 1902. $353 \mathrm{p}$.

${ }^{2}$ Actas de la comisión mista de senadores i diputados encargada de informar sobre el proyecto de código de procedimiento penal. Santiago, Impr. Cervantes, I902. $498 \mathrm{p}$.

${ }^{3}$ Código de procedimiento penal de la República de Chile. Ed. oficial. Santiago, Impr. Cervantes, I906. $248 \mathrm{p}$.

4 Código de procedimiento penal anotado por Carlos E. Ibañez A. Santiago, Imp. Barcelona, 1907. 568 p.

${ }^{5}$ Vera, Robustiano: Código de procedimiento penal comentado i concordado. Santiago, Impr. "Fl Debate," r go6. 648 p. 
opinions of authorities, particularly the doctrines of Emilio Reus, a noted commentator of the Spanish code of criminal procedure, upon which the Chilean code is largely based.

\section{CONSTITUTIONAL LAW}

The Chilean constitution now in force was adopted on May 25, 1833. From 1812 until that date five constitutions had existed. That of 1828 led to a revolution, which culminated in the constitutional convention which adopted the constitution of 1833 . While practically no changes occurred in the constitution until $\times 87 \mathrm{I}$, it has been amended very considerably since that date, the principal changes having been made between $187 \mathrm{I}$ and $\mathrm{I} 893$.

\section{TEXTS}

A small pocket edition ${ }^{1}$ of the constitution was officially published in 1910, containing the amendments adopted up to June 26, 1893. It includes the rules of the Senate and House, and the rules and orders of the important Executive Committee (Comision Conservadora). There are several translations of the constitution in English. One of these is contained in Rodriguez' "Constitutions of the American Republics" and another is the translation of C. W. Tooke," which includes the amendments to May I, 1899. The best and most recent translation is contained in Dodd's "Modern constitutions" (Chicago, 1909, vol. I, pp. 227-264).

The early constitutions and drafts of constitutions which were adopted or discussed in Chile between 1810 and 1849 may be found in a work by Ramón Briseño, ${ }^{3}$ whose title as

${ }^{1}$ Constitucion política de la República de Chile, jurada y promulgada el 25 de mayo de 1833 con las reformas efectuadas hasta el 26 de junio de 1893. Edicion oficial. San Antonio, Impr. Barcelona, rgro. $223 \mathrm{p}$.

2 Tooke, Charles Wesley: Political constitution of the Republic of Chile, promulgated May 25, 1833, with the amendments down to May I, 1899; translated by C. W. Tooke Urbana, Ill Press of the Herald, r899. $83 \mathrm{p}$.

${ }^{3}$ Briseño, Ramón: Memoria histórica crítica del derecho público chileno, desde r810 hasta nuestros días. Santiago, Imp. de Julio Belín and Co., 1849. 516 p. 
a critical and historical account of Chilean constitutional law is somewhat misleading.

A compilation of constitutions of various countries, compiled by Bañados Espinosa, ${ }^{1}$ professor of the subject, contains a valuable historical sketch of Chilean constitutional law and a bibliography. A collection of laws relating to the constitution in force in 1893 was compiled and published in that year by Orrego and Anguita. ${ }^{2}$

\section{LITERATURE}

There are several important commentaries on the Chilean constitution, although none of recent date. An early commentary of high reputation is that of Jose Victorino Lastarria, ${ }^{3}$ first published in 1856 with an historical introduction. In I865 Lastarria published a work entitled Elementos de derecho público constitucional positivo y politico," the first part being a theoretical and philosophical treatment of constitutional law and the second part a new edition of his commentary on the Chilean constitution. It was undoubtedly one of the best theoretical and practical works of its time. Somewhat later Jorge Huneeus, ${ }^{5}$ one of the ablest of Chilean publicists, published a two-volume quarto commentary on the Chilean constitution. It evidences sound scholarship. It commentates each article of the constitution extensively and explains the ambiguities and questions raised in its application in the debates in Congress. The two volumes were reprinted in 1891 as the first two volumes of

1 Bañados Espinosa, Julio: Derecho constitucional, Constituciones de Chile, Francia, Estados Unidos, República Argentina, . Brazil, Belgica, España, Inglaterra y Suiza. Santiago, Cervantes, r889. $626 \mathrm{p}$.

${ }^{2}$ Orrego Ovalle, Eduardo y Anguita Acuña, Ricardo: Recopilación de leyes constitucionales y administrativas vigentes en 18 de seticmbre de 1893 . Santiago, Imp. nacional, 1893.

${ }^{3}$ Iastarria, José Victorino: La constitución politica de la República de Chile comentada. Valparaiso, Imp. del Comercio, 1856. 229 p.

- Lastarria, José Victorino: Elementos de derecho publico constitu. cional teorico, positivo i politico. Primera parte. $3^{\mathrm{a}}$ ed. Segunda parte. 2. ed. Gante, Vanderhaeghen, 1865. 5 ro p.

s Hunecus, Jorge: La constitución ante el Congreso. Santiago, Imp. de Los Tiempos, $1879-80.2 \mathrm{v}$.

$71624^{\circ}-17-27$ 
Huneeus' collected works. A less important but interesting commentary is that of Carrasco Albano, ${ }^{1}$ published first in $185^{8}$ and in a second edition in 1874 . It is interesting by the fact that the author published it at the age of $2 \mathrm{I}$, receiving an award of a university prize and also by the fact that many of the theories it sets forth are original and have called forth discussion.

Among the treatises on Chilean constitutional law, one of the best and the most modern is Professor Roldán's " "Elements of Chilean constitutional law." In his discussion of constitutional legislation the author includes the electoral laws, the law of 1865 on the freedom of religious worship, the laws relating to the liberty of the press, the right of petition, the formation of the budget, the internal administration, and particularly an historical account of the various constitutions of Chile. The work is a revision of the author's lectures at the University and is regarded as a work of erudition. It is also a useful reference work.

José Victorino Lastarria ${ }^{3}$ also published a treatise in 1875 , consisting of his lectures on constitutional law before the Academia de Bellas Letras, a work which was subsequently reprinted in his collected works. One of the best studies of the Chilean constitution is the volume of Jorge Huneeus ${ }^{4}$ on comparative constitutional law, published in $189 \mathrm{I}$ as volume 3 of his collected works. A critical study of the Chilean constitution, particularly its history, the general characteristics of the constitution of 1833 , the various holders of governmental power, and the departments of the government was recently issued as a Paris doctoral dissertation by $\mathrm{J}$. Benavente. ${ }^{5}$

1 Carrasco Albano, Manuel: Comentarios sobre la constitución politica de 1833 . 2nd ed. Santiags, libreria del Mercurio, I874. 200 p.

${ }^{2}$ Roldán y Alvarcz, Alcibíades: Elementos de derecho constitucional de Chile. Santiago, Impr. "Barcelona," r9r3. 5 Iо p.

${ }^{3}$ Lastarria, José Victorino: Lecciones de política positiva. Paris, Lib. Bouret, I875. 504 p. Reprinted as v. I and 2 of Lastarria's Obras completas, Santiago, Imp. Barcelona, I906.

4 Huneeus, Jorge: Estudios sobre derecho constitucional comparado. Santiago, I89I.

${ }^{5}$ Benavente, J.: Etude critique de la constitution de la Republique du Chili. Paris, I9I5. 
Attention may also be directed to the constitutional essays of Rodriguez Bravo ${ }^{1}$ published in 1888 . The first chapters on the relations between the church and the state were awarded the Varela prize. Valentin Letelier ${ }^{2}$ is the author of a well-known, although now somewhat out-of-date, treatise on political science in Chile.

The Council of State, whose functions have been briefly referred to, operates under a regulation ${ }^{3}$ which was adopted in 1844 . It includes its organization, its sessions and order of discussion, voting, procedure in contentious matters and administration.

\section{PARLIAMENTARY LAW}

The rules of the Chamber of Deputies were adopted in 1904 and were published officially. ${ }^{4} \mathrm{~A}$ valuable work on parliamentary precedents, annotating and interpreting the rules of the Chamber of Deputies, was published in I9II by Néstor Sánchez. ${ }^{5}$ By including the rulings of the House and of its presiding officers, it attempts to do for Chile what Hinds' monumental work does for our Federal Congress. Attention may also be called to a two-volume work on Chilean parliamentary law published in 1896 by Larrain Zañartu. ${ }^{6}$

\section{ELECTIONS}

The election law of Chile has been amended on numerous occasions. The law ${ }^{7}$ now in force is No. 2883 of February 21 , I9I4.

1 Rodriguez Bravo, Joaquín: Estudios constitucionales. Santiago, Imp. Victoria, I888. 34I p.

${ }^{2}$ Letelier, Valentin: De la ciencia politica en Chile. Santiago, Imp.

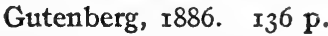

${ }^{3}$ Reglamento del Consejo de estado. Santiago, Impr. de la Opinion, I844. I4 p.

- Reglamento de la Cámara de disputados i leyes complementarias. Ed. oficial. Santiago, Impr. Barcelona, I904. $70 \mathrm{p}$.

- Sánchez, NÉstor: El derecho escrito i las prácticas; estudio sobre el reglamento interno de la Cámara de diputados. Valparaíso y Santiago, Sociedad Imprenta y litogr. Universo, rgrr. 442 p.

- Larrain y Zañartu, José Q.: Derecho parlamentario chileno. Santiago, Impr. nacional, $\mathrm{x} 896-97.2 \mathrm{v}$.

7 Lei de elecciones de la República de Chile. Ed. oficial. Santiago, Impr. nacional, rgr4. $85 \mathrm{p}$. 
A brief annotated edition of this law, with references to related laws, was published in 1914 by O. L. Valdivieso. ${ }^{1}$

\section{ADMINISTRATIVE LAW}

\section{ADMINISTRATIVE ORGANIZATION}

For purposes of administration the Republic of Chile is divided into provinces (provincias), at whose head is an intendente, the immediate representative of the President of the Republic. He is appointed for three years, with power of reappointment. The provinces are divided into departments, at whose head is a governor, subordinate to the intendente of the province. He is also named by the President on the nomination of the intendente. His term is also three years, renewable indefinitely. The departments are divided into subdelegaciones, at whose head is a subdelegado named by the intendente or governor for a term of two years, renewable indefinitely. The subdelegaciones are divided into distritos, governed by an inspectcr under the orders of the subdelegado, by whom he is appointed and removed.

One of the best developed features of local government is the large degree of local autonomy possessed by municipalities. The first law on the organization and powers of municipalities was enacted November 8,1854 , for the purpose of establishing a system of local administration. It was considerably modified in 1887 and entirely revised by the law of December 22, I89I, according to the plan of municipal government adopted in many parts of the United States. Its defect perhaps is that it attempted to engraft a foreign system upon Chilean customs, and the law has proven in many instances difficult to apply. The law fixed the number of municipalities at nine and provided also for alcaldes (heads of townships) and rejidores (of villages). The President was given power to increase the number of municipalities, which at the present time consists of 317 . The election of aldermen is provided for. In a general way the municipalities have control of their local health and sanitation, public morals, order, safety and police, streets and highways,

1. Valdivieso, O. I.: Nueva ley de elecciones de la Republica de Chile, anotado y complementada con las disposiciones legales correlativas. Santiago, Impr. Claret, I9r4. 80 p. 
agriculture, industry and trade, primary schools conducted with municipal money, hospitals and charitable institutions, local public services, the assessment and collection of municipal taxes, and the promotion of the general welfare of the city. The municipality is given power to punish infraction of the municipal ordinances. The literature on this law will be discussed presently.

The Chilean system of administration finds much of its origin in the system of colonial administration of Spain. For this reason it may not be without value to call attention to the general ordinance of Spain for the use of its governors in the administration of the colonies. ${ }^{1}$ This was published in Madrid in 1783 . Another edition in equal format was published by the same publisher in 1803 (194 p.). An additional regulation $^{2}$ to this ordinance was issued in Santiago in 1820 .

Reference has been made under the general collections of laws and decrees (supra, p. 374) to the compilations of administrative laws and decrees prepared by various compilers, principally Ramon Contardo Chaverría, Echeverría and Del Rio, Ovalle and Anguita, and the compilation of 1903 relating to the Ministry of Interior.

\section{LITERATURE}

One of the best general works on Chilean administrative law is the treatise of José $D$. Amunátegui, ${ }^{3}$ based on his notes as professor of administrative law in the University of Chile. An introduction by Carlos M. de Pena, now Minister of Uruguay in the United States, contains a cursory history of administrative theories. The work was first published in Montevideo in r 90 under the title Resumen de derecho administrativo. In the later edition both its theoretical and practical sections have been greatly amplified. The work, while intended for students, gives a good account of the administra-

1 Ordenanza general para el gobierno de Intendentes, subdelegados y demás empleados de Indias. Madrid, Imp. de Ibarra, I783. $3^{26} \mathrm{p}$.

${ }^{2}$ Reglamento adicional a la Ordenanza de Intendentes. Santiago, Impr. del Gobierno, I820. Io $\mathrm{p}$.

${ }^{8}$ Amunátegui y Rivera, José Domingo: Tratado jeneral de derecho administrativo aplicado á la lejislación de Chile . . . con un prólogo de D. Carlos M. de Pena. . . S Santiago, Impr. Barcelona, 1907. 469 p. 
tive system in Chile in its formal and its legal aspects, discusses the attributes of the Council of State (Consejo de Estado) and Tribunal of Accounts (Tribunal de Cuentas) and other administrative bodies. The contentious administrative jurisdiction known in continental law does not exist in Chile. While the work is less concerned with principles of administrative law, it nevertheless contains a useful discussion of the liability of officers and municipal corporations.

Another textbook prepared from the notes of the lectures of Professor Letelier, ${ }^{1}$ one of the foremost Chilean jurists, consists principally of a discussion of the public administration of Chile and the functions of the various governmental subdivisions and administrative bodies.

A somewhat earlier work by Santiago Prado, ${ }^{2}$ published in 1859, served until I887 as a textbook at the Instituto Nacional. It follows closely Colmeira's Spanish work, adapted to Chilean legislation. It is not now of much practical value.

An important study on the public administration of Chile from the economic point of view was published in 1878 by Miguel Cruchaga. ${ }^{3}$

Perez de Arce ${ }^{4}$ published in 1884 a collection of studies on the general principles of administration. In $1896^{5}$ he published a didactic work on the administration of public utilities, designed particularly for engineers taking the course at the University. It is considered a useful work.

The important law of January 22, 1886 , reorganizing the internal administration of the country has been commentated

1 Letelier, Valentin: Apuntaciones de derecho administrativo . . . I904. Santiago, Impr. Chile, I907. $33 \mathrm{I} \mathrm{p.}$

2 Prado, Santiago: Principios elementales de derecho administrativo chileno. Santiago, Impr. nacional, I859. 3 I8 p.

${ }^{3}$ Cruchaga, Miguei: Estudio sobre la organización economica i la hacienda publica de Chili. Santiago, "Los Tiempos," 1878-1880. 2 v. (v. 2, mining law, infra, p. 429.)

${ }^{4}$ Perez de Arce, Hermógenes: El administrador público. Santiago, Impr. Victoria, I884. $397 \mathrm{p}$.

5 Perez de Arce, Hermógenes: Tratado de administración pública aplicado al curso de injenieros de la Universidad de Chile . . . Santiago, Impr. de la Gaceta, I8g6. $37^{2} \mathrm{p}$. 
in a work called "The citizen and the state," published by Larrain Zañartu. ${ }^{1}$

\section{MUNICIPALITIES}

The organic law of December 22, I891, governing municipalities was amended in important particulars by law 2960 of December 18, 19r4. The organic law has been annotated by Correa $\mathrm{Bravo}^{2}$ in one of the ablest works published in Chile: The third edition of this book, published in r914, discusses each article of the law with its history, and includes critical annotations of the decisions of the courts, opinions of administrative authorities, and practical information not obtainable elsewhere. It deals with municipal and local government in all its forms, and an appendix contains an outline of municipal government in some 27 other countries. The text of the important amending law of December 18, 1914, is included in the third edition of Correa Bravo's work.

A less useful commentary on the law was published in 19r4 by Tagle Ríos. ${ }^{3}$ There are notes at the end of each article of the statute showing changes which have occurred in the law. In this connection it may be of interest to call attention to a collection ${ }^{4}$ of laws and ordinances in force in 1872 in the city of Valparaiso, the principal port on the west coast of South America. Very recently a compilation has appeared of the

${ }^{1}$ Larrain Zañartu, J. Joaquín: El ciudadano y el gobierno. Nueva ley del Régimen Interior, de 22 de enero de I886, concordada y comparada con todos los códigos del Estado. Santiago, Imp. de E1 Progreso, I886. $226 \mathrm{p}$.

${ }^{2}$ Correa Bravo, Agustín: Comentarios y concordancias de la ley de organización y atribuciones de las municipalidades de 22 de diciembre de r89r. . . . 3 3d ed., aum. con las leyes, decretos supremos y resoluciones judiciales posteriores sobre la materia. Santiago, C. Tornero, I9I4. $604 \mathrm{p}$.

3 Tagle Ríos, Ismael: La ley de organización y atribuciones de las municipalidades. Santiago, "Bellarista," rgI4.

"Recopilacion de las disposiciones vijentes en el departamento de Valparaiso sobre los distintos ramos de la administración local formada de órden del Sr. intendente D. Francisco Echáurren. Por Salustio Peña. Valparaiso, Imp. del Mercurio de Tornero y Letelier, 1872 . $682 \mathrm{p}$. 
municipal ordinances of Santiago ${ }^{1}$ relating particularly to matters of traffic.

A paper on the concept of municipal autonomy was read by Lazo de la Vega ${ }^{2}$ before the Congress on Local Government which met in Santiago in rir4.

\section{RESPONSIBILITY OF THE STATE}

A collection of opinions prepared by Ambrosio Montt ${ }^{8}$ as fiscal of the Supreme Court, published officially for their legal value, may be cited as of some importance in administrative law. Volume I deals with opinions on international claims, to which attention will be called in the section on international law, and Volume II with opinions on administrative and judicial matters.

The State as a litigant, a subject of considerable importance, is discussed in a small work published by Ríos Arias ${ }^{4}$ in 1913 . In this connection, attention should be called to the important annual volume of report and opinions of the Attorney General assigned to defend the fiscal interests of the Government. He represents the State in all litigations in which it is a party, including ordinary actions, tax matters, mining cases, expropriation matters, and others. This branch of the Attorney General's office is known as the Consejo de Defensa Fiscal, among whose duties is the approval of the by-laws of all corporations, which under Chilean law must petition the Government for the right to do business, submitting, at the same time, their by-laws for approval. The annual volume or Memoria ${ }^{5}$ of this Consejo contains an account of all the litigations of the year in which the Government has been a party,

${ }^{1}$ Disposiciones legales y municipales de policia y beneficiencia, que reglamentan los servicios de supervigilancia de la I. Municipalidad de Santiago y especialmente sobre tránsito y estacionamiento de vehículos, recop. por Guillermo del Fierro S. Santiago, Impr. A. Eyzaguirre, x916. $422 \mathrm{p}$.

${ }^{2}$ Lázo de la Vega, Moisés: Concepto de la autonomia municipal. Santiago, Impr. universitaria, I9I4. 3 I $\mathrm{p}$.

${ }^{3}$ Moritt, Ambrosio: Dictamenes del fiscal de la Corte suprema de justicia de Chile. Santiago, Imprenta nacional, 1894-95. 2 v.

- Ríos Arias, José Manuel: El fisco litigante. Santiago, Imp. Universo, I9r3. $70 \mathrm{p}$.

${ }^{5}$ Memoria del Consejo de defensa fiscal. Santiago, published annually. 
a collection of the important opinions of the Attorney General, important decisions rendered by the courts concerning the fiscal interests of the State (largely suits brought against the National Railroad), and a list of the corporations whose bylaws have been approved during the year.

\section{IMMIGRATION AND COLONIZATION}

Chile has from the beginning encouraged immigration. The last regulation ${ }^{1}$ on the matter is contained in law 1519 of September 25, 1907. An important compilation of the laws, decrees, and regulations relating to the internal development of Chile was published in 1896 by Zenteno Barros. ${ }^{2}$ Besides the laws relating to provincial administration it covers the entire field of colonization, including the civilization of the natives, the laws governing missionaries, matters of immigration, important laws relating to public lands, woods, waters, roads, fishing, docks, and similar matters. Part I deals with general provisions and Part II with special provisions relating to the development of different sections of the country. It also includes a bibliography of the works and publications on colonization and immigration. A somewhat similar work containing a compilation of all the laws, decrees, and provisions relating to colonization and internal development was edited by Ramón Briones ${ }^{3}$ and published in a fourth edition in 190.5 .

\section{AGRICULTURAL AND WATER LAWS}

Up to the present time there is no rural code in Chile, although the government named a commission to draft such a code in 1874 . Its draftsman was Jose V. Lastarria, but the revisory commission seems not to have accepted the theories

1 Reglamento de inmigración libre. Santiago, Imprenta nacional, I907. I4 p.

${ }^{2}$ Zenteno Barros, Julio: Recopilación de leyes i decretos supremos sobre colonizacion, I8ro-1896. 2 ed. Pub. por el Ministerio de colonización . . . Santiago, Imprenta nacional, I896. $I_{464} \mathrm{p}$.

${ }^{3}$ Briones Luco, Ramón: Glosario de colonización y exposición de las leyes, decretos y demás antecedentes relativos al despacho de colonización hasta el I de julio de I904, seguido de un apéndice hasta el I. de abril de 1905. Ed. oficial. 4th ed. Santiago, impr. Universitaria, 1905. $914 \mathrm{p}$. 
of the draftsman, and nothing has been done since to codify the various laws which would have made up the rural code. These laws relate to ownership of agricultural lands, animals, stock raising, waters, rural police, forests, and roads. The draft of the rural code ${ }^{1}$ was published officially in 1878 . In I 887 José Ravest ${ }^{2}$ published a codification of the agricultural laws including a draft of a rural code. A recent collection of industrial and agricultural laws, compiled and annotated by Egidio Poblete, ${ }^{3}$ professor of industrial law and political economy, warrants special mention. In this work, the only one of its kind in Chile, he deals with industrial law in general, the relation between the state and industry, public health administration, agriculture, mining, forestry, water law, agricultural law, manufacturing industries, labor laws, industrial property, and transportation law.

The civil code has provided various rules for the division and enjoyment of waters and for rural servitudes, and subsequent rules have been enacted governing the use of rivers, the cutting of woods, and the use of roads. In view of the important agricultural development of Chile the laws governing waters have become of great importance and a considerable proportion of the decisions now rendered by the Supreme Court relate to water rights.

A little compilation of the laws, decrees, rules, and ordinances relating to waters has recently been published. ${ }^{4} \mathrm{~A}$ compilation of laws governing waters and irrigation was published in 1899 (second edition) by Fortunato Venegas ${ }^{5}$ and another in 1915 by Rodolfo Ibañez ${ }^{6}$ as a thesis for the degree

1 Proyecto de código rural. Santiago, Imprenta nacional, I878. I9I p.

${ }^{2}$ Ravest, José: Codificación agrícola de Chile. Santiago, Impr. Gutenberg, $1887.335 \mathrm{p}$.

${ }^{3}$ Poblete E., Egidio: Elementos de derecho industrial. Valparaiso, Impr. Moderna, I9r2. $563 \mathrm{p}$.

${ }^{4}$ Diaz Lois, Luis and Portales Riesco, Arturo. Recopilación de leyes, decretos, reglamentos $\mathrm{i}$ ordenanzas sobre aguas. Santiago, Artes y Letras, rgr6. $82 \mathrm{p}$.

${ }^{5}$ Venegas, Fortunato: Lejislación chilena sobre aguas de regadio. 2nd ed. Santiago, E. M. T., I899. 127 p.

'Ibañez, Rodolfo: Legislación sobre aguas. (Mem. de prueba.) Santiago, Imp. Bellavista, I9I5. I9I p. 
of advocate. An important study on the law of waters was published as a doctor's dissertation in 1909 by Hector Claro Salas. ${ }^{1}$

A study on the legal status of waters in Chile by Carlos Aldunate Solar was published in volume $\mathrm{I}$ of the Revista de derecho y jurisprudencia-later published separately ${ }^{2}$-and a brief article on the distribution of waters by Fortunato Venegas was published in volume 5 of that periodical.

The Chilean law of waters was summarized in the appendix (by P. J. Eder) to the paper on the laws and regulations regarding the use of waters in Latin-American countries read by Rome G. Brown before the Pan-American Scientific Congress at Washington in January, 1916 (54 pp).

In 1873 a commission named to regulate the cutting of wood prepared its report, which was published officially. ${ }^{3}$

\section{MINING LAW}

As in nearly all the countries of South America, mining is one of the most important factors in Chilean economic wealth, and the laws governing the exploitation and development of mines have been numerous. Prior to the enactment of the code of I 874 much confusion prevailed in the mining laws because of their ancient origin, their divergence, and their conflicts. Chilean mining legislation actually goes back to the Ordenamiento de Alcalá, published in 1348 . The provisions of this law later passed into the Ordenanzas Reales (lei 8, Tit. I, lib. 6), compiled in 1484 by Alfonso Dias de Montalvo and thence into the Nueva (lei 2, Tit. ${ }_{13}$, lib. 6) and into the Novisima (Tit. 18, 1ib. 9) Recopilación.

The most definite sources, however, of Chilean mining laws are contained in the Ordenanzas del Peru and the Ordenanzas

${ }^{1}$ Claro Salas, Hector: Regimen legal de las aguas en Chile. Santiago, "Universo," I 909.

${ }^{2}$ Aldunate Solar, Carlos: Condición juridica de las augas en Chile. Santiago, Impr. Cervantes, I904.

- Comisión nombrada para la reglamentación de la corta de bosques. Informe de la Comisión nombrada para dictaminar esta materia i reglamento dictado por el presidente de la República. Santiago. Imprenta nacional, 1873 . $50 \mathrm{p}$. 
de Nueva España, many of the provisions of which are still in force in the present mining codes of the West Coast countries. The Ordenanzas del Peru consist of a compilation of decrees and orders issued by the viceroys for the administration of the vice royalty of Peru. This compilation was formed in I 683 by Tomas Ballesteros by order of the viceroy Melchor Navarra. Book III contains the mining ordinances. The ordinances of Nueva España, which are by far the most important source of Chilean mining legislation, were issued on May 22, 178.3 , and by cedula of December 8,1785 , directed to the viceroy of Peru, their adoption in Peru and Chile was ordered, except for local modifications duly enacted as decrecs. In 1787 certain additional declarations on mining were published, to be found in the collection of Zenteno at page 430 . (Supra, p. 372.) The Ordenanzas de Nueva España were adopted in Chile by the decree of June I I, 1833. A celebrated edition of the early mining ordinances are the Comentarios $a$ las ordenanzas de minas by Francisco Javier Gamboa pub.ished in $1761 .^{2}$

The confusion prevailing in the mining laws stimulated the movement for codification. In 1846 the first commission to draft a mining code was named. Their efforts were fruitless. In 1863 Vicente Quesada was commissioned to prepare a draft, and in 1864 his work was presented to a revisory commission which had been appointed. They met at Copiacó, the center of the mining industry. Their labors also were without result. One of the members of the commission, however, later prepared another draft, which was again submitted to a new commission. composed of lawyers and mining men. The revised draft was sent to Congress and adopted as the first mining code on November 18,1874 , coming into force on March i, 1875 . The many defects of this code, however, finally resulted in the adoption of a new code of December 20, 1888 (in force Jan. $\mathrm{I}$,

${ }^{1}$ Reales ordenanzas para la dirección régimen y gobierno del importante cuerpo de la minería de Nueva España y de su real tribunal general. De orden de Su Magestad impresa en Madrid año 1783. $214 \cdot$. Reempresa en Santiago, Imp. de La Opinión, r833. ro8, $3^{6}$ p.

${ }^{2}$ Gamboa, Francisco Javier ( 17 I $7-1$ 794): Comentarios á las ordenanzas de minas, dedicados al catholico rey, nuestro señor, Don Carlos III . . por Don Francisco Xavier de Gamboa . . Madrid, J. Ibarra,

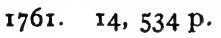


I889), in the preparation of which the Sociedad de Mineria took an important part.

Although written before the draft of the first code José Bcrnardo Lira's ${ }^{1}$ exposition of the mining laws of Chile is an exceedingly valuable work. Lira took a prominent part in the draft of the first code and taught the subject at the university. His book served for years as the standard textbook. Besides a valuable history of mining legislation he reprints a complete text of the early ordinances of New Spain showing the part in force and the part abrogated, with a concordance of these ordinances with the old ordinances of Spain and Pcru and a commentary on the modifications introduced by the laws of Chile, with the relevant decisions cf the courts.

A somewhat similar work, written with particular reference to the historical antecedents of the code of 1874 appears as a part of volume 2 of Miguel Cruchaga's economic study of Chile. $^{2}$

A compilation of laws on mining and nitrate exploitation in force in Chile, published in 1906 by Carlos Ibáñez, ${ }^{3}$ reprints Lira's historical introduction and the laws of $\mathrm{New}$ Spain with the subsequent codes and laws, decrecs, and regulations. An English translation of the mining code of December 20, r 888, was published in the volume for 1899 (pp. xiii-xxi) of the Padron jeneral de minas, an annual statistical publication of the Chilean Bureau of Mines.

There is no especially able commentary on the present mining code. Probably the most useful is that by Robustiano Vera, ${ }^{4}$ published in a second edition in 1897 . The articles of the code are annotated extensively, and the work contains

${ }^{1}$ Lira, José Bernardo: Exposición de las leyes de minería de Chile. 2nd ed. Valparaiso, Imp. del Mercurio, 1870. $285 \mathrm{p}$.

${ }^{2}$ Cruchaga, Miguel: Esstudio sobre la organización economica i la hacienda pública de Chile. Santiago, Gutenberg, I880. v. 2 (23I p.)

${ }^{3}$ Ibáñez Arzón, Carlos E.: Minas i salitreras. Contiene las leyes, decretos supremos dictados y jurisprudencia vijente sobre estas materias, recopiladas. Santiago, Impr. "La Lira," I906. 439 p.

"Vcra, Robustiano: Código de minería de la republica de Chile (promulgado el 20 de diciembre de 1888 , para que rija desde el $\mathrm{I}^{\circ}$. de enero 1889) comentado y anotado por Robustiano Vera: (2. ed. corr. i mejorada notablemente por el autor). Santiago, Impr. de "El Correo," 1897. $466 \mathrm{p}$. 
an interesting historical introduction. In an appendix sorne of the more important regulations are included. A much briefer edition of the mining code, containing occasional short annotations, was published in 1907 by Orlando Ghigliotto Salas. ${ }^{1}$ Santiago Lazo ${ }^{2}$ is the editor of an edition of the code which has been well recommended. He prints the text of the code with extensive commentaries, including its history, concordances, and decisions. A volume of notes on the mining code was published in 1905 by Fuente Ortiz ${ }^{3}$ and another in 1909 by students of Prof. Lillo i Lira. ${ }^{4}$

Drafts of new revised codes have been submitted to Coingress, but have not been acted upon. One was submitted in $1900^{5}$ and was printed with a report of a revisory commission, and another was prepared in 1912 by the Sociedad Nacional de Mineria and printed with an explanatory report. ${ }^{\circ}$

Nitrate is the most important natural resource of Chile. It covers most of the northern portion of the country, including the provinces ceded to Chile by Peru and Bolivia. The legislation on nitrate, which is prolific, is usually included among the mining legislation. Salas's work just mentioned includes the nitrate legislation, pointing out its specific origin in Peru, Bolivia, or Chile.

A special work, reprinting the laws, decrees, regulations, and other documents relating to the exploitation and development of the nitrate territories was compiled in 1907 by Carlos Aldunate Solar. ${ }^{7}$ It likewise includes the daws of Peru,

${ }^{1}$ Ghigliotto Salas, Orlando: Código de minería de la república de Chile, anotado. Santiago, Imp. Barcelona, r907. 135 p.

${ }^{2}$ Lazo, Santiago: Código de minería; Origenes, concordancias, jurisprudencia. Santiago, Poblete Cruzat [1907?]. I8o p.

${ }^{3}$ Fuente Ortiz, Ismael de la: Apuntes sobre el código de minería de Chile. 2nd ed. Santiago, G. E. Miranda, 1905. $\quad 15^{2} \mathrm{p}$.

* Lillo i Lira: Esplicaciones de derecho de minas. Santiago, Impr. Chile, r909. $144 \mathrm{p}$.

${ }^{5}$ Proyecto de código de minería presentado al Congreso nacional por el Presidente de la República. Mensaje i notas. Santiago, Impr. Nacional, rgoo. 86 p.

- Sociedad nacional de minería. Proyecto de código de minería. Santiago, Barcelona, I9I2. 63 p.

${ }^{7}$ Aldunate Solar, Carlos: Leyes, decretos i documentos relativos a salitreras, recopilados. Santiago, Impr. Cervantes, 1907. 178, 220, 215 p. 
Bolivia, and Chile which relate to what is now Chilean nitrate territory.

The late President Billinghurst, ${ }^{1}$ of Peru, published an extensive work in 1903 on the legislation concerning nitrate and borax in the province of Tarapaca, which includes also the legislation of Peruvian origin in the province. It is an important contribution to the history of the industry in Tarapacá.

Attention may be directed to an executive decree of August 7 , I9I , outlining the procedure to be followed in the payment of mining licenses. Provision is also made for the preparation of a list of all the mines of the Republic by the Sociedad Nacional de Mineria.

\section{PUBLIC WORKS}

The government published in 1896 a compilation of laws, decrees, and other provisions relating to public works and concessions for public service. The work ${ }^{2}$ is a valuable repository of the concessions granted by the government and the different decrees issued for the development of public works up to the date of its publication. In I9I4, a much more extensive compilation of laws, decrees, and rulings relating to administrative matters and particularly to public works was published. ${ }^{3}$ It was compiled privately, but received the official approval of the Ministry of Public Works.

In 1907 another compilation ${ }^{4}$ of laws, decrees, and provisions relating to matters within the jurisdiction of the Ministry of Industry and Public Works was published. Attention should be called to a three-volume compilation ${ }^{5}$ of regula-

${ }^{1}$ Billinghurst, Guillermo Eduardo: Legislación sobre salitre y bórax en Tarapacá. Santiago, Cervantes, I903. 672 p.

${ }^{2}$ Recopilación de leyes decretos i demas disposiciones sobre obras publicas ó privilejios esclusivos. Santiago, Imprenta nacional, r8g6. $473 \mathrm{p}$.

${ }^{3}$ Recopilación de leyes, reglamentos e instrucciones sobre la administración en general y especiales de obras públicas. Compiled by Barros Luca. Santiago, Impr. Universitaria, r9r4. 835 p.

- Recopilación de leyes, decretos i demas disposiciones de carácter jeneral relativas al Ministerio de industria i obras publicas. Santiago, Imp. lit. i encuadernación Barcelona, r907.

${ }^{5}$ Morales, Emilio: Recopilación de leyes, decretos y demás disposiciones sobre administración e inversión de fondos fiscales. Santiago, Impr. Barcelona, r900-rgo5. $3 \mathrm{v}$. 
tions relating to the expenditure of public moneys and the administration of public funds with the fiscal relations concerning public property. This work, compiled by Emilio Morales, was published in 1900-1905.

\section{POSTS AND TELEGRAPH}

In 1896 a compilation of the laws concerning posts and telegraphs ${ }^{1}$ was issued officially, with a supplement in 1897 . It contains the laws, decrees, departmental orders, regulations, tariffs, and concessions relating to the subject.

\section{EDUCATIONAL LAW}

The administration of the education of the country is divided between the central government and the municipalities, although practically all the laws and regulations are issued by the central government. A compilation of the legislation relating to primary instruction, by Manuel Ponce, ${ }^{2}$ was issued in I89o. It includes general regulations and matters of funds; inspection, classes of schools, internal administration, textbooks to be used, salaries of teachers, pensions, normal schools, pedagogical societies and private schools, and relevant historical matter. The work contains a chronological and a subject index.

A compilation of the laws in force on March I, 1906 relating to primary instruction was prepared officially in that year by J. R. Arriagada, ${ }^{3}$ Secretary of the Ministry of Public Instruction. It includes regulations, circulars, and orders, and is well indexed.

A compilation of the educational laws of the country was prepared, under the auspices of the government, by Justo

${ }^{1}$ Recopilación de leyes i decretos sobre correos i telégrafos vigentes en 31 de octubre de 1896. Santiago, Impr. nacional, r896. Ir29 p. Anexo a la Recopilación general . . . I897. 62 p.

${ }^{2}$ Ponce, Manuel Antonio: Prontuario de lejislación escolar; recopilación de leyes, decretos, circulares i resoluciones sobre instrucción primaria. Santiago, Impr. Ercilla, I89o. $472 \mathrm{p}$.

${ }^{2}$ Lejislación de la enseñanza primaria de Chile (pública i privada). Disposiciones vijentes en $\mathrm{I}^{\circ}$ de marzo de 1906 . Por J. Rómulo Arriagada M. Santiago, Imprenta nacional, 1906. 409 p. 
Abel Rosales ${ }^{1}$ in 1890 . It covers secondary, higher, and special education, and includes not only the laws and decrees but circulars, orders, and rules issued by the Council of Public Instruction at Santiago. A compilation of the laws in force relating to secondary, higher, and special education was published in $1905,{ }^{2}$ and another valuable compilation in $1912 .{ }^{3}$

By reason of the great authority of its compiler, Manuel E. Ballesteros, ${ }^{4}$ at that time division chief in the Ministry of Public Instruction, attention may be directed to a compilation of the laws and decrees in force in matters of public education published in 1872 .

\section{PUBLIC IHEALTH AND MORALS}

The alcohol problem has been an important one in Chile, and the movement for prohibition has made increasing headway during the last decade. The law of January I8, I902, deals with the production and distilling of alcohol, taxation, dispensaries, and penalties for violation of the law and for drunkenness. The law was published in a German translation $^{5}$ in the collection of foreign penal codes published in Berlin. It was amended in important particulars by law 3087 of April 13, I916.

' Rosales, Justo Abel: Instrucción pública en su parte secundaria, superior, especial é histórica. Recopilación de leyes, decretos supremos, circulares y acuerdos del Consejo de instrucción pública. Santiago, Impr. de "Los Debates," r89o-9r. 2 v.

2 Instruccion secundaria, superior i especial: disposiciones vigentes, 1905. Santiago, Impr. Barcelona, 1905. $580 \mathrm{p}$.

${ }^{3}$ Recopilación de leyes i reglamentos relativos á los servicios de instrucción superior, secundaria i especial. Santiago, Impr. Universitaria, I9r2. $607 \mathrm{p}$.

- Ballesteros, Manuel Ejidio: Compilación de leyes i decretos vijentes en materia de instrucción publica. Obra arreglada por M. E. Ballesteros. Santiago, Impr. de el Independiente, I872. $446 \mathrm{p}$.

5 Das alkoholgesetz in Chile vom. 18. januar I902. Ubers. von Alfredo Hartwig. Berlin, J. Guttentag, g. m. b. h., Igr2. 37 p.

${ }^{6}$ Lei 3087 sobre alcoholes, licores, vinos i cervezas. Antofogasta, Impr. Skarnic, rgr6. $49 \mathrm{p}$.

$71624^{\circ}-17-28$ 
A compilation of the legal provisions relating to sanitary affairs and public charities ${ }^{1}$ was issued in 1889 by the publishing house of Miranda.

In I 906 a law concerning workmen's dwellings ${ }^{2}$ was enacted. The general and local municipal provisions on the construction of buildings were edited in a work recently published by José Urmeneta. ${ }^{3}$

\section{FINANCIAL IEGISLATION}

\section{BANKING LAW}

The establishment of foreign banks in Chile is governed by article 13 of law 1054 of July 31,1898 , which repealed the law providing for conversion into metal and the gold standard established in 1895 . The law of 1898 provided that national and foreign banks were to remain subject to the bank of issue law of July 23, 1860. In 1910 Chile imposed a tax of 3 mills on a dollar on all capital employed in foreign branch banks. A compilation of laws and decrees in force in I912 relating to banking matters, including conversion, the issue of paper money, credit institutions, savings banks, mortgage banks, and foreign exchange, was published in 1912 by Gustavo Ibañez. ${ }^{4}$ Ramón Santelices ${ }^{5}$ is the author of another work, published in 1903, dealing with the banks and banking legislation of Chile. A doctrinal work on banking reform in Chile, with a proposed draft of a new banking law, was published in I9I 3 by Roberto Espinoza, professor of political economy in the University of Chile. Part I consists of a comparative study of European and American banks of issue. Part II deals with banking reform and Part III with monetary reform. Some account of banking conditions and prac-

${ }^{1}$ Iisposiciones vigentes en Chile sobre policía sanitaria y beneficencia pública. Santiago, R. Miranda, 1889. I72 p.

${ }^{2}$ Lei num. 1838 sobre habitaciones para obreros. Santiago, Impr. Cervantes, 1906 . $15 \mathrm{p}$.

${ }^{3}$ Urmeneta, José Tomás: Disposiciones legales y municipales para la construcción de edificios. Santiago, Impr. Diener, I9r5. 456 p.

${ }^{4}$ Ibañez, Gustavo: Recopilación de las disposiciones vigentes relativas á la conversión y emisión de billetes, á la acuñacion de monedas y á los bancos . . Santiago, Imprenta universitaria, rgr2. 395 p.

${ }^{5}$ Santelices, Ramón E.: Los bancos chilenos ó lejislación bancaria. Santiago, Impr. Barcelona, 1903. $467 \mathrm{p}$. 
tice in Chile is given in the monograph by Edward N. Hurley (pp. $5^{2-58)}$ on "Banking and credit in Argentina, Brazil, Chile, and Peru," published by the Department of Commerce in I9I4 as Special Agents series 90.

The mortgage bank (Banco Hipotecario de Chile), which makes loans on mortgage and real estate, was established by the Government by law of August 29, I855. The best commentary on the law and the history and functions of this institution is that by Luis Barros Borgoño, ${ }^{1}$ its director.

\section{DEBT AND TAXATION}

There is a dearth of Chilean literature on public finance. The best sources of information are the annual reports (Memoria) of the Minister of Finance, issued annually since $r 840$, and a Boletin issued since 1888 . The estimates are submitted in a Proyecto de lei de presupuestos and the annual budget is issued as the Lei de presupuestos $i$ de los gastos jenerales de la administración publica de Chile, published regularly since 1867 .

The only modern treatise on public finance appears to be that of Egidio Poblete, published in $1913 .{ }^{2}$ He divides his work into three parts: (I) Public finance in general and the functions of the State; (2) public expenditures in all fields, including estimates and the budget; (3) public revenue and its sources, including the incidence of taxation, and an analysis of the revenues of Chile. The work includes a chapter on the Chilean public debt. A little manual recently published by Prof. Guillermo Subercaseaux ${ }^{3}$ of the University of Santiago covers somewhat the same subjects, besides the monetary and banking systems.

Attention may again be called to the three-volume compilation by Emilio Morales (supra, p. 43I) of the laws and regulations relating to the expenditure of public moneys and the administration of the public funds.

1 Barros Borgoño, Luis: La caja de crédito hipotecario. Su organización y régimen económico, con un estudio sobre la constitución de la propiedad y el régimen hipotecario. Santiago, Impr. Cervantes, I912. v. I. $506 \mathrm{p}$.

2 Poblete E., Egidio: Tratado elemental de hacienda publica. Valparaiso [etc.], Soc. impr. y lit. Universo, I9r3. 645 p.

Subercascaux, Guillermo: Manual de economia politica. Santiago, Soc. Impr. Lit. Barcelona, I916. $177 \%$ 


\section{CUSTOMS LAWS}

Three-fifths of the customs revenue of Chile is derived from export duties on nitrate of soda and iodine.

Various compilations of the customs laws of Chile have been published from time to time. A one-volume collection ${ }^{1}$ of the tariff and customs laws was published in Valparaiso in 1894. In 1893 the International Bureau of American Republics ${ }^{2}$ published an English translation of the tariffs of the American republics in three volumes. They appeared as a Senate document. The tariff for Chile, but not the one now in force, is printed in volume 3 and also published separately in 1905 . The Department of Commerce ${ }^{3}$ issued a translation of the tariff under the law of December 23, 1897 , the tariff in force up to I9I4, as revised and corrected to August I, 1905, together with the general regulations affecting the application of the tariff.

In 1914 a bill was introduced and passed by the Chamber of Deputies, which was the result of the deliberations of a tariff commission in session since 1909, consisting of certain members of the Chilean Chamber of Deputies, appointed in 1909 to elaborate schedules for the revision of the 1897 tariff. As passed by the Chamber of Deputies, the bill was to carry a surtax of Io per cent, but this provision was not adopted by the Senate. The British Board of Trade 4 published a translation of the bill as it passed the Chamber of Deputies, and included a comparison of the rates as proposed with those then in force.

A new tariff, not differing greatly from that of 1914 , was adopted April 10, 1916 (law 3066), and went into effect May 10, 1916. A summary of it is published in the United States Con-

${ }^{1}$ Novísima recopilación de leyes y disposiciones gubernativas relativas al ministerio de hacienda. Por Carlos Ríos González. Valparaiso, Impr. de "I.a patria," I894. 5II p.

2 International Bureau of the American Republics. Tariffs of the American republics. Washington, Government Printing Office, 1893. 3 v.

${ }^{3}$ Customs tariff of the republic of Chile. From the U. S. Monthly summary of commerce and finance for October, 1905. Washington, G. P. O., 1905. p. 1215-1262.

4 Chile. Proposed new customs tarıff. Translation of a bill containing a proposed new customs tariff for Chile . . . London, H. M. Stationery Off. Darling and Son, r914. Cd. 7458. rro p. 
sular Reports and a complete translation will shortly be issued by the Department of Commerce. An excellent account in English of the preparation of the new tariff, its policy, form and provisions, treaty relations, customs and incidental duties and charges and customs procedure, is to be found at pages $143^{-1} 81$ of Dr. Rutter's "Tariff systems of South American countries," published as Tariff Series 34 of the Bureau of Foreign and Domestic Conmerce. A good account of the characteristics of the Chilean tariff and customhouse procedure is contained in the report (pp. 147-187) on trade and tariffs in certain South American countries recently published by the United States Federal Trade Commission (Washington, G. P. O., I916).

Three compilations of customs laws warrant mention. The first, by W. Washington Vergara, ${ }^{1}$ published officially in 1895 with four supplements to 1902 , is a collection of the laws and ordinances in force governing the administration of the Chilean customs. It includes the Ordenanza de Aduanas of December 26, I872, the Reglamento, and all subsequent decrees and circulars. Another, edited by Wenceslao Orellana Vilches, ${ }^{2}$ an ex-official of the customs service, was published in 1903 with a supplement in 1905. It includes, besides the tariff in force, all the decrees and rules of the customs administration of Valparaiso, including the rulings of the governing board and of the Board of Appraisers. It is exhaustively indexed.

The best and most recent compilation of customs laws, rules, and regulations is that of Olguin and Green, ${ }^{3}$ published in I9I4.

${ }^{1}$ Lejislación aduanera. Recopilación completa de las disposiciones vigentes ... arreglada por W. Washington Vergara. Ed. oficial. Santiago, Impr. nacional, I895-1902. I v. and 4 supplements.

${ }^{2}$ Lejislación de aduanas. Disposiciones vijentes arreglada por Wenceslao Orellana Vilches... Santiago, Impr. nacional, 1903. 1704 p. First supplement, Valparaiso, "Universo," 1905.

${ }^{3}$ Olguin, Arsenio, and Green, Marcos Walton: Novisima recopilacion de disposiciones aduaneras. Valparaiso, Escuela tip. salesiana, r914. ro6r $\mathrm{p}$. 


\section{MILITARY AND NAVAL, LAW}

Chilean military legislation had its beginning in different decrees issued by the government since the year 1819 . The most important law in the matter is the military code of April 25,1839 , Ordenanza general del ejercito, which in many respects also governs the navy without, however, abrogating the o.d Ordenanza Jeneral of Charles IV. The code of 1839 haș been amended in many particulars. One of the most important changes effected is contained in the compulsory military service law cf September 5 , 1900, by which all Chileans between the ages of 20 and 45 are required to serve in the army for purposes of military training.

One of the most useful commentaries on the military code, containing a.1 subsequent amendments by way of law, regulation, decree, circular, or military order so far as they were in force on January I, I 9or, was published in that year by Bravo Valdivieso and Gonzalez Bañados, ${ }^{1}$ under official auspices." At the end of each title of the Ordenanza, which covers volume I, there are notes explaining the scope and meaning of each article, and concordances and other annotations of laws and other provisions bearing on the subject. In volume 2 the laws, regulations, decrees, and circulars in force, constituting the legal, administrative, and judicial organization of the army, are printed.

Several compilations of laws relating to the army have been published. A three-volume compilation by Risopatrón Cañas, ${ }^{2}$ published in 1882 , contains in Volume I the provisions of the constitution and the codes and laws relating to military service, in Volume II the general ordinance of the army, annotated, with supplementary laws and decrees, and in Volume III the transitory provisions, with special reference to the war between Chile, Bolivia, and Peru. Between the years 1870 and i 888 a seven-volume compilation of laws and decrees relating to the

${ }^{1}$ Ordenanza jeneral del ejercito ... Ed. publicada en virtud de los decretos supremos de 28 de maizo de 1894 i de 17 de enero de 1900 por Carlos Bravo Valdivieso y Luis C. Gonzalez Bañados. Santiago, Imp. nacional, rgor-. $2 \mathrm{v}$.

${ }^{2}$ Risopatrón Cañas, Dario: Legislación militar de Chile. Santiago, Imp. Gutenberg, I882. $3 \mathrm{v}$. 
army was published by José Antonio Varas. ${ }^{1}$ It includes all the legislation from 1812 to 1887 . This was followed by a similar compilation, with the same arrangement, covering the years 1888 to $1893,{ }^{2}$ prepared by two division chiefs of the Ministry of War. The years $1896-1897$ were covered in another compilation, ${ }^{3}$ not so well arranged, but with exhaustive subject and chronological indexes. The legislation after I 899, relating to the army, was published officially in annual volumes up to $1903 .{ }^{4}$

The important naval ordinance, published in Madrid in two folio volumes in $1793,{ }^{5}$ is still in force to a limited extent in the navy of Chile and in that of Peru and other countries of Latin America.

In 1866 there was published a manual for the navy, which is a compilation of laws, decrees, regulations, orders, and circulars in force governing the navy and its administration. ${ }^{6}$ Under the same title of "Manual for the Navy," another compilation of the laws and decrees, orders, and circulars, relating to the navy, ${ }^{7}$ somewhat similar in form to the compilation of

1 Varas, José Antonio: Recopilación de leyes y decretos supremos concernientes el ejército. Santiago, 1870-1888. 7 v. v. I, Impr. nacional, 1870, (Apr., r8r2-Apr., r839); 583 p. v. 2, Impr. Chilena, 1860, (1839-1859); other ed., r889. v. 3 , Impr. Un. Americana, I866, (1859-1865). v. 4, Impr. nacional, $187 x$, (r865-1870). v. 5, Imp. El Correo, 1878, (1870-1877). v. 6, Imp. R. Varela, 1884, (1878-1883). v. 7 , Imp. El Correo, 1888 , (1884-1887).

${ }^{2}$ Recopilación de leyes, decretos, reglamentos y disposiciones de carácter jeneral del Ministerio de guerra r888-r893, por . . . Roberto Montt y Horacio Fabres. Santiago, Impr. nacional, x895. 769 p.

${ }^{3}$ Recopilación de leyes y disposiciones supremos referentes al ejército, r896-1897. Santiago, Impr. nacional, r899.

4 Recopilación de leyes i decretos referentes al ejército. Santiago, Impr. del Ministerio de Guerra o Impr. nacional. Year 1900 published 1908; 1902 published 1904; 1903 published r909.

${ }^{5}$ Ordenanzas generales de la Armada Naval. Madrid, Imp. de Ibarra, r793. $2 \mathrm{v}$.

${ }^{6}$ Manual del marino, o Guia comandante i oficial de guerra i de administración de la marina de la republica. Santiago, Impr. Independencia, $1866.406 \mathrm{p}$.

7 Manual del Marino. Colección de leyes, reglamentos, brdenes y formularios que deben tenerse presente en la Marina Militar. Santiago, r866-1889. v. I, Imp. La Independencia, 1866; 1817-1866. v. 2-3, By Don Manuel Salas Lavaqui, Impr. Gutenberg, x866-1882; 'r883-r885. v. 4, Imp. Gutenberg. By Don Emilio Bello Codecido, 1889; r886-88. v. 5 to 19 , imprint varies, cover years I889-1912. 
military law by Varas was begun in Santiago in 1866 . The legislation is printed chronologically. There were 19 volumes in the collection up to 1912. The various volumes were prepared by different compilers and issued by different publishers.

\section{ECCLESIASTICAL LAW}

Perhaps more than in any other country of Latin America the church has played an important part in the development of legal institutions in Chile. At the present time it is stated that the income of the church from church property is greater than the income of the government. A Chilean work on canon law by Justo Donoso, ${ }^{1}$ Bishop of La Serena, on the institutions of canon law in America has achieved a reputation extending far beyond Chile. It was first published in 1848 . It served as a textbook until 1855 , and will probably be used for a long time as a work of reference by reason of its extensive notes and references. The last edition of the work revised by Carlos Silva Cotapos was published in I 909.

Another work of some importance in ecclesiastical law is the two-volume treatise by Fernández Concha, ${ }^{2}$ first published in 1872 , and in a second edition in 1894 .

A study concerning the ecclesiastical legislation for the decade $1900-1910$, was published by Ramirez Lastarria ${ }^{3}$ in 1915. These studies first appeared in the Revista Catolica of Santiago.

\section{INTERNATIONAL LAW}

\section{TREATIES}

The earliest collection of Chilean treaties was published in two volumes, the first in 1857 and the second in $187 .^{4}$ The

1 Donoso, Justo: Instituciones de derecho canónico americano. Val-

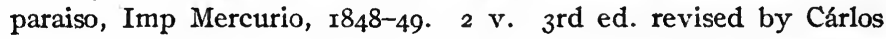
Silva Cotapos, Friburgo de Brisgovia, B. Herder, Lib. Ponteficio, I909. 7 r $5 \mathrm{p}$.

2 Fernández Concha, Rafael: Derecho público eclesiastico. Santiago, Impr. de E1 Correo, 1872. 2 v. 2nd ed. Santiago, Imp. de Emilio Perez L., 1894. 2 v.

${ }^{3}$ Ramirez Lastarria, Lisandro: Estudios acerca de la legislación canónica durante el decenio rgoo-rgio. Santiago, Imprenta San José, I9I5. $356 \mathrm{p}$.

- Coleccion de tratados celebrados por la República de Chile con los estados extranjeros. Santiago, Impr. nacional, 1857-75. 2 v. 
treaties are listed alphabetically by countries with which they were concluded, and at the end of volume 2 is a collection of notes showing to what extent the treaties were still in force in 1875. A new and much better edition of the treaties concluded by Chile with foreign countries was begun in 1894 , the treaties being compiled by period. The original compiler was Bascuñan Montes $;{ }^{1}$ Bernadino Toro and other compilers have been responsible for the later volumes. Six volumes were published down to 1913 .

A valuable study on the treaties with Peru and Bolivia of I 883-84, which terminated the four years' War of the Pacific, was published in 1912 by Luis Aldunate. ${ }^{2}$ They include the discussion of the celebrated Tacna-Arica controversy between Chile and Peru. The work is largely a reprint of articles published in "El Ferrocarril" in 1900.

\section{CONSULAR LEGISLATION}

The consular legislation of Chile has been compiled at various times. One of the best of these compilations containing the legislation and the rules, decrees, and circular instructions in force in 1909 was prepared by Venégas ${ }^{3}$ for the use of Chilean consuls abroad. The work contains the constitution, the consular law No. 928 of March 4, 1897, the consular regulation No. 360 of April 9, 1897, supplementary instructions and the treaties of commerce and extradition in force, besides certain laws relating to colonization and immigration. Another compilation of the laws relating to the diplomatic and consular services, intended as a practical manual, was published in 1912 by Castro Ruiz, ${ }^{4}$ until recently

${ }^{1}$ Bascuñán Montes, Aurelio y Toro C., Bernadino, etc.: Recopilación de tratados y convenciones celebrados entre la República de Chile y las potencias extranjeras. Edición autorizada por el supremo gobierno y revisada por el Ministerio de relaciones exteriores. Santiago, Impr. Cervantes, 1894-. $6 \mathrm{v}$. to 1914 .

${ }^{2}$ Aldunate, Luis: Los tratados de $1883-84$ a propósito de las declaraciones del mensaje presidencial de $\mathrm{I} .^{\circ}$ de junio en curso. Santiago, Impr. "Barcelona," I912. $288 \mathrm{p}$.

${ }^{3}$ Venégas, Florencio A.: I.ejislación consular de la república de Chile. Disposiciones vijentes, arreglada por la Sección consular del Ministerio de relaciones exteriores. Ed. oficial. Santiago, Impr. "Barcelona," rgog. 635 p.

"Castro Ruiz, Carlos and Mora, Luis R.: Lejislación diplomática i consular de Chile. Valparaiso, Scherrer y Herrmann, I9r2. $5^{22} \mathrm{p}$. 
Under Secretary of Foreign Affairs, and Luis R. Mora. The laws, decrees, and circulars governing the two services are separated and arranged by subject. A somewhat similar compilation separating the two services was published in I9I4 by Bustos and Montané. ${ }^{1}$

The regulation governing diplomatic ceremonial was issued as No. 1386 of August 16, 1910. ${ }^{2}$ This regulation and the regulation for consular fees of $1909^{3}$ have been separately published. The new tariff of consular fees considerably increased, which went into effect temporarily on April I, I9I6, was made permanent on January 8, 1917.

Attention may be directed to an exhaustive index of the laws and decrees of the Ministry of Foreign Affairs, issued or promulgated during the years $1897-1903 .^{4}$ A list of the Chilean consuls and of foreign consuls in Chile has recently been published..$^{5}$

\section{LITERATURE}

Among the treatises on international law Chile has made a few excellent contributions. The most celebrated of these is undoubtedly the classic treatise of Andres Bello, ${ }^{6}$ first published in 1832 . It is not generally known that this work largely influenced our own celebrated publicist, Wheaton, in the latter's work on international law. Three editions of Bello's work were published by Bello, the second in Valparaiso by the Imprenta Mercurio in 1844 and the third under

${ }^{1}$ Bustos, L., Emiliano and Montané U., Augusto: Lejislación diplomática i consular de Chile. Santiago, Impr. "La Ilustracion," rgr4. $375 \mathrm{p}$.

${ }^{2}$ Reglamento para el ceremonial diplomático de Chile. Santiago, Impr. Cervantes, I9ro. $20 \mathrm{p}$.

${ }^{3}$ Nuevo arancel consular, promulgado por ley $\mathrm{N}^{\circ} .2208 \mathrm{el}$ I9 de octubre de r909. Santiago, Impr. Bellavista, r909. 9 p.

${ }^{4}$ Indice de decretos i leyes del Ministerio de relaciones esteriores culto i colonizacion. r897 a 1903. Santiago, Taller tipográfico del Instituto de sordo-mudos, I905. 73I p. At head of title José Santos Lira Smith.

${ }^{5}$ Servicio consular de Chile y consules extranjeros constituidos en Chile

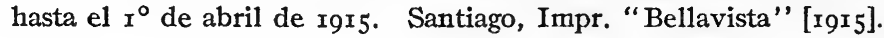
$45 \mathrm{p}$.

${ }^{6}$ Bello, Andres: Principios de derecho de gentes. Santiago, Imp. La Opinión, I832. $267 \mathrm{p}$. 
the title Principios de derecho internacional by the Imprenta La Patria in the same city in 1864 . Other editions of the work were published in Madrid, Paris, Caracas, and Bogotá. What is considered at the present time the best edition was issued as volume ro of his collected works ${ }^{1}$ published in 1886 , with an introduction by M. L. Amunátegui together with various articles of Bello on international law. José María Pando's work Elementos de derecho internacional, published in Valparaiso by the Imprenta del Mercurio in 1848 is but little more than a copy of Bello's celebrated work. A modern work by Miguel Cruchaga, ${ }^{2}$ a second edition of which appeared in 1902 , is not without merit.

\section{UTI POSSIDETIS}

A valuable study of the important question of $u t i$ possidetis in its relation to the boundaries of the South American countries and their international relations was published in 1903 by Vial Solar ${ }^{3}$ under the somewhat misleading title "The treaties of Chile." Volume I, covering the colonial period, deals with the various orders and other documents which determined the jurisdiction of the respective Audiencias and administrative divisions, as a historical aid in a study of the subsequent boundary disputes of the independent republics. It is also an important contribution to our knowledge of the commercial and other relations of the colonies. Volume 2 constitutes a historical study of the diplomatic relations of the South American states with the various European powers. The work is well documented.

\section{MARITIME WAR}

An important treatise on the law governing maritime war, particularly as illustrated by the actual cases in which Chile has been concerned, was published in 1899 by Oscar Vicl. ${ }^{4}$

${ }^{1}$ Bello, Andres: Obras completas. v. X. Derecho internacional. Santiago, Imp. Pedro G. Ramírez, I886. 627 p.

${ }^{2}$ Cruchaga Tocornal, Miguel: Nociones de derecho internacional. 2 d ed. Santiago, Imp. Barcelona, I902. $529 \mathrm{p}$.

"Vial Solar, Javier: Ios tratados de Chile. Santiago, "Barcelona," I903-4. $2 \mathrm{v}$.

${ }^{4}$ Viel C., Oscar: La guerra maritima ante el derecho internacional. Santiago, Ismeralda. I $899.304 \mathrm{p}$. 
It involves a study of maritime war, capture of private property at sea, neutrality and the rights and obligations of neutrals, contraband and blockade, visit and search, and prizes and prize courts. It is one of the few Latin-American books on the subject.

Alejandro Alvarez, ${ }^{1}$ one of the best known of the modern Chilean publicists, recently published a work on the European war, with a special discussion of its relation to the neutrality of Chile. It discusses various phases of international law in its relation to the war and the relation of America to the conflict. Part II deals with the neutrality of Chile and international law and the questions with which Chile has had to deal since the beginning of hostilities. Dr. Alvarez is also known in the United States for his previous work Le droit insernational americain ${ }^{2}$ published in Paris in 1909 and reprinted in part in an English translation in the American Journal of International Law. Dr. Alvarez is also the author of a work on the diplomatic history of Chile, ${ }^{3}$ which includes an account of the Chilean contributions to international law. Only one volume appears to have been published.

\section{CLAIMS}

It is appropriate to call attention to the opinions published by Ambrosio Montt ${ }^{4}$ as fiscal or attorney general assigned to the supreme court on the claims against Chile brought by Spanish and Ecuadorian citizens on account of the operations of the Chilean army and navy during the war with Peru. This volume of opinions constitutes an important

${ }^{1}$ Alvarez, Alejandro: La grande guerre européenne et la neutralité du Chili. Paris, A. Pedone, I9I5. 3I5 p.

${ }^{2}$ Alvarez, Alexandre: Le droit international americain. Paris, A. Pedone, r9ro. $386 \mathrm{p}$.

${ }^{3}$ Alvarez, Alejandro: Rasgos generales de la historia diplomática de Chile (r8ro-rgro). Santiago, Impr. "Barcelona," Igrr.

4 Montt, Ambrosio: Dictamen emitido al presidente de la república por el fiscal de la Corte suprema Don Ambrosio Montt sobre las reclamaciones interpuestas ante el supremo gobierno por ciudadanos ecuatorianos i súbditos españoles con motivo de las operaciones del ejército i cscuadra de Chile en la última guerra con el Perú. Santiago, Impr. nacional, I8go. $246 \mathrm{p}$. 
and well-known contribution to international law. It is included in a two volume edition of Montt's opinions which were subsequently published. Another important contribution of this order is the memorandum submitted by Eugenio Vergara ${ }^{1}$ as agent of the Chilean government before the mixed clains commissions sitting in Santiago in 1884 after the war of the Pacific, on the rights of domiciled aliens in belligerent territories and particularly their right to indemnity for injuries inflicted upon them during war.

\section{AIIIENS}

The legal status of aliens in Chile has been discussed in a recent monograph by Valdés, ${ }^{2}$ and in a series of articles by Correa Bravo, published in volumes 33,34 , and 35 of the Argentine Revista de derecho jurisprudencia y letras.

\section{CONFLICT OF LAWS}

Attention may be called to the important work of José Clemente Fabres on the conflict of laws in the municipal law of Chile, first published in 1892 and republished as volume I of his collected works, a summary of which was published in French in 1887 in Clunet's Journal $d u$ droit international privé. A somewhat elementary work on the conflict of laws, dealing with (I) general principles, (2) civil law, (3) commercial law, (4) criminal law, and (5) notarial law was published in 1902 by the versatile writer, Robustiano Vera. ${ }^{3}$

Attention may be directed to an interesting article by Dr. Julio Philippi, one of the leading lawyers of Chile, on the "most-favored-nation clause" as found in the treaties of Chile. The article was published in volume 9 of the Revista de derecho jurisprudencia $i$ ciencias sociales (I9I2), pages 53-65.

1 Vergara, Eugenio: Memorandum del Agente del Gobierno de Chile ante las comisiones mixtas internacionales de Santiago, 1884. Santiago, Imp. del Progreso, I884.

${ }^{2}$ Valdés Mendeville, Jorge: Los extranjeros ante el derecho. Memoria de prueba. Santiago, Universitaria, I9r3. $72 \mathrm{p}$.

Vera, Robustiano: Principios elementales de derecho internacional privado. Santiago, Centro edit. la Prensa, 1902. 433 p. 
This survey of the law and legal literature of Argentina, Brazil, and Chile will have indicated to the bench and bar of the United States the wealth of the contributions to the law made by the governments and jurists of those countries. In the study of comparative law, the legal institutions of the important Latin-American countries can not be left out of account. Their practical importance, with the constant strengthening of the economic bonds existing between North and South America, requires no commentary. The growing rapprochement in our material interests will inevitably lead to a greater appreciation and cultivation of our mutual intellectual interests. 


\section{GLOSSARY - SPANISH}

Abanderar. To register (a ship).

Abandono. Abandonment.

Abintestato. Intestate.

Abogado. Attorney at law, lawyer, barrister.

Abogado en ejercicio. Practicing attorney.

Abogado del estado. Attorney for the state.

Abogado de oficio. Attorney appointed to represent poor litigants.

Abogar. To argue or plead a case.

Abordaje. Collision.

Aborto. Abortion.

Absolución de posiciones. Answers to interrogatories.

Acaparar. To corner the market.

Acaparador. One who corners the market.

Acarreadores. Carters.

Accion. Share, certificate of stock; lawsuit.

Aceptación. Acceptance.

Aceptante. Acceptor of a bill of exchange.

Aceptante por intervención. Acceptor for honor.

Aclaración. Explanation, illustration.

Acomodación. Accommodation.

Acreedor. Creditor.

Acreedor escriturario. A creditor who proves his debt by means of a public notarial instrument.

Acreedor hipotecario. See hipoteca.

Acreedor refaccionario. A preferred creditor. One who has advanced money for building purposes.

Actuaciones. The record of pleadings in a case.

Actuario. Judicial officer who authenticates all the documents in the suit.

Acuerdo. Agreement, treaty.

Acusación. Impeachment; indictment.

Acusar la rebeldía. To disclose resistance to orders of a judicial authority.

Adelantado. A mediaeval Spanish officer formerly employed in the American colonies.

Adjudicación en pago. Judicial execution on property in payment of a debt.

Administracion. The direction, government and care which a man or corporation has of the property of an inheritance of a minor, of an insane person, of a prodigal, of an establishment or of an individual; so that every guardian, curator or executor has an administration. Administration is in reality a powcr of attorney or mandate, and consequently produces the same obligations and rights as this contract. 
Administrador. Manager.

Adulterio. Adultery.

Adulto. Adult; one who has ceased to be impuber.

Advertencia. Notice, remark, advice.

Agcnte. Agent.

Agente de cambios. Bill broker.

Agotado. Out of print.

Albaceazgo. Executorship.

Alcabala. Excise or tax on sales; transit duty; also (certain countries) tax for conveyance of real property.

Alcabala del viento. Duty paid by a visiting merchant.

Alcalde (of a town or city). Head of a district of a city. Tenientes alcaldes, all the alcaldes; alcalde mayor, president of the tenientes alcaldes.

Alcaldías. Municipal courts.

Alguacil. Bailiff, lowest officer in the scale of officials in the administration of justice.

Alguacil mayor. Sheriff.

Alianza. Alliance.

Alistamiento. Levy, conscription.

Almacén. Warehouse.

Almacenajes. Storage.

Almirantazgo. Court of admiralty jurisdiction.

Almojarifazgo. Duty on imports or exports.

Alzamiento. Making a higher bid at an auction.

Allanamiento. Trespass.

Allanamiento de morada. Breach of the house or home.

Allanarse á la demanda. Admission by defendant of allegations in the plaintiff's complaint.

Amenaza. Threat.

Amigables componedores. Amiable compositeurs, friendly arbitrators.

Amillaramiento. Assessment of a tax.

Amojonamiento. Setting of land marks.

Amortización. Mortmain; amortization.

Anatocismo. Compound interest.

Anotación preventiva. A preliminary and provisional entry of a claim upon real property. See Beneficio de inventario.

Anticipaciones. Advances.

Anticresis. Antichresis. An agreement by which the debtor gives to the creditor the income from the property which he has pledged, in lieu of the interest on his debt.

Anuario. Year-book.

Año económico. Fiscal year.

Antecedentes. Precedents, events leading up to.

Aparcería. Partnership.

Apelación. Appeal proper.

Apelación desierta. Abandonment of an appeal after it is entered.

Apercibimiento. Order of a judge or court enforcible by contempt proceedings. 
Apoderado. Grantee of a power of attorney; agent.

Apremio. Sale of attached property to pay the decreed debt.

Aprendizaje. Apprenticeship.

Apuntamiento. Extract from the record; note.

Arancel. Fee, tariff.

Arancel de derechos. Scale of fees.

Armada. Navy.

Armadores. Managing owners (of vessels).

Arras. Property given by a man to a woman either before or after their marriage. It must not exceed one-tenth of what he possesses; Earnest.

Arrendamiento. Renting, letting, lease.

Arrendador. Lessor.

Arrendante. Lessor.

Arrendatorio. Lessee.

Arribadas forzosas. Ports of refuge.

Asamblea general. General meeting (of corporation).

Asegurado. Insured.

Asegurador. Underwriter, insurer.

Aseguramiento. Insurance, security.

Asegurador. Insurer.

Asesinato. Killing with premeditation, etc. Corresponds to our murder in the first degree.

Asiento. Entry (on records); contract.

Asociacion. An association (company).

Atentado. Criminal attempt.

Atribución. Prerogative; duty.

Audiencia. Court of appeal, provincial court; colonial administrative subdivision; session (of court).

Autenticidad. Authenticity.

Auto. Decree or decision of a judicial body in regard to some question of fact, evidence or jurisdiction. Every judicial decision which is neither a final decision (sentencia) or decision referring to matters of procedure (providencia).

Auto acordado. A decision rendered by a consejo or superior court on some point applicable to its authority to be observed as a precedent. Also in plural it is used to denominate the decrees of the Council of Castile that were embodied in the Nueva and also the Novisima recopilación.

Autor, Principal (in a crime), author.

Autorización. Authorization.

Autos. Record, documents in a legal proceeding.

Auxilio. Cooperation, aid, assistance.

Aval. Guaranty by third person of payment of bill of exchange, recorded usually in separate instrument; the instrument itself.

Avalista. Third person guarantor of a bill of exchange.

Avaluo. Valuation, appraisal.

Avería común. General average.

$71624^{\circ}-17-29$ 
Averías. Average.

Aviso. A notice.

Ayuntamiento. Municipal government composed of a mayor and aldermen.

Balnearios. Public baths.

Bancarrota. Bankruptcy.

Bandera de paz. Flag of truce.

Barraqueros. Warehousemen.

Bastanteo. Examination or impeachment by counsel of the authority or right, conferred on the solicitor, for bringing the action.

Beneficencia. Poor laws, charity.

Beneficio de inventario. The provisional right which the heir has of remaining free from liability to pay the creditors of the deceased beyond the value of the inheritance.

Beneficios. Profits.

Bienes. Goods, assets, property.

Bienes gananciales. Property acquired by the husband and wife by a common title during their marriage and while they live together, or what the husband or wife or either of them during their marriage and living as one may acquire by purchase or by means of labor and industry, as also the fruits of the private property that each brings to the marriage.

Bienes muebles. Personal estate.

Bienes raíces. Real estate.

Bienes reservables. The property that can not be alienated but must be reserved for certain relatives.

Bigamia. Bigamy.

Billete. Bill, promissory note; ticket.

Billete de banco. Banknote.

Boletín oficial. Official gazette or bulletin of the province.

Bolsas. Exchanges.

Bolsas de comercio. Commercial exchanges.

Bonificación. Discount.

Buena fe. Bona fides.

Bufete. Irawyer's office, desk.

Buque. Vessel, ship.

Cadastro. Official assessment of the quantity and value of the real property in any district, made for the purpose of justly apportioning the taxes payable on such property.

Cadena (perpetua, temporal). Confinement with chains worn at ankles and waist. Considered next to death penalty in severity.

Caducidad. Lapse (of action or of a right); failure to take effect.

Caducidad de la instancia. Failure of the action for lack of prosecution.

Caja de pensiones y jubilaciones. Pensions and superannuation fund.

Cajero. Cashier.

Calumnia. False imputation of a crime, either oral or written, which was the cause of a prosecution, slander.

Cámara de compensación. Clearing house. 
Cámaras compensadoras. Clearing houses.

Cancelar. Cancellation, to cancel validly.

Capacidad. Capacity.

Capellanía colativa. The capital and interest of a foundation that requires its possessor to be a clergyman.

Careo. Confrontation of the prosecuting witnesses by the accused for purpose of cross-examining them.

Cargador. Consignor.

Cargo. Office, burden.

Carta de crédito. Letter of credit.

Carta de fletamento. Charter party.

Carta de naturaleza. Letters of naturalization.

Casacion. Annulment or quashing of a judgment.

Casas de depósito. Warehouses.

Caución. Bailbond or bail; security.

Caudal. Property, wealth, funds (plural).

Causa. A criminal suit or prosecution; consideration.

Causahabiente. Litigant; owner; legal successor of a former litigant.

Cautela. Temporary certificate.

Cederite. Transferor.

Cédula. Order emanating from some superior tribunal, promulgated in the name and by the authority of the sovereign. A bond.

Cédula personal. Legal document or personal certificate every Spanish citizen must possess.

Cédula real. Royal letters patent.

Cencerrada. A disturbance of the peace in the form of mock serenades with horns and bells upon the marriages of widows or mismated couples.

Censatario. Payer of ground rent, or one who pays an annuity out of his estate to another.

Censo. The contract whereby the right is acquired of receiving an annual pension on delivery of something. The right itself of receiving the pension. A perpetual annuity, or one for a term of years. Ground rent.

Censo de población. Census.

Censo electoral. List of voters.

Censo consignativo. Assigned ground rent; rents from one holding land of a debtor for benefit of creditor.

Censo de or por vida. Annuity for one or more lives.

Censo enfitéutico. Emphyteusis, a contract of a special nature in regard to use and occupation of land.

Censo frumentario. Grain rent.

Censo reservativo. Reservative ground rent.

Censualista. An annuitant; receiver of a ground rent.

Censuario. The person in whose favor an annuity is granted, or he who has the right to receive the annuity. (Some writers use the word to signify the party who pays the annuity.)

Certeza. Certainty. 
Cesión. Cession, transfer.

Cesionario. Transferee.

Cesion de bienes. Surrender of the estate of an insolvent debtor into the hands of his creditors.

Cheque cruzado. Crossed check.

Choques. Collisions.

Citación. Summons, notice, citation.

Citación de remate. Notice to debtor of intended sale of his goods to pay his debts.

Ciudadano. Citizen.

Clases pasivas. P^nsions.

Clausura. Closing, termination.

Coacción. Act of compulsion.

Cobrar. To collect, recover, obtain.

Cobro. Collection.

Cobranza. Collection.

Código. Code.

Cohecho. Bribery.

Comerciantes. Merchants.

Comercio. Commerce.

Comisión. Commission.

Comisión permanente. Standing committee.

Comisionista. A factor, commission merchant.

Comisionista de garantía. Del credere factor.

Comiso. Every description of confiscation. The reversion of the useful ownership of an enfiteutic property to the direct owner in case the party charged does not pay him the rent. Property confiscated is also styled comiso.

Comitente. The principal.

Compañía anónima. A limited stock company or business corporation. Compañía colectiva. Unlimited partnership.

Compañía de seguros. Insurance company.

Compañía en comandita. A limited partnership. A partnership where there are "silent" members who are only liable to the amount they invest.

Compañias. Companies, corporations.

Comparecer. To appear in the action.

Comparecencia en juicio. Act of appearing before a judge and demanding justice.

Compendio. Summary, abridgment, compendium.

Compensación de crédito liquido. Set off producing effect of payment.

Competencia. Jurisdiction.

Competencia ilícita or desleal. Unfair competition.

Cómplice. Accomplice.

Compra. Purchase.

Compraventa. Bargain and sale.

Comprobación. Proof, comprobation.

Con arreglo. In conformity with. 
Concejal or consejero. Member of a public board or city council.

Concejil. Referring to or concerning concejal.

Concejo. Civic body of a town.

Concejo abierto. Meeting of the inhabitants of a small town presided over by the mayor to deliberate upon public affairs.

Concordato. Composition with creditors.

Concurrencia. An equality of rights or privileges which several persons have over the same parcel of debtor's property:

Concurso. The suit instituted either by the debtor or by the creditors on insolvency. The meeting of creditors. A competition or contest.

Concurso civil de acreedores. Civil bankruptcy.

Condición resolutoria. The condition which, on being fulfilled, produces the revocation or invalidation of the contract, and places matters in statu quo.

Condición suspensiva. Condition precedent.

Confesión. Admission; confession.

Confianza. Confidence.

Confinamiento. Confinement, a species of banishment.

Congreso. Lower body of the Spanish parliament or cortes; Congress (in Latin-America).

Conocer. To take cognizance, to try a cause (by a court).

Conocimiento. Bill of lading; notice.

Consejo. Council.

Consejo de estado. Council of State.

Consentimiento. Assent, consent.

Considerandos. Paragraphs setting forth legal grounds on which a judgment is based.

Consignación. Consignment.

Consignatario. Consignee.

Conspiración. Conspiracy.

Constitución. Constitution.

Consulaje. Fees paid to consuls by all merchant vessels.

al Contado. For cash.

Contador. Accountant.

Contendor. Appellee.

Contenencia á la demanda. Demurrer.

Contestación. Answer.

Contrabando. Smuggling.

Contramaestre. Chief officer.

Contratación. Trade, commerce.

Contrato. Contract.

Contrato á la gruesa. Bottomry bond.

Contribución. Tax.

Contribuyente. Taxpayer, contributor.

Convenio. Agreement, treaty, convention.

Convocación de acreedores. Call for meeting of creditors.

Conyuges. A married couple, consorts, husband and wife. 
Copia original. The first copy, granted and signed by the identical notary who attested the original instrument.

Corona. Throne, crown.

Corporación. Corporation.

Corredor. Broker.

Corredor de cambios. Exchange broker.

Correduría. Brokerage.

Corregidor. Administrative head of a town, mayor. See alcalde.

Correo. Post, mail.

Correspondencia. Mail (correspondence).

Correspondiente indemnización. Due compensation.

Cosa juzgada. Res judicata.

Costas. Costs.

Costumbre. Custom, duty.

Créditos privilegiados. Privileged debts, liens.

Criminología. Criminology.

Cualificado. Qualified.

Cuasi contratos. Quasi contracts.

Cuenta. Account, calculation.

Cuentas de inversión. Expenditure accounts.

a Cuenta. On account, in part payment.

Cuenta corriente. Current account.

Cuenta de resacar recambio. Memorandum of expense of redraft.

Cuenta de venta. Account sales.

Cuerpo del delito. Corpus delicti.

Culpable. Guilty, negligent.

Culto. Worship, religious belief (also culture).

Cumplimiento. Performance.

Cupones. Coupons.

Curia. Ecclesiastical court, tribunal.

Curial. Member ecclesiastical court.

Cheque. Check.

Dar cuenta. To answer, to give account.

Dar fianza. To give bail or pledge, or earnest money in a trade.

Dar fe. To attest, to certify.

Dataría. Datary, office of the Chancery at Rome where the Pope's bulls are expedited.

Deber. Duty, obligation.

Deber (verb). To owe, ought.

Debido curso. Due course.

Declaración. Deposition.

Declinatoria. Plea to the jurisdiction of the court.

Decreto. Order similar to cédula in ecclesiastical matters.

Dedicarse. To practice (a profession).

Defensa. Defense.

Defraudaciones. Frauds.

Delincuente. Offender, criminal. 
Delito. One of the two divisions of crimes. This is the greater and comprehends crimes dangerous to the person and property, violations of laws committed intentionally. Felony.

Delito consumado. Consummated crime.

Delito frustrado. Crime not consummated on account of a cause purely independent of the will of the actor.

Delito de incendiar. Arson.

Demanda. Claim, complaint, declaration, action.

Demencia. Lunacy.

Derecho. Right, law in general, body of law.

Derecho administrativo. Law of administration of public business and the government; administrative law.

Derecho civil. Civil law.

Derecho canónico. Ecclesiastical or canon law.

Derecho común. The civil or general law of a place, as distinguished from the particular or municipal law of a province, district or city, or from any special or privileged law, as the military, ecclesiastical and commercial.

Derecho contencioso-administrativo. See jurisdicción.

Derecho de gentes. Natural law, such as prevailed among foreign nations, as contrasted with the Roman law. International law.

Derecho foral. Local statutory law. Special law of certain provinces.

Derecho internacional privado. Conflict of laws.

Derecho internacional público. International law.

Derecho no escrito. Unwritten law, established custom.

Derecho militar. Military law.

Derecho mercantil. Commercial law.

Derecho penal. Criminal law.

Derecho político. Political science (in broad sense). Constitutional law (in the restricted sense).

Derecho procesal. Procedural law.

Derecho real. Right in rem.

Derogación. Repeal.

Desahucio. Ejectment of tenant at expiration of term.

Desalojo. Ejectment.

Desamortizar. To disentail, to break an entail.

Descuento. Discount.

Desembolso. Disbursement; cash payment.

Desempeño. Performance, act of redeeming a pledge, exercise (of a profession).

Desistimiento. Abandonment [of an action]; discontinuance.

Deslinde. Demarcation.

Destierro. Exile, judicial banishment.

Detención. Arrest.

Detención ilegal. False imprisonment.

Detener. To arrest.

Deuda. Debt.

Deudor. Obligor, debtor. 
Día de trabajo. Working day.

Diario de avisos. Official gazette of the locality or district.

Diccionario. Dictionary, encyclopedia.

Dictamen pericial. Opinion of expert:witness in a trial.

Diligencia. Order, term, execution of a court order.

Dinero. Money.

Diputado. Representative in the lower House of Congress.

Dirimir. To settle (disputes).

Discernimiento. Appointment.

Discordia. Disagreement of the judges.

Disfrutar. To gain advantage, reap benefits, enjoy.

Disolución. Dissolution.

Disponible. Available.

Divorcio. Divorce.

Doctrina legal. Rules of law which the Supreme Court draws up in its judgments as a foundation for the ruling or decree.

Documental. Documentary.

Documento. Instrument, document.

Documento negociable. Negotiable instrument.

Domiciliado. Person who, though not sui juris, resides permanently in and forms part of the house of a vecino.

Domicilio. Permanent dwelling place of a vecino and domiciliado, domicile.

Dominio. Ownership.

Dominio directo. The right which a man has of concurring in the disposal of a thing the produce whereof he has assigned; or of receiving a certain pension or annual tribute in acknowledgment of his seigniorial right or superiority over the property (Spain). The right of superiority of a real estate without the right of useful ownership.

Dominio supremo. Eminent domain.

Dominio útil. The right of receiving all the fruits of a thing upon paying a contribution or tribute to the direct owner.

Dotación. Endowment, trust fund, marriage settlement.

Dote. Dowry, marriage portion.

Duelo. Duelling.

Dueño. Owner.

Dúplica. Rejoinder.

Edicto. Public order of a judge or court issued on default of a party or to notify a large number of people of an auction sale, etc.

Efecto. Effect, consequence.

Efecto devolutivo. The cognizance which by means of an appeal the superior judge takes of the decrees of the inferior court without suspending their execution, but referring them back for reconsideration.

Efecto suspensivo. The cognizance which in virtue of an appeal, the superior judge takes of the decrees of the inferior, suspending their execution.

Efectos. Effects, movables, drafts, assets. 
Efectos en cartera. Bills (or securities) in hand.

Efectos públicos. Public securities.

Efectos á pagar. Bills payabie.

Efectos á recibir. Bills receivable.

Ejercer. To practice (a profession).

Ejercito. Army.

Ejecución. Execution.

Ejecutivo. Execution or summary [action]-(Attachment in execution precedes pleas in defense.) Executive power.

Ejecutoria. Public document in which a final judgment is transcribed. Final decree.

Embajador. Embassador.

Embargo. Attachment of debtor's property, sequestration, embargo.

Embargo preventivo. Preliminary or provisional arrest, seizure, or attachment.

Emision de obligaciones. Issue of bonds.

Emitir. To issue.

Empate. Tie vote.

Emplazamiento. Summons, citation.

Emplazar. To summon.

Empleado. Employee.

Empresarios de transportes. Transportation contractors.

Enajenación. Alienation.

Enajenar. To alienate, transfer.

Encargado de negocios. Chargé d'affaires; agent, attorney (Mex.).

Encubridor. Accessory after the fact, concealer of goods, etc.

Endosante. Endorser.

Endosatario. Endorsee.

Endoso. Endorsement.

Enfiteusis. Lease.

Enjuiciamiento. Procedure.

Enmienda. The correction of some error or defect. The satisfaction and payment of losses incurred. The revocation or correction of some sentence.

Entrega. Delivery.

Entre sí. Inter se.

Equipaje. Baggage.

Error. Mistake.

Es bastante. "It is sufficient," formula used in certifying to sufficiency.

Escalamiento. Clandestine entry into a building or climbing the walls as opposed to burglarious entry.

Escribano. Clerk of court of first instance; notary.

Escrito. Writing.

Escritor. Writer, author.

Escritura pública. Document executed with legal formality before a notary.

Escusión. See excusion.

Espera. Extension of time in a debt, adjournment. 
Estadal. Statement.

Estado. State, commonwealth.

Estado seglar. Layman, secular or lay rank.

Estatuto. Statute law. Plural used for the charter or by-laws of a company, etc.

Estafa. Swindle.

Estelionato. A fraud, generally applied to the fraudulent sale or mortgage of property previously sold or mortgaged.

Estrago. Malicious destruction of property.

Estupro. Seduction.

Eventuales. Sundries.

Evicción. Eviction, implied warranty of title in sales.

Examen. Examination.

Excepción. Defense, plea.

Excepción dilatoria. Dilatory plea.

Excepción perentoria. Demurrer.

Excusión. The exhaustion of the judicial or extrajudicial proceedings so as to have recovered all the value of the debtor's property. Also the liquidation of the debtor's estate for benefit of his creditors.

Executivo. See ejecutivo.

Exhorto. Letters requisitorial sent by one judge to another.

Expedidor. Shipper, consignor.

Expendición. Sale.

Expropiado. Dispossessed.

Expropiación forzosa. Dispossession from ownership for public use or by eminent domain.

Extinción. Extinction.

Extradición. Extradition.

Extranjero. A foreigner (different country). See Forastero.

Extrañamiento. Expulsion.

Extravio. Deviation.

Factor. Manager, factor.

Fadiga. The right possessed by the seignior in the direct ownership (Spain) whenever the thing bailed or leased is alienated, so as to retain it for the sum that the purchaser offers.

Fallido. The insolvent, bankrupt.

Fallo. Synonymous with auto or sentencia; but especially the part of the latter in which the judge or court actually renders its decree or decides the questions in dispute is called the fallo. So called because that part by law must begin with the word fallo.

Falta. Division of lesser crimes, misdemeanor.

Falta de aceptación. Nonacceptance.

Falta de pago. Nonpayment.

Falsificación. Counterfeiting, also forgery.

Fazaña. Decision given in a suit.

Fecha. Date.

Fechado. Dated.

Feligresía. District of a parish, its inhabitants. 
Feriado. Holiday.

Fianza. Guaranty, security, bail.

Fideicomisario. A devisee or legatee who is to deliver the devise or legacy at some future time to another; also a legatee beneficially interested in property le.t to another in trust; also an executor; cestui que trust. Commonly used in sense of trustee.

Fideicomiso. Trust, the res of the trust, feoffment to use.

Fiduciario. Legatee, trustee or the heir of a legatee trustee.

Fieldad. Sequestration, security.

Filosofía. Philosophy.

Firma. Signature, partnership.

Firma entera. The complete signature comprising both the christian and surname.

Fiscal. State's attorney, prosecutor, etc.

Fiscalía. Business or office of a fiscal.

Fiscalización. Inspection (of corporations).

Fletador. Freighter.

Fletamento. Affreightment.

Fletante. Shipowner.

Fomento. Development, patronage.

Fomento, ministerio de. Department of public works (and in Spain) education, commerce, agriculture and manufactures.

Fondos. Funds.

Foral. (Used as adjective, with nouns like "law," "government," etc.) Special rights or the law of a province or town which was originally granted by the king of Spain in their charters. Local or provincial law.

Forastero. Foreign as between different provinces of same country. See extranjero.

Formación de causa. Process of law.

Frutos en specie. Fungible goods.

Fuera. Out, outside of.

Fuero. Statutory law, compilation of laws, jurisdiction of a court.

Fuerza mayor. Vis major (as "act of God").

Funcionario. Official, officer.

Funciones fiscales. Duties of the solicitors for the state in the superior and supreme courts in the interests of the public treasury and other public causes.

Fundación. Revenue established for any purpose, a foundation.

Gananciales. See bienes gananciales.

Garantía. Warranty; guaranty; security.

Garantía de evicción. Warranty of title.

Garantía por saneamiento. Warranty of hidden defects.

Garrote. The screw or apparatus used in Spain for the execution of criminals.

Gasto. Expenditure, cost.

Gastos. Expenses, disbursements, charges.

Girado. Drawee. 
Girador. Drawer.

Girar en descubierto. To overdraw; to draw on open account.

Giro. Draft note, bill, etc. (generat word).

Gobierno. The government.

Golfo. Vagabond, outlaw, term applied to the degenerate scum of a city.

Gravamen. Lien, encumbrance, mortgage, charge.

Haberes. Wealth.

Hábil (día). Day on which the court sits.

Habilitación. Licence; qualification; equipment.

Habilitación del letrado. The formal admission of a lawyer by the State to practice in the courts.

Habitante. Resident, but not necessarily citizen.

Hacer fe. To acknowledge, to certify. The sufficiency of any statement or writing, as proof, is acknowledged when it is said that it "makes faith."

Hacienda. Public property of all kinds, land, also public revenue.

Hacienda pública. Public treasury, finances.

Heredero. Heir.

Heredero legal. Heir at law.

Heredero fiduciario. Heir trustee.

Herencia. Inheritance.

Herencia vacante. Unclaimed inheritance.

Hijo. Child or other descendent, son.

Hipoteca. Mortgage, mortgage contract.

Hipoteca naval. Mortgage of ships.

Hipoteca en ejecución. Mortgage foreclosure.

Hológrafo (also ológrafo). Will or last testament of a person wholly written in his own hand, signed and dated by testator.

Hombre bueno. Arbitrator in the attempt to arbitrate legal disputes before suit is actually begun.

Homicidio. Manslaughter.

Honorario. Fee.

Huelga. A strike, lockout.

Hurto. Theft, thievery.

Imprudencia. Negligence.

Impuber. Male who is under 14, and female under 12.

Impuesto. Tax, impost.

Incendio. Fire.

Incendio premeditado. Arson.

Incidente. Question that arises between the parties in litigation during the course of the principal action. Interlocutory application.

Incoar un juicio. To bring suit.

Incomunicado. Solitary confinement in which prisoner is placed after arrest.

Indefensión. Unfairness; lack of defense caused by fraud.

Indemnización. Damages recovered by plaintiff.

Indicado. See recomendatorio.

Indultar. To pardon, to exempt. 
Industrial. Persons engaged in industries.

Infante. Infant who is under 7 years old.

Infanticidio. Infanticide.

Informa. Pleading, report.

Informe pericial. Expert evidence.

Infracción. Violation, breach.

Inhábil (dia). The day on which the courts do not sit, vacation day.

Inhabilitación. Disability, disqualification.

Inhibitoria. Motion before a judge having jurisdiction for removal of cause from court not having jurisdiction.

Inhumación. Interment.

Injuria. Slander and libel, outrage.

Inscripción. Record, as public record for mortgages, etc.

Inspección ocular. Personal inspection by judge of matter in evidence or place in which event in litigation occurred.

Interdicción civil. Deprival of all rights under the civil code over the family or property of the condemned.

Interdicto de recobrar. Summary proceeding to recover possession of converted chattel.

Interés. Interest.

Interés legal. Interest fixed by law.

Interés convencional. Stipulated interest.

Intervención en la aceptación y pago. Acceptance and payment for honor.

Inutilización. Mutilation.

Jactancia, juicio de. Action for quieting title.

Jornal diario. Daily wages.

Jubilación. Retirement of an officer or employee of the government on a pension or reduced pay on arrival at certain age.

Juego. Gambling, game.

Judicatura. Judiciary.

Juez. A judge.

Juez arbitrador. Umpire.

Juez de letras (juez letrado). A justice of the peace of a small district, who, being a counselor at law, has more authority in certain cases than other justices (Spain). Judge of first instance.

Juez instructor. Examining magistrate in criminal prosecutions. Investigation carried on while the accused is in solitary confinement.

Juez de primera instancia. Trial judge.

Juez ponente. The judge who draws up in writing the opinion of the court, himself and colleagues.

Juicio. Proceedings, form of action, suit.

Juicio executivo. Summary action.

Junta. Council, board, meeting, convention.

Junta de comercio. Board of trade.

Junta de gobierno. Executive committee.

Jurado. Jury.

Juramento. Oath. 
Juramento asertorio. Declaratory oath.

Juramento decisorio. Oath taken by deponent when party seeking his deposition admits whatever said as incontrovertible evidence.

Juramento falso. Perjury.

Juramento indecisorio. Oath that can only hurt the deponent.

Jurisdicción. Jurisdiction.

Jurisdiccion contencioso-administrativo. Jurisdiction in which are decided questions in litigation arising between the administration and individuals who consider their rights violated by administrative acts.

Jurisprudencia. Court decisions, "judge made" law, legal science.

Jurista. Jurist.

Jurisconsulto. Jurist.

Justicia. Justice.

Juzgado. Court of first instance.

Legítima. That part (usually $2 / 3$ ) of the paternal or maternal estate of which the testator can not disinherit his children without legal cause.

Legítimo. Legitimate.

Legislación. Legislation.

Lego. A novice. Laybrother in monastery.

Lesa majestad. Leze-majesty or high treason.

Lesión. Personal injury; violation of equitable rights.

Letra de cambio. Bill of exchange.

Letrado. Lawyer.

Levantamiento. Revocation, withdrawal.

Ley. Statute, act.

Liberación. Discharge.

Libertad. Liberty.

Librado. Drawee.

Librador. Drawer of a bill of exchange.

Librador por cuenta. Drawer on account.

Libros de comercio. Commercial books of account.

Licensia. Permission.

Lícito. Licit, lawful.

Liquidación. Liquidation, winding-up.

Litigar. To sue, to litigate.

Litis expensas. Costs (of proceedings).

Litis pendencia. Lis pendens.

Loco. Lunatic, insane person.

Magistrado. Magistrate.

Mala fe. Bad faith.

Malicia. Malice.

Malversación. Maladministration.

Mancebo. Assistant; apprentice.

Mancomunadamente. Jointly, by common consent.

Mandamiento. Order by judge to subordinate officer.

Mandato. Agency.

Maquinación. Artifice.

Marca (de comercio). Trade-mark (seller's). 
Marca (de fábrica). Trade-mark (manufacturer's).

Martilleros. Auctioneers.

Masa de la quiebra. The total assets of bankrupt estate liable to debts.

Matrícula de los comerciantes. Register of merchants.

Matrimonio. Marriage.

Matriz (escritura). The original of an instrument or document, stub of check book.

Mayor de edad. Of full age.

Mayoría. Majority.

Media firma. Surname.

Medida. Measure.

Medios de prueba. Methods of proof.

Mejora. Advantage, or the portion of the estate reserved as legitima by law, which the parent or testator may reserve for a particular child or descendant.

Menor de edad. Minor.

Mercados de comercio. Commercial markets, exchanges.

Ministro de hacienda. The Secretary of the Treasury.

Moneda. Coins, metallic money.

Mora. Delay, laches.

Morada. Dwelling house.

Mostrarse parte. To intervene or take part voluntarily in an official proceeding.

Muerte. Death.

Mujer casada. Married woman.

Multa. Fine, forfeit.

Municipio. Municipality.

Nacer. To be born.

Nacionalidad. Nationality.

Nato. Used with and to mean ex officio.

Naturaleza. Nature, naturalization.

Naufragio. Shipwreck.

Negado. Incapable, unfit.

Negar. To deny, to refute an accusation.

Negligencia. Negligence.

Niño. Child who is under" 7 years old.

Nombrado. Nominee.

Nombrador. Nominator.

Nombramiento. Appointment.

Nominador. Nominator.

Nominilla. Warrant or certificate enabling a pensioner of an office to draw his dues.

Nomino. Nominee.

Norma. Standard.

Notario. Notary.

Noto. Bastard, illegitimate.

Novación. Novation.

Novel. New, inexperienced. 
Nulidad. Nullity, appeal on ground of nullity.

Nulo. Invalid, null.

Numulario. A banker.

Nunciatura. Office or house of a nuncio.

Nuncio. Envoy or ambassador from the Pope.

Nuncupativo. Nuncupative.

Obligación. Bond; also a contract of obligation.

Obligación de probar. Burden of proof.

Obligado. Obliged; obligor.

Obrero. Workman.

Oferta. Tender.

Oficina de correos. Post office.

Oficina de patentes. Patent office.

Oído. A hearing

Ológrafo. See hológrafo.

Ordenador. Person on whose order or account a bill of exchange is drawn.

Ordenamiento. Orders emanating from the king and differing from cédula only in form and in mode of promulgation.

Otorgar. To declare, grant, issue.

Otorgante. Grantor, party who signs and executes any notarial instrument.

Otrosí, "Moreover." Technical word used to introduce a paragraph containing matter different from the principal object of the document.

Pacto. Agreement, pact.

Pagaré. Note to order, promissory note.

Pago. Payment.

Pago parcial. Installment.

Parafernales (bienes). Parapherna. Property of wife over which she retains separate control.

Parcería. See Aparcería.

Parricidio. Parricide. Includes all degrees of consanguinity as well as the relation of husband and wife.

Párroco. Rector or incumbent of a parish, a priest.

Parte beneficiada. Accommodated party.

Parte por acomodación. Accommodation party.

Partícipes. Coowners (of vessels).

Particular. Private person.

Partido. One of the judicial districts into which the provinces are divided; an agreement.

Parto. Childbirth.

Pasajero. Passenger.

Patente de giros. Trade licenses.

Patente de invención. Patent.

Patria potestad. Parental power.

Patronato. Patronage, patronship.

Patrono. Master, employer. 
Paz. Peace, truce.

Peculio. Estate or property which a child possesses as separated from the property of his father.

Pena. Punishment, penalty.

Pensión. Rent or annual tribute imposed on landed estate. Pension.

Perito. An expert.

Perjuicio. Prejudice.

Perjuicio (sin). Without prejudice.

Perjurio. Perjury.

Personarse en juicio. Appearance of defendant by attorney in court.

Personas jurídicas. Juridical persons. Corporations, associations, and institutions of public interest.

Pesquisa. Inquisition, name for old form of prosecution, search, investigation.

Petición. Petition.

Picota. Pillory.

Piratería. Piracy.

a Plazos. On credit.

Pleiteante. Litigant.

Pleitear. To sue, to go to court.

Pleito. Civil lawsuit; proceeding.

Plus minusve. More or less.

Plus petición. Excessive relief or damages.

Poder. Power of attorney.

Poderdante. Grantor of a power of attorney.

Poligamia. Polygamy.

Política. "The art of governing the people."

Policía. Police.

Póliza. Policy.

Póliza de fletamento. Charter party.

Portador. Bearer, holder.

Porteador. Carrier.

Posadero. Inn keeper.

Posición. An interrogatory (in writing) addressed to a party appearing as a witness.

Postura. Offer or bid at an auction.

Práctica. Practice.

Pragmática. See Ordenamiento.

Predio. An inheritance, land, or immovable possession.

Predio dominante. Land or property having an easement over other property. Dominant estate.

Predio serviente. Land or estate subject to an easement of a dominant estate. Servient estate.

Prejudicial. Requiring a previous judicial decision before the final judgment.

Prelación. Preference.

Prenda. Pledge.

$71624^{\circ}-17-80$ 
Prescripción. Prescription, statute of limitations.

Prescripción liberatoria: Discharge by prescription.

Presentación. Presentment.

Presidio. Punishment by hard labor, jail.

Presidio mayor. Major and minor arrest. Confinement for periods pro-

Presidio menor. $\}$ vided in the penal code at hard labor.

Prestamista. Pawnbroker; money lender.

Préstamo. Loan.

Préstamo á la gruesa. Bottomry loan.

Préstamo ả riesgo maritimo. Loan on maritime risk, bottomry.

Presunción. Presumption (legal or of fact).

Presunto. Suspected.

Presupuesto.: Budget of state, estimate.

Prima. Premium.

Previsión. Old-age pension.

Previsto. Provided (for or by).

Prisión. Imprisonment, confinement, seizure.

Probatoria. Time allowed for producing evidence; probatory.

Procesado. The accused, defendant.

Procurador. Attorney, attorney at law, solicitor.

Procurador fiscal. Public attorney named by the king to promote and defend in the supreme and superior courts the interests of the exchequer and other public causes (Spain).

Pródigo. A person who by judicial sentence has been deprived of the free administration of his property by reason of his being a spendthrift. He is put on the same footing with a lunatic and disqualified from undertaking legal acts.

Producto. Proceeds.

Profanos. Persons outside of legal profession, laymen.

Promotor fiscal. The minister appointed to promote the observance of penal laws, or he who in a criminal case is named by the judge to prepare and support the accusation against the criminal.

Promover. To begin, institute (action).

Prontuario. Compendium or digest.

Propiedad inmueble. Real property.

Propiedad mueble. Personal property.

Propiedad raiz. Real property.

Propietario. Proprietor.

Proponente. Bidder.

Prorrateo. Apportionment.

Protesto. Protest.

Protocolo. A file or archive of original instruments kept by a notary, the parties having certified copies only. A registry.

Protutor. Vigilant guardian, one appointed to see that the guardian does his duty and also to represent the ward in and out of court when his interests are adverse to those of the guardian.

Providencia. Judicial decision referring to matters of procedure.

Proyecto. Bill, scheme, design, plan. 
Proyecto de ley. Bill (introduced in legislative body), a proposed draft of a statute.

Prueba. Evidence, proof.

Prueba instrumental. Documentary proof.

Pueblo. Town, people.

Puerto. Port.

Quebrado. Bankrupt.

Quebrado alzado. A bankrupt who has fled from his business address to avoid creditors.

Quebrantamiento de forma. Violation of form or of a rule of procedure. Querella. The indictment or information in criminal investigations.

Quiebra. Bankruptcy.

Quinto. The one-fifth part of an estate which a man can by will dispose of to strangers.

Quita. Partial release by creditor.

Ramo separado. Separate file.

Rapto. Abduction.

Ratero. Pickpocket.

Ratificación. Ratification.

Razón social. Firm name.

Real cédula. Royal dispatch signed by the king and issued by some superior tribunal, wherein some favor is granted or some interlocutory decree is made (Spanish and colonial).

Real decreto. Royal decree.

Rebelde. In contempt.

Rebeldía. [In] default, contempt. (Used in both civil and criminal matters.)

Rebelión. Rebellion.

Recambio. Reexchange.

Recibo. Receipt.

Recobrar. To recover.

Recomendatario. Person requested to accept and pay a bill of exchange in default of drawer. Referee in case of need.

Reconvención. Counterclaim.

Recopilación. Digest, compilation.

Recurrente. Appellant.

Recurso. Appeal.

Recusación. Challenge (of judges); exception.

Reembolso. Reimbursement.

Refrendar. To countersign.

Regadío. Irrigation (waters).

Regente. The chief justice of a body composed of several tribunals in combination.

Regidor. Alderman of a city.

Régimen. Government, management.

Registro. Examination, act of searching, also a register.

Registro civil. The civil registry.

Registro mercantil. Commercial register. 
Registro público. Public register.

Reglamento. Written instruction given by a competent authority without the observance of any peculiar form; provision for carrying into execution a statute already enacted.

Regularizar. Adjust.

Rehabilitación. Discharge (in bankruptcy).

Reintegro. Repayment.

Reivindicación. Recovery of specific assets, replevin.

Reivindicar. To replevy, to recover.

Relator. Person appointed and deputed in every appelate court to prepare or read a summary of the facts of the various cases for the judge. Reporter.

Rematadores. Auctioneers.

Remate. Auction, highest bid at auction.

Remisión. Remitting. Release.

Remolque. Towage.

Rendición de cuentas. Rendering accounts.

Renuncia. Waiver.

Reo. Offender, criminal.

Repartimiento. Allotment, division.

Repertorio. Index, digest.

Repetición. Claim, action for accounting or for money had and receiveá.

Réplica. Replication in pleading.

Reponerse. To be annulled.

Reposición. Rehearing.

Reprensión. Reprimand (public).

Represalia. Reprisal.

Requerimiento. A demand.

Resaca. Cross bill (of exchange); redraft.

Resarcimiento. Indemnity damages, compensation.

Resguardo. A receipt, collateral security.

Residencia. Residence; also sometimes means place where one lives with certain constancy.

Residente. Resident. Refers popularly to both a vecino and domiciliado.

Resolución. Cancellation, decision, resolution.

Responsabilidad. Liability.

Retracto. Right of replevying or recovering a thing sold to another.

Resultandos. The setting forth of the facts forming the basis of the judicial decision.

Revisión. Review.

Revocar. To revoke.

Riego. Irrigation.

Rifa. Lottery.

Ritorno. Renvoi.

Robo. Robbery, and includes burglary.

Rúbrica. A mark or flourish usually placed under one's signature as an added obstacle to forgery. (It is not the signature.)

Sacar testimonio. To make a certified copy. 
Salario. Wage, earnings.

Salario medio diario. Average, daily earnings.

Saldo. Balance.

Salvaconducto. License or permission.

Salvaguardia. Protection.

Saneamiento. Security, indemnification, warranty. Also drainage.

Sano de juicio. Perfectly sound in mind.

Sedición. Sedition.

Seguro. Insurance.

Seguro dotal. Endowment insurance.

Seguro sobre vida. Life insurance.

Seguro contra incendio. Fire insurance.

Seguro contra accidentes (or) percances. Accident insurance.

Sello. Seal; stamp.

Senado. Senate.

Senador. Senator.

Sentencia. Final judicial decision.

Sentencia absolutoria. Judgment denying request. Acquittal.

Sentencia condenatoria. Decision in which something is commanded to be done or enjoined. Sentence of guilty.

Sentencia firme. An irrevocable judgment or decision.

Señoraje or señoreaje. Seigniorage.

Señorío. Seigniory.

Servidumbre. Easement, both personal and real.

Síndico. Assignee, receiver.

Sindicos liquidadores. Assignees in bankruptcy.

Sin perjuicio. Without prejudice.

Sisa. Excise.

Sobrecargo. Supercargo.

Sobreseimiento. Dismissal, discontinuance (of legal proceedings).

Sociedad. Association, partnership.

Sociedad anonima. Joint stock company.

Sociedad colectiva. Unlimited partnership.

Sociedad en comandita. Limited partnership.

Sociedad cooperativa. Cooperative society.

Socio. Partner, member.

Solidariamente. In solido; jointly and severally.

Subasta. Judicial sale of goods by public auction.

Súbdito. Subject of a country.

Subsidio. Subsidy; substitution.

Succesión. Succession, inheritance.

Suceso incierto. Contingency.

Sucesor inmediato. The heir presumptive, the next succeeding.

Sueldo. Salary, pay (not "wages").

Suma. Sum.

Sumario. Preliminary investigation in criminal suits, similar to our secret investigations by the grand jury. Preparation for trial. 
Sumariamente. Summarily.

Suplicatorio. Letters rogatory, or a writ or any legal instrument sent in the king's name by a tribunal or judge to another of equal authority that they may attend to what is solicited (Spain).

Suposición. Bogus representation.

Suspensión. Removal or suspension.

Suspensión de pagos. Suspension of payment; insolvency.

Sustracción. Abduction, pick pocket or purse snatching.

Tabernero. Saloon keeper or tavern keeper.

Tablón de edictos. Official bulletin board in the courthouse for advertising notices.

Tacha. Personal objections to evidence, incapacity.

Talón. Check, coupon, receipt, bill, etc.

Talonario. A coupon or check book.

Talón de transporte. Bill of lading.

Tanteo. Agreement or right to sell or buy at same price bid for by others at auction. Computation; average.

Tenedor. Bearer, holder.

Tener tacha. To be legally incapable.

Tentativa. Attempt.

Tercería. Intervention by third party in interlocutory proceeding.

Tercio. The third part of an estate a testator can dispose of as he pleases when he leaves no descendants, only ascendants. (Not in Chile, however).

Término. End, maturity, term.

Términos de gracia. Days of grace.

Territiorio. Territory.

Tesorería. Treasury.

'Tesorero. Treasurer.

Testador. Testator.

Testamento. A will.

Testigo. Witness.

Testimonio. Testimony.

Título. Title.

Títulos. Securities, bonds, instruments.

Tomador. Payee (of a bill of exchange).

Tontina. Tontine annuity insurance.

Trabajo. Work, labor.

Traducción. Translation.

Traición. Treason.

Tramitación. Proceedings (judicial).

Tramitación del incidente. Interlocutory proceedings.

Trámite. Judicial process; procecding.

Transacción. Contract, compromise, transaction.

Transeunte. Every person living in a place not a vecino or a domiciliado, transient.

Transgresión. Infringement.

Transporte de viajeros. Carriage of passengers, 
Traslado. Delivery, service of a copy, certified copy, extrast.

Tratado. Treaty, treatise.

Tribunal. Court.

Tribunal de cuentas. Exchequer.

Tribunal supremo. Supreme court.

Tutela. Guardianship.

Tutor. Guardian.

Uso. Usage; also type of usufruct.

Usufructo. Usufruct.

Usurpación. Usurpation.

Vales. Notes of hand.

Valor. Value.

Valor escrito. Face value.

Vecindad. Residence, right acquired by residing in a place given by law.

Vecino. Native Spaniard, sui juris, habitually and permanently residing in a place.

Vencimiento. Maturity (of a bill) sometimes "vencimiento de plazo." Expiration.

Vender. To sell.

Venta. Sale.

Verificación de créditos. Proof of debts.

Verificación provisoria de créditos. Provisional proof of debts.

Vinculación. Entail, act of entailing.

Vincular. To entail an estate.

Violación. Rape.

Visar. To mark "approved."

Vista. Customhouse inspector.

Visto bueno. The mark or formula "approved."

Vitalicio. During life.

Vitalicista. An annuitant or person with an income for life.

Viuda. Widow.

Voto. Vote.

Yusión. Order, precept. 


\section{GLOSSARY-PORTUGUESE}

Abalroação. Collision.

Abastecimento. Maintenance.

Absolver. Release, give judgment in favor of defendant.

Acção: Complaint; action.

Acção especial. Special action or proceeding.

Acção executiva. Summary (execution) proceeding.

Acção ordinaria. Ordinary (regular) proceeding.

Acção summaria. Summary proceeding.

Acceitação. Acceptance.

Acções. Actions.

Acções reaes. Real actions.

Accordam. Judgment, decision.

Accordão. Decision, ruling.

Acto. Proceeding; act.

Actos. Records, transaction; minutes.

Adiamento. Adjournment.

Adjudicação. Notification of and decree confirming a judicial sale.

Afretador. Shipper of freight; charterer.

Aggravo. Interlocutory allegation of error, similar to "certiorari."

Ajuste. Hiring, engagement.

Alçada. Jurisdiction; competence.

Alienado. Transferred.

Allegação. Allegation.

Allegações finaes. Closing arguments.

Alugueis. Rents.

Alvarás. Royal orders whose effect was limited to one year (when other-

wise intended, they were called alvaras de lei). They existed in

Brazil until the constitution of 1824 .

Apolice. Public bond or security, policy.

Apolices de seguro. Insurance policies.

Aposto. Wager.

Aprazimento. Approval.

Arbitramento. Arbitral award, arbitration.

Arrecadação. Execution, collection or levy.

Arrematação. Public sale in execution of judgnent (auction?).

Arrendamento. Hiring, leasing.

Arrhas. Marriage settlement, money set aside for wife after husband's death, dowry; earnest.

Artigo. Article, paragraph.

Assento. Opinion.

Assignatura. Signature, authentication.

Assistentes. Privies, persons notified.

Audiencia. Hearing, term. 
Autor. Plaintiff.

Autos. Deeds, documents, acts.

Avaliação. Estimate, evaluation.

Balanço. Balance sheet, account.

Banqueiro. Banker.

Bemfeitorias. Improvements, betterments.

Bens. Goods, property.

Bens de raiz. Real property.

Cabotagem. Coastwise trade.

Caixeiro. Cashier.

Cancellado. Cancelled, annulled, erased, crossed out.

Capitãe. Captain.

Carecer. To depend upon.

Carta de fretamento. Charter party.

Carta de sentença. Judgment roll.

Casa. House.

Casamento. Marriage.

Caução. Pledge, security.

Causa. Case, litigation.

Causa julgada. Res adjudicata.

Cautela. Precaution.

á Cautela. By fraud.

Certidões. Evidence, proof, certified extracts.

Cessionario. Assignee.

Chirographario. Creditor; also, instrument of indebtedness.

Citação. Citation, summons.

Commissões. Commissions, fees.

Comparecer. To appear.

Compensação. Compensation.

Competencia. Jurisdiction.

Coacção. Force, duress, compulsion, violence.

Collações. Patronage, church living, conferring a benefice.

Compra e venda. Purchase and sale.

Compromissos. Agreements.

Conciliação. Proceedings for conciliation of the parties.

Concordata. Friendly agreement.

Condemnar. To fine, condemn, give judgment against.

Conductores de generos. Freight carriers.

Confissão judicial. Confession in open court or in judicial procedure.

Contracto de dinheiro a risco. Bottomry contract.

Contas commerciaes. Commercial accounts, balances.

Contestação. Answer.

Contravenções. Misdemeanors.

Corre a causa. Action pending.

Corretagem. Brokerage.

Corretor. Broker.

Coupons de juras. Interest coupons.

Credores. Creditors. 
Crimes. Crimes and felonies.

Curador. Guardian.

Custas. Costs.

Decisão. Decree.

Decorrido. After expiration of.

Deferir juramento. Administer an oath.

Defesa. Defense, answer.

Demanda. Demand, complaint.

Demando. Sued.

Demorar. Delay.

Depoimento. Deposition, testimony, evidence.

Depoimento da parte. Testimony or deposition of the party to the litigation.

Depositarios. Depositaries, pledges.

Desappropriação. Expropriation.

Desembargado. Free from lien.

Desembargador. Chief justice.

Desembarqudo. Unencumbered.

Desordem. Illegality.

Despacho. Short order or decree.

Despedida. Dismissal, departure, release.

Desviar. To remove, conceal.

Dilação. Delay, term.

Dilação probatoria. Term for the taking of evidence.

Dilatoria. Dilatory.

Discussão. Proceedings, hearing, discussion.

Divida. Debt.

Divida publica. Public debt.

Doações. Gifts, donations.

Dolosamente. Fraudulently.

Edictos. Publication (service by).

Edificante. Building, builder.

Effeito. Effect.

Eleições. Elections.

Edição. Publication (Braz. Civil Code, art. r346-58), edition.

Embargar. To attach, embargo.

Embargo. Protest, claim of error, plea; attachment.

Emenda. Amendment, reform, indemnity, fine.

Emendado. Altered, corrected.

Empregados. Eimployees.

Empreitada. Piecework, job work.

Empreitario. Employer.

Emprestimo. Loan.

Endossador. Endorser.

Escola. School.

Escripto particular. Private document, paper, record, written instrument.

Escriptura publica. Public record, publicly attested document. 


\section{GLOSSARX-PORTUGUESE}

Escripturas publicas. Public or notarially sealed and witnessed instruments.

Escrivão de causa. Clerk of the court.

Especificação. Specification, details.

Estado civil. Personal civil status.

Estimativa. Estimate, valuation.

Estylo. Usage.

Excepções. Exceptions.

Execução. Execution of judgment.

Executado. Judgment debtor against whom execution has issued.

Extrangeiros. Aliens.

Factura. Invoice, account.

Falla. Speech.

Fallencia. Bankruptcy.

Falta. Neglect, fault, lack.

Fazenda. Finance.

Fé. Proof, faith.

Fé publica. Attestation, public authentication by a notary.

Feitor. Manager.

Feitores. Business managers.

Fiadores. Sureties (for bail).

Fiança. Bail, security, bond, guaranty.

Fiança ás custas. Security for costs.

Fisco. Fiscus, state treasury.

Folha. Deed.

Fornecimiento. Supply, delivery.

Fôro. Court.

Fretador. Freight carrier.

em Grosso. Wholesale.

Guarda-livro. Bookkeeper.

Guerra. War.

Habilitações. Capacities, faculties.

Herança jacente. An inheritance not enjoyed or possessed.

Heranças vagas. Vacant inheritances.

Herdeiro. Heir.

Idade. Age, time.

Igreja. Church.

Illegitimidade. Wrong party.

Illidir. Reject, contest, answer.

Immoveis. Real property, immovables.

Impedimento. Hinderance, impediment.

Impetrante. Attorney for petitioner.

Improcedentes. Invalid.

Incompetencia. Lack of jurisdiction.

Inquilino. Tenant, lodger, lessee.

Inquirição. Inquiry, hearing of witnesses.

Instrumentos. Documents, public records, instruments.

Intentar. To attempt, to begin action. 
Invenção. Invention.

Isenções. Exemptions, privileges.

Jogo. Gambling.

Juiz. Judge.

Juizo. Judgment, cognizance.

Julgamento. Judgment, sentence.

Julgar. To pass upon, determine, decide.

Juntar. Join, attach, accompany.

Juramento. Oath.

Juramento in litem. Oath in course of suit.

Juramento suppletorio. Confirmatory oath.

Juro. Interest, right.

Justiça. Justice.

Laudo. Award, judgment.

Lei. Law.

Leilãos, agentes de. Auctioneers.

Leiloeiros. Auctioneers.

Lesão. Injury, damage, wrong, tort, offense.

Letras de cambio. Bills of exchange.

Licitação. Public auction or sale.

Litispendencia. Another action pending.

Livros commerciaes. Books, ledgers, etc., books of account.

Locação. Letting, hiring.

Louvação. Evidence (oral), testimony.

Lugar. Place.

Má fé. Bad faith.

Magistrados. Judges.

Mandado de manutenção. Stay of execution.

Mandato. Order, request, agency.

Marido. Husband.

Mercadorias. Goods, merchandise.

Mestre de navio. Ship's master.

Moeda. Money, currency.

Mulher. Wife.

Multa. Fine, punishment.

Nascimento. Birth.

Navegação de cabotagem. Coasting trade, navigation.

Navio. Ship.

Negação. General denial.

Nobreza. Nobility.

Nomeação. Appointment, nomination.

Notas promissorias. Promissory notes.

Novaçao. Novation.

Obito. Death.

Obrigação. Obligation, debt, bond to bearer.

Obrigações preferenciaes. Debentures.

Obrigado. Indebted.

Offendido. Person injured.

Official. Officer. 


\section{GLOSSARY-PORTUGUESE}

Operarios. Workmen.

Oppoentes. Persons protesting, opponents.

Orçamento. Estimate, budget.

Ordem de vocação hereditaria. Order of inheritance.

Paciente. The person held (in "habeas corpus" proceedings).

Pagamento. Payment.

Parceria. Association; partnership; deed of partnership.

Parentes. Relatives.

Parte. Party.

Partilhas. Partition, share.

Pedido. Demand.

Penhór. Pawn, pledge, mortgage, security, bail, proof.

Penhora. Distraint, seizure, execution, attachment.

Peremptoria. Peremptory.

Peritos. Experts.

Pessoa. Person.

Petição. Petition, complaint.

Plena absoluta. Complete and unconditional (proof).

Plena relativa. Complete and conditional (proof).

Posses. Wealth, means, possessions.

Portador. Holder, bearer (of negotiable paper).

Porteiro. Marshal, bailiff of the court.

Postura. Ordinance, decree, statute.

Prazo. Term, time, a contract for rent in perpetuity.

Preço. Price, value.

Precatorio. Requisition (judicial).

Predio. Estate, realty, land.

Prescripção. Prescription.

Prestação. Loan, taking [of an oath], contribution.

Prestar o juramento. To take an oath.

Presumpções. Presumptions.

Presumpções communes. Presumptions based not upon law, but upon common occurrence.

Processo. Procedure.

Procurado. Agent, representative.

Proferir sentença. To render judgment.

Promotor publico. Public prosecutor, informer.

Provas. Proofs, evidence.

Quebra. Bankruptcy.

Quesitoes. Questions (of lawyers to witnesses); demands.

Quitações. Receipts, acknowledgments of payment.

Raspado. Erased.

Razões. Argument, proof, brief, reasons, grounds.

Razões commerciaes. Commercial names.

Recibo. Receipt.

Reconhecer. Recognize, acknowledge.

Reconvenção. Counterclaim.

Recusar. To refuse; to cliallenge (a judge).

Recurso. Remedy, appeal, relief. 
Remissão. Remission, return.

Remoção. Removal, withdrawal.

Renda. Rent, income, revenue.

Réo. Debtor, defendant.

Replicar. To make replication (pleading).

Requerante. Petitioner.

Requireménto. Request, demand.

Resposta. Answer.

Retribuições. Damages.

Retrovenda. Resale.

Reveldia. Default.

Revogação. Revocation.

Riscado. Crossed out, erased.

Rol. Iist.

Ruas. Streets.

Rubricado. Countersigned.

Sacador. Drawer (of a bill of exchange).

Salarios. Salary, wages.

Seguro. Insurance.

Sentença. Decision, judgment.

Sentença definitiva. Final judgment.

Sinistro. Damage; disaster at sea.

Sobrecarga. Supercargo.

Socio. Partner.

Sonegamento. Concealment, conversion.

Successores. Legal representatives.

Suspeição. Disqualification of the judge; suspicion.

Tabellião. Notary.

Tapagem. Enclosure, fencing.

Testamunhas. Witnesses.

Thezouro. Treasury.

Titulo. Title, bond.

Tradição. Delivery.

Traducçao. Translation.

Transacção. Transaction, agreement.

Trapicheiros de armazens de depositos. Warehousemen.

Treplicar. To make sur-rejoinder.

Tripolação. Crew.

Troca. Exchange, barter.

Tutor. Guardian.

Uso. Custom, usage.

Vencimento. Maturity, appointment, salary.

Vendas. Sales.

Vicio. Defect, lack.

Victualhas. Foodstuffs.

Vistorias. Personal inspection by the judge of the matter or the place or the facts involved in the dispute.

Vizinho. Neighbor, adjoining owner. 


\section{INDEX}

A. C., 204.

Abandonment (Maritime)-Brazil, 273.

(Comm. Code, Pt. 2), 273-276, 283-284. Abandonment of suit-Chile, 408.

(Code of Civ. Proc., Bk. I), 409-412.

Abbott, 74, 267, 396 .

Abeille, 174-175.

Abeledo, 17, 25, 42 .

Abranches:

O Brazil e o arbitramento, 351.

Tratados de commercio, 286, 350 .

Absent persons-Brazil, 245, 246, 299, 364. (Civ. Code, Gen. Pt., Bk. r: Spec. Pt., Bk. I), 248-253, 255-257.

Academia de derecho y ciencias sociales,

Anales, 49.

Academia Real das Sciencias, 228-229.

Accidents, Industrial:

Argentina, 70-71, 156, 158, 159.

São Paulo, 337.

Accounting:

Argentina, 42, 169.

Brazil, 340 .

Accounts:

Argentina, 78, r69.

(Comm. Code, Bk. x), 79-84.

Chile, 408 .

(Code of Civ. Proc., Bk. 3), 409-412.

Accounts, current:

Argentina, 79.

(Comm. Code, Bk. 2), 79-84.

Brazil, 278.

Chile, 39 .

(Comm. Code, Bk. 2), 399-400.

Acevedo, 62, 76, 119 .

Actions:

Brazil, 26I, 292, 293, 294-295.

Chile, 408 .

(Code of Civ. Proc., Bk. 2-3), 409-412.

Actions, Commercial-Brazil, 283, 296.

Actions, Criminal:

Argentina, 116, 118.

Brazil, 296, 302, 309-310

(Crim. Code, Bk. 1), 302-304

Actions, Possessory:

Argentina, 63, 69:

(Civ. Code, Bk. 3), 64-70.

Brazil, 258.

Chile, 390.

(Civ. Code, Bk. 2), 39I-394
Actions in rem-Argentina, 63 .

(Civ. Code, Bk. 3), 64-70.

Acuña, See Anguita Acuña.

Adalberto de Campos, See Campos.

Adherbal de Carvalho, See Carvalho.

Administration, judicial control of-Brazil, 326.

Administration of estates:

Argentina, 63,189 .

(Civ. Code, Bk. 4), 64-70.

Brazil, See Decedents' estates.

Chile, 390.

(Civ. Code, Bk. 3), 39r-394.

Administration of justice:

Argentina, 41-43, 67, 96, 98, $116,128$.

Buenos Aires (City), 100.

Buenos Aires (Prov.), 42, 59, 101-103. 140.

Brazil, 235-236, 273, 313,319.

(Comm. Code, Pt. 3), 273-277.

Federal Districi, 292, 310.

Portuguese Colonies, 235.

Administrative courts-Brazil, 326.

Administrative departments, See Depart ments.

Administrative law:

Argentina, 39-4I, 43, 45, 138- I7I.

Buenos Aires (Prov.), 24-25, 140 .

Brazil, 215, 218, 220-221, 324-346.

Chile, 374, 404, 420-437.

Administrative officers, See Officers.

Administrative organization:

Argentina, 139-142.

Chile, $420-423$.

Admiralty-Argentina, 93.

Adoption-Brazil, 246, 255.

(Civ. Code, Spec. Pt., Bk. I), 248-252, 255-257.

Affonsinas, Ordenacões, 228-230.

"Affonso de Albuquerque," $36 x$.

Affreightment:

Argentina, 79

(Comm. Code, Bk. 3), 79-84, 89-90.

Chile, 398.

(Comm. Code, Bk. 3), 399-400.

Afranio Peixoto, 306.

Agapito da Veiga, See Veiga.

Agapito Pereira, 217

Age of majority. Sce Majority.

Agency:

See also Commission agents. 
Agency-Continued.

Argentina, 63,78

(Civ. Code, Bk. 2), 64-70.

(Comm. Code, Bk. 2), 79-89.

Brazil, 247-248, 272, 297.

(Civ. Code, Spec. Pt., Bk. 3), 248-252, 262-263.

(Comm. Code, Pt. I), 273-277.

Chile, 39r, 397, 40r

(Civ. Code, Bk. 4), 391-394.

(Comm. Code, Bk. 1), 399-400.

Agote, I16, 167-168.

Agricultural associations-Brazil, 247.

(Civ. Code, Spec. Pt., Bk. 3), 248-252.

Agricultural banks:

Argentina, 165 .

Brazil, 338.

Agricultural cooperative organizations-

Brazil, 334.

Agricultural credit:

See also Agricultural warrants.

Argentina, 145, 166.

Brazil, 260, 338 .

Chile, See Credit institutions.

Agricultural education, See Education.

Agricultural industries-Argentina, 148 .

Agricultural insurance-Argentina, 85, 147.

Agricultural law:

See also Rural code.

Argentina, I44, I46-r48.

Buenos Aires, (Prov.), 147.

Brazil, 334 .

Chile, 421, 425-427.

Agricultural mortgage-Argentina, 72, 86 .

Agricultural schools, See Education, Agricultural.

Agricultural warrants:

Argentina, 147.

Brızil, 278.

Aguilar, 137-r 38 .

Aguirre:

Autos y sentencias, Ira.

Código penal, ro8.

Aguirre Vargas, 394.

See also Vargas.

Ahrens, 52.

Albano, See Carrasco Albano.

Alberdi, 125, I80.

"Bases," 123-124, 125, 129.

Código civil, 66.

"Elements," 125, 134.

Escritos postumos, 44

Estudios, 124, 125 .

Indice alfabetico, 375 .

Obras completas, 44,164 .

Organización de la Conf. Arg., r24-125.

Albuquerque:

See Affonso de Albuquerque.

Sá Albuquerque.
Alcalá, Ordenamiento de, 53, 57 .

Alcaldias-Argentina, 94.

Federal Territories, 93.

Alcides Cruz, See Cruz.

Alcides Lima, See Lima.

Alcindo Guanabara, See Guanabara.

Alcohol-Chile, 433.

Alcoholism, $112,158$.

Alcorta, 96

Derecho int. priv., 188.

Derecho int. púb., $x 75$.

Droit int. púb., I75.

Estudios sobre el cód. de com., 82.

Fuentes . . . del cód. de com.; 80 .

Garantias constitucionales, 132 .

Alcubilla, See Martinez Alcubilla.

Alderete, 49.

Aldunate, 44I.

Aldunate Solar:

Aguas, 427.

Corte Suprema, 412.

Salitreras, 430.

Alencar Araripe, See Araripe.

Alencar Piedade, 217.

Alencastro Autran, See Autran.

Alexander-Katz, 396.

Alfonso, 400 .

Alfredo, See Valladão Alfredo.

Aliens, 46 .

Argentina, 43, 1 78-r 79, 188 .

Brazil, 201, 354-355.

Chile, 445.

Almanchio Diniz, See Diniz.

Almeida:

See Cardozo de Almeida.

Lacerda de Almeida.

Mendes de Almeida.

Nogueira Almeida.

Almeida Lobão, See Lobão.

Almeida Oliveira:

A assignação de dez dias, 295.

A lei das execuções, 298.

A prescripção, 255, 283.

Alsina, 147 .

E1 obrero, 158 .

Alvarenga, 222.

Alvarez, See also Roldán y Alvarez.

Alvarez, 356.

Droit int. americain, 444.

La grande guerre européenne, 444

Historia diplomática, 444.

Alvaro de Souza Sá Vianna, See Sá Vianna.

Alves, 194 .

See also Ferreira Alves.

Alves de Azambuja Susano, See Azambuja Susano.

Alves de Paula Pessoa, See Paula Pessoa.

Alves do Sacramento Blake, See Sacramento Blake. 
Alves Lima, See Lima.

Alves Pereira, See Fulgencio Alves Pereira.

Alvez, 301 .

Amaral, 346.

Amaro Cavalcanti. See Cavalcanti.

Ambassadors-Argentina, 93.

American Bar Association, 65.

Amnesty-Brazil, 321 .

Amuchastegui:

Fallos del, 84 .

Fallos y escritos juridicos, 47 .

Amunátegui Reyes, $366,388,443$.

Bello y el código civil, 388 .

Enrique Cood, 389.

Imperfecciones $\mathrm{i}$ erratas, $39 \mathrm{r}$.

Leyes civiles, 389 .

Obras completas, $38 \mathrm{r}$.

Amunátegui y Rivera, 421.

Anales de la Academia de derecho, etc.Argentina, 49.

Anales de la Facultad de derecho, etc.-

Buenos Aires, 48.

Anales de la Universidad de Chile, 380.

Anarchism, 158.

Anastasio de Figueiredo Ribeiro. See Figueiredo Ribeiro.

Andrade:

See Gonçalves de Andrade. Pinheiro de Andrade.

Andrade e Silva, 233.

Andrade Figueira. See Figueira.

Angelis:

Historia antigua, 57 .

Recopilacion de las leyes, 24.

Anguita Acuña, 374, 41 7, 42 .

Lejislacion politica, 374 .

Leyes promulgadas en Chile, 372 .

Anido. See Rodriguez Anido.

Annuities-Brazil, 247.

(Civ. Code, Spec. Pt., Bk. 2), 248-252.

Anrique, 369.

Answer. See Civil procedure.

Antenuptial gifts. See Gifts.

Anticresis:

Argentina, 63.

(Civ. Code, Bk. 3), 64-70.

Brazil, 247.

(Civ. Code, Spec. Pt., Bk. 2), 248-252.

Antokoletz, 184, 186,

Diplomatie arg., 185 .

Anuario bibliográfico de la Rep. Arg., 14.

Anuario de la prensa chilena, 368 .

Apericio, 90.

Appeals:

Argentina, 95, 118 .

Brazil, 293-294.

Federal District, 290.

$$
71624^{\circ}-17-31
$$

Appeals-Continued.

Chile, 408,4 rr.

(Code of Civ. Proc., Bk. 1-3), 409$4^{\mathrm{r} 2}$.

Appellate courts. See Courts.

Appropriations-Argentina, 169 .

Aquino, 35.

Aranha Garça. See Garça.

Araoz, 151.

Araripe:

Codigo civil braz., 251.

Paraceres, 215.

E1 Araucano, 370.

Araujo:

See also Ferrer de Barros W. Araujo.

Herculano de Carvalho e Aratijo Monte Rodrigues d'Araujo. Vieira de Araujo.

Araujo, C., 47.

Araujo, N., 240, 296

Araujo Costa. See Orlando de Araujo

Costa.

Araujo Jorge, 358 .

Araya, I21, 126.

Arbitral procedure:

Argentina, 95.

Chile, 408.

(Code of Civ. Proc., Bk. 3), 409-4I2.

Arbitration, industrial-Argentina, 158 .

Arbitration, International:

Argentina, 177, $181-182$.

Brazil, 35r.

Arce. See Perez de Arce.

Archives:

Argentina, 88.

Brazil, 328.

Archives of the Indies in Sevilla, 59-60.

Archivo de jurisprudencia, 218.

Archivo judiciario, 217.

O Archivo juridico, 218.

Archivo publico nacional, 194 .

Archivos de psiquiatría y criminología, $\mathrm{II}_{4}$.

Areco, I. P., 39.

$\Lambda$ reco, J. A., 83 .

Argentina:

Bureau of Public Accounts, 169.

Department of Labor, Bulletin, I56.

Department of Posts and Telegraphs, 155.

Ministry of Agriculture, 75, 144, I48, 163.

Ministry of Foreign Affairs, 59-60, 127, 184,185 .

Library Catalogue, 16.

Ministry of Treasury, 152, 165, I68-1 70 .

Ministry of Interior, $132,150,154$.

Ministry of Justice, 88, I15, I1 7, 118 , 140 . Inspection bureau, 88.

National library, I7. 
Argentine law (General Works), 41-49. Argentine Year Book, 75 .

Arias. See Ríos Arias.

Aristides Augusto Milton. See Milton. Armando Vidal Leite Ribeiro. See Vidal [Leite Ribeiro], Armando.

Armengol, 90.

Arraignment. See Criminal procedure.

Arrest, Brazil, 300 .

Arriagada, M., 432.

Arriarán, 374.

Arrotea. See Molina Arrotea.

Arruda, 280.

Artistic property:

See also Copyright.

Argentina, 43.

International treaties, 187 .

Arzón. See Ibáñez Arzón.

Assessor forense, 296.

Assignments:

Argentina, 63.

(Civ. Code, Bk. 2), 64-70.

Brazil, 221, 247.

(Civ. Code, Spec. Pt., Bk. 3), 248252.

Chile, $391,398$.

(Civ. Code, Bk. 4), 391-394.

(Comm. Code, Bk. 2), 399-400.

Assis Figueiredo Ouro Preto. See Ouro Preto.

Association, Right of-Argentina, 158.

Associations:

Argentina, 63

(Civ. Code, Bk. 2), 64-70.

Brazil, 245, 254, 260, 272, 282, 313.

(Civ. Code, Gen. Pt., Bk. I), 248255.

(Comm. Code, Pt. 1), 273-277.

Chile, 398.

(Comm. Code, Bk. 2), 399-400.

Associations, Agricultural. See Agricultural associations.

Assumpção, 293.

Assumpcão Osorio, 306.

Astigueta, 74

Astolpho de Rezende, 258.

Attachment:

Argentina, 42, 95 .

Chile, 408.

(Code of Civ. Proc., Bk. 2-3), 409412.

Attorney General:

Argentina, 38-40.

I a Rioja, 113

Brazil, 299.

Chile, 424 .

Attorneys:

Argentina, 116.

Brazil, 293, 299, 3 ro.

Chile, 404.
Aubone, 155 .

Aubry, 6r.

Auctions and auctioneers:

Argentina, 78.

(Comm. Code, Bk. I), 79-84.

Brazil, 247, 272.

(Civ. Code, Spec. Pt., Bk. 2), 248252.

Chile, 397.

(Comm. Code, Bk. I), 399-400.

Aureliano Candido Tavares Bastos. See

Tavares Bastos.

Aurelino Leal. See Leal.

La Aurora, 369

Aurrecoechea, 39.

Authentication of documents-Argentina, 42.

Autran, 274.

Acções orphanalogicas, 296.

Fallencias, 286.

Avellaneda, 159 .

Avellaneda, M. A., I47.

Avellaneda, N.:

Escritos y discursos, 134.

Tierras publicas, 145 .

Avellaneda, N. A., rox.

Avellaneda, T., I67.

Average:

Argentina, 79, 90.

(Comm. Code, Bk. 3), 79-84.

Brazil, 373, 284.

(Comm. Code, Pt. 2), 273-277.

Chile, 398, 4 or.

(Comm. Code, Bk. 3), 299-400.

Ayarragaray, 158.

Azamiuja Susano, 234.

Azevedo, 352.

See also Duarte de Azevedo.

Azevedo Marques. See Candido de Azevedo Marques.

Bagué, 125 .

Bahia, Faculty of law, 223.

Bail:

Argentina, 116.

Brazil, 247, 309.

(Civ. Code, Spec. Pt., Bk. 3), 248252.

Bailly, 267.

Bailments:

Argentina, 63.

(Civ. Code, Bk. 2), 64-70.

Chile, 391, 398.

(Civ. Code, Bk. 4), 391-394.

(Comm. Code, Bk. 2 ), 399-400.

Baiocco, 89.

Baires, 73

Balbin, 155 .

Baldana, ro5.

Ballesteros, M. E., 4I4.

Indice jeneral, 375 . 
Ballesteros, M. E.-Continued.

Instrucción publica, 433.

Organización i atribuciones de los tribunales, 405 .

Ballesteros, T., 428.

Ballvé, II5.

Penitenciaria nacional, II4.

Bañados, See Gonzalez Bañados.

Bañados Espinosa, 417 .

Bancalari, See López Bancalari.

Banco hipotecario (Buenos Aires), 166.

Banco de la Nación Argentina, 165.

Bandeira:

See Souza Bandeira.

Torres Bandeira.

Banishment-Brazil, 300 .

Bank books-Brazil, 282.

Banking:

Argentina, 41, 72, 79, 164-167.

(Comm. Code, Bk. 2), 79-84.

Brazil, 278, 337-339.

Chile, 434-435.

Bankruptcy:

Argentina, 79, 82, 90-91, 188-189.

(Comm. Code, Bk. 4), 79-84.

Brazil, 201, 215, 219, 255, 263, 272-273 285,362 .

(Comm. Code, Pt. 3), 273-277.

Chile, 398-399, 402.

(Comm. Code, Bk. 4), 399-400.

Banks, Agricultural, See Agricultural banks.

Baptista, See Paula Baptista.

Baptista Cortines Laxe, See Cortines Laxe.

Baptista Marques Pinheiro, See Pinheiro.

Bar Association-Brazil, 222.

Barbalho, 3 I6.

Barbosa, P., 336.

Barbosa, R., 242-243, 253, 318, 335, 357.

Actos inconstitucionaes, 319.

Amnistia inversa, 321 .

Finanças e politica, 34I.

Sociedades anonymas, 282.

Barbosa de Rezende, 336.

Barboza Gonçalves, 330.

Barboza Luzitano, 254.

Barceló, 402 .

Barra, See Ruiz de la Barra.

Barraquero, 129.

Barreto de Menezes, 224-225.

Codigo criminal, 301 .

Estudos allemães, 225.

Estudos de direito, 225.

Menores e loucos, 304.

Barreto e Noronha, See Castilho Barreto e Noronha.

Barretto:

Imposto do sello, 342 .

Legislação de fazenda, 340 .

Barriga, 412.
Barrios, See Chacón y Barrios.

Barroetaveña, 70.

Barros:

See also Rego Barros.

$$
\text { Zenteno Barros. }
$$

Barros, E., 221.

Barros, J. M. F. P., 340.

Barros Borgoño, 435 .

Barros W. Araujo, See Ferrer de Barros W. Araujo.

Barter:

Brazil, 247, 272.

(Civ. Code, Spec. Pt., Bk. 3), 24. 252.

(Comm. Code, Pt. I), 273-277.

Chile, 398.

(Comm. Code, Bk. 2), 399-400

Barthez, 157 .

Bartolomäus, 128, 139, 274 .

Baruoso, 277.

Bas:

Derecho público, 235 .

Fallos, 37.

Bascuñán Montes, $44 \mathrm{I}$.

Bastos, See also Tavares Bastos.

Bastos:

"Administrative law," 325.

Direito penal, 304 .

Manual de direito publico, 3 I 7 .

Basualdo, 77.

Autos y sentencias, 35 .

Baudón, H. C., ro5.

Baudón, H. R., 136.

Bautista Alberdi, See Alberdi.

Beazley, 107, III.

Beccar Varela, 138.

Becú, C. A., 183.

Becú, T., 9 r.

Beéche, 369.

Beláustegui:

Dictamenes, 142.

Fallos, 36 .

Beleña, See Ventura Beleña.

Bell, 307 .

Bellarmino Braziliense Pessoa de Mello.

See Braziliense Pessoa de Mello Bellido, 196.

Bello, A., 6I, 188, 370, 391.

Derecho de gentes, 442.

Derecho internacional, 443.

Obras completas, $380,388,443$.

Proyectos de código civil, 388 .

Bello, O., 195.

Bello Codecido, 439.

Beltrán, 139.

Benavente, 418.

Benefit societies-Argentina, 174 .

Benevenuto Magalhies, See Magalhàes.

Bento de Faria, 213, 221, 222.

Codigo commercial, 275, 292. 
Bento de Faria-Continued.

Codigo penal, 303 .

Das fallencias, 286 .

Marcas de fabrica, 269.

Bermejo, 183 .

Bernaldo de Quirós, Ix4.

Bernardo Lira, See Lira.

Berne Convention, 265.

Berra:

Código de enseñanza primaria, r62.

Registro de la propiedad, $7 \mathbf{r}$.

Bessa, 225.

Betrothal-Brazil, 255.

Bevilaqua, 221, 227, 243, 282, 354 .

[Codigo civil], 248.

Criminologia e direito, 305 .

Defesa de projecto de codigo civil, 242.

Dircito civil, 253.

Direito da familia, 25 .

Direito das obrigações, 262.

Direito das successões, 264.

Direito internacional privado, 362 .

Direito privado, 252.

Direito publico internacional, 352.

Guerras e tractados, 352.

Juristas philosophos, 226.

Projecto do codigo civil, 24x.

Bewes, 89, 399.

Bialet Massé, $x 58$.

Clases obreras, $\times 57$.

Fallos, 37.

Responsabilidad civil, 7x, 159.

Socialismo arg., $x_{57}$.

Bianco, 167.

Bibliography:

Argentina, $x_{4}^{-17} 7,46,58,66,73$.

Brazil, 193-197.

Chile, 365-369, 425.

Spain, 58.

Bills of exchange-Argentina, 86.

Commercial law-

Argentina, 80.

Brazil, 275-276.

Constitutional law-Brazil, 3 I4.

Criminal law-Argentina, $1 \%$.

Criminal procedure-Argentina, $x 7$.

Criminology-Argentina, Ir4.

Intcrnational law $-x 75-176,362$.

Maritime law-Chile, 369 .

Bibliotheca Brazilica, 194.

Bidau, 176 .

Bilbao, Ordenanza de, 54, 57, 76, 384, 396.

Bill of rights-Brazil, 317 .

Billinghurst, 43 r.

Bills of excliange:

Argentina, 79, 86, 188 .

(Comm. Code, Bk. 2), 79-84.

Brazil, 272, 279-28I, 295, 362 .

(Comm. Code, Pt. x), 273-277.
Bills of exchange-Continued.

Chile, 398.

(Comm. Code, Bk. 2), 399-400.

Bills of lading:

Argentina, 170.

Brazil, 273, 282.

(Comm. Code, Pt. 2), 273-277.

Chile, 398.

(Comm. Code, Bk. 3), 399-400.

Bills to order-Brazil, 272.

Biography:

Argentina, 45, 51, 82, 126.

Brazil, 197, 249, 250.

Chile, 389, 397, 40 .

Biolchini, 276.

Births:

See also Registration of civil status.

Argentina, 62.

(Civ. Code, Bk. 1), 64-70.

Brazil, 245, 257.

(Civ. Code, Gen. Pt., Bk. r), 248-252.

Blake, See Sacramento Blake.

Blockade, 444.

Board of merchants-Argentina, 94.

Boards of trade--Argentina, 84

Boiler inspection-Argentina, 153

Boistel, 52.

Boletin bibliográfico (Lajouane), I 7 .

Boletin bibliográfico mensual (Museo Social), 14 .

Boletin judicial:

Argentina, 32.

San Juan, 38.

Bomfim Spindola, 335.

Bonds:

Argentina, 79, 87-88.

(Comm. Code, Bk. 3), 79-84.

Brazil, 219, 247, 263, 273, 282, 320 .

(Civ. Code, Spec. Pt., Bk. 3), 248-252.

Book reviews:

Argentina, 14, 48.

Brazil, 222-223.

Books, Mercantile. See Mercantile books.

Borax-Chile, 43 r.

Bordali Humíres, 400 .

Borgoño. See Barros Borgoño

Borja, 393.

Borne. See Puga Borne.

Botafogo, 340.

Bottomry:

Argentina, 79.

(Comm. Code, Bk. 3), 79-84.

Brazil, 273, 284.

(Comm. Code, Pt. 2), 273-274.

Chile, 398.

(Comm. Code, Bk. 3), 399-400.

Boundaries:

Argentina, 146, 183 . 
Boundaries-Continued.

Brazil, 36r-362.

Boza y Lillo, 374 .

Braga, 236.

Brandau, 4I4.

Bravo, 400.

See also Correa Bravo. Rodriguez Bravo.

Bravo Valdivieso, 438.

Bravo Zisternos, 407.

Brazil:

Councilof State, 21 5, 236, 326, 341, 346, 348 . Ministry of Finance, 34I.

Ministry of Foreign Affairs, 348.

Ministry of Industry and Public Works, 329.

Ministry of Interior, 327.

Ministry of Justice, 216, 306, 327.

National Institute of Deaf-Mutes, 335 .

National Institute of Music, 335.

National Library, I97, 266, 328.

National Museum, 328.

President, 313, 322, 325.

Tribunal of accounts, 217-218, 325, 343 .

Brazilian law (General Works), 218-223.

Brazilian Year Book, 218, 315.

Braziliense Pessoa de Mello, 215.

Breton. See Le Breton.

Briggs:

Cartas rogatorias, $3^{6} 3$.

Extradição, 354 .

Briones Luco, 425.

Briseño:

Biblioteca chileno-americana, 368 .

Derecho natural, 382 .

Derecho público, 387,416 .

Estadistica bibliográfica, 367 .

Brito. See Farias Brito.

Brokers:

Argentina, 78.

(Comm. Code, Bk. I), 79-84.

Brazil, 272, 273, 343.

(Cormm. Code, Pt. I), 273-277.

Federal Capital, 272-273.

Chile, 397.

(Comm. Code, Bk. 1), 399-400.

Brown, 146, 153, 330, 427 .

Buckle, 128.

Budget:

Argentina, 42, 168-169.

Brazil, 339-340.

Chile, 4 I8, 435.

Bueno. See Pimenta Bueno.

Buenos Aires (City).

Cámara de comercio, 84 .

University, 50.

Facultad de derecho . ., 44, 65 . Academic addresses, 46. Anales, 48, 49.
Buenos Aires (City)-Continued.

University-Continued.

Facultad de derecho-Continued.

Causas instruidas en B. A., etc., 59, II3.

Historia de la enseñanza de las ciencias juridicas, 50.

Library, 15 .

Revista, 48.

Facultad de filosofia . . ., 122 .

Building associations-Brazil, 260.

Building law:

Argentina, 152.

Brazil, 26r.

Chile, 434 .

Bulletin argentin de droit int. privé, 190.

Bunge, A., r6r.

Bunge, C. O.:

E1 derecho, 52.

El federalismo argentino, 129.

Historia del derecho, 57, 58.

Bunge, R., 75.

Bunge Guerrico, $9 x$.

Burgos, Ordenanzas de, 76.

Busschère, 324, 344.

Bustillo, $17 x$.

Busto. See Rodríguez del Busto.

Bustos, 442.

C. A., 204

Cabedo, 230.

Cabildos-Argentina, 127.

Cabinet officers-Argentina, I27, 131 .

Cable, Argentina, 555.

Cabral. See also Valle Cabral.

Cabral, J., 353.

Cabral, P. G. T. V., 325.

Caetano, 329.

Cactano Pereira e Souza. See Pereira e Souza.

Cactano Finto de Miranda Montenegro. $\mathrm{See}$ Montenegro.

Calandrelli, 89.

Codificación del derecho int. priv., 189.

Cuestiones de derecho int. priv., 189.

Derecho constitucional, r26.

Enciclopedia juridica, 44.

Calatayud, 83.

Calderón. See González Calderón.

Callo, r3r.

Calogeras. See Pandiá Calogeras.

Calvento, 100 .

Calvo:

Derecho internacional, 174, 175.

Dictionnaire de dr. int., 175 .

Traités, $176,349$.

Calvo doct rine, 183 .

Calzada. See Méndez Calzada. 
Camara:

See Phaelante da Camara.

Torres Camara.

Camilo Henriquez. See Henriquez.

Campaña. See Ravest y Campaña.

Campbell. See Llambi-Campbell.

Campos, 358.

Campos Porto, 347 .

Canale, 98.

Canals-Argentina, 153.

Cañas. See Risopatrón Cañas.

Cañas O'R., 394.

Candido dc Azevedo Marques, 203.

Candido de Oliveira, 26r.

Candido I. M. de Oliveira. See Oliveira.

Candido Martins, 284.

Candido Mendes de Almeida. See Mendes de Almeida.

Candido Tavares Bastos. See Tavares Bastos.

Cané, 179

Canedo, ro2.

Canon law. See Ecclesiastical law.

Canstatt, 195.

Cantilo, r22.

Capacity :

Argentina, 62-63, 78, 188-189.

(Civ. Code, Introd. Act. and Bk. 4), 64-70.

(Comm. Code, Bk. I), 79-84.

Brazil, 244, 248, 254, 354.

(Civ. Code, Gen. Pt., Bk. I, and Chile, 390.

Spec. Pt., Bk. 4), 248-255.

(Civ. Code, Bk. I), 391-394.

Capital punishment-Brazil, 300 .

Capture, 444

Carbonell, 134, 158, 179.

Cardoso de Castro, 306.

Cardoso de Oliveira:

Actos diplomaticos, 350

Consultas do conselho de estado, 349 .

Pactos internacionaes, 350 .

Cardozo de Almeida, $29 r$.

Carette, 40.

Diccionario de legislación, 22.

Diccionario de la jurisr rudencia, 40, 43.

Diccionario del código civil, 69 .

Carles, C., I54

Carlés, M., 44 .

Carneiro Pacheco. See Pacheco.

Carneiro Ribiero:

Ligeiras observações, 243.

Projecto do codigo civil, 243.

Carolino, Codigo, 384.

Carpmael, 74, 267, 396.

Carranza, A., 123.

Carranza, M. A., I35.

Carrasco Albano, ${ }_{418}$
Carreira. See Castro Carreira.

Carreras, 84.

Carriers:

Argentina, 79.

(Comm. Code, Bk. 3), 79-84.

Chile, 398.

(Comm. Code, Bk. 2), 399-400.

Carvalho, 414.

See also Moraes Carvalho.

Pereira de Carvalho.

Carvalho, Adherbal, 227, 3 Io.

Carvalho, Alfredo, 196.

Carvalho, C., 364.

Carvalho, C. A., 250.

Carvalho de Mendonca, J. X.:

Das fallencias, 285 .

Das firmas, 277.

Direito commercial, 275.

Dos livros dos commerciantes, 277.

Justiça de paz, 195 .

Carvalho de Mendonca, M. I., 22I, 261.

Contractos, 263.

Obrigações, 262.

O poder judicial, 290, 3 I8.

Rios e aguas correntes, 259, 330 .

Carvalho e Araujo, See Herculano de Carvalho e Araujo.

Carvallo, 412.

Casabal, 51.

Casarino:

Personas juridicas, 70 .

Procedimientos judiciales, 97.

Cassio Barbosa de Rezende, See Barbosa de

Rezende.

Castaño, See Larsen del Castaño.

Castellano, 83.

Castilho Barreto e Noronha, 361 .

Castilla, Ordenanzas reales de, $53,57$.

Castillo, J. A., ro5.

Castillo, R. S.:

Quiebras, 9r.

Sociedades comerciales, 87 .

Castro:

Derecho constitutional, 126.

Practica forense, 98-99.

See also Cardoso de Castro.

Mendes de Castro.

Pereira de Castro.

Viveiros de Castro.

Castro Carreisa, 340.

Castro Ruiz, 44r.

Catalogues

See Library catalogues.

Publisher's catalogues.

Cattle:

Argentina, 146, 16r.

Buenos Aires (Prov.), 547.

Cavalcanti, 290, 327.

Brazil, 340. 
Cavalcanti-Continued.

Financas, 341.

O meio circulante nacional, 338.

A neutralidade, 353-354.

Noticia historica dos serviços, 328 .

Regimen federativc, 3 I9.

Resenha financiera do ex-imperio, 340 .

Responsabilidade civil do Estado, 327.

Trabalhos na 3 d Conferencia internacional americana, 356.

Cayrú, 269.

Cedrés, 83 .

Celso de Assis Figueiredo Ouro Preto. See Ouro Preto.

Cemeteries:

Argentina, 174.

Centeno:

Brazil, 20r, 347.

Relaciones exteriores, 185 .

Tratados, 177.

Centro estudiantes de derecho, 7x, 150 .

Revista, 49.

Tierra publica, 145 .

Cerda Esscobar, See Escobar.

Cervini, 85 .

Chabot, 62.

Chacaltana, 174 .

Chacón y Barrios, 392.

Charitable institutions:

Argentina, 160, 173-1 74.

Chile, 421, 434.

Charter parties:

Brazil, 273.

(Comm. Code, Pt. 2), 273-277.

Chile, 398.

(Comm. Code, Bk. 3), 399-400.

Charters of corporations-Chile, 372-373.

Chat tel mortgages-Brazil, 219.

Chauveau, 299.

Chaverria, 374, 421.

Chaves de Gusmão, See Gusmão.

Chávez, F., 387 .

Cheques:

Argentina, 79, 86.

(Comm. Code, Bk. 2), 79-84.

Brazil, 272, 280-282.

Child labor-Argentina, $155-156$.

Children:

Argentina, 62, 105, 160, 163.

(Civ. Code, Bk. I), 64-70.

Brazil, 246, 255, 302 .

(Civ. Code, Spec. Pt., Bk. 1), 248252.

(Crim. Code, Bk. 2), 302-304.

Chile, 390.

(Civ. Code, Bk. I), 391-394.

Chile:

Conseja de Defensa Fiscal, 424 .

Council of State, 404, 419, 422.

Ministry of Finance, 435.
Chile-Continued.

Ministry of Foreign Affairs, 442.

Ministry of Interior, 374 .

Ministry of Justice, 404.

National Library, 368.

President, 387.

Tribunal of Accounts, 422.

Universidad. Anales, 380.

Chilean law (General Works), 378-382.

Cholera, 16r.

Chrysolito Chaves de Gusmão. See Gusmão.

Church and State:

Argentina, 39.

Brazil, 201, 347.

Chile, 4 I9.

Church law. See Ecclesiastical law.

Church property:

Argentina, 174 .

Chile, 404 .

Cicero Peregrino da Silva. See Peregrino da Silva.

Citation. See Civil procedure.

Cities. See Municipalities.

Citizenship:

Argentina, 41, 134, 158, 178-179, 188.

Brazil, 218, 317, 324, 351.

Civil code:

See also Civil law.

Argentina, 4r, 60-70.

Brazil, 238-252.

Chile, 378, 387-394.

Civil law:

Argentina, 40, 4I, 43, 45, 60-75, 175 .

Brazil, 215, 219-221, 238-269.

Chile, 378, 384, 387-396.

Civil pensions-Argentina, 140, 160-161.

Civil procedure:

Argentina, 4I, 94-105, 187.

Buenos Aires (City), 99-ror.

Buenos Aires (Prov.), 41, I0r-ro3.

Entre Rios, 103.

Salta, 103.

San Juan, r04.

Santa Fé, ro4.

Brazil, 215, 219-221, 250, 29r-299, 362. Federal District, 290.

Rio de Janeiro (State), 294.

Chile, 378, 387, 406-412.

Civil status registration:

Argentina, $\dot{v}_{3}, 65$. Buenos Aires (Prov.), 140.

Brazil, 219, 245, 257, 302, 328. (Civ. Code, Gen. Pt., Bk. I), 248-255. (Crim. Code, Bk. 2), 302-304.

Chile, 390.

Civil war claims-Argentina, 180.

Claims:

Argentina, 39, 142-143, 179-180.

Brazil, 35r.

Chile, 424, 444-445. 
Claims, mining-Argentina, 149.

Claro Salas, 427.

Claro Solar, 379.

Explicaciones de derecho civil, 387, 393.

Clearing houses-Argentina, 79.

(Comm. Code, Bk. 2), 79-84.

Clemente Fabres y Fernandez. See Fabres y Fernandez.

Clemente Pereira, 270.

Clementino de Oliveira. See Escorel.

Clerks-Chile, 398.

(Comm. Code, Bk. 2), 399-400.

Clerks of courts-Chile, 404, 4 ro.

Clovis Bevilaqua. See Bevilaqua.

Coast wise navigation:

Argentina, 153.

Brazil, 219, 284 .

Coastwise trade-Argentina, 90.

Code of criminal procedure. See Criminal procedure.

Codes (Collected):

See also separate codes.

Argentina, 40-42.

Buenos Aires (Prov.), 25, 42.

Corrientes, 27.

Brazil, 218-219.

Castile, 53-60.

Chile, 378.

Peru, 53-60.

Spain, $53-60$.

Codecido. See Bello Codecido.

Codigo Carolino, 384.

Codigo Philippino, 197, 230-235.

Coelho:

See also Gama Coelho.

Nogueira Coelho.

Coelho, H., 3 I8.

Coelho, I. A., 256.

Coelho da Rocha:

Direito civil, 249.

Historia do governo, 236.

Coelho Rodrigues, A., 221, 240-24I.

Motifs du projet de code civil, 24 I.

Parecer da commissão revisora ..., 24I.

Projecto de codigo civil, 24x.

Coelho Rodrigues, M., 354 .

Coinage-Argentina, 168.

Colegio nacional de escribanos, 49.

Colina. See De la Colina.

Collegio Pedro II, 335 .

Collisions:

Argentina, 7s, 82.

(Comm. Code, Bk. 3), 79-84.

Brazil, 273.

(Comm. Code, Pt. 2), 273-277.

Chile, 398.

(Comm. Code, Bk. 3), 399-400.

Colmo, 44, 50.

Colonial law. See History of law.
Colonization:

Argentina, 4I, 143-144, 179.

Buenos Aires (Prov.), 147.

Brazil, 333

Chile, 425, 44r.

Colombres, 77 .

Commerce, Acts of:

Brazil, 277.

Chile, 400.

Commercial actions. See Actions, Commercial.

Commercial agents. See Agents.

Commercial books. See Mercantile books.

Commercial cases. See Commercial decisions.

Commercial courts-Brazil, 236, 269.

Commercial code:

See also Commercial law.

Argentina, 41, 76-84, 188.

Brazil, $270-276$.

Chile, 378, 396-40r.

Commercial decisions:

Argentina, 83-84, 153.

Brazil, 214, 276.

Chile, 376.

Commercial documents:

Argentina, 79, 85-86, 95 .

(Comm. Code, Bk. 2), 79-84.

Brazil, 282.

Chile, 400.

Commercial education. See Education.

Commercial employees-Argentina, 78.

(Comm. Code, Bk. I), 79-84.

Commercial law:

Argentina, 40, 4I, 43, 45, 54, 57, 76-92,

144, $153,169,188$.

Brazil, 215, 219, 221, 269-286, 362.

Federal District, 219.

Chile, 378, 396-402.

Commercial laws of the world, 274.

Commercial markets-Argentina, 78.

(Comm. Code, B'. r), 79-84.

Commercial procedure:

Argentina, 4I, 45.

Buenos Aires (Prov.), 4I.

Brazil, 27I, 274, 292.

Commercial register:

Argentina, 78.

(Comm. Code, Bk. I), 79-84.

Chile, 397 .

Commercial travelers:

Argentina, 92.

Chile, 4 or.

Commercial treaties:

Argentina, 84, 153, 177-1 78.

Brazil, 286, 350.

Chile, 44r.

Commissior agents:

See also Agents. 
Commission agents-Continued.

Argentina, 78.

(Comm. Code, Bk. 2), 79-84.

Brazil, 272.

(Comm. Code, Pt. I), 273-277.

Chile, 398.

(Comm. Code, Bk. 2), 399-400.

Community of interest-Argentina, 63 .

(Civ. Code, Bk. 2), 64-70.

Companies-Brazil, $28 \mathrm{r}-282$.

Comparative Law Bureau, 65, 315.

Compensation:

Argentina, 62.

(Civ. Code, Bk. 2), 64-70.

Brazil, 247, 248.

(Civ. Code, Spec. Pt., Bk. 3), 248-252.

Composition of creditors:

Argentina, 79.

(Com. Code, Bk. 4), 79-84.

Brazil, 286.

Compromise:

Argentina, 62.

(Civ. Code, Bk. 2), 64-70.

Brazil, 247.

(Civ. Code, Spec. Pt., Bk. 3), 248252.

Comptroller of the Treasury-Brazil, 343.

Concessions:

Argentina, 39-40, 136, 144, 149-252.

Brazil, 259, 329-330, 332.

Chile, 431-432.

Concha. See Fernández Concha.

Conciliation-Brazil, 20r, 293.

Concordat-Argentina, 174 .

Concurrent jurisdiction-Argentina, 135.

Conferences, international, 180, 351, 353, 356-357.

Conflict of laws:

Argentina, 62, 187-189.

(Civ. Code, Introd. Act), 64-70.

Brazil, 244, 355, 362-364.

(Civ. Code, Introd. Act), 248-252.

Chile, $445-446$.

Confusion:

Argentina, 62.

(Civ. Code, Bk. 2), 64-70.

Brazil, 247.

(Civ. Code, Spec. Pt., Bk. 3), 248252.

Confusion of goods-Brazil, 245.

(Civ. Code, Gen. Pt., Bk. 2), 248-252.

Congress. See Legislature.

Congresso juridico brasileiro, 220.

Coni, Ir5.

Conservators-Chile, 404.

Consignments-Argentina, 78.

(Comm. Code, Bk. 2), 79-84.

Constant, 312.
Constitutional guaranties:

Argentina, 131-132.

Brazil, 3 I 7 .

Constitutional history:

Argentina, 120-I22.

Brazil, 312-315, 317.

Constitutional law:

Argentina, 4I, 43, 45-46, I19-138, 151-152.

Provinces, 134 .

Buenos Aires (Prov.), $135-136$.

Córdoba (Prov.), $27,136$.

Brazil, 215, 218, 220-221, 311-324, 347.

Chile, 378, 387, 416-420.

Constitutions:

See also Constitutional law.

Argentina, 41.

Provinces, 27, $41-42$.

Buenos Aires (Prov.), 42.

Córdoba, 27.

Brazil, 218, 315-316.

State, $3 \mathbf{I} 6$.

Chile, 378.

Consulado del Mar, 76 .

Consular conventions-Brazil, 354.

See also Treaties.

Consular fees:

Argentina, 153, 184 .

Chile, 442.

Consular invoices:

Argentina, 170 .

Brazil, 219, :72, 279, 282.

Consular reports:

Argentina, 185.

Brazil, 357.

Consuls:

Argentina, 92, 93, 153, 184-185, 189.

Brazil, 357.

Chile, 398, 441-443.

Contas assignadas-Brazil, 279.

Contardo Chaverria. Sec Chavarria.

Contentious administrative jurisdiction:

Argentina, $\mathbf{r}_{43}$.

Buenos Aires (Prov.), 102.

Brazil, 326.

Continentino, 220.

Contraband, 444.

Contracts (Obligations):

Argentina, 62-63, 70-71, 78, 188

(Civ. Code, Bk. 2), 64-70.

(Comm. Code, Bk. 2), 79-84.

Brazil, 247, 249, 255, 262-263, 272, 277 .

(Civ. Code, Spec. Pt., 13k. 3), 248-252.

(Comm. Code, Pt. I), 273-277.

Chile, 39I, 394, 398.

(Civ. Code, Bk. 4), 391-394.

(Comm. Code, 13k. 2), 399-400.

Convents-Argentina, 74 .

Conversion-Chile, 434 . 
Coo Tarle, 405.

Cood:

Antecedentes legislativos, $387,389$.

Marriage of non-Catholics, 395 .

Cooke:

Derecho constitucional, 127.

Sociedades comerciales, 87 .

Cooperative organizations:

Argentina, 89.

Brazil, 273, 334

Coownership-Argentina, 63 .

(Civ. Code, Bk. 3), 64-70.

Copyright:

Argentina, 43, 72-73.

Brazil, 197, 219, 247, 265-266.

(Civ. Code, Spec. Pt., Bk. 2), 248252.

Cordeiro: Chile, 368 .

Acções civeis, 296.

Acções criminaes, 296, 310.

Consultor criminal, 3 ro.

Córdoba University, 5o.

Corporation counsel-Brazil, 2 I5.

Corporations:

See also Juristic persons.

Argentina, 42, 62, 78, 79, 86-89, 188-189. (Civ. Code, Bk. I), 64-70.

(Comm. Code, Bk. 2), 79-84.

Brazil, 215, 218, 245, 254, 272-273, 281282, 295, 338, 354 .

(Civ. Code, Gen. Pt., Bk. I), 248255.

(Comm. Code, Pt. r), 273-277.

Chile, 372-373, 398, 400-401, 424-425.

(Comm. Code, Bk. 2), 399-400.

Corporations, taxat:on of-Brazil, 220, 342.

Corporations, foreign. See Foreign corporations.

Correa, 232.

Correa Bravo, 445 .

Estudios legales, $38 \mathrm{I}$.

Municipalidades, 423.

Corrêa Telles. See Homen Corrêa Telles.

Correctional cases-Argentina, Ir6.

Correia de Silva, 229.

Cortés:

Reforma constitucional, 137.

Vistas fiscales, 40.

Cortines Laxe, 328.

Corvalán, 151.

Costa, 284.

See also Jose da Costa.

Marianno da Costa.

Orlando de Araujo Costa.

Podestá Costa.

Silva Costa.

Costa Lima. See Drumiond.

Costas, 39 .
Costs:

Argentina, Ir6.

Brazil, 219, 292, 297-298, 342.

Chile, 405, 408.

(Code of Civ. Proc., Bk. I), 409-412.

Cotapos, See Silva Cotapos.

Council of the Indies:

Portugal, 235 .

Spain, 55-57.

Counterclaim, See Civil Procedure.

Counterfeiting-Argentina, 108.

Court costs, See Costs.

Court of accounts, See Brazil and Chile.

Court of appeal of the palace-Brazil, 236.

Court reports:

Argentina, 30-40, 83-84, 153.

Capital,See Buenos Aires (City).

Federal, 31-32.

Provincial, 31, 36-38.

Buenos Aires (City) -

Federal, 31-32.

Municipal, 31-35.

Buenos Aires (Prov.), 25, 36-37.

Cordoba-

Federal, 32.

Provincial, 37.

Corrientes, 37 .

Entre Rios, 37-38.

Jujuy, 38.

San Juan, 38.

Santa Fé, 38.

Brazil, 21 I-218, 276, 346.

Federal, 212-214.

Federal District, 213, 215.

State, 216-218.

Amazonas, 217.

Bahia, 217.

Ceará, 217.

Maranhão, 216.

Minas Geraes, 216.

Parahyba, 218.

Paraná, 216-217.

Pernambuco, 218.

Rio Grande do Norte, 217.

Rio Grande do Sul, 217.

Rio Janeiro (State), 214-215, 218.

Sĩo Paulo, 217.

Chile, 375-380.

Court rules:

Brazil, 290, 3 Iо.

Chile, 407.

(Code of Civ. Proc., Bk. r), 409-412.

Courts:

See also Court reports.

Argentina, 30-4I, 67, 92-94, 97, 103-104, 444.

Capital, See Buenos Aires (City).

Federal, 30-32, 92-93, 97.

Appellate, 30-32, 92-93. 
Courts-Continued.

Argentina-Continued.

Federal-Continued.

District, 92.

Supreme, 30, 93, 97.

Provincial, $31,36-38,94,103-104$.

Buenos Aires (City), 30-36, 93-94.

Federal, 30-32, 92-93.

Municipal, 30, 32-36, 93-94.

Buenos Aires (Prov.), 36-37.

Córdoba (Federal), 92-93.

La Plata (Federal), 92-93.

Paraní (Federal), 92-93.

Rosario (Federal), 92-93.

Salta, ro3.

San Juan, ro4.

Brazil, 201, 211-212, 215, 218, 235-236, 269, 286-291, 293, 295, 317, 325-326, 343.

Federal, 201, 211, 235-236, 286-290.

Federal District, 211, 215, 287-283, 290-291.

State, $211-212,287$.

Chile, 376, 378, 397, 403-404, 411, 422 .

Courts of appeal, See Courts.

Cranes-Argentina, 17 r.

Credit, Letters of, See Letters of credit.

Credit institutions-Chile, 434.

Creditors:

Argentina, 63.

(Civ. Code, Bk. 4), 64-70.

Brazil, 248, 263.

(Civ. Code, Spec. Pt., Bk. 3), 248-252.

Chile, 408.

(Code of Civ. Proc., Bk. 3), 409-412.

Creditors, composition of, See Composition of creditors.

Criminal actions, See Actions, criminal.

Criminal anthropology-Argentina, I $x_{3}$.

Criminal code, See Criminal law.

Criminal (Penal) code, naval-Brazil, 307.

Criminal defenses, See Defenses, Criminal.

Criminal delinquency-Argentina, rr4.

Criminal law:

See also Bibliography, Criminal law. Military criminal law.

Argentina, 39-41, 43, 106-115, 188.

Buenos Aires (Prov.), 59.

Brazil, 201, 215, 218-221, 299-307, 355.

Federal District, 219.

Chile, 378, 382, 412-414.

Criminal procedure:

See also Bibliography, Criminal procedure.

Argentina, 41, 110, 115-119, 188.

Federal, $116-118$.

Provincial, 117-119.

Territorial, II6-1 I8.

Buenos Aires (City), II6-118.
Criminal procedure-Continued.

Argentina-Continued.

Buenos Aires (Prov.), 41, 118-119.

San Juan, 104.

San Luis, Irg.

Brazil, 219-221, 307-31r, 362 .

Federal District, 308 .

Rio de Janeiro (State), 308.

Chile, 378, 4I4-4r6.

Criminal responsibility-Brazil, 302,304-306. (Crim. Code, Bk. I), 302-304.

Criminal statistics-Argentina, 115.

Criminals, Antecedents of, 112.

Criminology:

Argentina, Ir3-r14.

Brazil, 305-306.

Cruchaga:

Organización economica, 422, 429.

Sociedades anonimas, 40 r.

Cruchaga Tocornal, 443.

Cruz, A., 325.

Cruz, J. C., 86.

Derecho comercial, 83 .

Cunha Machado, 216.

Cunha Salas, 283.

Currency:

Argentina, 41, 168.

Brazil, 299, 302, 338.

(Crim. Code, Bk. 2), 302-304.

Current account. See Accounts current.

Customhouse procedure:

Argentina, 170.

Brazil, 345 .

Customs laws:

Argentina, 39, 169-171.

Brazil, 344-346.

Chile, $436-437$.

Daireaux, 178 .

El abogado, 43 .

$\mathrm{L}$ a vie et les moeurs, 43,50 .

Daireaux Molina, 43.

Damages-Brazil, 247, 262-263.

(Civ. Code, Spec. Pt., Bk. 3), 248-252.

Dareste, 123

Davila, 89.

Davila Izquierdo, 379 .

Davila J., 394.

de Busschère. See Busschèrc

Death penalties-Chile, 4 I4.

See also Penalties.

Deaths:

Argentina, 62.

(Civ. Code, Bk. x), 64-70.

Brazil, 245, 257.

(Civ. Code, Gen. Pt., Bk. I), 248-252.

\section{Debentures:}

Argentina, 79, 88

Brazil, 219, 273, 28I-282. 
Debtor and creditor:

Argentina, 63, 78-79, 95.

(Civ. Code, B k. 2, 4), 64-70.

(Comm. Code, Bk. 2), 79-84.

Brazil, 219, 247, 282, 294.

(Civ. Code, Spec. Pt., Bk. 3), 248-252.

Debts, public. See Public debts.

Decedents, estates:

See also Administration of estates, etc.

Argentina, 63

(Civ. Code, Bk. 4), 64-70.

Brazil, 247, 248, 264-265, 364 .

(Civ. Code, Spec. Pt., Bk. 2, 4), 248-252, 264-265.

Chile, 390 .

(Civ. Code, Bk. 3), 39r-394.

Deceit-Brazil, 245 .

(Civ. Code, Gen Pt., Bk. 3), 248-252.

Declaration. See Civil procedure.

Decurgez, 87 .

Deeds-Brazil, 250.

Default-Argentina, 116 .

Defenses-Brazil, 220.

Defenses, Criminal:

Argentina, 118

Brazil, 309 .

De la Colina:

Derecho . . . procesal, 98.

Proyecto de ley, ror-1o2.

Delaney, 2 I8.

Delfino y Hermano, 187 .

Delgado da Silva, 233.

Delivery-Chile, 390 .

(Civ. Code, Bk. 2), 39r-394.

Dellepiane:

Derecho penal, ir2.

Filosofia del derecho procesal, 5 r-52.

Filosofía juridica, 52.

Del Rio, 374, 42 r.

Del Valle, I21, 1 26-127.

Demolombe, 62.

Denunciation-Argentina, 148 .

Departments, Brazil, 322, 325.

Departments, Administrative-Argentina, 139-140.

Departments, Executive. See Executive departments.

Deportation-Argentina, ro8.

Deposit:

Argentina, 78.

(Comm. Code, Bk. 2), 79-84.

Brazil, 247, 272.

(Civ. Code, Spec. Pt., Bk. 3), 248-252.

(Comm. Code, Pt. r, Bk. r), 273-277.

Chile, 398.

(Comm. Code, Bk. 2), 399-400.

Depositaries-Chile, 404 .

Depositions-Argentina, 95.

Descartes de Magalhaes, 277.
Descent: See Decedents' estates, etc. Detention:

Argentina, II7.

Brazil, 309.

Diaz Lois, 426.

Didimo Agapito da Veiga. See Veiga.

Diego Arriarán. See Arriarán.

Diez Gómez, Ir3.

Digesto de Guerra, 172.

Digesto de justicia, 42.

Digests (Court Reports):

See also Court reports.

Argentina, 40.

Chile, $377-378$.

Diniz:

Codigo civil, 253.

Direito das cousas, 258.

Divorcio, 256.

Diniz Gonçalves:

Ensaios philosophicos, 226

Philosophia e direito, 226.

A sciencia do direito, 226 .

Dionysio Gama. See Gama.

Diplomatic ceremonial-Chile, 442.

Diplomatic history:

Argentina, 185-187.

Brazil, 358-362.

Chile, 444.

Diplomatic service:

Argentina, 184-185.

Brazil, 357.

Chile, 44I-442.

Directories, Notaries-Buenos Aires, 105.

O Direito, 213, 222.

Discovery-Argentina, 148.

Disinheritance-Brazil, 248.

(Civ. Code, Spec. Pt., Bk. 4), 248-252.

Disqualification of judges-Argentina, 95, I16.

Distribution:

Argentina, 63

(Civ. Code, Bk. 4), 64-70.

Brazil, 247, 248, 264-265.

(Civ. Code, Spec. Pt, Bk. 2, 4), 248252.

Chile, 390 .

(Civ. Code, Bk. 3), 39I-394.

District attorneys-Brazil, 299, 3 I0.

District courts. See Courts.

Divorce:

Argentina, 62, 70 .

(Civ. Code, Bk. x), 64-70.

Brazil, 201, 246, 256-257, 354, 364 . (Civ. Code, Spec. Pt., Bk. I), 248252.

Dobranich:

Derecho mercantil, 89.

Justicia militar, 173 .

Legislación de minas, 150 . 
Docks:

Brazil, 329.

Chile, 425 .

Documents-Argentina, 59-60.

Documents, Authentication of-Argentina, 42.

Documents, commercial. See Commercial documenis.

Dodd, 123, 3I5, 416.

Doldán, 38.

Domán. See Ramm Domán.

Domenech, r8o.

Domestic relations (Family law):

Argentina, 62,69.

(Civ. Code, Bk. I), 64-70.

Brazil, 246, 249, 255-257, 302, $3_{62}$.

(Civ. Code, Spec. Pt., Bk. I) 248-252.

(Crim. Code, Bk. 2), 302-304.

Domicil:

Chile. See Husband and wife, etc.

Argentina, 62, 104, I88-189.

(Civ. Code, Bk. I), 64-70.

Brazil, 245.

(Civ. Code, Gen. Pt., Bk. I), 248252.

Domingo Amunátegui y Rivera. See Amunátegui y Rivera.

Domingues Vianna:

Constituição federal . ., 316.

Elementos de direito, 317.

Funccionarios publicos, 326 .

Regimen penitenciario, 305 .

Dominguez, E., 172.

Dominguez, J. E., 3 I.

Donoso, 440.

Doria:

Arrazoades e estudos de direito, $22 \mathrm{I}$.

Questões juridicas, 22 I.

Dotal régime-Brazil, 246.

(Civ. Code, Spec. Pt., Bk. I), 248-252.

Dowery-Brazil, 255.

Drago:

Antropología criminal, Ir3.

El arbitraje de las pesquerias, 183 .

Colección de fallos, 35 .

Deudas públicas, 182 .

E1 procedimiento criminal, IIg.

La república argentina . ., , 182 .

Drago doctrine, 174, 182-183, 354 .

Dramatic representation-Brazil, 247.

(Civ. Code, Spec. Pt., Bk. 3), 248-252.

Drayage law-Buenos Aires(City), 171.

Dredging-Brazil, 329.

Druggists-Argentina, 162.

Drummond, A. de V. M.:

Diplomacia, 358 .

Direito internacional, 352.

Drummond, J. da C. L., 22 I, 305.

Direito criminal, 304.
Drunkenness-Chile, 433.

Dual nationality-Brazil, 363 .

Duarte, Don-Ordenaçc̃es de, 228-229.

Duarte de Azevedo, 215.

Duarte Nunez do Leão. See Nunez do Leão

Duel-Brazil, 304 .

Duffy, I 16.

Derecho penal, Ixx.

Marcas de fabrica, 75 .

Dunshee de Abranches. See Abranches.

Dupin, 254.

Durá, 179

Duranton, 62.

Duress-Brazil, 245.

(Civ. Code, Gen. Pt., Bk. 3), 248-252.

Duties. See Customs laws.

Dwellings, Workmen's-Chile, 434.

Easements-Brazil, 26r.

Ecclesiastical law:

Argentina, 173-174.

Brazil, 218, 347-348.

Chile, 378,440 .

Echeverria i Reyes:

Artículos de los códigos, 392.

Bibliografia de los códigos, 365,378 .

Biblioteca chilena, 366 .

Código de proc. civil, 409.

Recopilación de leyes, 374, 421.

Eder, 65, 146, 330, 427.

Education, Agricultural:

Argentina, $\mathbf{I} 6_{3}$.

Brazil, 334.

Education, commercial-Argentina, I63.

Education, Legal. See Legal education.

Educational institutions-Brazil, 328.

Educational law:

Argentina, I60, I62-I 63 .

Buenos Aires (City), 26.

Buenos Aires (Prov.), 42, 140, I62.

Entre Rios (Prov.), $\mathrm{I}_{3}$.

Brazil, 313, 325, 328, 334-336.

Chile, 42I, 432-433.

Egaña. See Mariano Egaña.

Eight-hour day-Argentina, 158.

Elections:

Argentina, 43, 46, 128, 130, 134, 13 7-138.

Buenos Aires (Prov.), 42, 138 .

Brazil, 322-323, 328, 354 .

Chile, 374, 418-420.

Elizalde, 392.

Emancipation-Brazil, 245.

(Civ. Code, Gen. Pt., Bk. I) 248-252.

Emigration. Sce Immigration.

Emiliani, 139.

Eminent domain:

Argentina, I3 r, 133.

Brazil, 33 .

Emphyteusis-Brazil, 247.

(Civ. Code, Spec. Pt., Bk. 2), 248-252. 
Employees, commercial. See Commercial employees.

Employment agencies-Argentina, 156.

Employers liability (Workmen's compensation):

Argentina, 156, 159.

Sĩo Paulo, 337 .

Enclosure-Brazil, 259.

Encyclopedias, Legal:

Argentina, 43, 44.

Chile, 378.

Engineers, Mining-Argentina, 149.

Enrollment-Argentina, 43.

Epitacio Pessoa. See Pessoa.

Ernesto Carneiro Ribeiro. See Carneiro Ribeiro.

Escalada. See Sosa Escalada.

Escalante, 77.

Apuntes de filosofia del derecho, $5 \mathrm{x}$. Lecciones de filosifia del derecho, 5 r.

Esscobar, 376 .

Escorel, 304 .

Escudero. See Fabié y Escudero.

Esmeraldino Olympio de Torres Bandeira See Torres Bandeira.

Espil, 97.

Espinola:

Actos juridicos, 254 .

Direito civil, 252, 263.

Prescripsão, 255.

Espinosa

See Bañados Espinosa. Otero Espinosa.

Espinoza, 434 .

Espirito Santo, 346.

Essays, legal. See Legal essays.

Estado de sito, 321.

Esteves Sagui, 98.

Esthetic instruction-Argentina, 160.

Estilo. See Leyes de Estilo.

Estrada, 126:

Derecho constitucional, I26, 139.

Obras completas, 45 .

Ethics, Legal-Argentina, 52.

Eugenio de Barros. See Barros.

Evaristo de Moraes. See Moraes.

Evidence:

Argentina, 51-52, 95, 98, II7-I 18 .

Brazil, 293-294.

Chile, 408.

(Code of Civ. Proc., Bk. 2), 409-412.

Examination, preliminary-Argentina, I16, II8.

Examinations, expert-Argentina, II6.

Exceptions:

Argentina, 95.

Brazil, 298.
Exchange and barter:

Brazil, 247.

(Civ. Code, Spec. Pt., Bk. 3), 248252.

Chile, 39r.

(Civ. Code, Bk. 4), 391-394.

Exchange, Foreign-Chile, 434

Exchanges:

Argentina, 78, 84 .

(Comm. Code, Bk. x), 79-84.

Brazil, 272.

(Comm. Code, Pt. x), 273-277.

Execution:

Argentina, 95.

Brazil, 293-294, 298-299, 302, 309, 364.

(Crim. Code, Bk. I), 302-304.

Federal District, 290.

Chile, 408.

(Code of Civ. Proc., Bk. I, 3), 4094 I2.

Executive departments:

Argentina, 131, 139-140.

Brazil, 327-328.

Executive action (juicio executivo)-Argen-

tina, 95 .

Executive power:

Argentina, 128, 130-131.

Brazil, 3 I8.

Executors-Chile, 390.

(Civ. Code, Bk. 3), 391-394.

See also related subjects.

Exemptions-Brazil, 245, 298.

(Civ. Code, Gen. Pt., Bk. 2), 248-252.

Expert examinations-Argentina, 116.

Export taxes:

Argentina, 170.

Brazil, 345.

Expropriation:

Argentina, 4I, 133, 160.

Buenos Aires (Prov.), 42.

Brazil, 219, 325, 321.

Chile, 424 .

Expulsion:

Argentina, 41, 108, 379.

Brazil, 354-355.

Extortion-Brazil, 302.

(Crim. Code, Bk. 2), 302-304.

Extradition:

Argentina, 4I, 179-180.

Brazil, 218, 300, 354-355.

Chile, 382, 404 .

Extradition treaties, 187.

Chile, 44I.

Extraterritoriality-Brazil, 244.

(Civ. Code, Introd. Act), 248-252.

Ezcurra, 170.

Fabié y Esscudero, 60. 
Fabres, 439.

Fabres y Fernandez, 41 2, 445.

Derecho civil, 393.

Obras completas, $38 \mathrm{r}$.

La porción conyugal, 395 .

Factors:

Brazil, 272.

(Comm. Code, Pt. r), 273-277.

Chile, 398.

(Comm. Code, Bk. 2), 399-400.

Faculties of law:

See also Law schools.

Bahia, 223.

Buenos Aires, 44

Anales, 48.

Recife, 193, $223,328$.

Rio de Janeiro, 223.

São Paulo, 193, 223, 328 .

Faculties of Medicine-Brazil, 328, 335 .

See also Medical schools.

Fallos do throno-Brazil, 314 .

False indication of origin-Brazil, 273

Falsification of currency-Brazil, 299.

Family law. See Domestic relations.

Faria:

See Bento de Faria.

Morrison Faria.

Faria Carneiro Pacheco. See Pacheco.

Farias Brito, 227.

Farming-Buenos Aires (Prov.), 147.

Federal courts. See Courts.

Federal departments-Brazil, 322.

Federal intervention:

krgentina, 132.

Brazil, 321.

Federal procedure-Brazil, 308.

Federal system-Brazil, 319-320.

"Federalist," 129.

Fees:

See also Consular fees.

Argentina, 42, 169, 17 r.

Brazil, 297-298.

Chile, 40r, 404-405, 408.

(Code of Civ. Proc., Bk. 3), 409-412.

Feldwick, 2 18.

Feliciano José da Costa. See José da Costa.

Felicio dos Santos, 240.

Projecto de codigo civil braz., 240

Felippe José Nogueira Coelho. See Nogueira Coelho.

Felisbelle de Oliveira Freire. See Freire.

Fernandes. See Manoel Fernandes.

Fernandes Thomaz, 203.

Repertorio geral, 235.

Fernandez. See also Fabres y Fernandez.

Fernandez, F., 39 .

Fernandez, J. S., 99.
Fernández, P. J., $4^{13}$.

Fernandez, R., 228.

Fernández Concha:

Derecho público eclesiastico, $44^{\circ}$.

Filosofia del derecho, 382 .

Fernandez Pradel. See Pradel.

Fernando Machado. See Machado.

Fernando Mendes de Almeida. See Mendes Almeida.

Ferreira. See also Vieira Ferreira.

Ferreira, D. R., 20.

Ferreira, F. I., 332.

Ferreira, J. O., 343.

Ferreira, M. J., 322.

Ferreira, R.:

Derecho internacional, I75.

Vistas fiscales, 39.

Ferreira Alves, 295.

Ferreira Bastos. See Bastos.

Ferreira Gordo, 232.

Ferreira Lopes. See Lopes.

Ferreira Marnoco e Souza. See Marnoco e Souza.

Ferreira Vianna, 240.

Ferrer de Barros W. Araujo, 219, 293, 309.

Ferreyra, ${ }_{3} 8$.

Ferri, $\mathrm{rr}_{3}$.

Feuerbach, 52.

Fierro S., 424.

Figueira, 242, 244.

Figueiredo Ouro Preto. See Ouro Preto.

Figueiredo Ribeiro, 229, 232.

Figueroa:

Diccionario biográfico, ${ }_{369}$.

La librería, 369.

Filinto Justiniano Ferreira Bastos. See Bastos.

Finance:

Argentina, 43, x64-I7I. Buenos Aires (City), 26.

Brazil, 325, 337-346.

Chile, 434-437.

Fire department-Brazil, 328 .

Firms, registration of-Brazil, 2 19, 273, 277 .

Fiscal:

Argentina, 38, 94 .

Brazil, 299 .

Chile, 404.

Fiscal dues-Argentina, 153.

Fiscallaws:

Argentina, 68.

Brazil, 340.

Fischer:

Marcas industriaes, 269.

Patents de invencão, 267.

Fisher, 25 . 
Fishing:

Argentina, 148, 152.

Buenos Aires (Prov.), 147.

Chile, 425.

Flags-Argentina, 152.

Fonseca, 3 r8.

See also Oliveira Fonseca.

Fontecilla. See Várgas Fontecilla.

Foral law-Brazil, 236.

Forced entry:

Argentina, 79.

(Comm. Code, Bk. 3), 79-84.

Brazil, 273.

(Comm. Code, Pt. 2), 273-277.

Foreign banks-Chile, 434.

Foreign consuls-Argentina, 93.

Foreign corporations (juristic persons):

Argentina, 87, 89.

Brazil, 244, 282.

(Civ. Code, Introd. Act), 248-252.

Chile, 4 or.

Foreign exchange-Chile, 434 .

Foreign insurance companies-Brazil, 283.

Foreign judgments-Erazil, 244, 299, 354, 364.

(Civ. Code, Introd. Act), 248-252.

Foreign juristic persons. See Foreign corporations.

Foreshore (terrenos de marinha)-Brazil, 32 .

Forestry:

Argentina, 144, 146.

Brazil, 334.

Chile, 426.

Forjaz, 36r.

Forms:

Argentina, 43, 63, 70, 105, 188. (Civ. Code, Bk. 2), 64-70.

Buenos Aires (City), ro3. Buenos Aires (Prov.), ro3.

Brazil, 292-293, 295-297, 299, 3 10-3 Ir.

Chile, 4 Io.

Forte, $360-36 x$.

Foucher, 30 .

Foundations-Brazil, 245.

(Civ. Code, Gen. Pt., Bk. I), 248-252.

Fraud-Brazil, 245.

(Civ. Code, Gen. Pt., Bk. 3), 248-252.

Freeman, 4 10.

Freire. See also Meilo Freire.

Freire, F. de O.:

As constituições, 3 I6.

Historia constitucional, 316 .

Freire, L., 227.

Freire de Fonseca. See Fonseca.

Freitas:

See Oliveira Freitas.

Teixeira de Freitas.

Freitas Villalva, 2I7.
Frers, 165.

Frías, J. A.:

Digesto de los fallos, 3 I.

Recopilación de codigos y leyes, 42, 96 .

Repertorio de jurisprudencia comercial, $34,83$.

Frias, U. S.:

Leyes nacionales, 2 I.

Trabajos legislativos, 18.

Fuente, 144.

Fuente Ortiz, 430 .

Fuenzalida, 413.

Fuero Juzgo, 53, 57, 385 .

Fuero Real, 53, 54, 57, 385 .

Fueros Municipales, 53, 54

Fulgencio Alves Pereira, 260

Función constitucional de los ministros, $13 x$.

Furtado de Mendonca. See Souza Furtado de Mendonça.

Gabaglia. See Raja Gabaglia.

Gaceta de los tribunales, 375.

(Index), 377-378.

Gaceta Mercantil, 16, 25.

Gacitúa. See Moyano Gacitúa.

Galdames, 414.

Galdino Siqueira. See Siqueira.

Gallo, 173.

Galvão. See Ramiz Galvão.

Gama. See also Saldanha da Gama.

Gama, 296.

Gama Coelho:

Consol. de leis do proc. civil . . . , 294.

Consol. de leis do proc. criminal, $3 \circ 8$.

Gama Lobo, 355.

Gambling:

Argentina, 85, 158.

Brazil, 247.

(Civ. Code, Spec. Pt., Bk. 3), 248252.

Gamboa, 428 .

Game:

Argentina, 148

Buenos Aires (Prov.), 147.

Gancedo, 129.

Gandarillas, 370.

Garça Aranha, 282.

Garcez:

Aggravos, 298.

Direito da familia, 256.

Do direito das cousas, 258 .

Leis civis, 239, 250.

Nullidades dos actos juridicos, 255, 294.

Da theoria geral do direito, 253.

Garcia, J. A., 46.

Ciencias sociales, $51,59$.

La ciudad indiana, 58 .

Proyecto de código penal, 106.

Garcia, R., 47.

García Goyena. See Goyena. 
Garcia López, 7I.

García Mérou, E., 97.

Garcia Merou, J., I62.

Garcia Mérou, M.:

Alberdi, 125.

Diplcmacia americana, 186.

Garcia Scabra, 306.

Garmendia:

Derecho civil, ror.

Jurisprudencia unificada; Derecho civil, 33.

Justicia en los territorios, 98.

Garraux, 195 .

Garzón, 37.

Gaspar Quesada. See Quesada.

Gazeta juridica, 21 7, 222.

Ghigliotto Salas, 430.

Gifts:

Argentina, 63, 69.

(Civ. Code, Bk. 2), 64-70.

Brazil, 246-247.

(Civ. Code, Spec. Pt., Bk. r, 3), 248252.

Chile, 390.

(Civ. Code, Bk. 3), 39r-394.

\section{Gil, A. L.:}

Recursos de inconstitucionalidad, 133 . Repertorio de la jurisprudencia, 36 .

Gil, E., r8r.

Giustinian, E., 83.

Giustinian, J.:

Indice, 22.

Intervenciones del Gobierno, ${ }_{32}$.

Glynn, 123.

Godofredo de Alencastro Autran. See Autran.

Goenaga, 89.

Góes e Vasconcellos, 274.

Goldsmith, 196 .

Gómez. See also Diez Gómez.

Gomez:

Criminologia, 17, 108.

Estudios penitenciarios, II4.

Gómez Langenheim, 145 .

Gonçalves:

See Barboza Gonçalves.

Diniz Gonçalves.

Gonçalves de Andrade, 240.

Gonçalves Maia:

Procurações, 297.

Questões forenses, 221.

Gonnet, L. M., 23.

Gonnet, M. B., 173 .

Gonzáles, 36-37.

González, C. N.:

Colección de fallos, 84 .

Fallos del tribunal . . , 83 .

Gonzalez, F., 407 .

$$
71624^{\circ}-17-32
$$

Gonzalez, J. V., 107, 138, 150.

La Argentina y sus amigos, 182 .

Debates constitucionales, $r_{33}$.

Educación y gobierno, 163 .

Escritos y opiniones, 46.

Expropriación, ${ }_{333}$.

International arbitration, 18I.

Jurisprudencia y politica, 46,133 .

Manual de la constitución, 125 .

Proyecto de ley . . . , 157 .

Reforma electoral, 137 .

González, L. M., ro4.

Gonzalez, M., 145.

Gonzalez, M. P., 2r.

Gonzalez Bañados, 438.

González Calderón:

Derecho público, 135 .

Función constitucional, r3r.

La función judicial, 96, 131.

Inconstitucionalidad de las leyes, 133 .

Nueva ley electoral, I38. $_{3}$

Poder legislativo, 130.

González Roura, rrg.

Gordo. See Ferreira Gordo.

Gormaz, M., 39r.

Gormaz, V., 377 .

Gourlie, 90, 284, 402.

Gouvea Pinto, 264.

Goyena, F. G., 6r.

Goyena, G., 388.

Goyena, J.:

Digesto de marina, 152, 172.

Digesto eclesiástico, 174 .

Digesto rural, $\mathbf{4}_{4} 6$.

Goyena, MI., 85.

Goyena, P., 7 r.

Goytia:

Fallos, 35 .

Repertorio juridico, 47.

Grain, 395.

Grasserie. See La Grasserie.

Grau:

Indice, 34 .

Jurisprudencia civil. Indice, 34 .

Manual juridico, 83 .

Greeley, 74, 267, 396.

Green, 437.

Gregorio Garcia Seabra, Ste Garcia Seabra.

Groussac, 179.

Guanabara, 34r.

Guaranty:

See also Constitutional guaranties.

Argentina, 78.

(Comm. Code, Bk. 2), 79-94.

Brazil, 263, 272.

(Comm. Code, Pt. I), 273-277.

Chile, 39r, 398.

(Civ. Code, Bk. 4), 391-394.

(Comm. Code, Bk. 2), 399-400. 
Guardia, 56, 386.

Guardianship:

Argentina, 62, 69, 105.

(Civ. Code, Bk. I), 64-70.

Brazil, 246, 255, 295.

(Civ. Code, Spec. Pt., Bk. I), 248252.

Chile, 390, 409.

(Civ. Code, Bk. 1), 391-394.

(Code of Civ. Proc., Bk. 4), 409-412.

Guastavino, J. E., 71.

Guastavino, J. M.:

Codigo civil, 69

Proyecto de correcciones, 65 .

Guerrero, V., 40r.

Guerrico. See Bunge Guerrico.

Guesalaga:

Agentes diplomáticos, 186

Derecho diplomático, 186 .

Leyes de la guerra, 184.

Tratados de comercio, 84, 177 .

Guide to the law and legal literature of

Spain, 57.

Guilds-Brazil, 334.

Guimarães de Araujo Jorge. See Araujo Jorge.

Guimarães Natal. See Natal.

Guiñazú. See Ruiz Guiñazú.

Gusmão, 307.

Gymnasio Nacional-Brazil, 335.

Habeas corpus:

Argentina, 132.

Brazil, 220, 289, 300, 309. 311 .

Hague Conference. See Conferences.

Hall:

Código de proc. civil, roo.

Formularios de escritos forenses, ro3.

Formularios de escrituras públicas, 70, ro3.

Instituta de la jurisprudencia, 34 .

Jurisprudencia civil. Repertorio, 33.

Harispe, 107.

Hartwig, 4I3, 433.

Health, public. See Public health.

Heineccius, 52.

Hélie, 299.

Helio Lobo. See Lobo.

Henriquez, 369.

Herculano de Carvalho e Araujo, 229, 237.

Herculano Marcos Inglez de Souza. See Inglez de Souza.

Hermano. See Delfino y Hermano.

Hernández, 34.

Herrera. See also Martin y Herrera.

Herrera, J., III.

Herrera, I. A., 360 .

Highways-Buenos Aires (Prov.), 147.
Hiring:

Argentina, 63.

(Civ. Code, Bk. 2), 64-70. =

Brazil, 247, 272.

(Civ. Code, Spec. Pt.,Bk. 3), 248-252.

(Comm. Code, Pt. I), 273-377.

History, Constitutional. See Constitutional history.

History, diplomatic, Argentina, 185-187.

History of law:

See also Special subject.

Argentina, 43, 53-60.

Brazil, 220, 228-238, 305.

Chile, $38 \mathrm{x}-387$.

Peru, 53-60.

Spain, 53-60.

Holidays, national-Brazil, 322.

Home labor-Argentina, 160 .

Homen Corrêa Telles, 254, 294.

Digesto portuguez, 249.

Homesteads-Brazil, 245, 298. (Civ. Code, Gen. Pt., Bk. 2), 248-252.

Hoskold:

Memoria . . . sobre las minas, 149.

Mines, 150.

Hospitals-Chile, 42 r.

Hours of labor-Argentina, $155^{-156,160 .}$

House of correction, Brazil, 328.

House of detention:

Argentina, 88.

Federal Capital (Braz.), 306.

House manual-Brazil, 322.

House rules-Argentina, 130 .

Husrgo, 85 .

Huméres. See Bordali Huméres.

Huneeus, A., 379.

Huneeus, J.:

La constitución, 41 .

Derecho constitucional, 418 .

Hurley, 166, 435.

Husband and wife:

Brazil, 246.

(Civ. Code, Spec. Pt., Bk. r), 248252.

Chile, 390.

(Civ. Code, Bk. 1), 391-394.

Hygiene, public. See Public health.

Ibañez, G., 434.

Ibañez, M., 401 .

Ibañez, R., 426.

Ibañez Arzón:

Código de proc. penal, 415 .

Minas i salitreras, 429.

Iberlucea, See Valle Iberlucea.

Ignacio Carvalho de Mendonça. See Carvalho de Mendonça.

Ignacio Ferreira. See Ferreira. 
Ignacio Ramalho. See Ramalho. Ignacio Vaz Vieira. See Vieira. Illegitimacy:

See also Legitimation.

Argentina, 62. (Civ. Code, Bk. I), 64-70.

Brazil, 255.

Immigration:

Argentina, 41, 108, 143-144, 148, 158, 160,

- 179.

Brazil, 313, 333

Chile, 425, 44I.

Imposts (Import taxes)-Argentina, I69I7I.

Imprisonment for debt-Chile, 398.

Incompetents:

Argentina, 62, 188.

(Civ. Code, Bk. I), 64-70.

Brazil, 245, 304.

(Civ. Code, Gen. Pt., Bk. I), 248252.

Indians-Brazil, 337.

Indigenous law. See Natives.

Industrial accidents. See Accidents, Industrial.

Industrial arbitration. See Arbitration.

Industrial cooperative organizationsBrazil, 334.

Industrial insurance. See Insurance, Industrial.

Industrial law:

Argentina, 144, 148, 169 .

Chile, $421,426$.

Industrial property:

Argentina, 72-75.

Brazil, 265-269.

Chile, $396,426$.

Infante, D. A., 145 .

Infante, F., 145 .

Infanticide-Brazil, 304.

Infants. See Children.

Ingegnieros, II4.

Criminologia, Ir3.

Derecho penal, II4.

Evolución sociologica, 160.

Législacion du travail, 157.

Sistema penitenciario, II4.

Inglez de Souza, 239.

Direito commercial, 276.

Projecto de código commercial, $27 x$.

Titulos ao portador, $263,282$.

Inheritance:

See also related subjects.

Argentina, 63.

(Civ. Code, Bk. 4), 64-70.

Brazil, 248, 264-265.

(Civ. Code, Spec. Pt., Bk. 4), 248252.

Inheritance tax-Brazil, 265 .
Iñiguez, 10 .

Insane asylums-Brazil, 328.

Insanity-Brazil, 337.

Insolvency:

Brazil, 248.

(Civ. Code, Spec. Pt., Bk. 3), 248252.

Chile, 399, 408.

(Code of Civ. Proc., Bk. 3), 409-412.

Inspection-Buenos Aires (Prov.), 140.

Institute of Advocates (Rio de Janeiro), 224.

Institute of Lawyers-Brazil, 222.

Institutions-Brazil, 254, 328.

See also Local institutions.

Instituto Benjamin Constant, 335 .

Instituto da ordem dos advogados brazileiros, 193.

Instruments-Brazil, 247, 255, 263, 273, 282, 302.

(Civ. Code, Spec. Pt., Bk. 3), 248252.

(Crim. Code, Bk. 2), 302-304.

See also Private instruments.

Public instruments.

Sealed instruments.

Insurance:

Argentina, 78, 85 .

(Comm. Code, Bk. 2), 79-84.

Brazil, 219, 247, 273, 283.

(Civ. Code, Spec. Pt., Bk. 3), 248252.

Chile, 398 .

(Comm. Code, Bk. 2), 399-400.

Insurance, agricultural-Argentina, 85, 147. Insurance, industrial-Argentina, ${ }_{59}$.

Insurance, life. See Life insurance.

Insurance, marine. See Marine insurance.

Insurance, transportation-Argentina, 79.

(Comm. Code, Bk. 3), 79-84.

Intellectual property-International law, I88.

Interdicts-Chile, 408.

(Code of Civ. Proc., Bk. 3), 409-412.

Interest:

Argentina, 78.

(Comm. Code, Bk. 2), 79-84.

Brazil, 272.

(Comm. Code, Pt. r), 273-277.

Interlocutory decrees-Chile, 408.

(Code of Civ. Proc., Bk. I), 409-412.

Internal revenue:

Argentina, 168

Brazil, 346.

Int. Bur. for the protection of industrial property, 396.

Int. Bur. of the Am. Rep.:

Arg. Rep., 149.

Constitution of the Arg. Rep., 123.

Patent and trade-mark laws, 396.

Tariffs . . ., 436. 
International Commission of Jurists, 356, 363.

International Conferences, 180-181, 35I, 353, 356-357.

International documents-Argentina, 176178.

International law:

Argentine literature, 43, 46, 174-189.

Brazilian literature, 221, 347-364.

Chilean literature, $440-446$.

Interpretation of laws:

Argentina, 104, rog.

Brazil, 244, 253-254, 293. (Civ. Code, Introd. Act), 248-252. Chile, 390 .

Intervenção nos estados, $32 \mathrm{r}$.

Intervention-Argentina, 117,1 18.

Intervention, Federal:

Argentina, $\mathbf{1 3 2}^{2}$.

Brazil, 32 I.

Intestate Succession. See Succession.

Intoxicating liquors. See Alcohol.

Inventory-Brazil, 248, 264-265.

(Civ. Code, Spec. Pt., Bk. 4), 248-252.

Invoices, Consular. See Consular invoices.

Irigoyen, 97

Irrigation:

Argentina, 146, 153

Chile, ${ }_{426}$

Isidoro Simões. See Simões.

Itagyba, See Nogueira Itagyba.

Iturburu, Ir3.

Izarra. See Pinto Izarra.

Izidoro Martins. See Martins Junior.

Izquierdo. See Davila Izquierdo.

Januario da Assumpcão Osorio. See Assumpção Osorio.

Javier Fernández. See Fernández.

Javier Gamboa. See Gamboa.

Jeronymo da Silva Pereira. See Silva Pereira.

Jesuino Ferreira. See Ferreira.

Joannini, 65 ,

Jofré, IIg.

Administración de justicia, ror.

Causas instruidas en B. A., 59, 113.

Código de proc. penal, 1 ig.

Manual de proc. criminal, ir 8 .

E1 nuevo código de proc. penal, rig.

Procedimiento criminal, rr6.

Joint-stock companies-Chile, 400.

Joppert da Silva, 362 .

Jorge. See A raujo Jorge.

Jorge de Cabedo. See Cabedo.

José da Costa, 350.

José da Rocha. See Rocha.

José da Silva Costa. See Silva Costa.

José da Silva Lisboa. Sce Silva Lisboa.

José de Mello Freire. See Mello Freire.
José de Mello Moraes. See Mello Moraes.

José de Monte, $2 \mathrm{r}_{3}$.

Josino do Nascimento Silva. See Silva.

Joze Ignacio Vaz Vieira. See Vieira.

Judges:

Argentina, 94, 95, 116-117.

Brazil, 287-288, 293.

Chile, $403-404,407$

(Code of Civ. Proc., Bk. x), 409-412.

Judgment:

See also Foreign judgments.

Argentina, 95.

Brazil, 293.

Chile, 408.

(Code of Civ. Proc., Bk. I), 409-4I2.

Judicial control of administration-Brazil, 326.

Judicial officers:

Brazil, 293.

Chile, 408 .

(Code of Civ. Proc., Bk. x), 409-412.

Judicial organization:

See also Courts.

Argentina, 4I, 46, 92-94, 96-99.

Buenos Aires (City), 4I, 99-ror.

Salta, I03.

Brazil, 201, 219, 286-29r, 328.

Federal District, 288 .

São Paulo, $29 r$.

Chile, 378, 381, 402-406.

Judicial power:

Argentina, 13 r.

Buenos Aires (Prov.), r3r.

Brazil, 318.

Judiciary Act. See Judicial organization.

Juez 'etrado, 94.

Junta commercial-Federal District (Brazil), 272-273.

Jurisdiction:

See also Concurrent jurisdiction.

Contentious administrative jurisdiction.

Argentina, 92-93, 96-98, II6, II8, I35, 143.

Brazil, 215, 221, 286-291, 293, 309, 325.

Chile, 400, 403-404, 408-409, 4 II.

(Code of Civ. Proc., Bk. I), 409-412. Jurisdiction, A ppellate-A rgentina, 92-93. Jurisdiction, Criminal-A rgentina, 116.

Jurisdiction, noncontentious. See Noncontentious jurisdiction.

Jurisprudence:

Argentina, 50-52.

Brazil, 224-228, 347 .

Jurisprudencia de los tribunales nacionales, 32.

Juristic acts-Brazil, 245, 254-255.

(Civ. Code, Gen. Pt., Bk. 3), 248-252. 
Juristic persons:

See also Corporations.

Argentina, 70, 188.

Brazil, 244-245, 254.

(Civ. Code, Introd. Act; Gen. Pt., Bk. I), 248-252.

Jury system:

Argentina, 118.

Brazil, 308, 3 II.

Justices of the peace:

Argentina, 88, 94, 146.

Federal territories, 93.

Brazil, 295.

Justiniano Ferreira Bastos. See Bastos.

Justino de Andrade e Silva. See Andrade e Silva.

Justino Gonçalves de Andrade. See Goncalves de Andrade.

Justo Donoso. See Donoso.

Justo Mendes de Moraes. See Moraes.

Juvenal Pacheco. See Pacheco.

Katz. See Alexander-Katz.

Kelly, 214.

Labor contract-Argentina, 159.

Labor laws:

Argentina, 155-160.

Brazil, 337 .

Chile, 426.

Labor statistics-Argentina, 157 .

Lacerda:

Abertura de credito, 278.

A cambial, 280 .

Codigo civil, 248.

Conta-corrente, 278.

Lacerda de Almeida, 26r.

Lacerda de Almeida, F. de P.:

Direito das cousas, 257.

Expulsão de extrangeiros, 355.

Obrigações, 262.

Das pessoas juridicas, 254.

Successões, 264.

Lafaille, $7 x$.

Lafayette Rodrigues Pereira, 240, 263.

Direito das cousas, 258.

Direitos da familia, 256.

Direito internacional, 352.

Vindiciae, 225.

La Grasserie:

Code civil chilien, 391 .

Lois civiles du Bresil, 25 I.

La Guardia. See Guardia.

Lajouane and Co., 17, 25.

Lamartine, 224 .

Land insurance-Brazil, 283.

Land laws:

Argentina, 39-41, 135, 143-146.

Buenos Aires (Prov.), 42, 140, 146.

Cordoba, 146.

Corrientes, 146.
Land laws-Continued.

Argentina-Continued. Mendoza, 146.

Brazil, 333.

Chile, 425.

Land registration. See Registration of property.

Landlord and tenant-Brazil, 26r.

Langenheim. See Gómez Langenheim.

Langgaard Menezes. See Octavio de Lang. gaard Menezes.

La Plata Public library, $x 6$.

La Plata University, Is.

Larguía, 140.

Larrain Zañartu, J. I., 373.

Larrain Zañartu, J. J.:

Boletin de las principales leyes, 373 .

El ciudadano y el gobierno, 423.

Larrain Zañartu, J. Q., 419.

Larsen del Castaño, 83.

Laspiur, 75.

Lastarria, 425.

See also Ramirez Lastarria.

Bosquejo histórico de la Const., 387 .

La constitución politica, 387,417 .

Derecho civil chileno, 393.

Derecho publico constitucional, 4I 7 .

Estudios juridicos, 393.

Obras completas, 380 .

Politica positiva, 418.

Latorre, 379, 394.

Codigo civil, $386,389$.

Ley de matrimonio civil, 394 .

Memorias y discursos universidarios, 386,394 .

Laudelino Freire. See Freire.

Laurindo, 225.

Laval, 368.

Lavaqui. See Salas Lavaqui.

Law officer-Argentina, 38-39.

Law Schools:

See also Faculties of law.

Argentina, 49.

Brazil, 224, 334.

Laxe. See Cortines Laxe.

Lazo, 381 .

Código de mineria, 430.

Codigo penal, 414 .

Indice general, 375 .

Lazo de la Vega, 424.

Leal, 3 I6.

A reforma do ensino do direito, 224.

Technica constitucional, $32 \mathrm{x}$.

Leal Sobrinho, 347 .

Leão:

See Lopes de Leăo.

Nunez do Leăo.

Leases-Brazil, 26 r.

Le Breton, 74 . 
L,egacies:

Brazil, 248.

(Civ. Code, Spec. Pt., Bk. 4), 248252.

Chile, 390.

(Civ. Code, Bk. 3), 39r-394.

Legal acts-Brazil, 254-255, 362 .

Legal culture-Argentina, 44.

Legal education:

Argentina, 44, 49-50.

Brazil, 220-221, 223-224.

Legal encyclopedias. See Encyclopedias, legal.

Legal essays:

Brazil, 22x.

Chile, $38 \mathrm{r}-382$.

Legal ethics-Argentina, 52.

Legal history. See History of law.

Legal institutions-Argentina, 59.

Legal interpretation. See Interpretation of laws.

Legal liability-Argentina, 70-7I.

Legal medicine:

Argentina, 115, 161.

Brazil, 306-307.

Chile, 414

Legal persons-Brazil, 254.

See also Juristic persons.

Legal philosophy. See Philosophy of law.

Legal separation. 'See Separation.

Legislação e jurisprudencia do Brasil, 202, 214.

Legislación rural argentina, 147 .

Legislation:

See also History of law.

Argentina, 18-30, 40, 43, 53-60. Provincial, 22-30, 40, 43 .

Territorial, 29-30, 40, 43 .

Buenos Aires (City), 25.

Buenos Aires (Prov.), 23-26.

Catamarca, 26.

Córdoba, 26-27.

Corrientes, 27.

Entre Rios, 27.

Jujuy, 27.

La Rioja, 27-28.

Mendoza, 28.

National territories, 29-30.

Salta, 28.

San Juan, 28.

San L,uis, 28.

Santa Fé, 28-29.

Santiago del Estero, 29.

Spanish colonies, 53-60.

Tucumán, 29.

Brazil, 197-211, 228-235.

States, 204-2II.

Alagôas, 205.

Amazonas, 205-205.
Legislation-Continued. Brazil-Continued.

Bahia, 206.

Ceará, 206.

Espirito Santo, 206.

Federal District, $21 x$.

Goyaz, 207.

Gram-Pará, 207.

Maranhão, 207.

Matto Grosso, 207.

Minas Geraes, 207.

Pará, 207-208.

Parahyba do Norte, 208.

Paraná, 208.

Pernambuco, 208.

Piauhy, 208-209.

Rio Grande do Norte, 209.

Rio Grande do Sul, 209.

Rio de Janeiro, 209.

Santa Catharina, 209-2 to.

São Paulo, 210.

Sergipe, 2 ro.

Chile, 369-375.

Legislative assemblies-Brazil, 313.

Legislative power:

Argentina, 130.

Brazil, 318.

Legislature (Congress):

Argentina, 130.

Brazil, 325.

Legitimation:

Argentina, 62.

(Civ. Code, Bk. 1), 64-70.

Brazil, 246, 255.

(Civ. Code, Spec. Pt., Bk. 1), 248-252.

Chile, 409.

(Code of Civ. Proc., Bk. 4), 409-412.

Leguizamon, 66.

Lehmann, 178.

Lehr, 175 .

Leite Ribeiro. See Vidal [Leite Ribeiro],

Armando.

Leite Solidonio. See Solidonio.

Lessa, 221,224

O determinismo psychico, 304 .

Dissertações e polemicas, 220.

Philosophia do direito, 227.

O poder judicial, 290, 318, 319.

Letelier, 386, 397.

Ciencia politica, $4 \mathrm{rg}$.

Derecho administrativo, 422.

Letra de terra-Brazil, 279.

Letters of credit:

Argentina, 78.

(Comm. Code, Bk. 2), 79-84.

Brazil, 272.

(Comm. Code, Pt. I), 273-277.

Chile, 398.

(Comm. Code, Bk. 2), 399-400. 
Letters rogatory: Argentina, 42.

Brazil, 354, 363 .

Letting: See Hiring.

Levasseur, $\mathbf{1} 66$.

Levene, 58-59.

Levindo Ferreira Lopes. See L,opes.

Lewandowski, 72, 166 .

Leyes de Estilo, 385 .

Leyes de Toro, 53, 57 .

Leyes Marianas, 407.

Liberato Baruoso. See Baruoso.

Liberato de Castro Carreira. See Castro Carreira.

Liberty-Argentina, 132.

Libraries:

Argentina, 164 .

Brazil, 197, 266, 328.

Chile, 368 .

Library catalogues:

Argentina-

Buenos Aires-

Ministry of Foreign Affairs, 16.

National Library, $\mathbf{I}$.

University. Faculty of law.

Library, 15 .

University. Faculty of philosophy. Library, 17.

La Plata-

Public library, 16.

University, 15

Museo Mitre, 16.

Brazil-

Recife-

Faculty of law, 193.

Rio de Janeiro-

Municipal library, 194 .

Archivo publico nacional, 194.

National library, 196.

São Paulo-

Faculty of law, 193.

Libre comercio, 384 .

Libreria Nacional, I7

Liberia Rivadavia, 17.

Licenses-Argentina, 42, 169 .

Liens-Brazil, 21 5, 258.

Liens, Maritime. See Maritime liens.

Life insurance-Brazil, 247, 283.

(Civ. Code, Spec. Pt., Bk. 3), 248-252.

Lighthouses-Argentina, 153.

Lillo. See Boza y Lillo.

Lillo i Lira, 430.

Lima

See also Machado Pinheiro Lima.

Oliveira Lima.

Souza Lima.

Lima, A., 260.

Lima, F. A., 227.
Lima Drummond. See Drummond, J. da C. L.

Limitations, statute of-Argentina, 79 . (Comm. Code, Bk. 3), 248-252.

Limited companies-Chile, 398 .

Limited liability companies-Brazil, $28 \mathrm{r}$.

Limited partnerships-Brazil, $28 \mathrm{r}$.

Liquor. See Alcohol.

Lira. See also Lillo i Lira.

Lira, J. A., 382.

Lira, J. B., 387, 391, 403, 407, 414.

La lejislacion chilena, 373 .

Leyes de mineria, 429.

Procedimientos judiciales, 410.

Lira Smith, 442.

Lisboa, 358 .

See also Silva Lisboa.

Literary property:

Argentina, 43, 72-75.

Brazil, 219, 265-269.

International treaties, $\mathbf{1 8 7}$.

Llamazares, 85 .

Llambi-Campbell, 128, 139.

Llerena, B.:

Código civil, 68.

Derecho civil, 67

Estudios juridicos, 69.

Llerena, R. R., 84.

Lloyd, 218, $3 \times 5$.

Loan associations-Brazil, 260.

Loans:

Argentina, 78.

(Comm. Code, Bk. 2), 79-84.

Brazil, 247, 272.

(Civ. Code, Spec. Pt., Bk. 3), 248252.

(Comm. Code, Pt. I), 273-277.

Chile, 398.

(Comm. Code, Bk. 2), 399-400.

Loans, maritime-Argentina, 79.

(Comm. Code, Bk. 3), 79-84.

Loans, bottomry-Brazil, 284 .

Lobão, 259.

Lobo. See also Gama Lobo.

Lobo:

Antes da guerra, 359 .

Brasil, terra chara, 358 .

Neutralidade, 353 .

Lobos, 177.

Tierras, 145.

Local government-Chile, 423.

Local institutions-Argentina, 132.

Lois. See Diaz Lois.

Lombroso, $113,114$.

Lopes, 292, 295.

Devisões, demarcaçōes . . . 259.

Juizes de paz, 295.

Lopes de Leão, 313. 
López. See also Garcia López.

López, J. F., r31.

López, L. V., 40, 45.

Derecho administrativo, 138 .

López, V. A., 378

López, V. F., 85.

López Bancalari, 87.

Lottery taxes-Brazil, 342.

Loureiro, 250.

Lourenç Trigo de Loureiro. See Loureiro.

Lowndes, 90, 284, 402.

Lozano, 119.

Luca, 43 I.

Lucio de Mendonça. See Mendoriça.

Luco. See Briones Luco.

Ludgero Antonio Coelho. See Coelho.

Luna Olmos, 7 .

Luzitano. See Barboza Luzitano.

Mabragaña, 122 .

Macedo, 197.

Macedo Soares, 264.

Macedo Soares, A. J.:

Medições e demarcasões de terras, 259.

Titulos ao portador, 282.

Macedo Soares, O., 296, 3 ro.

Casamento civil, 256.

Codigo penal, 303 .

Codigo penal militar, 307 .

Consultor eleitoral, 323.

Machado:

See also Cunha Machado. Oliveira Machado.

Machado, F., 326.

Machado, J. O.:

Codigo civil, 69.

Contratos, 71 .

Exposición . . . del código civil, 68.

Instituta del código civil, 66.

Machado Pereira Vianna. See also Pereira Vianna.

Machado Pinheiro Lima, 217.

Machado Portella, 3 I2.

Mackeldey, 52.

Mackenna. See Vicuña Mackenna.

Mafra, 213.

Magalhães. See also Descartes de Magalhães.

Magalhães, B., 347.

Magalhães, O., 350.

Magalhães Pinto, 216, 223.

Magnasco, Irr.

Maia. See Gonçalves Maia

Mail steamers-Argentina, 153.

Maintenance-Brazil, 255.

Majority, Age of:

Brazil, 245.

(Civ. Code, Gen. Pt., Bk. I), 248-253.

Chile, 390.

Malagarriga, C. (Hijo), 52.
Malagarriga, C. C., Ior, I13, 145.

Código de procedimientos, ror.

Código penal, 112.

Derecho comercial, 83.

Derecho mercantil maritimo, 90

Estudio del derecho, $5 \mathrm{I}$.

Procedimiento penal, II7.

Prueba judiciaria, 98.

Malarino:

Derecho administrativo, 139 .

Legislación minera, 150.

Las municipalidades, 133 .

Malaver, 45, 47, 119.

Procedimientos civiles, 99.

Malheiro. See Perdigão Malheiro.

Managers-Chile, 398.

(Comm. Code, Bk. 2), 399-400.

Manifests, Ships'-A rgentina, 170.

Manoel Fernandes, 203.

Manquero, 159.

Manual del marino, 439.

Manual do deputado, 322.

Manual do senador, 322.

Manuelinas, Ordenações, 230.

Manufacturing industries-Chile, 426.

Marcadé, 62.

Marcellino da Gama Coelho. See Gama Coelho.

Marcos Inglez de Souza. See Inglez de Souza.

Marginal sea-Argentina, 127 .

Maria Frederico de Souza Pinto. See Souza

Pinto.

Marianas. See Leyes Marianas.

Marianno da Costa, 216.

Mariano Egaña, 407.

Marin Vicuña, $1_{53}$.

Marine insurance:

Argentina, 79, 85, 188

(Comm. Code, Bk. 3), 79-84.

Brazil, 273, 283-284.

(Comm. Code, Pt. 2), 273-277.

Chile, 398.

(Comm. Code, Bk. 3), 399-400.

Marital portion-Chile, 395.

Maritime commerce:

Argentina, 153

Brazil, 283-285.

Chile, 398.

(Comm. Code, Bk. 3), 399-400.

Maritime law:

Argentina, 79, 89-90, 188-189.

(Comm. Code, Bk. 3), 79-84.

Brazil, 283-285, 362 .

Chile, 369, 398, 402.

International law, 353.

Maritime liens:

Argentina, 79.

(Comm. Code, Bk. 3), 79-84.

Brazil, 284. 
Maritime mortgage:

Argentina, 79.

(Comm. Code, Bk. 3), 79-84.

$$
\text { Chile, } 402 .
$$

Maritime sanitation-Argentina, 153, 16r.

Maritime war-Chile, 443-444.

Market judges-Argentina, 94.

Markets, commercial. See Commercial markets.

Markham, I95.

Marnoco e Souza, 237.

Marques. See Candido de Azevedo Marques.

Marques de Moura. See Romeiro.

Marques de Vilhena. See Vilhena

MarquesPerdigão. See Perdigão.

Marques Perdigão Malheiro. See Perdigão

Malheiro.

Marques Pinheiro. See Pinheiro.

Márquez, 375.

Marriage:

Argentina, 62-65, 69-70, 174, 188-189. (Civ. Code, Bk. x), 64-70.

Brazil, 20r, 219, 245-246, 255-257, 302, 354. (Civ. Code, Gen. Pt., Bk. I, and Spec. Pt., Bk. 1), 248-252. (Crim. Code, Bk. 2), 302-304.

Chile, 390, 394-395, 408.

(Civ. Code, Bk. I), 391-394.

(Code of Civ. Proc., Bk. 3), 409-412.

Marriage settlement-Brazil, 247.

(Civ. Code, Spec. Pt., Bk. 3), 248-252.

Martial law:

Argentina, 132.

Brazil, 320-321.

Martin, 313.

Martín y Herrera:

Codigo de instruccion primaria, 162 .

Naturaleza juridica, I74.

Martinez, A. B.

Argentina, 72, 166.

Presupuesto nacional, 168.

Martinez, E. T., 24.

Martinez, M., 382 .

Martinez, Z., 38.

Martínez Alcubilla, 385 .

Martunez Paz:

D. Velez Sarsfield, 6r.

Enseñanza del derecho, 50.

Martinho Garcez, See Garcez.

Martins. See also Candido Martins.

Martins, P., 236-237.

Martins, S.:

Assistencia maritima, 284 .

Conversão das accões nominativas, 283.

Direito autoral, 266.

Execuçoẽs das sentenças estrangeiras, 299, 364.

Successões commerciaes, 282.
Martins Junior:

Fragmentos juridico-philosophicos, 225.

Historia do direito nacional, 237.

Historia geral do direito, 238.

Martos, 44.

Masse. See also Bialet Masse.

Massé, 6r.

Matienzo, 106-107.

Derecho constitucional, $127,138$.

Función const. de los ministros, I $_{3} 1$.

Gobierno representativo, 127.

Suf rajio popular, 138 .

Matraya y Ricci, 56,383 .

Matrimonial community of interest-Argentina, 63 .

(Civ. Code, Bk. 2), 64-70.

Matrimonial property:

Brazil, 255.

Chile, 390.

(Civ. Code, Bk. I), 39r-394.

Maynz, 62

Medical jurisprudence. See Legal medicine.

Medical schools-Brazil, 334.

See also Faculties of medicine.

Medina, F., 89.

Medina, J. T.:

Bibliografia, 367 .

Biblioteca hispano-chilena, 366 .

Historia y bibliografia de la imprenta, 15.

Meeting of creditors-Chile, 408.

(Code of Civ. Proc., Bk. 3), 409-412.

Meetings-Argentina, ro8.

Meira, 342.

Meirelles. See Vieto de Meirelles.

Mejia. See Ramos Mejia.

Mello.

See Braziliense Pessoa de Mello.

Soares de Mello.

Sobreira de Mello.

Mello Freire, 250-251.

Historiae juris civilis L usitani, 236 .

Institutionum juris civilis Lusitani, 249.

Mello Moraes, 3 I2.

Melo, 9r.

Derecho mercantil maritimo, 90 .

Mendes. See also Ribeiro Mendes,

Mendes, João:

Indice da Gazeta juridica, 222.

Livro das leis, 228.

Mendes, José:

Direito hypothecario, 260.

Philosophia do direito, 227.

Mendes de Almeida, C. 202, 214, 276.

Arestos do supremo tribunal, 212.

Auxiliar juridico, 232.

Codigo Philippino, 23r.

Direito civil ecclesiastico, 348.

Mendes de Almeida, F., 212. 
Menules de Almeida, João, jr., 309.

Mendes de Castro, 234.

Mendes de Moraes. See Moraes.

Mendes, Pimentel, 216, 223.

Mendesky and Son, 17 .

Mendeville. See Valdés Mendeville.

Méndez. See Ramón Méndez.

Méndez Calzada, 159.

Mendicancy-Argentina, 160.

Mendonça, 221.

See also Carvalho de Mendonça.

Menezes, 264-265. Sousa Furtado de Mendonça.

See also Barreto de Menezes.

Doria.

Drummond.

Menjou, 168

Octavio de Langgaard Menezes.

Mercan. 74.

Mercantile books (Commercial books):

Argentina, 78.

(Comm. Code, Bk. I), $79-84$.

Brazil, 277-278.

Mercantile deposit. See Deposit.

Merchant marine:

Argentina, 152-r 53 .

Brazil, 284.

Chile, 398 .

Merchants:

Argentina, $78,188$.

(Comm. Code, Bk. 1), 79-84.

Brazil, 272.

(Comm. Code, Pt. r), 273-277.

Chile, 397.

(Comm. Code, Bk. I), 399-400.

Mercurio, 23.

Mérou. See García Mérou.

Miall, 166.

Miatello, 148.

Military courts-Brazil, 346.

Military criminal law-Brazil, 307.

Military law:

Argentina, 4x, 118, 132, 171-1 73 .

Brazil, 218, 307, 325, 346-347.

Chile, $438-440$.

Military procedure-Argentina, 118 .

Military schools-Brazil, 334

Militia-Buenos Aires (Prov.), 140.

Milton, 317.

"Mindello," 36 r.

Mines, School of-Brazil, 334-335.

Mining engineers-Argentina, 149.

Mining concessions-Argentina, 149.

See also Concessions.

Mining law:

Argentina, 4I, 46, 146, 148-i 50.

Brazil, 33I-333.

Chile, 378, 424, 426-431.
Minors:

Argentina, 62.

(Civ. Code, Bk. I), 64-70.

Brazil, 302, 304

(Crim. Code, Bk. 2), 302-304.

Mint-Argentina, 167.

Miranda, ${ }^{6} 6$.

Miranda Montenegro. See Montenegro.

Miranda Naon, rro.

Misdemeanors-Argentina, II6.

Missionaries-Chile, 425 .

Mistake-Brazil, 245.

(Civ, Code, Gen, Pt., Bk. 3), 248-252.

Mittermaier, 52.

Molina, 188.

See also Daireaux Molina. Silva y Molina.

Molina Arrotea, 35.

Molina Ramos, 376, 41r.

Molitor, 62.

Money (Monetary system):

Argentina, 68.

Brazil, 338.

Chile, 382, 434.

Monguillot, 37 .

Moniz, 282.

Moniz Sodré, 305.

Monroe doctrine, 183 .

Monsegur, r89.

Montalvo, Ordenamiento de, 53 .

Montané, U., 442.

Monte. See José de Monte.

Monte Rodrigues d'A raujo, 348.

Monteiro:

Applicações de direito, 220.

Direito das acções, 294.

Processo civil, 292.

Universalisação do direito, 220.

Montemayor, 386 .

Montenegro:

Leyes usuaes, $218,274$.

Trabalhos judiciarios, 214 .

Montero, 160 .

Montes. See Bascuñán Montes.

Montes de Oca, J. J., 45, 47, 118.

Apuntes biograficos, $5 \mathrm{r}$.

Estudio del derecho, 43, 5I.

Procedimientos civiles, 99.

Montes de Oca, M. A., 48, 116 .

Cuestiones constitucionales, 127 .

Derecho constitucional, 121, 127.

Estudio del derecho, 51, 59.

Montt, A., 370.

Dictamen . . s sobre las reclamaciones, 444.

Dictamenes, 424, 445 .

Montt, L., 367.

Montt, R., 439.

Moore, 357. 
Mora, 44I.

Moraes. See also Mello Moraes.

Moraes, E., 306.

Moraes, J. M., 3 II.

Moraes Carvalho, 292.

Morales, 435.

Fondos fiscales, $43 \mathrm{r}$.

Moratorium-Argentina, 9r.

Morelli, 174.

Moreno. See also Ruiz Moreno.

Moreno, J. M., 47, 67, 99.

Obras juridicas, 45 .

Quiebras, 9r.

Moreno, R., 143.

Ley penal, irx.

Las personas, 70.

Moritán, 37.

Morrison Faria, 214.

Mortgage banks:

Argentina, 72, 165-166.

Brazil, 339.

Chile, 434-435.

Mortgages:

Argentina, 63, 71-72, 147 .

(Civ. Code, Bk. 3), 64-70.

Brazil, 20I, 219-220, 247, 258-261, $272,282$. (Civ. Code, Spec. Pt., Bk. 2), 248-252. (Comm. Code, Pt. r), 273-277.

Chile, 391, 395, 402.

(Civ. Code, Bk. 4), 39r-394.

Mortgages, agricultural-Argentina, 72, 86.

Mortgages, chattel-Brazil, 2 I9.

Mortgages, maritime. See Maritime mortgage.

Mortmain-Brazil, 295.

Most-favored-nation clause, 177,445 .

Moulin, 182.

Moura, 26r.

Moura Romeiro. See Romeiro.

Moyano Gacitúa, ro7, Irr.

Ciencia criminal, r ro.

Delincuencia arg., ris.

Municipal corporations. See Municipalities.

Municipal courts (Alcaldias)-Argentina, 93-94.

See also Courts.

Municipal officers-Brazil, 328.

Municipal ordinances:

Buenos Aires (City), 25-26.

Chile, 423-424.

Municipal organization-Federal District

(Brazil), $211,320,329$.

Municipalities (Cities):

Argentina, 4I, 14I-142, 146. Buenos Aires (Prov.), 42, 140.

Brazil, 313, 325, 328-329. Federal District, 322 .

Chile, 420, 422-424.

Muñoz, E. W., I13.
Muñoz, F. R., 376.

"Museo Mitre," 16.

Museo Social Argentino, 14.

Museum, National-Brazil, 328.

Muzlera:

Recopilación de leyes, 24.

Tierras públicas, 146 .

Nabuco de Araujo. See Araujo.

Names, Commercial. See Trade-marks.

Naon. See also Miranda Naon.

Naón:

Argentine constitutional ideas, 129.

Derecho comercial maritimo, 89.

Nascimento e Silva:

Consultas de conselho de estado, 346 .

Synopsis de legislação, 346 .

Nascimento Silva. See Silva.

Natal, 326.

National archives. See Archives.

National banks:

Argentina, 164-165.

Chile, 434 .

National debt. See Public debts.

National Guard:

Argentina, 173.

Brazil, 313, 328, 347.

National holidays-Brazil, 322.

National organization-Brazil, 320.

National territories. See Territories.

Nationality:

Argentina, 134, I7x, 179, 188-189.

Brazil, 320, 354, 363 .

Natives (Indigenous law):

Argentina, 58-59.

Chile, 425 .

Natural law:

Argentina, 174

Brazil, 347.

Naturalization:

Argentina, 134, 158, 178-1 79.

Brazil, 201 , 218, 220, 324, 328, 351, 354-356

Naturalization treaties-Brazil, $35 \mathrm{I}$.

Naturalized citizens-Brazil, 35x.

Naval law:

Argentina, 54, 153, $171-173$.

Brazil, 218, 307, 325, 346-347.

Chile, 438-440.

Spanish, 54

Naval penal code-Brazil, 307 .

Naval school-Brazil, 334.

Navarro Viola, A., 14.

Navarro Viola, E., 14

Navarro Viola, M., 47.

Patronato, 174.

Navigation:

Argentina, 76, 152-153, 169 .

Brazil, 219, 284.

Chile, 398, 401-403. 
Negotiable instruments-Brazil, 272, 294.

(Comm. Code, Pt. r), 273-277.

Negotiorum gestio-Brazil, 247.

(Civ. Code, Spec. Pt., Bk. 3), 248-252.

Neira. See Rueda y Neira.

Neutrality:

Brazil, 353-354.

Chile, 444 .

Newmann, 4r4.

Nicolas Anrique. See Anrique.

Night work-Argentina, 156.

Nitrate-Chile, 429-43I.

Nogueira Almeida:

Direito da União, 343.

Emprestitos externos, 343.

Fiança ás custas, 297.

Marcas industriaes, 269.

Patentes de invencão, 267.

Nogueira Coelho, 254

Nogueira Itagyba:

A posse, 258.

Seguros de vida, 283

Noncontentious jurisdiction:

Chile, $403,409$.

(Code of Civ. Proc., Bk. 4), 409-4I 2. Federal District (Braz.), 290.

Noronha. See Castilho Barreto a Noronha. Notaries:

Argentina, 42, 88, 104-105.

Buenos Aires, ro5.

Chile, 404, 410-4Ir.

Notice, ten-day-Brazil, 294.

Novaro, 35

Novation:

Argentina, 62.

(Civ. Code, Bk. 2), 64-70.

Brazil, 247.

(Civ. Code, Spec. Pt., Bk.3), 248-252.

Novisima Recopilacion, 53, 54, 384, 406 .

Nueva Recopilacion, 53, 57.

Nueva revista de Buenos Aires, 47.

Nunez do Leão, 230.

Nuno Pinheiro de Andrade. See Pinheiro de Andrade.

Nurnberg Novels, 76 .

Nys, 176.

Oaths-Brazil, 293.

Obarrio, 80, 119.

Codigo de comercio, 80-8r.

Derecho comercial, 8I.

Derecho comercial maritimo, 89.

Derecho penal, iro.

Digesto de ordenanzas, 26.

Proyecto, I15, II6.

Quiebras, 91.

\section{Obligations:}

Argentina, 62-63, 69, 78, 188-189.

(Civ. Code, Bk. 2), 64-70.

(Comm. Code, Bk. 2), 79-84.

Brazil, 247-249, 262-263, 272, 277, 362 .

(Civ. Code, Spec. Pt., Bk. 3), 248252.

(Comm. Code, Pt. I), 273-277.

Chile, 391, 394, 398.

(Civ. Code, Bk. 4), 391-394.

(Comm. Code, Bk. 2), 399-400.

Oca. See Montes de Oca.

Ocampo, 397.

Ocantos, 22.

Occupation. See Use and occupation.

Octaviano Ferreira. See Ferreira.

Octavio de Langgaard Menezes, Rodrigo,

$215,254,257,266,274,279,280,297,324,354$,

355,363 .

Do cheque, $28 \mathrm{r}$.

A codificação do dir. int. priv., 363 .

Constituições federacs, 316.

Direito do estrangeiro, 354, 362, 363 .

Direito int. privado, 362 .

Dominio da união e dos estados, 320.

Droit international privé, 299, 362 .

Elementos de direito, 317.

Festas nacionaes, 322.

Letra de cambio, 280 .

Le mariage, 257.

Terras particulares, 259.

L'union juridique de nations, 363 .

Octavio Kelly. See Kelly.

O'Dena, 162.

Officers, Administrative:

Argentina, 102.

Buenos Aires (Prov.), ro2.

Officers, municipal-Brazil, 328.

Officers, Public. See Public officers.

Official gazettes:

Argentina (Boletin oficial), 20.

Buenos Aires (Prov.), 15-16, 23.

Other provinces, 26-29.

Brazil, 198-r99. States, $21 r$.

Chile, 369-37I.

Official register (Notaries)-Argentina, ro4. Olascoaga, 134, 138 .

Old-age pensions-Argentina, 158.

Olguin, 437.

Oliveira.

See also Almeida Oliveira.

Candido de Oliveira.

Cardoso de Oliveira.

Escorel.

Oliveira, C. L. M., 252 
Oliveiro Bello. See Bello.

Oliveira Fonseca, 243.

Oliveira Frcire. See Freire.

Oliveira Freitas, 353.

Oliveira Lima:

The evolution of Brazil, 313 .

Historia diplomatica, 358 .

Relations of Brazil with the United

States, 359.

Oliveira Machado:

Aggravos, 298.

Guia dos tabelliães ou o notariado, 298.

O Habeas corpus, 31 r.

Registro geral, 26r.

Olivera, 154 .

Olmos. See Luna Olmos.

Olympio Barretto. See Barretto.

Olympio de Torres Bandeira. See Torres Bandeira.

Olympio Viveiros de Castro. See Viveiros de Castro.

Olyntho de Magalhães. See Magalhães.

Oneto y Viana, 360.

Ordenações Affonsinas, 228-230.

Ordenações de Don Duarte, 228-229.

Ordenações Manuelinas, 230.

Ordenações Philippinas, 230.

Ordenações do Reino, 229.

Ordenamiento de Alcalá, 53, 57.

Ordenamiento de Montalvo, 53.

Ordenanza de Bilbao, 54, 57, 76, 384, 396.

Ordenanza de Intendentes, 56,384 .

Ordenanza de Matriculas, 54 .

Ordenanza Naval, 54 .

Ordenanzas de Minería de Nueva Esspaña, 384 .

Ordenanzas de Nueva España, 148, 427-428. Ordenanzas del Pcru, 427-428.

Ordenanzas de Toledo, 54-56.

Ordenanzas Generales de la Armada Naval,

54.

Ordenanzas Militares, 54 .

Ordenanzas de Burgos, 76 .

Ordenanzas Reales de Castilla, 53, 57.

Orellana Vilches. See Vilches.

Orgaz:

Funcion const., de los ministros, I3I.

Sociedades anonimas, 189 .

Oriental pest-Argentina, $16 \mathrm{r}$.

Orlando, 226.

Orlando de Araujo Costa, 274, 292.

- Orma, 139.

Orosimbo, 33r.

Orphans-Argentina, 160.

Orphan's court-Brazil, 296.

Orrego Ovalle, 374, 417, 421 .
Ortiz. See Fuente Ortiz.

Osorio. See Assump zão Osorio.

Otero Espinosa, 409.

Ouro Preto, 221, 305.

Credito movel, 279.

Marcas industriaes, 269.

Ovalle. See Orrego Ovalle.

Ovidio da Gama Lobo. See Gama Lobo.

Ownership:

Argentina, 63.

(Civ. Code, Bk. 3), 64-70.

Brazil, 246.

(Civ. Code, Spec. Pt., Bk. 2), 248-252.

Chile, 390.

(Civ. Code, Bk. 2), 39r-394.

Pablo Figueroa. See Figueroa.

Pacheco, A. F. C.:

Direito de retenção, 258 .

Privilegios creditorios, 263 .

Pacheco, J. E., 242.

Padrón jeneral de minas, 429.

Palacios, A. L.:

Acción socialista, 159 .

Actuacién parlamentaria, 159 .

En defensa de los trabajadores, 159.

Justicia militar, 173 .

Palacios, F. M., 9x, 156.

Palma, A., 395.

Palma, G. L., 38r.

Palomeque:

Código de proc. penal, rrg.

La jurisdiccićn del Plata, 186.

Pamphilo d'Assump;ão. See Assumpção.

Pan American conference, 180.

Pan American Convention, 265, 267.

Pan American Union:

Arg. tariff law, I7r.

Brazil, 3 I5.

Patent and trade-mark laws, 74, 75, 266-267, 268.

Pandiá Calogeras, 332.

Pando, 443.

Pappafava, 355.

Parcel-post convention:

Argentina, 154.

Brazil, 35r.

Pardons-Brazil, 306, 3Ix.

Parent and child:

Argentina, 62.

(Civ. Code, Bk. I), 64-75.

Brazil, 246, 255.

(Civ. Code, Spec. Pt., Bk. I), 248252.

Chile, 390 .

(Civ. Code, Bk. I), 39r-394. 
Parliamentary government - Argentina, I30.

Parliamentary law:

Argentina, 130.

Brazil, 322.

Chile, 4 Ig.

Parliamentary precedents-Argentina, 130.

Parody, I04.

Partidas, Siete, 53, 54, 57, 385, 406.

Parties to actions-Brazil, 293.

Partition-Brazil, 248, 259, 264-265.

(Civ. Code, Spec. Pt., Bk. 4), 248-252. Partnership:

Argentina, 63, 69, 78.

(Civ. Code, Bk. 2), 64-70.

(Comm. Code, Bk. 2), 79-84.

Brazil, 247, 28r.

(Civ. Code, Spec. Pt., Bk. 3), 248252.

Chile, 391, 398.

(Civ. Code, Bk. 4), 39r-394.

(Comm. Code, Bk. 2), 399-400.

Pascoal José de Mello Freire. See Mello

Freire.

Passage tickets-Brazil, 282.

Passenger traffic-Argentina, 79, 153.

(Comm. Code, Bk. 3), 79-84.

Patentes y marcas, 74

Patents:

Argentina, 42, 73-74, 79, $88 \mathrm{x}$.

Brazil, 219, 247, 266-267.

(Civ. Code, Spec. Pt., Bk. 2), 248252.

Chile, 396.

International treaties, 187 .

Paternal power (Patria potestas):

Argentina, 62.

(Civ. Code, Bk. I), 64-70.

Brazil, 246.

(Civ. Code, Spec. Pt., Bk. I), 248252.

Patria potestas. See Paternal power.

Patronato-Argentina, I73.

Paula Baptista:

Hermeneutica juridica, 254, 293.

Processo civil, 293.

Paula Lacerda de Almeida. See Lacerda de Almcida.

Panla Pessoa, 309.

Paulo de Lacerda. See Lacerda.

Paulo Domingues Vianna. See Domingues

Vianna.

Paulo Orosimbo. See Orosimbo.

Payment:

Argentina, 62-63.

(Civ. Code, Bk. 2), 64-70.

Brazil, 247.

(Civ. Code, Spec. Pt., Bk. 3), 248-
Paz, 64, 67.

See also Martinez Paz.

Pedro II, Collegio, 335.

Peixoto. See Afranio Peixoto.

Pellegrini, 166.

Pelliza, 44

Peña. See also Saenz Peña.

Pena, C. M., 421.

Pena, J., I67.

Peña, S., 423.

Penal actions. See Actions, criminal.

Penal code. See Criminal law.

Penalties:

Argentina, Io9, III, 116

Brazil, 247, 302 .

(Civ. Code, Spec. Pt., Bk. 3), 248252.

(Crim. Code, Bk. r), 302-304.

Chile, 4I4.

Penitentiaries:

Argentina, 114

Brazil, 305 .

Penology-Argentina, Ix4-115.

Pensions-Argentina, 39, 42, 140, 158, 16016r, r69.

Perdigão, 222.

Codigo penal, 30 .

Perdigão Malheiro, 323.

Peregrino da Silva, 193.

Pereira:

See Agapito Pereira.

Clemente Pereira.

Fulgencio Alves Pereira.

Lafayette Rodrigues Pereira.

Silva Pereira.

Pereira da Silva Continentino. See Continentino.

Pereira da Silva Ramos. See Silva Ramos.

Pereira de Barros. See Barros.

Pereira de Carvalho, 295.

Pereira de Castro, 232.

Pereira do Rego. See Rego.

Pereira e Souza, 292.

Percira Leal Sobrinho. See Leal Sobrinho.

Pereira Monteiro. See Monteiro.

Pereira Pinto; 349.

Pereira Vianna, 335.

Pereyra. See Solórzano y Pereyra.

Pérez, 3 I.

Perez de Arce:

Administración pública, 422.

El administrador público, 422.

Performance-Brazil, 262.

Periodicals:

Argentina, 15, 47-49.

Brazil, 212-213, 221-223.

Chile, $379-380$.

Personal property. See Property and Things. 
Personal status. See Civil status registration.

Persons:

See also Juristic persons.

Argentina, 62, 7o.

(Civ. Code, Bk. I), 64-70.

Brazil, 244, 254, 302, 362 .

(Civ. Code, Gen. Pt., Bk. I), 248-252

(Crim. Code, Bk. 2), 302-304.

Chile, 390

(Civ. Code, Bk. r), 39r-394

Peruvian law, 53-6o.

Pessoa, See also Paula Pessoa.

Pessoa:

Projecto do codigo de direito int. privado, 363 .

Projecto de codigo de direito int. pub-

lico, 353.

Terrenos de marinha, 322 .

Pessoa de Mello, See Braziliense Pessoa de Mello.

Pest, Oriental-Argentina, 16 r.

Pestalardo, 50.

Petition, Right of-Chile, 418.

Peyret, 84

Phaelante da Camara, 304 .

Pharmacy-Argentina, 16r.

Philippi, 399, 445.

Philippino, Codigo, 197, 230-235.

Phillips, 196.

Philosophy of law:

Argentina, 51-52.

Brazil, 224-227.

Chile, 382 .

Piedade, See Alencar Piedade.

Pillado:

Ley de cabotaje, 153.

Politica comercial, 171 .

Tratados de comercio, 84, 177 .

Pilots-Argentina, 153

Pimenta Bueno:

Direito int. privado, 363 .

Direito publico, 313, 325.

Formalidades, 294.

Processo criminal, 309.

Pimentel. See Mendes Pimentel.

Pinedo, 188.

Piñera, E., 377 .

Piñero, N., 106-107, IIr.

Apuntes de derecho penal, Iro.

Funcion const. de los ministros, 13 r.

Piñero, O. M.:

Derecho penal. Apuntes ..., IIr.

Derecho penal; conferencias, 1 rr.

Pinheiro, 2i4, 276.

Pinheiro de Andrade, 326.

Pinheiro Lima. See Machado Pinheiro Lima.
Pinto:

See Gouvea Pinto.

Magalhães Pinto.

Pereira Pinto.

Souza Pinto.

Pinto de Miranda Montenegro. See Montenegro.

Pinto Izarra, 400

Pinto S., 410.

Pires Machado Portella. See Machado Portella.

Placido Barbosa. See Barbosa.

Plaza, 377.

Pleading:

See also Civil procedure and Criminal procedure.

Brazil, 294.

Buenos Aires (City), 103.

Buenos Aires (Prov.), ro3.

Chile, 407.

(Code of Civ. Proc., Bk. I), 409-412.

Pledge:

Argentina, 63, 78 .

(Civ. Code, Bk. 3), 64-70.

(Comm. Code, Bk. 2), 79-84.

Brazil, 247, 272, 278, 282.

(Civ. Code, Spec. Pt., Bk. 2), 248252.

(Comm. Code, Pt. r), 273-277.

Chile, 398.

(Comm. Code, Bk. 2), 399-400.

Pledge, agricultural-Argentina, 86

Poblete:

Derecho industrial, 426 .

Hacienda publica, 435 .

Podestá Costa, 180 .

Police:

Argentina, 146, 152, I6r.

Buenos Aires (City), 26.

Buenos Aires (Prov.), 140 .

Brazil, 309, 313, 325, 328.

Federal District, 306 .

Chile, $415,420$.

Political crimes-Brazil, 302.

(Crim. Code, Bk. 2), 302-304.

Pclitical parties-Argentina, $\mathbf{1}_{32}, 134$

Polycarpo Lopes de Leão, See Lopes de

Leão.

Ponce, M., 33.

Ponce, M. A., 432.

Poor laws-Argentina, 160.

Porchat, 254.

Portella, See Machado Portella.

Porto. See Campos Porto.

Port dues-Argentina, 153, 171.

Portales Riesco, 426.

Portella, 222 
Ports:

Argentina, 153, I71.

Brazil, 329-330.

Portugaliae Monumenta historica, 228.

Posada, 125.

La República Argentina, 158.

Possession:

Argentina, 63, 71-72.

(Civ. Code, Bk. 3), 64-70.

Brazil, 246, 258-259.

(Civ. Code, Spes. Pt., Bk. 2), 248-252.

Chile, 390.

(Civ. Code, Bk. 2), 391-394.

Possessory actions. See Actions, possessory.

Postal conventions-Argentina, 154 .

Postal laws:

Argentina, 39, 42, 153-155.

Brazil, 325, 33I.

Chile, 374, 432.

Postal savings banks:

Argentina, 166.

Brazil, 338.

Pothier, 62.

Powers of attorney-Brazil, 296-297.

Pozzo, 168.

Prack, 102.

Pradel, 399.

Prado, 422.

Prado y Rojas, 24.

Prayones, 72.

Preliminary examination-Argentina, 116 II8.

Prescription:

Argentina, 63, 69 .

(Civ. Code, Bk. 4), 64-70.

Brazil, 245, 255, 272, 283.

(Civ. Code, Gen. Pt., Bk. 3), 248-252.

(Comm. Code, Pt. x), 273-277.

Chile, $391,398$.

(Civ. Code, Bk. 4), 391-394.

(Comm. Code, Bk. 2, 3), 399-400.

President-Brazil, 313, 322, 325.

Presidential messages:

Brazil, 322.

Chile, 387 .

Press:

Argentina, 108, 117-118.

Chile, $4^{18} 8$.

Presumptions-Brazil, 293.

Preto. See Ouro Preto.

Prince of Wales, $360-36 \mathrm{r}$.

Prison reform-Argentina, II4.

Prisoners-Argentina, 88.

Prisons:

Argentina, 42, 88.

Buenos Aires (Prov.), r40

Brazil, 306.
Private instruments:

Argentina, 63.

(Civ. Code, Bk. 2), 64-70.

Brazil, 299.

Private international law, See Conflict of laws.

Private law:

Argentina, 44, 59.

Brazil, 221, 252, 347.

Privilege-Brazil, 263.

Prize-Chile, 404, 444.

Prize courts-Chile, 444 .

Probate law-Brazil, 219.

Federal District, 2 I9.

Probation-Brazil, 305.

Procedure:

Argentina, 42.

Brazil, 221, 292-293, 308.

Chile, 387,408 .

(Code of Civ. Proc., Bk. 3), 409-412.

Procedurc, Arbitral, See Arbitral procedure.

Procedure, Commercial, See Commercial procedure.

Procedure, military-Argentina, Ir8.

Procurators,-Chile, 404.

Produce exchanges-Argentina, 84. See also Exchanges.

Professional titles-Buenos Aires (Prov.), 140.

Professional unions and organizationsBrazil, 273.

Professions:

Argentina-

Medical, $\mathbf{x 6 r .}$

Pharmacy, 16r-162.

International treaties, 187 .

Promissory notes:

Argentina, 79.

(Com. Code, Bk. 2), 79-84.

Brazil, 272, 279.

(Com. Code, Pt. r), 273-277.

Chile, 398.

Property:

(Com. Code, Bk. 2), 399-400.

See also Public property and Things.

Argentina, 63, 189 .

(Civ. Code, Bk. 3), 64-70.

Brazil, 245-246, 250, 261, 302, 362.

(Civ. Code, Gen. Pt., Bk. 2; Spec.

Pt., Bk. 2), 248-252.

(Crim. Code, Bk. 2), 302-304.

Chile, 390 .

(Civ. Code, Bk. 2), 391-394.

Proportional representation - Argentina, 128.

Prosecuting attorneys-Argentina, 116

Protocol (Notaries)-Argentina, ro4.

Provedoria-Brazil, 295. 
Provinces-Brazil, $31_{3}$.

Provincial courts, See Courts.

Provisional remedies:

Brazil, 293.

Chile, 408.

(Code of Civ. Proc., Bk. 2), 409-412.

\section{Prudhomme:}

Code civil chilien, 391.

Code de commerce chilien, 399.

Loi argentine sur la faillite, 90 .

Psychology of law-Brazil, 227.

Public accounting-Argentina, 169.

Public administration-Brazil, 302.

(Crim. Code, Bk. 2), 302-304.

Public debts:

Argentina, 39, 85, 167-169, 182.

Brazil, 313, 339-344.

Chile, 435.

Public education, See Educational law.

Public defenders-Chile, 404.

Public faith-Brazil, 302.

(Crim. Code, Bk. 2), 302-304.

Public health:

Argentina, 16r-162.

Buenos Aires (City), 26.

Brazil, 328, 336.

Chile, 374, 420, 426, 433-434.

Public instruments:

Argentina, 105.

Brazil, 299.

Chile, 410-4II.

Public lands, See L,and laws.

Public law:

Argentina, 44, 175.

Cordoba, 137 .

Other provinces, 134-135.

Brazil, 220-221, 236, 317, 347 .

Chile, 387,416 .

Public libraries-Argentina, 164 .

Public ministers-Argentina, 93.

Public moneys-Chile, 432.

Public morality:

Argentina, 160.

Chile, 420, 433-434.

Public officers:

Argentina, 102.

Buenos Aires (Prov.), 102.

Brazil, 218, 320, 326-328.

Chile, 422.

Public order-Argentina, 132.

Public property:

Brazil, 245, 302.

(Civ. Code, Gen. Pt., Bk. 2), 248-252. (Crim. Code, Bk. 2), 302-304.

Chile, 432.

Public prosecution-Brazil, 299, 308. Public records,-Argentina, 63, 104.

(Civ. Code, Bk. 2), 64-70.

$$
71624^{\circ}-17-33
$$

Public registry (Notaries):

Argentina, 88, 104.

Chile, 411 .

Public safety-Argentina, 142.

Public service. See Public utilities.

Public tranquillity, Crimes against-Brazil. 302.

(Crim. Code, Bk. 2), 302-304.

Public utilities (Public service):

Argentina, 152, 160 .

Chile, 422.

Public welfare-Argentina, 160-16x.

Public works:

Argentina, 39-42, 136, 142, 152, 160. Mendoza (Prov.), 152.

Brazil, 313, 329, 33 I.

Chile, 43 r-432.

Publication-Brazil, 247.

(Civ. Code, Spec. Pt., Bk. 3), 248-252.

Publisher's catalogues:

Argentina-

Abeledo, 17.

Lajouane and co., 17 .

Mendesky and son, 17 .

Brazil-

Alves, 194

Ribeiro dos Santos, r94.

Pueyrredon, 97.

Puga Borne, 414.

Pujol, 309.

Punishment:

Argentina, 109-III, 114.

Brazil, $300,302$.

(Crim. Code, Bk. I), 302-304.

Purchase and sale:

Argentina, 63, 69, 78 .

(Civ. Code, Bk. 2), 64-70.

(Comm. Code, Bk. 2), 79-84.

Brazil, 247, 272.

(Civ. Code, Spec. Pt., Bk. 3), 248-252.

(Comm. Code, Pt. I), 273-277.

Chile, 391, 398.

(Civ. Code, Bk. 4), 391-394.

(Comm. Code, Bk. 2), 399-400.

Quarantine-Brazil, 336.

Quasi-contract:

Argentina, 63.

(Civ. Code, Bk. 2), 64-70.

Chile, $39 x$.

(Civ. Code, Bk. 4,) 39r-394.

Quesada, E., 14, 47, 8r, 99, ro3.

Commercial .. . law, 80 .

Comprobacion de la reincidencia, $1 x$.

Politica argentina, 183 .

Politica chilena, 183.

Propriedad intelectual, 73.

Relormas del codigo civil, 64 . 
Quesada, S. J.:

El Banco hipotecario, 166.

Bancos hipotecarios, 165 .

Economia politica, 167 .

Las finanzas, 167 .

Proyecto de reformas, 77.

Quesada, V., 428.

Quesada, V. G., 47.

Derecho de patronato, 174.

Derecho internacional, 183 .

Mis memorias diplomaticas, 359.

Quesney M., 372.

Quijada, B., 402.

Quinquennial inspections-Chile, 404 .

Quiroga, 39.

Quirós, 139.

See also Bernaldo de Quirós.

Rae. See Wilson-Rae.

Railroad concessions-Argentina, 150-152. See also Concessions.

Railroads:

Argentina, 39-41, 136, 150-152, 160 .

Brazil, 325, 329.

Chile, 374 .

Raja Gabaglia, 222.

Ramalho, 293.

Ramirez, G., 169.

Ramirez, T. A., 4 Ir.

Ciencias juridicas, 382 .

Ramirez Lastarria, 440.

Ramiz Galvão, 194.

Ramiro de Valenzuela, 57

Ramm Domán, 85 .

Ramon Briseño, See Briseño.

Ramón Méndez, ri6.

Ramos:

See also Molina Ramos. Silva Ramos.

Derecho público, 134 .

Instrucción primaria, 162 .

Poder ejecutivo, r3I.

Ramos Mejia, F., I13.

Federalismo argentino, 121, 128.

Ramos Mejia, J. M., 107, 111.

Instrucción primaria, 162.

Rau, 6r.

Raul Adalberto de Campos, See Campos.

Ravest y Campaña:

Codificación agrícola, 426.

Diccionario de jurisprudencia, 377 .

Rayneli, 185 .

Real property-Brazil, 26r. See also Property and Things.

Rebello, See Velloso-Rebello.

Rébora, 86.

Recife, Faculty of Law, 193, 223, 328 .

Recopilación de las Indias, 55, 56, 57, 383$384,385,406$.
"Recurso de casación en fondo"-Chile, 411.

Register, 269.

Register, commercial, See Commercial register.

Registration of civil status, See Civil status registration.

Registration of corporations, See Corporations.

Registration of firms-Brazil, 219, 273, 277. Registration of property:

Argentina, $7 \mathrm{r}$.

Brazil, 20r, 247, 261.

(Civ. Code, Spec. Pt., Bk. 2), 248-252.

Chile, 390.

Registration of titles of indebtedness and bonds-Brazil, 2 r9.

Registry, Public, See Public registry.

Rego, 325 .

Rego Barros, 326.

Relatives, obligation of-Argentina, 62 . (Civ. Code, Bk. I), 64-70.

Relators-Chile, 404 .

Release from prison-Argentina, 116.

Religious corporations-Brazil, 295.

Religious persons-Argentina, 174 .

Religious worship-Chile, 418.

Remijio de Bellido, See Bellido.

Remission of debt:

Argentina, 63. (Civ. Code, Bk. 2), 64-70.

Brazil, 247.

(Civ. Code, Spec. Pt., Bk. 3), 248-252.

Removal of causes-Argentina, 96 .

Rengifo, 4I2.

Rents-Chile, 408.

(Code of Civ. Proc., Bk. 3), 409-412.

Renunciation-Argentina, 63 .

(Civ. Code, Bk. 2), 64-70.

Representation:

Argentina, 128.

Brazil, 248.

(Civ. Code, Spec. Pt., Bk. 4) 248-252.

Reputation and honor, Crimes againstBrazil, 302.

(Crim. Code, Bk. 2), 302-304.

Requena, 22.

Resistance, Right of-Argentina, 132.

Responsibility, criminal, See Criminal responsibility.

Responsibility of the State:

Argentina, 180 .

Brazil, 221, 325, 327.

Chile, 424-425.

Restell1, 134. 
Restitution-Brazil, 245.

(Civ. Code, Gen. Pt., Bk. I), 248-252.

Retention, right of-Brazil, 258.

Retirement funds-Argentina, 160 .

Retroactivity of law:

Brazil, 254.

Chile, 390.

Reunion-Argentina, 158.

Reus, 4 r6.

Revenue-Brazil, 3 I9.

Revenue, Internal. See Internal revenue.

Revista annual, 217 .

Revista argentina de ciencias politicas, 48 .

Revista da Faculdade de Direito, 223.

Revista de bibliografia chilena y extranjera, 368.

La Revista de Buenos Aires, 47.

Revista de derecho, historia y letras, 48 .

Revista de derecho, jurisprudencia y ciencias sociales, 376,379 .

Revista de derecho y jurisprudencia, 379 .

Revista de direito civil, comercial e criminal, 213, 222.

Revista de direito e processo penal, 306 .

Revista de jurisprudencia, 22.

Revista de la Facultad de derecho y ciencias sociales (Buenos Aires), 48

Revista de legislación y jurisprudencia, $22,40,49$.

Revista de lejislacion y jurisprudencia, 47.

Revista de los tribunales, 376 .

Revista de tribunales, 379 .

Revista del centro estudiantes de derecho, 49.

Revista del notariado, 49.

Revista diplomatica y consular argentina, 186.

Revista do fôro, 2 I8.

Revista do Instituto da ordem dos advogados brazileiros, 222.

Revista do instituto historica e geographico brazileiro, 196 .

Revista do Supremo Tribunal, 2 I2.

Revista dos tribunaes, 217 .

Revista forense (Minas Geraes), 2 r6, 223.

Revista forense (Sergipe), 218.

Revista forense chilena, 379.

Revista juridica y de ciencias sociales, 48 .

Revista mensal das decisões, 217.

Revista predial, 26 r.

Revocation (wills)-Brazil, 248.

(Civ. Code, Spec. Pt., Bk. 4), 248-252.

Reward-Brazil, 247.

(Civ. Code, Spec. Pt., Bk. 3), 248-252. Reyes

See also Amunátegui Reyes. Echeverria y Reyes.
Reyes, A., 412, 413, 414.

Reyes, A. G., $4 \mathrm{rr}$.

Reyes, C., 40, II3.

Reynaldo Porchat. See Porchat.

Rezende

See Astolpho de Rezende. Barbosa de Rezende.

Ribas, A. J., 240.

Direito administrativo, 325 .

Direito civil, 228, 25 I.

Da posse, 258.

Processo civil, 291.

Ribas, J. A., 291.

Ribeiro

See also Carneiro Ribeiro.

Figueiredo Ribelro.

Vidal [Leite Ribeiro], Armanda.

Ribeiro, Annibal A., 274

Ribeiro, Antonio, 232.

Ribeiro, J. P., 232.

Indice chronologico, 229, 234

Synopsis chronologica, 229.

Ribeiro de Moura. See Moura.

Ribeiro dos Santos, 194.

Ribeiro Mendes, 215

Ricci. See Matraya y Ricci.

Riesco

See Portales Riesco.

Valdés Riesco.

Right of petition-Chile, 418.

Rio. See Del Rio.

Rio de Janeiro:

Faculty of law, 223.

Municipal library, 194.

National library, 196.

Ríos. See Tagle Ríos.

Ríos Arias, 424.

Riparian rights-Brazil, 330.

Risopatrón:

Código de procedimiento civil, 4 ro.

Diccionario, 379.

Tribunales, 405 .

Risopatrón Cañas, 438.

Rivarola, 48, 106, 107, III, 131

Código penal, rog.

Derecho civil, 69.

Derecho penal, rog.

J. M. Fistrada, 126 .

Justicia en lo criminal, xr8.

Proyecto de ley, ror-roz.

Regimen federativo, 128 .

Rivera, See Amunátegui y Rivera.

Rivers:

See also Waters.

Argentina, 127.

Brazil, 259, 330.

Rivier, 176 . 
Roads:

Argentina, 147.

Buenos Aires (Prov.), 147.

Chile, $425-426$.

Roberto da Cunha Salas, See Cunha Salas.

Rocha, See also Coelho da Rocha.

Rocha, F. J.:

Commandita por acşōes, 281 .

Sociedades em commandita, 281.

Rocha, T. J., 193.

Rocha Vianna, 348.

Rodrigo Octavio de Langgaard Menezes, See Octavio de Langgaard Menezes.

Rodrigues, See also Coelho Rodrigues.

Rodrigues, João J.:

Consultas juridicas, $22 \mathrm{r}$.

Miscellanea juridica, 2 rg.

Rodrigues, José C., 195.

Rodrigues d'Araujo. See Monte Rodrigues d'Araujo.

Rodrigues de Sousa, 313.

Rodrigues Pereira. See L,afayette Rodrigues Pereira.

Rodriguez, Abraham, 388.

Rodríguez, Agustin, 4II.

Rodriguez, Alberto M., 100.

Rodriguez, Aristobulo, 189.

Rodriguez, E., 152.

Código de minería, $\mathbf{1 4}^{8}$.

Rodriguez, J. I., I23, 315, 416.

Rodriguez Anido, 168.

Rodriguez Bravo, $4 \mathrm{I} 9$.

Rodriguez de la Torre, 74 .

Rodriguez del Busto, 130 .

Rodriguez Muñoz. See Muñoz.

Rojas. See also Prado y Rojas.

Rojas, J. A., II3.

Rojas, R., 46.

Roldán, 159.

Roldán y Alvarez, 418.

Romañach, Iro.

Romeiro, 304.

Romero, M., 139.

Contencioso administrativo, 143.

El parlamento, $x 30$.

Roméro, S., 225, 238, 242, 253.

Extradicão, 300.

Philosophia do direito, 225 .

Rómez, 39s.

Romualdo Antonio de Seixas. See Seixas.

Rómulo Arriagada M. See Arriagada M.

Rosales, 433.

Roth, 86.

Roura. See González Roura.

Rueda y Neira, 414 .

Ruz. See Castro Ruiz.

Ruiz de la Barra, 409.

Ruiz Guiñazú:

Quiebras, 90.

Seguros agricolas, 85

Ruiz Moreno, 13r.
Rules, House and Senate-Argentina, 130.

Rural code:

Argentina, 4I, 43, 146-148. Territories, 4I.

Buenos Aires (Prov.), 4I, 247 .

Rural police-Argentina, 146.

Russi, 23.

Russo, 158.

Rutter, 170, 345, 437.

Ruy Barbosa. See Barbosa.

Ruy Fernandez. See Fernandez.

Sá Albuquerque, 261, 294, 298.

Casamento civil, 257.

Leis das alfandegas, 344 .

Reforma judiciaria, 290.

Repertorio juridico, 219 .

Utilidade publica, 33 I.

Sá Vianna.

See also Vianna.

Augusto Teixcira de Freitas, 250.

Direito internacional, 353.

Das fallencias, 285.

Saavedra, I07, III.

Sacramento Blake, 193.

Sáenz, 52.

Saenz Peña:

Derecho publico, 18 a.

Escritos, 46.

Saenz Valiente, 49.

Régimen municipal, $\mathbf{4} 4$.

Saez, 67 .

Safety of the state-Brazil, 302.

(Crim. Code, B1. 2), 302-304.

Sagarna, II 8

Sagui. See Esteves Sagui.

Sala, 386.

Salaries-Argentina, I69.

Salas.

See also Claro Salas.

Cunha Salas.

Ghigliotto Salas.

Salas, 165

Salas Lavaqui, 439.

Saldanha da Gama, 194.

Saldias.

Historia de la constitución, 121.

Politique italienne, 178 .

Un siglo de instituciones, 136 .

Sale. See Purchase and sale.

Salustiano Orlando de Araujo Costa. See

Orlando de Araujo Costa.

Salvador, I0I-102.

Salvador Moniz. See Moniz.

Salvage-Brazil, 273, 284.

(Comm. Code, Pt. 2), 273-277.

Sánchez, 419.

Sanchez Sorondo, G., 80 .

Sanchez Sorondo, M. G., 150.

Minas y rural, $x 50$.

Posesión hereditaria, 72.

Tierra publica, $\mathbf{4} 4$. 
Sanchez Sorondo, M. H., 147 .

Sanitary affairs:

Argentina, 142, 147, 153, $161-162,181$.

Brazil, 336.

Chile, 420, 434 .

Santelices, 434.

Santiago, 424.

Santiago Lazo. See Lazo.

Santíago Prado. See Prado.

Santo. See Esplrito Santo.

Santos.

See Felicio dos Santos.

Ribeiro dos Santos.

Santos Lira Smith. See Lira Smith.

São Paulo, Faculty of Law, 193, 223, 328.

Saraiva:

A cambial, 280 .

Direito cambial, 279 .

Sarmiento, 46, 127 .

La constitución, 124-135.

Discursos populares, 46 .

Obras de . ., 45.

Sarsfield. See Velez Sarsfield.

Sasso, 117 .

Savigny, 52, 62.

Savings banks:

Argentina, 165-166.

Brazil, 338.

Chile, 434.

School law. See Education.

Schools:

See also Law schools.

Medical schools.

Military schools.

Naval school.

School of mines-Brazil, 334-335.

Schools of criminal law:

Argentina, 107-110, 111, 113-114.

Brazil, 305 .

Scientific institutions-Brazil, 328.

Seashore (Terrenos de marinha)-Brazil, 321.

Seabra. See Garcia Seabra.

Sealed instruments-Argentina, 63, 104. (Civ. Code, Bk. 2), 64-70.

Securities:

Argentina, 85 .

Brazil, 302.

(Crim. Code, Bk. 2), 302-304.

Security-Brazil, 247.

(Civ. Code, Spec. Pt., Bk. 3), 248=252.

Security for costs-Brazil, 244, 297.

(Civ. Code, Introd. Act), 248-252.

Security of person and life, Crimes agaiustBrazil, z०o?.

(Crim. Code, Bk. 2), 302-304.

Seeber, 36 .

Segovia, 52, 61, 76, 77 .

Codigo civil argentino, 68.

Código civil del la Rep. Arg., 67.
Segovia-Continued.

Código de comercio, 8i-82.

Derecho internacional, 187.

Seixas, 256.

Seizure of merchandise-Brazil, 273.

Senate manual-Brazil, $3^{22}$.

Senate rules-Argentina, 130 .

Sentences:

Argentina, 116, 118.

Brazil, 302.

(Crim. Code, Bk. I), 302-304.

Separation:

Argentina, 70.

Brazil, 201, 246, 256.

(Civ. Code, Spec. Pt., Bk. 1), 248252.

Serú:

Fallos, 32.

Repertorio, I9.

Servitudes:

Argentina, 63.

(Civ. Code, Bk. 3), 64-70.

Brazil, 247, 258, 26r, 332.

(Civ. Code, Spec. Pt., Bk. 2), 24 $^{8-}$

252.

Chile, 390, 426.

(Civ. Code, Bk. 2), 39x-394.

Severo Vidal. See Vidal.

Sevilla. Archives of the Indies, 59-60.

Shares of stock-Brazil, 282.

Sheriffs-Chile, $4^{\text {Io. }}$

Shilton, $18 \mathrm{r}$.

Ship brokers-Brazil, 273.

Ships and shipping:

Argentina, 79, 152-153.

(Comm. Code, Bk. 3), 79-84.

Brazil, 273, 284.

(Comm. Code, Pt. 2), 273-277.

Chile, 398.

(Comm. Code, Bk. 3), 399-400.

Shipwrecks:

Argentina, 79.

(Comm. Code, Bk. 3), 79-84.

Brazil, 273 .

(Comm. Code, Pt. 2), 273-277.

Chile, 398.

(Comm. Code, Bk. 3), 399-400.

Siburu, 82.

Sicte Partidas, 53, 54, 57, 385, 406.

Silgueira:

Estudios sobre procedimientos, 97.

Procedimientos judiciales, 96.

Silva, 308 .

See also Andrade e Silva.

Correia da Silva.

Delgado da Silva.

Joppert da Silva.

Nascimento e Silva.

Peregrino da Silva. 
Silva Alves de Azambuja Susano, See Azambuja Susano.

Silva Continentino. See Continentino. Silva Costa:

Brazil, 283.

Contracto de conta-corrente, 278 .

Direito commercial maritimo, 283.

Satisfacão do damno, 26.

Seguros maritimos e terrestres, 283,284 .

Silva Cotapos, 440.

Silva Lisboa, 269-270.

Direito mercantil, 276.

Regras da Praça, 270.

Silva Mafra. See Mafra.

Silva Pereira, 234.

Silva Ramos:

Arşões commerciaes, 296.

Contractos, 277.

Silva y Molina, 406 .

Simão Vaz Barboza L,uzitano. See Barboza Luzitano.

Simões, 342.

Singer:

Copyright laws, 73.

Trade-mark laws. 75, 268, 396.

Siqueira:

O estado civil, 257.

Practica forensa, 296.

Processo criminal, 309 .

Slander-Brazil, $22 x$.

Slavery-Brazil, 323-324.

Smith. See Lira Smith.

Saõ Paulo judiciario, O, 217.

Soares. See also Macedo Soares.

Soares, A. F., 7r.

Soares, C. F., 167 .

Soares de Mcllo, 329.

Sobreira de Mello, E. X., 326.

Sobreira de Mello, Eduardo Xavier, 364.

Sobreira de Mello, Emilio X., 342.

Sobrinho. See Leal Sobrinho.

Social legislation-Argentina, 155-161.

Social security-Argentina, Ic8.

Sociedad nacional de mineria, $430-431$.

Sodré. See Moniz Sodré.

Solar:

See Aldunate Solar.

Claro Solar.

Vial Solar.

Solicitors-Argentina-38, 39, 404.

Solidonio, 33 I.

Solórzano y Pereyra, 57, 128.

Solveyra, 165 .

Sommariva, 87 .

Soria, 26.

Soriano de Souza:

Direito publico, 3 I 7 .

Philosophia do direito, 225.

Sorondo. See Sanchez Sorondo.
Sosa Escalada, 360.

Sousa. See Rodrigues de Sousa.

South American Congress, 187.

Souza:

See also Inglez de Souza.

Marnoco e Souza.

Pereira e Souza.

Soriano de Souza.

Tarquinio de Souza.

Souza Bandeira, 218, 221, 315 .

$\mathrm{O}$ recurso de graça, 3 II.

Souza Furtado de Mendonça, 203.

Souza Lima, 306.

Souza Pinto, 354 .

Souza Pinto, A., 275.

Souza Pinto, J. M. F., 292.

Souza Sá Vianna. See Sá Vianna.

Sovereignty-Brazil, 31 7, 319-32x.

Special proceedings-Argentina, 116,118 .

Spence, 274, 312.

Spencer, 52, 128 .

Spencer Vampré, 282.

Spindola. See Bomfim Spindola.

Stamp laws-Buenos Aires (Prov.), 25.

Stamp taxes-Brazil, 342-343.

Stamped paper:

Argentina, 42, 169.

Buenos Aires (Prov.), 42-43.

Chile, 4 ro.

The State-Argentina, 134.

State courts. See Courts.

Statistics:

See also Criminal statistics.

Buenos Aires (Prov.), 140.

Status-Argentina, 188.

Statute of limitations-Argentina, 79.

(Comm. Code, Bk. 2), 79-84

Stead, 357 .

Steam-boiler inspection-Argentina, 153.

Steam packets-Argentina, 153.

Stock, registered-Brazil, 283.

Stock and stockholders-Brazil, 282.

Stock breeding-Argentina, 148 .

Stock companies:

Brazil, 219.

Chile, 400 .

Stock corporations-Brazil, 273, 28I-282, 338 .

Stock exchanges:

See also Exchanges.

Argentina, 84-85.

Story, 125 .

Die Strafgesetzgebung der gegenwart, 303 .

Stranding-Chile, 398.

(Comm. Code, Bk. 3), 399-400.

Streams-Brazil, 330 .

Street railways:

Argentina, 151 .

Buenos Aires (City), r5I. 


\section{INDEX.}

Streets and highways:

Buenos Aires (City), 26

Chile, 420

Stricker, 227.

Strikes-Argentina, $158,160$.

Suarez, I80, 185

Subercaseaux, 435 .

Submarine cable-Argentina, 155 .

Substitution (wills)-Brazil, 248.

(Civ. Code, Spec. Pt., Bk. 4), 248-252.

Substitution of penalties-Argentina, 116.

Succession:

Argentina, 63, 67, 72, 188 .

(Civ. Code, Bk. 4), 64-70.

Brazil, 248, 264-265, 295, 354, 362.

(Civ. Code, Spec. Pt., Bk. 4), 248252.

Chile, 390, 395, 409 .

(Civ. Code, Bk. 3), 39x-394.

(Code of Civ. Proc., Bk. 4), 409-4r2.

Succession taxes-Argentina, 72.

Suff rage-Argentina, $137-138$.

Sugasti, 5 r.

Suits in forma pauperis-Chile, 408.

(Code of Civ. Proc., Bk. I), 409-412.

Sumario de la Recopilación general de leyes, 55.

Summary "execution" action-Chile, 408.

(Code of Civ. Proc., Bk. 3), 409-412.

Summary procedure-Chile, 408.

(Code of Civ. Proc., Bk. 3), 409-412.

Summons-Argentina, 95.

Sunday law-Argentina, 156.

Sunday rest-Argentina, 155, 158.

Supeña, 21 .

Supercargoes-Argentina, 79.

(Comm. Code, Bk. 3), 79-84.

Supreme military council-Brazil, 236.

Suretyship:

Argentina, 63.

(Civ. Code, Bk. 2), 64-70.

Brazil, 272.

(Comm. Code, Pt. x), 273-277.

Surrogate's court-Brazil, 295.

Survivorship-Brazil, 245.

(Civ. Code, Gen. Pt., Bk. I), 248-252.

Susano. See Azambuja Susano.

Sylvio Roméro. See Roméro.

Syndicates-Brazil, 334 .

Taboada, 115.

Tagle. See Coo Tagle.

Tagle Ríos, 423.

Taine, 128.

Tariff:

Argentina, 153, 169-171, 178

Brazil, 344-346.

Chile, 436-437.

Tarquinio de Souza, 218, 274.

Taussac, 127.
Tavares Bastos, A. C., 313.

Tavares Bastos, J.:

Decreto No. 3084, 289.

Custas judiciarias, 297.

Inventarios, 265.

Jurisprudencia do Supremo Tribunal 213.

Jurisprudencia dos tribunaes, 213.

O jury, 3 Ir.

Organisação judiciaria federal, 289.

Promotor publico, 299, 3 ro.

$O$ registro civil, 257.

Transmissão de propriedade, $26 r$.

Taxation:

Argentina, 42, 72, 135, 153, 167-1 70 .

Buenos Aires (City), 26, $14 \mathrm{I}$.

Buenos Aires (Prov.), 25, 43, 140.

Brazil, 219-2 20, 261, 265, 313, 319-320, 325, $331-332,339-345$.

Chile, 421, 424, 435 .

Taxation, Corporations-Brazil, 220, 342.

Taxation, Inheritance-Brazil, 265.

Taxation, Succession-A rgentina, 72.

Taxation, Transfer-Brazil, 26r, 265, 342.

Taxation, Water-Brazil, 331.

Teixeira de Freitas, A., 238-240, 250, 264, 292. Additamentos ao codigo do commercio, 274.

Consolidação das leis civis, 238-239, 250, 252.

Código civil, 65.

“Doutrina das acções," 294.

Ësboço de codigo civil, 61, 239.

Legislacão do Brazil. Additamentos, 250.

Promptuario das leis civis, 250.

Regras de direito, 254.

Vocabulario juridico, 219.

Teixeira de Freitas, jr., A., 323.

Teixeira de Freitas, M. A., 362.

Tejedor, 106, rog.

Derecho criminal, iro.

Derecho mercantil, 82.

Telegraph conventions-Argentina, 854 .

Telegraph law:

Argentina, 39, 153-155.

Brazil, 325.

Chile, 374,432 .

Telles. See Homen Corréa Telles.

Ten-day notice-Brazil, 294.

Terrenos de marinha-Brazil, 321.

Territories:

Argentina, 29-30, 41, 141, 147.

Brazil, 313, 325 .

Terry:

La crisis, 166.

Finanzas, 166, 169.

Testamentary law. See Wills

Testimony-Argentina, 95 . 
Thaumaturgo de Azevedo. See Azevedo.

Theater tickets-Brazil, 282.

Things-Brazil, 257-262, 362 .

Thomaz. See Fernandes Thomaz.

Thomaz do Bomfim Spindola. See Bomfim Spindola.

Thompson, 74, 267.

Tiburcio José da Rocha. See Rocha.

Tickets-Brazil, 282.

Time:

Argentina, 62, 98, 103.

(Civ. Code, Introd. Act), 64-70.

Brazil, 245.

(Civ. Code, Gen. Pt., Bk. 3), 248-252.

Tito Fulgencio Alves Pereira. See Fulgencio Alves Pereira.

Tobias Barreto de Menezes. See Barreto de Menezes.

Tocornal, 395.

See also Cruchaga Tocornal.

Toledo, Ordenanzas de, $54^{-55}, 56$.

Tooke, 4 16.

Toro, Leyes de, 53, 57 .

Toro C., 44x.

Toro Melo, 379, 387 .

Código de procedimiento civil, 409 .

Torre. See Rodriguez de la Torre.

Torrens system:

Argentina, 71.

Brazil, 201, 26r.

'Torres:

A organização nacionaí, 320.

O problema nacional, 320.

Torres Bandeira, 305.

Torrez Camara, 222.

Torts-Argentina, 63 .

(Civ. Code, Bk. 2), 64-70.

Trade-Chile, 421.

Trade unions-Brazil, 334.

Trade-marks:

Argentina, 42, 74-75, 79, I81.

Brazil, 219, 247, 268-269, 288.

(Civ. Code, Spec. Pt., Bk. 2), 248252.

Chile, 396.

International treaties, 187 .

Trade-names-Brazil, 269.

Transfer of property-Chile, 390.

(Civ. Code, Bk. 2), 391-394.

Transfer taxes-Brazil, 261, 265, 342.

Transportation:

Argentina, 188.

Chile, 426 .

Transportation by water-Argentina, 152I53.

Transportation insurance. See Insurance, Transportation.

Trant, 168.

Travelers. See Commercial travelers.
Treasury-Brazil, 302.

(Crim. Code, Bk. 2), 302-304.

Treasury Department (Argentina) Solleitor. 39.

Treaties:

See also Commercial.

Argentina, 42, 84, I 53, I54, 176-178.

Brazil, 265-269, 286, 349-351, 354 .

Chile, 396, 440-441.

South (Latin) America, 176, 187.

Treaties, arbitration-Brazil, 351 .

Trial-Argentina, Ir6, 118 .

Tribal (indigenous) law-Argentina, 58-59.

Tribunal del Consulado (Chile), 397.

Tribunals. See Courts.

Trigo de Loureiro. See I.oureiro.

Tristão de Alencar Araripe. See Araripe.

Troplong, 62.

Trübner, 194.

Trusts and trustees-Brazil, 246-247, 295.

(Civ. Code, Spec. Pt., Bk. 1, 3), 248-252.

Tuberculosis-Argentina, 160 .

Ugarriza, 106.

Ugarte Zenteno, 400.

Ulysses Machado Pereira Vianna, See Pe reira Vianna.

Unconstitutionality of legislation:

Argentina, 132-133.

Brazil, 318-319.

U. S. Bur. of For. and Dom. Com., 75.

U. S. Department of Commerce, 170, 171 .

U. S. Federal Trade Com., 170, 437.

Universidad de Chile, Anales de, 380.

University reform-Argentina, $\mathbf{1 6}_{3}$.

Unsain, 108.

Legislación obrero, 158.

Leyes obreras, 156.

Urien, 183 .

Urmeneta, 434 .

Urrutia, 394.

Urrútia, M. A., 132.

Uruguay. Min. de rel. ext., 359.

Uruguay:

Administraçăo, 325.

Direito administrativo, 325.

Use and occupation:

Argentina, 63.

(Civ. Code, Bk. 3), 64-70.

Brazil, 247.

(Civ. Code, Spec. Pt., Bk. 2), 248252.

Usufruct:

Argentina, 63.

(Civ. Code, Bk. 3), 64-70.

Brazil, 247.

(Civ. Code, Spec. Pt., Bk. 2), 248252.

Chile, 390.

(Civ. Code, Bk. 2), 391-394 
Uti possidetis-Chile, 443.

Vaccination-Brazil, 336.

Valdes, A., 40x.

Valdés, C., 37 .

Valdés, M. L.. 405.

Valdés Mendeville, 445.

Valdés Riesco, 379.

Quiebras, 402.

Valdivieso, 420

See also Bravo Valdivieso.

Valentín Gormaz. See Gormaz.

Valenzuela. See Ramiro de Valenzuela.

Valiente. See Saenz Valiente.

Valladão:

Codigo das aguas, 330.

Dos rios publicos e particulares, 330.

Valle. See Del Valle.

Valle Cabral, 195.

Valle Iberlucea, 160 .

Valparaiso, 423.

Vampré. See Spencer Vampré.

Van Dyne, 357.

Vanni, 52.

Varangot, 104.

Varas, 439.

Varela. See also Beccar Varela.

Varela, A., 317.

Varela, I. V., II2.

Código civil, 66.

Código de procedimientos, $103,142$.

Concesiones provinciales, 136 .

Constitucion de Buenos Aires, 135.

Constitución nacional, 132.

Debates de la convencion constituyente, r35.

Historia constitucional, rzo.

I a intervencion, 86.

Proyecto de codigo, 102.

Reformas á la constitución, 136 .

Vargas. See also Aguirre Vargas.

Vargas, $38 x$.

Várgas Fontecilla, 403.

Vargas Videla, 188.

Vasconcellos, 333 .

See also Góez e Vasconcellos.

Vasconcellos Menezes. See Drummond.

Vaz Barboza Luzitano. See Barboza Luzitano.

Vaz Vieira. See Vieira.

Vedia, A. de, 165.

El banco nacional, 164 .

Constitución argentina, 126.

Intervencion, 132.

Martin Garcia, 186.

Proyecto de correcciones, 65 .

Tierras pablicas, 145.

Vedia, E. de, I3x.

Vedia, J. M de 162 .

Vega. See Lazo de la Vega.
Veiga, D. A. da, $22 x$.

Codigo commercial, 275.

Direito hypothecario, 260.

Veiga, D. A., jr.

As sociedades anonimas, $28 x$.

Veiga, I. F. da, 323 .

Veiga Cabral. See Cabral.

Veiga Filho, J. P., 34x.

Velar, 74.

Velez, 392.

Velez Sarsfield, 45, 60, 6r, 64-68, ;6.

Derecho publico eclesiastico, 173.

Velloso-Rebello, 257, $311,333$.

Sources historiques du dr. brésilien, 237

Vendors and purchasers. See Purchase and sale.

Venégas, Florencio A., 44r.

Venegas, Fortunato, 427.

Lejislación chilena sobre aguas, 426 .

Ventura Beleña, 386 .

Vera, B., 370.

Vera, R.:

Codigo civil, 392.

Código de mineria, 429.

Código de procedimiento penal, 415.

Código penal, $4 x_{3}$.

Derecho internacional, 445.

Estudios juridicos, $\mathbf{3 8 2}$.

La jurisprudencia práctica, $38 \mathrm{r}$.

Notario publico, 4 Ir.

Vergara, E., 445 .

Vergara, I.., 409.

Vergara, R. G., 40r.

Vergara, W. W.. 437 .

Vergé, 6r.

Vessels. See Ships and shipping.

Veyga, F. de, 115 .

Veyga, T. de, 98.

Vial Solar, 443.

Viana. See Oneto y Viana.

Vianna.

See also Domingues Vianna.

Ferreira Vianna.

Pereira Vianna.

Rocha Vianne.

Sá Vianna.

Vianna, Sá, 357, 358.

Nonexistence d'un droit int. americain, 356.

Vicente Gaspar Quesada. See Quesada.

Vicente Pereira do Rego. See Rego.

Vicento Alves de Paula Pessoa. See Paula Pessoa.

Vicento Ferrer de Barros W. Araujo. See Ferrer de Barros W. Araujo.

Victoria, 39.

Vicuña. See Marin Vicuña.

Vicuña Mackenna, 369.

Vidal, 377 . 
Vidal de Oliveira Freitas. See Oliveira Freitas.

Vidal [Leite Ribeiro], Armando: Processo civil, 29r. Propriedade litteraria, 266. Warrants agricolas, 278 .

Videla, 139 . See a lso Vargas Videla.

Vieira, 234.

Vieira de Araujo, 301. Codigo criminal, 301 .

Codigo penal commentado, 302. $O$ codigo penal interpretado, 303 . Direito penal do exercito e armada, 307 . Processos penaes, 3 IO.

Vieira Ferreira, $2 ; 6$.

Viel, C., 443.

Vieto de Meirelles, 199.

Vilches, 437.

Vilhena, 228

Villalón, 394.

Villalonga, 105.

Villalva. See Freitas Villalva.

Villamayor, 140.

Villegaș, 77, 106.

Vindication, right of-Chile, 390 .

(Civ. Code, Bk. 2), 39x-394.

Viola. See Navarro Viola.

Visconde Cayrú. See Cayrú.

Visconde de Ouro Preto. See Ouro Preto.

Visconde de Uruguay. See Uruguay.

Visigothic Code, 53.

Visit and search, 444

Viveiros de Castro, A. O., 221, 344.

Dircito publico, 320, 343 .

Impostos, 342 .

Sciencia da administração, 325.

Viveiros de Castro, F. J.:

Delictos contra a honra de mulher, 304 . Direito penal, 304 .

Jurisprudencia criminal, 215, 306.

A nova escola penal, 305 .

Sentencas e decisões, 306 .

Vivot, 182.

Wagering contracts-Brazil, 247.

(Civ. Code, Spec. Pt., Bk. 3), 248-252.

Wages-Argentina, 157, 158.

Wallace, 123, 315.

Walmesley, 333 .

Walton, 386.

War, 184, 443-444.

Warehouse certificates-Argentina, 85

Warehouse receipts-Brazil, 278.

Warehouses and warehousemen:

Argentina, 78, I7 I.

(Comm. Code, Bk. I), 78-84. Brazil, 272.

(Comm. Code, Pt. 1), 273-277.

Warrant of arrest-Brazil, 300 .
Warrants:

See also Agricultural warrants.

Argentina, 42, 79, 85, 147 .

Brazil, 219, 278-279, 282.

Warships-Argentina, I53.

Washington Vergara. See Vergara.

Water power:

Brazil, 259, 330.

Chile, 390.

Waters:

See also Rivers.

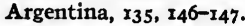

Buenos Aires (Prov.), 42.

Brazil, 259, 330.

Chile, 390, 408, 425-427.

(Code of Civ. Proc., Bk. 3). 409-412.

Weights and measures-Argentina, 4I, 155 .

Weiss, I89.

Welfare assistance-Brazil, 325 .

Wheless, 248.

Wileman, 218, 315.

Brazilian exchange, 338 .

Wills (Testamentary law):

Argentina, 63, 69.

(Civ. Code, Bk. 4), 64-70.

Brazil, 2 20-22I, 248, 250, 255, 264-265, 295.

(Civ. Code, Spec. Pt., Bk. 4), 248-252. Chile, 390.

(Civ. Code, Bk. 3), 39x-394.

Wilmart, 84

Función const. de los ministros, 13 .

Wilson-Rae, 80.

Winsor, 194.

Witnesses:

Argentina, 95, 118.

Brazil, 293.

Women:

Argentina, ${ }_{55}-156,158$.

Brazil, 304.

Woods-Chile, 425, 427.

Workmen's compensation. See Employer's

liability.

Working day-Argentina, 160.

Working men-Argentina, 157 .

Workmen's dwellings-Chile, 434.

Workmen's pensions-Argentina, 158,160 .

Wright, 218.

Writs of error-Brazil, 293-294.

Written instruments-Brc zil, 255.

Wurtemberg Code, 76-77.

Xavier Carvalho de Mendonca. See Carvalho de Mendonca.

Xavier Sobreira de Mello. See Sobreira de Mello.

Yáñez, 379.

Yellow tever-Argentina, 161 .

Yof ré, 14r.

Zacarias de Góes e Vasconcellos. See Gócz e Vasconcellos. 
Zachariae, 52, 6r.

Zañartu. See Larrain Zafiartu.

Zeballos, 48, 73, 77, 89, 96, 174, 190, 260, 395 . Argentine constitution, 129.

Conferencias internacionales, $18 x$.

L,e crédit . . . 7I.

Justicia internacional, $x 88$.

La nationalité, 179.

Zenteno, 372, 428.

See also Ugarte Zenteno.
Zenteno Barros, 425.

Zinny:

Bibliografia histórica, 16.

Efemeriodografia, 15.

L,a gaceta mercantil, I6.

Historia de los gobernadores, 121.

Zisternos. See Bravo Zisternos.

Zorilla, 245. 





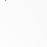



2 Borcherd, Edwin Montefiore

6458 Guide to the law and legal

A7B6 Iiterature of Argentinat, Brazil and Chile

\section{PLEASE DO NOT REMOVE}

CARDS OR SLIPS FROM THIS POCKET

UNIVERSITY OF TORONTO LIBRARY 
